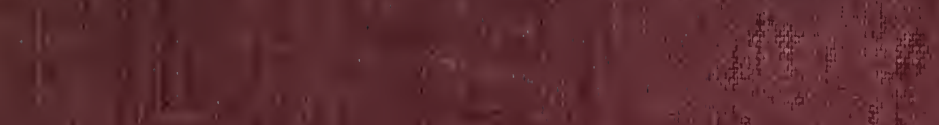

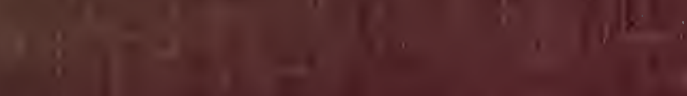
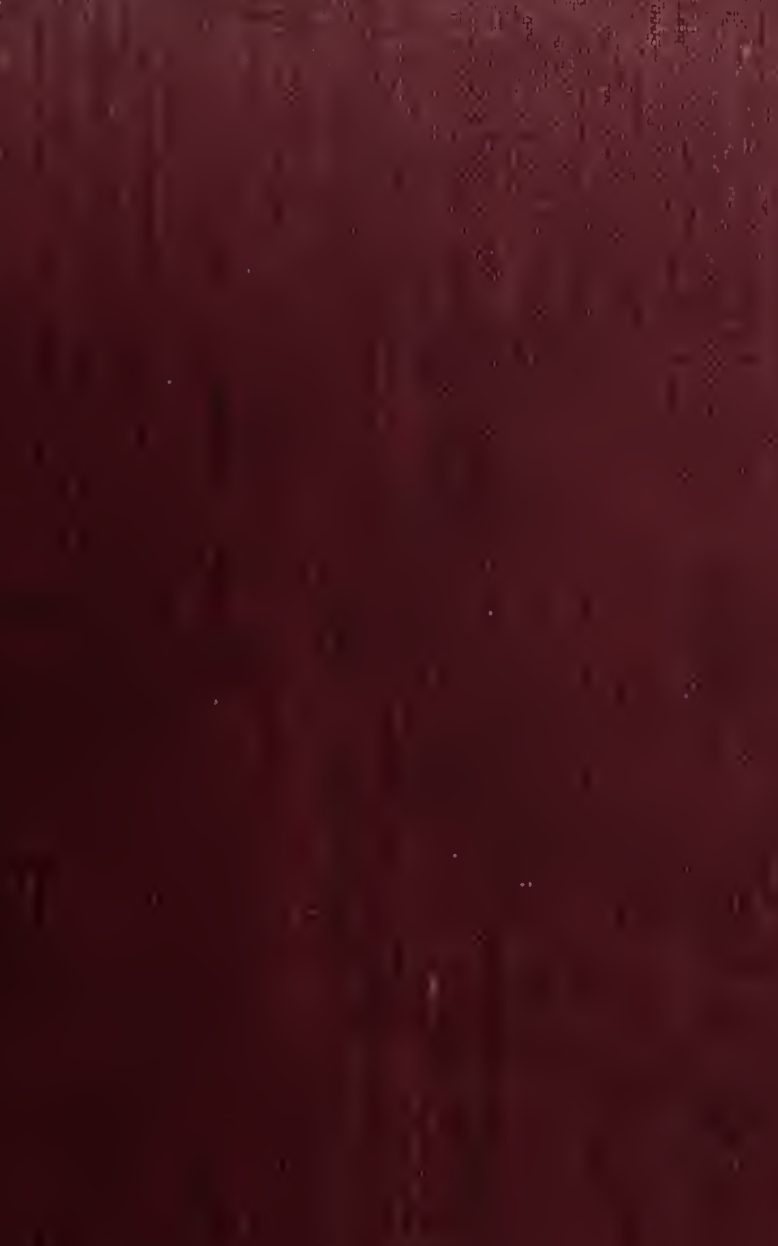


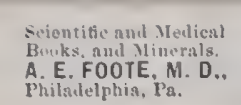

Lavid Tagqant

- Corthumbitaind.

bec 20.1836

$2 d c$

$A b$ 




\section{GE NER A L S Y S TE M}

$\mathrm{OF}$

\section{TREESA N D SHR UBS.}

FOR A L L

USEFUL AND ORNAMENTAL PLANTATIONS, Hohn in jegkark

GARDENS, PLEASURE-GROUNDS, SHRUBBERIES, PARKS, PADDOCKS, WOODS, GROVES, WALKS, AVENUES, CLUMPS, THICKETS, HEDGES, HEDGEROWS, ARBOURS, ORCHARDE, FRUIT-TREE PLANTATIONS,

AN D ALL OTHER

PLANTATION DISTRICTS, ELIGIBLE FOR THE IMPROVEMENT AND IMBELLISH. MENT OF GARDENS, ESTATES, \&E.

FOR MING

A C O M P E A T GENERAL S Y T E M O

TREES A N D SHR UBS,

AGREEABLE TO THE LINNRAN SYSTEM;

Being arranged in their refpective Genera or Families, under the Generical or Botanic Family Names, Latin and Englifh.

$B Y J O H N \underset{\equiv}{A} B E R C R O M B I E$, (AUTHOR Of EVERY MAN HIS OWN GARDENER.)

$$
L \quad O \quad N \quad D O O N:
$$

- rinted for C. STALKER, BLAcKFriar's-RoAd, SURRY ; H. D. SYMONDS, PATERNoster. Row; and fold by all other Bookfellers in ENGLAND, SCOThAND, and IRELAND. 



\title{
GARDENER'S VEGETABLE SYSTEM,
}

\author{
A N D \\ B O T A N I G A L D I S P L A Y \\ O F A L L
}

\section{PLANTS, TREES, SHRUBS, FLOWERS, AND FRUITS.}

\section{P A R T I.}

\section{SYSTEM OF TREES AND SHRUBS,}

For all Userul and Ornamental Plantations, in Gardens, Pleafure-Grounds, Shrubberries, Parks, Paddocks, Woods, Groves, Walks, Aqjenues, Clumps, Thickets, Hedges, Hedge-Rouvs, Arbours, Orchards, FruitTree Plantations, and all otber Plantation Diftrits eligible for the Improvement and Embellifinent of GarSirzs, Efates, \&c.

$\mathrm{C}$ OMPREHENDING a general and fyftematic difplay and defcription of all the genera, fpecies and varieties of the grand tribc of hardy trees and Ihrubs, both deciduous and ever-green kinds, valuable for compofing the various profitable, ornamental and pleafurable plantations as above; confifting of the great and ufeful collection of foreft or timber trees for forming woods, groves, coppices, \&c. the numerous tribe of ornamental trees and flowering thrubs for Mrubberrics and other decorative plantations in pleafurc-grounds; and all the forts of fruit trees for planting in gardens and orchards: the whole arranged fyftematically, claffing all the numerous different pecies and varieties in their proper families or genera, agrecable to the Linnacan fyftem of botany, diftinguinhing and ex. plaining the botanic claffes and orders to which the different genera and their refpective fpecies belong; all the genera and fpecies ranged under their botanic; Latin and Englifh names; defcribing the generai growth and effential characters of the different genera, and general dimenfions of growth of the refpective fpecies of each genus or family, whether trees, thrubs, or under-fhrubs, with their fpecific dirtinction and difference of growth and general ftructure; thewing alfo the places of their original refidences, o: where they grow naturally in the different parts of the world; explaining their refpeetive merits, particular and general ufes for the feveral plantations, different methods of propagation, and manner of raifing and training in the nurfery: together with the fereral or- 
ders and methods of final tranfplanting, to form the various plantations for which the different kinds are adapted and defigned, and with full directions for their effential culture in the feveral compartments.

That in the whole, by thus arranging the great and valuable tribe of hardy trees and thrubs under one diftinct or feparate divifion, it will prove materially convenient and effentially ufeful to gardeners, nurferymen and planters in general, as well as to all owners and occupiers of eftates, farms, \&c. where improvement in plantations may be neceffary, as they will readily diftinguifh the proper or particular forts wanted for the different occafions of planting.

This firft part, or divifion, comprifing the fyftem of hardy trees and fhrubs that are generally cultivated or eligible to cultivate in gardens and other diftricts, for forming the various ufeful and ornamentai plantations, \&c. they confint of many genera or families, fome furnifhing feveral of many fpecies, others but one, two, or three, and many of the refpective fpecies are fportive in varicties, differing either in growth, flowers, fruit, \&ic. amounting in the whole to feveral hundred fpecies and varieties, all of which are of fufficiently hardy temperation to grow in the open ground, and will profper in moft common foils and expofures, and in their different natures may be fuited to various fituations, or the greater part will grow freely almoft in any; or as fome forts are of a more tenderifh nature, require a particular foil and fituation, and fometimes demand a heltered, warm, compartment: thefe particulars are generally intimated under their refpective heads, in the directions explaining their general cultures; and as this fyttem comprifes all forts of foreft trees, ornamental trees and Mrubs, and the different forts of fruit trees, as alfo deciduous and ever-green kind, each is explained under their refpective genera.

And as in the numerous different fpecies, fome are of upright growth, as in the greater part, and fome are of trailing and creeping growth, others climbers; all of which have their particular ufes in the different plantations.

That as plantations of hardy trees and hrubs are importantly ufeful and ornamental in general gardening, and of great utility for the embellifhment and improvement of eftates, farms, \&c. all the different genera, fpecies and varieties thereof being collected under one general fyftem, the defired forts for the purpofes intended will be readily difcovered; and of which, the forming any plantations defigned, no time fhould be loft in furnining the allotted diftricts, that they may be advancing in their refpective growths, either of the ornamental kinds in fhrubberries or other decorative compartments in pleafure grounds, parks, \&cc. or of foreft trees difpofed in out-grounds for timber and undoxwood, and of the fruit trees in gardens and orchards, moft valuable in their annual.productions of fruit, as it will be feveral years before many of the different forts of trees and hrubs acquire any confiderable growth, either for appearance or utility; and as gardens and eftates, however defirably fituated, and of favourable foils and expofures, if deflitute of plantation, or not furnifhed therewith, more or lefs in fome degree proportionate to the extent of the ground, appear naked and lefs important, as well as prove much lefs valuable to the owners and occupiers thereof; and befides the ornamental appearance of tree and hrubberry plantations, they afford theiter and thade to particular diftricts, and thofe of the foreft-tree kind, in plantations for timber, \&c. and of the fruit-tree tribe, for their fruit, yield great profit, both in many domeftic occafions, and for fale, where it may be defired to make all poffible advantage of thefe productions.

And as moft gardens, pleafure grounds, \&cc. are of eligible foils, fituations, and expofures, fuitable for plantations of the different or defirable forts of hardy trees and fhrubs, they may be admitted in any defired collection, moftly in the common or general foil of the allotted diftricts; as likewife in moit eftates and grounds of any confiderable extent, they, as well as fertile foils and fituations eligible for principal, ufeful, and ornamental plantations of the more defirable kinds, furnith wafte lands, either in low and marhy premires, or hilly and mountainous fituations not well adapted for other cultivation, are often applicable to plantations of many forts of foreft and other large tree kinds, both for profit, ornament, and to diverfify the refpective divifions, and afford Melter to others; as there are many hardy trees and fhrubs which will grow in almoft any foil and fituation, and others require foils of a.more favourable nature: though it may alfo be obferved, that moft forts will profper in any common foil of gardens and other ditiriets, where it may be thought eligible or convenient to have any kind of plantations.

Therefore, in gardens and other grounds, either of fnall, moderate, or large extent, having plantations lefs or more accordingly, either of various different forts of trees and thrubs, or only of the molt defirable kinds, fuch as the mof beautiful floweriug fhrubs, and of other principal ornamental mrubs and trees, both of the deciduous and ever-green tribes, difpofed in fhrubberries, borders, clunips, and other compartments in a diverfified afiemblage, and larger trees arranged in groves, thickets, woods, grand walks, avenues, rows, and in boundary plantations, in pleafure grounis, yarks, fields, hedge-rows, \&c. they, in all of which,ifferent plastations, are great embellifhments to the rrouncis, and difplay an entertaining variety in their different refpective growths, flowers, fruit, \&c. and in exte live out-grounds, having plantations of foreft trees for their timber and underwood, are of important value, as likewife in gardens in general, 
never omitning to have collections of fruit trees, which are particularly valuable in their annual productions, both for the fervice of a family and public fupply, and may be admitted both in kitchengardens, in ftandards, wall trees and efpalicrs, and in ltandards, in orchards, pleafure grounds, hedge-rows, \&c.

As this divifion confits of TREES, $S_{H R U B S}$, and UNDER-SHRUBS, and of deciduous and ever-green kinds, their principal difference is - that a tree is generally confidered as differing from a thrub, principally in being of larger growth, and rifing with a fingle upright ftem or trunk to a confiderable height before it divides into arms or large branches, growing fifteen or twenty, to fifty, fixty, or an hundred feet high.-A thrub either rifes with feveral ftems immediately from or near the root, or the main ftem divides low into feveral fmaller ones, and is every way of lefs growth and dimenfions than a tree; and that the general growth of the various different fpecies of thrubs is from two or three, to five, ten, or fifteen feet high-and the difference between a thrub and an under-hrubby plant is, a full or perfeet fhrub affumes a more woody, large, firm growth, next to a tree; the under-fhrubs are of lower, more weak, and infirm growth, rifing with fmaller, more foft Items, fomewhat between a woody and herbaceous nature, growing from fix or eight inches, to one, two, or three feet high, as in thyme, fage, hyffop, winter-favory, fouthern-wood, and teveral forts of heath; and fome are of trailing growth, as periwinkle, \&c.

In the general growth of trees, Thrubs and underShrubs, all the tree kinds are confequently of upright, frong, firm growth; the hrubs alfo, in the greater part, are upright; fome are of declining and trailing growth, others are climbers, and the fame of the under-fhrubs; all of which being explained under their refpective genera and fpecies, as they occur, in the courfe of the following work.

Trees and Shrubs differ from herbaceous plants, by having woody ftrong ftems of long duration; the herbaceous tribe rifing with foft, fucculent, flender fiems, mottly annual, or but of one fummer's growth, rifing in the fpring, and in the greater part perion in autumn or winter following; but trees and hrubs are durable in ftem and branches.

And as to the diftinction between deciduous and ever-green trees and hrubs; the deciduous kinds are fuch as expand their leaves only in fummer, from April or May till October, then decay and fall from the trees, \&cc. in that month, or wholly, early in November, remaining defoliated or leaflefs all winter and until May aforefaid; and the ever-green trees and fhrubs continue in green leaves all the year, as in holly, \&ic. the old leaves continuing till difplaced by the young ones in the fpring.
All or moft of the different fpecies and varieties be longing to this fyftem of hardy trees and thrubs, are raifed and cultivated in the numerous nurfery grounds in the different parts of the kingdom, for plit). lic fupply, in furnifhing the various plantations in noblemens and gentlemens gardens and eflates, and of others, as may occafionally be required; and molt of the principal forts may be occafionally raifed in private nurferies to afift in fupplying the aforelaid plantations, as numerous forts may be propagated and raifed abundantly from feed, berries, nuts, Sec. foived in the natural ground; many by fuckers, layers, cuttings, flips, \&c. the whole, when, according to their nature and dimenfions of growth, they are from one, two or three, to five or ten feet high, are of eligible fize for final tranfplanting for the different occafions for which they may be defigned; or fome tree kinds may occafionally be tranfplanted when of more advanced growth, of from ten or twelve to fifteen fect high, or more; efpecially deciduous kinds, when required to form any confpicuous plantation as expeditious as poffible, or for immediate thade, fhelter, \&c. in particular compartments; or allo, for which occafions, fome deciduous trees, as elm, lime, poplar, \&c. admit of tranfplanting when of eighteen or twenty feet high, removing them with a full expanfion of roots, or more fuccefsfully when convenient, to remove them with fome ball of earth thereto.

However, for general planting of trees, thofe of five or fix to eight or ten feet are in the greater part moft eligible for good fuccefs, as young trees fooner ftrike good root to grow freely, and eftablith themfelves effeetually, than thofe removed of larger growth; and thofe defigned for foreft or timber trees particularly, it is of advantage to tranfplant them finally where they are to remain, while they are of young growth, of from one, two, or three, to five or fix feet high, that they may root effectually from the beginning; and in many of the ever-green tree kinds, as pines, firs, cedars, \&c. they are always confiderably the moft fuccefsful when finally tranfplanted while young, of two or three, to four, five, or fix feet, in which they generally acquire a more free growth, advancing expeditio oufly in a Itraight lofty ftature, and fo of various other forts; and as to the fhrub and under-hrubby kinds in general, they, according to their fmaller or larger growth, may be planted of from one foot, or half that fize, to two, three, or four, to five or ten feet; always: in the plantations, difpofing the lower plants towards the front, and the larger more or lefs backward.

The general feafon for planting, is either autumn or fpring; or the more hardy kinds, may be occafionally planted any time in open weather, from October or November, till March or April, more efpecially tho deciduous tribe; though in a dry or light foil, it is of advantage to plant early in autumn, at the decay of the leaf, in Oetober and November, and they will 
quickly take root the fame fcafon; but in wet ground, or of a ftrong loamy or clayey nature, the fpring, about February or March, may be a more eligible time for planting in fuch foils, or at leaft either in that feafon, or early in autumn, not too freely in winter, except in dryilh, light ground; and as to ever-greens, it is advifeable to plant them either principally in autumn, about September, Oetober, and beginning of November, or in the fpring, February, March, or April, as moft of thefe kinds, when tranfplanted in cold feafons, in winter, or early in fpring, are more liable, before they ftrike good root, to fuffer by the feverity of froft and other inclement weathers, than moft of the deciduous forts, unlefs where they can be removed with balls of earth, efpecially any of the more curious or tender fpecies, fo as not to receive any or but little check by removal.

And in the general planting of trees and fhrubs for ornament, or alfo in woods, \&cc. for timber plantations, it is advifeable to have the deciduous and ever-green kinds moftly in feparate compartments, or in clumps alternately of the former and latter; or may occafionally interfperfe fome ever-greens in the deciduous plantations to encreafe the variety, and for the ever-greens in their continuing leaves, to difplay a more confpicuous and lively appearance in the plantations in winter, when the deciduous kinds are deftitute of their foliage.

But for the particular directions relative to the different fpecies, \&c. methods of propagation, planting, and general culture, fee the refpective articles under their principal heads, in the following fyftem and difplay; to which, after the foregoing oifervations, we inall now proceed.

\section{Acer MAPLE TREE and Sycamore.} In the Botanic Syftem the Maples belong to the

Clafs and Order

Polygamia Monoecia, Many Marriages, One Habitation;

\section{Or Flowers of different Sexes, as Hermaphrodite and} Males, feparated on the fame Tree.

THE family of Maples are principally of the tree kind, of middling and large growth, from twenty or thirty to fifty or fixty feet high, or more; all of the deciduous tribe, and hardy to grow in any open fituations. \& c. fome proper to cultivate for foreft or timber trees, others principally to plant for ornament and variety, in pleafurable plantations, both for the diverfity of their different growths and foliage; and fome, for their ornamental flowering, are garnifhed in fummer, to the end of autumn, with fimple leaves of moderate, middling, and large expanfion, divided lefs or more into three or five lobes, and with fmall flowers of five petals, in racemus clufters, corymbus and aggregate bunches, fucceeded by winged capfules, furnifhed with roundifh feeds: ripe in fummer and autumn, for fowing the fame feafon, or in fpring, to raife fupplies of young trees; and which may alfo be propagated by. layers and cuttings.

The Generic Charafters are-Hermaphrodite and male flowers apart on the fame plant-the calyx or outer cup one-leaved, deeply cut into five acute fegmentscorolla or flower, five oval fpreading perils, containing in the centre eight fhort faminas male organs, crowned with procumbent crofs-plar 'd anthera-and in the hermaphrodite flowers, a compreffed germen in the bottom of the calyx, farmounted by a double ftigma or female part, which becomes two winged capfules, each furnifhed with one roundifh feed.

\section{The Species are,}

1. Acer campeftre, Champagne or common fmalle: Maple.

A moderate tree, growing twenty or thirty feet high; the bark rough, leaves (middling fize) lobated, three-parted, obtufe emarginated or end-notched.- Native of the fouthern parts of Europe, England, \&c. in woods and hedges.

2. Acer Pfeudo-Platanus, (Pfeudo-Platanus, or falfe Plane Tree) greater Maple or Sycamore.

A largin tree, growing forty or fifty feet high, or more; the leaves (large, broad) five lobed, unequally fawed on the edges, and with flowers in large racemus clufters, fucceeded by bunches of winged feed veffels -Native of England, Switzerland and Auftria.

\section{Variety of this. Striped-leaved Sycamore.}

\section{Ace r rubrum, Redior Scarlet flowering Maple of Virginia.}

A moderate tree, growing twenty-five to thirty feet high; the leaves (middling) five lobed, a little indented or teethed, glaucous or whitifn fea-green underneath, and with fimple peduncles or flower-ftalks aggregated; the flowers reddifh.-Native of Virginia, in INorth America.

Variety. Sir Charles. Wager's flowering Maple; flowers pale red, in large bunches, appearing very ornamental in the fpring, April, or May.

4. Acer Platanoides, (Platanoides, or Plane-Treè like) Norway Maple.

A largifh tree, growing thirty or forty to fifty feet high; the leaves (largifh, hining green) five lobed, pointed, Tharply indented, fmooth, and with flowers 
in corymbus bunches, - Native of the northern parts of Europe, mountains of Stiria, and Savoy.

\section{Varicties. Jagged-leaved Norway Maple. Striped-leaved Norway Maple.}

5. ACER faccbarinum, Sacchariferous or Sugar Maple of America.

A middling tree, thirty or forty feet high; the leaves (largihh, r. ep green) five-parted paimated, fharply indented, a ga-green underneath. - Native of Penfylvania and other parts of North America, where, by tapping the growing trees in the fpring, is extracted a faccharine juice, of which is made a tolerably good fugar.

\section{ACE R tataricum, Tartarian Heart-leaved Maple.}

A fmallifh or moderate tree, twenty to thirty feet high ; the leaves (middling, deep green) hearted, undivided, the lobes obfolete or flight, and flowers growing in long racemus clufters. - Native of 'Tartaria, Afia, \&.c.

\section{Acrr penfjlvanicum, Penfylvanian American Ma- ple.}

A largith tree, thirty or forty feet high; the deaves (large) three lobed, pointed, finc-fawed, and with flowers in racemus clufters, (pendulous.) - Native of Penfylvania, in North America.

ACER manspefuldanum, Montpelier French Maple.

A moderate fize tree, growing eighteen or twenty feet high; the leaves (middling fize, hining green) three lobed, very intire, and fmooth.-Native of Montpelier, in France, alfo of Italy.

\section{Acer Negundo, (Negundo) or Alh-leaved Virgi- nia Maple.}

A large tree, growing forty or fifty feet high; the leaves (largith, light green) compound, three and five lobed, and flowers growing in racemus bunches.Native of Virginia, in North America.

\section{Acer creticum, Cretun Ivy-leaved Maple.}

$\Delta$ fmallifh tree, growing eighteen or twenty fcet high; the leaves (middling fize) three lobed, intire, and downy.-Native of the Eaft, in the Levant.

11. Acer Opalus, (Opalus) or Italian round-leaved
Maple.

A largifh tree, thirty feet high or more; the leaves (large) lobated, nightly cut, and flowers and fruit growing in racemus buxches. - Native of Italy.
The foregoing being the principal fpecies and va. rieties of hardy Maples at prefent known and cultivated in the Britifh gardens and plantations, are alf eafily raifed from feed fowed in autusin, or early in the fpring, in beds of light earth; and moft of the forts alfo, by layers and cuttings of the young wood is the fame feafons.

They are all deciduous trees, or fuch as defoliate 0 : fhed their leaves at the approach of winter; the leaves moftly fimple, or of one expanfion, from three or four to fix or eight inches broad, in the difierent fpecies, beginning their expanfion in May, and continue till October, then decay and fall from the trees; and the trees flower in fpring and early part of the fummer, moftly in largin bunches on the young branches; the flowers fmall and greenifh, except the Scarlet Maples, which, in particular, difplays a good ornamental appearance in its numerous large clufters of flowers; and it moft of the fpecies the feeds ripen abundantly, in furn. mer and early part of autumn, for fowing.

The trees are all of tolerably hardy growth, and will thrive in almoft any common foil, fituation, and expo: fure; and are eligible both for profitable and ornamental plantations: the Common Maple, Sycamore, and all the larger kinds, are proper to affemble in forefttree, plantations for timber, in coppices for underwood, and in hedge-rows, fields, \&c. and all the forts are alfo adapted to arange with other trees in any confiderable decorative plantations in extenfive pleafuregrounds, thrubberries, parks, and any out-premifes, as in their different growths, foliage, and modes of flowering, \&c. will effect a confpicuous and agreeable variety; or for fmaller plantation compartments, thrub. berries, clumps, \&c. may have only fome of the nore curious forts, fuch as the Striped-leaved Greater Maple, Scarlet-flowering, Sacchariferous, 'Tartarian, Montpelicr, and Cretan Maples.

To cultivate for foreft trees in woods, to grow to large ftandards for timber, any of the larger growing kinds, as before obferved, may be admitted; fuch particularly as the Comnon and Greater Maple, the Platanoides or Norway Maple, Penfylvanian and Sugar Maple, and the Negundo or afl-leaved kind. The wood of the Maples, for its whitcnefs, was formerly in much eftimation for working into various articles in the cabinet-making branch, as tables, chairs, \&c. and is ufeful for the turner, and feveral other trades, but not of any confiderable value for teeng tis, in the building way, or any very ftrong purpofes.

They may be planted for the above occafions, both in aflemblage with other foreft trees, and fome in feparate plantations, wholly of the Maple kind; and in all of which, may either be planted in clofe row's, only. five or fix feet diftance, that they may draw up one another fraight and morc expeditiounly in height, and 
to allow for thinning by degrees in their advanced young growth, leaving a fufficiency of the finelt and molt promifing plants to run for full ftandards; or fome planted at once in wide rows or open groves, ten to fifteen, or twenty feet afunder, to remain in full growti, to acquire a large fize for timber.

For ornamental plantations, any of the defirable forts of Maples may be introduced in affemblage with other tree kinds and large fhrubs, and in which are eligible to admit in large boundary diftricts, extending along next the outward fences of pleafure-grounds, parks, \&c. fides of capacious lawns, and in confiderable thrubberry compartments; and alfo in forming clumps of trees in any confiderable open fpaces of grafs ground, in extenfive lawns, parks, \&c. and are very proper to affemble in plantations defigned for thelter in particular diftricts, to break off cutting blasts and boifterous winds from interior divifions; as alfo to arrange in groves and other compartments of planting, for ornament, variety, and obfervation.

And for all of which plantation, fupplies of young trees may be obtained in full collection at moft of the principal public nurfery gardens; and the feafon for planting them is any time in open weather, from October or November, to March or the beginning of April.

Or all the forts of Maples may be eafily raifed for the feveral plantations required, by the different methods of propagation following, as by feed, layers, cuttings, \&c.

By feed all the fpecies of Maples may be plentifully raifed, efpecially fuch as ripen feed in fufficient abuncance in this country, or that can be obtained of the foreign forts from abroad, which, in the greater part, may be procured of the nurfery-men and principalfeedfmen, in the proper feafons, in autumn and fpring, and may be fowed either in autumn, about September, October, November, or in February and March, but moft fuccefsfully in autumn; all fowed in beds of light earth, in drills or broad-caft, and earthed in half an inch to an inch deep; they will germinate and come up in the fpring: keep them clear from weeds all the fummer, and by autumn following will be advanced fix or eight to ten or twelve inches high; when in October, November, or the following fpring, if they ftand very thick, fome may be thinned out and tranfplanted in nurfery rows, or all of them may be tranfplanted from the feed-bed the firft or fecond year, fetting them in sows in the nurfery, two to three feet afunder, by eighteen inches in each row, and in which to remain three, four, or five years, or more, till advanced five or fix, to eight or ten feet high; then will be of proper fize for final tranfplanting in the feveral planations for which they may be defigned.
Likewife, by cuttings and layers of the young Thoots and branches, molt of the forts of Maples may be propagated, performing it in autumn or fpring, and will be rooted by the Michalmas following: obferving generally for the cuttings, chufe the ftraight young thoots of the former fummer, cut in lengths of ten or twelve inches, and dibbled in rows a foot afunder, ant after being well rooted may be tranfplanted at wider diftances; and for layers, having young trees, for ftools, cut down near the ground, to furnith bottom fhoots, which, when of one or two fummers growth, Thould be laid down, previouny gafhing or cutting a flit on the under fide; then lay and peg them into the earth, having the tops upright feveral inches above ground; and in autumn, when rooted, cut them from the ftools and plant them in nutfery rows.

In the feveral varieties of Maple, they are generally propagated by cuttings or layers to continue them permanent in their refpective properties, as feedling-raired plants thereof may vary, though the Striped-leaved Sycamore in particular, will often, or in the general part, come the fame from feed; or the defirable varieties may alfo be propagated by budding and grafting, inferting a bud or graft of the variety intended into young ftocks raifed from feed, \&zc. of the parent trees of the refpective forts, as the Striped-leaved Greater Maple, budded upon ftocks of the plain green leaved kind.

In raifing the young Maples by any of the methods above, and being planted in nurfery rows for training to the proper fize, their principal culture is to keep them clear from weeds, by hoeing between the rows in fummer, and digging the ground in winter and fpring; and according as the trees advance in growth, prune off the ftrong fide-thoots from the ftem, preferving the tops intire to afpire in height, in an upright growth, continuing each to a fingle ftem, and a moderate head of branches above.

When the trees are advanced from three, four, five, or fix, to eight, or ten feet high, or little more, they may be finally tranfplanted, where they are required, in the intended plantations.

They may be planted or tranfplanted finally any time in autumn, about Oetober or November, or in open weather, till February, March, or beginning or middle of April: and as to future culture, after timal tranfplanting into the refpective plantations, is principally to prune off low and rude lateral thoots from the ftems, cafual low ftraggling branches of the head, with any ftray or rambling branches above, and cut out dead wood, ftill continuing the whole to one principal main ftem, permitting the main top leader to afpire in height. 
Esculus, Horse-CH ESN U T Tree. Clafs and Order.

Heptandria Monogynia, Seven Males, One Female;

Or Hermapbrodite Flowers, baving feven Stamina or Malcs, and one Piftillum, or Female, all witbin the Same Cover.

THE HORSE-CHESNUTS are hardy, deciduous trees, growing twenty to thirty, or forty feet high, or more; of a beautiful ornamental growth, garnifhed with moft ample digitated foliage and numerous large and fpecious spike of flowers; are peculiarly adapted to plant for ornament and fhade, in pleafure-grounds, parks, \&c. not of material value for timber plantations: they grow with large, regular, branchy heads, of a conical form, clofely garnithed with confiderable Large leaves, digitated in the palmated order, into fix or feven large, oblong-oval lobes, united at the bafe, and joined to the fummit of one common petiole or foot-ftalk, fpreading out above like the expanded fingers of a hand, and with large pyramidal fpikes of white, and fcarlet flowers, of five oval petals, containing the ftamina and nylus in the centre, furcceeded by large, roundifh, prickly capfules, furnifhed with fubglobular nuts: ripe in autumn, but not eatable, except for deer and fwine, and by which the trees are propagated by fowing them in autumn or fpring.

Generic Charaders are-The flower Hermaphrodite, or containing both male and female organs, (Stamina and Stylus) - the calyx or cup fwoln, one-leaved, cut into five parts; corolla or flower, five oval petals, with folded borders, narrow at the bafe, and inferted into the calyx; Piftillum, a roundifh germen in the centre of the corolla, fupporting a fingle ftyle crowned by a pointed ftigma; Stamina, feven the length of the petals, declinated and terminated by afcending anthera; and the calyx becomes a large, roundifh, echinated, or prickly capfule, of three internal cells, furnilhed witn one or two large fub-globular nuts.

\section{The Species of $Æ S C U L U S$ are,}

\section{Esculus Hippo-Caßanum, (Hippo-Caftanum) or Horie-Chefnut, (common.)}

A large tree, of conical growth, forty to fifty, or fixty feet high; the leaves (large, palmated, dark green) of feven oblong lobes, and with flowers baving feven ftamina.-Native of the northern parts of Afia.

\section{Varicties. Silver-ftriped-leaved common Horfe- Chernut.}

Gold-ftriped-leaved common HorfeChernut.
2. Asculus Pavia, (Pavia) or Scarlet HorfeChefnut.

A fmall tree, growing eighteen or twenty feet high; the leaves (large, palmated, light green) tix or teven looed, and flowers having eight ttamina.-Native of Carolina and the Brafils.

\section{Varieties. Common Scarlet-flowered Pavia. Yellow-flowered Pavia.}

Both thefe fpecies of $E$ fculus, and their refpective varieties, are very defirable trees to plant for orna. ment; are of fwift and beautiful regular growth, particularly the common Horfe-Chefnut, which foon runs up to a confiderable height, making remarkable ftrong fhoots, advancing a yard in length, or more, in a few weeks; are all of the deciduous tribe, expanding their luxuriant foliage from May till Oetober, and produce their numerous pyramidal, large, erect flower-fpikes, in May and June, difplaying a beautiful appearance; fucceeded by the large prickly pericarpiums, pregnant with nuts, which, ripening in autumn, drop out of the capfules, and may then be gathered for fowing or planting the fame feafon, or in the fpring following.

Thefe trees have peculiar merit to plant for ornament and -fhade, and to introduce in large pleafurable plantations.

The common Horfe-Chefnut particularly, is a moft defirable tree to plant in groves, avenues, hady walks, and in rows in any out-boundaries; and to plant in affemblage in running plantations, towards the boundaries of parks, fpacious lawns, and other extenfive premifes; as alfo to difpofe in ranges, clumps, groups, and fingly, on extenfive lawns, parks, and other capacioufly open fpaces of grafs ground; and in all of which methods of difpofition it may both be planted diftinet, occafionally, and in afiemblage, with other tree kinds, and fhould generally be planted at fome confiderable diftance from one another and other trees, that each tree may have fufficient fcope to branch out freely all round in its natural orcier, without the extended branches of the feparate trees in advanced growth interfering, whereby they will branch moft regularly, and form beautiful pyramidal heads, which in fummer, being clofely adorned with the luxuriant digitated foliage, and beautiful large fpikes of white flowers at the ends of the branches, will effect a confpicuouny noble appearance, and, where in affemblage, make a very diftinguifhable variety in the plantation; the trees may alfo be admitted in the foreft-tree plantations, only, however, in moderate fupply, as the wood or timber is not valuable for any ftrong occafions, but may ferve for various light purpofes.

This fort flowers in May and beginning of June, appearing very ornamental; the flowers white, tinged $\mathrm{B} 2$ 
with a blufh red; and the nuts produced in fummer ripen abundantly in autumn, which, when the trees are difpofed in parks, afford food for deer, as thefe animals and fwine will eat them as they fall from the trees; and are not valuable for any other occafion, except for fowing, wherewith to raife fupplies of young trees when required.

Though abroad, where the trees grow naturally in great abundance, the nuts are occafionally cut or ground into a coarfe meal, \&c. and given to horfes: hence the original name Hippo-Caftanum, or HorfeCliefnut.

The Scarlet Horfe-Chefnut, in its fmaller growth, is alfo very defirable to plant for ornament in large finrubberry compartments, and other ornamental plantations as above; its lcaves nearly fimilar to the others, and produces bright red flowers, in long loofe fpikes -appearing in June or July.

Both thefe fpecies, and their varieties, may be obtained, for planting, at all the principal nurferies, or may be expeditiounly and abundantly raifed by planting the nuts, \&c.

The feafon for planting the trees is any time from the decay of the leaves, in Oetober or November, till March or beginning of April.

They are propagated by fowing or planting the nuts, either in October or November; or, for fear of rotting, in winter, or difturbed by vermin, in that feafon, may be preferved in fand for planting in February, generally allotting them a bed or beds of light earth, planting them in drills two or three inches deep, the drills a foot afunder, or may be planted by dibble the above depth and diftance; or alfo by raking two or three inches of earth off the beds into the alleys, place the nuts on the furface, prefs them a little into the earth, then earth them over from the alleys two or three inches deep: they will germinate freely in the fpring, and generally come up in April or May, when keep them clear from weeds, and they will advance fix or eight inches to a foot high, or more, by Oetober following.

When they are of one or two fummers growth, Should be planted out from the feed beds, taking them up with full roots; prune the downright tap root, and cut off fide-twigs from the Items, preferving the top leader intire; then plant them in nurfery rows a yard afunder, by twelve to fifteen or eighteen inches diftance in the lines, where let them continue in growth three, four, five ycars, or more, training each with a fingle ftem, pruning off fide-thoots below, continuing the top leading-Thoot always intire, as before intimated; and when the young trees are advanced about four, five, or fix, to eight or ten feet high, are of a proper growth for hial iranflacting where they may be intended.
The two varicties of the Common Horfe-Chefrut are propagated by budding them upon feedling flocks of the common fort, in July or Auguit, or alfo by grafting upon the fame fort of ftocks in the fpring; which methods of propagation is neceflary in the varieties to continue them diftinet in their refpective properties, which cannot be effected with certainty from feed.

Likewife the Scarlet Horfe Chefnut is alfo occafionally propagated, by grafting and budding upon ftocks of the common fort.

The final tranfplanting of all the forts from the nurfery, \&c. may be effeeted when the trees are advanced from four or five to ten or twelve feet high; though, if performed when in young growth, of five, fix, or eight feet, they will generally ftrike root more effeetually, and grow more fuccefsfully, than when removed of larger fizes.

After the final tranfplanting in the refpective diftrikts, the principal culture is, while in young growth, to defend or fence them from cattle, and give fupport of ftakes where it may appear neceffary; and in their advancing ftate, and large growth, may occafionally prune lower and firaggling branches, to liave a clean ftem below and regular head above.

$$
\begin{gathered}
\text { AMORP н A, BASTAR D IN D I G O. } \\
\text { Clafs and Order. } \\
\text { Diadelphia Decandria, } \\
\text { Two Brotherbods, Tett Males; }
\end{gathered}
$$

Or Papilionaceous Hermapbrodite Flowers, baving ten Stamina or Males, in truo Sets or Brotberboods.

THE Amorpha is a very ornamental flowering Thrub, of the deciduous kind, decorated with long pinnated or winged leaves, of many pairs of fniall leaflets affixed to one common petiole; and long fpikes of Imall papilionaceous or butterfly-haped prole fowers, furnithed with ten Ramina, and one ftyle in the centre, fucceeded by leguminous thort pods, furnifhed with roundifh, kidney-thaped feeds, not always ripening in perfection in this country, but is raifed plentifully by layers.

Generic Charadters-Hermaphrodite flowers, or containing both male and female parts of generation (the Stanina and Stylus)-Calyx or cup monophyllous, or one-leaved, tubulous cylindric, and obtuíely five-parted at the brim.-Corolla, or flower papilionaceous, or butterfly-like, of four unequal petals, confifting of a ftandard, two wings, and a carina or keel below; the tandard, or upper petal, fmall concave, cover the other three.- Stamina ten, joined at the bafe, and terminated each by fmall anthera.-Piftllum, a roundin oblong germen in the centre, fupporting an awl-fhaped ftyle, 
Ayle, the length of the ftamina, and becomes an oblong-roundifh pod, having two fmall, roundith feeds.

\section{One Species.}

AmorphA fruticofa, Thrubby Amorpha, or Baftard Indigo of America.

A largin thrub, ten or twelve feet high, making large thoots; the leaves (large, very long) pinnated of many pair of fmall folioles or leafets, and fmall purple flowers in fummer.-Grows naturally in Carolina, where, of its young thoots, is made a coarfe fort of Indigo.

This fpecies is proper to cultivate as an ornamental flowering thrub, very eligible to affemble in the principal fhrubberry compartments, pleafure-grounds, \&c. is hardy to grow in any common dry foil, and will fucceed in moft fituations; and may be obtained for planting, at moft of the public nurferies, or may eafily be raifed from feeds and layers: they may be pianted in fhrubberries any time in open, mild weather, from October or November, till March or April.

It is propagated by feeds and layers: the feed may be had at the nurferies and of feedfmen; and which generally fow in the fpring in a bed of light earth, and the plants tranfplanted in nurfery rows, till of a proper fize for the Mrubberry; or, in want of feeds, may eafily be raifed by layers of the young thoots and branches in the fpring, which will be rooted in one fummer, then planted off in a nurfery, to have one, two or three years growth, and may then be tranfplanted into the thrubberry compartments.
Amygdalus, Almon t TreE, comprizing alfo the Peach and Nectarine.
Clafs and Order.
Icorandria Monogynia,
quenty or more Males, One Female;

Or Plants with Hernaphrodite Flowers, having twenty or more Stamina or Males, and one Pifillum or Femaie Organ.

'THIS Genus, Amygdalus, confuts principally of thoice fruit trees, for training chiefy in the wall-tree order, and fome for ftandards, with fome proper to introduce in firubberries as beautiful flowering trees and Thrubs; comprizing, in the different fpecies, the Almond, Peach, and Nectarine, all of the moderate tree kind, ten or twelve to fifteen or twenty feet high, and fome of low shrubby growth; all of the deciduous tribe, furnithed with leaves in fummer, moftly fpear-fhaped, long and narrow, three to four or five inches length, and with pale red flowers growing by pairs, and fingly along the ficles of the young thoots, compofed of five oval petals, twenty or more ftamina, and roundih germen in the centre, which becomes a large, oval, and roundifh, downy fruit, furnithed with an internal nut or ftone, including a fingle kernel, which, in the Almond in particular, is the only eatable part, but in the Peach and Nectarine the whole outer flefhy fubttance, furrounding the ftone, is the eatable part of the fruit: ripening from the end of July or beginning of Auguit, till Oetober, in the different varieties.

Generic charafters. - The flowers all hermaphrodite, having male and female ivithin the fame cover-calix, or cup, one-leaved, obtufely five parted at the brim. -Corolla, or flower, of five obtufe concave petals inferted into the cup. - Stamina, tiventy or more, flender and fhorter than the petals of the Corolla, crow el with fmall anthera.-Piftilum, a roundin, downy germen, in the centre of the flower, elevating a fingle $\mathrm{ft}$ le, the length of the Stamina terminated by a heacel fligma, fucceeded in the germen by a large oval and roundilh, downy, leathery, and fleihy fruit, marked with a longitudinal furrow, inclofing a hard nut or ftone furrowed and netted, and in whici is included a fingle feed or kernel.

\section{The Species of AMYGDALUS are,}

\section{AMYGDALUS communis, Common Almond Tree.}

A moderate tree, growing eighteen or twenty feet high; the leaves (long, narrorw, fining) fpear-thaped, fawed on the edges, and fmall glands at the bafe, and twin flowers, or in pairs, feffile; fruit roundifh-oval, compreffed, downy and tough outer cover, inclofing the ftone and kernel: ripe in the autumn.-Native of Mauritania, in hedges.

\section{$V$ arieties of the Almond.-Common red-flowered Al- mond 'Tree. \\ White-flowered Almond Tree. \\ Silvery-leaved Almond Tree. \\ Bitter-kernelled common Almond. \\ Sweet-kernelled common Almond. \\ Tender-fhelled, fweet, or Jordan Almond.}

\section{Amygdius nana, Dwarf Pcach-leaved Almond Tree.}

A fmall fhrub, four or five feet high; the leaves (finall, narrow) fpear-fhaped, leficned at the bafe; producing numerous fowers early in the fpring, very ornamental.-Native of the northern parts of Afia.

\section{Varicties.-Common fingle-flowered divarf Almond. Double-flowered dwart Almond.}

\section{Amygdalus Perjzca, (Perfica) or Peach Tree.}

A moderate tree, growing ten or fifteen feet high; the lcaves (long, narionu) fpear-haped, acuie at both ends, fawed, and Aowers folitary or fingly, and feffic or clofe-fitting; fucicceded by large, roundih, downy 
fuit: ripeuing from July or Auguft to October. $-\mathrm{Na}$ tive of dia.

Farieties of Peacl, Tree.-Common fing!e-flowered Feach Tree.

Double-flowered Peach Tree.

Dwarf Peach 'Tree. Of the Fruit.

Early white nutmcg Peach; fmall white fruit: ripe in July.

Early red nutmeg Peach; fmall, round, red fruit, larger tilan the former: ripe the end of July or beginning of Auguit.

Early Anne Peach; a middling-roundifh fruit: ripe the beginning of fuguft.

Early purple Peach; large, round, red. fruit: ripe the middle of Auguft.

Early fmall Mignon; middle fize, roundiih fruit, red next the fun: ripe the beginning of Auguft.

Large French Mignon; large, oblongifhround fruit, fwelling a little on one fide, beautifully reddened: ripe the middle and end of Augurt.

Early Newington Peach; middle fize, roundin fruit, red next the fun: ripe the end of Auguit.

Late Newington Peach; large, beautiful, roundifh fruit: ripe in September.

White Magdalen Peach; middling-largin, white fruit: ripe the end of Auguit.

Red Magdalen Peach; large, round, red fruit: ripe the latter end of Auguit.

Bellegarde, or Gallande Peach; very large, round fruit, deep purple-red next the fun: ripe early in September.

Chancellor Peach; large, roundin-oblong, moft excellent fruit: ripe the end of Auguft and in September,

Admirable Peach; large, round fruit, red on the fide towards the fun: ripe the beginning and middle of September.

Rombouillet, or Rumbullion Peach ; middling-large, roundifh fruit, deeply furrowed, and red next the fun: ripe towards the middle of September.

MIontauban Peach; largin-middling fize, roundifh fruit, deep purplifh-red towards the fun: ripe the middle and end of Auguit.

Nobleffe Peach; large fine fruit, brightred towards the fun: ripe the end of Auguft and in September.

Lifle, or Little Violet Peach; middle fize, roundifh fruit, violet-coloured towards the fun: ripe the beginning and middle of September.
Varicties. Bourdine Peach; large, round, fine fruit. red towards the fun: ripe the beginning of September.

Belle Chevreufe Peach; middling-large, roundih-oblong fruit, beautiful red, and moft excellent: ripe the end of Auguit and in September.

Rofiana Peach; a large, oblongin fruit, reddifh-purple towards the fun, yellowflefhed, and very fine: ripe the beginning of September.

Yellow Alberge Peach; middling fize, oblongin fruit, yellow fefled: ripe towards the middle of Auguft.

Malta, or Italian Peach; middle fize, roundin fruit, finely reddened towards the fun: ripe the end of Auguft and beginning of September.

(La Teton de Venus) Breaft of Venus Peach; middling large, roundith oblong fruit, having a fwelling or rifing refembling a teat or breaft, pale-red next the fun: ripe the middle and latter end of September.

Late Purple Peach; large, round, purple fruit, very fine: ripe towards the latter end of September.

La Belle de Vitry Peach; middle fize, round fruit, pale-red towards the fun: ripe in September.

Portugal Peach; large, roundifh,. fine fruit, red towards the fun, fomewhat fpotted: ripe about the middle of September.

Perifque Peach; large, oblongifh, handfome fruit, reddened beautifully towards the fun: ripe towards the end of September.

Nivette Peach; large, oblong, roundin, fruit, bright red towards the fun, the other fide yellowin, very fine: ripe about the middle of September.

Royal Peach; large, round fruit, deep red towards the fun, the other fide palereddifh, a moft excellent Peach: ripe towards the middle and end of September.

Royal George Peach; large, roundish, fruit, beautifully reddened towards the fun: ripe the end of Auguft and in September.

Swalch or Dutch Peach; large, roundilh fruit: ripe in September.

Bloody Peach; middle fize fruit, deep red towards the fun, and red flefhed: ripe in October.

Sion Peach; large, roundih, fruit: ripe in September. 
Ycrictics. Monftrous Pavy of Pomponne; very large, round fruit, beautifully reddened towards the fun, the other fide blufh red: ripe the middle or end of October.

Catharine Peach; Iarge, round, moft beautiful fruit, deep-red next the fun: a moft excellent late Peach: ripe in oetober.

Golden Peach; largiih, round, yeilowith, and red fruit, very fine: ripe in September.

Incomparable Peach; a large, beautiful, roundin, fine fruit: ripe the end of Auguft and September:

Hoxton Mignon Peach; moderately large, roundin fruit: ripe the end of Auguft and in September.

Double Montagne Peach; large, finefruit: ripe in September.

The above being the principal varieties of Peaches, the moft generally known and cultivated in the Britifh garder:s and nurferies, there are fome other of lefs note, retained in fome collections, diftinguined by the following names.

Vanguard Peach; ripe in September.

Cambray Peach.

Narbonne Peach.

Eaton Peach.

Yellow Admirable Peach.

Carline Peach.

\section{Amyadalus Nuci-Perfica, (Nuci-Perfica) or Neetarine Tree.}

A moderate tree, growing ten or twelve feet high ;: the leaves (long, narrow) fpear-thaped, acute at both ends, generally fawed, wholly fimilar to thofe of the peach, and with alfo folitary and fefile flowers; fucceeded by large, roundifh fruit, fmooth rinded and. firm flefhed: ripening in Augult and September.Native of Afia.

This tree, and its fruit, is by the botanifts fuppofed to be accidental varieties of the peach, as the tree difcovers no fpecific diftinction from that of the peachtree, cither in its growth, leaves, or flowers, though 2 very obvious difference in the fruit, which in the peach is always more or lefs downy-rinded, with a foft pulp, and the Nectarine a fmooth, firm rind, and firm flefh: however, fome have afferted that they have feen Nectarines produced naturally and accidentally on a peach-tree, and on the fame twig along with the peaches; but as we never have had the opportunity of obferving this fingularity, cannot either pretend to confute or inculcate the belief of it; though, as there is fuch $2 n$ apparent difference in the fruit, have arranged them feparate accordingly, confifting of the following varieties.

Varieties of the Nectarine. Fairchild's Early Nectarine; fmallin, round fruit, beautifully red: ripe the beginning of $\mathrm{Au}-$ guif.

Elruge Nectarine; middle fize, fine fruit, deep-red towards the fun, the other fide yellowifh: ripe the beginning or middle of Auguit.

Newington Neetarine; large, beautiful fruit, beautifully red next the fun, the other fide yellow: ripe the end of Auguft and in September.

Red Roman NeEtarine; large, fine, round fruit, moftly of a deep-red, a little yellowin on the fide next the wall: ripe the end of Auguft and carly part of September.

Scarlet Nectarine; a moderately large good fruit, moftly of a fine fcarlet colour towards the fun, gradually paler on the other fide: ripe the beginning of September.

Murry-coloured Nectarine; a middle fize fruit, of a dingy-reddin colour towards the fun, yellowifh-green on the other fide: ripe the beginning and middle of September.

Temple Nectarine; a moderate fize fineeating fruit, of a delicate red towards the fun, yellowifh-green next the wall: ripe towards the end of September.

Brugnon Italian Nectarine; a fine, large, beautiful fruit, of a deep-red towards the fun, inclining to a yellow colour on the other fide: ripe the end of Auguft, or beginning or middle of September.

Violet Nectarine; a handfome, fine fruit, of a delicate violet colour: ripe in Septeniber.

Late Peterborough Nectarine; a moderate fize fruit, of a pale-greenifh colour on the outward fide, the other whitioh green: ripe in October.

White Brompton Nectarine; a middle fize fine fruit, wholly white: ripe the end of Auguft and in September.

Golden Nectarine; a largin, beautiful fruit, of a delicate reddin colour on the outward fide, the other of a brightyellow, and yellow pulp: ripe towards the middle of Septemiber.

Having thus far given the defcription of the fpecies and varieties of the Almond, Peach, and Nectarine Trees, with that of their sefpective varieties of fruit, all which, both fpecies and varicties, agreeing in their 
Gencric characters, conformable to the fexual botanic fylem, the modern Botanifts corfider them fo nearly allied, that they range the whole in the fame Genus or family, under the Generic name Amygdalus: we have accordingly followed the fame order in their arrangement, dittinguilhing the varieties beionging to each fpecies under its refpective head; and as the trees are nearly fimilar in growth and mode of bearing, there is but little difference in their general culture; re generally all propagated by budding the defirable varietiss of the refpective forts, principally upon plum-tree ftocis, to render the trees more hardy and curable, and fometimes alfo, particular forts are inoculated upon Peach, Almond, and Apricot focks; and the Common Almond is alfo raifed from the trones of the fruit.

Though it may be proper to obferve that all the different varieties of Peaches, Nectarincs, \&ic. were originally obtained from feed or the nuts or ftones of the fruit fowed in the fpring, and the young trees tranfplanted in nurfery rows, till they advance to a proper age for bearing; and then thofe as produce fruit of good properties are propagateri by inoculating buds thereof, in July or Auguft, into proper ftocks, generally one bud into the fide of each; and in fpring following, the head of the flock being cut off rear the infertion of the bud, this pufhes forth one ftrong thoot, two or three feet long, the firft fummer, and forms the new tree, acquiring a bearing ftate, in two, three, or four years, and produces fruit always conftantly the fame as that of the parent trees, from which the buds were obtained; which thews the great utility of propagation by budding; for the trees raifed from feed never come' of the fame varieties, or produce fruit like the original, but vary to other different forts, and probably, in many fo raifed, fome may produce fruit of defirable properties, as above intimated; and that, to encreafe or multiply thefe new varieties, it can be effected by no other method than by budding aforefaid, and thereby always continued permanent in their refpeetive kinds.

The trees of the Common Almond, Peaches, and Nectarines, are moftly of fimilar growth and mode of bearing, all producing their-fruit principally upon the young fhoots of a year old, and fometimes upon fmall fpurs on the two or three years wood: they all make Jong, ftraight fhoots annually, for fuccefion bearing wood each following year, as the fame fhoots do not generally bear but once, . except upon cafual fmall fpurs, as above remarked, : but always produce the principal fupplies of fruit upon the year-old thoots; the blofloms coming out early in the fpring, rife immediately from the eyes or buds of the fhoots along the fides of them, and the fame hoots both produce fruit, and a fufficient fupply of young wood, for bearing, each fucceeding year, particularly the Peach and Nectarine, which, being commonly trained in wall trees, require an annual pruning every fummer and winter, to cut out the fuperfuous or over-abundant, ill-pliced, and ufelefs fhoots, to preferve the regularity, \&c. of the trees; and in performing which, great care is required to retain a general fupply of the regularplaced, proper thoots, of each year, to train in for beasing the enfuing fummer; and at the fame time, in the winter-pruning, particularly, part of the former year's bearers, and naked old branches, are cut out to make roon for the fucceffional fupply of young bearers, which in fummer are generally laid in at their whole length, but commonly fhortened in the winterpruning, to encourage or promote their producing more effectually an eligible fucceffion of young thoots, for future bearcrs, the year following; and trained in clofe to the wall all fummer, in proper abundance, to chufe from in the winter-pruning aforefaid; when cutting out the fuper-abundant and ill-placed, leaving a general fupply of the beft moderately ftrong fhoots, in all parts of the tree, to train in about four, five, or fix inches afunder, and then nailed to the wall horizontally at that diftance, to remain for bearing the following fummer's fruit: and thus thefe trees, of Peaches and Nectarines, are managed every year in the article of pruning, as hereafter more fully explained.

Thefe trees in general, both Almonds, Peaches, and Nectarines, in all their varieties, bloffom or flower early in the fpring, from about the middle or latter end of February, and beginning of March, to April: the Almond, in its different varieties, is the eariieft in flower, which, in all the above trees, arife principally on the young fhoots, as before obferved, generally twin on the Almond, though numerous on each fhoot; and on the Peach and Nectarine are produced by pairs and fingly; each flower furnithed with the generative organs of famina, ftyle, and germen, in the centre; the latter roundin, becomes the fruit, oral and roundifh in the different fpecies and varieties, and which in the Almond and Peach has always a downy, foft rind, and in the Nectarine fmooth, fhining, and firm: in the Almond, the fiefh of the fruit is dry, tough, and not eatable, only in the kernel contained in the ftone; but in the Peach and Nectarine, the fieth is fucculent, rich, and the only eatable part; foft and melting in the Peach, and in the Nectarine, is of a more firm texture, juicy, and rich-flavoured.

In the different fpecies of the Almond, Peacti, and Nectarine, the former has not equal merit as a fruittree as the twolatter, the fruit being confiderably lefs valuable, and only fome varieties thereof' ripen in good perfection in our gardens; particularly the Common Almond, which feldom ripens its kernel before autumn, generally about September, when the likathery cover opens naturally and difcharges the ftone, containing the kernel or eatable part, which in the two varieties of the Common Almond aforefaid, "comprifing the bitter and fweet kernelled kinds, aften i- 
per abundantly upon common ftandard trees; though the trces are more generally cultivated for their ornamental flowering than as fruit trees; and the Jordan Almond, and the other varieties, feldom produce fruit in this country in good perfection, fo are admitted principally for variety in pleafurable plantations; but in the Peach and Nectarine, all the forts are valuable in their fruit, which, on wall-trees, againft fouthern walls, ripen in full maturity; and fome of the varieties of the trees in ftandards, are alfo introduced in Thrubberies, \&c. for ornament.

The fruit, in the different varieties of Peaches and Nectarines, attaining perfection of full growth, from July or beginning of Auguft, to the latter end of October, they ripen in regular fuccefion for three months, for immediate eating; or, at leaft, will not keep any confiderable time after being gathered, like apples and pears, but are continued, occafionally, in a prcferved preparation; and in their young, green 1tate, the Nectarines, in particular, when produced thick on the trees, are thinned off for making tarts, \&c. gencrally in May or early in June, before the nut or ftone hardens; but the Peaches, on account of their downy rind, are not fo well adapted for that occafion.

In the ripe Atate of thefe fruit, $\mathrm{Pe}$ aches and $\mathrm{NeC}$ tarines, fomc are remarkable for quiting or parting freely from the ftone, and others for adhering clofe thereto; but in the Nectarines particularly, the greater part adhcre clofe, and fome having a melting pulp, feparate from the ftone freely in eating; and in which particularities, thofe which quit the ftone, have generally a more foft and mclting, flehy pulp than thofe as clofcly adhere.

The Amygdalus communis, or Common Almond, may bc cultivated both as a fruit-tree, in its two varieties of the bitter and fwcet-kernelled kinds, and for the beauty of its ornamental bloom, early in the fpring, in March, or April; and for both of which occafions are gencrally trained in half and full ftandards: raifed both from the ftones of the fruit, and by budding unon Plum, Almond, or Peach itocks, efpecially for fruittrees; and trained with clean, ftraight litms, four or five, to fix or feven feet high, branching out at top into full heads; and are then planted in gardens and orchards to produce fruit; alfo in plcafure-grounds, Thrubberies, fore-cours, \&c. as ornamental foweringtrees, making a fine appearancc in the fpring, in their numerous reddifh flowers: they are likcwife traincd, occafionally in wall-trccs and efpalicrs, to produce fruit in greater perfection; and in all which methods, they, in favourable fprings, produce plenty of Almonds, ripening the kerneis in autumn, very good for prefert eating: but as to thc Jordan Almord, tenderer than the Common, requires a warm fituation, or planted againt a fouth wall, if defigned as a fruit-tree, though feldom produces fruit plentife!! y, or in good perfection, in this country; and therefort this, and the filver-leaved kind, are commonly planted for ornameni and variety, in Shruboeries, \&c.

And the Dwarf Almond (Amygdalus nana) both in its fingle and double-flowered varieties, being very ornaineatal flowering - plants, of low, hrubby growth, producing numerous pale-red flowers, furrounding the Thoots their whole length, early in the fpring, (March and April) make a confpicuounly preity appenrance: are commonly admitted in fhrubbery collections as moft beautiful flowering-hrubs; planted towards the front of the clumps and other compartments, and propagates abundantly by fuckers and layers.

But the Peach and Nectarine being valuable, pri: cipally as choice fruit-trees, for the many fine varieti-s of their rcfpective fruits, and being of the mor tender kinds of fruit-trees, at leaft in their bloffors and young fruit, require to be trained in the wall-tree order, againit warm fouth walls, or others of a foutherly afpect, as fouth-eaft and fouth-weft expofures; but the princinal fupply allotted full fouth walls, for, without the aft it ance of warm walls, both to defend thc tender, early bloffom and young fruit, in March and April, \&c. as well as by the expanfion of the branches againft the walls to have all poffible benefit of the full fun, in the advanced growth of the fruit, it will not acquire good maturity, nor ripen effectually, in the peculiar - perfection and rich flavour; and therefore the trees of all the different varieties of thefe two defirable fpecies thould always bc traincd principally in dwarf and halfftandard wall-trees, planted againit the beft foutherly walls aforefaid, at twelve to fifteen or eighteen feet diftance, and the branches arranged horizontally clofe to the wall, in the moft regular order, that they may have the beft protection thereof, when bloffoming and fetting their young, tender fruit, and to enjoy al! portible benefit of thc fun's influence to forward its general growth, and ripening freely in proper feafon; as in this country thefe fruit do not ripen effectually well on detached-ftandard trees, nor in good perfection in efpaliers; though, for variety and experiment, fome dwar-ftrees may be planted in both thofe methods, in a warm, fheltered fituation.

For ornamental planting in fhrubberies, and other decorative compartments in pleafure-grounds, may introduce all the forts of Almonds and any varicties of Peaches, principally as beautiful, fpring flowering - trees, and to encreafe the variety in their gencral growth; particularly the Common Almond, in its two principal hardy varietics of the bitter and fivect-kernelled linds; or alfo the Jordan Almond, whitc-fiowered and filver-leaved forts, almitted in warm fituations; likewife the two varictics of Anygdalus nana or Dwarf Almond, both very ornamental fowering-fhrubs; together with the double-flowcred and Dwarf Peach; all of which are very defirable ornaments for the finrubbery, in their great profufion of early blofiom in the fpring; and for 
which occafions are trained the tree kinds in full and half ftandards, to branch out in full heads in their natural order; and the dwarf forts, naturally of low, Srrubby growth, hould be trained accordingly, and the whole difpofed confpicuoufly in the principal fhrubbery compartments in affemblage, with other ornamental trees and Mrubs, in a diverfified manner.

Having thus far, in the foregoing general obfervations, given intimations of the nature and general and particular utility of the fpecies and varieties of the Almond, Peach and Nectarine, we now proceed to explain the general culture of each under feparate heads.

\section{i. The Culture of the Almonds.}

The Almond trees, as before remarked, are cultivated botll occafionally for fruit-bearing, in the prin cipal varieties of Amygdalus cummunis or Common Almond; and thefe, and the other varieties thereof, alfo principally for ornamental planting; and for which latter purpofe the two varieties of the Amygdalus nana, have alfo particular merit as very pretty flowering-hrubs, to affemble in the front part of principal fhrubberry compartments; likewife the Common Almond is generally in greater eftimation to cultivate for the beauty of its flowers than the value of its fruit; as are alfo the white-flowered, Jordan and filvery-leaved; though the three latter are feldom very fruitful in the Britifh gardens.

All the varieties of the Common Almond are propagated or raifed by budding them either on Plum ftocks, obtained from fuckers, feed, or layers, or on feedling ftocks of Almond or Peaches; or the common varieties of Bitter and Sweet Almond may be raifed from the ftones of the fruit; but when defirous to continue the improved or particular forts permanent in their refpective kinds or for fruit-trees, it is effected moft eligibly by budding them as above, as the feedling-raifed trees vary to different or inferior forts, and are longer before they bear than thofe propagated by budding or inoculation; and therefore, to continue any principal forts for their fiuit, always propagate them by inoculating buds thereof into Plum, Almond, or Peach ftocks, as above mentioned, and the refpective kinds will be continued, and fooner become bearers than thofe raifed from feed.

However, to raife them from the ftones, they may be fowed either in Oetober or November, or preferved in fand till February or March, for fowing in that feafon; and in either of which they may be fowed in drills, or bedded in two inches deep; and when the feedling plants are of one or two years old, fhould be tranfplanted, in autumn or fpring, into nurfery rows, two or three feet diftance, and trained each with a fingle fem, three or four feet for half, and five to fix or feven feet for full ftandards, clearing their ftems from lateral fhoots; and then may either inoculate them at the above-mentioned heights, with buds of the defir:ble varieties; or others, that may be intended to continue in their own natural heads, fhould be topped in the fpring with the pruning knife, at the leights it is required they thall branch out; thereby promote a more regular fpread of branches to form a full head; the fame fhould alfo be obferved in the budded trees, by pruning down the firft hoots to a few eyes, to cbtain lateral branches, to form a regular head as aforefaid: and when they have effected this, with heads of one, two, three, or feveral years old, they are proper to tranfplant where they are defigned to remain for the purpofes for which they may be intended; continuing to kesp them to clean fingle ftems, and permit the heads to branch out freely in a full expanfion, keeping them to fomewhat regular order; efpecially in their advancing young growth, by giving occafional pruning to retrench or reduce any fingularly rampant and ram. bling diforderly fhoots, or to thin others, where confiderably crowded; but, except in thefe occafions, permit the whole to advance in their natural manner.

But in the propagation of the Almond trees, budding is the molt advifeable, general method, both whereby to continue the defirable or improved varieties with certainty, and to have them fooner acquire a plentiful flowering and bearing ftate; and which is performed by inoculating buds of the defired or intended forts, into Plum, Almond, or Peach ftocks raifed from the thones of the fruit, as directed, for raifing the feedling Almond trees; and the young ftocks being tranfplanted in nurfery rows, train them to clean ftems the proper height for half and full Atandards; and then perform the budding in July or beginning of Augurt, infert ing a bud into the fide of each ltock, at three, four, to five or fix feet high, for half and full itandards : or may occafionally be budded low, within a foot or fix inches of the bottom, to form dwarf trees, or alfo, occafionally for ftandards, and the firt bud-hoot run up to form a ftem the height above-mentioned, and, in either method, the head of the ltock to remain intire till March following, and the inferted bud remaining dormant till that time, when fhould top, head, or cut down the ftock, a little above the infertion of the bud; which after this, will pun forth with vigour, producing each one ftrong fhoot, two or three feet long, or more, the fame year; and this fhould generally, either the fame fummer, in June, or in the following fpring, in March, be pruned down to four or five eyes, to obtain a fupply of lateral thoots below, near the ftem, to form the firft proper fet of branches for the regular formation of the head; or in low budded trees, which are defigned for ftandards, the main fhoot muft run a proper height for a ftem, then fhould be headed in the part where it is intended to have the firft fet of branches commence; and thus, in each method, having obtained three, four, or five, lateral thoots below, for the beginning branches, thefe form a proper bafis, as 
it were, to furnith others eligibly fituated to form the head in a regular expanfion.

Or where it may be intended to have any of the above Almonds trained for wall and efpalier fruit trees, for variety, or to obtain earlier and finer fruit, they thould be budded lower in the ftocks, within fix or eight inches of the bottom, and the firtt main hoot from the inferted bud be headed down in March, to a few eyes, as advifed above, in order to gain a fupply of lateral hoots from thore lower eyes, to form a firft regular fet of branches, proceeding from near the ground; and that thefe may alfo furnifh an encreared fupply of others, fo as tu cover the wall or efpalier in a proper expanfion, regularly froin the bottom upward; and for which allot them an exporure to the full fun, planted in autumn or fpring, twelve to fifteen or eighteen feet diltance; training the general branches from the beginning in a fpreading, fanned order, horizontally to the wall, \&c. four to five or fix inches afunder; and continue to encreafe the number of branches every year, giving an annual pruning to cut out the fuper-abundant and ill-placed fhoots, and to retain a proper fupply of each year's beft well-placed hoots for bearers; cutting out part of the old in winter, to make room for training in the bearing hoots, generally extended at their full length all fummer; and in winterpruning, thofe felected for bearers, \&c. may be thort ened about one third, or a little more, or lefs, according to their ftrength; r.ot however to cut below the bloffom buds, and generally leave the ftrong Thoots longeft, the others in proportion; obferving in the whole, nearly the fame as directed for the Peaches and Nectarines.

The Divarf Almond, in both the varieties thereof, fingle and double-flowered, propagate plentifully by fuckers, arifing annually from the roots, which may be readily taken up with root fibres to each, in autumn or fpring, or any time in oper weather, from October or November to March, and planted either in a nurfery, for a year or two, or till of a proper fize for the thrubberry; or fome of ftronger growth may be planted at once where they are to remain.

Or thefe two varieties may alfo be propagated by budding upon Plum, Almond, or Peach flocks, to have them of larger growth, inferting the buds at two or three to four or five feet, to form clean ftems, elevating the head that height, to plant for particular occafions.

\section{2d. The Practical Culture of the Peach and Neetarine.}

Having, in the foregoing, given the defcription of the different fpecies and varieties of the Peach and Neetarine, and relative obfervations thereon, we now come to give the particulars of the practical culture of both the forts, which being very defirable fruit, the trees of each claim admittance as principal wall trees; and for which they are propagated and raifed by inoculating or budding the approved kinds and the varieties in general, priucipally upon Plum ftocks; and when the young trees are of from one, two, or three, to four cr five years growth, thefe are proper for planting against walls, where they are to remain, performing the planting in autumn or fpring, or almoft any time in mild weather, from October or November, to the middle or end of March: they will begin bearing at two or three years old, and in their advancing and general growth, require an annual pruning, and nailing every fummer and winter; all of which different operations of culture, to be performed according to the following general directions.

As the Peach and Nectarine are fimilar in their gene. ral growth, and manner of bearing, one method of propagation. and culture being applicable to both, hall accordingly include them in the following general directions, confriting of the method of propagations, raifing, training, planting, pruning, \&c. and in each of which the fame directions ferve for all the different varieties of both thefe fpecies of trees.

All the varieties of Peaches and Nectarines being of the choiceft kinds of ftone fruit, of rich, delicious fla. vour, deferve principal culture in every garden, more or lefs, where there is the accommodation of proper fouth walls or good clofe palings, of proper height.

For the trees of all the varieties of Peaches and Nectarines frould always be trained as wall-trees, principally againft fouth walls, on account that as they flower early in the fpring, when tharp cold weather often prevail, and that the bloflom and young fruit being of tender nature, require the afiftance of the warmelt walls, to protect and forward them in proper growth; and having the branches arranged clofe to the wall, in a thin, fpreading order, to adnit the full power of the fun to ripen the fruit effectually, in good maturity, in their peculiar ricli farour, as without the trees being trained in that order, to walls of a fouth or foutherly afpect, thefe fruit cannot be obtained in tolerable crops, nor in any defirable degree of perfection, in the proper feafons, and therefore fhould allot fouth walls for the trees of the principal varieties; and others may be planted againf fouth-eaft and fouth-went walls, in which they will alfo, in fine feafons, ripen fruit tolcrably well, and in fucceffion to thofe in full fouth exporiures; and in which different afpects they are planted twelic or fifteen to eighteen feet afunder.

They are foldom trained in detached fandard-erees, as on which, not having the advantage of walls, this friit does not ripen in good perfection; though, for variet $y^{\prime}$, a few inight be trained in divarf and half ltand ards, and planted in a warm fituation in the full fun. 
But for wall trees, they are trained both in common dwarf trees, with low or fhort fiems, only fix or eight incines high, to branch out low, to cover the wall regularly, from the bottom to the top, and are the common wall-trees for the general fupply; and in half fandard wall-trees, with items three or four, to fivc or $f_{1 x}$ feet high, branching out at thefe heights, and are planted occafionally, betwcen the common dwarf walltrees abovementioned, to cover the upper parts of high wails, while the others are advancing below.

Thefe trees will grow freely in borders of any good, rich garden earth, of two fpades, or, at leaft, one full ipade, deep; or where the ground is poor, it thould be improved with plenty of rotten dung; or would be of much benefit if augmented alfo with a quantity of frem, loamy foil; or where the borders are naturally of that kind of earth, it will be of particular advantage, enriching it alfo occafionally with a fupply of good, rotten dung, as above obferved.

Young trees for planting may be obtained, of the different varieties, or as required, at all the public nurfcry-grounds, either of one or two years old, for training by degrees in the requifite form; or may be procured in ready-trained trees of two, three, to four or five years old, or more, with a large expanfion of regular branches, and of a proper growth for immediate bearing; and thereby have the walls either wholly, or in part, furnifhed at once with bearing trees that may produce fruit the firft feafon; and in which the planter can fuit his convenience or inclination, as there is fome confiderable difference in the prices between thofe of the quite young trees of only one or two years old, and thofe as are trained of feveral years growth.

Or the different varieties may be eafily propagated, raifed, and trained to a bearing ftate, according to the following directions.

The general method of propagating Peach and Nectarine trees, is by budding the different or defirable varieties, principally upon Plum ftocks; or fome of the more curious or particular forts, are alfo inoculated occafionally on Almond and Peach ftocks, raifed from the ftones; but for the principal fupply, the Plum ftock is advifeable, as the moft hardy, durable, and making the moft profperous trees; raifing the faid ftocks from the ftones of the fruit, fowed in autumn or fpring, in drills, or bedded in two inches deep; and when the feedling plants are a year old, they fould be tranfplanted in nurfery rows, or may alfo be raifed by fuckers arifing from Plum-tree roots: though as the Mufcle-Plum ftock, in particular, is generally preferred, as the moft favourabie and profperous for Peaches, \&c. that to obtain thofe with certainty of the particular kind, they are raifed by layers, cuttings, fuckers, as if raifed from feed, (Itones of the fruit) they vary to other forts of a different quality; and in either method of raifing the ftocks, tiey, when from two, or three, to four, five, or fix feet high, and of half an inch to $2:$ inch thick below, are of proper fize for budling, keeping them pruned up from lateral hoots; and of which fizes, they are budded low or near the ground, for common dwar $\mathrm{k}$ all-trees; and at three, four, to five or fix feet, for half and full ltandard wall trees, to plant between the common or dwarf trees, efpecially where high walls, and defirous to have all parts thereof covered as expeditioufly as poffible.

The operation of budding them is performed in July, and beginning to the middle of Auguft; obferving, as above hinted, thofe for common wall-trees muft be budded low, inferting the bud within fix or eight inches of the ground, whereby to obtain branches proceeding near the bottom, to cover the wail thereivith, in a regular expanfion, from the bottom to the top; and for half or full ftandard wall-trees, to plant between the dwarfs, in high walls: the budding is performed either on tall ltocks, at three or four feet for half, and five or fix feet for tall ftandards, and each to be trained with a fanned, fpreading head, or for thefe two latter, they may be budded low in the frock, and the firft fhoot from the bud trained up for a ftem, to th above-mentioned height.

Obferving, for this occafion of budding, to provids cuttings of the young thoots of the year, from trees of the forts intended, chufing the moderately-ftrong fhoots, cutting them off nearly at full length, and from which hoots, after cutting off the leaves all to about half an inch of the petiole or foot-ftalk of each, the buds are to be detached one at a time, and inferted into the fide of the ftock, at the height from the ground above-mentioned, for common and lialf atandard walltrees; the head of the ftocks continued intire, till the fpring following, and the inferted buds uniting with the ftocks, the fame year, but remaining dormant till next fpring aforefaid; at which time, generally in March, juft before the buds begin to purh, cut down the head of the ftocks, a little above and behind the place of infertion of the bud, which will then, foon after, advance in one ftrong thoot, attaining two feet or a yard in length, or more, by the end of the enfuing fummer, forming the new tree of the refpcetive kind with which it was budded; and which, in the autumn, or fpring following, may either be tranfplanted into the garden, agaiuft the proper walls to remain, or planted againft any fence in the nurfery, or where convenient for training, one, two, or three years, or more, in a proper expanfion, in the wall-tree manner, to a bearing ftate, and then tranfplanted finally into the garden aforefaid, againft fouth walls, at twelve or fifteen to eighteen feet diftance; and being thus previouny trained, will commence immediate bearers the enfuing feafon. 
But generally obferve, in refpect to the firtt requifite training, that as the firft proper thoot, produced immediately from the budding, commonly runs up into a ttem, naked below, it must be headed down when a year old, in the fpring, after its firt fummer's growth, to force out a regular fupply of lower branches from the beginning; therefore, generally about Miarch, juft as the young trees begin to make an effort for thooting, cutting them down to about five, fix, or eight eyes, in a foping cut upward, next the wall; and will then foon after produce feveral lateral thoots, from the remaining lower eyes, to give the head its beginning formation, arranging the faid fhoots horizontally to the wall, equally to the right and left, in a regular expanfion, as before obferved; or, in order to form the head, as above, as expeditioufly as poffible, the firft principal fhoot advancing immediately from the bud, might be pinched or pruned to a few eyes, the fame fummer it: is produced, about the beginning or middle of June, and it will furnith laterals the fame feafon for training to the wall, \&c. and thereby gain a year's growth in furnifhing the firft fet of branches.

Obferve likewife, that in either of the above methods, in heading down the firft leading fhoot, and obtaining a fupply of lateral thoots below, thefe, either the fame year, early in June, or in the following fpring, fhould a'iu be pruned fhort, to about fix, eight, ten, or twelve inches, according to their ftrength, to obtain a further fupply of lower branches trom the beginning, that they may form a regular full fpreading head, advancing immediately from or near the bottom, to furnith the wall regularly upward; and of which new-acquired hoots, rub of or cut away all the fore-right productions, and others that are ill-placed, and train in all the reft to the wall, at their full length, all fummer; or may occafionally pinch particular Thoots, in May or June, in vacant parts, to provide a requifite fupply of wood the fame feafon: and thus continue the management of the young trees, the firit two or three years; for in this depends the whole fuccefs in giving them the proper formation for walltrees, covering the walls completely from bottom to top, in a regular expaniron of branches; and, as they will produce numerous fhoots in fummer, thefe muft be regulated, by pruning out the ill-placed and ufelefs, and the others trained - the wall at their whole length, all that feafon till winter-pruning, when the beft of which being felected for bearers, cutting out the fuperaburdancy, the retained fhoots muft generally then be fhortened more or lefs, as hereafter explained.

Thus far re!ating to the methods of raifing and firft training, thall proceed to give fome neceflary intimations for planting and general culture.

For the planting of Peach and Nectarine trees, allotting principal fouth walls, \&c. having proper borders under them, three, four, or five, to eight or ten feet wide, and two feet depth of good earth, which, if of a loamy nature, will be of the greater advaniage; but if the foil is unfavourable, or of a very light, uniubftantial kind, it thould be improved with a fupply of $:$ iefh furface loam, from a common or pafture-ground, or where convenient, either immediately applied, or after being prepared with a portion of rotten dung, for feveral months, in a compoft heap, or in default of loan, have any good mellow earth and rotten dung; and which improvements may either be added wholly, or only for the prefent, to the parts where the trees are to be planted; or where the borders or places intended for the trees, is gravel, rubbiny, very ftony, or finallow, of proper itaple, the bad or fhallow foil fhould be removed, or rough-icreened, and a proper depth, and the place fupplied with fubftantial good earth and rotten dung. as above.

Though it may alfo be proper to remark, that thofe trees will thrive fufficiently well in borders, confiiting of any common, mellow, garden earth, as that of a kitchen garden, \&c. or, if rather poor, may be augmented with rotten dung, or that, and fome good loam, added either fully, or to the places where the trees are $t \theta$ ftand, three or four feet width.

The feafon for planting is either in autumn, about the decay of the leaves, in Oetober and November, or in the fpring, in February and March; though may be performed any time in open, mild weather, from October or November till March aforefaid; however, if performed foon after the leaves begin to decay in autumn, it will be of advantage, as they will almoft immediately ftrike root the fame feafon, and be more effectually rooted before the drought of next fpring and fummer.

The trees for planting, as before remarked, may either be of one or two years old heads, or fuch as are of three, four, or five years training, furnifhed with fome confiderable expanfion of branches, and advanced to a proper growth, for immediate bearers; either wholly of that itate, or part, and thereby have the walls covered at once with bearing trees; and is of importance to have a collection, more or le $\int_{s}$, of the principal varieties, both of early, middle, and la te kinds, to have a regular fuccefition of the fruit: ripening from July, or beginning of Auguft, to the end of October, all of which, or any of the varieties, if not furnificd with home-raifea. trees, may be obtained at the nurferies, either in young or trained growth, as thall be required, agreeable to former intimations, being careful to chufe thofe of good growth, with moderately-ftrong fhoots : and have them digged up with a full fpread of roots, as intire as poffible.

Then mark out the places for the trees, allotting the principal fupply the beft fouth walls, both of Peaches and Nectarines, not lefs than twelve or fifteen, nor more than cighteen feet diftance; fome may alio be planted againit fouth-eafterly, and went walls, at the 
fame diftances; and tor all of which, dig a wide, round hole for cacli tree, a foot, or more, deep, and fuliciently capacious to receive the roots freely in their full fpread.

The trees then ready, let the roots be pruned as $\mathrm{rc}$. quired, by cutting or fhortening any long fraggling parts; prune the end of all the others, and cut out any that are broken or bruifed; and as to the licad, if one-year-old trees; continue them intire for the prefent ; or if trained trees, cut off only any fore-right and other ill-placed ihoots; and thus prepared, proceed to planting: place the trees one in each hole, with the Item about three, to four or five inches from the wall, inclining the head thereto, making the roots fpread equally in the hole; break and trim in the c:1rth regularly over the roots; fhake the tree. gently by the feem up and down, that the earth may fall in clofe about all the roots and fibres, filling up the looles, and tread down the earth moderately, firft towards the outfide, continuing to the middle, round the ftem of the tree; and then, if dry ground, in early autumn planting, or late in the fpring, give each tree a tolerable watering to the earth, about the roots; after this, juft nail the head or principal branches to the wall, to fecure them being ditturbed by the winds, till pruned; likewife, mulch the ground over the roots, both to keep out froft in winter, and the drought in fpring and fummer, till the trees have taken good root; and in very dry weather, in fpring, and beginning of fummer, give occafional waterings to the earth, and fometimes over the heads, after they begin to hoot.

Having thus planted the young trees of the Peaches and Nectarines, the next care is the article of pruning and training; obferving firlt, that if the new-planted trees are only one year old, and with the firt head from the budding intire, this mult be cut down in the beginning or middle of March, to four, five, or fix eyes, as formerly advifed, to obtain lateral fhoots below; or if the trees are fuch as have been previoufly trained, and the head already furnifhed with fome tolerable expanfion of branches and hoots, thefe being continued, hould be pruned according to the general method, either foon after planting, or in the fpring, about February or March, agrecable to former intimations, and as fully explained hereafter, under the pruning directions, cutting out the fore-right, and other ill-placed, and very weak, trifing hoots, and fuch as are fuperfluous, or too abundant, in any part ; as alfo, any as cafually appear fingularly more luxuriant than the generality, efpecially if one, or more, advances irregularly on one fide of the tree; retaining the well-placed moderately-ftrong fhoots; and prune them from fix or eight, to ten, twelve, or fifteen inches, according to their ftrength, and then nailed to the wall horizontally, four to five, or fix inches ciftance; and refpecting the younger trees of one year, advifed above to be headed down in the fpring; if they, in confequence of that operation, produced feveral lower fhoots in fummer, thefe fhould be trained in at full length, rubbing off, or difplacing, any of fore-right growth; or if only two or three fhoots are produced, thefe, the fame feafon, in May, o: the beginning of June, may be pinched or pruned at top, or cut to five or fix eyes, whereby they will furnifh an increafed fupply of more hoots in fummer, to furnifh the wall fooner with a proper fpread of branches; continuing all the proper fhoots, both of the young and trained trees, nailed in regularly to the wall all fummer, till winter-pruning; and the whole afterwards, in the fummer and winter regulation, managed according to the following directions in the general pruning.

With regard to general culture of Peaches and Nec. tarine trees, after their firt training, agreeable to the foregoing obfervations, they, in their advanced growth, and fu!l trained ftate, will require pruning and nailing every fummer and winter, to preferve regularity and fruitfulnefs; a fummer-pruning, \&c. to regulate the hoots of the year; and a winterpruning, to give a general regulation, both in the young and old branches; and in all of which it muft be obferved, that as thefe trees bear principally upon the young wood, or hoots of the preceding fummer's production, a general fupply of thefe muft be every where retained annually, for fucceffional bearers and part of the former bearers and old wood cut out in proportion, in winter, to make room for the young fupply; which being trained at their full length all fummer, they, in the winter-pruning, fhould be fhortened more or lefs, to promote their producing a more plentiful fucceffion of thoots, eligibly fituated to felect for next year's bearing wood; as the fame fhoots both produce fruit, and a fupply of fuccefion bearers at the fame time.

The fummer-pruning of Peaches and Nectarines fhould be commenced in May or June, when the thoots of the year are advanced from three or four, to $f(x)$ or eight inches, to a foot long; though it is adrifeable to proceed in this operation in the early growth, or when the fhoot-buds are advanced only two or three inches, in which, juit to rub of the fore-right and other evidently ill-placed and uunecefiary productions, which, before they become long and woody, may be expeditioufly detached with the finger and thumb; bu: which, in a more advanced woody ftate, mult be effected with the pruning-knife; fo difplacing all fore-right fhoots iffuing immediately from the front part of the branches, and all others, which by their fituation cannot be trained with proper regularity to the wall; and is of much importance to commerce this operation before the hoots are confiderab!y advanced, or grown into confufion, as the bufiners can be confiderably, more expeditioufly and accurately performed, as well as prove of more particular advantage to the growth and regularity of the trees, and beneficial to the ad- 
vancing fruit; but when the work is delayed too long, till the trees are run iuto great diforder in the fhoots of the year, is both very unfightly, and of great difadvantage; more particularly to the fruit in its advancing growth, as well as caufe confiderable perplexity in making the neceffary regulation.

Therefore, after proceeding in the early regulation in difplacing the ufelefs hoot-buds, begin the general operation in the more advanced growth of the fhoots in June at fartheft, taking of any remaining fore-rights, and others ill-placed; and carefully felecting a large fupply of all the beft regular-placed fide-fhoots, and a leading one to each branch, for fucceffion bearers next funmer, difplace the fuperfious or fuch as are evidently over-abundant, or more than can be trained in with proper regularity; and where two advance from the fame eye, leave but one, taking off the moft unpromiffing: likewife cut out clofe any that affume a bad habit of growth, bunched, crooked, very weak, or of a long, llender infirm, ttate; as alfo any very rank, or fingularly luxuriant thoots, appearing confiderably more vigorous than the generality, not being adapted fo: bearing, but which would draw the nourinment from the others of more moderate growth, proper for the production of fruit the year enfuing: though where any tree cafually affumes a general luxuriant, unfruitful ftate, cut out the moft unfavourable, and retain as many of the beft-placed, Arong thoots thereof as can be conveniently trained in with fome tolerable regularity, in order to divide and carry off the exuberancy of fap amongit a great number, more effectually than would be the cafe in a fmaller quantity, and thereby have the trees fooner reduced to a moderate ftate of growth for good bearing; and then, according to the above obfervations, difplacing or pruning out.all fore-right, other ufelefs and unneceffary thoots, taking them off quite clofe, leaving plentifully of the proper moderately-ftrong thoots, as before advifed, both of the fide production and leaders to the branches in all parts of the tree; the whole preferved at their full length at this feafon, and nailed in clofe and regular to the wall, all fummer, in an abundant fupply to chufe from in the winter-pruning to retain for next year's bearing wood; not thortening any of the fhoots during their fummer growth, except in any cafual, vacant parts; may occafionally pinch off the top, or prune down any contiguous young thoot in May or June, to furnifh laerals the fame year to fupply the deficiency, or any extending confiderably out of the proper bounds, either fide-ways or over-topping the wall, may be difcretionally fhortened more or lefs, as may feem expedient; but, except in thefe cafes, keep all the other thoots extended at their whole length all fummer, as fhortening at this feafon makes them throw out a great quantity of afelefs wood, hurtful to the faid moots in their prefent growth, and detrimental to their bearing the year following.
After the general fummer regulation. in pruning out the ufelefs and training in the ufeful fupply of thoots. continue a proper attention during their fummer's growth, by going over the trees once a week or fortnight, to keep them divefted of all ufelers after-productions; and according as the retained general fupply of felect hoots encreafe in length, or any cafually detach from the wall, nail or train them in clofe and re. gular, both to preferve the requifite uniformity and beauty of the trees; and that, by continuing the whole clofely trained in regular order, admits the full benefit of the air, fun, rain, \&c. effentially neceffary to improve the growth and goodnefs of the fruit, and to promote its ripening with a proper flavour.

The winter-pruning of the Peach and Nectarine Trees, comprifes a general regulation both in the fuyply of young wood produced and trained in the preceding fummer, and in the whole expanfion of older branches, in pruning out the moft unferviceable, to make room for the fucceffional fupply of young, bearing wood, and the whole new trained and nailed in regular order; in which operation keeping in mind, as obferved in the fummer-runing, that as the trees produce their fruit principally upon the young thoots of the preceding fummer, and occafionally in the two years wood, upon fmall, natural fpurs thereon; though the general fupply is always produced upon the laft year's hoots, and which feldom bear after, except fometimes on cafual fmall fpurs, aforefaid, the fecond and third year; and therefore a general fupply of thefe young thoots of laft fummer muit be annually preferved in all parts of the trees, now in the winter-pruning for bearing the enfuing feafon; and at the fame time part of the former bearing wood, and naked old branches, not furnifhed with proper bearers, cut out, to give room for introducing the requifite fupply of young, bearing thoots, about four or five to fix inches diftance, cutting out the fuper-abundancy; and'all the retained fhoots, or the greater part, to be fhortened more or lefs in this pruning to promote a fucceffional production of thoots from the lower eyes, which otherwife would moftly advance towards the upper parts, and the trees would thereby, in time, become naked below.

This general winter-pruning may be commenced foon after the fall of the leaf in autumn, or continued any time in open, mild weather, from November till the fpring, and thould be wholly finithed in February or March.

In proceeding to this pruning, as it confifts of a general regulation, it is proper to un-nail moft of the principal branches and all the young wood, both that you may more conveniently examine and determine what to cut out and retain, have liberty for the operation of the knife, and, after pruning, to have the opportunity of new-training the trees accordingly; and

generally, 
generaily, for this bufinefs, have a fnall, narrow-pointed pruning-knife, that it may be admitted readily between the finall clifts or forkings of the branches, having a larger knife for cutting out large, ltubborn wood.

Then proceeding to the operation, felecing a proper fupply of the laft fummer's young fhoots, for the following year's bearing wood, to retain in all parts of the tree, for laying in four to five or fix inches diftance ; chufing the beft, moderately-ftrong, well-placed thoots, fituated principally on the upper and under fide of the mother branches; and from which cut out the fuperabundancy, with any fore-right, and others not wellplaced for training with regularity; as alfo weak tivigs and cafual, rank luxuriants, cutting the whole clofe to the old wood; at the fame time, to prune out a proportional part of the laft year's and other former bearers, cut down either to the firft moft eligible young fhoot fituated thereon, or fome quite out to their origin, as it may feem expedient, according to the fupply of proper young wood in particular parts, and to make room for the requifite fupply in gencral; likewife, for the fame occafion, in old trees, cut out cafual, old, naked branches, advanced of fome confiderable length, unfurnithed with any eligible fupply of young, bearing wood, or not fupporting branches fupplied therewith, cutting them down either to their origin or to fome younger and more fruitful branch, where any is fituated on the lower part thereof, and hereby making room for training contiguous branches fupporting young wood for bearing; and, as you proceed, thorten the retained thoots, more or lefs, about one third, or fmall ones, half; and divent them of all lateral twigs, to have all the main fhoots clear andfingle; obferving if any particular, very luxuriant thoots occur, cut them out, or if, in or near vacant fpaces, one or more of which may be retained and fhortened, to produce laterals of more moderate growth to fupply the deficiencies.

Obferve in this pruning, that as the young wood, now proper to retain for bearers the enfuing feafon, is produced principally upon the bearers of lift year, or on the two years branches, having probably two, three, or more fhoots on each; and as it may now be neceffary to retain on fome branches but one, others two, or more, as the cafe may require, thall here endeavour to explain it as well as poffible; in which examining what may be proper, and how many neceffary to retain, or leave on the particular or different branches or former bearers, that if the uppermolt fhoot, and only one appears neceffary to remain, cut away all thofe below on the faid branch; or if the lowermoft or middle fhoot may feem moft eligible to continue, cut down the upper part of the branch and hoots thereon, to the continuing fhnot, cuiting alfo away any hoot below this on the fame brancn; or if two or more thoots, on particulai branches, appear requifite to be retained, either the lower and uppermoft, or fuch as may appear moft favourable for the purpofe, prune out any intervening fhoots, or others, above or below; and if any part of the refpective branches extends above the uppermolt thoot proper to retain thereon, cut that part of the branch clofe to the faid moot, fo as every branch may terminate in a good thoot for a leader; or any particular branches having but one fhoot, there is no choice; this, if necefiary, muft be retained either fituated naturally at the termination of the branch, or if in the lower part, prune down the branch to the faid hoot, both for a terminal thereto and for bearing as the others; all which thorten more or lefs, as formerly advifed; and where they have any lateral orfide-twigs, thefe hould be cut clean off to their origin.

Further obferve, that as you proceed in the above pruning and retaining the proper fhoots for bearing, as it is moftly advifeable to fhorten the faid fhoots, more or lefs, it fhould be performed as you go on; for, as before noticed, the thortening the fhoots of thefe trees in winter-pruning is neceflary, whereby to have them produce more effectually a fupply of future bearing fhoots from their lower parts, next fpring and fummer, which otherwife would rife moftly above, and leave the bottom naked; therefore, prune each thoot according to its Atrength, and that of the trees, leaving the ftrong thoots longeft, the others in proportion, or generally pruning the ftronger fhoots about one third or fourth of their natural length; as for infance, a ftrong thoot of two feet may be cut to fifteen or eighteen inches, and in proportion to others of ftronger growth; the more moderate or weak moots, may be cut about one third, or near half their length; and-generally obferving, agreeable to thofe intimations, that in ftrong, healthy trees, to leave the moots longer than in thofe of a more weakly ftate; and in all of which, commonly perforn the cut floping behind, and a little above a hoot-bud, to advance for a terminal leader.

Obferving, however, in the operation of fhortening, that where you prune principally for fruit, not to cut below all the bloffom buds, eafily diftinguifhed by their round, turgid, or fwelling appearance, and generally cut either to a hoot-bud, difcoverable from the others, by being more oblong and thinner, fometimes placed difinet, or fometimes at the fame cye with a blofom-bud, or prune to a twin bloflom, or where two flower buds are at the fame eye, and which often furnithes a thoot-bud between them for a leader; for it is effential that each bearer have a leading terminal fhoot produced in fummer, to draw nourifhment to the fruit.

But where neceflary to pruneparticular hoots, principally to furnifh wood for fupplying vacancies, they may be cut thorter than intinated in the above general directions, for the bearing thoots, and without paying any particular regard to the bloffom buds; fo, according to their ftrength, may be cut to fix, eight, ten, or 
twelve inches, or fome in particular parts; fmall thoots may be pruned to three or four eyes.

Or in trees affuming a luxuriant habit, having in general, or moftly, very ftrong, vigorous fhoots, as fometimes occur in Peaches and Nectarines, running mofily to wood, without furnifhing much fruit, they fhould be but very moderately thortened; fome not more than about one fourth, others, more luxuriant, not hortened at all, or, but only topped a few inches down; for, in fuch vigorous trees, the more they are fhortened, they will thoot with greater luxuriance, and never form good bearers; but by Icaving the fhoots thicker, or more abundant, and but very moderately fhortened, the exuberancy of fap, or redundant nourifhment, being thereby divided amongft a greater number and larger extent of branches, reduces them, by degrees, to a more moderate habit of growth, adapted for fruit bearing: then may be pruned agreeable to the general method.

Generally obferve, in pruning the Peach and Nectarine Trees, to retain a fufficient fupply of proper thoots in all parts, bottom, middle, and upper expanfion, advancing, as it were, one under or after another, in the moft reguiar order, and always keep the lower parts, and all vacant fpaces, well fupplied.

Likewife obferve, that as thefe trees alfo fometimes bear upon fmall fpurs on the two or three ycars wood, of from halt an inch to an inch, or longer, they may generally be retained, where of a fruitful ftate, in being furnifhed with feveral bloffom buds.

According as each trce is pruned, agreeable to the foregoing obfervations, it hould be nailed directly; in which, arrange the general thoots and branches more or lefs horizontally, in proportion to the expanfion of the head; and as the allotted fpace of walling, both fide-ways and in height, admit, extending them equally to the right and left, at regular diftances, one above another, beginning with the lower branches firtt, laying them in fraight, fo proceed with the others upwards, equally on both fides; or where any are irregular and crooked, they may be extended fraight, by means of the nails, \&c. in nailing, by bending the branch, lefs or mo:c, up or down, as required, to have it in its regular pofition; for the branches thould generally range in a fraight, darting direction, as it were, and in a parallel manner, four, to five or fix inches afunder, and nailed clofe to the wall; in which generally place the Arreds neatly between the joints or eyes of the fhoots, \&cc. with both ends meeting even, and nail them accordingly.

For nailing, thefe trees, as above, fhould bc furnithed with proper nails and Shreds; the nails gerew "ly flortin and thick-pointed, that will occafionally drive into the bricks as well as in the joints bets. 36.2 , and which may be obtained at all the iron-nougery fhops, at per thoufand, \&c. or cheaper by weight, where large quantities are required; or for nailing to paiings, thinner-pointed nails may be eligible; and for fhreds, have either broad-cloth lifting, which generally rend down the middle, half an inch broad, or but litile more, cut into lengths of two or three inches, for fmall and general nailing; longer for larger branches; or, in default of lifting, any cuttings of cloth may be ufed, cut to the above breadth and length, the ends fquare or even: never have the threds too long, for the ends to hang down loofe, which has a flovenly appearance.

Having now finihed the principal obfervations relating to the general culture of Peaches and Nectarines, fiall conclude with fone further remarks with regard to the management of the trees when flowering and fruiting, and fome other effentials.

As Peach and Nectarine trees bloflom early in the fpring, when cutting, cold weather, and frofts, often prevail, that it is advifeable to give them occafional protection, by covering them with mats, \&c. efpecially fome principal trees of the choicer kinds; and which care is neceffary principally about March or April, when the blofom expands, and while the young fruit is fetting; when, in frofty or very cutting weather, either nail up fome large mats againft the trees every night, or continued, occafionally, of days, when tharp froft and no fun; but when funny, or mild open weather, remove the covering; and thus continued, occafiomally, till the fruit is fet and out of danger; or, inftead of mats, or not having a fufficiency for the covering intended, either ufe cuttings of cvergreen trees and fhrubs, as being furnifhed with the leaves, and ftick them between the branches in a fpreading manner, to cover the bloflom, \&c. as well as poffible, and to remain conftantly night and day, till the fruit is fet, and advanced a little in fizc; or may ufc large, old finhing nets, nailed up before the trees, to continue conftantly, as obferved of the evergreen cuttings, both of which will break oft part of the keen cutting effects of the frolt; or may fometimes ftick the trees with branches of dried fern, where attainable, as advifed for the evcr-greens a forcfaid, which will alfo afford fome protection to the bloffom and yourg fetting fruit; and all of which protcetions fhould gensrally be continued till the crop of fruit is fet, and incrcafed to the fizc of laigc peas, or middling green goofeberries, or nuts, and ticn, in the end of April, or beginning or middlc of May, according to the feàfon or adsanced growth of the fruit, the coverings may be wholly difcontinued and removed away.

In favourable, warm fcafons, fometimes thefe trees fet very abundant crops of fruit, and often too many, or clofe together on the refpective hoots, as to reyuire thinning; for if permitted to remain too abundantly, thicy would both prove greatly detrimental to the trees, fo as to draw the whole nourinment, weaken and pre- 
vent their making proper fhoots for fuccefional bearers, and the fruit would be impoverifhed, and, in their advanced clofe growth, thrutt one another off the trees, or would nct acquire proper fize, or perfccion of maturity; therefore this fhould be timeoufly attended to, while the fruit is in young growth, in May, or early in June, at farthelt; when, examining the general branches, and where the fruit is croudedly thick, thin of the moft unpromifing, leaving the others, four to five, or fix inches afunder; or, according to the frength of the different trees, and that of the bearirig hoots, in which leave the fruit thinner upon thofe of a wcakly or moderate ftate, than others of a ftronger, free growth.

The thinned-off young fruit of the Nectarines particularly, as being fmooth-rinded, and more poignant tafted than the Peaches, may be ufed for tarts, efpecially before they begin to ftone hard in the heart.

In the advancing fate of the fruit, continue the trees always divefted of the ufelefs thoots of the year, and the others trained in clofe and regular to the wall, as advifed in the fummer-pruning, to admit the neceffary benefit of the fun, air, rains, dews, \&zc, all very effential to forward and improve its growth, both in fize, colour, and goodnefs; and when advanced towards maturity, be particularly careful to keep all the fhoots clofely trained, to give free accefs to the action, or power of the fun; or alfo, where the leaves are very thick, thading the fruit too confiderably, fome fhould be removed in a moderate, thinning manner, not to expofe the fruit fully, or fliddenly, at once, but to continue ftill a flight fhade, where any was before; and by thus keeping the general thoots trained clofe, and thicket leaves thinned, that the beneficial inluence of the fun is admitted, the fruit will ripen in all defirable perfection.

According as the fruit ripens in its refpective feafon of the different varieties, it fhould be gathered while in beft perfection, moderately mellow, when in full flavour, and before too foft, and the rich flavour evaporated; and during hot weather, it would be advifeable to gather it in the early part of the day, before heated too much, and the flavour reduced by the power of the fun; and depofited in a cool, dry place, till ferved to table.

Thefe trees being fometimes attacked by blights and infects, in fummer, the former often attacking them fuddenly, either general, or fometimes only particular branches, frequently in a fevere degree, that the malady cannot be prevented, efpecially a dry blight, or blaft; in others, it comes on more gradually; fometimes the leaves and young flioots become clammy, the former crumpled, and the latter bunchy at the ends, \&c. and neither thefe nor the fruit make any progrefs in growth; in which, as it is often occafioned by the depredations of numerous fmall infects, may lometimes pull off the worft of the infected leaves, and cutting away the diftempered part of the fhoots; aftcrwards, may frew tobacco-duft, fnuff, \&c. over the general branches and leaves; and fometines in dry, hot weather, water over the whole trees, with a garden engine pump, difcharging the water with force againft the branches, which repeated, will prove beneficial; alfe, water the borders plentifully out of a watering-pot, fufficient to reach the roots.

And as blights and infects are fometimes occafioned by a weakly habit of the trees, or fome internal diftemper in the branches, or root, it would bc proper, when the trees affume a weakly, or difeafed appearance, or attacked with the above-mentioned maladies, to dig the ground open about the roots, not to difturb them; and apply fome frefh eartl, or compost of loam and thoroughiy-rotted dung, clofe about the extreme and general roots; give water, and clofe the earth over the roots a proper depth; or, in weakly, funted, or diftenipered trees, may, in autumn, or fpring, open the ground about the extreme roots; prune the ends thereof floping on the under fide, and cut out any decayed parts that appear, then add frefh earth, or compott, as above; the roots, where pruned, will emit frefh fibres into the renewed foil, which may prove beneficial in promoting a revived growth above in the head of branches.

To the borders in general, in which thcfe trees are growing, thould give occafional manure of dung, applied in autumn, winter, or fpring, once in two years, or as convenient; and if good, rotten dung, it will be of greater advantage, digged in one fpade deep; it will prove beneficial, both to the trees, in continuing them in a healthful, frec growth, and promote the production of good fruit, large, and well flavoured.

\section{To obtain the Fruit early by forcint}

Early Peaches and Nectarines, by forcing, are obtained, by having trees of the defirable varieties, planted in forcing itoves, and forwarded by artificial heat of fire, or fometinies allifed alfo by bark-bed heat; beginning the forcing about the end of January, or bcginning, or middle of February, continuing it till May; and by which, ripe fruit are acquired in that month, or in June, $\& \mathrm{c}$.

For this cccafion, proper glafiary apartments are erected, ranged long ways, cant and welt, twenty, or thirty, to fifty feet long, or more, as may be required, ten, to twelve, or fifteen feet wide; a brick wall behind, on the north fide, upright glafs work in the ends and front, and floping faines above, and with flues within, ranged along the ends, front, and back wall ; and having internal borders of rich earth ranged long ways, towards the back and front, in which 
to piant the trees; or fome forcing-houfes have alfo na internal fit, nearly the whole length, five or fix feet wide, or more, formed by a furrounding, thin, brick wall, raifed two feet, or more, above the floor, or bottom fpace; to have the pit a yard deep, for a bark-bed.

The trees of Peaches and Nectarines, for planting in thefe apartments, thould generally be fuch as have been trained in the open-ground, two, three, or four ycars, to a proper age and growth for immediate bearers; and which hould be planted in autumn, about October, or beginning of November, in the borders within the forcing-houfe; and having a trellis of poles, or rails, clofe behind the trees, train the branches thereto, in the wall-tree manner; and have occafional pruning, as directed, for thofe in the full ground.

The forcing by fire-heat is commenced in the end of January, or beginning or middle of February; or alfo, make the bark-bed at the fame time where intended, or that there is the accommodation of a pit for that purpofe: the fires to be made moderately every evening, about fun-fet, till nine, or ten o'clock; and alfo, in cold mornings, or fupported all day in very cold weather; and the bark-bed, if any, continued conftantly: admit air, in mild, funny days, in the warment time, by opering fome of the glaffes a few inches; and fornetimes give moderate waterings to the borders, when the earth appears dry; as likewife occafionally to the branches of the trees, before and after they bloflom, but never while they are in flower, and fetting the fruit; continuing the fire heat, as before-mentioned, every night, and all cold weather, but more moderate, as the ivarm feafon advances, and only principally in the evenings, and cold mornings, \&c. in warm, funny days will not be required, but when cloudy, will be occafionally neceffary; and thus fupport the fire-heat, in a regular, moderate degree, till beginning or middle of May, according to the temperature of the feafon; and the bark-bed, if any, will remain in a good heat, two or three months; being careful to encreafe the admiffion of air every day, according to the advanced warm weather, by liding open fome of the glaffes, more or lefs, about ten or eleven o'clock, when a warm fun, and always thutting clofe, towards the afternoon, or evening, to preferve the internal heat of a proper temperature.

The trees will thus bloffom early, and fet fruit in March or April, encreafe in growth till May or June, \&c. when attaining full fize: will ripen, fome probably in May, or the principal part in June and July.

When the fruit of thefe forced trees is all gathered, generally remove the glaffes, to admit the full air, \&c. to Arengthen the trees and fhoots of the year, and to harden the latter to a mature flate, proper for producing fruit the following feafon.
ANDROMEDA, (ANDROMEDA) or Marfh Ciftus.

$$
\text { Clafs and Order. }
$$

Decandria Monogynia.

Teiz Males, One Femole;

Or Plants with Hermaphrodite Flowers, furnified with ten Stamina, or Males, and one Pifillum, or Female Part.

The Andromedas are monly low, buhy thrubs, for:e ever-green, others deciduous, adapted principally to affemble in Mrubbery compartments, for variety ; grow from two or three, to four, five, or fix feet high, producing flender branches, adorned with fma!l, oval, oblong, and lance-fhaped leaves, and with bunches and fpikes, of fmall bell-hape, greenith flowers, confifting of a cup, five-parted, a monopetalous, beil. fhape corolla, five-parted and reflexed, containing ten ftamina, one ftyle, and a roundifh germen, fuccieded, by pentangular capfules, furnifhed with roundish feeds, by which the plants are occafionally raifed; alio by fuckers and layers.

Generic Charaklers are-Hermaphrodite flowers; the calyx one-leaved, coloured, cut into five parts, and permanent; corolla, or flower, one bell-hape petal, five-parted, the fegments reflexed; ftamina, ten, awlhape filaments, fhorter than the petal, and crowned with nodding, two-horned anthera; Piftillum, a round germen, lo:ig, cylindrical ftyle, crowned with an obtufe ftigma, and the germen becomes a peittagonal, quinquelocular capfule, filled with roundifh feeds.

\section{The Species are, \\ 1. ANDROMEDA mariana, Maryland Broad-leaved Andromeda.}

A fmall under-Thrub, two feet high; the leaves (fmall) ovate, intire, and placed alternate; and the peduncles or flower-italks aggregate; the corolla, or flower cylindric.-Native of Maryland, in North America.

\section{Andromeda paniculata, Panicle fowering An- dromeda.}

A low Mrub, three or four feet high; the leaves (fmall) oblong, crenulated, or fine-notched, and placed alternate; flower-fpikes panicled, naked, the flowers ranged on one fide; and the corolla or flower fub-cylindric.-Native of Virginia.

\section{Andromeda caljeulata, Calyculated or Double. cupped, Box-leaved Andromeda.}

A low, hrubby plant, two or three feet high; the leaves (fmall) oval, lance-Thape obtufe, punetured, and placed alternate; and witl leafy racems of flowers, ranged on one fide, the corolla fub-cylindric. Native of Virginia, Canada, Sibcria, and Ingria.

$\mathrm{D}_{2}$

AN. 
4. Andromeda Polifolia, (Yolifolia, or Mountain Poly-like) Rofemary-leaved Andromeda.

A fmall, Mrubby plant; the leaves (fmall) fpearThape, reflexed, placed alternate; and peduncles or flower-ftalks aggregate; the corolla, or flower, ovate. -Native of the northern, cold parts of Europe, in bogs.

5. ANDROMEDA racemofa, Racemus-flowered Andromeda.

A low, Mrubby plant; the leaves ( $m$ mall) oblong, fawed, and placed alternate; and fmall racemus clufters of flowers, ranged on one fide, bracteated, or floralleaved, being imall leaves between the fowers, the corolla, or fiower gibbous-cylindric.-Grows naturally in Penfylvania.

6. ANDROMEDA arborea, Arboraceous, or Tree Andromeda.

A largin, tree-like fhrtb, fix or eight feet high, with flender, drooping branches; the leaves (fmallifh) oblong-ovate, acuminated, or pointed; and long racems of fowers ranged on one fide, naked; the corolia roundish-ovate.-Native of Virginia, Carolina.

\section{Andromeda Daboccii, (Daboecii) or Cantabrian} Heath, or Irifh Andromeda.

Low, fhrubby plant; the leaves (fmall) ovate-fpear, shape, downy underneath, placed alternate; and terminal long racems of flowers.-Native of Hibernia, on the mountains of Galloway, \&x.

The above feven fpecies, being thofe the moft generally known and cultivated, there are fome others which are lefs common or noted, thall juft mention the names by which they are diftinguifhed.

8. ANDROMEDA myrtifolia, Myrtle-leaved Andro-

9. Andromeda pilulifera, Pill-bearing Andromeda.

Producing pill-thaped fowers.

10. ANdRomeda globulifera, Globular, or globebearing Andromeda.

Producing globe-thape flowers.

11. ANDROMEDA lucida, Lucid or fhining-leaved Andromeda.

12. ANDROMEDA axillaris, Axillary-flowering Andromeda.

Flowers produced at the axillas, or angles, of the branches.
Moft of thefe fpecies of Andromeda, are fmall, thrubby plants; the tree Andromeda is confiderably largeft; but of the others, the greater part are creeping-rooted plants, fending up feveral fuckers; and in all the fpecies the branches are clofely garnifhed with their fmall leaves; the flowers are alfo fmall, greenifh, growing in fpikes and clufters, at the fides and ends of the branches; appearing principally in June and July; the plants are moltly hardy, to grow in any common foil and fituation, though, are moft fuccefsful in mio?t ground, as they are naturally inhabitants of fuch fituations: but the Andromeda arborea, a native of warmer countries than the others, is rather more tender, and fhould generally have a warmer fituation, and fometimes be theltered from fevere frofts; or of which fort may alfo be kept a plant or two, in pots, to place under fhelter in winter.

All the forts may be employed, to diverfify the Inrubbery compartments, moftly towards the fromt part, in affemblage with other low, hrubby kinds, of fimilar growth; they are all cultivated in the nurferies, for fale, where they may be obtained for planting; which perform in autumn or fpring; and are propagated by fuckers from the roots, layers of the young branches, and by feed; all generally in the fprung.

Topropagate or raife thefe fhrubs, may fow the feed in the fpring, in a bed of lightioh, moift earth, half an inch deep; and when the plants are one or two years old, tranfplant them into a nurfery, \&c. or by fuckers from the root, moft of the forts may be more expeditiounly raifed, and which may be tranfplanted in autumn or fpring, with roots to each, either into a nurfery, or at once where they are to remain; and may alfo be raifed by layers of the lower, young branches, in the fpring, \&c. aforefaid.

In thrubberies, \&c. they may be planted in autumn or fpring, or any time in mild weather, from Ociober to March or April, and in which they do not require any particular culture, only to detach encreafed fuckers occafionally, and to prune any ftraggling fhoots, \&c. of the heads.

ANNONA, PAPAW TREE, (or Cuftard Apple)

$$
\begin{aligned}
& \text { Clars and Order. } \\
& \text { Polyandria Polygynia, } \\
& \text { Many Males, Many Females; }
\end{aligned}
$$

Or Plants having Hermapbrodite Flowers, whicb are furnifhed each with many Stanina, or Males, and many Piffillums, or Females.

THE ANNONA furnifhes two hardy fpecies of deciduous trees, of moderate growtl.- Natives of America, curious, and defirable to introduce in thrubberies, and other fimilar pleafurable plantations: grow 
ten to fifteen, or twenty feet high; ornamented with large, fpear-hhaped leaves and bunclies of largith flowers, dark coloured, of fix petals, alternately large and fmall, containing many minute ftamina ard pigmas; and fucceeded by large, oblong, or ovalis, ioft, yellow fruit, having many oval feeds; but the firuit and feeds feldom ripen in this country, being obtained moftly from America, and by which the trees are raifed.

Generic Cbaraders.-Hermaphrodite flowers; the calyx three concave, pointed leaves.-Corolla, or flower, fix petals, alternately larger and fmaller.Stamina, many very fmall filaments, crowned with anthera.-Piftilum, an oval germen at the bottom, no Atyles, but many figmas; and the germen becomes a large, oval or oblong, fcaly-rinded fruit, of one cell, furnifhed with many fmooth, oval, or roundifh feeds.

\section{The hardy Species are,}

1. ANNONA triloba, Three-lobed or Trifi-fruited Annona, or Common Papaw.

A fmall tree, ten to fifteen or fixteen feet high; the leaves (middling-large) fpear-fhaped, and trifid fruit, fomewhat pear-fhaped inverted. - Native of Carolina.

\section{AnNona glabra, Smooth-fruited Annona.}

A larger tree; the leaves (iargifl, broad) fpearhaped, ovate; large, conical, fmouth fruit.-Native of Carolina.

Both there fpecies of Annona are in eftimation as ornamental trees to adorn thrubberies, \&c. in affemblage with other deciduous kinds; are moderately hardy after the firlt two or three ycars of their young growth, and may then be planted in any warm, dry fituation.

Thefe trees merit admittance in a!l curious fhrubbery plantations of the deciduous tribe, in which they will effect a very confpicuous variety and ornamental appearance : may be had at moft of the nurfcries, and planted in autumn or fpring.

They are propagated by feeds, which are commonly obtained from America, and fhould be fowed in the fpring in a bed of light earth, fome in pots, to have fhelter in winter; or if the pots are placed in a hotbed, the plants will come up fooner; and which, when of one fummers growth, may be planted, part in pots, to have fhelter of a frame in winter, the firt two or three years, others planted in a warm fituation in the fpring; and when the whole is advanced two or threc feet, or more, in growth, may be tranfplanted into the mrubbery, \&cc. where they are to remain.
Their after-culture in the fhrubbery, \&c. is only to give occafional pruning when required, to regulate any diforderly growth, or to cut out decayed wood, \&c.

\section{Aralia, ANGELICA TREE, (Berry-bearing An- gelica.) \\ Clafs and Order. \\ Pentandris Pcrtagynia, \\ Five Males, Five Fomcles;}

Or Plants producing Hersinapbrodite Flowers, baving each five Stamina, or Male, and five Piftilluans, or $F_{B-}$ males.

THIS Genus furnithes but one fpecies for this place, principally of the large, fhrubby, deciduous tribe; a plant of curious fingularity to admit in fhrubbery compartments, for ornament and variety ; is of hardy growth, rifing with an upright fem fix or eight feet, adorned with large, fingular, compound, winged leaves; and confiderable umbcllate bunches of fmall, greenith, quinquepetalous flowers; fucceeded by oblong-roundifh berries, containing each five feeds; fcldom ripening in England, \&c. but generally obtained from America, by which to raife the p'ants.

Generic Charakters.-Hermaphrodite flowers, growing in umbellate bunches, each compofed of many florets; each umbel having a fmall involucrum, or ge neral calyx underneath.-Corolla, or flower, the florets formed each of five fmall, oval, reflexed petals; five awl-fhaped ftamina, terminated by roundifh anthera; a piftillun, confifing of a roundifh germen under the cup, fupporting five fhort fyles, crowned each with a fingle ftigma; and the germen becomes a roundin, channelled-berry, five-celled, each cel! furnißhed with an oblong, hard feed.

\section{The Species is,}

Aralia fpinofa, Spinous or Thorny Angelica Tree.

A largifh, fhrubby plant, growing fix or eight feet high; having a tree-like, thorny ftem; and large, compound, branching, fpinous leaves, of many oblong lobes; and produce large umbels of greenith flowers. -Native of Virginia.

This is a curious, thrubby plant in its gencral growth, large, compound, branching leaves, and confiderable loofe umbels of Howers at the ends of the branches; and deferves a place in every principal collection of ornamental fhrubs and trees: is cultivated for fale at all the nurferies, and may be planted in autumn or fpring, in fome moft confpicuous compartments in a dry foil.

It is propagated by feeds, and occafionally by cuttings of the root. 
inc fecds are moft!y obtained from North America, by the orincipal fecuffinen, arriving gencrally in the inriag. Wlicn in March, or April, fow them in a bei or pot of light earth, placing them in a flady fituation, to have only the morning fun a!l fummer, and under thelter of a warm wall, or garden frame, in winter; or if expofed in the full air, cover them, in frolly weather; or if the pots are plunged in a hot-bed in the fpring, the plants will come up fooner in a free growth: give water in lummer, and defend them in winter from the rigours of freit, one or two years; then, in the fpring, when a year or two old, tranfplant them, iome into pots fingly, others into the nurfery, and in both of which may continue till they acquire froner ftrength and fize, of two, three, or four feet; and may llum be finaliy tranfplanted into Mrubberies, \&e. to remain.

Or to propagate them nccafionally by roots, thefe zcnerally fprcading lorizontally, take off fome cuttings in the fpring, five or tix inches long, plant them in pots, and, placed in hot-beds, they will grow and produce hoots above.

The culture of this fpecies in advanced growth, in the fhrubbery, scc. is principally to prune to order any irregular productions of thoots, \&c. and, as fometimes, in rigorous winters, the froft kills the extreme or upper fucculent parts of the fhoots, cut off the dead parts, and the fems and branches of niore hardy and woody growth below will thoot out again in fpring and fummer.

\section{ARButus, STRAWBERRY TREE.}

\section{Clafs and Order.}

Decandria Monogynia,

Ten Males, One Female;

\section{Or Hermaphrodite Flowers, containing ten Stamina, or Males, and one Pifil, or Female, withen the fame Cover.}

THE ARBUTUS confift of feveral fpecies and varieties, moderate tree, and fmall hrubby kinds, all of the ever-green tribe; very beautiful, both as principal, ornamental ever-greens, and moft elegant flowering-trees and fhrubs, as well as fingularly ornamental in their production of Strawberry-like fruit; are adorned at all feafons, with oblong and oval lcaves, and numerous pendulous clufters of fmall, monopetalous, pitcherfhaped, white flowers in autumn, fucceeded by large, ovate, and oblong red berries, ripening in the following autumn and winter; furnifhed with many fmall feeds, by which the trees are propagated by fowing them in the fpring; alfo by layers of the young Thoots.
Generic Charadters. - Hermaphrodite flowers, in fmall, pendulous clufters; - the calyx fmall, sive-parted. Corolla, or flower, monopetalous, or of onc pitcher Thape petal, five-parted and reflexed at the brim; ten fhort ftamina, crowned with bifid anthera:-A piftillum, confifting of a glcbular germen at the botiom of the Hower, having a cylindric fyle terminated by an obtufe ftigma; and the germen grows a rounulif berry of five cells, filled with fmall, hard feeds.

The Species are,

\section{Arbutus Unedo, (Unedo) or Common Straw- berry Tree.}

A moderate tree, or large fhrub, growing eight, teil, or tweive feet high.-A tree-like ftem; the leaves (middling fize) ovate, fmooth, ferrated or fawed, and large red berries, having many feeds.-Native of the fouthern parts of Europe, the Ealt, and of Ireland.

\section{Varieties of this.-Common Arbutus, with fingle flowers.}

Double-flowered Common Arbutus. Scarlet-flowered Common Arbutus. Waved-leaved Common Arbutus. Oval-fruited Common Arbutus. Round Berried.

Yellow Berried.

None of thefe berries are eatable.

\section{Arburus Andrachne, (Andrachne) or Eaftern Broad-leaved Arbutus.}

A moderate tree, growing ten to twelve, or fifteen feet high, or more: the ftem tree-like, branching irregular; leaves (largifh) ovate, fmooth, intire; and large, red berries, having many feeds.-Native of the Eaft-in the Levant.

\section{Areutus Uva-urfis, (Uva-urfi) Bear-berry, or Dwarf Arbutus.}

A low, trailing, fhrubby plant; the ftems nender, branchy, and procumbent; leaves ( $/$ mall) ovate, and intire; and fmall, red berries.-Native of the cold parts of Europe, Canada, \&c.

\section{ARBUTUS alpina, Alpine, or Mountain, trailing Arbutus.}

A fmall, trailing, Rrubby plant; the ftems flender and procumbent; leaves (fmall) oblong, roughifh, and fawed; and fmall berries, black when ripe.Native of the mountains in Lapland, Switzerland, Siberia, England, \& $c$. 
Of the above four fpecies of Arbutus, the firft two are of the fmall and moderate tree kind, growing with an upright ftem, and branchy head; and the Comnon Arbutus particularly, has generally red hoots : are both very beautiful ever-greens, and fingularly ornamental in their numerous clufters of flowers, in autumn, about September, Oftober, and November, fucceedcd by the fruit in the fams feafon; but do not attain perfection till autumn following, requiring a whole year to grow to maturity : fo that the trees, in autumn, being in full flower, and furnifhed with young and ripe fruit, all at the fame time, make a remarkably fine appearance, and the greateft ornaments of the feafon; and the different varieties of the Common Arbutus difplay an entertaining diverfity, efpecially the Double and Scarlet-fiowered kinds, more particularly the latter; and all of which, both of the fpecies and varieties, are moft defirable furniture to introduce in principal fhrubberies, in affemblage with other tree and hrub kinds, placing them confpicuoufly, cr fome difpofed fingiy, upon lawns and other grafs-plats; generally allotting them a heltered, warm fituation.

The other two fpecies are dwarfith, trailing, Thrubby plants, fometimes admitted in collections to increafe the variety; placing them towards the front of fmall compartments, in moift fituations; or, as in the places of their natural growth, they generally inhabit boggy, or moift, moffy ground, if they could be allotted fomewhat fimilar foils in gardens, or in pots placed in fuch fituations, the plants may prove more profperous and durable. They are propagated by fowing the feed, and by layers and cuttings of the trailing branches; though they are plants rather reluctant to culture.

However, for ornamental purpofes in pleafure-grounds, the Common and Eaftern sirbutus have particular merit; the former of which is the molt prevailing, and generally cultivated, as producing more plenty of ripe berries and feed, wherewith to raife the plants in greater abundance than the other fort: both the fpecies are fomewhat tender in their young growth, but fufficiently hardy, in their more advanced ftate, to fucceed in the open ground in any common foil, in a fheltered fituation, or in any principal compartments where they may enjoy the fun in winter, and if where fomewhat defended from the northerly blafts, it will be the greater advantage.

Thefe defirable, ornamental trees are cultivated abundantly in all the principal nurieries, more particularly the Common Arbutus, and where they may be obtained for planting, either in young or more advanced growth, from two or three, to five or fix fect.

The beft feafon for planting the Arbutus is, principally, either in autumn, about the middle or latter end of September, if rain has fallen abundantly, or in October and November; otherwife in the fpring, in mild weather, froin February or March to the beginning or middle of April; and, where convenient, to remove or tranifplant them, with balls of earth to their roots, that they may not receive much check by removal, will be of heneficial advantage; and, in either cafe, give water at planting; efpecially if carly in autumn, or advanced part of the fpring feafon.

The Arbutus is propagated principally by feed contained in the berries, which, ripenin: in aucumn, gather in dry weather, and fowed, fome at that feafon, in a bed or pots' of light earth; or the berries may be preferved in dry fand till February or March, then fowed; previoully bruifing the berries to feparate the feed, which then fow, fome either in beds, half an inch deep, or wholly, or part, in pots of light carth ; and if in fpring the pots are placed in a hot-bed it will forward the germination of the feed, and the growth of the young plants, which give frequent waterings, and plenty of free air; or removed fully therein at the approach of fummer, to where they may be thaded from the mid-day fun; and in autumn, or fpring following, tranfplant them, fingly, in fmall pots, in order to move under thelter of a frame, the firlt two or three winters; giving, however, the full air all that feafon, in mild weather, and only defended with glaffes or mats, \&c. in fevere froft; and when the feedling plants are two or three feet high, fhould be tranfplanted with balls of earth into the open ground; and when of two or three to four or five feet, are proper for the fhrubbery. \&c.

Or they may be raifed by fowing in the open ground, in the fpring, planting fome of the young plants in pots as above, to have occafional protection in fevere weather in winter, for a year or twa.

The Eaftern Arbutus is propagated alfo by the fame method as above ; but, is the berries do not ripen fo plentifully in this country, they are obtained from the Levant, where the trees grow naturally in great abundance.

Both thefe fpecies and the varieties are alfo propagated, bccafionally, by layers of the lower young wood, in autumn or fpring, and fometimes by cuttings, but is often two years before they make any progrels; and. the cuttings feldom root frecly; or the latter may be forwarded in a hot-bed in the fpring : but generally obferve, the different varicties of the Common Arbutus muft be propagated either by laycrs or cutting; or more certainly by budding or inarching them upon feedling frocks of that fpecies, as they will not come the fame in their diftinct properties when raifed from feed. 
Aristolochis, BIRTHWORT.

Clafs and Order.

Gynandria Hexandria,

Male and.Female joined, Six Males, or Stamina;

Or Plants with Hermaplurodite Flowers, barving the Stamina, or Malcs, growing cithir uport the Style, or Female, or both Male and Female upon a Stjle-Form Receptacle, and baving $\int_{2 x}$ Staminn, or Males.

FOR this divifion, the Ariftolochia furnifhes a low, under-Ahrubby plant for the nhrubbery, \&c. adorned with fnear-fhaped, hearted leares, and irregular flowers, fingly; fucceeded by oblong capfules, furnithed with feed.

Generic Charafers.-Hermaphrodite flowers, no caIyx or cup; corolla, or flower, irregular, gibbous, or fivelling at the bafe, cylindric-tubulous upward, fpreading at the brim, extended in the under part, tongueform: fix Atamina, or rather only anthera, placed on the ftyle under the ftigma. Piftillum, an oblong, angular germen, under the flower, fupporting a globular, fix-parted ftigma; and the germen grows a large, trivalved, unilocular capfule, different formed, flled with numerous fmall feeds.

The Species is, ArIstoloch!A arborefcens, 'T'ree or Shrub Birth.
wort.

A frall under-Shrub, two or three feet high; the ftems and branches thrubbyifh, creet; leaves heartedfoear-fhape, and dark-purplifh fowers, fingly at the axillas of the leaves. - Native of North America.

This fmall, fhrubby plant, is proper to admit in Thrubberies towards the front part; but being fomewhat tender, fhould have a warm, fheltered fituation, or, occafionally, protected in fevere frofts; or fome "may alfo be kept in pots, to move under fhelter in winter: it may be propagated by feeds fowed in the fpring, in a bed or pots of light earth: give fhelter in winter; and when the plants are one or two years old, tranfplant them in nurfery beds or pots, till of proper fize for final tranfplanting.

Artemisia, (Mugwort) WORMWOOD, \&c. Clafs and Order.

Syngenefia Pclygamia Superniua, Conjoined Males, Many Marriages, Superfluous Females;

Or compound Flowers, compofed of Hermapbrodite and Femaie Florets; the Stamina, or Males, joined together at top; and Female Florets fuperfuous or unnecefary.

OF the Artemefia family, are two hardy fipecies, of Mrubby and under-fhrubby plants, of the ever-green and daciduous tribes, valuable principally for orna. ment and variety in fhrubbery compartments; growing upright, three to four or five feet high; adorned with compound, multifid, and finely-divided staves; and the branches terminated by fpilies and heads of fmall, greenifh, compound flowers, of many. fmall florets within one general cup, each floret fucceeded by a naked feed.

General Choracters. - Compound flowers, of many finall florets, in one general calyx: the calyx roundifh fcaly, and round fcales. Compound flower, compofed of female florets on the border or radius, furnifhed each with a fmali, germen, flender ftylus, crowned with a bifid ftigma; and hermaphrodite, tubulous florets in the difk, or middle, five-parted at the brim, having each a fmall germen, telle anr? ftigma, as the females, and five ftanina crowned by cylindric anthera, five-dented; and in all the florets the germen becomes a naked, fingle feed.

\section{The Species are,}

\section{Artemesia Abfinthium arborefcens, Tree} Wormivood.

Ever-green fhrub, four to five or fix feet high; the ftem hrubby, upright; leaves compound, (fmall, boary) multifid, or dividea into many linear fegments; and imall, fub-globular, greenih howers.- Native of Italy and the Eait.

\section{Artemisia Abrotanum, (Abrotanum) or South ernwood.}

A deciduous under-fhrub, three feet high; the ftems and branches fhrubby, upright; the leaves branching, finely-divided into numerous, briftly fegments; and terminal fpikes of fmall, greenifh flowers. - Native of Styria, Cappadocia, Italy, Montpelier, \&c. on hills. Varieties of this.-Common narrow-leaved South-
ernwood.

Broad-leaved Southernivood.

Dwarf Southernwood.

Broad-leaved, Scentlefs, Southernwood. Hoary narrow-leaved Southernwood.

Both the above fpecies of Arteris $2 a$, and the refpective varieties, being hrubby plants of moderate and finall growti, are adapted for the fhrubbery, to diverfify clumps and other compartments; the firft as' an ever-green, effecting a confpicuous variety in its hoary, compound-leaves, at all feafons of the year; the fecond as a deciduous under-fhrub, efteenned for its fragrant fcent; and is proper to introduce towards the front of fhrubbery-clumps, 8xc. and to adorn flower borders, or to plant in pots occafionally; and of which two fpecies, the ever-green fort, or Tree Wormwood, 
wood, being fomewhat tender, hould generally have a defended, warm fituation; but the Southernwoods may be planted any where, as they grow freely in any foil and fitt :ion: are all eafily propagated by cuttings or flips of the branches, and the Southernwood alfo by tucicers; training the whole generally with a fingle fiem below, and branchy, bufhy heads above; and as the Southernwood particularly, fends up numerous bottom fuckers, thefe fhould be occafionally detached in winter or fpring, to preferve the plants fingle, to grow with more regular, full heads; and the flipped-off fuckers, if wanted, are proper for planting, and each will immediately form a new plant.

Thefe thrubs are raifed in all the nurferies, for public fupply; and of the Southernwood particularly, the fetting gardeners, in the vicinity of London, raife amazing quantities, trained with buthy heads, for the fupply of the markets of that city, and the hawkers, to fell about the fireets, and environs of the metropolis, for furnifhing their fmall gardens, courts, balconies, \&c. as they will grow any where.

The feafon for planting thefe fhrubs is any of the fpring months, till May, and in autumn, from September to Norember; or the Southernwood, 35 it readily removes with a ball of earth, may be tranfplanted at almoft any feafon, occafionally.

The propagation, or method of raifing thefe two fpecies, is by cuttings, nips, layers, fuckers, according to the following direction.

The tree Wormwood is propagated either by cuttings or lips of the young fhoots and branches, in fpring or fummer, till July, detaching them fix or eight inches long; clear off the under leaves, and plant them in a hady border; give water, and they foon ftrike root the fame feafon; or may alfo be propagated by layers of the young branches in fpring, which will be well rooted, for planting off, in autumn following; and when, in either method, they are two, three, or four feet high, are proper for the Ahrubbery, \&c. or may likewife plant fome in pots, to remove under thelter in winter, when frofts prevail.

And the Southernwood propagates abundantly both by fuckers advancing from the bottom, and by cuttings and nips of the moots and branches: the fuckcrs may be detached in any of the fpring or autumn montlis; either flip them off from old plants, or large plants, confiderably increafed in many fuckers, may be taken up and lipped, or divided into feparate fets, cach furnifhed with roots, planted in any beds, or borders, a foot apart, or larger fuckers, planted at once where they are to continue; and by lips or cuttings of the branches, may be performed in March, April, and May; the Moots Mipped, or cut off, fix or cight, to ten or twelve isches, planted in a fhady border, or any beds of common earth, in rows, fir to twelve inches afunder, well watered; and they will all foon emit roots, and grow freely: generaily train the whole with a fhort, fingle fem below, and with regular full heads, either permitted to run, or the long ton fhoots cut down occafionally, to keep the heakls buthy; and when, from one to two, or three feet high, may be tranfplanted into hrubberies, flower-borders, \&:c.

The principal culture of both the above fpecies, after final planting, is chiefly to prune c.fual, irregular growths; or to cut rambling thoots on the fides. or above, as may feem neceflary, and where the Southernwood increafe confiderably in bottom fuckers, they fhould be flipped off more or lefs, to preferve the main plants in regular growtl.

\section{ASH TREE (FraXINUS.)}

In the Botanic Syftem, the Afhes belong to the Clafs and Order

$$
\begin{gathered}
\text { Polygamia Dioccia, } \\
\text { Many Marriages, Trwo Habitations; } \\
\text { Or Male, Female, and iIermapbrodite Flowers, on teso } \\
\text { Separate Trees. }
\end{gathered}
$$

THE AsHes, comprifing feveral fpecies and varieties, are all of the tree kind, growing from twenty or. thirty to fifty or fixty feet high, or more; fome of which are of confiderable valuable, as foreft or timber trees, both in their large ftandard growth, and in underwood, for coppices, \&c. and of which the Common Ath is fuperior, for its loftieft ftature and greateft magnitude in the body: its timber abundantly ufeful in many employments, and moft eligible to atfemble largely in foreft-tree plantations; and the others are proper to introduce in finaller fupplies, and for variety: are all of the deciduous tribe, or fuch as defoliate, or thed their leaves in winter; the leaves all of the compound, pinuated kind, compoled of from three, four, to five pair of fmall folioles, or leaflets, terminated by an odd or end foliole; and fman. greenif flowers, collected into fpiked bunches, moltly apetalous, (without petals, or flower leaves) and fucceeded by bunches of compreffed, lanceolate pericarpiums, or feed-veffels, called Afh-keys: ripe about Oetober; efpecially in the Common Afh in this country ; proper for fowing the fame feafon, or the follow. ing fpring, for raifing fupplies of young trees of the forts required.

The Species of FRAXINUS are,

\section{Fraxinus excelfior, Loftieft, or Common Afh} Trce.

A lofty-growing large tree, fixty or feventy fect high; the leaves pinnated or winged, ine Aly of cle-s 
ven leaflets fawed; and the flowers without petals. -Native of England and other parts of Europe, \&c. in hedges and woods.

\section{Varieties of this.-Silver-ftriped-leaved Common Ath. \\ Gold-Ariped-leaved Common Ant.}

2. Fraxintis antricalsis, American Intire-leaved An.

A tree of middling growth, thirty or forty feet higly; the leaves pinnated, of feven or nin folioles or lcaflets inire, and the petiole or foot-ftalk round. - Native of Carolina and Virginia, in North America.

Varicties of this.-Black American Afh. White American AR.

\section{Fraxixus Ornus, (Ornus) or Flowering-Afh.}

A fmall tree, fifteen or twenty feet high; leaves pinnated, of three or four pair of leaflets fawed, and the flowers furnifhed with a corolla, or petals.-Native of the fouthern parts of Europe and of America.

\section{Varieties of this.-Dwarf, Flowering-Ah. Panicled Flowering-Afh. \\ Round-folioled Flowering-A h, or Mana- Afn of Calabria.}

All thefe fpecies and varieties of Afh are hardy, deciduous trces, that will fucceed in ary common foil and fituation; are valuable to cultivate or plant, fome for ufeful and others for ornamental plantations, and variety, in affemblage with other hardy trees and fhrubs; of which the Common AR furpafies all the reft in its ftraight, fivift prccerier growth, with a trunk or ftem of confiderable fubftance; proper to rank as a firtt rate foreft, or timber-tree: the next in growth and value, is the American Af, which may alfo arrange in the foreft-tree collection, in a moderate proportion; and the Ornus, or flowering Alhes, with the different varieties thereof, and thofe of the other fpecies, are admitted principally in large decorative, or pleafurable tree plantations and fhrubberies; or may alfo, for the fame occafion, introduce the Afhes in general, efpecially in any confiderable outward plantations, in pleafure-grounds, parks, boundaries of capacious lawns, and in any out-grounds, in extenfive premifes, to increafe the variety in a diverfified manner.

But the Common Afh in particular, confidered as a principal foreft-tree, deferves general culture in all plantations of that kind, for its fuperior growth and great ufefulnefs of its timber, \&zc. in various material occafions, and for which it is valuable to cultivate both in woods, \&c. in large ftandard trees, for timber, and in coppices for underwood; and may alfo be planted in hedge-rows of fields, for the fame purpo-' fes, as the trees will profper in any common foil, and in any fituation where convenient, not fubject to ftanding water; and in which plantations the fandards will advance in a fivift, fraight growth, for timber trees, and the underwood will run up expeditiouly for poles, and other occafions, to fell in a thinning order, while in young growth, of from ten to fiftcen or twenty feet high, leaving plenty of the moft promifing to run up for large ftandards.

The different fpecies and varieties of Anes are raifed in all the nurferies, for public fupply of common plantations; but where confiderable plantations are intended to form woods and coppices, for timber and underwood, it would be much faving to raife them in home nurferies, on the eftate where fuch plantations are defigned to be formed.

The feafon for planting Afhes is any time after the fall of the leaves, in Oetober or November, or during the winter months, in open weather; or to compleat the whole in fpring.

The Afhes are propagated, or raifed from feed, and the varieties are continued permanent by raifing them by layers, grafting and budding, \&c.

The feed may be fowed in autumn, about Oetober, November, or December, or in the fpring, in $\mathrm{Fe}$ bruary and March, on beds of light earth, either in drills, fix inches, or a foot afunder, or on the furface, and earthed over one or tivo inches thick, they will come up in the fpring; and when the young trees are of two years growth, hould be tranfplanted from the feed-beds, in autumn or fpring, and placed in nurfery rows, two feet, or two and a half afunder; kept clear from weeds, by hoeing in fummer, and by digging between the rows in winter, or fpring; and according as they advance in growth, prune up ftrong fide-fhoots of the ftem, preferving the main top-hcor intire, to afpire in height; and thus, when the young trees are advanced from three, four, five, or fix, to eight or ten feet high, they are of proper fize for final tranfplanting in the different plantations intended.

To raife the varieties by layers, have fome young trees cut down to the bottom to produce lower hoots, near the earth convenient for laying, which may be performed in autumn or fpring, and will be rooted in one fummer for planting off in autumn, into nurfery rows, as advifed for the feedling trees, to acquire a proper growth for final tranfplantation.

The Flowering-Afh, or any particular variety, may be propagated by innoculating buds thereof into ftocks of the Common Af, or any other fpecies of the fame family.

When the trees, raifed by either of the above methods, are three or four, to fix, eight, or ten feet high, 
high, they are of eligible growth for final tranfplant ing, or occafionally, young trees of twelve or fifteen feet, or more, may be tranfplanted; though, when planted younger, they fooner root more effectually, and advance in a more free growth; and for timber plantations particularly, if planted where they are to remain, when from about three or four, to five or fix feet, they will root freely, and eftablifh themfelves more effectually, to make handfomer large trees, in the end, than thofe planted of larger growth: however, for this occafion, fhould never be more than eight or ten feet high for any general plantation.

To plant Afhes for timber and underwood, they may be planted both in affemblage with other deciduous foreft-trees, as maples, birches, \&c. and fome in diftinct plantations, wholly of the Afh kind; and in both of which, when defigned to plant in clofe rows, to allow for thinning in advanced growth, or to remain clofe, for coppices, to fall every fix, feven, eight, or ten years for fniall wood, it would be of advantage, if the ground, where practicable, could be prepared, by ploughing, \&c. but where intending to plant at wide diftances, to continue wholly for large itandards, may only dig apertures for the trees: the clofe planting for the above occafions, may be in rows, from three or four, to five or fix feet afunder, by the fame diftances in the rows; or for wider planting, to continue in full growth, they may be from ten to twelve, or fifteen feet afunder, or at greater diftances, in particular places, as may be thought convenient.

Or fometimes plantations of Afhes are raifed by fowing the feed in the places where the trees are always to ftand, both feparately and fometimes with thofe of other foreft-trees; either fowed in thallow drills, drawn by a plough, \&c. three or four, to five or fix feet diftance, or fometimes broad-caft, and ploughed in a moderate depth; and when the young trees come up, fome may be thinned out, where too thick, and planted in other places, if wanted.

The young plantations, in either methods, thould be defended with outward fences, as ditches, hedges, \&c. from the depredations of cattle.

In the advancing young growth of the trees, keep them clear from large over-topping weeds; and in thofe defigned for continuing ftandards, prune away lower lateral thoots from the ftem, that they may run up clean and ftraight, and occafionally lop low itraggling branches of the head, continuing the main-top leader, and other general top-branches, in full growth; and the plantations of clofe planting, defigned for thinning by degrees, for poles and other light purpofes, or thofe allotted for coppices, they, when advaneed in growth, Mou!d be thinned accordingly, felecting a fufficiency of the finett, Araight plants, at moderate diftances, to run for Randards, cutting down the others; the fools remaining will hoot out again, and will thus afford a cutting once in feven, eight or ten years, or according to their increafed growth, or the purpofes for which they may be intended; the fandards alfo being left iat fmall diftances at firft, thefe, in advanced growth, may likewife be thinned for particular occafions, leaving enough, at from ten to fifteen or twenty feet, to advance to full fize for large timber.

\section{ATRITLE, (OrACh) SEA PURSLANE TREL.} Clafs and Order.

Polygamia Monoecia, Many Marriages, One Habitation;

Or Flowers of different Sexes, as Females and Hermaphrodites, feparate, on the fame Plant.

Tu e Atriplex furnifhes two hardy ever-green thrubs. curious in their whitifh-green leaves, to affemble in the Anrubbery; are plants of moderate and finaller growth. in the different fpecies, adorned with delta-form and ovate, filvery leaves, and apetalous flowers, fucceeded each by one roundifh, orbicular feed; but which is feldom ufed in propagating the plants, they being generally raifed by cuttings, \&c.

Generic Characters.-Female and hermaphrodite fow ers, feparate on the fame plant; calyx, in the hermaphrodites, five-leaved; the leaves oval, concave, and permanent, no corolla or petals; five awl-fhape ftamina, crowned with double anthera, an orbicular, central germen, fhort two-parted ftyle, terminated by reflexed ftigma; a two-leaved calyx in the female flower; no petals nor ftamina, but a germen and ftyle, \&cc. and in each the germen becomes an orbicular feed, lodged in the calyx.

The Species are,

\section{ATriplex Halimus-(Halimus) or Broad-leaved Thrubby Atriplex, called Sea-Purflane Tree.}

Ever-green fhrub, growing five or fix feet high. or more; the ftem thrubby, branches fpreading; leaves (moderate fmall) delta-fhape, filver-coloured.- Native of Spain, Portugal, and Virginia, in hedges, \&c. near the fea. (Any common foil.)

\section{Atr I P LEX Portulacoides-(Portulacoides) Purflane-}

leaved Atriplex," or narrow-leaved Sea-Purflane Shrub.

Ever-green under-fhrub, three or four feet high; the fterh thrubby, head bufhy; leaves ( mall, narrorw) obovate, whitin-green.-Native of England and other northern parts of Europe, by the fea-fide. (Any foil.)

Thefe two fhrubby ever-greens are eligible to intrcaltec in the pleafure-ground, for ornament and va- 
riety, in aftemblage with other ever-green fhrubs, and occafionally deciduous kinds, in clumps and other fhrubbery compartments; in which they will difplay a very confpicuous and agreeable variety and diverfity, is their white, filvery-coloured leaves; gencrally allotting them fome principal diftricts: are both of hardy growth, to fucceed in any fituation, and in moft foils of a moderately dry semperature.

They may be obtained at moft of the nurferies, of a proper fize for planting, which may be performed in the fpring or autumn.

Both the forts are propagated by cuttings of the young thoots, in fpring and fummer: planted in a Shady border, and frequently watered in dry weather, they will root freely the fame feafon, to admit of tranfplanting in altumn or fpring following, either in nurfery rows, to acquire a proper growth for the fhrubbery; or fome, of larger growth, may be tranfplanted at once into the places where they are to remain.

As to general culture, may only give occafional pruning, to reduce to order any irregular branches, and to cut out dead wood when any occurs, and in common with other fhrubs kept clean from weeds in fummer; and the ground digged in autumn, winter, or fpring.

\section{Azalea, AMERICAN HONEYSUCKLE.}

\section{Clars and Order. \\ Pentandria Monogynia, \\ Five Males, One Female;}

Or Plants baving Hermapbrodite Flowers, firnißed each roith five Stamina, or Males, and one Piftillum, or Female Part.

THE Azaleas are deciduous flowering Shrubs, producing very ornamental flowers; defirable plants to affemble in principal thrubberies; borders, \&c. in the pleafure-ground: are of moderate and middling fhrubby growth, advancing moftly with feveral ftems, four or five, to fix or eight feet high; adorned in fummer with lanceolate and ovate fimple leaves; and at the extremity and axillas of the branches, clufters of white and red, long tubulous, fragrant flowers, five-parted at top; laving five internal ftamina and one pittil, fucceeded by roundith capfules, filled with roundith feeds, by which (obtained from America, where the plants grow naturally) they may be raifed; but in default of which, are propagated by fickers and layers.

General Cbarallers. - Hermaphrodite flowers; the calyx fmall, five-parted, acute, coloured, and permanent; corolla or flower, funnel-fhape, with a long naked tube, five-parted above, the two upper fegments reflexed back, the two fidcs bent inward, and the low. er fegment turning downward: ftamina, five fmall, unequal filaments, terminated by oblong anthera ; piftillum, a round germen, long, hender ftyle, crowned with an obtufe ftigma; and the germen grows a roundifh capfule, containing many roundinh feeds.

The Species of AZALEA are,

I. AzAlea vifcofa, Vifcous-flowered White American Honeyfuckle.

A moderate, deciduous thrub, growing three or four feet high; the leaves (pear-(hape, (middlingfize) with rough edges; and corolla of the flower hairy, glutinous or clammy; (flowers white, \&c.)-Native of Virginia. (Moift or any foil.)

2. Azaze a nudifora, Naked-flowered Red Azalea.

Middle fize deciduous thrub, growing fix or eight feet high; the leaves ovate (middle fize) and corolla of the flower hairy, and longet famina; (the flowers red, on long naked foot-italks.) - Native of Virginia. (Moift or any foil.)

\section{Varieties of the two Species are.-Early White-flow- ered. \\ Late White-flowered. \\ Red-flowered. \\ Pale-Red-flowered. \\ Scarlet-flowered. \\ Late Red-flowered.}

Thefe thrubs flower very ornamentally in July; the flowers long, tubulous, deeply cut at top into five parts, and fomewhat refenbling thofe of the commos honeyfuckle, and impart an agreeable odour; fo that the plants have great merit to arrange in principal forubberies, and other compartments of the pleafureground; and are hardy to grow in any common foil and fituation, though they generally thrive more fuccefsfully in moift ground.

They are cultivated plentifully in the nurferies, where they may be procured for planting, at the proper feafons.

The feafons for planting them is either in autumn, about the decay of the leaves, in Oetober and November, or in the fpring, before they begin to fhoot; or may be planted in any of the winter months, in mild, open weather; difpofing them generally in thrubberies, and any ornamental plantations, in affemblage with other deciduous fhrubs, \&xc. placed according to their fizes, more or lefs forward in the deftined compartments, to arrange confpicuoufly with fhrubs nearly of fimilar growth.

They are propagated principally by fuckers produced from the bottom, which may be taken up in 
autumn or fpring, with roots to each, and planted either in a nurfery, or fome of the largeft, at once where they are to remain; and the others, when of two, three, or four feet growth, may alfo be tranfplanted into the places where they are finally to continue; likewife, may propagate them by layers of the young thoots of the year, or preceding fummer, layed down in autumn, or following fpring: they will be moltly fufficiently rooted for planting off in the autumn or fpring enfuing; alfo by feed, where attainable, fowing it in the fpring, in a bed of light earth; and when the plants are one or two years old, tranfplant them in nurfery-beds to acquire a proper growth for the fhrubbery, \& c. though in general, the propagation by fuckers is the moft common and expeditious method; and when the plants, raifed by either method, are two or three feet high, or more, they are proper for the intended plantations.

In their future culture in the fhrubbery, \&c. they will only require a little occafional pruning to reduce any irregular growth.

BAccharis, (Ploughman's Spikenard) GROUNDSEL TREE.

\section{$\mathrm{Clafs}$ and Order.}

Syngenefia Polygamia Superflua,

United Males, Many Marriages, Superfluous Females;

Or compound Flowers, compofed of Hermapbrodite and

Female Florets diftinct; the Stamina or Males united

by their Tops; Female Florets fuperfiucus, or unnecefSary.

THE Baccharis has one hardy, Thrub'y fpecies, a largin, curious ever-green, to admit in the thrubbesy, decorated with ovate, glaucous leaves, and fpikes of compound, white flowers, having one general calyx or cup, containing many fmall hermaphrodite florets in the difk, and females in the circumference; the former having five fmall Atamina and one pitil, and the females a fmall germen and ftyle; fucceeded in all the florets, by one feed in each: ripe in autumn for fowing; but the plant is more generally propagated by layers and cuttings.

\section{One Species.}

BAсснAR Is balimifolia, Sea-Purflane-leaved Baccharis, or Groundfel Tree.

Ever-green thrub, four to five or fix feet high; the leaves ob-ovate, (glaucous or fea-green) the upper ones emarginated-crenated.-Native of Virginis. (Any foil.)

This hrub claims a place in the collection of evergreens, or to introduce in any principal thrubbcry compartments, is a confpicuous fituation, where it will effect an arreeable variety in its glaucous, whitifh-green leaves, at all feafons; may be procured at moft of the nurferies, for planting, in autumn or fpring; and is propagated by layers and cattings of the young wood, in the fame feaions or early part of fummer, which will be rooted by the autumn following; and may be forwarded in tie nurfery till of two or three feet growth, and is then proper for the thrubbery, \&c. where it requires only the common culture of other hardy thrubs; as hoeing the ground occafionally in fummer, to keep down weeds, and to dig the ground annually in autumn, winter, or fpring.

\section{BERBER15, BERBERRY TREE.}

Clafs and Order.

Hexandria Monogynia,

Six Males, One Female;

Or Hermaphrodite Flowvers, furnifhed with fix Stamina, or Males, and one Piffillum, or Ferisale.

The BERBERRY confifts of two fpecies, and feveral varieties, of the fmall tree, or large thrub kinds, all of the deciduous tribe; in eftimation both for their production of fruit, (fmall berries) for domettic occafions, and to plant in fhrubberies, or any ornamental compartments, in pleafure-grounds, for variety, \&c. in their general growth, foliage, flowers and fruit, grow about fix or eight, to ten feet high, armed with triple thorns, and garnifhed in fummer with fmall, oval leaves, and fmall, pendulous clufters of yellow flowers; the flowers fmall, having each a fmall calyx or cup of fix leaves, $f_{1 x}$ fmall oval petals, fix thort ftamina, a piftillum, confifting of a fmall germen and one fyle; and the germen becomes a cylindric berry, containing an oblong feed; the berries growing many together, in fmall, loofe bunches: ripen in autumn, for ufe, to preferve, pickle, \&cc. and for fowing, by which to raife the trees, or are alto propagated by layers, fuckers and cuttings.

\section{The Species of BERBERIS are,}

\section{BERBER Is vulgaris, Common Berberry Tree.}

A fmall tree or large thrub, (deciduous) growing eight or ten feet high; the head bufhy, leaves oval, (Smallifh, light-gre?n) and pcduncles or flower-ftalks, having flowers in racems or clufters, fucceeded by fmall pendulous clufters of rcd berries of an acid tafte. - Native of England and moft parts of Europe, in woods, the Eart, and Mount Lebanus. (Any foil.)

Varieties.- Common Red-fruited Berberry.
Red-fruited, without fone or feed.
White-fruited Berberry.
Black-fruied Berberry. 2. BER 
2. BERBERIS canadenfis, Canada broad-leaved Berberry, (Suppofed a Variety of the Common.)

A fmall tree, or moderate fhrub (deciduous) growing fix or eight feet high; the leaves oblong-oral, (larger, light-green) and flowers in clufters.- Native of Canada. (Any Joil.)

Both thefe fpecies and varietics of Berberis are very hardy to grow in almoft any foil and fituation; they rife with an erect ftem, branching out low into many upright branches, defended with three-parted fpincs; and the trees commonly fend up feveral root fuckers.

They are eligibie to cultivate in gardens and orchards, both as fmall ftandard fruit-trees, in a moderate fupply, where the berries may be in requeft, for candying, \&c. and to introduce in firubberics for variety and ornament, in which the flowers in fummer, and the clufters of berries in autumn, effect an agreeable diverfity; and may be admitted in any plantation compartments of the pleafure-ground, where thought necefiary; or planted fingly in capacious borders, \&c. and, in any method of planting, they produce plentiful crops of berries, ripe in autumn, about September and October; and which, in many families, are in great eftimation for preferving or candying, being of an agreeable, acid relifh; and are aifo fometimes pickled, and ufed occafionally for garnih to difhes ferved up to table; but for thefe occafions the Common Red-berried kinds only are proper; and for candying particularly, the ftonelefs-fruited fort is confiderably preferable to the Common.

For the above different occafions, the trees are trained in ftandards, generally each with a fingle ltem, three to four or five feet, and then permitted to branch out at top in full growth; they were alfo, formerly, fometimes planted for garden hedges, and in which, by proper clipping, will grow clofe and regular.

The different fpecies and varieties are cultivated in mot of the public nurferies, where they may be obtained for planting, which may be performed any time from the decay of the leaves, in October and November, in open weather, to March or beginning of April; and inay be planted in any common foil and fituation; though, where the berries are required for ufe, the trees growing in an open expofure to the full fun will produce them in the beft perfection.

They are propagated by feed, fuckers, layers, or cuttings; but by feed, is eligible occafionally, only for the common fort, as in the varieties, the feedling plants do not always come the fame; and of which, the ftonelefs fort being deftitute of feed in the berries, it can be propagated only by the other methods; and which is alfo the moft certain way whereby to continue anylother varieties difinet: however, when required to raife any forts indifferently from tne feed or berries, fow them in Oftober or November, \&cc. in a bed of light earth, an inch deep; and when the young plants are of one or two fummers growth, tranfplant them into nurfery beds, sc. Suckers advancing from the roots of old trees, may be taken up with roots, in autumn, winter, or fpring, and planted in a nurfery, they at once form proper plants; and layers and cuttings of the young wood in autumn or fpring, will be rooted in one year; and in which methods continue them trained in the nurfery, with a fingle fem below, and a full head above; and when from three or fotr, to five or fix feet growth, are of proper fizes to tranfplant finally where they may be in tended.

In their general culture in gardens, \&xc. keep them cleared from root fuckers, prune out rampant hoots of the ftem and head, with any irregular branches and dead wood.

\section{BETULA, BIRCH TREE, including alfo the} ALDER.

\author{
Clafs and Order. \\ Monoecia Tetrandria, \\ One Habitation, . Four Males;
}

Or. Male and Female Flowers, feparate on the fame Plane or Habitation; and Male Flowers, with four Stamina.

THIS Genus, or Family of Bctula, comprifing alfo the Alnus, or Alder, furnifhes feveral fpecies of large, moderate, and fmall deciduous trees, valuable both for timber and underwood plantations, and to introduce in large pleafurable plantations, Thrubberies, \&c. for variety; are all of molt hardy growth, twenty or thirty, to fifty or fixty feet high, one of dwarfifh fize; and garnifhed with ovate, and heart-maped, oblong, and roundih leaves, all fimple, fmall, middling, and largin; and with fmall male and female flowers, in ?eparate, cylindric, and roundin amentums, or catkins, compofed of fcaly calyxes, and very fmall florets, fucceeded in the female amentums, by a fingle feed in each floret: ripe in autumn, proper for fowing to raife fupplies of the trees; and which are alfo propagated by layers, and fome moltly by cuttings.

Charakters.-Male and female flowers, apart, on the fame tree, in feparate amentums; the males col: lected in cylindric, loofe, fcaly amentums, each fcale having three fmall fiorets, of one petal, four-parted, and have each four ftamina; and female flowers in fcaly, imbricated amentums, and roundifh heads, two florets in each fcale, no vifible petals, a minute oval 
germen, two briftly ftyles, and fucceeded in each female foret by an oval feed.

The Species of BETULA are,

\section{Betula alba, White, or Common European Birch Tree.}

A lofty-growing, ftraight tree, forty or fifty feet high; the bark white, leaves ( $(m a l l i f$ ) ovate, aciminated or pointed, and fawed on the edges. - Native of Britain and the cold parts of Europe, \&c. (Moijt or any foil.)

\section{Betula nigra, Black Virginia Birch.}

A lofty tree, fixty feet high or more; the leaves (Smallifh) rhomboid-ovate, pointed and doubly-fawed.-Native of Virginia and Canada, in North Ame. rica. (Any foil or moift.)

\section{Varieties of this.-Common fmaller-leaved Black Birch. \\ Broad-leaved Black Birch. \\ Poplar-leaved Black Birch. \\ Paper-barked Black Birch. \\ Brown Birch.}

\section{Bervia lenta, Lenta-twigged, or Poplar-leaved Canada Birch.}

A lofty, large tree, growing fixty feet high or more; the leaves ( $f m a l l i f i s$, dark green) hearted-oblong ovate, pointed and tharply fawed.-Native of Canada and Virginia. (Any foil or moifs.)

\section{Betula nana, Dwarf Lapland Birch.}

A fmall tree, Thrub-like, four or five feet high; the leaves (fmall) orbicular or roundith, and crenated.Native of the Alps of Lapland, Swamps of Sweden and Ruflia. (Any moift or other foil.)

\section{Betula Alnus-(Alnus) or Alder Tree (Com- mon.)}

A middling tree, growing twerty-five to thirty feet high; the leaves (middling large) ovate-oblong, and the peduncles or flower-ftalks branching; roundir fruit.-Native of England and other parts of Europe, and in America. (Moif fituations.)

\footnotetext{
Varieties.-Long-leaved American Alder Tree. Glutinous, Round-leaved Turky Alder Tree.

Hoary-leaved Alder Tree.

Black Alder.

Scarlet Alder.
}

Thefe five fpecies of Betula are all deciduous, o: expand their leaves only in fummer; the leaves fimple, from one or two, to three inches broad, two or three, to four inches long, in the different fpecies.

All the above fpecies and varieties, both of the Birches and Alder, are very hardy, deciduous trees, eafily propagated or raifed abundantly by feed, layers, and the Alders alfo by cuttings; and are all adapted to grow in any fituation where they may be required, for profitable or ornamental planting, or for variety; the common Birch and Alders growing naturally in moft parts of Britain, the former both in moift, fwampy foils, dry and other fituations, and the latter chiefly in fwampy grounds and near water: the trees of both the fpecies are proper to cultivate accordingly in fimilar foils, as are likewife all the other forts of Birches and Alder, they being equally hardy; and the Birch kinds in general may occupy any fituation, moift, dry, low, or upland; the Alders principally in moift land, though they will alfo grow almoft any where; fo that the trees of all the forts of Birch and Alder admit of cultivation in moft fituations, and are eligible to introduce in wafte or other grounds, either diftinct, or to affift in compofing any plantations of large, deciduous trees, defigned for profit, variety, hade, fhelter, \&c. in extenfive or other premifes, as may be thought convenient; or the Alders being naturally aquatics, they always grow the moft thrivingly in moift, fwampy, or watery places.

In regard to the particular and general utility of the different fpecies in plantations, all the tree kinds are eligible to cultivate both as foreft-trees, in full ftandards, for timber, and in coppices of under-growth, to cut for fmall wood; or likewife any particular fpecies, or the whole occafionally to introduce for variety, or to diverfify any hardy tree plantations, in extenfive pleafure-grounds, parks, and other capacious difriets, difpofed in groves, thickets, woods, clumps, \&c. and in iny running boundary plantations extending along the borders or verges of parks, paddocks, and other fimilar diftricts; and for all of which purpofes, thefe hardy trees may be admitted in any fituations; though the Alders particularly, as aforefaid, may be cultivated to the moft confiderable advantage, for profit, in any marhy land, or by the fides of water, and in walte, fwampy ground, adapted principally for the growth of aquatic trees; likewife the Birches will grow in low, fwampy fituations, and will alfo profper in upland grounds, moif or dry, and barren foils, as fcarcely any place comes amifs to thefe trees in their gencral growth.

Or thefe trees, both of the Pirches and Alders, might be planted in any low, moift lands, to very beneficial improvement and profit, both to grow for large fandards, for timber, and to form coppices, to cut in fmall growth, for poles, \&c. and the Birches alfo for the brufh-wood loppings for the broom-makers, which. 
which, in large cities and towns, is in great demand, and of which, amaring quartities are brought to lolidon by land and water carriage, and tacked up in yards and warehoufes for nie as wanted.

The nood of the Birch and Alder is ureful in f:reral trades; the finall wood for poles, ltakes, \&.c. and that of the Birches, for hoops to carks or tubs, barrels and other veffels; and the fnaller loppings is in great requeft for birch-brooms, and in both forts, the larger wood is ufed by the turners, and for making feveral hubandry inplements; and that of the Alder is alfo adapted for any under-ground occafions, or laid in witter, \&c. as it will continue found in long duration; and the wood of both forts is eligible for fuel.

So that for profitable pliantations, thefe trees deferve admittance plentifully in all extenfive fituations, and particularly in any infertile or wafte lands, or unculti. vated grounds, where but few other plants will profper; or in any fituation where it may be thought eligible or convenient, and where of fome confiderable extent.

The Alders, as before obferved, may be planted to much advantage in fwampy, walte grounds, or contiguous to water, as in which places they profper exceedingly, advancing expeditioufly to a large fize, requiring but very little culture; and are profitable both to have in clofe growth, for coppice wood, to cut every five, fix or eight years, for various fmall purpofes, and in plantations for large ftandards for timber; and in both of which, they, in their fwift regetation, afford a quick profit, efpecially as they may occupy fituations and foils not eligible for other cultivation; and in each falling or curting, they, being cut down low, will hoot up again from the bottom : this tree is alfo very ufeful to plant occafionally in young plants, or in fmall or large cuttings along river fides, or other running water, where liable to undermine the banks; and being planted in a clore row along the edges, will root thickly and fupport the banks fecurely; and is likewife well adapted to plant for hedges in any low, marhy fituations, either as boundary or divifion fences, to fuch places where it may be thought neceflary; and for which different occafions they may be raifed froin feed, cuttings and layers in a nurfery, and afterwards tranfplanted as above, or by fmall or large cuttings or truncheons, half a yard to three or four feet long, or more, planted in the fpring at once where they are to remain; in whick generally making a deep hole with a ttake or inftrument, \&c. for each cutting; or in moift, foft foils, the ends of the cuttings being tharpened, inay be thruft into the ground; but in planting rooted trees, a wide aperture muft be opened with a fpade for each plant; and of which, thofe planted clofe for coppice wood, hould be headed down low, to have each ad. vance with feveral ftems from the bottom; but thofe defigned for full ftandards, Mould rov? $;$ " wis "sih a fingle iten.

Likewife, all the tree Birches may be planted in fimilar plantations, as above, in any fituation or foil, where it may beconvenient, or thought eligible; and for which, are raifed principally from feed in a nurfery, and planted therein rifi of proper growth, of three, four, five or fix feet, or more, then tranfplanted finally for the above occafions; or they fometimes propagate by fuckers; and likewife, for the fame purpofe, young feediing plants, rifing naturally in Birch woods, or in thofe where Bircli trees abound, are collected for planting in the proper feafon; and in all of which methods, the trees being planted in the continuinc plantation, are managed as obferved before, for the Alders, to havethem for underwood and large ftandards.

As to the Dwarf Birch (Betuia nana) it being of low, Mrub-like growth, is principally for variety, and is fonetimes admitted in Arubbery collections.

All the forts of Birclies and Alders are raifed in molt of the public nurferies, where they may be procured in fufficient fupplies, to introduce in plantations, for variety, \&c. and other occafions; though, where confiderable quantities are required for timber and underwood plantations, it would be of much advantage to raife them in private nurferies, to plant occafionally as required: propagated by feed principally, in all the Birches; alfo the Alders, and the latter likewife, by cuttings and layers, and fometimes the Birches, by fuckers from the roots of the trees; a!l the plants raifed by either method, being forwarded in a nurfery, till of two, three, to five, fix or feven feet growth, for final tranfplanting.

The feafon for planting ali the forts is any time in open weather, from O\&tober or November, to March.

When defigned to plant there trees in any general plantation, for variety, \&cc. either in affemblage, or occafionally in dittinct clumps; they are of proper fize for this, when of five or fix, to eight, ten or twelve feet high, and which may be planted both in a thickety order, and in more open plantations, groves, clumps, sec. occafionally in extenfive out-grounds and parks; or fome might be difpofed in feparate compartinents, Birches and Alders diftinet.

But to plant them as foreft-trees, in woods, for full ftandards, and in coppices, for underwood, it is molt advifeable to perform it while the trees are in young growth, three or four, to five or fix feet, efpecially for continuing large ftandard trees; and for both purpofes they may either be planted in clofe rows, four to five, or fix feet afunder, to draw each other up more expeditioufly in a fraight growth; and to ad- 
mith of thinning, by degrees, in their advanced ftate, leaving a fufficiency to grow for large ttandards, at moderate diftances; or fome planted at wider diftarces, in grores or other open plantations, fet ten or fifteen fect afunder, wholly to remain for acquiring a confiderable fize, before any is thinned or cut down; and where intending to plant principally for underwood growths, the trees may be fet only three or four, to five or fix feet fquare; and may alfo be headed, that they may advance with feveral bottom-ttems, and that when advanced of fivc, fix or feven years grow th, they may admit of cutting for various fmall ures, and for fuel, \&c. and the Birches to cut for hoops once in feven, eight, ten or twelve years; generally, in both cafes, retaining fome finelt ftems, fingly, to run for ftandards; and the underwood trees, when cut down, fhoot again from the bottom, for cutting on future occafions.

he propagation or method of raifing all thefe trees of Birches and Alders, is by feed, for principal large fupplies; efpecially of the Birch trees, or likewife, occafionally, the Alders, and both the forts alfo by lavers; and the Alders particularly, propagate freely by cuttings, and by which they are commonly raifed. and fomctimes both the Birches and Alders by fuckers; all the methods of propagation performed either in autumn or fpring, or by feed and layers, principally in autumn, about Oetober or Novcmber; and the cuttings moftly in the fpring feafon, February or March: the feeds ripen in autumn, and thould then be gathered in proper timc, before the fcales of the amenwims open to diffeninate them on the ground.

Sow the feed in beds of any common earth, broadcart or in drills, and earticd in, not exceeding an inch deep; and when the feedling plants are come up, and advanced one or two years in growth, tranfplant them in nurfery lines two or threc feet afunder, to attain proper fize for the plantations intended.

Or by cuttings and layers all the forts of Alders may be propagated, and the Birches alfo by layers occafionally; and by which two methods of propagation is generally the moft certain procefs whercby to increafe and continue the different varieties of the particular fpecies, diftinet in their rcfpective kinds; however, by cuttings, may raife the Alders in general in the fpring, both of the young thoots and larger branches in truncheons or poles, thrce or four feet long, or more, planting the fmaller cuttings in a nurfery, for a ycar or two, or more; the others, of a larger fizc, may be planted at once where they are to rcmain, in moift grounds, loofening the foil, if hard, and make dcep holes with a ftake or iron infrument, to infert the cuttings half a yard or two feet in the ground; or to raife any of the forts by layers, perform it in autumn or fpring, taking the lower, young thoots and branches, nit-cut them a little on the un- der fide, lay them down into the carth, and they will be rooted in one year; then in autumn, \&c. plant them off into the nurfery, or large plants fet at once where they are to continue.

In the above different methods of raifing the Birches and Alders, thofe advancing in a nurfery to obtain proper fize for final planting, generally train thofe for ftandards with fingle clean ftems, cutting away laterai or fide-fhoots below, cont aing the top-fhoots intire; and when advanced three or four, to fix, eight or ten feet, are cligible for the refpective plantations, in which they may be tranfplanted, as required, in the feafons and order before intimated.

In final planting, all the nurfery-raifed plants, furrithed with roots, both Birches and Alders; loofen the ground, and dig a hole for each, a moderate depth, plant them regular in the holes, upright, cover in the roots directly with the earth, and tiead is down.

The general culture of all thefe trees, after thcit: final planting in their deftined diftricts, is principally in thofe growing for ftandards, to prune up fide-fhoots of the Item, or ftraggling undcr-branches of the head, to have the item advance in a clean, itraight growtl, or likewife in underwood plantations, the young plants in the beginning, may have lateral thoots below cut away, to encourage the ftems to run up clean and ftraight; and in the young plantations in general, while the trees are finall, keep down large, tall weeds in fummer, the firft ycar or two, till the trees advance in their top growth.

The cutting or felling thefe trees in fmall or large growth, may be performed any time after the deciy of the leaves in. autumn, or principally towards the fpring.

From Birch trees of large growth, in woods, the fap is extracted wherewith to make Birch wine, effected by tapping the growing trees in the fpring, when the liquid fap will flow abundantly.

\section{BIGNONIA, TRUMPET FLOWER. Clars and Order. Didynamia Angiofpermia,
Two Porvers, Seeds covered;}

Or. Plants with Hermaphrodite Flowers, having four Stamina, two of them longer than the otber two; and the Seeds contained or covered in a Vefel.

THE Genus Bignonia furnifhes an elegant, upright tree, and fome nirubby climbing kinds; all for ornament and variety in the hrubbery plantations: one fpecies being a beautiful, deciduous tree, adorned with large heart-form leaves, the others Mrubby climbers, deciduous and evcr-grcen, garnifhed with 


\section{VEGETABLE S Y S T E M}

nated, lance-Thape and ovate leaves; and all the fpecies produce clufters of bell-fhape, long tubulous, and trumpet-Thape fowers; fome beautifully ornamental, formed of one long tubulous fivelling petal, five-parted at top, and fucceeded by bivalvous pods, contain. ing many feeds; by which the fpecies may be propagatcd, alfo by layers and cuttings.

Cbarakters.-Flowers hermaphrodite; the calyx cupshaped, one-leaved, quinquefid or five-parted; corolla or flower, ringer:- or grinning, long tubulous, bell-Shape, five-parted at top, the two upper parts refiexed, the others fpreading. Stamina, four awl-fhape filaments, two longer than the others; and crowned with reflexed anthera. Piftillum, an oblong germen, flender ftyle, having a roundith ftigma; and the germen grows a bilvalvous pod, filled with compreffed, winged feeds, placed imbricatim.

\section{The Species of BIGNONIA are,}

3. Bignonia Catalpa-(Catalpa) or Tree Bignonia.

A deciduous tree of moderate growth, twenty-five to thirty feet high ; ftem erect, branchy upward-the leaves (very large, light-green) fimple,. heart-thape, by threes and oppofite; and large panicles of whitifh flowers, having but two ftamina or anthera.-Native of Carolina and Japan. (Moif, warm foil, or any conmon.)

2. BIGNON.14 radicans, Radicant, or rooting-ftalked climbing Bignonia, or Scarlet Trumpet Flower.

A climbing, deciduous fhrub, afeending thirty or forty feet high; the ftem and branches climbing, rooting at the joints-leaves (large, dark-green) pinnated or winged, of many pair of folioles or leaflets, deeply cut at the edges; and large bunches of long trubulous, reddifh and fcarlet flowers, moft beautiful. - Native of America. (Dryfituation.)

\section{Varieties.-Greater Trumpet Flower. \\ Minor, or fmaller Trumpet Flower.}

3. B1G KON $1 \mathrm{~A}$ unguis cati, (Cat-claw tendrilled) or Four-leaved climbing Bignonia.

A climbing, Thrubby plant, mounting twenty to thirty feet high-the leaves (largi $ß$ ) conjugated, or by twc pairs together, oppofite, with cirrhi or tendrils, fhort, arched or hooked, and three-parted; and bunches of yellow flowers.-Native of Barbadoes, Domingo, \&c. (Warm, dry fituations.)

\section{B 1 GNON1A fempervirens, Ever-green climbing Big- nonia.}

Evergreen climbing thrub, afcending thirty feet high; the flem volubilate or twining, climbiag-the leaves fimple, (middling fize) Spear-fhape, oppofite; and odorous yellow flowers.-Native of Virginia. (Warm fituation.)

Thefe four fpecies of hardy tree and thrub Bignonia; are defirable furniture for the Thrubbery and other des corative plantations; the firft of which, Catalpa, to introduce as a beautiful, upright ftandard tree, adorned with fingularly, large elegant leaves, and large branching clufters of dingy-white flowers; the other threc fpecies being all climbers, are eligible to plant as fuch, in any principal compartments, and againft walls, buildings, ftems of trees, arbours, and other fupport, by which they will afcend many feet high; fome climbing by their tendrils, others by their twining ftems, and the Bignonia radicans alfo by its radicant or rooting ftems, emitting roots into the walls, ftems of trees, or any adjacent fapport, thereby mounting to a lofty growth; and is tery ornamental in its trumpet-thape, beautiful, fcarlet flowers in fummer.

In their temperatur of nowth, the firft and recond fpecies are very hardy so fucceed in any common foil and fituation, the others are more tender, and in this country, demand a fomewhat Theltered, warm compartment in the fun.

For principal fhrubbery plantations, never omithaving fome of the Bignonia Catalpa, as a moft elégant ftandard tree, cloathed with noble, beautiful leaves in fummer, and is proper to occupy the moft confpicuous fituations; and the climbing forts are proper to admit in particular compartments, and will effeet an agreeable variety in their afcending growth; and of which the Radicant Bignonia is a very beautiful floweringclimber, which, and the other climbing kinds, Thould either be planted againft fome fupport, or have ftakes to afcend upon, or planted againit walis, buildings, ftems of trees, \&rc.

All the forts are cultivated in the nurferies, where they may be had in autumn or fpring, for planting.

They are propagated by feeds, moltly obtained from America, \&c. by the feedfmen in the fpring; and are alfo raifed from cuttings and layers of the young wood: fow the feed in the fpring, either in a bed, or pots of light earth, in a warm fituation, or fome in pots, placed in a hot-bed or moderate barkbed, to forward the germination of the feed, having moftly the free air, and the plants, when up, fully expofed, by degrees, all fummer, giving them occafional thelter the firt year or two, in winter from froft; and afterwards in the fpring, planted into the murfery in a warm compartment: cuttings of the Catalpa, young thoots, may be planted in the fpring months; and if fome are alfo planted in pots, and affifted in 2 bark or other hot-bed, they will root more expeditioufly 
ouly in a free growth; or may alfo be raifed by layers of the young wood; and the climbing forts alfo propagate freely by cuttings or layers, fome alfo by fuckers from the roots, and which methods of raifing thefe forts is the molt advifeable, as the plants will flower muih fooner than feedlings; the cuttings of which climbing forts will moftly root freely in the full ground, efpecially the Radicant Bignonia, or which, and the others, may be forwarded in a hot-bed occafionally.

For final planting in Ahrubberies, \&c. the Bignonia Catalpa is of proper fize, when three or four, to fix or eight feet high, or more; the others when two or three, to feveral feet, in their climbing growtin.

They may be planted in the allotted plantations, either in autumn, about Oetober or November, \&c. or in any of the fpring months, till April, or occafionally any time in winter, in mild, open weather, difpofing them according to their growth before explained; and in their advancing ftate, the principal care is to train the climbers to fome fupoort, and the Catalpa, in its ftardard growth, will only need to have cafual, ftraggling branches pruned to order in winter; likewife in the clinibers, when of advanced growth, have the fmall, weakly hoots cut out in winter, the ftrong ones retained, and occafionally thortened more or lefs, to obtain plenty of lateral young thoots for flowering in fummer.

\section{BUPLEURUM, (HARTWORT) or Hare's Ear.}

Clafs and Order.

$$
\begin{aligned}
& \text { Pentandria Digynia, } \\
& \text { Five Males, T.wo Females; }
\end{aligned}
$$

Or Flowers baving five Stamina or Male Parts, and two Piftillums or Females.

THE BUPLEURUM furnithes for this place a pretty ever-green fhrub, of upright, bufhy growth, and eligible for the fhrubbery; garnithed with ovalinh leaves, and umbelliferous yellow flowers; the main umbel formed of ten fmaller, each compofed of many fmall florets of five petals, fucceeded by roundin fruit, furnifhed with two ovate feeds, by which may raife the plants, and alio by cuttings.

General Charaders.-Flowers growing in umbels, of many hermaphrodite florets in each; the main umbel formed of ten fmaller, having, to the general umbel, a many-leaved involucrum, and five-leaved in the fmaller or partial umbels; the corolla of the florets five heart-fhape petals; ftamina five filaments, crowned with roundifh anthera; piftillum, a germen under the floret, fupporting two fmall reflexud ityles; and the germen grows a roundin-comprefted, chanselled, two-parted fruit, having two oblong feeds.

\section{One Species, viz.}

BUPLEURUM fraticofum, Shrubby, Willow-leaved Hare's Ear, or Ethiopian Hartwort.

An ever-green thrub, fix or eight feet high; the ftem thrubby, branching in a bufny growth-leaves (middlingfize) ovate-oblong and intire, fmooth, feagreen; and yellow umbels of flowers, July or duguft. - Native of the South of France and the Eant, upon rocks, near the fea. (Warm, dry foil.)

This fpecies being in ornamental ever-green, and a flowering-fhrub of buthy growth, claims a place in principal fhrubbery compartments, afingning it a fomewhat varm fituation and dry foil; and for which occafion it may be procured at the public nurferies, for planting in autumn or in the foring ; and is raifed from feeds and cuttings.

To propagate this thrub, may fow the feed in the pring, in a warm border, or in pots, and forwarded in a hot-bed; and cuttings of the young thoots planted in pots of loamy or other good earth, in autumn or fpring, and if affited by a hot-bed in the fpring, they will fooner emit roots, or if planted in the full ground in April or May, they will alfo grow and form proper rooted plants by autumn; when, or in the fpring fol lowing, may be tranfplanted into the nurfery to acquire two, three, or four feet growth, then is proper for fnal tranfplanting into the intended plantations.

\section{BuXus, BOX TREE, or Box.}

$$
\text { Clars and Order. }
$$

Monoecia Tetrandria,
One Habitation, Four Males;

O. Male and Female Flowers, feparate on the fane Plant, and the Male Flowers baving four Stamina.

THE family of Buxus confift of fmall tree kinds and low under-hrubby plants, all of the hardy evergreen tribe, to introduce in fhrubl:-ies, and the dwarf fort eminent for edgings to beds and borders; are moftly of bufhy growth, garnithed with fuall, oval leaves, and very imall male and feinale flowers, of two petals the former, the latter three; fucceeded by fmall, roundifh, trilocular capfules, furnifhed with two oblong feeds; fometimes ufed for fowing; but the plants are more commonly raifed by cuttings, llips, and fome abundantly by bottom-rooted fuckers or off-fets.

Generic Charackers.-The flowers male and female, feparate; the males having a three-leaved calyx, and the females a four-leaved cup, concave in each; corolla or flower, in the males two, and the females three concave petals; ftamina, four in the males,

$$
F_{2}
$$

crowsed 
crowned with ereet, double anthera; and in the females, a trigonal germen, three fhort ftyles, terminated by obtufe ftigmas, and the fiowers fucceeded by a roundifh capfule of three cells, containing each two oblong feeds.

\section{The Species and Varieties of BUXUS are,}

\section{Buxus arberefcens, Arborefcent, or 'Tree-Box.}

Ever-green, fmall tree, growing $f_{i x}$ or eight, to ten or fifteen feet high, or more; the ftem ereet, very branchy, bufhy head-leaves fmall, oval, thining green; and very fmall, greenith flowers.-Native of the fouthern parts of Europe and of Box-hill, near Dorking, in Surry. (Dry, or any foil and fituation.)

\section{Farieties of this.-Broad-leaved Trec-Box. Narrow fpear-leaved Tree-Box. Waved-curled-leaved Tree-Box. Silver-ftriped-leaved Tree-Box. Gold-ftriped-leared Tree-Box. Silver-tipped-leared Tree-Box, Gold-tipped-leaved Tree-Box. Gold-edged Trec-Box.}

\section{Buxu's fuffruticofus, Under-Thrubby, or Dwarf- Box.}

A fmall, dwarf ever-green, twelve to fifteen or eighteen inches high; the ltem fmall, very fhort and branchy from the bottom-ieaves (very fmall) roundith-oval; and minute greenifh flowers. - Native of Europe. (Any foil and fituation.)

\section{$\checkmark$ arieties of this.-Common Green Dwarf-Box. Silver-ftriped-leaved Dwarf-Box. Myrtle-leaved Dwarf-Box.}

The Boxes are molt hardy ever-greens, of very branchy and moltly of buhy growth, very clofely fet with their fmall leaves: both the fpecies and their different varieties are proper to introduce in any farubbery compartments, cluinps, \&c. in which, being ftationed according to their degrees of growth, they will effect an agreeable contraft and diverfity at a!l feafons, difpofed either principally in compartments of ever-greens, or fometimes in affemblage, in fmall clumps of deciduous thrubs: the Tree-Box alfo admits of planting for ornamental hedgesin gardens; and the Dwarf-Box is peculiarly adapted to form edgings to borders, fuperior to all other plants for that occafion, as the moft effectual, beautiful, and durable edging; and all the forts admit of being occafionally trained into fancy figures, as pyramids, globes, \&c. and the Tree-Box likewife to cultivate for its wood, which, being of a peculiar hard, ponderous nature, is of fingular value and eftimation in many mechanical trades, and for making various curious utenfils and implements.

All the varieties are cultivated plentifully in the nurferies for the fupply of the public, and may be propagated by cuttings, layers, flips, and the DwarfBox alfo by parting the roots, the Tree-Boxes likewife by feed.

The feafon for planting thefe ever-greens is, the Tree-Boxes, either principally in autumn, about October and November, or in the fpring, or even any time in winter, in open weather, efpecially if removed. with fome ball of earth to the roots; but the DwarfBex may be tranfplanted almoit any time in open wea. ther, from September till May; or for edgings, may be occafionally tranfplanted at almoft any feafon of the year, even in fummer, if well watered.

To propagate the 'T'ree-Boxes, it may be effected both by planting cuttings or flips of the young wood, in autumn or fpring, in a thady border, and watered; alfo by layers of the lower young branches, layed down in the earth in the above feafons; and in either method, when they are well rooted, tranfplant them into a nurfery, to acquire a proper growth for final planting in the thrubbery compartments, \&c.

The Dwarf-Box propagates naturally in very plentiful fupplies, by bottom off-fet fuckers, abundantly well rooted, which may be flipped or divided into rooted fets, at almoft any feafon; and may likewife be increafed by flips of the unrooted branches and fnooss, planted in autumn or fpring, in a hady border, and watered in dry weather; though, as this ipecies of Buxus increafes very plentifully in numerous rooted off-fets froin the bottom, it is moft commonly propagated thereby, which may either be flipped off from remaining old plants, with roots to each, or rather a quantity of the plants taken up and llipped, or divided top and root together, clean to the bottom, into feparate rooted flips or fets, larger or fmaller, as may be required, either to plant for training in fmall, buthy thrubs, or to plant for edgings, as may b: required.

For box edgings, the Common Dwarf-Box is the proper fort, and is of great utility in general gardening, for forming principal edgings to borders and other compartments, being the moit neat, effectual, and eafily kept in regular order, of nany years duration; and may be planted in any foil at moft feafons of the year, or principally any time from September or October, to March, April or May, or will even fucceed tolerably by planting in fummer, when particularly required, if well watered; and for which purpofe it hould always be planted clofe in the rows, as at once to form a compleat, regular edging. 
In regard to the method of planting thefe edgings, generally have the Box plants for this purpofe, of hort buhy growth, and making up the edge of the border, \&c. firm, and the top even by line, ftakes, or by direction of the eve, as the different compartments may admit; then, with the fpade, cut out a fmall narrow trench, the infide upright, five or fix inches deep, turning out the earth towards the walk; and then, dividing or flipping the Bax fmall, into rooted fets, cut the long roots horter, and the ftraggling tops even: plant then in the trench, againit the upright fide, clofe, or fo near together, as to form at once a compact ed ging, inferting the fets within an inch, or little more or lefs, of the tops, drawing in the earth, about the roots and ftems, as you proceed in placing them, raifing it near the tops, a forefaid, in a regular manner, and tread it down even, and if dry weather, finifh with a good watering.

The after-culture of the Box edgings, is to keepthem regular, by clipping once every year at leaft, in fummer, about June, July, and, or in any of the autumu months, till October; or if omitted at the above feafons, may be performed in the fpring, about March, April, or May; cutting it cven at top and fides, keeping the edging moderately low and thin, not exceeding three or four inches high at molt, and two inches broad, it will then appear neat and regular; and generally in the fummer clipping it is moft advifeable to perform it principally when moift weather, as if cut when hot and dry, is apt to change of a difagreeable, withered, or decayed-like afpearance.

$$
\text { Caircanthus, ALL-SPICE TREE. }
$$

$$
\text { Clafs and Order. }
$$

$$
\begin{gathered}
\text { Icofandria } \\
\text { Toxenty or more Males, Numerous Females; }
\end{gathered}
$$

Or Plants winh Hermapbrodite Flowers, having each swenty Staniza or IMales, and many Piftils or Female Parts.

THE CALYCANTHUS furnithes one hardy fpecies; a fmall deciduous flowering. Shrub for the Thrubbery, garnifhed with oval leaves, and apetalous, purple flowers, fingly, having many ftamina and germina, fucceeded by an oval-roundilh berry, with many caudated feeds: feldom ripening in England, but the plant propagates by layers and cuttings.

Characters.-The flower hermaphrodite; the calyx many-parted, coloured like petals; no corolla ; tiventy or morc hort ftamina, with obiufe anthera; many oval germina, crowned with ftigmas, and the germens grow an oval roundith berry-like fruit, furnithed with oblong feeds.
One Species.

\author{
Calycanthus foridus, Florid, Carolina Ali-Spice \\ Tree.
}

Deciduous thrub, four or five feet high; the ftem Shrubby and branchy-leaves (middling) oval, intire, and placed oppofite; and fordid-purple flowers, in May or June, having the interior petals longeft.- $-\mathrm{N}_{2}-$ tive of Carolina, (Dry foil, moffly.)

This fpecies is of branchy, buhy growth, eligible to introduce in principal thrubbery compartments, as a flowering-hrub, and for variety; its bark imparting an aromatic odour, obtained the name All-fpice in America: fhould generally have a fomewhat dry foil and warm fituation; may be had at molt of the nurferies, and planted either early in the autumn, or principally in the fpring, admitted in a confpicuous fituation:" is propagated by layers of the young fhoots, in. fpring and fummer, properly watered; alfo by cuttings of the fhoots, in the fpring months, planted in a fhady border, or in pots and placed in a hot-bed, to forward their rooting in a more free growth; they, in either method, will be rooted in one feafon, then tranfplanted in the fpring, and trained each with a bufhy head.

\section{CARPINUS, HORNBEAM, or Hornbeam Tree.}

$$
\text { Clafs and Order. }
$$

Monoecia Polyandria,
One Habitation, Many Males;

Or Male and Female Flowers, feparate, on the fame Plant; and the Male Flowers baving many Stamina.

The family of CARPINUS confifts principally of two fpecies and feveral varieties, all hardy deciduous tree kinds, cultivated for foreft trees, in ftandards and underwood, and in pleafurable plantations, for ornament and variety; growing twenty to thirty, or forty feet high; cloathed in fummer with oval and oblong fimple leaves, and fmall male and female flowers, feparate; collected in loofe fcaly amentums or catkins; no pctals to the male forets; a fix-parted corolla, ta thofe of the female, amentums, which enlarges to a fcaly cone, containing angular nuts, or feed: ripe in autumn, and by which the trees are commonily raifed, and occafionally by layers.

Charadters.-Flowers male and femate, apart, in the fame tree, in feparate amentums; the males, collected in cylindric, loofe, fcaly amentums, each fcale havin one îoret, without petals, containing many minute ftamina, crowned by hairy anthera; and females in fcaly imbricated catkins, having one flower in each fcale, of one fmall cup-hape, fix-parted petal, two gcrasina, fupporting four fmall ttyles, terminated by 
fingle ftigmas; and the amentum eniarges to a fealy cone, containing in each fcale an oval, angular nut.

The Species of CARPINUs are,

1. CAR:1Nus Betulus-(Betulus) or Common Fiornbeam.

Middling tree, growing t:venty or thirty, to forty feet high-the leawes (middling, dark-green) oval, ipear-fhape, and roughifh, remaining on the trees in a withered fate all winter; and the ftrobilus, or feed cones, having plain or fiat fcales.-Native of Britain, and molt parts of Europe, and in Canada, \&c. (Any foil and fituation.)

\section{Fariclies of this.-Common Hornbeam.}

Gold-ftriped-leaved Common Hornbeam.

Virginia Common Hornbeam, with longeft leaves and cones.

Eaftern, or Dwarf Hornbeam, of fmaller growth, (eight to ten, or twelve feet) imall leaves, and thorter fruit.

\section{CaRP1n us Oftra- (Oftrya Italica) or Hop Horn- beam.}

A moderate tree, growing twenty feet high or more-the leaves (midding fize, dark-green) oblongoval, and rough; and the amentums of fruit fomewhat like bunches of hops, inflated or fwoln fcales.Native of Italy, Germany, and Virginia. (Any foil and fituation.)

\section{Variaty.-Virginia, Flowering Hop Hornbeam, with lanceolate, pointed, deep-green} leaves.

Thefe are all very hardy, deciduous trees, that will grow in any foils and fituations, not inundated in water, either low or high grounds, or fides of hills, or any where, both in barren and fertile foils, as may be sequired or convenient, for any plantations intended; and in which both the fuecies are valuable to cultivate, in foreft-tree plantations, in ftandard timber-trees, and in underwood, to cut frequently in fmaller growth; as likewife all the forts have merit to arrainge in any ornamental diltrias of plantation, in pleafure-grounds, parks, or where thought neceffary; and to difpofe in fingle ftandards, groups, clumps, \&c. reparate or dittinet, and in concert with other deciduous trees, in extenfive lawns, in parks, and other grounds, for variety, \&c. and the Common Hornbeam is adapted to affemble confiderably with other hardy trees, planted cowards any out-boundaries, in expofed fituations, to afford thelter to interior plantations, and other diftricts, in the winter, as the old leaves, though withering in autumn, remain clofely attached to the branches all that feafon, whereby they more effectually break off the force of winds and cold, from internal compartments; and as both the fpecies are of a clofe branchy growth, they were formerly in great repute for garden hedges, both for fences, fheiter, and ornamental purpofes; though, in the prefent defigns of ornamental gardening, thele and other hedges are feldom admitted; however; as the trees are moltly of an upright growth, with clofe branchy, regular heads, they, in ftandards, claim adinittance in all ufeful and decorative planting.

Confidered as foreft-trees, both in ftandards and under-growth, the two fpecies may be cultivated to good advantage, or particularly the common fort; the wood or timber being ftrong and tough, is ufeful for many purpofes, and in the turnery way, mill work, \&c. and profitable for fuel; as is likewife the underwood, and for poles, ftakes, and many other light occafions: and for which the trees may be planted any where, either in aflemblage or diftinct plantation, fet moderately clofe at firft, four to five, or fix feet diftance, to draw each other up, in a more fivift, tall growth, and to admit of thinning fome in a few years, for fmall wood, leaving abundance of the beft ftems to run for full ftandards, and the underwood to advance between them, for future cutting, as occafionally required; or others may be planted at wider diftances, to ftand wholly for large timber, or to attain fome confiderable fize, before any are cut down: and are fonetimes cultivated in hedge-rows of fields, \&c. buth in low pollard ftandards, for frequent loppings of the branches, and to advance in tall ftems and full heads.

For ornamental plinting, both the fpecies, and their refpective varieties, are eligible to introduze in a diverfified manner, in confiderable plantations and large fhrubberies; or, for the latter, may liave only fome particular forts, as the Eaftern and Flowering Hornbeam. ftriped-leaved, or any others, as may be thought eligible for variety, \&c. difpofed more or lefs, towards the back or fore-part, with trees of fimilar growth; and either pruned up to ftems, fome confiderable height, or permitted to branch out nearly in their natural order.

The trees of all the forts are raifed from feed and layers, in autumn, and when from three or four, to fix, eight or ten feet growth, are proper for the feveral plantations for which they are adapted or defigned; or all thefe trees are cultivated in the nurferies, for fupply of the different plantations, for which they may be occafionally required; and where they may be procured of proper growth for the purpofes intended.

The feafons for planting them is the fame as for other hardy trees, either principally in autumn, about November or December, or any time in open weather, from the decay of the leaf to March, \&c.

They being propagated by feed and layers; the former is moft eligible for raifing any confiderable fup- 
plies of the Common and Hop Hornbeam, for full ftandards, for timber-trees and other occafions, or alfo large quantities for underwood; and for which latter purpofe, and for liedge-plants, or occafionally for ornamental ftandards, they may alfo be raifed by layers; though the feedling-raifed plants generally make the handfomeft itandard-trees: however, the different varieties of the two fpecies, may alfo be raifed diftinet in their kinds, in the propagation, by layers of the young wood, and fometimes raifed by grafting them upon feedling-ftocks of the Common Horn beam.

To raife them from feeds, they fhould generally be fowed in autumn, about Oetober, November, \&c. or in the fpring; but if fowed in the former feafon, they commonly germinate freely in the fpring enfuing; fowing them in beds of common earth, and covered in an inch deep; and when the plants are one or two years old, plant them in nurfery lines, till of proper growth for final transplanting.

By layers, this may be performed in autumn, or any time from Oetober to $M a r c h$, in open weather; the lower young wood or hoots of laft fummer, are proper: being laid down into the earth, will be rooted in one year for planting off from the parent ftools into the nurfery.

Or to raife any particular forts by grafting, it is effected by inferting thoots of the defired forts into focks of the Common Hornbeam in the fpring.

In the different methods of propagating them in the nurfery, \&c. let thofe intended for full ftandards be trained each with a fingle ftem, continuing the top intire; and prune off low and frong collateral thoots from the ftem gradually, to form them of a clean, ftraight growth, of five, fix or feven feet, clear of branches, then to branch out above in full heads; but thofe defigned for under-growth or hedge-plants, may branch out low, or for the latter, if run up to naked ftems, they may be headed down or fhortened at top, to gain lateral branches, though they commonly are tolerably branchy quite from the bottom in their nasural growth.

When defigned to plant the Hornbeam in woods, \&c. for timber-ftandards, it is moft advifcable to tranfplant them in young growth, from two or three, to four, five or fix feet; or fo: other occafions, they may alfo either be planted young, as above, or of larger fizes, as required; that in planting for timber and underwood, they, as before intimated; may be planted only at fmall diftances, five or fix feet, more of lefs; and in their advanced growth, cut down fome for underwood, by degrees, leaving fufficiency of the noft promifing to grow for timber.

Where hedges of Hornbeam may occafionally be inrended, any of the forts are cligible; the Common fors is the moft generally adopted, or any of the fmaller kinds may alfo be employed for this purpofe; and for which occafions are principally ufed for internal hedges, either for inclofing, dividing or Theltering, particular compartments; or may alfo be planted for outwara fences, efpecially in a double hedge, as they grow very clofe; and in all of which, if kept neatly clipped every year, they will appear ornamental in fummer; and the Common Hornbeam, retaining its leaves in their decayed ftate all winter, render the hedge more effectual for thelter in that feafon, than other deciduous kinds; though it may be obferved, that during the continuance of the withered leaves, the hedge appears rather Thabby. To plant hedges of this kind, have young plants, well feathered or branchy to the bottom, one or two, to three or four feet high, or more, planted a foot to eighteen inches afunder; and may run them up to five, fix, eight or ten feet high ; clipping them every fummer or autumn, on both fides, cutting the top at firft, rather fparingly, juit to kcep it a little regular, till advanced to the intended height, then to cut it clofe and even accordingly.

\section{CEAnorhus, NEW-JERSEY TEA.}

\section{Class and Order.}

\section{Pentandria Monogynia, Five Males, One Female;}

Or Plants with Hermaphrodite Flowers, baving cach five Stamina or. Male Genitals, and one Piftillum or Female.

ONE deciduous, very ornamental flowering-Thrub, of. low growth, eligible to adorn principal fhrubbery compartments; garnifhed in fummer with oval leaves, and numerous, thick fpikes. of pentapetalous, or fiveleaved white flowers, of beautiful appearance, in July and autumn ; fucceeded by obtufe, dry berries, furnifhed with oval feeds, proper wherewith to raife fupplies of the plant, alfo by layers.

The Characters-calyx, turbinated, one-leaved, acutely five-parted and permanent; corolla, fiveroundif, fpreading petals; five erect ftamina, of unequal length, crowned by roundifh anthera ; piftillum, a trigonal germen, cylindric ftyle, with an obtufe ftig$\mathrm{ma}$; and the germen grows a trilocular, dry capfular berry, with three oval feeds.

\section{The Species is,}

Cennothus americanus, American Cernothus, on New-Jerfey Tea.

A bufhy firub, three, four or five feet high, branchy from the bottom-leaves (fmallift) oval, and three- 
nerved.-Native of Virginia and Carolina. (Dry fituation.)

This fmall mrab demands a place in the beft Mrub. berics, for its ornamental flowering in numerous, white fpikes, terminating the branches; is fomcwliat tender while young, and thould generally have a warm, dry fituation; and is propagated by feeds and layers: fow the feed in autumn or fpring, in a waym border, or in pots, and theltered from froft; or if the pots are plaeed in a lot-bed in the fpring, the plants will come up fooncr; give them the full air in fummer, protect them from frolt in winter, and when a year olu plant tome feparate in fmall pots, others in the nurfery, and when two or three feet high, are proper for the fhrubbery; or bavers of the youmg brancles, in autumn or pring, will be routed to plant off in the fpring following.

CrLastrus-(CELASTRUS) or Stafí-Tree.

$\mathrm{Cla}$ s and Order.

Pentandria Monogynia,

Firse Males, One Fimale;

Or. Hernapbrodite Flonvers, having five Stamina or Males, and one Piflillum or Female.

TWO fpeeies of fhrubs, one cver-green, of upright growth, the other a elimber; both very defirable plants for adorning the fhrubbery; grow fix or eight, to ten or twelve feet high, ornamented with oval and oblong leaves, placed alternate, and loofe fpikes of white and greenifh flowers of five petals; fucceeded by three-cornered, red eapfules, furnifhed each with three oval feeds, by which the plants may be raifed, or may be propagated principally by layers of the young wood.

Characters.-Flowers hermaphrodite, ealyx or cup, fmall, one-leaved, obtufely, five-parted; corolla, fiveoval, fpreading petals; five ftamina, the length of the flower, crowned with fmall anthera; a fmall germen, placed on a large receptacle, deeply ter-channelled, fupporting a fingle tyle, terminated by an obtufe, trifid fligma; the germen becomes an obtufe, threecornered trilocular capfule, containing three oval feeds.

\section{The Species are,}

1. Cenastrus bullatus, Bullated, or Studded-fruited, upright Celaftrus.

A largih, ever-green thrub, branehing eight or ten feet high, unarmed or thornlefs-leaves (moderate fize) ovate and intire; and white flowers in July, fucceeded by fcarlet fruit, elegantly ftudded. - Native of Virginia. (Moift or any common foil.)

2. Cenastrisfeandicns, Climbing Celaftrus, or Baftard Climbing Spindle-Tree.

A twining-elimbing fhrub, afeending twelve or four teen feet high, unarmed or thornlefs; the them volubilate or twining-leaves (middling) oblong and fawed; and greenith flowers in June, fuceeeded by red feed-capfuies, opening and difplay the feed.-Native of Canada. (Moiftijh or any foil.)

Thefe two fpecies are very hardy fhrubs, demand adnittanee in all prineipal hrubbery collections, for ormament and variety, one as an upright ever-green and fowering-fhrub, and the other as a climber, and for the curiofity and pretty appearance of their red capfules: they may be admitted in moift or any common foil and fituation; the firft, as an upright hrub, fhnuld be difpofed confpicuoufly, either prineipaily with other ever-greens, or where it may be required; and the recond is proper to introduce as a twining elimber, in any hrubbery and tree plantations, giving it fupport of tall ftakes or poles, or will twin round the trees and thrubs, or their flexible ftems will twilt round one another, or any adjacent fupport: both the fpecies will difplay an agreeable variety; they flower in fummer, which in the firlt, are white, appearing in July, and in the feeond, greenifh, coming out in June; and are fueceeded by ripe feed-eaplules, in autumn, but more abundantly in the latter fort.

Both thofe fhrubs are cultivated plentifully in all the general nurferies, for public kupply, and may be eafily raifed by layers and feeds.

'To propagate tilefe Arrubs, it being effected both by layers and feeds, autumn or fpring is the proper feafon; though, as they grow freely by layers, that method is more generally practifed; the young fhoots are proper, which bow down and lay in the earth: they will be rooted in one year, then eut them from the parent ftools, and planted in the nurfery; or feeds may be fowed in the above feafons, in a bed or pots of loamy or other earth, and if in pots, may be placed in a thady place all fummer, and plunged in a warm fituation in winter, they will come up in the fpring, or fometimes not till the fecond year; and when the plants are of one or two fummer's growth, tranfplant them into the nurfery, where, having attained, swo, three or four feet growth, are proper for the mrubbery, \&c.

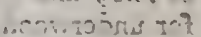

The feafon for planting them in fhrubberies, ac. is either in allumn, about Odober or dexernbefrofie. or in the fpring.
Sil to y ISE COELTis 
CELTIS, (Lote) or NETTLE-TREE.

$$
\text { Clafs and Order. }
$$

\section{Polygamia Monoecia, Many Marriages, One Houfe or Habitation; \\ Or Flowers of different Sexes, as Males and Hermaphro- dites, Separate on the fame Plont.}

THE Celtis family confifts of large, deciduous tree kinds, proper both to introduce in foreft-tree plantations, and for ornament and variety in pleafuregrounds, parks, \&c. grow thirty or forty, to fifty feet high, or more, and fome of fmaller growth; all adorned in fuinmer, with largifh and fmall oblong, ipear-fhape, oval and heart-hhape, roughifh nettlelike leaves, two, to three or four inches long, and half as broad; and fmall male and hermaphrodite, greenith flowers, without corolla or petals; fucceeded in the latter by fmall, round, drupaceous black, and purplin berries: ripe in autumn; and by which the trees are commonly propagated.

Generic Charakters.-Flowers hermaphrodite and males; the hermaphrodites having a five-parted cup, no petals, five fhort ftamina, crowned with quadrangular, four-furrowed anthera; a central, oval germen, two reflexed ftyles, terminated by fingle ftigma; male flowers with a fix-parted cup, no petals, five ftamina, as in the hermaphrodites, no germen or ftyles; and the hermaphrodite flowers fucceeded by fmall, globofe berries, of one cell, furnifhed with a round nut.

\section{The Species of CELTIS are,}

\section{CELtis auftralis, Southern Black-fruited Nettle-} Tree.

A large, deciduous tree, growing forty or fitty feet high-leaves (moderately large) oval-fpear-fhaped, placed alternate; and fmall, black fruit.-Native of the fouthern parts of Europe, in France, Spain, Italy, \&c. (Any tolerable good joil.)

2. Centis occidentalis, Occidental, or Weftern, Purple-fruited Nettle-Tree.

Moderate, deciduous tree, thirty to forty feet high -leaves (moderatcly largu) oblique ovate, fawed, pointed, and placed alternate; and fmall, obfcurepurple fruit. - Native of North America, principally in Virginia. (Any culerable good foil.)

3. Celtis orientalis, Oriental, or Eaftern, Yillowfruited Nettle-'Tree.

A fmall, deciduous tree, ten or twelve, to fifteen fcet high, branching horizontally-leaves ( $\mathrm{m}$ rall) oblique-hearted, fawed, hairy on the underfide, and placed alternate; and fmall, yellow fruit.-Native of the Eaft, in the Levant, and in India. (Dry fituation.)

Thefe three fpecies of Celtis are hardy to grow in the open ground, in any common fituation and foil, though are moft thriving in lightifh, rich land; however, they will fucceed well enough in any tolerably fertile ground or that in common with other hardy trees, in ornamental and other plantations, in pleafuregrounds, parks, \&c. are all raifed from fecd, principally in the general propagation, and occafionally by layers, and fome by fuckers: the young feedling plants are fometimes a little tenderion in their infant ftate, though not materially fo, and they foon harden gradually in a year or two; and when of advanced growth, of from three or four, to five or fix feet, or more, may be planted out where they are to remain, in any open expofures, or where required; and the trees, when advanced to fome confiderable large fize, will produce plenty of ripe fruit for fowing, as occurs in many of the Britih gardens, in which there are large trees of thefe forts.

All the fpecies are proper to introduce, moderately, in any ornamental planting, and for variety, both in pleafure-ground plantations, and large thrubbery diftricts; as alfo to diverfify plantations in parks and other grounds, to affemble principally with other trees of the deciduous tribe; and the firft and fecond fpecies are alfo eligible to difpofe in deciduous, forefttree plantations for timber, the wood being of a tough, pliant nature, is ufeful in feveral trades, where wood of that texture may be in requeft; and in all of which plantations, the trees will difplay a confpicuous variety in their general growth, different foliage, \&c.

The trees of all the forts are obtained at the nurferies, for any occafions in which they may be intended or required, for planting.

They may be planted either in autumn, foon after the fall of the leaves, or any time from that feafon, in open, mild weather, till the fpring, or principally in the laft-mentioned feafon, in February and March.

The propagation or method of raifing all the forts is principally by feed, or fome, occafionally, by layers of the young fhoots; and fometimes they afford fuckers from the roots, particularly the Celtis orientalis: the feeds are often procured from abroad, by the feedfmen, gencrally arriving in the fpring; at which feafon they may be fowed, or, if attainable, to fow in autumn, about Oetober or November, they will we nerally come up more freely in the fpring following they may be fowed in abed of light, s cllow earah, or fone fowed in pots, to have fhelter from fe"ste frof 
in wirter; or if the pots are plunged in a hot-bed, in the fpring, it will forward the germination of the feed, and the plants will come up fooner, when give them the free air all fummer; give occafional watering, in dry weather, both to thofe in the pots and beds; and if the young plants have Theltcr the firft winter, from froft, it will prove of advantage; then in the fpring, about March, plant them in nurfery-beds, in rows a foot afunder, till advanced of one or two years growth, when they may be tranfplanted at wider diftances, or fome of the largent planted where they are to remain; or the whole, when three or four, to five or fix feet, are proper for final tranfplantation: layers and cutrings of the yourg wood, in autumn or fpring, will root in one fummer, efpecially the layers; and fuckers from the root may be tranfplanted in the fame fealon.

In the above different methods of rifing the trees, and in the final tranfplanted growth, train each with a fingle ftem, cutting off lower-fhoots, and ftrong, lateral wood from the item, and fraggling under-branches of the head.

CePhalanthus, BUTTON TREE. Clars and Order.

Tetrandria Monogynia, Four ilales, One Female;

Or Flewers (Hermatbrodite) barsing four Stamina or Male Fruttification; and one Piftil or Female.

THE Cepbalantbus, or Button Tree, fo called from its headed flowers, is an elegant, deciduous, floweringforub, to admit in principal fhrubberies; is of middling growth, with oblong lcaves; and loore fpikes of many globular heads of yellowin flowers, each head, or aggregate, compofed of numerous, fmall, funnelfiaped forets, of one petal, fucceeded by a fingle feed, collected into round heads: ripe in autumn; and by which the plants are raifed, and alfo by layers and cuttings.

Generic Charatters.-Numerous, fmall flowers, collekted into globofe heads; a one-leaved funnel-fhaped cup to each fioret, four-parted at top; the corolla of the florets one funnel-thaped petal, the top divided into four parts; four fhort ftamina, inferted into the petal, crowned with globular anthera; a fmall germen, a fingle tyle longer than the flower, terminated by a round ftigma; and the germens grow oblongin feeds, in a globular head.

\section{One Species, viz.}

Cepualanthus occidentalis, Occidental, or Weftern, Button Tree of America.

A moderate, deciduous thrub, five or fix feet high, branching by pairs opposte-leaves (middling, light- green) oblong-narrow, placed oppofite, and by three together; and yellowin-white flowers in Juily.- $\mathrm{Na}$ tive of North America. (Moift, ligbt foil.)

This is a defirable, flowering-hrub, to introduce for the embellifhment of fhrubberies and other compartments, in pleafure-grounds, \&c. where it will effect a pretty varicty, and flower very ornamentally in fum. iner; delights moft in fonewhat moift ground, but may alfo be planted in any common foil where it may be required, and fhould generally have a principal fituation: may be had at the nurferies, and planted in atumn or fpring; and is propagated by feed, layers and cuttings.

To raife this thrub, the feed may be fowed either in the autumn, if it can be obtained, or in the fpring, in a bed of lightion earth, or in pots, and placed in a mady border, \&c. in fumnier, giving water in that feafon; and when the plants are one or tivo years old, tranfplant them into nurfery-beds, where train them, till of two or three feet growth, proper for Thrubbery; or to propagate it by layers and cuttings of the young wood, perform it in autumn or in the fpring, or the cuttings principally in the laft-mentioned feafon; they will be rooted, both layers and cuttings, to plant of in autumn, or ppring following, into the nurfery, to acquire a proper fize, as obferved of the feedling plants.

\section{CERc1s, JUDAS TREE, (Arbor Judx) Clafs and Order.}

Decandria Monogynia, Ten Males, One Female;

Or the Flowers Hermaphrodite, having ten Stamina or Males, and one Stylus or Female.

THIS Genus, Cercis, comprifes two curious fpecies of fmall or moderate, deciduous trees, of the ornamental kind, for adorning fhrubberies and other decorative compartments, of planting in pleafure-grounds; grow ten or twelve feet high, branching out low and irregular, garnifhed with large, heart-roundinh leaves, on long foot-ftalks, placed without order; and large clufters of papilionaceous-like, bright-purple, and reddifh, very ornamental flowers, of five unequal petals, having ten ftamina, and one germen and ftyle, growing a long, unilocular, flat pod, containing roundifh feeds, by which the trees are generally propagated; fowed in the fpring.

Generic Characters.-Hermaphrodite flowers; the caly $x$ bell-Thape, one-leaved, convex at bottom, the top five-parted; corolla, or flower papilionaceous, or butterfly-flower-like, having five unequal petals, the two fide-ones or wings reflexed, and rifing above the ftandard or middle petal, which is round, and two heart.. 
Ihaped under-petals, forming the carina or keel, encl Jing the fructifications; ftamina, ten diftinct, declinated filaments, crowned with oblong, incumbent anthera; an oblong germen and flender ftyle, terminated by an obture figma, and the germen fucceeded by a long, acuminated pod, of one cell, containing a row of roundish feeds.

\section{The Species of CERCIS are,}

\section{Cercrs Siliquaftrum-(Siliquaftrum) or Common European Judas Tree.}

A fmall or moderate deciduous tree, twelve or four tecn feet high-ihe leaves (large, ligbt-green) heartthape, roundin and fmooth; and numerous cluiters of ornamental flowers from the fides of tha branches. Native of Italy, Spain, Narbonne, and the Eaft, in Afia, \&c. (Anj common foil.)

\section{Varietics.-Purple-flowered Common Judas Tree. White-fowered Common Judas Tree. Bluin or Fleth-coloured, flowered. Narrow podded. Broaù padded.}

\section{Cercis conadenfis, Canadian Downy-leaved Judas Tree.}

A fmall deciduous tree, ten or twelve feet high, generally branching out near the bottom-the leaves (large, light-greens) heart-fnaped, pointed, and downy; and clufters of fmaller purple flowers at the fides of the branches.-Native of Canada and Virginia. (Any common foil.)

Thefe two curious trees have particular merit, to affemble in ornamental compartments of trees and thrubs; they are both of hardy growth, to plant in any common foil and fituation, and may be admitted in principal thrubberies, wilderners quarters, clumps, and other decorative diftricts of plantations, in pleafuregrounds, in which they will difplay a difinguifhably agreeable variety and ornamental appearance in fummer, in their general growth, fingular and elegant leaves, and numerous olufters of beautiful flowers; and, if in warm fituations, are fometimes fucceeded by curious, long feed-pods: the trees may be obtained at the nurferies, of proper growth for planting; and are generally propagated by feed fowed in the fpring, and when raifed three or four, to five or fix feet, are of proper fize for the thrubbery or other garden plantations, in which they may be planted in autumn or fpring feafon.

They are propagated principally by feed, which may generally be had of the feedrmen and nurferymen, in the fpring; at which feafon, in March or April, thould be fowed in a bed of light carth, covered in half an inch to an inch deep; or fome fowed in pots, and plunged in a gentle hot-bed, along with any exotic tree and thrub feeds, as occafionally have that affit ance, it will bring them on forwarder; and, in either method, when the plants are up, give water fometimes in dry weather in fummer; and in winter it would be of much advantage to give them Shelter from fevere frolt, with mats, \&c.

Then when the feedling-trees are a year old, they may be tranfplanted from the feed-bed, \&c. into nurfery-rows, performing it generally in the fpring, about March or beginning of April, training them, in their advancing ftate, eacl with a fingle ftem, more or lefs, and a full head; and after having two, three, or four years growth, or advanced fo many feet or more in height, they are then eligible for final tranfplanting in the places where they are to remain.

Or the propagation may alfo be tried ocafionally by layers and cuttings, efpecially the varieties; or thefe likewife by grafting upon feedling-Itocks of the Common Judas Tree.

The beft feafon for planting thofe trees in the frrubbery, \&c. is the fpring, but may alfo be performed in autumn, at the decay of the leaves, in Ostober, November, \&c. and in which planting, generally dif pofe them in fome principal compartments and confpicuous fituation; where permit them to grow with full heads, and in their culture, will only require any cafual irregular branches pruned to order, and to cut out dead wood.

\section{CHIONANTHUS, FRINGE Or SNOW-DROP TREE.}

Clafs and Order.

Diandria Monogynia,
Trwo Males One Female;

Or Plants with Hermaphrodite Flowers, having eacb two Stamina or Male, and one Style or Female Fruelification.

THE Chionanthus furnifhes but one hardy fpecies, a very curious deciduous flowering-tree, of thrub-like growth, for adorning the fhrubbery, garnifhed with large oblong foliage; and numerous long bunches of fringed fnow-white flowers, of one funnel-haped petal; fucceeded by a fmall roundin berry, with one feed, but do not attain perfection plentifully in England: are obtained from America, by which to propagate the plants, and are alfo raifed by layers.

Generic Cbaraflers.-The flower hermaphrodite; calyx or cup monophyllous, ereet, acutely four-parted; corolla, monopetalous, funnel-fhaped, with a fiort fpreading tube, sut above into four long ereet $10 \mathrm{~g}$ - 
ments; ftamina, two Thort filaments, crowned by heartform anthera; and the piftillum confifts of an oval germen, fingle ftyle, terminated by an obtufe, trifid thigma; the germen becomes a round unilocular berry, containing a friated feed or nut.

\section{The Species is,}

Cндом а тн и s virginica, Virginia Snow-Drop Tree.

A fmall deciduous tree, thrub-like, eight to ten, or twelve feet high - the leaves (large, dark-green)oblong, ovate; and peduncles or flower-ltalks, trifid or threeparted, fuftaining three flowers. -Native of North America. (Moijt joil.)

This curious fowering-thrub deferves a place in all principal thrubbery collections, beautiful in its large, laurel-like leaves, and long bunches of flowers in May, which being fringed and of a nowy whitenefs, the plant obtained the name Fringe or Snow-Drop Tree; it delights moftly in a fomewhat moift fituation, but may be planted in any common, mellow foil, or as the fituation affords; is raifed for fale in all the nurferies; and propagated generally by feed, and occafionally by layers; and when the plants are advanced two, three, to four or five feet, is of a proper fize for the Anrubbery; and may be planted in autumn or in the fpring.

To propagate this fhrub by feed, this may be fowed in autumn, if attainable at that feafon: is commonly obtained from America, and may be had of the feedfmen in the fpring, when, about March or April, fow it in beds or pots of loamy or other good earth; and if in rots, place them in a Thady or ealt border in fummer; or if plunged in a hot-bed as foon as fowed, they will come up fooner the fame year, otherwife, fometimes, remain dormant till the fecond fpring, in which cafe, if the pots are then placed in a hot-bed, it will forward them confiderably; obferving that as the young feedling-plants are rather tenderinh ${ }_{2}$ it would be advifeable to give occafional thelter in winter, from froft; and when they are a year old tranfplant them in the fpring, fome fingly in pots, others in a warm fituation in the nurfery; or thefe in pots may have occafional protection the firlt winter or two; training the plants, in either method, with a fingle ftem and full heads; and when two, three or four feet high, they are proper for the fhrubbery, \&c. in which thofe in pots particularly, may be tranfplanted with balls.

Or to raife them by layers, the young fhoots of laft fummer are proper, nit-laying them in autumn or fpring; they will probably be rooted fome in one, others will be two years before they are well rooted; or may wy the young thoots of the fame year in June or July.
CIsTUS,-(CISTUS) or ROCK.ROSE.

\section{Clars and Order.}

\section{Polyandria Monogynia,} Müny Malcs, One Female;

Or Flowers Hermapbrodite, having many Stamina or Male Fructifications, and one Piffillum or Female.

THE $C_{15 T U S}$ is fertile in a numerous family of ever-green, ornamental flowering-Thrubs, elegant furniture for the fhrubbery; moftly of fmall and moderate growth, from one, two, or three, to five or fix feet, generally diffufely-branchy and buthy, cloathed with fimple leaves, oblong, fpear-thape, oval, heart-hape, \&xc. of various fizes, and different thades of light and dark-green, hoary, white, \&cc. in the different fpecies, moft of them exuding a gummy fubltance; and at the fides and ends of the branches, numerous large purple, and white flowers, of five fpreading petals. cortaining numerous ftamina and one piftillum, fucceeded by a roundifh capfule, filled with feeds, ripening in autumn in moft of the forts, and by which the plants are raifed; and are propagated alfo by cutkings.

Generic Characters.-The flower hermaphrodite; calyx or cup five-leaved, two alternately fmaller; corolla or flower, five large, roundin, fpreading petals; ftamina, numerous fmall, fhort filanients, crowned with roundifh anthera; a piftillum in the centre, confifting of a roundifh germen, fingle ftylus, terminated by an orbicular ftigma; and the germen fwells to a roundith, covered capfule, of five to ten loculi or cells, filled with roundih feeds.

\section{The hardy Species of CISTUS are,}

\section{Cistus populifolius, Poplar-leaved Ciftus or Rock-} Rofe.

A moderate fhrub, firm ftem, very branchy, five or fix feet high-the leaves (largin) heart-Thape, acuminated, fmooth, and petiolated or foot-ftalked; and large white flowers in June and July. - Native of Porv tugal.

\section{Cistus laurifolius, Bay-leaved Gum Cifus.}

A middling fhrub, ftronge ftem, branching ereet, five or fix feet high-the leaves (moderate) oblongovate, three-nerved, fmooth above, with the, footftalks connated or joined at the bafe; and large, white flowers; June, July, \&c.-Native of Spain.

\section{Cistus ladaniferus, Ladanum-bearing or Com- mon Gum Ciftus.}

A middling ftrong Thrub, ftem very branchy, five or fix feet high-the leaves. (middling) fpear-hape, 
fmooth above, with the foot-ftalks joining at the bafe and theathing; and white flowers, in umbels, fpotted at the bafe; June, July, \&c. the whole plant gummy. -Native of Spain and Portugal.

\section{Varieties.-Common fpotted-flowered Gum Ciftus. Entire-white-flowered, without fpots.}

\section{C1stus incanus, Hoary-leaved Ciftus.}

A moderate fhrub, ftrongifh ftem, having many hairy branches-the leaves (middling, wbitif) ob-ovate spatula-thape, hoary, rougin, with the interior bafe, theathing and joining; and reddin-purple flowers; June, July, \&c.-Native of Spain and Narbona.

\section{Crstus monspelienfe, Montpelier Gum Ciftus.}

A moderate fhrub, flenderifh ftem, very branchy, four feet high-the leaves (narrow, dark-green) linearfpear-fhape, both fides hairy, three-nerved, and fefile or fitting clofe; and long peduncles, fuftaining many white flowers:; June, July, \&c.-Native of France.

\section{Cistus albidus, White-leaved Ciftus.}

A middling fhrub, branching ereet, four or five feet high-the leaves (midaling, wbite) ovate-lance-fhape, hoary and white, three-nerved, fefille or clofe-fitting; and large, bright-purple flowers; May, June, July, \&c.-Native of France and Spain.

\section{Cistus creticus, Cretan Gum Ciftus.}

A fmaller fhrub, the ftem branchy, three or four feet high-the leaves (middling) fpatulate-ovate, without nerves, rough, and baving foot-ftalks; red flowers, having the leaves of the calyx fpear-thape.-Native of the Inland Creta, and in Syria.

\section{Cistus falvifolius, Sage-leaved fpreading Ciftus.}

A fmall Thrub, three feet high, the ftem flender, branching horizontally and fpreading-the leaves (middling) ovate, hairy on both fides and foot-ftalked; and long peduncles or flower-ftalks, having one or two white flowers; June, July, \&c.-Native of Italy, Sicily, and Narbona.

\section{C1stuscrifpus, Curled or waved-leaved Gum Ciftus.}

A moderate (hrub, three or four feet high-the Leaves (long, narrow, whitiß) fpear-thape, three-nerved, downy, and the borders waved and curled; and deep-purple flowers at the end of the branches; June, July, \&c. - Native of Portugal.
10. Crștus ḅalimifolius, Sea-Purflane-leaved Ciftus.

A middling thrub, branching four or five feet high, of bufhy growth-the leaves (middling, very white) oval, obtufe, hoary; two leaflets of the calyx linear; and large, yellow flowers, on very long footftalks at the ends of the branches; June, July, \&c. - Native of Portugal, near the fea.

\section{Varieties.-Broad-leaved, Sea-Purflane-leaved Ciftus \\ Narrow-leaved, Sea-Purflane-leaved Ciftus.}

\section{Crstus pilofus, Hairy-leaved Ciftus.}

A middling, frong fhrub, ftem very branchy, of bufhy growth, three or four feet high - the leaves (middling) ovate, very hairy, and petiolated or foot-italked; and purple flower terminating the branches; May, june, \&c. $\rightarrow$ Native of Italy and Spain.

\section{Cist us libanotis, Rofemary, narrow-leaved Cifus,}

A moderate fhrub, ftem purplifi, branching three or four feet high; the leaves revolute, linear and narrow; and white flowers in terminal umbels.-Native of Spain.

\section{C1stus apenninus, Apennine Mountain Ciftus.}

A fmall, fhrubby plant, of low, flender, fpreading: growth-the leaves (fmall) fpear-fhape, hairy, the under fide hoary, and white flowers.-Native of the Apennines and Italiar mountains.

\section{C1stus.bumilis, Dwarf Thyme-leaved Ciftus.}

A fmall, under-Mrubby plant, of very low growth -the leaves (very fmall) linear, narrow, two-furrowed. underneath, and hoary; a fmooth calyx, with white flowers.-Native of Montpelier.

\section{Cistus Heliantbemum-(Helianthemum) or Sun-} flower Dwarf Ciftus.

A fmall, under-fhrubby, trailing plant, of flender growth-the leaves (fmall) oblong, revolute, fomewhat hairy, with fpear-hape ftipula; and largifh, ycllow flowers.-Native of Europe, in dry paftures, \&ec.

\section{Cist us italicas, Italian Dwarf Ciftus.}

A low, under-fhrubby plant, ftem erect, branches oppofite, Spreading - hie leaves (very fimall). oppofite, lowes 
lower ones ovate, the upper fpear-Shape; and pale flowcrs.-Native of Italy.

Thus far comprifing the principal hardy fpecies of Mrubby Citus, their merit for garden culture, is to adnit them ai ornamenta! crerereens aisd beautiful flcwering-thrubs, in pieafure-ground compartments; in which it may be oblerv : d, thit as in their native places of growth, tiley n:oitly inhabit dry, warm foils, may generally be pianted in finilar fituations, in thrubberies, sc. or ivill fucceed in any comimon, toicrably dry ground; and if fomewhat theltered compartments, it will be of advantage to the plants in winter, when fevere frolt; though they may alio be planted in any expofure, in affemblage with other ever-greens and flowering-Thrubs, where they may be required; but the Cretan Ciftus, and Cijzus balmifulius, being of rather more tender cuality, in wirter, tian molt of the others, particularly the latter, they fhould generally have a warm, dry fituation; however, in our ordinary feafons, the fpecies in general here enumerated, wiil moltly fand all weathers, and may all be propagated plentifully by feed, layers and cuttings.

However, as mof of thefe hrubs are liable to fuffer, more or lefs, in very fevere winters, it will alfo be proper, where convenient, to have fome of the principal or defirable forts planted in pots, in order for placing under thelter in rigorous frofts, in a frame or glars care, or under awnings of mats, \&c. with other ihrubs of fimilar temperature; efpecially in their young growth, the firit year or two after being raifed from feed, \&c.

All or moft thefe fpecies of $C_{i f f u s}$ are cultivated in the nurferies, for fupplying thrubberies and other compartments in pleafure-grounds, either in full collection, or of any particular or defirable forts required, for planting in the proper feafons, autumn or fpring; and when defigned to propagate or raife any of the forts, it is effected by fowing the feed in the fpring, in a bed of light earth; and by layers and cuttings in the fame feafon and early part of fummer.

Thefe ever-green flowering-fhrubs of the different fpecies, are defirable furniture to introduce in principal thrubberies, for ornament and variety, or to beautify any compartments, borders, \&c. of pleafuregrounds; difpofed, more or lefs forward, according to their fizes, difinguifhable to fight at all feafons; or fome principal forts likewife planted in pots.

In their general growth they are moftly branchy and buthy; many of them rifing with an ereet ftem, branching on every fide, their whole length; fome grow more Shrubby-like, advancing with feveral ftems from the bottom; others are low, under-fhrubby plants; and the whole difplay a pleafing diverfity in their different growths, of from a foot or lefs, to two, three o: four, to five or fix feet; fome ereet, others fpreading, and fome procumbent; as alfo in their various foliage, in the different fpecies, at all feafons, and numerous, ornamental llowers in fummer, fome very large and fpreading, cthers middling, and fome fmaller; appearing fome in May, or the whole principally in June or July, till Aliguft; all confpicuous and of long continuance in daily fucceffion; for though they are only flowers of a day, or the fame flowers being but of one diay's duration, they are fucceeded by new ones every following day, abundantly for feveral weeks, in moft of the fpecies, and in many of which are fucceeded by ripe reeds.

Several fpecies of thefe Cifufes are remarkable for imparting a gummy'matter from the furface of their leaves and thoots, efpecially in hot weather; which, in the places where they grow naturally in great abundance, is collected for nedical preparations, efpecially Gum Ladanum or Labdanum.

The beft feafon for planting thefe fhrubs is principaily either in autumn, about September, October or November, or in the fpring, in March and April, when the weather is fettled in mild.

They may be introduced botin in compartments of ever-greens, and in any general Thrubbery compartments, compofed of ever-greens and deciduous thrubs, in affemblage, and in borders, \&c. contiguous to principal walks and lawns; and fome planted in pots, to move to any particular compartments, occafionally.

To propagate there hrubs, it may be performed both by feed, as before obferved, and by cuttings of the young thoots, alfo by layers.

Sow the reed generally in fpring, about March or A pril, either in a bed or border of light earth, and molded in half an inch to an inch deep; or fome fowed in pots, and thofe plunged in a hot-bed, to forward the germination of the feed and growth of the young plants, which muft have plenty of air admitted; they, in either method, when come up, and when two or three inches high, if very thick, fome may be thinned out and pricked in a border, or fome fingly in pots, or the whole pricked out the following fpring; giving them protection in winter from revere frolt, and in fummer, occafionally watered; and according as they increafe in growth, may be tranfplanted in nurferyrows, one or two feet diftance; or when of one, two or three feet fize, are proper for final tranfplanting in the Shrubbery, or where they are intended; in which, if convenient, to remove them witl fmall balls of earth to the roots would be of particular advantage.

By cuttings, there thould be of the young fhoots, in April, May or June, planted either in a Nhady border, or feveral together, in largin pots of good earth. 
earth, for moving to a fhady fituation, occafionally in fummer, and to fhelter in winter; cr fome cuttings planted in pots in fpring, and plunged in any hot-bed of moderate heat, it will forward their ronting fooner, giving the whole thade and neceffary watering, they will all root freely the fame feafon, in fix or eight weeks; and when a little advanced in a top-growth, plant them out, fome fingly in fmall pots, others in a bed or border; give water and thade in hot veather, thelter them in winter, and may afterwards be traniplanted into the full ground.

Likewife by layers of the under-branches, the larger and other kinds may alfo be propagated, layed in autumn or fpring.

In their general culture they may be permitted to advance in their natural, branchy, bufny growth; or any of the large forts may have irregular or low, ftraggling branches pruned; and to cut out cafusl, dead hoots, killed by froft or other accidents.

\section{CleMatIS, (Climber) or VIRGIN's BOWER. Clars and Order.}

Polyandria Polygynia, Many Males, Many Females;

Or Flcwers (Hermaphrodite) baving many Stamina or Males, and many Pifillums or Females.

THE CLEMATIs comprife feveral fpecies of climbing, fhrubby plants, to admit in thrubberies and other compartments of the pleafure-grounu, for variety, as climbers, and fome for theis ormamental flowering; producing long, Shender, trailing ftems, afceuding upon fupport of trees, fhrubs, buines, poles, \&cc. many feet in one feafon; clcathed, fome with compound, winged leaves of many folioles, others with trifoliate, ternate and fimple leaves; and numerous flowers, fingly and in clufters in the different fpecies, blue, red, white, \&cc. each formed of four oblong petals, without any calyx, containing many ftamina and piftillums; fucceeded in the latter by many roundith feeds, terminated by the permanent ftyles, which in fome forts ripen plentifully in this country, others not, and by which the plarits may be raifed; lut as they grow freely by cuttings and layers, they are more commonly propagated by thofe methods.

Charakers.-The flowers hermaphrodite, no calyx or cup; corolla or flower, four oblong, loofe petals; ftamina, numerous, thort filaments, having the anthera attached to the fides; piftillum, many roundincompreffed germira, fupporting awl-thaped ftyles, longer than the ftamina, terminated each by a fingle ftigma; and the germina become roundifh-ccmpreffed feeds, collected into a head, and terminated by the ftyles, forming a tail to each feed.
The Species of the hardy Shrubby CLEMATIS are,

$$
\begin{gathered}
\text { 1. Clematis Viticella-(Viticella) or Virgin's } \\
\text { Bower. }
\end{gathered}
$$

A climbing, fhrubby plant, rifing with many fems or branches, ten to fifteen or twenty feet high-the leaves double-compoind, branching into divifions compofed of many oval, intire foiloles or leaflets,' by threes; and blue and other coloured Howers fingly; June and July.-Native of Italy and Spain, in hedges. (Any foil.)

\section{Varieties.-Common fingle Blue Virgin's Bower. Pnrple-flowered Virgin's Bower. \\ Red-flowered Virgin's Bower. Double-fiowered Virgin's Bower.}

\section{Clematis Viorna-(Viorna) or Purple Ameri- can Virgin's Bower.}

A climbing, fhrubby plant, afcending ten or twelve feet high-the leaves double-compound, of many heart-Thape folioles, by threes, the folioles fometimes trind; and purple flowers fingly, with coriaceous petals; July.-Native of Carolina and Virginia. (Any foil.)

\section{Clematis crifpa, Curled-flowered American Climber.}

A moderate, Mrubby climber, growing four; to five or fix feet-the leaves fimple and three folioled, with the folioles of the leaves both intire and three-lobed; and purple flowers fingly, curled or waved internally; July.-Native of Carolina. (Any foil.)

\section{Clematrs orientalis, Oriental or Eaftern Cle- matis.}

A moderate, thrubby climber, extending eight or ten feet-the leaves compound, nine-folioled, with the leaflets cut, angular, lobated wedge-Thape; and yellow-green flowers, having the petals liury within; April and May.-Native of the Eaft.

\section{Cizmatrs cirrbofa, Cirrhole or Climbing-tell- trilled, Ever-green Virgin's Bowcr.}

An ever-green, Mrubby climber, extending fix or eight feet, branchy and buthy - the leaves fimple, ovate, fometimes fingle, double and ternate; and with climbing cirrhi or clafpers; large, greenifh flowers in winter,-Native of Spain and Portugal. (Any foil.) 


\section{Cleмatis rirginiana, Virginia broad three-leav-} ed Clematis.

A ftrong, fhrubby climber, extending many feet -the leaves ternate or three-folioled, having the folioles heart-thape, fub-lobated angular and climbing; and dioecous, white flowers; June, July.-Native of North America. (Any foil.)

\section{Clematrs V"italla-(Vitalla, White Vine) White, wild Climber, or 'Traveller's Joy.}

A ftrong, Arubby climber, extending twenty or thirty fect-the leaves pinnated, of many heart-fhape, climbing leaflets, by fives or fevens; and many bunches of white flowers; June, July, with feeds, having long, white beards. - Native of England and moft parts of Europe and America, in hedges, \&c.-(Any foil.)

\section{Varitties.-Indented-leaved Traveller's Joy. Intire-leaved Traveller's Joy.}

\section{Clematis maritinza, Maritime or Sea Clematis.}

An under-thrubby plant, crectin and trailing; the ftem fimple, fix-angled-leaves pinnated and linear. - Native near the Adriatic Sea, Venice, and Montpelier.

Thefe eight fpecies of Clematis are very hardy plants, to grow in any common foil and fituation, and to admit in hrubberies and other compartments, for variety in their climbing growth and ornamental flowering; and are all eafily propagated, fome by feed occafionally, or the whole more commonly and expeditioufly by layers, and fometimes by cuttings; each method performed, either in fpring or autumn, or the layers and cuttings alfo in fummer, and will root the fame feafon.

They being mofly trailing and climbing plants, advance with long, flender ftems and branches, extending many feet, in a fwift growth, in their peculiar manner, either trailing on the ground or afcend upon any adjacent fupport, fome in a creeping order, others climbing by their tendrils or clafpers, attaching themfelves to trees, buthes, hedges, \&c. and as they afcend, flower at the joints, in their refpective feafons, feveral of which appear very ornamental ; others, though lefs confpicuous, difplay an entertaining variety; and therefore the plants confidered as climbers, are proper to introduce in particular compartments, where they can have fupport, or fome to run over rural bowers, arbours and feats, more particularly the Common Virgin's Bower, for the fuperior beauty of its flowers, which is alfo eligible to train againft walls, trellifes, poles, \&c. in any confpicuous fituation; and which, and the other forts, may alfo be admitted in fhrubberies, wood-walks, wildernefs compartments, receffes, to afcend upon trees, fhrubs, bufhes, or other fupport ; in all of which, they will have an agreeable effect in their climbing growth, various foliage and flowers; but of which, the Clematis Viticella, or particularly the double variety thereof, exceeds moft of the others in its ornamental Aowers; however, all, or any of the other forts, are eligible to admit in the order above-mentioned, for variety, and to diverfify particular diftricts, where thought neceflary.

Moft of thefe plants are raifed in the nurferies for fale, where any defirable forts may be procurcd for planting.

They may he planted in autumn or fpring, or almoft any time in mild weaticr, from Oetober, to March or April.

They are propagated fometimes by feed, fowed in autumn or fpring; but principally by layers, in fpring and fummer, which will foon emit roots the fame year; clufing the young thoots, or branches furnifhed therewith; peg them down in the ground, and lay the thoots in earth, the ftem of each two or three inches deep, the top continued upright, a few inches above the furface; they will be fufficiently rooted to plant off in autunin; or likewife cuttings planted in the fpring will be rooted the following fummer: and in all of which, when the plants have advanced in top-fhoots, of one, two or three years growth, they are proper for tranfplanting where they may be required.

When in the allotted compartments in the pleafureground, \&c. being planted where they may have fupport, conduct the ftems thereto; or where any are againft arbours, walls or trellifes, train them with fome regularity, and in their advanced growth, prune out weak, or very crouding and irregular wood, or where any extend out of bounds, fhorten them accordingly; but thore planted to afcend up trees, poles, scc. may run in their natural order.

\section{Clethra-(CLETHRA)}

$$
\mathrm{Clars} \text { and Order. }
$$

\section{Decandria Monogynia,} T'en Males, One Female;

\section{Or Flowers (Hermapbrodite) baving ten Stanina or} Males, and one Piffillum or Female.

THIS genus Clethra furnifhes but one fpecies, a deciduous flowering-(hrub, of upright, moderate growth, having oblong leaves, and terminal rpikes of white, ornamental flowers, of five petals, fucceeded by roundifh capfules, filled with angular feeds; not always ripening plentifully in this country: are obtained 
from America for fowing, or the plant propagates by layers, cuttings, and fuckers.

Generic Charaders. - The flower hermaphrodite; the calyx one-leaved, five-parted, and permanent; corolla or flower, five oblong petals, longer than the cup; ten ftaminas the length of the petals, crowned with oblong, erect anthera; piftllum, confifting of a roundifh, central germen, an erect, permanent ftyle, terminated by a trifid ftigma; and the germen grows a roundifh, trivalved capfule, full of angular feeds.

\section{One Species, viz.}

CL et r a alnifolia, Alder-leaved Clethra.

A moderate thrub, five or fix feet high-the leaves (middling large) oblong fpear-fhaped, fawed, and placed alternate; and fpikes of white flowers at the ends of the branches; July.-Native of Carolina, Virginia, and Penfylvania. (Moifz ftuations, or any common foil.)

This being an ornamental flowering-Thrub, demands a place in principal thrubberies; delights moft in moift ground, but will grow in any common foil and fituations: may be obtained at the nurferies for planting, in autumn or fpring, generally allotting it fome principal compartment in a confpicuous fituation, in which it will make a pretty appearance when in flower, and effeet variety in its general growth.

It is propagated by layers, cuttings, fuckers, and occafionally by feed; by layers and cuttings the woung fhoots are proper, in autumn or fpring, they will be rooted, fome probably by the autumn following, or fometimes not fufficiently till the fecond autumn; or may lay young thoots of the year in June, to root fooner; and cuttings of the young fhoots may be planted in the fpring, in a thady border; likewife fuckers from the root, digged up with fibres, form at once rooted plants, which fet in a nurfery for a year or two; and when the plants, by either method, are of two or three feet growth, they are proper for the fhrubbery.

By feed, generally obtaincd in the fpring, fow it in March or April, in a bed or pot of good earth; give occafional hade and water in hot weather; and when the plants are a year old, tranfplant them in the nurfery till of proper fize, as above.

\section{Cneorum, WIDOW WAIL.}

$\mathrm{Cla}$ ss and Order.

Triandria Monogynia,

Three Males One Female;

Or Flowers Hermapbrodite, having three Stamina or Male Frualifications, and one Pifillum or Female.

THE CNEOR U M comprifes but one fpecies, a fmall buhy ever-green, for the fhrubbery, flowering orna- mentally great part of fummer and autumn; is clofely adorned with fmall leaves, and many fmall, yellow flowers, fingly, of three narrow petals, fucceeded by a globular, trilobated, dry berry, having three feeds: ripe in autumn, and by which, fowed in autumn or fpring, the plant is propagated, alfo by cuttings.

Characters. - The flower hermaphrodite; calyx fmall, tridented, and permanent; corolla, three oblong. narrow petals, erect; three ftamina, ereet, and thorter than the flower, crowned by fmall anthera; a central, obtufe, three-cornered germen, having a fhort, erect ityle, terminated by a fpreading, trifid ftigma; and the germen becomes a globular, trilobated, dry berry, of three round feeds.

One Species, viz.

CNEOR U M tricoccum, Three-feeded Cneorum or Widow-Wail.

A low, ever-green thrub, clofely branching and bufhy, three feet high-the leaves (fmall) oblongoval, narrow, and clofely placed; and yellow flowers, fingly, in May or June, to the end of the fummer.Native of Spain and Narbona. (Dry fituation or any.)

This dwarf, ever-green fhrub, being ornamental both in its clofe, bufhy growth, and long continuance in flower, claims a place in all principal Shrubbery collections, allotting it a front fituation; either in affemblage, chiefly in ever-green clumps, \&xc. or towards the front of other compartments; in a dry, gravelly, or any foil as may be convenient: may be had at the nurferies for planting, in autumn or fpring, and is eafily raifed by feeds and cuttings in the fame feafons; and young plants often rife naturally from fcattered feeds.

To propagate the plant, fow the feed in the autumn or fpring, but if the former feafon, they will generally come up more freely the fpring following; fowing it half an inch to an inch deepin any light earth; and when the feedlings are one year old plant them in a nurfery; and may plant cuttings or flips of the young thoots in a fhady border, or forwarded in a lot-bed in the fpring.

In either method of raifing the plants, they, when advanced in the nurfery twelve to eighteen inches, or two feet, may be planted in the Ihrubbery; there proceed in their natural growth.

$$
\begin{aligned}
& \text { Colutea, BLADDER SENNA. } \\
& \text { Clafs and Order. } \\
& \text { Diadelphia Decandria, } \\
& \text { Two Brotberboods, Ten Males; }
\end{aligned}
$$

Or Papilionaccous Flowers, baving two Sets of Stamina or ten Stamina or Males in two Sets or Brotberboods.

THE CoLuTEa furnithes three hardy deciduous flowering-Thrubs, defirable furniture for Mrubbery 
plantations; are of large and moderate growth, garnifhed with pinnated leaves, of many pair of oval and hearted folioles or leaflets, terminated by an odd or end foliole; and long loofe clufters of papilionaceous or butterfly-fhaped, yellow, and red flowers, with unequal petals, confiting of a ftandard, two wings, and a carina or keel below, fucceeded by large, inflated, bladder-thaped pods, of one cell, containing many kidney-fhaped feeds: ripe in autunın, and by which the fhrubs are generally propagated.

Generic Cbaracters.-The flower hermaphrodite; of the papilionaceous or butterfly-thaped kind; the calyx bell-hape, monophyllous, five-dented and permanent; corolla or flower, four unequal petals, confifting of a large ftandard above, two fide-wings and a carina below, all varying in thape; ftamina, ten filaments, in two fets, nine being joined, one ftanding feparate, each crowned bv fingle anthera; a piftillum, confifting of an oblong central germen, an afcending ftyle, terminated by a linear, bearded ftigma; and the germen grows an inflated or fwoln, bladder-like, unilocular pod, furnifhed with feveral kidney-fhape feeds.

\section{The hardy Species of COLUTEA are,}

1. Colutea arborefcens, Tree Colutea, or Common Bladder Senna.

A large deciduous fhrub, eight to ten, or twelve feet high; the ftem tree-like-leaves winged or pinnated (middling, ligbt-green) of four or five pair and an end foliole; the folioles obcordate-oval; and pale, yellow flowers, in June and July.-Native of France, Italy, and Auftria. (Any common foil.)

$V$ arieties.-The two following are fuppofed accidental varieties of the common fort.

\section{Colutea media, Middle or Pocock's Ihrubby Colutea.}

A middling thrub, (deciduous) more flender, fpreading branches, fix to feven, or eight feet higli; the ftem thrubby-leaves pinnated (middling $f_{i} z e$ ) of eight or nine pair and an odd foliole, the folioles oval, intire ; and bright, yellow flowers; May or June.-Native of the Eaft. (Dry or any foil.)

\section{Calutea orientalis, Oriental Shrub Colutea.}

A middling thrub (deciduous) branching in a regular head, fix or feven feet high-leaves pinnated (middling fixe) of five or fix pair and an end foliole, heartmaped; and dark red flowers, fpotted with yellow; June or July.- Native of the Levant. (Dry or any Soil.)

All thefe fpecies and varieties are of hardy growth, to fucceed in any common foil and fituation; and are principal thrubs to aftemble in Mrubbery clumps, and other decorative plantations of middling Rrubs and trees, in pleafure grounds, in which they will effect a diftinguifhable variety and ornamental appearance in fummer, in their pinnated leaves, numerous papilionaceous flowers, and curious inflated or puffed, bladderlike pods; efpecially if in difpofing them in the allotted compartments, they are judiciounly placed, more or lefs, behind or forward, according to their growth, and that of the other fhrubs, with which they are to affemble, fo as the whole may be diftinctly confpicu. ous.

'They may be obtained for planting, at all the public nurferies, in proper growth, of two or three, to four or five feet; and the planting performed in autumu, or any time in open weather, from October to March, or April ; and are propagated or raifed abundantly by feed, and occafionally by layers.

The propagation or raifing thefe fhrubs is generally by feed, in the fpring, fowed in a bed of common earth, either in drills or broad-caft, and earthed in an inch deep; or may alfo try layers, in the fame feafon, or in autumn, of the young thoots: the feeds will foon vegetate and the plants come up freely, and attain fome tolerable growth by the end of fummer; and the layers will be rooted for planting off in autumn or fpring; when tranfplant the feedlings from the feedbeds, and alfo the layers from the ftools, each in nurfery-rows, to acquire eligible fize for the hrubbery or other plantation diftricts intended.

When the feedling-fhrubs, and others, raifed as above, are from two, to three or four feet high, they are of proper growth for final planting, in fhrubberies and othe: places, where required, for ornament and variety.

The general feafon for planting thefe fhrubs is either in autumn, at the decay of the leaves, or in the fpring, or even any time from October or November to April ; obferving generally in planting, if any have long perpendicular tap-roots, they thould be pruned, that they may throw out lateral roots horizontally, after being planted.

In their general growth, they require but very little culture, only to prune up low, ftraggling, or cafual, rude thoots, in the head.

CORIARIA (Tanner's Shrub) Or MYRTLE-LEAV. ED SUMACH.

Clafs and Order.

Dioecia Decandria,

Two Habitations Ten Males;

Or Flowers Male and Female, difinct, on two separate Plants; and the Male Flowers having ten Snamina.

THIS Genus affords but one hardy fpecies a fmall flowering-hrub, of the deciduous tribe, of thicketty, 
buffy growth, garnifhed with imall, oblong leaves, and fikes of whitith flowers, male and females on feparate plants, of five oval petals; and fucceeded in the females by an angular berry, with five feeds, which are feldom ufed for fowing, as the plants propagate plenteoufly by fuckers.

Characters.-Flowers male and female, feparate on two different plants, having a calyx five-leaved; a corolla or flower, five oval petals attached to the cup; and in the male flowers ten ftamina, crowned by oblong anthera; the females furnifhed with a piftillum, becoming an angular berry, containing five kidneyfhaped feeds.

\section{One Species of hardy CORIARIA, viz.}

Coriaria myrtifolia, Myrtle-leaved Sumach.

A fmall inrub, with many flender ftems, three or four feet high-the leaves ( inall) ovate-oblong, and fmall fpikes of whition flowers in fummer.-Native of Montpelier, in France. (Loamy or any foil.)
Varieties.-Male Coriaria, producing male flowers only.
Female Coriaria, producing female flow- ers only.

Thefe fhrubs having creeping roots, fend up many fucker-Items in a thicketty growth; is employed in fhrubberies for variety, and to fupply vacancies, where a full growth is required in any particular compartments: they may be had at molt of the nurfories, for planting, in the proper feafons ; and may be propagated pletifully by the abundant root-fuckers taken up in autumn or fpring, with roots, and planted in a nurfery for a year or two, or fome at once where they are to remain, or will grow by layers.

In their growth in thrubberies, it does not require any particular culture, only, if thought neceffary, to clear out-fuckers where too confiderably increafed.

\section{Cornus, CORNEL TREE, or Cornelian' CHERRY, Dog-Wood, \&C.

$$
\text { Clafs and Order. }
$$

Tetrandria Monogynia,
Four Males, One Female;

Or Plants, barjing Flowers, containing four Stamina or Males, and one Pifillum or Female Part.

THE Cornel family furnimes three hardy fpecies, and feveral varieties, of moderate tree and thrub kinds, all of the deciduous tribe; employed, principally, for diverfifying thrubberies, as flowering-trees and Mrubs; and fome, occafionally, for their fruit : grow eight or ten, to fifteen or twenty feet high, in the different fpecies; garnifhed in fummer with oblong, oval and heart-hape leaves, of middling fizes; and many fmall, yellowith and white flowers, in umbellate clufters, in a four-leaved involucrum ; with each floret, 2 monophyllous four-dented cup, four petals, four ftamina, and a roundifh germen and flender ftyle; fucceeded by a roundilh berry, including a fmall nut or ftone: ripe in autumn, by which the fpecies are propagated, alfo by layers and cuttings.

Generic CharaEters.-Hermaphrodite flowers, many together in an umbellate bunch, contained in one general involucrum, four-leaved and coloured; a finall calyx one-leaved, four-dented to each flower; the corella or flower, four fmall, plane petals; ftamina, four erect filaments, higher than the petals, crowned by roundith anthera; a round germen under the calyx, having a flender ttyle, terminated by an obtufe ftigma; and the germen grows a roundifh or oval, drupaceous berry, containing a nut, furnithed with an oblong ker. nel.

\section{The Species of Woody CORNUS are,}

\section{Cornus mas, Male, Cornel Tree, or Cornelian Cherry.}

A fmall, deciduous tree, growing fifteen feet high or more; a tree ftem-the leaves oblong obverfehearted; and flower-umbells and involucrums equal; with clofe growing flowers in February or March, fucceeded by cherry like, eatable fruit, for tarts.- $\mathrm{Na}$. tive of Auftria, America, \&c. ' (Any common foil.)

\section{Varieties.-Red-berried Common Cornel Tree, or Cornelian Cherry. White-fruited Cornel Tree.}

\section{Cornus fanguinea, Bloody Twig, Female Cor- nus, or Common Dogwood.}

A fmaller tree or large fhrub, eight, to ten or twelve feet high, with blood-red thoots-the leaves (middling fize) oblong-cordate, pointed; and cymore, naked flower umbells. - Native of England and moft parts of Europe, in hedges, and in America. (Any foil.)

\section{Corn us forida, Florid, Male Cornus, or Virginia Dogwood.}

A large Shrub, eight or ten feet high, with red moots-the leaves (largiß) oblong; and white fowers in corymbus bunches, having a large, white involucrum, folioles obverfe-hearted.-Native of Virginia and other parts of North America. (Any common foil.) 
Varieties.-Common Broad-leaved Virginia Dogwood.

Narrow-leaved Virginia Dogwood.

White-involucrumed Virginia Dogwood.

Red-involucrumed Virginia Dogwood.

Blue-berried American Dogwood.

White-berried Penfylvanian Dogivood.

White-leaved American Dogwoad.

All thefe fpecies and varieties of Cornus are eftecmed principally to plant for ormanent and variety, io pleafure-grounds, \&c. and the Cornelian Cherry alfn, occafionally, as a fruit-trce, in fmall ftandards or in efpaliers, for its cherry-like berries, particularly the red fort: which ripening in autumn, of an acid relifh, are fometincs preferved for making tarts; but the trees of which, in both the varieties, and thofe of all the other fpecies of Cornel, are more generally employed in compofing thrubberies, and in diverfifying any decorative plantations; and for all of which occafions they are eafily raifed abuidantly by feed, layers, cuttings, and grafting.

They are all very hardy, deciduous tree and fhrub kinds, to grow in any common foil and fituation; and from thcir natural growth, modes of flowering and fruiting, are commionly adapted to introduce in ornamental plantations, and any large clumps or other compartments of flowering-trees and hrubs, in pleafure-grounds, in which they will difplay a proper diverfity in their different growths, fome fingular in their red hoots; and the whole effect a confpicuous variety in their different leaves, and umbells of flowers, in fpring and fummer, which in the Cornus mas, and fome of the Virginia Dogwoods, appear early in the fpring, at the fides and ends of the branches, in fmall, clofe umbells; others appearing in fummer, in large, white umbells, terminating the branches and fhoots ornamentally?; fucceeded in moft of the forts by clufters of red, white, blue, and other coloured berries: ripe in autumn, and fome continue in winter; and in which feafon the red-twigged Dogwoods cxhibit an agreeable appearance.

So that for any ornamental planting in large thrubbery compartments, both in clumps and running plaintations, all the fpecies of Cornzs are proper to arrange in aftemblage; and for which may be had at all the nurferies, and planted any time in open weather, from the decay of the leaves in autumn to March.

Likewife the Cornus mas, or Cornelian Chcrry, may be admitted in the fruit-tree collection, particularly the red-berried kind, for its fruit, which in fome families is eftecmed for its acid quality to preferve for tarts; and for which the trees may be trained either in fmall ftandards, in gardens or orchards, or trained in efpaliers, to obtain the fruit in beft perfection: generally ripening in autumn, about September.
All the forts of Cornus are propagated or raifed by feed, layers, fuckers, and fomctimes by cuttings, and occafionally by grafting any particular variety.

By feed or berries, thefe ripening in autumn, may be fowed in that feafon, or in the fpring; but if fowed in autumn they will more certainly all come up next fpring, the others probably not fo freely, or fometimes not wholly till the year following: they may be fowed in any beds of common earth, and covered in an inch or two deep: when the plants come up, give occafional watering in dry weather; and when of one or two fummers growth, tranfplant them in autumn or fpring into a nurfery, trained with a fingle ftem and branchy head; and when advanced two or three, to four or five feet, are of proper fize for final tranfplanting in the places where intended.

Or by layers, cuttings and fuckers; chufe for the two former, the young thoots, which lay and plant in autumn or fpring, and will be rooted by the following autumn, more efpecially the layers; and fuckers rifing from the roots, may be taken off in the autumn or fpring; and all of which planted in a nurfery for a year or two, or till of proper growth, or wanted for the intended plantations.

When, by either of the above methods of propagation, they are raifed to three, four or five feet growth, they are of eligible fize for the thrubbery and other plantation diftricts intended, planted therein at the proper feafon; and in which plantations the principal culture is only to prune out any low, fraggling branches, or to reduce long ramblers of the head.

Or if any of the Cornelian Cherry are planted for fruit-trees, permit the Atandards to advance in full heads, or, occafionally, prune any cafual irregularly, as above; and where any are trained in the efpalier order, arrange the branches to the trellis moftly at their full length, horizontally, four or five inches afunder, and have a regulation of pruning and training annually, as direct. $\mathrm{d}$ for the Common Cherry-Tree.

\section{Coronilla, JOINTED-PODDED COLUTEA, and Scorpion Sena.}

Clafs and Order. $\begin{array}{ll}\text { Diadelphia } & \text { Decandria, } \\ \text { Trwa Brotberboods, Ten Males; }\end{array}$

Or Papilionaceous, Hermaphrodite Flowers, having ton Stamina or Males, in two Sets or Brotberboods.

THE family of Coronilla affords four hardy flowering-thrubs of the ever-green and deciduous tribes, to admit in the hrubbery; all of upright, fmall and mid- 
dling growth, cloathed with pinnated or winged leaves, formed of many pair of fmall folioles, terminated by an odd one; and papilionaceous or butterfly-fhapcd, or pea-bloom, yellow flowers, in bunches and loofe fpikes at the fides and end of the branches; each flower compofed of a heart-hape vexillum or ftandard, two oval vings, and a fhort carina or keel, with ten internal ftamina, an oblong germen, and fingle ftyle; and the germen becomes a Jointed-Pod, containing oblong feed, ripe in autunn, proper for lowing to raife fupplies of the plants, which are alfo propagated by layers.

Charakters.-The flowers, hermaphrodite, papilionaceous-the calyx one-leaved, very fhort, bifid, ereet and permanent; corolla or flower, a heart-haped, and in fome a narrow vixillum or ftandard, two oval or oblong wings, and a hort, compreffed pointed keel or carina; ftamina, ten filaments in two fets, nine being joined and one ftanding feparate, broad at top, crowned with finall anthera; a piftillum, confifting of a long, taper germen, fupporting a briftly, afcending ftyle, terminated by an obtufe ftigma; and the germen grows a jointed taper pod, having oblong, kidney-thaped feeds.

\section{The Species are,}

3. Coronilla coronata, Coronated Jointed-Podded Colutea.

A fmall, ever-green fhrub, two feet high-the leaves pinnated (/mall) of nine ob-oval lobes, the inncr ones approaching the ftalk, with two-parted, oppofite fipula; and clofe bunches of yellow flowers; May or June.-Native of the South parts of Europe. (Warm, dryfotuation.)

\section{Coronilla glauca, Glaucous or Sea-green Co- ronilla.}

A fmall, ever-green fhrub, two feet high-the leaves pinnated, (Small, glaucous or fea-grecn) of feven lobes, with lanceolatc ftipula, and roundifh bunches of bright-yellow flowers, in April or May. -Native of France. (Warm, dry foil.)

\section{CORONilla argenten, Silvery-leaved Coronilla of Creta.}

A fmall, ever-grcen fhrub, two feet high-the leaves pinnated, (finall, fliver-colourcd) of cleven filky filvery lobes, the outer ones largeft, and bunches of yellow flowers, in April or May.-Native of Cre. ta. (Warm, dry fituation.)

\section{Coronilla Emerus-(Emerus) or Scorpion Sena.}

A middling, docidusus fhrub, feven or airht fẹt high-the ftem angular, leaves pinnated (middling, ligbt-green) of feven lobes; and long peciuncles, generally with three yellow flowers; the claws of the co:olla triply longer than the calyx; flowering in May, June, \&zc.-Native of Meflilea and Montpelier. (Any common foil.)

\section{Variety.-Dwarf, Scorpion Sena.}

Of the above fpecies of Coronilla, the firft three are fomewhat tenderifh in winter, more liable to fuffer by fevere froft than the fourth fort; fo hould, generally, have a warm, dry fituation, and fome of each kept in pots, to move under protection of a frame or green-houfe, in rigorous weather, or during the winter feafon; and are likewifc admitted wholly in the green-houfe collection, more particularly, the fecond and third: however, they being planted in a dry foil and theltered fituation, in the full ground, will ftand our ordinary winters tolerably well; but the fourth fort, Coronilla Emerus or Scorpion Sena, is fufficiently hardy to grow in any common foil and fituation, and is more generally known and cultivated as a hardy floweringfhrub, than the others.

They are all defirable furniture, as ornamental flowering-thrubs, to admit in pleafure-grounds, in beautifying the Thrubbery and other compartments: may be obtained at molt of the nurferies, to plant in autumn or fpring; but morc commonly the Scorpion Sena; difpofing the three fmaller ones towards front, in a warm fituation; the other piace any where, more or lefs inward, to affemble with other fhrubs of fipvilar dimenfions of growth; they will make a pretty varicty in their pinnated leaves, and papilionaceous flowers in fummcr.

They are propagated mortly by feeds, and occafion. ally by layers.

By feed, which ripening in moft of the forts in autamn, but more abundantly in the Scorpion Scna, is fowed in March or April; the firft three forts fow in a warm border, the other in any bed of light earth, an inch decp; give water in dry wcather, both before and after the plants arc up; and when thofe of the three former are two or three inches high, prick fome in pots or in a border, watered and fhaded from the fun, till freth rooted; and the fourth fort, having one or two fummers growth in the fecd-bed, hould be tranfplanted in autumn or fpring, in nurfery-rows; and in which the different forts to continue for two or thrce years, or ill of proper fize for the Shrubbery.

Likerife 
Likewife by layers of the young thoots the Coronillas are, occafionally, propagated, or more generally the Scorpion Sena, laying the tender hoots in the fpring, and they will be rooted to plant off in autumn or ipring following, and managed as the fcedlings.

When defigned to plant thefe Coronilla fnrubs, it may be proper to remark, that as they generally run with long, naked tap-roots, efpecially, the Scorpion Sena, it is advifeable to tranfplant them finally into the nirubbery, or where intended, while they are of but moderate growth, in which, the roots being fmaller and more fibroufy, they will fooner root effectually than large plants of this kind; and as to future culture, it is the fame as intimated for other floweringThrubs.

\section{CORYLUS, HAZEL-NUT' TREE, FILBER'T, $\&$ c.}

Clafs and Order.

\section{Monoecia Polyandria,} One Houfe, Many Males;

Or Male and Female Flowers, Separate on the faste Tree, and the Mals Flowers baving many Stamina.

THE Corylus furnithes feveral fpecies and varieties of hardy, deciduous trees and Ahrubs, all of the nuciferous or nut-bearing tribe, proper both to cultivate as fruit-trees, \& c. in gardens and orchards, and in pleafurable plantations, for variety; confifting of moderate tree kinds, ten to fifteen or twenty feet high, and fome of a thrubby growth; garnithed, in fummer, with largifh, cordate-roundin, rough leaves; and male and female flowers, apart, on the fame tree; the males collected in fmall, loofe, fcaly amentums, and the females in large, two-leaved cups, having in each female an oval germen and two briftly ftyles; and the germen grows an oval nut, containing an eatable kernel, each nut inclofed in its large, lacerated cup, defending it to maturity: ripening in Auguft and September, in perfection for eating, and by which the trees are propagated ; alfo by fuckers, layers and grafting.

Characters.-Male and female flowers, growing feparate on the fame tree-the males confifting of many fmall florets, are collected into long, fmall, fcaly amentums or catkins, each fcale including a fmall floret, having each many minute ftamina, crowned with oblong anthera; and female flowers without petals, inclofed in roundith buds, fitting clofe to the branches, furnifhed each with a two-leaved torn cup, fitting under the flower, enlarging and continuing, a round germen in the centre, with two briftly fyles longer than the cup, terminated by fingle ftigmas; and the germen becomes an oval, pointed nut, inclofed in the permanent torn cup.

\section{The Species of CORYLUS are,}

\section{¿. Corrues Avellana-(Avellana) or Common Hazel-Nut 'I'ree.}

A moderate or fmall, deciduous tree, growing ten to fifteen or twenty feet high, or more-the leaves (middling) hearted-roundifh; ovate-obtufe, ftipula at the bafe; and nuts oval, roundih and oblong, in the different varieties.-Native of Britain and moit other parts of Europe, in woods and hedges. (Moif, frong land, or any foil and fituation.)
Farietics.-Common Hazel, of the woods and hedges. (Oval-roundifh nuts.)
Long Wood Nut. (The nuts veryalong.)
Clufter Wood Nut. (Large Nuts in Cluf- ters.)
Great Cob Nut. (Remarkably large, oval- ißh.)

2. Corylus fativa, Cultivated Nut Tree or Filbert, fuppofed a feminal, improved variety of the Common Hazel.

A moderate tree, branching more erect, ten to fifteen feet high, or more-the leaves (largi/ß) heartedroundin, with oblongifh, obtufe ftipula; and larger oblong nuts. - Native, principally, of gardens and orchards. (Rich or any common foil.)

\section{Varieties.-White-kernelled Filbert. Red-kernelled Filbert.}

3. CORY LUS tranfylvanica, Tranfylvanian or Eaftern Nut Tree, fuppofed a Variety of the Common.

A middling tree, twenty feet high or more-the leaves (large) cordate-roundih, and large, roundifh nuts.-Native of Tranfylvania. (Any common foil.)

\section{Corxu us Colurna-(Colurna) or Dwarf Byzan. tine Nut Tree.}

A fmall tree, (mrub-like) four to five or fix feet high-the leaves (middling) cordate-roundifh, with linear, acute ftipula; and large, roundifh nuts.- Native of Byzantium or near Conftantinople. (Any common foil.)
Varisty. - (Corylus barcelona) or Barcelona Nut, fup- pofed a variety of the Bazantian, or probably of the Common; (the nuts large, roundif.) - Native of Spain.




\section{CORYuUs cornuta, Cornuted or Horned American Nut.}

All thofe fpecies and varieties of Corylis are hardy, deciduous trees, adapred to grow in any common foils of a garden; orchard, or that of any tree and Thrub plantations, in pleafure-grounds; and are proper both to cultivate for their production of nuts, as being ail of the eatable kind, and to effect variety in frubberies, \&c. as alfo the Common Hazel, to raife in woods, as a foreft-tree, or principally for underwood, in coppices and hedge-rows; and for which occafions they inay all be raifed abundantly, by fowing the nuts in autumn or fpring; and the defirable varieties, principally, either by layers or fuckers, and, occafionally, by grafting or budding any principal kinds upon Common Hazel Stocks, as the varieties feldom come the fame from the feed or nuts, in thorough perfection.

The Corylus, in all the different fpecies in their mode of bearing, produce the flowers at the fides of branches; the males catkins appearing in winter and fpring. and the females in the latter feafon; and being then impregnated by the farina of the males, they advanc in a flow growth till Auguft or September, defended all the while by the large calyx, which, at the maturity of the fruit, changes brown at top, at which time the nuts are in perfection for eating.

For the different purpofes of planting in gardens, orchards, fhrubberies, \&c. they fhould generally be trained in fmall ftandards, either with quarter, half or full ftems, from two or three, to four, five or fix feet, to branch out above in full heads, in their natural order, in which they will produce plentiful crops of nuts, annually, without much trouble of culture; and they may alfo be occafionally trained in rough hedges, in particular diftricts, to run up at top, in a natural growth, without cutting; or in the fame manner, may have filberts in fingle or double ranges, to form thady walks; and in both of which, all the forts will bear very agreeably in plentiful productions.

To cultivate as fruit-trees, fome of all the forts may be admitted in gardens and orchards, both in quarter, half and full ftandards, as before obferred, to branch out above in full heads; and for which may have any of the principal varieties of the Common Hazel Nut, but more abundantly of the two varieties of Filbert, for the fuperior excellence of their large nuts, with kernels of the fineft flavour; and may alfo have fome trees of the Tranfylvanian, Byzantine and Barcelona kinds, all which produce nuts of large fize; though the Filbert claims precedence for general culture in their more plentiful production of fineft fruit, fooner acquiring maturity in fulleft perfection of ripenefs in the kernels, in Auguft and September.
Likewife in thrubberies, and other plantations, in pleafure-grounds, may introduce all or any approved fpecies and varieties of Corylus, both of the Common Hazel kinds, Filberts and other forts, trained in fmaller or larger ftandards, fuitable to different compartments, and difpored in affemblage with any hardy trees and fhrubs, and on the borders of wood walks, thady walks, \&rc. in which they will add to the collection, and effect a pleafing diverfity, both in their growth and production of fruit.

And to cultivate as foreft-trees or underwood, the Common Wood Hazel is of confiderable utility, more particularly in plantations of under-growth, in clofe coppices and in hedge-rows, to run up to ftems of larger or fmaller fize, to cut for poles, exceedingly ufeful in numerous occafions, as hurdles, hoops, \&c. and being raifed in clofe growth, each plant may run up with feveral ftems in their natural order, to cut once in five, fix or feven years, as they will thoot out again in numerous bottom-fuckers and ftems; or fome may be left fingle, for ftandards, clearing away all fuckers to one main ftem on each ftool; and to prune up the faid ftems from lateral branches, that they may advance in a clean growth for larger wood.

All or moft of the principal forts of Corylus, are raifed in the public nurferies, in which they may be obtained in a collection, or as may be required, for furnifhing garden plantations, both in fruit-trees and for variety; but for any confiderable planting, they may be expeditioufly and abundantly raifed with great facility, in the feveral methods of propagation.

They will ficceed in any common foil and fituation; and the Common Hazel, where required in large fupplies, in coppice-wood, \&c. may be cultivated in any ftrong, moitt land, or in low or high ground, in moift or dry foils, as the prcmifes afford, or where thought convenient or eligible to have plantations thereof.

The feafon for planting thefe trecs of the different fpecies and varieties of Corylus, is any time in open weather, from Oetober or November, to March or beginning of Aprit.

For planting, may cither, occafionally, have ftrong fuckers arifing fron the roots of the trees, cliufing thofe of one or two years growth, two to three or four feet high, taken up with good roots; and planted at once where they are to remain, they will foon advance in confiderable growth, in full heads, and produce fruit of thcir refpective varieties; or have trees that have been previoufly trained in a nurfery, raifed either from fuckers, layers or nuts, \&c. to three, four or five feet growth; though it hould be remarked, that for the approved varitties, both of the Common 
Hazel and the Filberts, thofe raifed from fuckers and layers, more certainly produce fruit the fame in their relpective propertics, which is not the cafe in feedling-plants; for although the Filberts will fometimes come the fame from the nuts, yet the fruit is generaily inferior in fize and goodnefs, and the plants longer before they bear than the fucker and layer-raifed trees, or generally the layers are preferable to the fuckers; or thefe forts (Filberts) are alfo fometimes propagated by grafting, as an effectual method to continue the permanency of the two varieties thereof.

The propagation or method of raifing thefe trees being by nuts, fuckers, layers, and grafting, each is according to the following praftice.

By nuts, thefe may be fowed in autumn or fpring; or to avoid their being devoured in winter by vermin, ordeftroyed by the weather, they may be preferved in a box of diy fand, in a cellar or other clofe apartment, until February, then fowed; performing it either in drills, a foot afunder, and two inches deep, or the earth raked off the top of the bed, the above depth: fow the nuts thickly on the furface and earth them over evenly; and when the plants are come up of one or two years.growth, tranfplant them in nurfery-rows, in which to advance two or three years or till of proper fize for final tranfplanting.

By fuckers, thefe rife plentifully from the roots of old trees, and when of one or two years growth, they may be digged ap in autumn, winter, or fpring, with roots, forming at once proper plants, and may be planted in a nurfery, or large ones at once, where they are to remain.

Or by layers, this is an effectual method by which to propagate the principal varieties, to continue them permanent in their refpective kinds, fuch as the Filberts or any other forts; and which is performed in the young wood in autumn or fpring, bowing down fome pliant lower branches, peg them fecurely into the earth, then lay the young hoots thereof, admitting the ftem of each three or four inches deep, keeping the top upright feveral inches above ground; they will root freely, ready for planting off next autumn, into a nurfery for a year or two, or till of a proper growth for garden plantations; and will produce fruit fimilar to that of the parent tree.

Alfo by grafting, may propagate the Filberts, or any other particular forts, having feedling or fucker-ftocks of the Common Hazel or Filberts, raifed two to three, or four feet high, or more; and upon which perform the grafting in February or March, with grafts of the defirable kinds; inferted either low in the ftock, and the firft main-thoot of the graft run up, more or lefs, for a ftem, or grafted at two, three, or four feet height; and in either method permit them to branch out above in full heads.

In the above different methods of propagating thefe trees, they, in their advancing growth, may be trained each with a fingle ftem, either low, of one, two, or three, to form dwarf trees, or with four or five feet ftems, for taller ftandards; and fo agrecable to there intimations, cut away lateral hoots below accordingly, to the height the ften is intended, and then permitted to branch out freely above, in their natural manner; or for particular occafions, fome may advance with feveral ftems from the beginning, in a branchy, buhy growtl.

When intending to plant thefe trees in gardens, orchards, \&c. in ftandards, fuch as Filberts, or any other principal kinds, they may be planted at ten, to fifteen or twenty feet diftance; or if only in one fingle row in any particular parts, ten, or twelve feet may be fufficient; or may occafionally plant fome to form Nut and Filbert hedges, planted three to four, or five feet afunder in the row, to run up in full growth without cutting; or fometimes planted in the fame manner, in double or fingle range, for a thady Filbert walk, permitted to run up in a natural order below and above; but generally obferving, that where planted in detached ftandards, it is proper to keep them clear below from bottom-fuckers, as alfo to cut away Atrong, rambling thoots, from the ftem and head; or alfo any planted in a clofe row in gardens, hedge-fanion, that as they will encreafe in numerous fuckers in a thicketty growth, the fuckers hould be eradicated occafionally in the fides, to keep the bottom within fome regular limits, more open to admit the fun and air, and to encourage and continue the upper parts in a good ftate of bearing, which will alfo have the fame effect as the ftandards.

The fruit, or nuts of thefe trees, ripen in autumn, principally in Auguft and September, in which their mature ripenefs is generally when the outer cover or cup, in which the nuts are contained and inclofed, begin to change brown, or when the nuts readily quit the faid cover; for if gathered before they attain that ftate of maturity the kernels have not their proper flavour, but eat watery and infipid; or however, hould not be gathered generally before they acquire tolerable perfection, only when required to have fome as foon as they begin to ripen, gather but a few at a time, as wanted for immediate eating; and when required for keeping any confiderable time, they thould be ripe in the fulleft maturity: are generally gathered in their hufks, except when dead ripe, in which they naturally drop out, or may eafily be detached from the cups; that to preferve them for future ufe, depofit a quantity, when thorough ripe and dry, in a box, cafk, \&c. and clofe covered with ftraw, a foot thick, or more. 
Where it may be defigned to have a coppice of the Common Hazel, they may either be planted in fuckers, in rows, three or four, to five or fix feet afunder; or the nuts fowed in drills, that diftance, to remain.

\section{Crategus, WILD SERVICE, and HAWTHORN, \&C.}

Ciafs and Order.

Icorandria -. Digynia,

Twenty or more Males, Trwo Females;

Or Plants with Hermapbrodite Flowers, having twenty or more Stanina or Males, and two Piftillums or Females.

THE CRATEGUs comprifes a large family of many fpecies and varieties of deciduous, berry-bearing trees and Thrubs, for ufeful and ornamental planting, fome of which both for fruit-trees in gardens and orchards, and for variety in thrubberies, \&c. others molt valuable for hedges, (the Hawtborn) and the whole to arrange in decorative plantations; are of fmaller and larger growth in the different fpecies, ten, fifteen, to twenty or thirty feet high, moftly armed more or lefs with thorns, and in fummer cloathed with fimple leaves heart-Thape-lobated, three-lobed, oval, fpear-Thape, \&c. and numerous umbellate bunches of fmall white flowers in May and June, compored each of a fiveparted cup, five roundinh petals, many ftamina, and two ftyles; fucceeded by bunches of fmall and large, roundifh, flethy berries, with two feeds: ripe in autumn; and by which, fowed in autumn or fpring, the trees are raifed, alfo by layers, grafting and budding.

\section{The Species of CRAT ÆEGUS are,}

3. CRAT IEGUstorminalis, Torminal-fruited, or Common Wild-Service Tree.

A middling or largith tree, growing thirty or forty feet high, or more-the leaves (moderate fize) hearted, feven-angled, the lobes divaricated afunder; and bunches of brownith-red, eatable berries.-Native of Fingland, Germany, Switzerland, Burgundy, \&c. (Loamy or any foil.)

\section{Varieties.-Sawed-leaved Wild-Service. Round-leaved Wild-Service.}

\section{CRAT ECUS Oxyacantba-(Oxyacantha) Hawthorn} or White-thorn Tree.

A fmall or moderate tree, of bufhy growth, growing fifteen or twenty feet high-the leaves (Imallifh, dark-green) obtufe, fub-trifid or three-lobed, and-fawed; flowering in May and Jnne: the haw-berries ripe in autumn.- Native of molt parts of Europe, and of great value for hedges. (Any foil.)

Varieties.-Common, fingle-blofromed, Red-berried Hawthorn, White-thorn or Quickfet.

Double-bloffom Hawthorn.

Scarlet-beried Hawthorn.

Yellow-berried Hawthorn.

White-berried Hawthorn.

Glaftonbury, Early-blowing Hawthorn, or Glaftonbury Thorn.

Maple-leaved Hawthorn.

\section{Crat AE us Aria-(Aria) White-Beam or White- leaf Tree.}

A middling large tree, growing thirty or forty feet high-the leaves (largifh, whitifh-green) ovate, unequally fawed, and hoary underneath.-Native of England and moft parts of Europe. ('.oamy, chalky, or any foil.)

\section{Variety.-(Cralcgus Aria fuecia) or Swedin White- Beam Tree-branches thornlefs; the leaves elliptic fawed, tranfverfe finuat- ed, and hairy underneath.-Native of Sweden and England.}

\section{Crategus Azarolus-(Azarolus) or Azarole Thorn.}

A fmaller tree, eighteen or twenty feet high-the leaves (largiß) obtufe fub-trifid, or fomewhat threelobed and a little indented; and bunches of largin, red, eatable berries; in autumn.-Native of Italy and Montpelier. (Any common foil.)

Varieties._Strong-thorned Azarole.

Thornlefs Azarolc.

Jagged-leaved Azarole.

Double-flowered Azarolc.

Large, Red-fruited Azarole.

Smaller, Yellow-fruited Azarole.

Long-fruited Ararole.

(Aronia) or Eaftern Parfley-leaved Aza. role.

\section{Crategus coccinea, Scarlet-fruited Azarole} Thorn, or Great Amcrican Azarole.

A fmaller tree, twenty feet high-the leaves (middling) ovate, repand or waved..angulated, fawed, and fmooth; large, fcarlet fruit.-Native of Virginia and Canada. (Any common foil.) 
6. CRATEGUS Crus-galli-(Crus-galli) or Cock-fpur Thorn, or Virginia Azarole.

A fmaller tree, eightcen or twenty feet high-branches thorny, robutt fpines; the laves (middling) fpearrhape-ovate, fawed and fmooth; and large, red berries.-Native of Virginia. (Any foil.)

Varieties.-Long-thorned Cock-fpur Thorn. Short-thorned Cock-fpur Thorn. Pear-leaved Cock-fpur Thorn. Plum-leaved Cock-fpur Thorn. Willow-leaved Cock-fpur Thorn.

7. CRAT 2 GUS tomentofa, Downy, Goofeberry-leaved Cratagus.

A fmaller tree, ten or fifteen feet high-the branches thorny; leaves (moderate) wedge-forn-ovate, fomewhat angulated, fawed and downy-hairy underneath; and yellow fruit.-Native of Virginia. (Any fituation.)

\section{Crategus riridis, Green-leaved, thornlefs Cra- tagus.}

A fmall tree, ten or fifteen feet high-branches thornlefs; the leaves ( $\mathrm{mall}$ ) lance-ovate, fomcwhat three-lobed, fawed, and fmooth, green on both fides. Native of Virginia. (Any foil and fituation.)

Thefe fpecics and varieties of Cratxgus are all of very hardy growth to plant in any common foil and fituation; their principal merit is, in the greater part, to diverfify tree and thrub plantations in pleafuregrounds; fome alfo for their production of fruit, and the Common Hawthorn, in particular, for hedges: are all of the deciduous tribe, garnifhed with leaves, from May to Oetober; flower moftly in May and June; the flowers principally white, produced in bunches at the fides and ends of the branches, fucceeded by clufters of berries, ripening in September and Oftober; principally, in moft of the fpecies, for fowing, and fome for eating, fuch as the Common WildService, and occafionally the Azarolus; and by which all the fpecies are eafily propagated, or any particular fpecies and varieties, by layers, grafting and inoculation.

They being valuable both for ufeful and ornamental planting, we may reckon among the more ufeful kinds the Common Hawthorn, for its great utility in forming the mort effectual of all hedge fences, commonly calleâ quick-fet hedges, fuperior to all for outward fences, or where required for a Atrong, durable hedge, fencible, againft man and beaft, and grows alfo very clofe to afford Thelter; and the Wild-Service and Crategus Azarolus to cultivate in the fruit-tree

\section{VEGETABLE SYSTEM}

collections for their eatable berries, which ripening in October, and being then gathered in their bunches, and hung up acrors lines in any dry apartment till they become foft and mellow, they eat with an agreeable tartin flavour; and the trees of which two ipecies may be admitted, as fruit-trees, in a moderate portion, or as required, in gardens, orchards, pleafure-grounds, parks, avenues, \&c. in full ftandards; likewife the frit, and fome other fpecies, advancing to fome confiderable ftature and large growth, may be introduced in foreft-trec plantations, in company with other deciduous timber trees, or in any large plantation diftricts, for variety.

Or all the different fpecies and their refpective varieties are very eligible to affemble in ornamental plantations and Thrubberies, in which they will increafe the collection, and feveral forts, both of the fpecies and varieties, appear very ornamental and curious in their different growths, flowers and fruit; and the fpecies in general will difplay a proper diverfity and entertaining variety; and are well adapted to arrange in extenfive or large pleafurable plantations, confiderable firubberies, and in clumps; and the larger tree kinds alfo to difpofe in groves, avenues, grand walks, and other diftrits, affociatcd principally with other hardy, deciduous trces.

The Hawthorn, for hedges, is a molt ufeful tree in: its clofe, bufhy, thorny growth, branchy from the bottom, proper botl for outward hedges in gardens. and fields, and for internal divifions, both as a fence and for Thelter to particular diftricts; and may be kept clofe and regular, by an annual clipping towards the latter end of fummer, or in autumn or winter; or in field hedges they are often permitted to run up rough, and when grown tall and the bottom naked, are plafhed and laid down to thicken all parts cqually, in a clofe, regular manner, in which, and thofe kept regular by clipping, as before obferved, they form clofe. impenetrable hedges.

For this occafion of hedges, proper fets for plant: ing are raifed by fowing the laws in autumn, which, on account of the hard, bony nature of the feed, feldom vegetate or come up in lefs than two years; and when the flants are one to two or three ycars old, are proper for planting, which for outward hedges, a ditch and bank being formed, is effeeted generally, either by inferting them into the fide or top of the bank, principally in a double row, fix inches to a foot afunder; or otherwife, if planted on lcvel ground, are defended with fome kird of ferce till advanced in growth; but for interior hedres, efpecially in gardens, are commonly planted in the levei ground; or for divifion hedges in felds, a bark is generally raifed two or three feet by means of a ditch on each fide, and the hedge planted along the to;, in a fingle or double row; the ditch and bank defends it till grown up in proper 
proper ftrength, and afterwards during its continuance.

Or fometimes the haw-berries are fowed at once in the place where the hedge is intended, keeping the grourd very clean till the plants come up, and during their young growth.

The Wild-Service and Azarolus, when any are intended principally for fruit-trees, they being raifed in fandards three or four, to five or fix feet growth, may then be planted in gardens or crchards, or where thought proper, at fifteen to twenty or thirty feet diftance, kept trained to clean ftems, and permitted to branch out above in full heads; they, when of a proper age, will produce plentiful crops of berries annually, which ripening in Oetober, gather in bunches; and the Services in particular, hang them up in the fruitery, or any apartment, till they become mellow, and may then be eaten, as wanted, in winter.

All or molt of the fpecies and varieties of the Cratrgats are cultivated in the common nurferies, for public fupply, and where they may be had in collection, or in any approved fpecies or varieties, as fhall be required, occafionally, for planting.

The general feafon for planting thefe trees is any time after the decay or fall of the leaves, in autumn, in open weather, till the fpring, middle or beginning of April; or the Hawthorn, for hedges, may be planted principally in the fpring, or any time when convenient, during the above-mentioned planting feafon.

They are propagated in the different fpecies by feed, and occafionally by layers, in any particular fpecies and varieties, or alfo by grafting and budding, as before intimated.

By feed or berries, which in moft of the forts ripen plentifully in autumn, and may be fowed in that feafon, fuch as the Hawthorn, and all others as can be procured at that time, or early in the fping, either fowcd at once in beds of common earth two inches deep, or as the feeds or ftones of the berries being of a very hard, bony nature, that they gencrally remain till the fecond year before they germinate, they, previous to fowing, are very commonly in autumn, buricd in a heap together in a trench in dry ground, or in large pots plunged therein, covered over with earth fix inches thick, or more, raifed in a ridge above; and thus to remain a year, or till next autunin following, or fecond fpring, to prepare for vegetation, then taken up and fowed either in drills or broad-caft on the furface, and earthed in two inches; thcy will thus come up freely in the fpring, advancing $f_{1} x$ inches to a foot in growth, or more, by the end of fummer, and then, or when they are one or two year's old, hould be tranfplanted in nurfery-rows, to grow to a proper fize of three or four, to five or fix fect, or more, for the different plantations for whicl they are defigned or adapted; or the Hawthorn plants particularly, intended for hedges, are proper fets for that purpofe, both immediately from the feed-bed, and after having one, two or three years tranfplanted growth in nurfery-rows; the latter of which may be moft cligible, when defirous of having the hedge formed more expeditiouny in good ftrength from the beginning: however, in regard to the other fpecies, intended ge-. nerally for detached ftandards, larger or fmaller, they being tranfplanted in nurfery-lines, thould remain therein till trained up to a requifite fize of three or four, to five or fix feet high, or more, as intimated above, for final tranfplantation in the particular diftricts where they may be required.

By layers of the young fhoots may, occafionally, propagate any particular fpecies or variety, performing it in autumn, chufing thofe as are fituated low, convenient for laying, or that are placed on pliantbranches, which can be readily bowed down to the ground; fo laying the fhoots in the earth three inches deep, keeping the tops upright, they will be rooted, for planting off next autumn, into the nurfery, for training.

Alfo by grafting and budding any defirable variety, to continue it permanent in its refpective kind, may be performed upon any feedling-ftocks of the Cratagus family, fuch as the Hawthorn, or any other raifed in the nurfery, as has been directed; the grafting is performed in the fpring, by inferting young fhoots of the former year into the proper ftocks, and the budding in July or beginning of Auguft, by inoculating buds of the intended forts into the fides of the faid ftocks, at fix inches, to one, two, three, or four feet high, or more ; they will each unite with the ftocks, advance in fhoots above, and form new trees of the refpective varieties.

In the above different methods of raifing the feveral fpecies and varieties of Cratcegus, continue them traincd to a proper growth in the nurfery, fome with clean ftems for ftandards, others may branch out low when defigned to have them of a Thrub-like growth; and in the whole, when they are advanced from three or four, to five, fix or eight feet, are proper for the refpective plantations; or the Common Havthorn plants, defigned for hedges, are eligible for this, when of from one, to two or three feet high.

Hawthorn hedges being of great utility as growing fences, both, occafionally, for gardens, and more generally for inclofing fields and any out-grounds, they are raifed different ways, as either by planting young fets previoufly raifd in a nurfery, to one, two or three fcet growth, or fomctimes by fowing the feed or haws at once where the hedges are intended, though I 2 IIOre 
more generally by fets or ready-raifed plants; and which in the order of planting is, for outward fences, generally performed by inferting the fets either horizontally into the fide, or upright on the top of a bank, raifed by the excavated earth in forming the outward ditch, the latter ferving alfo as a defence to the young hodge; or fometimes for divifion hedges in fields, a bank four or five feet wide at bottom is formed with the earth of a Imall ditch on each fide, raifed two or three feet high, faced with fquare fpits of turf from the top of the ditch, or elfewhere, and the middle filled up with earth from the excavation of the ditch aforefaid; the "bank being two or three feet wide at top, the hedge is planted thereon in a double row; or for interior hedges in gardens, or where they can be fenced from cattle, the hedge is planted on level rround, without forming any ditch and bank; but in the other methods, the funk ditch and raifed bank ferves as a proper guard to keep off cattle, \&c. from annoying the hedge in its advancing growtli.

For thefe different methods of planting quick-fet or Hawthorn hedges, the fets or plants may be of one or two years old; or of three or four years, having been tranfplanted in nurfery-rows one or two years, or more; the fets being the fize of a goofe quill, to the thicknefs of a finger, and, previous to planting, if naked below, may be headed down one third, or half way, to have them branch out ftrongly quite from the bottom.

Where neceflary to plant outward hedges for fences, it, as before explained, is expedient to form a ditch and bank, the ditch to be on the outfide, forming the bank clofe along the inner edge, with the excavated earth, as digged and thrown out of the ditch; raifing the bank therewith moderately, floping inward, and either in advancing in the formation of the ditch and bank, the fets being headed to fix or eight inches, plant or lay them horizcntally or flanting into the fide of the bank, firft one row, placing the roots inward and the tops out, three or four inches, or more, landing over the roots with earth from the ditch, and raifed fix, eight, to ten or twelve inches, another row is placed and earthed over in the fame manner; or fometimes the ditch and bank being previoufly formed, the fets are dibbled into the fides, horizontally, in two rows, the above diftance; or alfo, fometimes, inftead of planting into the fides, the ditch and bank formed as above, are planted upright at top, which being previoufly levelled for their reception.

The general methods are, line out the ditch a yard wide at top, then to be digged out floping on the fides, two or three feet deep, and the firft fpits of earth laid along the top of the inner edge of the ditch to form the beginning of the bank; or, where convenient, previoufly lay a row of fquare fpit turfs, grafs fide downward, and in either method, back up behind with earth from the ditch; then, if intended to plant in the fide of the bank, lay a row of fets upon this bed of earth, the roots inward, a little floping to the back part, with the tops towards the ditch in a rifing direction, two, three or four inches out of the ground, and about fix inches afunder, earthing then over with mold from the ditch, forming the ditch and bank as you proceed; and having advanced fix, eight or ten inclaes higher in the banking, lay a nother layer of fets, each oppofite the intervals of thofe of the firft row, and earth them over in the fame manner; fo finith the formation of the ditch and bank, each moderately lloping, raifing the latter fix inches to a foot or more above the fets; or as before obferved, if quite fmall fets, and the ditch and bank is firft formed, may plant the fets. by dibble, horizontally, or a little more or lefs towards an upright pofition; but if judged more eligib!e or convenient, may firft form the ditch and bank as juft intimated, raifing the bank to its full intended height of one, two or three feet, forming a level border at top; plant two rows of quick in an upright direction, either by dibble, if fmall-rooted fets, or if large, cut a fmall trench for each row, one fide upright; plant the fets againft the upright fide, turn in the earth. about the roots, and tread it gently thereto.

Or where propofed to have middle or divifion hed ges in fields, \& c and that a doubie ditch with a raifed bank between is intended, in order for planting the liedge at top, line out the bafis of the bank five feet wide, allowing alfo for a two or three feet wide ditch on each fide, forming the face of the bank with fquare fpits of grafs turf where attainable, placed either the grafs fide outward, or laid topfy-turvy or grafs downwards, beginning the firt layer clofe along the inmex edre of the ditches, which at the fame time proceed in digging out and forming, employing the excavated earth thereof in backing up the turfs or outer furfaces of the banks, and filling up the middle fpace; continuing to raife the front, drawing each fide in gradually, finifing the whole two feet to a yard high, by two or three feet wide at top, where, forming a level bed or border of earth, plant two rows of 1 wis therein a foot afunder, and upright, in the manner explained in the foregoing directions.

To plant thefe hedges on level ground in a garden, \&c. or for outward hedges, where they can be defended with fome kind of temporary fence in their young growth; and in either of which, the ground being digged and levelled, the planting is eficited by cutting out with a fpade, a fmall trench fix or eight inches deep, one fide formed upright; plant the fets againft the upright fide, as advifed in planting on the top of a bank, placed fix inches apart, and earth in the roots and body of the fets; and if a double hedge is intended, plant another row in the fame manner, fis or eight inches to a foot, from the firt planted, treading the earth gently to the plants of each row. 
Or where it may be intended to raife a quick-fct hedge, by fowing the haws at once in the place where the hedge is required, they hould be fowcd as foon as gathered, in autumn, September, October or November; when digging and levelling the ground either equal with the geveral furface, or for fowing on the top of a raifed bask, draw drills with an hoe, two or three inches deep, in a fingle or double row; fow the haws in thedrills moderate tnick, and mold them over; then ubferving, as they will not vegetate till the fecond fpring, hould kecp the ground clear from weeds in the interim; and when the plants come up, if too abundant, fome may be drawn out, leaving a fufficiency of the beft to form the hedge.

In the different methods of planting there hedges, where it appcars receffary in expored places, to liave fome defence againit the depredations of cattle, till the hedge is grown up in ftrength; it hould be added foon after planting, either with rails, open paling, hurdlcs, or a dead hedge of ftakes and buthes, as may be convenient; likewile, keep the young hedges clear from rampant and climbing weeds, till the quick is advanced in growth, which, though often negleeted in thofe plantcci for outward fences, thould be attended to with particular care.

The ycung hodges in their advancing growth, efpecially trofe defigr.ed for regular training, thould be managed accordingly, that when advanced in young fhoots, flotild be clipped moderately at the fides, but cut fpari-giy at :op, till arrived to the proper or intende - height, only juft run over with the garden Shears, toppiig ary rampant moots which out grow the others confiderably, that the whole may advance equally, and foon ativin the defired height aforefaid, of four, five or fix feet; and thus may run over the whole top lightly every year while tie hedge is in training, to have it advance even and rcogular, as well as to make it thoot out below, tnickening as it advances, clipping the fides alfo even; and where the hedge is required to afpire to fomc confiderable height of five, fix or feven feet, to afford thelter againft winds and cold bla:ts, in particular diftricts, it may be permitted to run up fafter at top, and generally cut up taper on the fides in a gradual rianner, to have the top confiderably thinner or narrower than the bottom part.

However, where defigned as a ftrong outer-fence, a hedge of three, four or five fcet height may be fufficient, efpecially if growing on the top of a bark, and may be cut more at top accordingly, that it may thicken confiderably quite from the bottom, in a ftrong, robuft growth ; but if on level ground, may be run up five or fix feet, or morc; and then, in all of which, kcpt to the proper ftandard, by an asmual clipping.

Then when the trained hedges are advanced to the irtended height of four, to five, fix or feven fect, agreeable to the above intimations, they thould be kept in regular order, by conftant cliping once every year at fides and top, to continue them of the proper width and height; generally in thofe arrived to full grcwth, cutting them in generally to the old cut of the former year, and the clipping performed ftraight and even, commonly keeping the hedge narrowelt upward to the top in a gradual manner.

The proper feafon for clipping thefe hedges is principally in fummer, from the middle or latter end of June, to Auguft or September, when the thoots being green and tender, the clipping is performed with confiderable facility, expedition and exactnefs; or where any particular nedges are required to be kept in the neateft order all fummer, two clippings fhould be performed twice every year in that feafon; the firt about the middle or latter end of June, and the fecond towards the latter end of Auguft; but where only one clipping in fummer is allotted, it thould generally be performed in July or Auguft, or bcginning of September, after the hedge has done fhooting, that it may continue clofe for the remainder of autumn, and all winter, till following fummer; if, however, the clipping is omitted in the above feafons, it may be performed any time in winter; but the thoots being then hardoned, the work cannot be fo eafily effected as in fummer or autumn.

Though, as to common thorn hedges in fields, they, in the grcater part, are permitied to run up rough without any clipping, till advanced to a tall growth; then generally, when grown $\mathrm{up}$ in large ftems and branclies, and naked in the lower parts, the large naked wood is thinned out, and the remaining fmaller ftems and branchcs are plafned or laid down horizontaily, to thicken the hedge in a clofe growth, quite from the bottom; is effected by leaving fome of the Atrongeft ftems for growing ftakes, then the other fiems and large branches are ganhed with a hedge-bill in a loping cut, efpecially thofe not fufficiently pliant to bend down, fo laying the whole along in a flanting pofition the way of the hedge, plathing them between the upright, ftanding ftems, which frould be headed to the intended height of the hedge, three or four fect; when thus plathed, and the whole is layed, then with a hedge-bill a forefaid, trim the fides and top fomewhat regular; it thus forms a ftrong, thick hedge, equally clofe from top to bottom.

\section{CuPRESSUS, CYPRESS TREE. Clafs and Order. Monoecia Monadelphia, One Houfe, One lsrotberbood;}

Or Male and Female Flowers, feparate, on the fame Tree, and the Malc Flowers taving the Stamina, or Anthera unived in one Body.

THIS Genus of CUPRESS $s$ furnithes three fpecies and fiveral varictic of cminently beautiful ever- 
green trees, and one deciduous kind; all of the coniferous or cone-bearing tribe, princip:lly for ornamental plantations, and fome alio to introduce in the foreft-tree collection; grow to a confiderable lofty ftature, moftly very branchy quite from the bottom, in a regular, pyramidal growth; fome with upright, others in fpreading branches, very clofely fet with minute, imbricated, and fpreading leaves; and fmall male and female flowers apart on the fame tree; the males in oval amentums, and the females in roundifh, fcaly cones, no corolla or petals; and in the males no ftamina, but feveral united anthera; in the female fiorets, a very thort Atyle; and the conical female lieads become fmall, roundifh, fcaly cones, furnifhed with angular feeds, involved in the fcales, ripe late in autunn; and by which the trees are commonly propagated, fowed in the fpring, in beds of light earth.

\section{The Species of hardy CUPRESSUS are,}

\section{Cupressus fempervirens, Ever-green Common Cyprefs T'ree.}

A largifh, ever-green tree, growing thirty to forty feet high, or more-the branches quadrangular; leaves ( $(m a l l$, dark greeiz) imbricated or lying over one another, and erect.- Native of Creta and other parts of the Levant. (Gracully, or any dry fituation.)

Varieties.-Upright Common Cypress Tree-having ereft branches; growing thirty, to forty or fifty feet high.

Horizontal or Spreading Cyprefs Treethe branclies fpreading horizontally; growing twenty to thirty feet high.

Portugal Cyprefs Tree, or Cedar of Goa-the branches irregular-fpreading ; growing twenty to twenty-five feethigh.

\section{CUPRESSUSThyoides-(Thyoides, or Arbor-vitæ- like) Dwarf Cyprefs, or White Cedar.}

A fmall, ever-green tree, twelve to fifteen feet high; - the branches two-edged; leaves (Jmall, dark green) imbricated or lying over one another; and fmall, blue, berry-like cones.-Native of Canada. (Moififh or any common foil.)

\section{Cupressus difficha, Diftichous-leaved, or deci- duous Cyprefs.}

A large, deciduous tree, growing forty or fifty feet high-the leaves ( $/$ mall, light green, pinnated-like) placed diftichous or two-ranked, and fpreading.-Native of Virginia and Carolina. (Moift or any common foil.)
Moft of thefe fpecies and varieties of Cyprefs are fuperbly-beautiful trees in their clofe, branchy, pyramidical growth, clofely garnifhed with very fmail leaves, imbricated or lying over one another in the ever-green kinds, in the other fpreading and tworanked on the branches; and in all of which, are defirable ornaments for beautifying pleafure-ground plan. tations, principal hrubberies, and other compartments; and to difpofe in ranges, in forming grand walks, groves, \&c. likewife to plant in clumps and fingle ftandards, upon capacious lawns and other open compartments of grafs ground; are alfo peculiarly adapted to adorn avenue walks, leading to any ornamental garden edifices, as temples, grottos, \&c. and the larger tree kinds, both of the ever-green and decióuous fpecies, are proper to afiemble in foreft-tree plantations, as the timber is of the utmoft value for its rreat diuturnity and aromatic property; more particularly the feveral varieties of the Cuprefus jempervirens; and the trees in general, in their growing fate, impart a very fragrant, balfamic odour, efteemed exceedingly falutiferous; fo that the fe curious trees demand admittance in all principal plantation diftricts, both for ornament and utility.

They are all fufficiently hardy to grow in any fituation and common foil, in general with other trees, or where they may be required, in larger or fmaller fupplies, for the above-mentioned occafions of planting ; which may be performed either principally in autumn, in October or November, or in the fpring, February or March, to the beginning or middle of April, efpecially the ever-green kinds.

Thefe trees, in their native places of growth, in the Levant and America, rife to a coniderable altitude or height, and grow to a very large fubftance in the trunk, for principal timber trees, efpecially the firft and third fpecies; and of which there are trees of a large fize in many of our Brition gardens, in which all the forts thrive abundantly well, and effect a fingularly fine variety, and fuperbly ornamental appearance in their mode of growth and clofely-placed foliage ; the flowers not very confpicuous, are produced in the fpring at the fides of the young branches, in male and female amentums and heads, which, in the latter, are fucceeded by the fmall feed-cones: ripening in the end of autumn and beginning of winter, or, when not ripening in fufficient abundance, are obtained, from abroad, by the feedfmen, for fowing in the fpring.

All the forts are raifed abundantly in the public nurferies, of a proper growth, of two or three, to four, five or fix feet, or more, for planting; and where they may be obtained, in the proper feafons of autumn and fpring, for Thrubberies, and other plantations in which they are intended. 
The general feafon for planting thefe trees is principally either in the autumn or fpring; the ever-green kinds may be transplanted early in autumn, from about the middle or latter end of Septenber, or any time in October and beginning of November; or alfo any time in the laft-mentioned month, in open weather, not generally in tie dead of winter, except they can be tranfplanted with balls, or is a very mild feafon, but declined if appearance of fevere froft, and may be planted freely in the fpring months, till April; and where corvenient to remove any witl balls of earth, it will be of fingular advantage; or the deciduous Cyprefs may be tranfilanted in the general planting feafons, October, Norember, \&rc. or, occafionally, any time during the winter, when nild, and in the fpring.

In planting thefe trees, that when defigned to affociaie them in any general fhrubbery or other plantations of different trees and Mrubs, it is advifeable to difpofe the ever-green forts principally in compartments, confifting moftly of tiuat tribe; or fometimes dotted thinly in fome principal deciduous clumps, \&c. likewife may obferve thic fame order in planting the deciduous Cyprefs; and likewife trees of all the forts may be dotted fingly on grafs lawns, or, occafionally, in fmall ciumps or groujs of threc or more together, in the fume places, and in other fimilar comsartments, in a diverfified order.

Sometimes, in the ancient file of gardening, the Upright Ever-green Cyprefs was formed into handfome, tall hedges in pleafure-grounds, for ornament, though feldom cmployed now for that occafion, fince mott forts of ornamental hedge-work is abolifhed the Englih gardens.

To propagate or raife the Cyprenes, it is effected principally by feed fowce in the fipring, which may be had of the feedfmen, and being clearcd out of cones, fow in Niarch or April, in a bed of light ground, either in fmall drills or on the furface, and covered in with mold half an inch deep; or fome fowed in pots of light earth, to move to thade in fummer and fhelter in winter, the feed will foon gerulinate, and the plants come up fretly the fame feafon, or early part of funmer; give water occafionally in that fafon, and thade when very hot, as likewife give occantonal Shelter in winter from fevere froit; and when tiley are advanced of one or two years growth in the fecl-beds, tranfplant them in the fpring, March or Afril, into nurfery-beds, in rows a toot afunder, and when of advanced growth, in a year or two, tranfplanted at wider diftances, to obtain eligible fizc, of three or four, to five, fix or feven fect height, for final tranfplanting into the continuing plantations in which they may be intended.

They may alfo be propagated, occafionally, by layers and cuttings of the young thoots in the fpring.
In the general growth of thefe trees, they, in Thrubberies, and other ornamental diftriets, may be permitted to affume their natural, branchy manner; or fume occafionally pruned up modurately in the under, ftraggiing branches, to form a clean ftem below, and let the whole advance abcve in full growth; and when any are planted in foreft-tree plantations, they fhou!d be trimmed up below gradually, to run up with clean, fingle ftems, in a tall, ftraight growth.

\section{Cytisus-(CYTISUS) or Bafe Trefoil Tree, and Laburnum.}

\section{Clars and Order.}

\section{Diadelphia Decandria, Two Brotberboods, Ten Males;}

\section{Or Plants with Hermaphrodite Flowers, having the Stamina or Males difpofed in two Sets, and in each Flower ten Stamina.}

THE CYTisus family confifts of feveral fpecies and varieties of deciduous flowering -fhrubs and trees, and one ever-green flowering-fhrub; all employed for ornamenting hrubberies and other decorative planting; are of fmall, moderate, and large growth, three or four, to five or fix feet high in the leffer Mrubs, and. the larger or tree-like kinds, fifteen to twenty feet high, or more; the whole garnifhed with trifuliate leaves, or confifting each of three diftinet folioles or leaflets; and numerous, long pendulous and ereet fpikes, and umbellate clufters, of papilionaceous, yellow flowers, at the fides and ends of the branches, in May and June; having each a bell-hape bilabiate cup; a corolla, compofed of an oval vesillum or ftandard, two obtufe vings, and a bellied carina or keel, with ten ftamina in two fets, and ore ftylc; fucceeded by oblong legumenous pods, containing kidneyhape feeds : ripe in autunn, and by which the fpecies are propagated, alfo by cuttings of the young Ihoots.

\section{The hardy Specics of CYTISUS are,}

\section{Cyтsus Laburnum-(Laburnum) or Tree Cy-} tifus, commonly called LABURNUM.

A moderate, deciduous tree, fifteen or twenty to thirty feet high-the leaves (large) trifoliate, with the li.bes or folioles ovate.oblorg; and long, pendulous, fingle frikes of yellow flowers; May or June. - N3tive of Helvetia, Savoy, the Alps, \&c. (Any foil.)

\footnotetext{
irarietics.- road-leaved Laburnum. Narrow-leaved Laburnum. Long-friked Laburnum. Short-1piked Laburnum. Variegated-leaved Laburnum.
} 


\section{VEGETABLE SYSTEM}

\section{Crrisus fefilifolius, Sefile-leaved Cytifus.}

A middling, deciduous thrub, five or fix feet high -the leaves ( $($ maller ) trifoliate, with the folioles orlobes soundifh, and with the floral leaves feffile or fitting clofe to the branches; and erect fpikes of yellow hlowers, having the calyx bractea leaves triple.-Native of Italy and France. (Ary foil.)

\section{Cyrisus nigricans, Black Cytifus.}

A middling, decidnous thrub, five or fix feet high -the leaves (jinall, dark green) trifoliate, the folioles or lobes ovate-oblong; and upright, fingle fpikes of yellow flowers.-Native of Aufaria, Hungary, Bohemia, and Italy. (Any foil and fatuation.)

\section{CYrrsus fupinus, Supine or Trailing Cytifus.}

A fmall, deciduous, procumbent hrub, of three or four feet growth - the branches procumbent or trailing; leaves ( $/ \mathrm{mall}$ ) trifoliate, the folioles or lobes ovate; and terminal umbels of yellow flowers. - Native of Siberia, Italy, Sicily, and France. (Any foil.)

\section{Cytisus aufriacus, Auftrian Upright Cytifus.}

A middling, deciduous thrub, four, to five or fix feet high-the ftem erect; leaves ( $/$ mall) trifoliate, the lobes or folioles fpear-hhape; and yellow flowers in terminal umbels.-Native of Aultria, Siberia, and Italy. (Any fotuation.)

\section{Cyт1sus birfutus, Hirfuted or Shaggy-cupped Ëver-green Cytifus.}

An ever-green fhrub, fix or feven feet high-the leaves ( fimall) trifoliate, with the folioles or lobes oval; and fimple, lateral peduncles or flower ftalks, fuftaining yellow flowers, having hairy or haggy, trifid cups, which are bellied-oblong. - Native of Spain, Siberia, Auftria, and Italy. (Any' common foil.)

All thefe fpecies of $C_{y t i f u s}$ are hardy to grow in any common foil and fituation; very defirable, ornamental flowering-trees and thrubs, for the pleafure-ground; and the Tree Cytifus or Laburnum is alfo eligible to affemble in any large, deciduous tree plantations, and likewife, occafionally, among foreft-trees, as it grows fwiftly to fome confiderable fize, or to plant among coppice wood; though this, as well as all the other fpecies of Cytifus, is generally efleemed principally for orramental planting; in which they effeet an agreeable variety in their trifoliate leaves in fummer, and flower very confpicuoufly in May and June, in numerous fpikes and bunches of yellow flowers, all of the pea-bloom form, or what the botarifts call papilionaceous or butterfly-shaped; and are fucceeded by many longin, narrow pods of the legumenous kinds, furnifhing plenty of ripe feed in autumn, ufeful for fowing, when required, for the propagation of the fpecies, as all the forts are generally raifed by that means, and fometimes by layers and cuttings, to propagate particular fpecies and varieties.

They may all be had at the nurferies, in full collection, or of any particular forts required, of proper growth for planting; which may be performed in autumn or fpring, or any time in open weather, from OEtober to March; efpecially all the deciduous kinds.

For ornamental planting, they may be introduced in any principal or general thrubbery diftricts, clumps, and otlier compartments; in which generally affemble all the deciduous tree and fhrub kinds, principally with others of that tribe; and the ever-green Cytifus may either have a coufpicuous fituation, moftly in the ever-green clumps, \&c. or in any other principal part of the pleafure-ground, where it may be diftinguifhable both as a neat ever-green, beautiful at all feafons, and as a pretty flowering-hirub, like the others of the fame family, in fummer.

They are all eafily propagated generally by feed, and fome, occafionally, by layers and cuttings.

Sow the feed in March, in a bed of common, light earth, each fort leparate, either in drills or broad-caft, and earthed over an inch deep; the feed will foon vegetate, and the plants come up the fame year, and ad. vance feveral inches to a foot high, by the end of fummer; continuing them in the feed-bed till next fpring, then tranfplant them into nurfery-rows, in which train them with a fingle ftem below, and run them with full heads above, to a prope: growth of two, three or four, to five or fix feet, according to that of the different forts eligible for the fhrubbery, \&c. or the Laburnum, in its largifh growth, will tranfplant fuccefsfully of fix, feven or eight feet.

Layers and cuttings of the young thoots in autumn or fpring, will be properly rooted by the autumn following, when, or in fpring, may be tranfplanted into the nurfery, and trained as intimated above, for the feedling plants.

DaPHNE, WOOD LAUREL, and Mezereon. Clafs and Order. OEtandria Monogynia, Eight Males, One Female;

Or Plants with Hermapbrodite Flowers, baving eight Stamina or Male Fructification, and one Pifilliam or Female.

THE family of DAPHNE comprifes feveral hardy fpecies of fmall and moderate thrub kinds for the 
hrubbery, confifting of one ever-green, and the others deciduous flowering - Thrubs, from two or three, to four or five feet high in the different fpecies, garnifhed with fpear- Thape ovate and linear fimple leaves, and numerous, fmall flowers in fpring and fummer, produced moftly along the fides of the fhoots; compofed each of one fmall funnel-thape, four-parted corolla, containing eight fhort ftamina, an oval germen fupporting one fyle; and the germen grows a roundin berry, furnithed with one roundinh, flemy feed, ripening in fummer and autumn; and by which, fowed in the autunin or fpring, the plants are propagated; alfo fome, occafionally, by layers of the young thoots and fuckers from the root.

The Species of DAPHNE are,

\section{DAPHNE Laureola-(Laureola) or Common Wood Laurel.}

A fmall, ever-green thrub, with flender, upright ftems, two or three feet high-the leaves (long, narrow) fpear-Thape, fmooth; and racems of fmall, greenif flowers at the axillas or angles.-Native of Britain, \&c. in woods, Switzerland, France, and Mount Baldo. (Any ligbtif foil.)

Variety.-Striped-leaved Laureola.

2. DAPH NE Mczereum-(Mezereum) commonly called Mezereon.

A moderate, deciduous fhrub, of buhy growth, three, to four or five feet high-the leaves (fmallifi). orate-fpear-thape; and numerous, fmall, purple and other coloured flowers along the fides of the thoots, by threes together, fefile or fitting clofe; February and March.-Native of England and the northern parts of Europe, in woods. (Light, or any foil.)

\section{Varieties.-Purple-flowered Mezereon; red berries. Red-flowered Mezereon; red berries. \\ Crimfon-flowered Mezereon; red berries. White-flowered, Yellow-berried Mezeron. Variegated-leaved Mczereon.}

\section{DaphNe Cneorum-(Cneorum) Clufter-flowercd, Narrow-leaved Daphne.}

A fmall, beautiful, deciduous fhrub, one or two feet growth-the leaves (finall) fpear-hrape, naked; ard clufters of purple flowers, terminating the branches, fenle or clofe-fitting. - Native of Switzerland, Iungary, Pyrenean Mountains, \&c. (Any common foil.)

4. DА н ке alpina, Alpine Downy-leaved Daphne.

A fmall, deciduous thrub, of two or three feetthe lezves ( $\mathrm{fmall}$ ) fpear-fhape, fomewhat obtufe, hoary on the under fide; and clofe-fitting flowers in aggregates at the fides of the branches.-Native of the Alps of Switzerland, Geneva, Italy, and Auftria. (Any ligbt foil.)

\section{DAPHNE Tarton-raira-(Tarton-raira) or Sil- - very-leaved Daphne.}

A low, fpreading, deciduous firub, of one or two feet - the leaves ( finall, wbitilh) ovate, nervous, both fides downy, filky, and filvery-like; and clofefitting white howers in aggregates at the fides of the branches.-Native of France. (Ligbtifh, ricífoil, or any.)

\section{DAPHN Thymelaa-(Thymelæa) or Milkwort- leaved Daphne.}

A moderate, decidunus fhrub, of three or four feet growth-the ftem fingle; leaves ( mall) fpear-(hape; and clofe-fitting greenin flowers at the axilla6. - Native of Spain. (Light, or any common foil.)

\section{DAPHNE Gnidium-(Gnidium) or Flax-leaved Daphne.}

A fmall, deciduous Shrub, two or three feet-the leaves (fmall, narrorw) linear-fpear-thape, pointed; and flowers in panicles at the end of the branches.Native of Spain, Italy, and France. (Ligbtifh, or any common foil.)

\section{Dapkne villofa, Villofe or Hairy-leaved Daphne?}

A fmall, deciduous Thrub, two or three feet growth-the leaves ( $/$ mall) fpear-thape, plane, ciliated, hairy. crouded; and clofe-fitting lateral flowers, fingly.Native of Portugal, Spain, \&c. (Any ligbt, common foil.)

All thefe fpecies of Dapbne are proper furniture to introduce in thrubberies for ornament and variety; the firft fort, Laureola, is a curious hardy, little evergreen; and the Mezereon is a defirable floweringfhrub, fingularly beautiful in its early flowers, in January or February, when but very few others appear, produced numeroufly along the upper part of the fhoots, and impart a fragrant odour; the Cneorum and Tarton-raira are alfo deliglitful, little fhrubs, as alfo the Alpine Daphne; and which three laft-mentioned fpecies, and the Laureola and the Mezereon, are the moft noted, and deferving of culture; the other three forts are eligible to admit for varicsy: are all hardy enough to grow in any ccmmon, lightifh foil, or where they may be required; difpofed principally to. wardsthe front of thrubbery compartments, and in 
borders, sc. and are all eafily raifed from feed; alfo by layers, and fome by fuckers.

They are all cultivated in the nurferies for fale, more particularly the firft five fpecies, where they may be procured for planting in the proper feafons.

The feafon for planting them, may be oither in Autumn, about Oetober or November, or any time in mild open weather during the winter, or in any of the fpring months, February, March, and beginning of April; generally allot them principal compartments of the firubbery, difpofed more or lefs towards the front part, in a diverfified order, in affemblage with other hardy fowering fhrubs of moderate growth; or the Lawreola introduced principally in the front of evergreen clumps, and in the borders of wood walks, as being naturally a wood plant.

To propagate thefe fhrubs, it is effected principally by feed, (the berries) fowed in autumn, in Oetober or November, or in the fpring, February or March, in beds of light earth, either in drills, fix inches to a foot diftance, or broad-caft on the furface, and earthed over an inch deep, they will come up freely the firft year; keep them clean from weeds, and when they are of one or two fummers' growth, four or five to fix or eight inches high, tranfplant them in autumn or fpring into nurfery-beds, trained to a fingle ftem below, and permitted to branch out above; and in their advanced growth of about a foot and a half to two or three feet, are proper for the Shrubbery.

Or, by layers of the young thoots, in autumn or fpring, molt of the forts may alfo be propagated, efpecially in default of feeds, or to propagate the varieties, to continue them more certainly in their diftinctive differences; they will be rooted for planting off in autumn following.

Likewife where fuckers from the roots occur, they may be taken up in autumn or fpring, with roots to each; and planted, they at once form young plants.

When the plants, raifed by any of the above methods of propagation, are from a foot and a half to two or three feet growth in the nurfery, they are of proper fize for final tranfplanting into the pleafureground, in Thrubberies, clumps, borders, \&c. in which the requifite to culture is that in common with other thrubs, hoed clean from weeds in fummer, and the ground digged between them in winter, when you may. prune cafual irregula: thoots or branches.

The rosts of old Mezereon thrubs are valuable in medical preparations, and for which the druggifts give a good price per pound.

\section{DIOSPYROS, INDIAN DATE PLUM.}

$$
\text { Clafs and Order. }
$$

\author{
Polygamia Dioecia, \\ Many Marriages, Two Houfes;
}

Or Flowers of diferent Sexes, as Hermaphrodite, Male and Female, ition two Separate Plants in the. fane Species.

THE Diospyros comprifes two hardy deciduous trees, of moderate and fmailer growth, employed in pleafure-ground plantations for ornament and variety; cloathed in fummer with oblong, fimple leaves, ir one fpecies, curious in being of different colours; and hermaphrodite and female flowers on the fame, and male flowers cn ditinet plants; compored of monophyllous or one-leaved four-parted cups, a corolla, monopetalous, or of one petal four-parted, containing eight ftamina and one quadrifid ftylus, fucceeded, in the hermaphrodite and female flowers, by large globular, baccaceous or berried fruit, furnithed with many feeds, by which the trees are propagated.

\section{The Species of DIOSPYROS are,}

\section{Diospyros Lotus-(Lotus) Falfe Lotus, or Indian Date Plum.}

A moderate deciduous tree, growing twenty feet high or more-the leaves (moderately iarge) cblong, the furfaces of different colours.-Native of Mauritania, France and Italy. (Dry fituation.)

$$
\begin{array}{r}
\text { Varieties. - Broad-leaved Date Plum. } \\
\text { Narrow-laaved African Date Plum. }
\end{array}
$$

\section{DIOSPYROS ajirginian-Tirginian Diofpyros, or Piohamin Pium.}

A fmall deciduous tree, growing fifteen or eighteen feet high-the leaves (moderctily large) oblong, with the furfaces all of one colour (green)-Native of North America. (Diy, or any common foil.)

Thefe two fpecies of Diofpyros are proper to anemble in Thrubberies, and other plantation compartments in pleafure-grounds, principally in the deciduous tree collections, in which they will increafe the variety very agrceably; and may be planted in any fitcation in a moderately dry, or any common foil, in company with other trces and furubs; and for witicla occafion they may be had at the public nurferies, and planted in autumn or fpring.

They are propagated by feed, which may be fowed in the fpring in a bed of light earth, an inch deep, or in pots, plunged into a gestle hot-bed to forward the germination of the feed, and bring up the plants fooner, 
fooner, to obtain a ftronger growth before winter, when it would be of advantage to give them thelter from froft; and then tranfplanted into the nurfery in the fpring to acquire proper growth of three, four, or five feet, for final tranfplanting in the intended plantations.

\section{DIRCA, LEATHERWOOD. \\ Clafs and Order.}

OAandria Monogynia. Eight Males, One Female;

Or Plants with Hermaphrodite Flowers, baving eight Stamina, or Males, and one Piftillum, or Female.

THIS Genus, Dirca, furnithes but one fpecies, a fmall deciduous thrub, proper to introduce in thrubbery compartments for variety; is garnifhed with ovate leaves in fummer, and club-thape ventricofe flowers, of one petal, containing eight ftamina and one ftyle; fucceeded by roundifh berries, having each one feed; and by which the fhrub is propagated, alfo by layers and cuttings.

\section{Dirca palufrus, Marh Leatherwood.}

A fmall deciduous fhrub, with tenacious thoots and bark - the leaves (moderate) oblong, and pointed, and white flowers.-Native of Virginia. (Moift, or any fituation.)

This thrub may be introduced in fhrubbery campartments to encreafe the variety; delights in moift fituations, or may be planted in any common foil, in autumn or fpring.

It is propagated by feed fowed in the fpring, alfo by layers and cuttings of the young thoots.- Sow the feed in a bed of common earth, in February or March, and earthed in an inch deep; and when the plants are come up, and of one year's growth, tranfplant them in autumn or fpring into the nurfery, to attain proper firength for the hrubbery: layers and cuttings in zutumn or fpring will be rooted in one year; and when, by either method of propagation, the fhrubs are two or three feet high, they thould be finally tranfplanted in the plantations intended.

ELEAGNUS, WILD OLIVE, or Oleafter. $\mathrm{Cla}$ ss and Order.

Tetrandria Monogynia,

Four Males, One Female;

Or Plants with Hermaphrodite Flowers, baving four Stamina, or Male Fruclifications, and one Pifillum, or Female.

THE EL EA GNUs furnithes one large hard deciduous flowering-hrub, for ormamenting the Arubbery. growing ten or twelve to fifteen feet high, cloathed with fpear-Ihape filvery leaves, and fmall apetalous flowers, compofed of quadrifid or four-parted coloured cups, no corolla or petals; four ftamina, and one ftyle, fucceeded by fmall oval, olive-thape, drupaceous fruit, furnithed with an oblongin obtufe nut, by which, wherc attainable, the fpecies may be propagated, but is nore generally raifed from layers, and occafionally by cuttings of the young fhoots.

ELEAGN Us angufifolia, Narrow-leaved Wild Olive.

A large Thrub, or fmall tree, growing twelve to fifteen or fixteen feet high-the leaves (fmallifls) fpear-fhape, light green, whitith, Mining.-Native of Bohemia, Spain, Syria, and Cappadocia. (Any common foil.)

This thrub merits a place in principal hrubberies for ornament and varıety, in affemblage with other hardy Ihrubs and trees; may be had at the nurferies for planting, which may be performed in autumn or fpring: affign it a confpicuous and fomewhat warm fituation, and it will fucceed in any common foil.

It is propagated principally by layers of the young wood, and occafionally by cuttings: perform the laying in autumn or fpring, they will be rooted by autumn following; when, or in fpring, feparate them from the ftools, and planted in a nurfery; or cuttings of the young thoots in the fpring may be planted in pots, and placed in a hot-bed to forward their rooting more effectually, and afterward tranfplanted in nurfery-rows; and when the plants, in either method, are three or four to five or fix feet high, they are of proper growth for the Thrubbery.

\section{EMPETRUM, BLACK-BERRIED HEATH, or Crow-Berry. \\ Clafs and Order. \\ Dioecia Tetrandria, \\ Two Habitations, Four Males ; \\ Or Flowers, Male and Female, diffinet on two feparate Plants of the fame Species, and the Male Flowers baving four Stamina.}

THIS Genus furnithes but one hardy fpecies; a low procumbent under-Ihrubby ever-green, garnifhed with very fmall ovate leaves, and fmall tripetalous male and female flowers feparat: on two difinet plants; the males having four fanina, and the females one piftilum, fucceeded by roundion berries, containing fmall feeds, and by which the fhrub is propagated, alfo by layers, and bottom-fuckers and off-fets. 
One Species, viz.

EMPETRUM nigrum, Black-berried Empetrum.

A low ever-green of trailing growth-the branches procumbent or trailing; leaves (minute) ovate, and fmall flowers, fucceeded by black berries.-Native of the cold parts of Europe, on mountainous and boggy places. (Moift foil.)

This under-fhrub may be admitted in fmall thrubbery clumps for variety, allotting it a moift fituation; may be planted in autumn or fpring, placing it fomewhat forward in the intended compartments; is pro. pagated by feeds, layers, and off-fet and fuckers from the bottom. Sow the feed in the fpring in a thady border of moift foil; and the plants, when of a few inches growth, tranfplanted, either where they are to continue, or in a nurfery, to obtain a little ftrength for final planting; layers of the branches in autumn or fpring will root freely; and off-fets or fuckers may be taken up at the fame feafons, with roots, and planted.

\section{EPHEDRA, SHRUBBY HORSE-TAIL.}

$$
\text { Clafs and Order. }
$$

$$
\begin{array}{cl}
\text { Dioecia } & \text { Monadelphia, } \\
\text { Two Habitations, } & \text { One Brotberbood; }
\end{array}
$$

\section{Or Male and Female Flowers difindt, on two Separate Plants, and the Stamina of the Males joined in one Body.}

THE EPHREDRA comprehends two fpecies of fmall fhrubby ever-greens, employed in Trubberies for ornament and variety; are fmall under-fhrubs of three or four feet growth, branching in many flender rufhylike thoots, and fimilar fmall, jointed leaves, and male and female flowers, feparate on two diftinct plants, collected in amentums or catkins; the flowers are without corolla or petals, males feven ftamina in one body, and in the female florets two oval germens and fhort ftyles; the germen grows a fmall berry-like fquamous fruit with tivo oval feeds, which, when they can be obtained, may be fowed to raife the plants; but thefe are more generally propagated by fuckers, or occafionally by layers.

\section{The Species of EPHEDRA are,}

1. EP B EDR i diftacbya, Twin-fpiked, Shrubby HorfeTail.

A fmall, Thrubby ever-green, three feet highthe fhoots and leaves fmall, rufhy-like, jointed, and peduncles or flower-italks oppofite, with the flowerfpikes or amentums in pairs.- Native of Narbone in France, and Spain, on rocks and hills by the fea. (Any common foil.)

\section{EPHEDRA monofacbya, Single-rpiked Dwart Shrubby Horfe-Tail.}

A low under-fhrubby ever-green, two or three feet high-the thoots and leaves fhorter and fmaller; many peduncles or flower-ftalks; and the flower-fpikes or amentums folitary or fingle. -Native of Siberia, on mountains and fterile places. (Any dry foil.)

Thefe two thrubby ever greens are admitted in cu. rious Ahrubbery collections for the fingularity of their growth, in which they effect an agreeable diverfity at all feafons of the year in their thoots and leaves: they may be obtained for planting, at moft of the nurferies, in autumn or fpring; may be planted in any common foil, and thould generally have a forward fituation towards the front part of the intended compartments of Shrubbery clumps, \& $c$.

They are propagated principally by fuckers, whick may be taken off in autumn or fpring with roots, forming at once rooted young plants, and either planted where they are to remain, or in a rurfery for a year or two, or till they acquire more ftrength and larger fize for final tranfplanting.

Likewife many proparate them by layers, in the autumn or fpring, and will be rooted for planting off the autumn following.

\section{EPIGAA, TRAILING ARBUTUS.}

\section{Clars and Order.}

\section{Decandria Monogynia,} Ten Males, One Female;

Or Plants with Hermaphrodite Flawers, having each ten Stamina or Males, and one Pifillum or Ferralo Part.

ONE fpecies, a trailing, creeping evergreen, flow. ering-Thrub of fmall growth, adorned with ovate leaves, and loofe, terminal bunches of monopetalcus, white flowers, havirg a duuble, fix-leaved calyx or cup, a tubulous, falver-hape corolla, of one retal, cut at top into five parts ; ten ftamina, a globofe germen crowned by a quinquefic or five-part ftigma, fucceeded by a roundith pentangular fruit with mary feeds; by which the plant may be raifed; but it commonly propagates plentifully by its rooting branches and off-fet fuckers ; likewife by layers and cuttings.

$$
\text { One Species, viz. }
$$

\section{EPIG IEA repens, Creeping Epigxa, or Trailing Arbutus.}

A low, trailing ever-green, with creeping, rootingShoots; - leaves ( mallifi) ovate-oblong, rough;, 
and fmall bunches of white flowers at the ends of the branches.-Native of Virginia and Canada. (Any) common foil.)

It is admitted in fhrubberies as an ever-green and fowering-hrub; may be procured at the nurferies, and planted in fpring or autumn, affigning it a forward fituation : is propagated by the trailing rooting flems, and off-fet fuckers, taken off in the autumn or fpring, and planted in the Thrubbery, or in a nurfery, for a year or two, alfo by layers and cuttings of the thoots.

\section{ERICA, HEATH.}

\section{Clars and Order.}

\section{Oetandria Monogynia,}

Eight Males, One Female;

Or Plants producing Hermapbrodite Flowers, baving eight Stamina, or Males, and one Pifillum, or Female.

THE ER ICA furnifhes feveral hardy fpecies of fmall under-fhrubby, ever-green, flowering plants, for the thrubbery, of fpreading and upright bufhy growth, one to two or three feet high, clofely garmined with minute fimple leaves, by two, three, four, and five together; and many fmall quadrifid lowers; purple, red, \&c. arranged along the upper part of the fhoots; havirg four-leaved, coloured cups, the corolla or flower fmall, monopetalous, fwelling, four-parted, containing eight smail ftamina, and cne pittillum, fucceeded by a qualrilocular or four-called feed capfules, ripening fetd in autumn; by which the plants may be raifed, and are propagated alfo plentiounly by off-fet fuckers, and layers of the brancises.

The principal hardy ERICAS are,

1. ERICa vulgaris, Ccmmon Wiid Heati.

A fmal, , fpreading fhrubby plant- he leaves (very fmali) arrow-Thape, oppofitc; and the crirola or flower bell-form, unequal, with the anthera twohorned, insluded.-Natıe of England and moit parts of Europe, on fterile commons, or heaths. (Any foil.)

Farieties.-Common Purple-flowered Heath. White-flowered Common Heath.

\section{ER ICA ciliaris, Ciliated-leaved Portugal Heath.}

A fmall, finubby plant, two feet high-the leaves (Imali) cvarc-oblong, acute, placed by threes, the edges ciliated or hairy; and the corolla ovate, irregular; the flowers threed-cluftered, with the anthera fimple, included.-Native of P'ortugal. (Any dry foil.)

\section{ErIcA cinerea, Afh-coloured-barked Heath.}

A dwarfin under-fhrub, the bark whitifh-the leaves (fmall narrow) linear, fmooth, growing by threes; and ovate flowers cluitered; with two-horned anthera, included.-Native of the middle parts of Europe and the Ealt. (Any common foil.)

\section{ER ica multifora, Many Flowered Heath.}

A fmall thrub of two feet growth-the leaves (Swall, long) by fives, and fpreading; with flowers cylindric, numerous, purple- with fimple bifid anthera. -Native of England, Fronce, and the Eaft. (Any common foil.)

\section{ERICA Tetralix-(Tetralix) or Four-leaved Red Heath.}

A fmall under-fhrub-the leaves ( $\mathrm{mall}$ ) awl-fhape, ciliated, or hair-edged, placed by fours, fpreading; and flowers (dark-red) fub-globofe, crouded, longer than the leaves, with anthera two-horned, included.Native of the northern parts of Europe, in marthy places. (Moift, or any foil.)

\section{ER1CA trifiora, Three-flowered African Heath.}

A fmall fhrub-the leaves (frall) growing by threes, flowers fab-globofe, fomewhat hairy, placed by threes together, peduncles or flower-ftalks threeleaved, and with bifid anthera, inciuded.-Native of Ethiopia. (Warm, dry frtuation.)

The three following, which, like the foregning, are fmall frubby ever-greens, are alfo fometumes introduced among the hardy Ericas, but fhould have a warm fheltered fituation.

\section{ER1CA mediterranea, Mediterranean Purplc Yeath.}

8. Erica aufralis, Southern Heath.

9. Eric a longifora, Long-flowered Heath.

All thefe fpecies of ERICA are admitted in Thrubberies, flower-borders, and other compartments of the pleafure-ground, for variety and ornament, both as fmall hrubby ever-greens, and feveral of themalfo are very pretty iittle flowering thrubs, of very ornamental appearance in fummer, in their fmall but numerous flowers; wiil all fucceed in any common foil, but generally allot the laft four forts a warm fheltered fituation; or fome alfo plasted in pots to move under helter of a frame or green-houfe in winter: may be fupplied with inoft or all the forts at the nurferies for planting, which may be performed in autumn or in any of the fpring months, affigning them places in fome principal compartments and front fituation confpi- 
confricuous to fight, $\cdots$ where they may not be overipread by larger $\therefore$.

They re propag:ıed by off-fet bottom fuckers from the roots, and occafionaliy by layers and feed; the fuckers may be detacied in autumn or fpring, and planted in a nurfery till they acquire a little ftrength for the Mrubbery, or fome planted therein at once to remain: layers and cuttings in the fpring will be rooted by the following autumn; or cuttings or llips of any principal forts planted in pots in the fpring, and plunged in a hot-bed, or corered clofe with a hand-glars, it will forward their rooting fooner.

Or where feeds can be obrained, they may be fowed in the fpring, in a bed of light earth; and when the plants are come up, and advanced a few inches in growth, thould be tranfplanted in nurfery-beds, or fome of the tendereff forts planted in pots, to move under thelter in winter.

When the plants, raifed by either of the above methods, are of one or two feet growth, they may be tranfplanted in the places where intended.

EUONYMUS-(Euonymus) or SPINDLE TREE. Clars and Order.

Pentandria Monogynia, Five Males, One Female;

Or Plants with Hermaphrodite Flowers, having five Stamina or Males, asd one Pifillum or Female.

THE EUONYMUS comprife two principal fpecies, confifting of a large deciduous flowering-hrub, or fmall tree, and an ever-green of middling growth, with feveral varieties of the former, and one of the latter; all employed in the fhrubbery plantations for variety and ornament; are of upright branchy growth, garnifhed with oblong-ovate, and fpear-Thape leaves; and fpreading whitioh flowers, in clufters and fingly; having in each flower a monophyllous or one-leaved cup, four or five-parted, a corolla of four or five oval fpreading petals, five ftamina and one piftillum; and the germen grows a quadrangular and pentangular fucculent capfule, of five loculi or cells, furnithed with red berry-like feeds; the capfules, when ripe, opening naturally and difclofe the feeds, ripening in autumn; and by which, and by layers and cuttings, the fpecies are propagated.

\section{The Species of EUONYMUS are,}

\section{Euonymus europeus, European, or Common Spindle Tree.}

A large deciduous thrub, or fmall tree, growing twelve to fifteen feet high-the leaves (moderate fize) oblong-ovate, and white flowers moftly quadrifid or cut. into four parts; fucceeded by four-cornered feed-pods, opening when ripe, and difclofe the red, granulous feed.-Native of England and moft parts of Europe, in hedges, \&c. (Any common foil.)

\author{
Varieties.-(-tenuifolins) or Small-leaved Common \\ Spindle Trec. \\ (一latifolius) or Broad-leaved Common \\ Spindle Tree. \\ Striped-lcaved Common Spindle Tree. \\ Red-feeded Common Spindle Tree. \\ Pale Red-feeded \\ White-feeded Spindle Tres.
}

\section{Euonymus americana, American Ever-green Spindle Tree.}

A middling fize ever-green thrub, growing fix or cight feet high-the leaves fpear-Thape, (middling $f i z e)$ and all the flowers quinquefid or five-parted.Native of Virginia. (Any common foil.)

Variety.-Striped-leaved Ever-green Spindle Tree.

Thefe fhrubs are adapted to affemble in any common fhrubbery compartments and other decorative plantations, in pleafure-grounds, both as fluweringThrubs; and the firft fpeciesalfo for the curious fingularity of its feed-pods, opening naturally, and difplay the red, granulous feeds very ornamentally in autumn, and great part of winter; and the fecond fort is a Thewy ever-green thrub, to increafe the variety in compartments of that tribe, or where it may be required; are all very hardy, will grow in any common foil and fituation, and are eafily raifed by feed, layers, and cuttings.

They are cultivated in all the nurferies for fale, in which they may be had, of proper growth for planting, in autumn or fpring, or any time in open weather, from Odtober to March.

To propagate or raife fupplies of thefe hrubs, it is effected by feed, layers, and cuttings, as before intimated. Sow the feed in autumn or fpring, in a bed of common earth, and covered in about an inch deep; and when the plants are one or two years old, plant them into the nurfery to obtain proper growth for final tranfplanting in Thrubberies, or where they may be defigned: layers of the lower thoots and branches, in autumn or fpring, will root in one fummer, to plant off in the proper feafon following; and cuttings of the young thoots planted in a thady border, will alfo emit roots and grow.

In the different methods of propagation, when the plants advance in growth, prune thems up a little be- 
Jow, from low ftraggling branches, to have them form full heads above; and when they are advanced from two or three, to four or five feet high, they are proper for the firubbery, \&c.

They may be planted in autumn or fpring, or any timc in mild weather, from October or Novcmber, to March or April.

FAGUS, BEECH TREE, and CHESNUT.

$$
\text { Class and Order. }
$$

Monoecia Polyandria,

Or Male and Female Flowers, feparate, on one and the fame Plant; and the Male Flowers baving many Stamina.

THIS Genus comprife three fpecies and feveral varieties, all of the deciduous tree kind, of large, lofty, moderate, and fmall growth; confinting of foreit, fruit, and ornamental trees; fome growing fixty, to feventy or eighty feet high, or more; others not exceeding fifteen or twenty feet: adorned in fummer with large oval and fpear-hiape fimple leaves; and fmall male and female apetalcus flowers apart on the fame tree, collected in globular and cylindric amentums or catkins, each flcwer having a four or five-parted calyx, no corolla or petals; the male flowers having many ftamina, and the fimales three ftyles; and in the female fowcrs the germen grows a large roundifh echinated prickly cariule, furnithed with two or more nuts, fmall in the Beech, in the Chefnut large, with eatable kernels, ripening in autumn; and by which the trees are prircipally raifd or propagated, alfo any particuiar varieties, by layers, or, occafionally, by budding and grafting.

\section{The Species of FAGUS are,}

\section{Fagus fylvatica, Wood or Common Beech Tree.}

A large, lofty, deciduous tree, of ftraight haרdfome growth, fixty or feventy, to eighty fect high, or more - the lcaves (middling) ovate, nlightly fawed, and roundifh amentums of fiovers, fucceeded in the females by triangular nuts, callcd Beech-Maft.-Native of England, other parts cf Europe, and of $\mathrm{Ca}-$ nada. (Chalky, feny, or any common foil.)

\section{Varieties.-Yellow-Itriped-leaved Becch Tree. White-ftriped-leaved Beech Trae. American Purple-leaved Beech Tree.}

\section{FAcus Caftanea-(Caftanea) or Chefnut Tree.}

A large, lofty deciduous tree, growing fifty or fixty feet high, with a noble fpreading head-the leaves (large, ßining green) (pear-fhape, pointedfawed, naked underneats; and flowers in longith amentums, fucceeded in the females by large prickly capfules, containing two or three roundifh nuts, with eatable kernels. - Native of Spain, Italy, and other fouthern parts of Europe. (Dry, or any common joil.)

Farieties.-Cultivated or large Sveet-kernelled Common Spanith Chefnut.

Wild or fmaller Cheinut.

Gold Striped-leaved Chefnut Tree.

\section{Fagus pumila, Dwarf American Chefnut Tree, or Chinquepin.}

A fmall, deciduous tree, growing ten, to fifteen or tiventy feet high-the leaves (middling) fpear-Thapeovate, acutely fawed, hoary on the under-fide; and the female flowers fucceeded by clufters of round prickly capfules, containing fmall nuts fingly, having fweet eatable kernels. - Native of North America. (Moift, or any foil.)

Thefe three fpecies of $\mathrm{F}_{\mathrm{AG}} \mathrm{US}$, and their refpective varieties, have great merit, as ufeful and ornamental trees, to difpofe in all principal large plantations, in extenfive pleafure-grounds, parks, \&c. but of which the Beech and Common Chefnut taave confraerable merit to cultivate as moft valuable foref or timber-trees, they growing to a lofty ftupendous ftature, with a ftem of great magnitude; the timber firong and durable, of fuperior worth in many ufeful occafions in which fubftance and ftrength is required, as alfo to cultivate in under-wood, in coppices, to cut for poles, and other fnall or lightpurpofes; likewife, the trees, being of handfome growth, are of great elimation to afemble in large, pleafurable cecidjous plastitions, in groves, thickets, woods, clumps, \&ce. and the Chefnut Tree in particular, growing with a boautiful fpreading head and molt ample foiiaze, forms a delightful umbragc in fummer, is yeculiarly adarted to arrange in avenues, or in forming grand hady walks and groves; and is likewife valuable to plant as a fruit trec, in parks, alid on the boundarics of crchards, and in avenues in any out-grounds, or where converient, in any open fituation; they, whrn advanced of fome confiderable growth, will produce flentifui crops of nuts, which, in fuvourable jeafons, ripcn, in tolerable perfcetion, in autumn.

The Fagus pumila, or Dwarf Chefnut, being of fmall growth, is cmployed principally to alfitt in contpofing large fhrubberies and other decorative plantations, in pleafure-grounds, in affembiagc with other deciduous trecs and thrubs.

And the Bech Tree, befides its utility for the beforc-menticned purpofcs, was formerly in much eftimation for ornamental garden hic djes, and hedges 
for Shelter, thade, \&-c. as, in its freft growth, it branches out thickly from the fides quite to the bottom, and, with proper cutting, is readily formed into clofe handiome hedges of any height required, fix, eight, or ten, to fifteen feet high, or more.

All the fpecies of Fazus being of the deciduous kind, expanding their lcaves only in fummer, thould afiemble principally in plantations of the fame tribe of trees, or fome occaficmally in dininet plantations of the reffective forts, efpecrally of the Beech and Common Chefnut, in finaller or larger compartments, in groves, clumps, \&c.

The different fpecies of thefe trees in their general growth and foliage in fummer, make an agreeable variety in plantations; and the tree:, when of advanced growth, flower in April, May, and June, in the different forts, but the flowers are not confpicuous; they grow in amentums and roundin heads, which, in the Beech, are fucceeded by plenty of fmall triangular nuts, falling from the captules in autumn, when they may be gathered up, as many as wanted, for fowing; and where they are produced in abundance, are excellent for feeding and fattening fwine, and the larger forts of poultry; and in the Chefnut and Chinquepin, the fruit being produced in large, round, prickly capfules, thefe, when ripe, open and difclofe the nuts, having brown menbraneous fhells, filled with a tender fweet kernel, which, in the Chefnut in particular, often ripens abundantly in fome tolerable perfection in September, in warm diy autumns, and of which may felect a quantity of the largeft and bett-ripened to preferve for eating in winter; though they feldom ripen with equal goodnefs of flavor as thofe which are annually imported from Spain and Portugal.

The trees of all the forts are hardy to grow in any fituation, and will profper in almoft any common foil.

To cultivate for foreft or timber-trees, the Beech and Common Cheinut thould be admitted as principal forts, both in affemblage with other trees, and occafionally in diftinet plantations of thefe kinds feparately; and in either of which the plantations may be formed both of young plants previoufly raifed in a nurfery, two or three to four, five, or fix feet growth, and planted five or fix to eight, ten, or fifteen feet diftance; and occafionally by the feed or nuts, fowed in the places where the trees are to remain, the ground being plowed and harrowed, and drills formed four to five or fix feet afunder, and three inches deep, fowing the nuts in the drills, and earthed over; and in the advanced growth of the young trees, fome may be tranfplanted elfewhere, or when of larger fize, fome cut down in a thinning order for poles, \&c. leaving abundance of the ftrongeft fingly, to run for large ftandards for timber.
The Chefnut, when defigned to have any as fruittrees for their production of nuts, may be planted in orchards, farks, hedge-rows, and in avenues, at thirty or forty feet diftance ; or fome dotted fingly, or in fmall clumps on extenfive lawns, and other open fpaces of grafs ground, and all permittcd to branch out in full heads, mottly in their natural order.

Proper trees of all the forts for planting, in any plantations intended, may be had in eligible fupplies at the public nurferies, of three or four to fix, eight or ten feet growth, to plant in altumn or fpring; or where large fupplies of the Beech and Chefnut are required for confiderable plantations in woods for timbertrees, they may be raifed abundantly in home nurferies for that occafion, by fowing the mait and nuts in autumn or foring, raifing the trees three or four to five or fix feet for final planting.

The general feafon for planting thefe trees, is either in the autumn, at the decay of the leaves, or in the fpring months, or performed, occafionally, any time in open weather, from Oetober or November till the latter end of March.

The propagation or method of raifing all the fpecies of Fagus is principally by the feed or nuts, and by which, fowed in autumn and fpring, the trees may be raifed with great facility and abundance; and will advance in a free growth; or any particular or defirable varieties of the Beech and Common Chefnut, are propagated by layers, graf́ting and budding, to have them continued permanent in their refpective properties with greater certainty than by feed.

However, to raife the common fpecies, being provided with proper fupplies of Beech-mait and nuts, in autumn or fpring, the former may be fowed in autumn, about October or November, or in winter, in open weather, or in any of the fpring months, in beds of common light earth, and covered in two inches deep, as directed below for the Chefnuts; but thefe latter, and the Chinquepin Nuts, will be molt advifeable to fow principally in the fpring, about February or March, they being preferved found till that time; when they fhould be fowed either in drilis two inches deep; or the earth raked off the bed that depth, fow the nuts on the furface moderately thin, prefs them down gently into the earth with the back of the fpade, then, with the earth raked off, cover them in regularly; they will all germinate freely in the fpring, come up in that feafon, or early part of fummer, when keep them clear from weeds; and when the young trees are of one or two fummr's growth, they muft be tranfplanted in autumn or fpring, into the nurfery, in rows two or three feet afunder; in which, train'each with a clean iningle ftem, by pruning up lateral thoots below gradually, as the plants advance in growth, preferving the top-fhnots entire, and always the main leader to afpire in height 
as fait as poffible in full growth, and having attained three or four to five, fix, eight or ten feet ftature, they are proper for final tranfplanting in the intended plantations.

Likewife by layers of the lower young thoots, any particular forts may alfo be propagated: they will root in one feafon for planting off in autumn or fpring following.

Alfo by grafting or budding any defirable varieties upon feedling-ftocks of their refpective fpecies, is a certain method whereby to propagate them permanent in their particular kinds.

When defigned to make plantations of the Common Beech and Chefnut in woods, for foreft or timber-trees, it is advifeable to plant them while of moderately young growth, of three or four to five or fix feet, or not exceeding eight or ten; and the planting may be performed any time in open weather, from the fall of the leaf in October or November to March, in whicn fome may be planted in clofe rows of five or fix feet diftance to admit of having fome in coppice-lvood, to cut occafionally, when of fome advanced growth, in a thinning order for poles, \&c. as formerly obferved, leaving a fufficiency of the moft promifing trees, at ten to fifteen feet, to grow up for timber ftandards; others may be planted at once.at proper diftances, of ten to fifteen feet, to remain wholly for ftandards to acquile a large growth before any are felled for timber; generally obferving, in the advancing growth of thofe defigned for large trees, it is advifeable to keep them to clean ftems, by fruning up the lateral and underbranches by degrees, in order to encourage their running up more expeditioufly and ftraight.

In planting any of thefe trees for ornament, they may generally be difpofed in affemblage with other tree kinds, in forming any large plantations in pleafure-grounds, parks, groves, thickets, clumps, \&c. or fome planted to form Beech and Chefnut compartments difinet; and in their advancing growth, prune up the lateral and fraggling under-branches, and permitted to brancl out above in full heads, or in which may reduce any confiderable irregularity that may cafually occur.

\section{Ficus, FIG TREE.}

\section{Clars and Order.}

\section{Polygamia Trioecia, Many Marriages, Three Habitations;}

Or with Flowers of diffrent Sexes, as Male, Fenale, and Androgynous, upon three feparate Trees.

THE FIcus furnithes but one hardy fpecies, an eminent fruit-tree, which affords many fine varietics of the fruit; is a deciduous tree of moderate growth, with large, palmated leaves; and with flowers male, female, and androgynous, on three diftinct trees, all wholly concealed within the common receptacle, or outer cover, which appears firft like a fmall, round, green bud, arifing from the fides of the young thoots, enlarging by degrees, forming a fort of general cover, inclofing, in a concealed marner, numerous, minute chaffy horets, without petals, lining, as it were, the internal furface thereof, having in each male floret three ftamina, and the females two piftillums; and the faid general receptacle, or cover, and the contained flowers, \&c. become the fruit gradually increafing to a large fize, attaining maturity in autumn, full of a foft pulpy fubftance, ripening, tender, delicious, and rich for eating, in Auguft and September; fome roundifh others top and pear-fhape, and full of large feeds, not always ripening in good perfection in this country for fowing, but the feveral varieties of the trees propagate freely by fuckers, layers, and cuttings.

\section{Only one hardy Species of FICUS, viz.}

\section{Ficus Carica-(Carica) or Common Fig Tree.}

A moderate deciduous tree, growing ten to fifteen or twenty feet, producing large, long, fucculent fhoots-the leaves (large) palmated or hand-thape, cut into three or five lobes; and fruit-buds at the fides of the young fhoots in the fpring.-Native of the fouthern warm parts of Europe and Afia. (Rich, loamy, or any good garden earth.)

\section{Varieties.-Common Fig Tree. Dwarf Fig Tree.}

\section{Many Varieties of the Fruit, viz.}

Early white Fig-a fmall, roundin fruit, flatted at the top, ripening of a whitifh yellow colour, for eating, in Auguft.

Early blue or purple Fig-a middlingfize, longih, pear-Shape fruit, ripening of a blueifh or purple colour, for eating, beginning or middle of Aaguft.

L'arge common blue Fig-a large, longith, pear-thape fruit, ripening of a dark-blucifh purple colour, for eat. ing, the end of Auguft and in September.

Brown Ifchia Fig - a large, thortifh, globular fruit, ripening brown or chefnut colour without, purple within: ripe beginning and middle of Auguft.

Elack Ifchin Fig-a middle-fize, thort, roundith-top-thape fruit, almo!t black when ripe, but red within; ripening in Auguft. 
White Genoa Fig-alarge, fhortifh, globular, or fomewhat top-Thape fruit, ripening of a whitifh-yellow without, red within; ripe in Auguft and September.

Black Genoi Fig - a largith, long fruit, ripening of a dark-purple colour, or almoft black, covered with a purple farina, bright red within; ripe the beginning or middle of $\mathrm{Au}$ guit.

Malta Fig-a fmall, hort fruit, flat at top, ripening of a brownith colour without, andpurplifh-browninternally; ripe in Auguft and September.

Green Ifchia Fig-a moderate fize, oblongifh fruit, globular at the crown, ripening greenih without, purple within, end of Augut and in September.

B rown Naples Fig-a large globular fruit, ripening of a lightifh brown colour, marked with white, and purpiifh-brown within ; ripe end of Auguft and in September.

Long brown Naples Fig-a largith, long fruit, ripening of a dark brown, - reddih within; ripe in September.

Small brown Ifchia Fig-a fmall pearthape fruit, ripening of a lightifhbrown without, the pulp fomewhat purple; ripe middle or latter end of September.

Madonna, or Brunfwick Fig-a large, long, pear-fhape fruit, ripening of a brown colour without, and a lightinh-brown pulp; ripe end of Augutt and in September.

Yellow Ifchia Fig-a large, long, pyriform fruit, ripening yellow without, the infide purple; ripe in September.

Black Provence Fig-a large fruit, ri, pening of a blackifh-purple colour, for eating, end of Augult and in September.

Thcfe are the principal varieties of Figs the moft general known in the Britifh gardens, though these are feveral others occafionally cultivated, but the forts above defcribed are fuch as will moftly ripen in perfection, and the trees, in mont of the varieties, produce plentiful crops; however, there are but few gardens which are furnilhed with all the forts here mentioned; and in the greater part the Common Blue and the White Figs are the forts principally cultivated for the general fupply, as they more commonly produce the moft abundant crops, ripening in full maturi. $y$; but where there is plenty of garden-room, it is proper to have feveral different varieties, efpecially where there is fome confiderable extent of walling, as they generally require to be trained as wall-trees, againft walls of a fouth afpect, full to the fun, in order to obtain the fruit in the beft perfection; or feveral forts will alfo produce tolerable crops of fruit on efpaliers, plantcd in a theltered, funny expofure, as likewife on ftandards, in fimilar fituations.

The trees of all the varieties will profper in any common foil of a garden; or where the ground is loamy, it generally promotes plentiful crops of large fruit; however, all the forts may be planted in any tolerably-good ground that the garden affords, or in common with other fruit-trees, both againft walls, and fome in efpaliers and ftandards, as above intimated.

But, for the general fupply, it is proper to allot a principal portion in wall-trees, planted in borders againft fouth walls, both to obtain the fruit earlier in all poffible perfection, and that the trees may have better protection in winter from feverc froft, which, as the young fhoots are fucculent, is apt to kill many of them where detached and full expofed ; and even thofe trained clofe to walls are alfo fometimes greatly damaged in rigorous winters, when not covered with mats, or the branches un-nailed, tied together in fmall bundles, faftened down low to takes, and covered with fraw; for, as the Fig trees bear only upon the young thoots of the preceding year, if thefe are greatly injured by the froft, the production of fruit will be proportionably lefs.

All the varieties of Fig trees produce the fruit alviays upon the young fhoots of a yearold, the fruitbuds arifing principally on the upper parts of the faid fhoots, and likewife the young thoots of the fame year yield a fecondary production of fruit in fummer and autumn; but thefe never or rarely acquire any tolerable perfection in this country, as may be obferved by their remaining of a green inmature ftate upon the fhoots in winter, after the leavęs are fallen, and hould generally be then pulled off, and to depend only on the fpring producion arifing on the fhoots of the laft year, for the principal crop ripening in full maturity ; and therefore, in thofe trained in wall-trees and efpaliers, requiring a regulation of pruning and training every fummer and winter, a general fupply of the young hoots of each year muft be retained in all parts of the trees for bearing, and fome proportionable part of the old cut out in the winter-pruning, to give room for training the fucceffional fupply of the young bearing wood to produce the Figs next fummer, as the fame individual hoots never bear but once, though they produce others, as likewife the older branches, for future bearers, and thofe produced one year bear the fruit the year following; and thus the fuccelfion of bearing wood is continued. annually; the fruit being 
entitted in fpring immediately from the eyes of the fhoots, gradually increafes in volume till Auguft and September, then ripening of a white, blueith, purple, black and brown colour, as in the defcription of the different varieties.

As the Fig tree furnifhes many varieties in regard to the different-forts of the fruit, proper trees of the defired kinds for planting may be had at noft of the nurferies, either young or of a trained growth, to conmence immediate bearers; or may be expeditioufly raifed by fuckers, layers, cuttings, and either planted at once in young growth, where they are to remain, or trained in a nurfery for two or three years, till furuifhed with a tolerable head of branches, then traniplanted in the garden.

The feafon for planting Fig trees is principally either in autumn, about Oetober or November, at the decay of the leaves, or in February, March, or beginning of April ; or may alfo be occafionally planted in any of the winter months in open, mild weather.

In planing Fig trees, it muit be obferved, that as they are originally exotics, from fouthern, warm counties, they in this require warm fituations in the full fun, to have them produce fruit in good perfection; fo thould be prircipally planted as wall-trees, againft fouth walls, and fome on thofe of fouth-eaft and weft afpects, but mofly full fouth walls for the principal fupply; for although the trees will grow any where, they will not ripen fruit effeEtualiy, unlafs they have the advantage of warm, funny expofures; they may likewife be planted in efpaliers, in fimilar aipects, in the full fun, to promote good crops of fruit; and in all of which, for wall-trees and efpaliers, fhould be planted fifteen or eighteen to twenty feet diftance, to have good fcope to extend the branches, at their full growth, and thefe arranged to the wall, \&c. horizontally, five or fix, to eight or ten inches afunder, with the fhoots always extended at their whole length; and the trees will requirc a regulation of prening and nailing every fummer and winter, when obferve always to referve a general fupply of the young thoots of cach year at the above diftances, for fucceflive bearers, as formerly intimated; and, at the fame time, in winterpruning particularly, to cut out a proportionate part of the old bearcrs and long-extended, naked, old branches, to afford proper fcope to arrange the fucceffion-bearing thoots, which, as before obferved, muft never be fhortened in thefe trees, as the thoots mofly bear towards the upper parts; that, if fhortened, it would deftroy thofe parts lefs or more on which the fruit is principally produced, and force out from the lower eyes a confiderable fuperfluity of ufelefs wood in fummer; and thercfore, generally, both in the fummer and winter-pruning, lct the moots neceffary to retain for trainirig to the wall, \&sc. remain entire, unlefs any have the top parts injured by frolt in winter, when may prune them down to the live wood; but all the others train in at their natural length.

But as Figs will alfo fucceed in ftandards, efpecially' the white and blue forts of the earlieft ripeners, and which being trained in dwarf or half-ftandards, with ftems of one or two, to three, four, or five feet, branching out above in full heads, they may be planted in a warm fituation, expofed to the fun; and they will often produce tolerably good crops of Figs, ripe, for eating, in Auguft and Sepember.

Having thus far given the general intimations relative to the fpecies and different varieties of the Fig, with their nature of growth, order of bearing, diffe: rent methods of propagation, planting and training. thall now proceed to explain the particulars of culture.

Firit, with refpect to the methods of propagating and raifing Fig trees, all the varieties propagate freely by fuckers, layers, and cuttings; though the two latter methods are generally preferred to the former, as the fuckers from the roots are ofien lefs compact and firm than the thoots produced above on the branches, more fucculent, and liable to injury from froft, and difpofed to run more to fuekers and fuperfluous wood than the trees as are raifed from layers and cuttings of the branch fhoots; however, good trees are occafionally raifed by all the above methods.

The feafon for performing the propagation in the different methods, is either in autumn, at the fall of the leaf, or in any of the fpring montlis.

Suckers from the roots of the trees are proper to detach for planting when of one fummer's growth, taken off either in autumn or fpring following, dig.ging them up with as much root as polfible; and of which, chufe the ftrongeft, robuft and firm, rejecting long, flender, foft fhoots, and planted either in rows in a nurfery, in order to be trained of proper growth for tranfplanting in the garden; or fome may be planted at once where they are to remain, efpecially thofe defigned for walls and efpaliers; and, for which they Thould be topped in the fpring to promote their thooting out below for a fupply of lateral branches, advancing immediately from or near the bottom, to furnifh the wall, in a proper expanfion, regularly from the bottom aforefaid, upward; but thofe defigncd for ftandards thould not be topped, but permitted to run with a fingle ftem, two, three, to four or five feet, then encouraged to branch out above, and form a full head.

Layers of the young fhoots and branches, in autumn or fpring, will be rooted in onc year; for which chufe ftrong, robuft, compact, firm thoots, of a year or one fummer's growth, fituated on fome of the lower 
pliant branches, or occafionally young branches of two or three years old, furnifhed with a terminal fhoot; and to perform the laying, bow down the thoots or branches, opening an oblong cavity in the earth, lay the item or body of the branch, or thoot therein three or four, to five or fix inches deep, pegged down and earthed over, raifing the top of each layer feveral iuches to a foot above ground, not hortened, but preferved intire, they will be properly rooted by the following October, when, or in November or fpring, may be feparated from parent tree or flool, witl good roots, and planted either in a nurfery for one, two, or three years, to increafe in growth, and acquire a head of branches; or fome of the ftrongelt may be planted at once in the places where they are to continue; efpecially for wall and efpalier trees, and in either methods train them as advifed for the fucker-raifed trees, to have them for walls, efpaliers, and ftandards, or either of which, as recuired.

And cuttings of nloots in autumn, or early in fpring, will root well in one fummer; chufe, for this occafion, fome robult, fhort-jointed thoots, of well-ripened firm growtl, which cut off at their full length; or alfo, where convenient, may take off an inch or two of the former years wood, adhering at the bottonis of the cutting; though this is not abfolutely neceffary, cnly as it may readily occur; preferving each cutiing Intire at top; fo plant them in a thady border, inferted fix or eight inches into the ground, in rows a foot or eighteen inches diftance : they will be rooted by the end of the following autumn, when, or in fpring, they may be tranfplanted either into a nurfery, at wider diftances, to train of proper growth, for walls, efpaliers, or fandards, as obferved of the others, or planted at cnce, for wall-trees, where they are to remain.

In the above different methods of raifing Fig trees, train them for the purpores intended, either principally for wall-trees, in which they may be topped in the fpring to make them emit lateral fhoots, to form a proper fpread from the beginning, to furnith a regular expanfion of buanches from the bottom upward, as before intimated; and after being thus formed in the firft fetting off, all the after-hoots that are wellplaced may be continued intire, cutting off fore-rights, and others as are ill-placed, for training, and train in the regular fupply of branches horizontally to the wall at their full length: the fame method hould alfo be obferved in thofe trees defigned for efpaliers; but for flandards, run up the main thoot for a ftem, two or three, to four, five or fix feet, cutting away all laterals till advanced to thofe heights, then permitted to branch out at top to form the head, branching out all round; and of which prune cafual irregular-growing, or crofs-placed branches, and permit the otlier general branches to advance in their natural growth.
The planting of Fig trees, either for walls, efpaliers, or ftandards, Thould generally be performed while they are of moderately young growth, of three or four, to five or fix feet extent, or but little more, as thefe trees do not, like feveral others of the fruittree kind, fucceed well when tranfplanted of any confiderable large fize; or where finally planted, when young, immediately in fuckers, or rooted layers and cuttings of one or two years old, they commonly fooner eftablifh their roots more effectually, and make profperous trees.

To plant them for wall-trees, allot fouth walls, as before obferved, for the principal fupply; and fome may be planted on eaft and weft walls, or alfo in efpaliers; and, in all of which, planted at fifteen or eighteen, to twenty feet diftance; or if planted twenty, a. leaft, afunder, their extending branches will compleatly fill that fpace, which, according as they advance, arrange horizontally to the wall and efpalier, five, fix, or eight inches afunder, increafing the number of branches annually and trained in at the above diftances, one above another, till they cover the wall, \&c. in a regular expanfion, generally extending the fhoots and branches at their whole length; that is, not to horten the ends of the thoots, for the reafons before explained.

For ftandard Figs, fome trees may be planted in a warm fituation, at twenty or thirty feet diftance, and the heads permitted to branch out all round nearly in their natural order, except, occafionally, to prune out any crouding or ill-growing branches; and when the tops of the fhoots, or others, are wholly killed by the rigours of froft, prune them in the fpring, down to the live wood.

The wall and efpalier Fig trees will require a fummer and winter pruning and training every year, to continue them in eligible regularity, and abundantly fruitful.

The fummer-pruning and dreffing of Fig trees confifts of giving a regulation in the young fhoots of the fame year, in cutting out the irregular and fuperabundant, and nailing in the requifite fupply of the proper and well-placed thoots, both for increafe of branches, where neceffary, and for fuccefion bearers the year following; and this operation may be comnenced in June or July at fartheft, when the year's floots will be confiderably advanced; obferving of which, at this time, to difplace principally only the fore-rights, advancing from the front of branches, with oihers as are remarkably ill-placed for training; and being careful now to felect and retain an abundant fupply of all the fide-shoots and terminals at the end of the branches, with all other regular-placed thoots that can be polfibly trained to the wall with tolerable regularity, 
regularity, in order to have plenty to chufe from in the principsl winter pruning, both for increafe of wood, where wanted, and very abundantly for next year's bearers, in all parts of the trees; cutting out clofe all the ill-placed productions; and let the fupply of retained thoots be nailed in clofe and regular to the wall, all at their full length, never fhortened, neither in funimer or winter-pruning, in thefe trees, for the reafons before given; or in calual vacant fpaces, where additional fupplies of wood is neceffary, may pinch or prune the tops of contiguous fhoots of the year, early in June, to a few eyes or buds, to obtain laterals the fame feafon to furnifh the vacancy; but, except in this particular, continue the general hoots intire, and according as they extend in their fumnier's growth, nail them along regular, and keep the whole trained clofe, to admit the beneficial influence of the fun, air, \&cc. to promote the growth of the prefent fruit, to ripen in proper feafon with a rich flavour.

The maturity of the fruit is principally in Auguft and September, when having acquired full fize, they change from green to their refpective colours of white, blue, purple, black, \&c. become foft, the fkin, or outer cover, thin, and loofe at the end next the ftalk; and at which tokens of mature ripenefs they fhould be gathered while in good perfection.

In autumn, when the fruit is all gathered, and the leaves of the trees are fallen, in October or November, it will gencraily be obferved, thai many green fruit, quarter or half grown, remain on the branches, which being the after production in the fhoots of the year, and which never attain perfection in this country, Shou'd be puiled off, and then all the projecting fhoots fhould be nailed up clofe to the wall, that they may remain more fecure from being injured by fevere froft, to have a proper abundance, in found concition, to chufe from in winter-pruning, to train in for next year's bearers; or in rigorous fiofts, if fome principal trees are either defended with laige thick mais, or the branches un-nailed from the wall, faitened down low to ftakes, and covered thick with ftraw litter, it will more effectually protect the fhoots; but in mild weather remove all the covering.

The winter-pruning of Figs comprifes a general regulation, both in the young wood and older branclies; and which operation may be procceded in either in autumn, after the decay of the leaves, or deferred till fpring, the latter of which is rather mof advifeable, on account, that as the thoots, in their peculiar fucculent nature, are liable, in fevere winters, to be many of them killed, or greatly damaged, by the froft; and that if the trees are pruned in autumn, or beginning of winter, cutting out the fuperabundant, and leaving only what are necefrary to furnith the tree in regular order for bearers, and rigorous frofts fucceed the operacion, and kill or injure molt of the retained fhoots, there is no refouree for more that year, to make good the deficiency; but by leaving the whole till the end of winter, or early part of fpring, February, or beginning of March, there is greater chance, out of the whole, to find enough that have efcaped the depredations of the frof, for training to the wall in fufficient fupply for bearing the fruit the enfuing year in full crops.

Thus, agreeable to thefe intimations, proceeding to the opcration of winter-pruning, and in which obferve, that having advifed in fummer to lay in abundant fupplies of young wood to have plenty to chufe from in this prining, thefe will now probably require thinning more or less, cutting out the worft or moit unpromifing, leaving a fuficiency of the beft in all parts; and at the fame tine to prune out part of the old bearers and naked branches to make room for the fucceffive bearing wood, as explained be?ow in the general particulars.

Obferve, previous to this pruning, it is proper to un-nail all the young fhoots, and moit of the fmaller branches; then, proceeding to the bufine $\{$, be careful to feleet, for bearing, and occafional fupplies of wood, the molt robuft, Mort-jointed, firm thoots, of moderate length, and that are belt placed on the ficies and at the termination of the mother branches, to be left in all parts from tire bottom to the top, and utmolt extent of the tree, for training in, fix or eight inches afunder ; and from which prune away the fuperfiuous, with all weak and improper fhoots, fore-right and others ill-placed, cutting them clofe to whence they proceed or originate, logetiser with part of the former bearers, to adnit of proper room for the fucceffion fupply, as above obferved; either fome cut clean out to their origin, or others pruned cown to fome eligible young thoot fituated thereon, as it may fecm proper, according to circumftances in different parts of the tree; likewife cafual, long, naked, old branches, extencled a confiderable lewgth, and not furnifhed with lateral young wood, or that the faid wood is fit.lated principally only at the extrernity, thould be retrenched, or cut down either to the bottom, or to fome convenient lower fnoot or young branch it may fupport, this. then terminating the reduced old branch; and in the gencral pruning, always contrive every mother branch to tcrminate in a young fhoot; either naturaliy fituated at the end, or where any particular branch is extended confiderably, it may be pruned down to an eligible fhoot to remain for a leader, continuirig all the retained fhoots intire, and to be trained at their whole length to the. wall.

$\Lambda$ s foon as one tree is pruned, nail the whole regularly to the wall, arranging the fhoots and branches horizontally, fix or eight inches diftance, extended ftraight, and equaily on bothi fides of the tree. 
Where any are trained in efpaliers, they thould be managed as directed above for the wall Figs, in regard to the fummer and winter-pruning, \&c.

Early Fins are abtained by having trees planted in forcing-houfes, or hot-walls, \&ic. and forced by means of fire-heat, commencing in January or beginning of February, and continued every light and cold days all the fpring months, till the beginning or middle of May; thereby forwards the trees in fruiting, to produce ripe fruit in June and July, and fornetimes will furnifh a fecond crop ripening in September.

They may be forced along eithcr with other choice fruit-trees, as peaches, nectarines, vines, \&c. or in a feparate or dittint forcing-houfe or hot-wall, \&c. as may be convenieut.

The trees for this purpofe fhould be fuch as are trained principally in the wall-tree manner, or fome occafionally in fmall ftandards : they are planted in the borders of the forcing apartments, either in young plants, or trained trees, obtained at the nurferies, to commence bearing as foon as pofible, and may fometimes be procurediu pots, for cran!planting, with balls of earth to their zoots, or fome to continue in the pots for forcing; or the trees may be removed fuccefsfully fron the full ground: they flon!d be planted in the forcing places principally in autuinn, about October or November, placed fome in the borders torvards the back wall, and the branches trained to a light treliis-work of pofts and rails; the forcing them by fire may be commenced the laiter end of January, or beginning or midule of February; but the glaftes may be put on clofe a month or more before, to protect the fhoots from frott, and prepare the trees for forcing; in which make rivoderate fires in the furnace of the flues every evening, and fupported till nine or ten o'clock to heat the flues fufficiently, to warm the internal air till morning, when alfo make a moderate fire, and in very cold weather may be continued all day; and when the trees begin to bud, admit air, in mild, open weather, in the warmert time of the day, efpecially when funny; and as the warm feafon advances, encreafe the portion of air, by drawing open fome of the top or front glafies two or three to five or fix inches, thut clofe when cold; likewife give occafional weterings to the borders, and over the branches of the trees; fo continuing the affiftance of fire-heat, frefh air, water, \&c. till May, the Figs will fet in tolerable abundance, fwell, and begin to ripen in June or July.

Or fometimes the trees are forced by means of barkbed heat, having a long capacious pit within the forcing-houfe, in which is made the bark-bed, in January or beginning of February, to continue in conftant heat day and night; or the forcing is fometimes effected by bark-bed and fire heat together, making the fires only principally of nights or cold mornings.

\section{VEGETABLE SYSTEM}

\section{GaUlthrRIA-(GAULTHERIA)}

Clafs and Order.

\author{
Decandria Monogynia, \\ Ten Males, One Female;
}

\section{O. Flowers (Hermapbrodite) baving ten Stamina or Malcs, and one Pifillume or Female.}

THIS Genus, Gaultheria, furnithes but one fpecies, a low, trailing, under-fhrubby ever-green, having ovate leares, and fmall greenifh flowers, with a double caiys, and a monopetalous five-parted corolla, containing ten ttamina, and one piftillum, or Ifyle, fucceeded by a pentangular capfule, with many feeds, by which the plant is propagated, and by layers and cuttings.

\section{One Species, viz.}

\section{Gaultheria procumbens, Procumbent or Trailing Gaultheria.}

A fmall, trailing under-fhrub, of two or three feet growth-the leaves (finall) ovate.-Native of $\mathrm{Ca}$ nada. (Sandy, or any' common foil.)

This fmall thrub is admitted in fhrubberies for variety and ornament, may be obtained at the nurferies, and planted in autumn or fpring; and is propagated by feed, fowed in March or April; and the plants of one or two fummers growth, tranfplanted in nurferyrows, to acquire ftrength for the fhrubbery; likewife by layers and cuttings of the trailing fhoots, in autumn or fpring, will be rooted in one fummer.

\section{Genista, Divarf, or JOINTED BROOM. Clars and Order.}

$$
\begin{array}{ll}
\text { Diadelphia } & \text { Decandria, } \\
\text { Truo Bratberboods, Ten Males; }
\end{array}
$$

Or Flowers (Hermapbrodite) baving the Stamina or Males dippofed in two Sets, and in each Flower ten Stanina.

THE Genifta Family comprife eight or ten hardy fpecies of fmall deciduous flowering-ihrubs, very floriferous and ornamental for adorning the hrubbery ; are of moderate, or fmall, and flender growth, two or three to four or five feet; garnifhed in fummer with fmall ovate-lanceolate, fpear-hhape, linear, and ternate leaves in the different fpecies, and many papilionaceous yellow flowers, fingly, and in bunches at the fides and ends of the branches; having monophyllous, or one-leaved, two-lipped calyxes, a corolia of four unequal petals, confifting of an oval rellexed vexillum, or ftandard, two fhort wings, and a long: 
a long carina, or keel, and with ten ftamina in two fets, or nine joined; the other feparate, and one piftillum, fucceeded by roundirh, bilvalve, leguminous pods, containing kidney-thaped feeds, ripe in autumn, and by which the fhrubs are generally propagated, fowed in autumn or fpring.

Principal Charaflers.-Flowers hermaphrodite; having a monophyllous, or one-leaved, :ubulous, bilabiated cup, with the upper lip two, and the under three-parted; corolla or flower papilionaceous, compofed of an oval, acute, reflexed ftandard, two fhorter wings loofe, a long, erect carina, or keel, the top indented; ten ftamina in two fets, or nine joined, one feparate, crowned with fingle anthera; an oblong gcrmen, fupporting a rifing ftyle, terminated by an acute, twifted ftigma; and the germen grow's a roundi?h, fwelling pod, two-valved, with one cell, containing kidney-haped feedis.

The hardy thrubby GENISTAS are,

1. Genista fagillalis, Arrowed, Dwarf, Jointed Broom.

A fmall, under-fhrubby, herbaceous-like plant-the branches two-edged jointed, fpreading on the ground; leaves ovate-lanceolate; clofc fpikes of yellow flowers at the ends of the branches; June and July.-Native of Germany and France, in fandy fterile ground.

2. Genista tincioria, Tinctorous, or Dyers Genifta, or Common Dyers Broom.

A low Mrub, three fect high-the branches roundin, ftriated, or channel?ed, erect; and fmall, lanceolate, or fpear-fhape, fmooth leaves, with terminal, loofe fpikes of fmall yellow flowers; June, July.-Native of England and Germany.

\section{V'arieties.-Broad-leaved Dyers Broom.} Narrow-leaved Dyers Broon.

The branches of this fpecies being ufed in dying yellow, derives the name Dyers Broom.

3. Gexist a florida, Florid, Spanin Dyers Broom.

A fmail Mrub, three feet high-the branches ftriated, or channellcd-leaves ( mall) fpcar-hape, hoary-filky; flower-racems, one-ranked, with the flowers yellow; June and Jily.-Native of Spain.

4. Genista iridentaia, Tridented-leaved Genifta, or Portugal Dyers Broom.

A fma!!, low under-thrub, one to two or three feet ; -the brasshes three-fided, fomewhat jointed; leaves (finall) tricufpidate, or three-piked, and loofe ipikes of yellow flowers at the ends of the branches; June and July.-Native of Portugal.

5. Gexista anglica, Engliph Dwarf Brocm, or Petty. Whin (Little Furze.)

A low, fhrubby plant, two or th:ee feet highthe $1 \mathrm{lcm}$ s armed with fpines, fingly, flower-branches thornlefs; leaves (finall) Spear-ihape; witl yellow flowers in terminal clufters; April and May.-Native of England, \&c. on heatlis and commons.

\section{Genista candicans, Upright Montpelier Broom.}

A moderate hrub, three to four :or five feet.ligh ftem erect; the leaves (friall) ternate, or by threes, hairy underneath; peduncles or flower-Atatks latcral, moftly five-flowered and leafy, with yellow howers, fucceeded by hairy pods.- Native of Montpelier and Italy.

\section{Genista germanica, German Dwarf Broom.}

A fmall Thrub, three feet high-the ftem thorny, with the fpines compound-branching; fower-branches thornlefs, and leaves ( $\mathrm{fmall}$ ) fpear-fnape, with thort terminal fpikes of yellow Aowers, in June.-Native of Germany.

\section{Genista pilcfa, Hairy Divarf Broom.}

A fmall, decumbent, branchy fhrub, two or three fest ligh-the ftems decumbent, or declining to the ground, and fet with tubercles; leaves (finall) fpearhisape, obtufe; and terminal loofe' fpikes of fnall yellow flowers; June, July:-Native of Hungary, Germany, and Narbonne, in France.

\section{Gesista purgans, Purgant, Dwarf Montpelies Brooin.}

A fmall, low flrub, two feet high-the $f \mathrm{~cm}$ and branches armed with terminal thorris, branchcs round, ftriate, or channelled; and fmall, fpear-thape, down leaves; yellow flowers.-Native of Montpclier.

10. Genista bifpanica, Spanin, lincar-lcaved Genifta.

A moderate Anrub, four or five feet high-the branchcs armcd with thorns, with the thorns doublecompound, or doubly-branching; flower-branches thornlefs, leaves (fmail) linear and bairy; and terminal 
minal clufters of yellow flowers; May, June, \&c.Pative of Spain and Narbonne.

\section{Genista italica, Italian Genifa, or Lucca Brooin.}

All thefe fnrubby Geniftas are eligible, as floweringMrubs, for adorning fhrubbery compartments of the pleafure-ground, and are hardy to grow in moft fituations, in dry, or almof any common foil ; proper to afremble with other thrubs of fimilar, moderate, and fmall wrowth, and will effect an agreeable diverfity and ornaimental appearance in their flowering feafon, May, June, July, \&cc. and all or moft of the fpecies may be obtained at the nurferies for planting, efpecially the fir $f$ fix or feven forts; and planted in autumn or fpring, or any trine in mild open weather, from Odtober to March or Aprii ; placing them nore or lefs forward, according to their different fizes, and in diverfifed order.

They are propagated principaliy by feed, fowed in October or November, or in the fpring months, February, March, or beginning of April, on beds of light earth, either in drills or broad-caft, and cartied in an inch deep; and the young feedling-plants, when of one or two fummers growth, tranfplanted into nurfery-rows in autumn or fpring, to train for the fhrubbery, permitting them to grow with branchy heads, one to two or three feet, for finalt:anfplanting.

\section{GLEDITS1A, THREE-THORNED ACACIA.}

\section{Clars and Order.}

$$
\begin{array}{ll}
\text { Polygamia } & \text { Dioecia, } \\
\text { Many Marriages, Tro Habitations; }
\end{array}
$$

\section{Or Flowers of different Sexes, as Males, Hermapbiodite, and F tmales, on two difinet Plants.}

THE Family of Gleditfia confifts of deciduous ornamental trees of the pinnated-leaved tribe, moft defircable to introduce in all pleafureable plantations; a re of moderately-large growth, witl fpreading branches, in fome armed with frong thorns, and all adorned, in fummer, with beantiful doubly-pinnated or winged leaves, compofed each of many pair of pinnæ, or diftinct lobes, arranged along both fides of the pedicles or main footftalks; and long, cylindric, and loofe amentums, of fmall, greenifh, and purple colour, tripetalous, and five-petalled, of three different fexes, as males, hermaphrodite, and females, oin two diftinet trees, furnifhed with three and five-parted calyxes, a fmall corolla, of three to five rourndifh petals, fix famina in the males and hermaphrodite flowers, and in the latter and the females a broad germen, fupporting one ftylus; and the germen grows a large, that, legumenous peri- carpium, containing round hard feeds; and by which the trees are principally raifed, by fowing them in the fpring.

Generic Charaders.-Male, hermaphrodite, and female fowers, on two feparate trees; the males and hermaphrodite on one, and the females on the other; the males and hermaphrodite flowers produced in long. cylindric, compact amentums, having fmall three-leaved cups, three roundif-fpreading petals, fix fmall framina, longer than the petals, crowned with oblong comprefled inthera; the hermaphrodite flowers being in the end of the fame catkin, have alfo cups, petals, and ftamina, like the males, and with a germen and fylus; the female fowers, on a feparate tree, in loofe catkins, have five-leaved cups, five oblong petals, a broad germen, longer than the petals, having a reflexed ftyle, terminated by a thick ftigma; and the germen, in the hermaphrodite and female flowers, frows a large flat pod, of feveral tranfverfe partitions, each containing one roundin hard feed, furrounced by a foft pulp.

\section{'The Species and Varieties of GLEDITSIA are,}

\section{GLEDiTS1A triacantbos, Triple or Three-thorned Acacia.}

A large deciduous tree, growing thirty or forty feet high-armed with long, ftrong, triple thorns at the axillas or angles of the ftem and branches; the leaves (long, frining) pinnated or doubly-pinnated, of many pair of fmall pinnæ or lobes; greeninh flowers, and very Jong feed-pods. - Native of Virginia and other parts of North America. (Loamy, or any common foil.)

\section{Varicty. - (GLEDITS1A triacantbos monopperma) Monofpermous or Single-feeded Gledit- fia, or Water Acacia. \\ A nuiddling tree, growing thirty feet high -armed with long triple thorns; the leaves (fraller) pinnated, of many pair of fmall lobes; greenifh flowers, and oval pods, having generally but one feed. - Native of Carolina and North America. (Loamy, or any foil.)}

\section{Glebitsia inermis, Unarmed, or Thornlefs Eaftern Acacia.}

A moderate deciduous tree, growing twenty feet high-the ftem and branches without thorns; leaves (long, fplendent) doubly-pinnated, of many pair of fmall folioles; purple flowers. - Native of the Eaft. (Any common fait.)

Thefe beautiful deciduous trees merit admittance in all principal decorative plantations, in pleafure-grounds, parks, 
parks, \&c. and large Shrubbery diftricts, affembled with other ornamental trees and large fhrubs of the deciduous tribe, in which they will difplay a confpicuouflyfine variety, efpecially in fummer, when cloathed with their abundant and moft curious bi-pinnated leaves, of fome confiderable length in their compound order, in numerous lobes; and they are hardy to grow in moft fituations, delight in a deep, loamy foil, but will alfo fucceed in any tolerably good ground, or almoft any common foil, where they may be required for planting. .

They may be procured at moft of the public nurferies for planting, which may be effected in autumn, at the decay of the leaves, or any time during the winter, in mild weather, or in the fpring months, till the middle of April.

The trees are propagated principally by feed, which, in the firt and fecond forts particularly, is commonly obtained from Anerica, \&c. by the feedfmen, in the fpring; and in which feafon, about March or April, they hould be fowed in a bed of light earth, half an inch to an inch deep, giving water in dry weather; or fome may be fowed in pots, and plunged in a moderate hot-bed to lave them come up fooner, and the plants forwarder in growth; in which expofe the plants, by degrees, to the full air, giving frequent waterings in dry weather, in fummer; and in winter, thofe in pots may have fhelter of a frame, \&c. from fevere fro:t; and next fpring, in March or April, the whole, both in the beds and pots, hould be tranfplanted into nurfery-rows, a foot afunder, by fix or eight inches in the rows; and when of one or two years advanced growth, may be tranflplanted at widęr diltances, training them with clean fingle ftems, by pruning up lateral moots by degrees, pernitting them to run with full heads, to a proper fize for final tranfplanting.

When the trees raifed as above, either in private or public nurferies, are grown three or four, to five or fix feet high, they are of eligible fizes for tranfplanting in the different intended plantations, in pleafureground, fhrubberies, \&c.

\section{GLrCINE (Liquorice Vetch) KIDNEY-BEAN TREE.}

\section{Clafs and Order.}

\section{Diadelphia * Decandria, \\ Two Brotherboods, Ten Males;}

Or the Flowers (Hermaphrodite) having the Stanina, or Males, in two Sets, and in each Florver ten Males, or Stamina.

THIS Genus of Glycine furnithes one Thrubby, climbing plant, to admit as a climber in fhrubbery compartments; grows with volubilate or twining-climbing ftalks, afcending many feet high; garnifted, in fummer, with pinnated or winged leaves, and papilionaceous purple flowers in clufters, having bilabiated cups, a corolla, with hearted ftandard, ovate wings, and bent carina, ten diadelphous ftamina, one fylus; and fucceeded by oblong legumenous pods, containing kidneythape feeds, by which the plants may be raifed, alfo by layers.

\section{One Speciss, viz.}

GuYcine frutefcens, Shrubby Climbing Glycine, or Carolina Kidney-Bean Tree.

A volubilate climbing thrub, mounting, by fupport, fifteen or twenty feet high - the ftems twining-climbing, and perennial; leaves (large, ligbi-green) compleat-pinnated or winged, of many pair of lobes, terminated by an end one; bunches of purple flowers, and long cylindric pods, fomewhat refembling the Scarlet Kidney-Bean.-Native of Carolina. '(V arm fituation.)

This curions climber is proper to admit in thrubberies, and other pleafurable plantations, to increafe the variety in its climbing growth, in which it will twine round trees, poles, or any fimilar fupport, to a confiderable height, and effect a diftinguirhable diverfity and ornamental appearance in its pinnated foliage, papilionaccous flowers, and fingular feed-pods: may be obtained at moft of the nurferies, for planting in autumn or fpring; and is propagated by layers of the branches in the fame feafons, which will be rooted for planting off in the following autumn, \&c. is likewife propagated by feed from Anierica; fowed in the fpring; and in both methods, the young plants tranfplanted in a nurfery for a year or two, or more, then planted where they are to remain.

They thould be planted in a warm, dry fituation, and have fupport of poles, or placed to twine round trees, \&c.

\section{Guilandina, BONDUC, or Nickar Tree. Clafs and Order.}

Decandria Monogynia, Ten Males, One Female;

\section{Or Flowers (Hermaphrodite) baving ton Stamina, or Males, and one Piffillum, or Female.}

THIS Genus affords but one hardy fpecies, a moderate deciduous tree, for ornamental plantations; garnifhed, in fummer, with bcautiful large doubly-winged leaves; flowers having bell-fhape cups five-parted at the brim; a corolla of five fpear-Thape equal petals, inferted into the calyx; ten awl-fhape ftamina, alternately fhorter, crowned by obtufe anthera; an oblonf germen, with a flender ftylus, terninated by a fingle fligma; and the germen grows a rhomboid, fivelling. comprefted pod, including roundifh iompreffed fceds; 
by which, obtained from America, the tree is propagated, alfo by layers of the branclies, and cuttings of roots.

The hardy GUILANDINA is,

Gull ANDINA dioica, Dioicous-flowered Guilandina, or Canada Bonduc.

$\Lambda$ middling deciduous tree, growing twenty or thirty feet high-the ftem and branches without thorns; leaves (large, dark-grecn) doubly-pinnated or winged, the bafe and apex fingly-pinnated; compofed of many ovate alternate folioles. - Native of Canada, in North America. (Light, dry, or any comman foil.)

This is a defirable ornamental tree to affit in compofing principal plantations in pleafure-grounds, and in beautifying fhrubberies, in allemblage vith other deciduous kinds; and in all of which thould occupy a confpicuous fituation: is cultivated in molt of the nurferies, where it may be procured for planting; and is propagated by layers of the young branches, fometimes fuckers from the bottom, and by cuttings of the upper roots; as alfo by cutting fome of the remaining roots through in fpring, to promote their fending up thoots, and then may be tranfplanted from the main roots in autumn; and is alfo raifed by feed, fowed in the fpring months, and the plants tranfplanted in the nurfery; and when the young trees are raifed in the different methods, three or four, to five or fix feet, they are proper for the intended p!antations.

$$
\begin{gathered}
\text { HALESIA-(HALESIA.) } \\
\text { Claîs and Order. }
\end{gathered}
$$

Dodecandria Monogynia, Truelve Males, One Female;

\section{Or Plants with Hermaphrodite Flowers, having twelve Stanina and one Piftillum.}

THE HALESIa furnifhes two fpecies of large deciduous flowering-fnrubs, eligible to affemble in hrubberies, for ornament and variety: are of tall, upright growth, adorned in fummer with lanceolate and ovate fimple leaves; and campanulate or bell-fhape wilite flowers, in clufters, having each twelve ftamina and one piftillum, fucceeded by oblong quadrangular and biangular nuts, containing fingle feeds; and by which the thrubs are propagated, fowed in the fpring; likewife by layers.

\section{The Species of HALESIA are,}

- Hales1 a tetraptera, Four-winged or Quadrangularfruited Halefia, or Silver-Bell Tree.

A large deciduc is hrub, growing ten, to twelve or fifteen feet high-ihe leaves (largif) (pear-shape-

\section{VEGETABLE SYSTEM}

ovate, with the petioles or foot-ftalks glandulous; and white bell-hape flowers, fucceeded by thick, quadrangled, or four-winged fruit.-Native of Carolina. (Any common foil.)

\section{HaLEsIa diptera, Two-winged-fruited Halefia.}

A large deciduous thrub, ten or twelve fect highthe leaves (larger) ovate, with the foot-lialks fmooth, and bell-thape flowers, fucceeded by pointed twowinged fruit. - Native of Carolina. (Any commenz foil.)

Thefe two curious flowering-fhrubs are cultivated in pleafure-grounds, to adorn thrubberies and other plantations; and for which they may be had at the nurferies, for pianting in the proper feafons; and are raifed by feeds and layers: the feeds are generally obtained from America, by the feedímen; fhould be fowed in the fpring, in a fheltered bed, or border of light earth; or fome fowed in pots, in order for placing in a warm fituation till fummer, then removed to an eait or thady border, and in winter placed under theiter from frot; and the young feeding-plants transplanted in a nurfery, in the fpring; or may likewire pot fome fingly, for moving, to a place of thelter from froft, the firt winter or two, then planted in the rull ground: layers. of the young wood, in autumn or fpring, will root in. one year for planting off from the mother piants.

When the Rrubs, raifed as above, are from two or three, to four or five feet growth, they are proper for the fhrubbery, \&c.

\section{HAMAMEL1s, WITCH HAZEL. $\mathrm{Clafs}$ and Order.}

Tetrandria Digynia, Four Males, Two Females;

\section{Or Plants with Hermaphrodite Flowers, baving four} Stamina, or Males, and one Pifillum, or Female.

THERE is but one fpecies, a fmall deciduous thrub, cultivated in fhrubberies for variety; is of nender, branchy growth, garnifhed with oval rough leaves, refembling thofe of the Common Hazel; and fmall four-petalous fowers, in clufters, which lave a three or four-leaved involucrum, and to each flower, a double fix-leaved cup; the corolla, or flower, four long, narrow petals, containing four hort ftanina, with horned anthera; an oval germen, fupporting two ftyles, crowned with headed ftigmas; and the germen becomes an oval hard nut in the permanent calyx, by which the plant may, be raifed, and by layers of the young branches. 


\section{One Species, viz.}

HAMAMEL 1 s virginiana, Virginian Hazel-leaved Hamamelis, or Witch Hazel.

A moderate deciduous thrub, three or four feet high-the leaves (middling) ovate-roundin, indented on the edges, and placed alternate; and fmall clufters of flowers late in autumn.-Native of Virginia. (Moift, or any foil.)

This fhrub is introduced in thrubberies, for variety; and for which occafion, may be obtained at the nurfe ries, and planted in autumn, winter, or fpring; and is propagated by feeds and layers; the feeds commonly obtained from America, with others, in the fpring, when they may be fowed in beds or pots of common earth; they will probably not come up till the fecond fpring, and in the interim, thofe in pots may have fhelter in winter; the plants coming up in the fpring aforefaid, may be tranfplanted in autumn or fpring following, in the nurfery, and in two or three years, will be of proper growth for the Anrubbery: layers of the young branches will be rooted in one yearfor tra:lfplanting.

\section{HEDERA, IVY TREE. Clafs and Order.}

\section{Pentandria Monogynia, Five Males, One Female;}

Or Plants with Hermaphrodite Flowers, baving five Stamina, or Males, and one Pifillum, or Female.

THE HEDER A furnifhes two noted fpecies of thrubby, climbing plants; one an ever-green, the other decidcous, remarkable for their lofty, climbing growth, afending, by their rooting-ftems, upon walls; buildings, trees, \&c. fifty or fixty feet, or more; garnifhcd their whole length with lobated ovate, and fivelobed leaves, in the different fpecies; and umbellate or corymbus clufters of fmall greenifh fowers, of five petals, having five ftamina, an oval germen below, fupporting one ftylus; and are fucceeded by clufters of round berries, containing four or five feeds, ripe in autumn and winter; and by which the plants may be raifed, alfo by cuttings and layer.

Generic Charakiers.-Flowers in umbellate or corymbus bunches, furnifhed with a many-parted general involucrum, and to the flowers, a five-parted ca. lyx, fotting on the germen; a corolla or fiower, five oblong fpreading petals, with the points incurved; the ftamina five aivl-haped filaments, crosvned by proftrate anthera, two-parted at the bafe; a roundifh germen under the flower, having a hort ftyle, terminated by a fingle figma; and the germen grows a globular, unilocular berry, containing four or five large gibbous feeds.

\section{The Species of HEDERA are,}

\section{Hedera Helix-(Helix) or Common Ever-green Ivy.}

A moft lofty-climbing, Thrubby ever-green, mounting, by its rooting-ftems, forty or fifty to fixty feet high, or more-the leaves (middling, darkngreen) ovate and lobated; clufters of greenifh flowers in autumn. -Native of England, and moit parts of Europe, in woods and hedges. (Any foil and fituation.)
Varieties.-Common green Ivy.
Silver-itriped-leaved Ivy.
Gold-ftriped-leaved Ivy.
Black-berried Ivy.
Yellow-berried Poet's Ivy.
Dwarf-creeping ivy.

\section{HEDER A quinquefolia, Five-leaved deciduous Ivy, or Virginia Creeper.}

A moft lofty-climbing, deciduous Thrubby plant, afcending, by its rooting-ttems, thirty to forty or fifty feet high, or more-the leaves (middling, ligbt-green) compofed of five oval, fawed lobes, expanding in a fingered manner.-Native of Virginia, Canada, and other parts of America. (Any foil and fituation.)

There two fhrubby climbers are moft hardy and lofty growers, in their climbing nature, by their rocting ftems, emitting cirrhofe fibres into walls, bark of trees, \&c, attaching themfelves clofe thercto, and mount to the tops; fucceed in any foil, and in clofe and open expofures; and are therefore eligible to plant, as climbers, againft walls, buildings, fences, $8 \mathrm{c}$. in particular parts, where required to have them covered, or for variety; or likewife to plant againft large old trees to afcend upon their fteras; or the Ivy to plant, detaclied, in fhrubberies, and trained to ftakes, in upright - ftems and bufhy heads; or, in want of fupport, will run along the ground, root, fpread, and cover the furface; and the Hedera quinquefolia, or Virginia Creep$\mathrm{er}$, is often planted in courts, yards, areas, and in cities and towns, as frequently practifed in London, to afcend upon and cover naked walls, in which the ftem will root, and thereby mount to the tops of the higheft buildings; and for which occafion it may be planted in clofe, or open places, as it will thrive any where, in fituations where other plants will not profper.

Plants, of the different forts for planting, may be had at the nurferies, in young growth, and planted iil autun:n or fpring. 


\section{2

Or both the fpecies, and refpective varietics, may bc expeditioufly raifd, by cuttings of the rooting young thoots and branches, in autumn cr fpring; which being clit off and planted, will molt frely grow, either planted where they are defigned to remain, or in a nurfery, for a year or two, or till wanted tor the purpoies intended; they will likewife grow freely by layers; and alio the Common Ivy, furrithing plenty of ripe feed, may be raifed by fowing it in a fhady border, and the feedling-plants tranfplanted as above.

When defigned to plant thefe fhrubs as climbers, they nay be fet clofe to walls, pales, buildings, \&c. or near the ftems of large old trees, they will fhoot, and afix their rooting fibres t:erein, afcend in height, and fpread on every fide, without any future culture, except to cut out cafual dead wood; or, in particular compartments, the Common Ivy may be planted detached, and trained with an upright ftem and branchy head; or in fome places, as in the borders of thady walks, \&c. be permitted to run on the ground, and cover the furface, keeping it trimmed within proper bounds.

\section{Hibiscus (SYrian Mallow) ALTHeEA Fru- TEX, (Shrub Althaa.)}

Clars and Order. Monadelphia Polyandria,
One Brotberbood, Many Males;

Dr Plants with Flowers (Hermaphrodite) baving all the Stamina, or Males, united in one Set, and with. numerous Stamina in each Flower.

THIS Genus, Hiвiscus, furnithes one hardy, fhrubby fpecies, a large, upright, deciduous, very ornamental flowering-Mrub, growing with a regular, branchy, bufhy head; acorned in fummer with wedgefhape-lobate leaves, and numerous, large, beautiful flowers, in daily fucceftion; having double, manyparted cups, five heart-flape petals, many joined ftamina, and one ftyle, fucceeded by capfules, containing kidney-fhape feeds; by which, fowed in the fpring, the thrub is propagated; alfo by layers and cuttings of rie young thoots.

Principal Characters.-Calyx of the flower double and permanent, compofed of an outer feries of many narrow leaves, an inner, monophyllous, or one-leaved cup, cut into five acute parts, at the brim; a corolia of five broad heart-mape petals, joined at the bafe; many ftamina joined in a column below, expanding at top, and crowned with kidney-Thape anthera; a roundin germen, flender flyle, terminated by a round figma; the germen grows a five-valved capfule, of five cells, containing kidney. Thape feeds.
One Species, viz.

\section{Hrarscus fyriaca, Syrian Shrubby Hibifcus, com- monly called Althæa Frutex.}

A deciduous fhrub, of branchy growth, five to fix or feven feet high-a tree-iike ftem; the leaves (moderate) wedge-iliape-cvate, the upper parts cut-indented, fometimes three-lobed; and many large flowerswat the fides of the brarches, in July or Auguit, till September.-Native of Syria. (Ligbt, or any common foil.)

\section{Varieties.-Purple-flowered Althæa, with dark bot- toms. \\ Red and white-flowered, with dark bottoms. \\ Bright-purple-flowered, with twack bot- toms. \\ White-flowered, with purple bottoms. \\ Yellow-flowered, with dark bottoms. \\ Variegated-flowered, with dark bottoms. \\ Silver-ftriped leaved. \\ Gold-ftriped leaved.}

This is an admirable fire fowering-Thrub, to plant for ornamenting Thrubberies, and other parts of pleafure and flower-gardens; in which, when in flower, it makes a fingularly fine appearance, for a month or five weeks, and one of the fineft ornaments of the feafon; begins flowcring, fometimes the end of July, but principally in Auguft; the flowers numerous, and continue in abundant fuccefion all that month till September; and therefore, this fine fhrub deferves a principal fituation in thrubberies, and is adapted to place frngiy on plats, borders, \& c.

The different varicties are cultivated, for fale, at all nurferies, where they may be obtained in collection, or any particular variety; and plarted in autamis, or any time from Oetober or Novenber to $.1 \mathrm{arch}$, or beginning of April, or principally in tile fpring months.

They are propagated by feeds and layers, or the varieties by grafting upon feedling-ftocks, of any of the forts.

To raife them from feed, fow it in the fpring in a bed of light earth, or fome fowed in pots, and if plunged in a gentle hot-bed, it will forward the germination of the feed, and the plants will come up much fooner, when they fnould be expofed by degrees to the full air; however, they will alfo fucceed, fowed in the common ground, or in pots, to move to a fheltered place in winter, to proted the yourg plants from froft; and in fpring, in March or beginning of Apsil, tranfplant them in nurfery-rows in beds, or foune planted 
planted in pots fin ly: trin the plants with a fingle ftem below, and d manchy head above; and when two, to three or four feet nigh, are proper for the thrubbery.

Layers of the lower young fhoots, in autumn or fprirg, wili root in one year, for planting off in thefe. feafons; and by this method of propagation, any of the varieties are continued permanent in their refpective differerces.

Likewife, by grafting or budding upon feedlingftocks of any of the forts, the different varicties, are propagated, and continued the fame; and fometimes, for curiofity, different varieties are budded or grafted on branches of the fame ftock or ftem; as the two forts of ftriped-leaved kinds, and the purple and whiteflowered, \&c.

HI P POPAAE, SEA-BUCKTHORN.

Clafs and Order.

Dioecia Tetrandria,
Two Habitations, Four Males;

Or Male and Female Flowers, difinez on two feparate

Plants, and the Male Flowers baving four Stamina.

THIS Genus comprifes two large, hardy, decidaous Ahrubs, employed in Arrubberies, and any orna. inental plantations, for varicty; a re garnithed in fummer with fmall, narrow, fpear-thaped, and broader, ovate leaves; and fmall clufters of male and female flowers, feparate on two diftinct plants; have no petals, the male flower a one-leaved cup', two-parted, and contain four fhort ftamina, with oblong, angular, anthera; female has a one-leaved calyx, oblong, tubulous, bifid: at top, contains a roundifh germen, fupporting a fitort ftyle, crowned by an oblong, thick ftigma, and the germen becomes a globular, unilocular berry, with one rourdifh feed; by which the fhrubs may bc raifed, but are more commonly propagated by fuckers and layers.

The Species of HIPPOPHAE are,

3. Hi pOPAAE Rhamnoides-(Rhamnoides) or Baftard Rhamnus, or Sea-Buckthorn.

A large, deciduous Shrub, branching irregularly, eight cr ten feet high, with a brown, filvery barkthe leaves (narrors) (pear-Thape, hairy underneath; ard fmall cluftcrs of male and female flowers, fucceeded, in the latter, by ripe berries in autumn.Native of England, and other parts of Europe, neas the fea. (Sandy, or any foil.)
2. Hip POPHAE conadenfis, Canada Sea-Buckthorn.

A large, deciduous thrub, growing eight or ten feet high-the leaves (niiddling) ovate, hoary, filvery on the under fide.-Native of Canada. (Sandy, or any common foil.)

Thefe two deciduous thrubs may be admitted in large fhrubberies, and other plantations in pleafure grounds, to encreafe the variety; they may be procured at the nurieries, for planting, particularly the Rboinnoides, or Common Sea-Buckthorn; and both the forts may be planted in any fituation, in autumn or fpring: may be propagated plentifully by bottom-fuckers, ariing from the roots, and tranfplanted in a nurfery for one or two years, or more, till proper for the hrubbeiy, \&c. ox may likewife be raifed by layers; alfo by feed fowed in autumn or fpring; and when, by either methods of propagation, the piants are three, to four or five feet high, they are of proper fize for any intended plan. tations.

\section{HYDRANGEA-(HYDRANGEA.)}

Clafs and Order.

$\begin{array}{ll}\text { Decandria } & \text { Digynia, } \\ \text { Ten Males, } & \text { Two Females: }\end{array}$

Or Plants with Hermapbrodite Flowers, baving ten Stamina, or Males, and two Pifillums, or Females.

The Hydrangea comprifes but one fpecies; a low, deciduous under-Thrub, admitted in fhrubbery collections for variety; having heart-hape leaves, and terminal bunches of white fowers in cymofe umbels; the calyx of the flowers one-leaved, five-dented; corolla, five ro'ndifn petals, ten ftamina, alternately longer, crowned by roundin anthera; a roundith germen under the flower, fupporting two hort ftyles, ftanding diftant, terminated by obtufe ftigmas; and the germen becomes a roundin capfule, crowned by the permanent ftigmas, and filled with fmall angular reeds; feldom ufed for fowing, as this plant propagates plentifully by off-fet fuckers, and parting the roots.

\section{One Species, viz.}

HYDRANGEA arborefcens, Arborefcent, or Shrubby Hydiarigea.

A fmall, ander-fhrubby plant, rifing with foft ligneous ftems, two or three to four feet high-the leaves (large, light-grcent) oblong-heart-fhape, placed oppofite; and cymofe bunches of white flowers at the top of the ftems; July and Auguft,-Native of Virginia. (Any common foil.) 
This fhrub may be introduced in any frubbery compartments; it will effect a proper variety in its growth, foliage, and flowers: may be planted in autumn or foring; and is propagated by off-fet fuckers, or dividing the roots and ftems together, in autumn, or in any of the fpring months; and planted either where they are to remain, or in a nurfery, for a year or two, then rranfolanted into the fnrubbery.

\section{HYPERICUM, St. JOHN'S WORT.}

Clafs and Order.

Polyadelphia
Many Brotberboods, Many Males;

Or Plants with Flowers (Herm.) barving many Sets of united Stamina, and nany Stamina, or Males, in each Flower.

THE HYPER I C M Family comprifes fereral fpecies of deciduous flowering-Thrubs and under-Phrubby plants, for adorning the fhrubbery, rifing moftly with feveral ftems; others fingly, from two or three, to four, five, or fix feethigh; garnithed, in fummer, with fimple leares, oblong-hiped, oval, fpear, and heart-lhape in the different fpecies, mortly in oppointe pairs; and the branches terminated by numerous pentapetalous yellow flowers, in clulters; having five-parted perfiftent cups, tive oval petals; many ftamina in feveral fets; and one, three, or five Atyles, fucected by roundifh capfules, filled with numerous feeds; proper for fowing to propagate the fpecies, which are alfo raifed, plentifully, by fuckers, and dividing or flipping the reots.

Generic Cbaraztcrs. - Flowers hermaphrodite; the calyx one-leaved, divided into five oral fegments, and permanent; corolla or flower, five oblong-oval petals, fpreading open; numerous fmall ftamina, joined below in feveral bodies, terminated by fmall anthera; a roundif germen in the centre, fupporting one, three, or five ityles, as long as the ftamina, crowned by fingle ftigmas; and the germen grows a roundifh capfule, having one, to three, or five cells, according to the number of ftyles, containing many oblong feeds.

\section{The Species of HYPERICUM are,}

\section{HYPERICUM bircizum, Stinking Shrubby St. John's Wort.}

A fmall fhrtibby plant, rifing with feveral ftems, three feet high, branching at each joint-the ftems fhrubby, two-edged; leaves (moderate fze) oblong-ovate, by pairs, oppofite; and terminal clufters of yellow flowers, with the 1tamina longer than the corolla; and three ityles.-Native of Sicily, Spain, Portugal, and Creta. (Anj conmon Joil.)

\author{
Varieties. - Common Rank-fcented Shrubby St, \\ John's Wort. \\ Inodorous or Scentlefs. \\ Variegated-leaved.
}

\section{HYPERICUM Androfamum-(Androfemum) or Common Tutfan or Park Leaves.}

A fmall narubby piant, rifing with a branchy ftalk, two feet high-the ftems fhrubby, two-edged; leaves (middling) ovate-lieart-fhape, by pairs, oppofite; and terminal clufters of yellow flowers, having three ftyles, and the pericarpium, or fruit, berried.-Native of England, France, and Italy, in woods, \&c. (Moif, or ony joil.)

3. HYPER I C M olympicum, Olympian, or Eaftern, St. John's Wort.

A fmall under-fhrub, one to two or three feet high, with flender ligneous ftalks - the ftems Rrubby; leaves (Jimall) Spear-?hape, by pairs, oppofite; and largith bright-yellow flowers, terminating the ftalks in fmall clulters, having acute cups, ftamina thorter than the petals, and three ftyles.-Native of Mount Olympus and the Pyrences. (Diy, or any common foil, and warm futuation.)

\section{HYPERICUM canarienfe, Canary St. John's Wort,}

A middling fhrub, rifing with upright branchy ftem, fix or feven feet high - the ftem fhrubby; leaves (middling) oblong, by pairs; and terminal clufters of many yellow flowers, having obtufe cups, ftamina longer than the petals, and three ftyles.-Native of the $C_{a-}$ naries. (Dry, or any common foil.)

\section{Hypericum monogynum, Monogynota, or One- Ityled China Hypericum.}

A fmall fhrubby plant, two feet ligh-the ftem fhrubby, purplih ; leaves ( $/$ mall) oblong, narrow ; fmall terminal clufters of bright yellow flowers, having a coloured calyx, the ftamin longer than the corolla; and the flowers have but one ftyle. - Native of China. (Warm, dry fituation; and jome ported, to place under Belter in winter.)

All thefe fpecies of St. John's Wort are defirable. flowering - thrubs and under-Thrubby plants, for ornamenting the fhrubbery; they being all very floriferous, producing numerous yellow flowers, terminating tice branches in clufters, in May, June, July, or great. part of fummer, in the different fpecies, and appear. very confpicuous; though, in fome of the forts, the flower impart a frrong, rank, odour, particularly the Hypericunt bircinum and Canary St. John's Wort; but as the whole make a gocd appearance during the feafon: 
of their flowering, they deferve admittance in principal and general fhrubbery compartinents.

They are hardy to fucceed in any common foil and fituation, except the Hypericum monogynum, which fhould have a w'arm, fheltered fituation; and fome kept in pots, to move, under protection of a frame or greenhoufe, in winter; but all the others may be planted any where in the full ground; or generally allot the Olympian St. John's Wort a place in forne dry, warm compartment; or likewire, keep fome of that fort in pots.

All the forts may be obtained at the public nurferies, for planting in autumn or fpring; or may be saifed, plentifully, by different methods of propagation, as teed, fuckers, off-fets of roots, \&c.

The propagation, or methods of raifing thefe plants, is effected principally by fuckers, from the bottom flips of, and dividing the roots; likewife, occafionally, by cuttings, and leeds; fickers are produced from the roots in molt of the forts, but more abundantly in the firn, and Canary Hypericum, and in which, and cther forts, where fuckers occur, they may be taken up with roots in autumn and fpring, and planted either at once where they are to remain, or in a nurfery, for a year or two, ready for the fhrubbery; or any of the fmaller under-fhrubby kinds, and others, not furnining feparate fucker-fhoots, may be propagated by parting the roots; likewife by cuttings of the young hoots in the fpring; and feed fowed in the autumn or fpring months, in a bed of light carth, will grow freely, and the plants, when a year old, tranfplanted in a nurfery, or fome of the more tender forts flanted in pots, to place under thelter in winter.

When the plants, raifed by any of the above methods, are from one to two or three feet growth, according to their different dizes, they are proper for the fhrubbery.

They may be planted in hrubberies, in autumn or fpring, difporing them, according to their growtl, placing the fmaller kinds in the front part, the taller forts tationed behind, more or lefs, in proportion to their height, and the whole difpofed in a diverfified manner, in afiemblage with other deciduous floweringfrrubs, and permitted to fhoot and branch nearly in their natural order; and they will flower abundantly feveral months every fummer.

\section{JASMINUM, JASMINE TREE. Clafs and Order. Diandria Monogynia, Two Males, One F emale;}

Or Plants with Hernapbredite Florvers, baving two Stamina, or Males, a.rd one Piffillum, or Female.

THE JАรм1и Uм affords three fpccies of hardy, decialto ous flowcring-surubs, others more tender; all very ornamental in the pleafure-ground, in their numerous flowers in fummer: are moftly of trailing growth, Mooting with long, nender, flexible ftems and branches; adorned in fummer with fmall pinnated and ternate leaves; and namerous fmall, long. tubulous, white and yeliow fragrant flowers, in bunches, in June, July and Auguff; each fiower having a monophyllous cup, a corolla of one long, tubulous, five-parted petal, containing two ftamina and one flylus; fucceeded by oval berries, furnithed with two feeds, which ripen in England, but are feldom uied for fowing, as the plants propagate plentifully by layers, cuttings, and fometimes by fuckers.

Principal Cbaracters.-The flowers hermaphrodite: the calyx or cup one-leaved, tubulous, five-parted at the brim; corolla, one long, tubulous petal, divided above in five fpreading fegments; two fhort lamina, crowned by fmall anthera; a roundifh centril germen, having a flender ftyle, terminated by a bifid itigma; and the germen grows an oval berry, containing two oval and oblong feeds, one fide flat, the other convex.

\section{The hardy Species of JASMINUMS are,}

\section{JAs:11NUm officinale_-Oficinal, or Common White Jafmine.}

A deciduous thrub, growing with long, flender, Alexible ftems and hoots, extending eight or ten feet in length, or more-the leaves (fmall, dark-green) pinnated, placed oppofite, with the lobes acute-pointed; and numerous white fowers, in fmall bunches, terminating the young hoots; June, July, and Auguft. - Native of Mialabar, and other parts of the Eaft-Indies. (Any foil and fituation.)

\section{I'aricsics.-Silver-friped-leaved Common Jafinine. Gold-Atriped-leaved Common Jafmine.}

\section{JASMINUM fruticans, Shrubby Yellow Jaímine.}

A deciduous fhrub, with nender, flexible branches, of fix or eight feet growth-the branches angular; leaves (finall, dark-green) ternate or trifoliate, and fimple, placed alternate; yellow flowers, June, July, \&c. - Native of the fouth parts of Europe, and all parts of the Eart. (Any foil and fruation.)

\section{Jasminum bumile, Humble or Dwarf Italian Jaf mine.}

A fmaller deciduous thrub, with weak branches, of three or four, to five or fix feet growth-the branches angular; leaves ( $\mathrm{mall}$, dark-green) ternate and pinnated, placed alternately; and larger yellow flowcrs produced at the crids of the Moots, June, July, 
\&cc. Native of the fouth of Europe. (Dry foil, wuarm fituation.) : i :

\section{Jasninum grandiforum, Great-fowered Cata- lonian Jafmine.}

A deciduous thrub, with long flexible ftems and branches, extending eight or ten feet, or more-the leaves (larger) pinnated, placed oppofite, compofed of three pair of thort obtufe lobes, acute-pointed; and large flowers, bluth colour, and white; July, Auguit, to October, \&c. (very beautiful.)-Native of India. (Warm, dry foil, fbeltered fituation, againft a foutb wall, and jome in pots, to place in a green-bousfe.)

5. JASMINUm azoricum, or Azorian White Jafmine.

A deciduous fhrub, with long, flender frems and branches, extending ten to fifteen or twenty feet-the Jeaves (larger, frining-green) trifoliate, placed oppofite, with large heart lobes; and bunches of brightwhite flowers at the ends of the fhoots; June, July, \&cc.-Native of the Azores, in India. (Dry, warm fiturtion, againfit a foutb rvall, and in pots, to kave Belter in rinter.)

\section{JASMINUM odoratifimum, Moft-odoro:is Yellow Indian Jafmine.}

A deciduous thrub, with an upright flem and firm branches, growing eight or ten feet high-the leaves (middling, ßining-green) ternate and pinnated, placed alternately, with the lobes ovai; and bright-yellow flowers at the ends of the fhoots; July, Auguft, and September; impart a moft fweet odour.-Native of India. (A dry, warm, fituation, againft a fouth wall; and alfo in pots, to move under Belter in winter.)

Of the above five fpecies of $\mathcal{F}$ afminum, the firt three are hardy fhrubs that will moftly profper in any common foil and fituation, particularly the firft and fecond; but the third is advifeable to plant in a warm compartment, or fome planted againft a fouth wall; and the fourth, fifth, and fixth forts, are more tender, generally kept in gresen-houfe collections, in pots, and houfed in winter; but fometimes they are planted againft a fouth wall, and defended in winter, when fevere froft, with mats; likewife, the two ftriped-leaved varieties of the Common Jafmine fhould generally have a fheltered fituation, but do not require covering in wirter.

The Jafmines merit culture in pleafire-grounds and flower-gardens, as very ornamental ?owering-Shrubs, producing numerous flowers in June or July, and Auguft, of a delicare pretty appearance, and diffuie an agreeable odour; particulariy the Common White, not 10 much in the fecond and third yellow forts, but very fragant in the Azorian White, and Odorous Yellow In. dian Jafmine.

As moft of the Jafmines grow with long, flendis, declining ftems and branches, requiring fupport, they are proper to train againt walls; and for which the Common White Jafmine is moft commonly employed, as it fhoots ftronger, and confiderably more floriferous than the other two hardy kinds, which are alfo, occafionally, planted and trained againft walls: they all produce numerous long green thoots, in fummer, and on which the flowers are produced; and as the branches and hoots are of flender, declining growth, require training to fome fupport of walls, palings, buildings, \&.c. they fhould be trained thereto accordingly, four or five inches afunder, either erect, or horizontally, as the fpace of walling admits; or if required to run them in height againt high walls, or that of a houfe, they fhould be trained in an upright direction, generally training them with feveral fhoots, or ftenss, from the bottom, cutting out the fuperfluous and weak; thofe retained, may be pruned at top, to three, four, five, or fix feet, according to their ftrength, and nailed up regular, either ercct, or horizontally, as aforefaid, and kept to regular order, by pruning them annually with a knife, not clipped, but generally kept pruned in winter or fpring, cutting out the fuperabundant fhoots of the preceding fummer, to continue them to diftinet ftems, and training in occafional fupplies of the frrongelt thoots below, in vacancies, or to fupply the place of any old naked flems, to be cut out acçordingly; and by this method, they will always have a neat appearance, and flower in greater perfection.

Though, fometimes, they are only trained up in a proper fupply of thoots at firft to the wall, and afterwards the numerous, fuperabundant, and projecting ftraggling thoots of each ycar, are clipped with garden fhears; but by this method, they, in a year or two, grow into a confufed, diforderly thicket, of a difagreeable appearance.

Therefore it is advifeable to keep the branches thin and regular, by knife-pruning, training in plenty of the flrongeft young thoots in fummer, for flowering, cutting out the overabundant; and in winter, to prune out the unneceffary fhoots, with dead and any irregular, naked, old wood, and train in young.

Or Jafmines may likewife be trained in fingle ftandards, detached from walls, to plant in Thrubberies, borders, \&c. trimming them up to a fingle fiem, one, two, or three feet, and branching out at top; prune the fraggling fhoots fhort, to form buthy heads.

But in fummer-pruning Jafmines, flould not thorten the flowering-thoots, or cut off long ftragglers; and 
train in the others intire, as they flower moftly at the extremities.

All the forts of Jafnines may be had at the nurferies, for planting, or more generally the firt three fpecies, and all which may be propagated plentifully by cuttings, layers, and fuckers; and occafionally by grafting, budding, and inarching, particularly the Italian, and fome of the three tenderer forts, as the Catalonian, Azorian, and Yellow Indian Jarmine.

The planting of Jafmines may be performed in autumn or fpring ; or the common, and other hardy forts, may be planted any time in open weather, from the fall of the leaves, till March or April; but the tenderer forts only in the fpring: the Common Jafmine is often planted againit buildings, and to train againft naked walls and fences, in pleafure-grounds, fore-courts, or where required to have the walls, \&c. covered, and the plants to appear orramental in flowering, training them to the wall regularly with feveral thoots for ftems, as formerly obfervcd, proceeding from or near the bottom; the weak topi fhortened, and nailed erect or horizontally, as may feem expedient or convenient, three or four, to five or fix inches afunder; the Shrubby Italian, and Dwarf yellow forts, may alfo be planted and trained as above; likewife, all the above three forts may be planted detached in Thrubberies, borders, \&c. and irained each with a fingle ftem below, fupported with a ftake in an upright polition; and the long, ftraggling branches pruned in, more or lefs, to form a bufhy head, as before intimated; obferving, in giving occafional pruning in fummer, both in the Wall Jafmines and detached plants, not to cut all the thoots clofe, but leave plenty of the fhorter growths for flowering, as the flowers generally rife at the ends of the young fhoots of the year.

The propagating, or raifing Jafmines, is by cuttings and layers of the ftrong; young fhoots; and likewife by fuckers, efpecially the mrubby, Yellow Jafmine, and others occafionally; alfo fome forts are propagated by budding, inarching, and grafting, particularly the Dwarf Italian Jafmine and Catalonian forts, on ftocks of the common white and yellow kinds.

To propagate them by layers and cuttings; the former may be performed in autumn or fpring, in the young thoots, and cuttings planted principally in the fpring, about March or beginning of April; they will all, both layers and cuttings, be rooted in one fummer; and in autumn or fpring tranfplant them, eithes fome where they are to remain, others, or the whole, into a nurfery, for one or two years, or more, then tranfplanted to the places where they are defigned.

Suckers from the roots may be taken up in autumn or fpring, and flanted as above.
When defigned to propagate the Dwarf Italian Jafmine, by grafting or budding, or the other tenderer forts by budding or inarching, it mar: be performed upon ftocks of the common white and yellow; and, by this method of propagation, plants of thefe for ts are annually brought or fent from Italy to this country in the fpring; and, in London, are fold at the Italian warehoufes, where they may be purchafed for planting, in which it is advifeable to plant the tenderer forts, as the Catalonian, \&c. in pots, and plunged in a bark-bed to ftrike, and run them off fooner, giving water and frefh air, and expored thereto, by degrees, in fummer.

The Azorian and Yellow Indian Jafmine are alfo raifed from layers and cuttings; likewife by feed fowed in the fpring in a hot-bed.

When defigned to plant any of the tenderer Jafmines in the full ground, it hould be clofe to warm, fouth walls, their branches trained thereto; and, in winter, cover them with mats in all frofty weather; as alfo to mulch the ground over the roots.

The Common Jafmine, and others trained againft walls, will require a regulation of pruning and training every year, in fummer and winter; go over them in fummer, and with your knife prune the mott irregular, long-projecting and ftraggling thoots of the year, and train in the others to the wall, with fome degree of regularity, for flowering the fame feafon; preferving the flowering-fhoots moftly at their full length, or thorten very long ramblers; and let all the long-extending productions be kept trained in tolerably clofe order all fummer; and in winter, or rather towards the fpring, February or March, give a more general pruning, cutting out the fuperabundant thoots of laft fummer, and decayed branches, retaining requifite fupplies of the ftrongeft thoots in vacant parts, and prune off the weak tops, or upper part; and then nail the whole to the wall in a regular man. ner, agreeable to former intimations.

Or, if any are trained in ftandard Thrubs, they Thould have the long ftraggling shoots pruned, to keep the head in fome regular order.

\section{ILEX, HOLLY TREE.}

\section{Clafs and Order.}

Tetrandria Tetragynia,
Four Males, Four Females;

Or Plants with Flowers (Herm.) having four Stamina, or Males, and four Piffillums, or Females.

THE ILEX, Or HoLLY, comprife two principal hardy fpecies, of moderate tree and thrub kinds, furrifhing many fine varieties; all molt beautiful ever- 
greens, ten or fifteen to twenty or thirty feet, of regular branchy growth, adorned, all the year, with oblong-ovate, and fpear-hape, prickly-edged, and fmooth leaves; and in fumme:, hort, clofe clufters of fmall monopetalous white flowers, having one-leaved, four-parted cups; the corolla cut in four parts, containing four ftanina, a roundifh gernien; and tho fowers fucceeded by clufters of roundifh quadrilocular berries, with four leeds, ripe in autumn and winter; and by which the fpecies are propagated, likewife by budding and grafting, to continue any particular varieties.

Principal Cbarakers.-Flowers hermaphrodite; the calyx, or cup, one-leaved, indented in four parts; corolla, or flower, monopetalous, or of one petal, diviced into four fegments; four awl-fhape fhort famina, crowned by fmall anthera; a roundith germen, moftly without ftyles, but crowned by four obtufe ftigmas; and the germen grows a roundilh berry, of four loculi, or cells, containing each a fingle, oblongith, hard, bony feed.

The hardy Species of ILEX are,

\section{IL EX Aquifolium-(Aquifolium) or Common Holly Tree.}

A middling-large ever-green tree, growing fifteen or twenty, to thirty feet high-the leaves (middling, Bining-green) oblong-ovate, waved, and indented on the edges, acute fpines terminating each denticle; and fmall clufters of whitifh flowers, in May or June; fucceeded by red and other coloused berries. Native of England, fouth parts of Europe, America, Japan, \&c. (Loamy, or any common foil.)

Varieties.-Common Green prickly Holly.

Smooth or thornlefs Green-leaved.

Narrow-leaved Holly.

Box-leaved Holly.

Red-berried Holly. (Common.)

White-berried Holly.

Yellow-berried Holly.

Bloached-leaved Holly.

White-bloached-leaved Holly.

Yellow-bloached-leaved Holly.

White-Itriped-leaved Holly.

Yellow-ftriped-leaved Holly.

Cream-coloured-leaved Holly.

Silver-edged-leaved Holly.

Gold-edged-leaved Holly.

Mottle-leaved Holly.

Copper-coloured-leaved Holly.

Variegated-leaved Painted-Lady Holly.

Yellow-leaved Holly.

Long-leaved Holly.
(ILEXecbinata) or Hedge-hog Holly; the edges of the leaves thorny, and the up. per furface clofely fet with aculi, or prickles.

Common Green-leaved Hedge-Hog Holly . Gold-bloached-leaved Hedge-Hog Holly. Gold-edged Hedge-Hog Holly.

Silver-edged Hedge-Hog Holly.

With may other feminal varieties of the Common Holly, known in the nurferies by different fancy names, as

Milk-Maids Holly.

Glory of the Ealt Holly.

Glory of the Weft Holly.

Chimney-fweepers Holly; with fevera! others.

2. Ilex Cafine-(Cafine) or Cafine Holly of Carolina, commonly called Dahoon Holly.

A moderate ever-green tree, growing fffteen to twenty feet high-the leaves (middling, ligbt-green) ovate, fpear-fhape, fawed; and fmall white flowers in thick clufters; fucceeded by fmall red berries.-Native of Carolina. (Loamy, or any common foil; warm fituation while young.)

$$
\begin{gathered}
\text { Varieties. - Brosd-leaved Carolina, or Dahoon } \\
\text { Holly. } \\
\text { Narrow-leaved Dahoon Holly. }
\end{gathered}
$$

Both the fpeciss of Holly, and their refpective varieties, are very ornamental ever-green trees, growing with a fingle upright ftem, very branchy quite to the bottom, and in their natural growth, forms a conical head, particularly the Common Holly; all very clofely garnithed with leaves of a thick, firm confiance: are proper to cultivate both in ornamental and ufeful plantations; the Common Holly particularly, being alfo proper to affemble with ever-green forefttrees, in plantations for timber, as when permitted to advance in full growth, it attains fome confiderable ftature and fubftance in the ftem or trunk, and its wood being very white, is valued by the cabinet-makers, and fome other trades; the wood is alfo made into hones, for razors, and of the bark of the tree is made the bird-lime.

The Common Holly, and all its varieties, are very hardy to grow any where in any common foil and fituation, to plant both in ftandards, for ornament in fhrubberies, and other plantations in pleafure-grounds; and from its clofe, branchy growth, admits of training, by clipping, into feveral formal devices, as globes, pyramids, \&c. as was formerly practifed in the ancient method of gardening; and is well adapted for forming hedges, both for ornament in pleafure-gardens, and for fences and for the different purpofes, the trees fhould generally have the final tranfplanting while mo- 
serately young, as, when old, the roots become woody and naked, and do not fucceed well when tranfplanted of a large fize.

But the Dahoon Holly is more tender, efpecially in its young growth, requiring a warm fituation, or protection in winter, till it obtains ftrength, then may be flanted in the full ground; is principaily cultivated in firubberies, \&c. for ornament and variety.

Both the Epecies of Holly are raifed by the feed or berries, fowed in autumn or fpring, which will not come up till the fecond year after; and the different varietics are propagated by grafting and budding them vipon the Conimon Holly; each as hereafter explained.

Ali the forts of Hollies are cultivated in the nurfegies, for inle, where tiney may be obtained of proper crowth for planting; in which it is generally advifeible, to perform it while the trees are of moderately young growth, as before intimated, from two or three, to four or five feet at molt ; as, when older or larger, they feldom fucceed well, and often fail, when removed of a large fize, unlefs where convenient to tranfplant them with complete balls of earth to the roots.

The feafon for planting Hollies is either principally in autumn, the middle or end of September, any tinie in October, or early part of November; not fo eligible in winter, unlefs a very mild feafon, but may be tranfplanted fuccefsfully in the fpring, in February, March, and beginning of April.

For ornamental planting, they thould affemble principally in ever-green plantations in frubberies, and other plantation diftriets, in pleafure-grounds, parks, \&c. or occafionally dotted in fome principal deciduous plantations, in which both the common and variegated kinds, will add to the variety, and give a more lively appearance in winter, when the deciduous firubs and trees are defticute of foliage, and in which the common and variegated forts will effect a very agreeable diverfity; or in any plantat ons the variegated kinds are beautifully crnamental at all feafons, and when interfperfed, thefe and the green-leaved, in principal clumps of ever-greens, they have a fine effect; and in which plantations, fome may either be permitied to advance principally in their natural growth, bufhy from the bottom, or occafionally trimmed up below, by degrees, one, two, or feveral feet, to clean ftems, to run up more in heiglit, where required, and permitted to branch out above in full heads.

IJedges of Holly ivere formerly in great eftimation, for their clofe, beautiful ever-green growth, both for ornament, in interior divifions of pleafure-grrounds, and for affording helter to particular compartments, and to tender plants, and forms a very effoctual inipe- netrable fence; and for which purpores, the Common Green Holly, as being the moft readily raifed in abur. dance, is principally employed, efpecially for any confiderable extent; and the variegated forts, in particular parts, for their ornamental appearance, in their diverfified colours; and, in all of which, they admit of training in low, middling, and lofty hedges, five or fix, to eight or ten feet high, or more.

The Hollies, likewife, in the former defigns in ornamenting pleafure-grounds, were in great repute for training by clipping, into various forms, as pyramids, fpheres, arches, porticoes, galleries, and other rural devices, and kept in their refpective forms by clipping every year, in fummer; which, according to the then prevailing tafte in gardening, together with yews trained in a fimilar ftile, were confidered as great ornaments to gardens; but are now moftly excluded, at leaft feldom admitted in modern plans.

The propagation, or methods of raifing Hollies, is principally by feed, in the two fpecies, the Common Green, and Dahoon Holly; the former of which, Common Holly, produces abundance of berrics, ripe in autumn and winter for fowing, but not ripening fo freely in the Dahoon kind: they are obtained from America by the feedfmen; but the different variegated forts, and other curious varieties, are propagated, and continued in their refpective differences, by grafting or budding them upon feedling-ftocks of the Common Holly, as they will not come the fame from feed; and the Dahoon Holly is alfo occafionally propagated by grafting and budding upon the common forts.

To raife the Common Holly, it ripening berries in great plenty late in autumn, they fhould be gathered in November or December, and either fowed at once in beds, an inch deep; or, as the feeds of the berries are of a hard, bony nature, and the outer pulp adhering clofe, that they remain in the ground a whole year before they begin to germinate or grow, they, previous to fowing, are generally prepared by burying th.em in an heap in a pit, or depofited in large garden pris; thefe plunged in fome dry ground, and earthed over eight or ten inches deep, to remain thus for a year, preparing for vegetation, then taken up in October or November, and fowed in beds, either broadcaft, and covered in an inch or two deep with earth, or fowed in drills that depth, and they will thus come up in the fpring following; but thofe fowed at once from the trees remain dormant till the fecond fpring.

When the young Hollies are come up, keep them clean from wceds, and, if very dry weather, moderate waterings will prove very beneficial; and after the plants are of one or two years growth, they fhould be tranfplanted in nurfery-beds, in autumn, about October, or in March, in rows, fix inches to a foot afun. der; and, after liaving two years growtl: in thefe beds. 
if any are deligned for hedges, they will be of a proper fize for that purpore; or thofe intended to train for ftandard fhrubs and trees, fhould be tranfplanted again into nurfery-rows, two feet and a half diftance, by a foot to fifteen or eighteen inches in the rows, in which, growing two or three years, or till they have attained two or three, to four or five feet growth, are proper for the plantations for which they are intended; as they flouid generally have their final tranfplanting in the allotted places where they are to remain, before they grow large; or, when of advanced fizc, they may be removed, with balls of earth to their roots, both for hedges and other occafions.

'The Dahoon Holly is likewife raifed from feed, and Dccafionally by grafting or budding it upon ftocks of the common fort: the feed thould be managed and fowcd as direkted for the Common Fiolly, or fowed in pots, placed under helter from froft; and if in March they are plunged in a hot. bed, it will bring up the plants foon, and forward them in growth, when harden them to the full air in fummer, and theltered under a framc, in winter, from froft; and when the plants, in either method, are one or two years old, tranfplant them in a warm fituation, in the fpring, or fome in pots, to have protection, in winter, for two or three years; then may be turned out into the full ground, in a nurfery, or where they are to remain; the others planted in the nurfery, may alfo be tranfplanted finally, when two, to three or four feet growth, into the fhrubbeту.

To propagate the different varieties of the species of Holly, it is effected, only, by grafting or budding them upon ftocks of the common kind, for they will not come the fame from feed; but the ftocks, on which to graft and bud them, are always raifed from feed, by the methods already explained, and the plants fet out in nurfery-rows, to have one or two years growth, with ftems a quarter to half an inch thick; then may be grafted or budded with grafts and buds of the variegated forts: the grafting is performed in the fpring, March, or beginning of April, by whipgrafting for fmall ftocks, and flit or cleft-grafting for larger; and the budding is effeeted in July or Auguft, in the comnion method; and in both of which is performed generally low in the ftock, within a few inches of the bottom, or occafionally at one or two feet height in taller ftocks; and when, after this operation, the grafted and budded plants have remained two or three years, or more, to make proper thoots from the grafts and buds, and form the beginning-heads of the refpective kinds, with which they were grafted and budded, they are proper for tranfplanting into fhrubberies, and other ornamental plantations, and for hedges, \&c. or, when they are occafionally to be tranfplanted of larger fize, if they could be removed with balls to the roots, it would be of particular advan- tage, in having them fucceed more certainly in $a$ profperous growth.

The Hollies, planted in thrubberies, \&c. or in fingle, detached fandards, in any particular compartments, may either be permitted to branch in their natural order, or the under-branches pruned up moderately by degrees, and the whole encouraged to thoot above in full heads, or of which may only prune to order any cafual rambling branches and thoots.

Or, if any are defigned for foreft-tree plantations, the Common Green Holly, raifed from feed, is the only proper fort for this purpore, and may be introduced among others of the ever-green tribe; though, as the Holly trees are of flow growth, they are not much planted for this purpore; but in fome parts of this country, where the trees are growing naturally in woods and forefts, they are of a confiderable fize, thirty or forty fect high, and large trunks; fo that fome trees may be admitted among other ever-green, forelt-trees, generally planted out in young growth, and, in their advancing ftate, prune up the underbranches by degrees; and run them with the leading top-Thoot entire, that they may advance with a fingle. clean ftem, of ftraight growth, and permitted to grow with full heads.

For Holly hedges, the Common Green, raifed from feed, is proper for general ufe, and any of the variegated kinds principally for ornament; though all the forts, or varieties of the llex Áquifolium, are admirably adapted for hedges, moit beautiful and ufeful, both for ornament, and for thelter to particular divifions, and to afford protection to tender plants from cold; as alfo for outward fences, and for which purpofe it is fingularly effectual, as well as ornamental, at all feafons; and the plants may be as eafily raifed for hedges as the Hawthorn, and planted and trained nearly as directed for that fpecies, in liedges, under the Genus Cratagus; only the Hollies are rather of flow growth in the beginning, but when oncc well eftablifhed in the ground, they advance freely in a clofe, branchy growth, from the bottom upward, and thoot at top proportionally, to admit of training the hedge, five or fix, to eight, ten, or fifteen fcet high, or more.

Where Holly hedges are intended, they may be formed either by planting young plants from a nurfery, of two or three years old, or by feed, prepated as before direeted, previous to fowing, then fowed in alltumn or fpring, in the place where the hedge is intended, in a drill; and, in either of which, where a double tlick hedge is required for an outwäd fence, may plant two rows of fets a foot afunder, the plants fix inches to a foot apart in the row; and if fecd is intended, it may alfo be fowed in two drills, the fame 
difance, having the drills one to two inches deep, the berries, or feed, fowed moderately thick, and earthed over; and when the plants are come up, if too clofe, fome may be drawn out; or, for a moderate hedge, efpecially in any internal divifion, a fingle row of plants, or feed, may be fufficient: keep the whole clean from weeds; or, if any are in outward hedges for fences, \&:c. they thould be defended on the outfide, either by a ditch, rails, paling, \&c. or a ftake and bufh-liedge, while the plants are advancing.

In the advancing growth of the hedge, give a requifite training, when they advance in ftrong fide-fhoots, by cutting them moderately, to form and thicken the hedge, permitting it to fhcot in height, or only cutting any run-away top-fncot; or top the whole but little, or very moderately, till the hedge is arrived to the height intended; then fhould have a regular clipping annually, in fummer, at fides and top, to lieep the hedge regular; generally, in hedges intended to run up high, fhould clip them up taper, or gradually thin, or narrowing to the top, cutting both fides equally.

The hedges raifed and trained as above, will require an annual clipping once or twice every fummer; (never cut in winter) but to pieferve the hedge in the moft regular, neat order, two clippings in fummer would be wecefiary, the firt in June, and the feond cutting in Augult; but, if they have only one ciipping, July or Auguet is the profer lime to periorn the operation: generally keep the hedge of a moderate width, a foot to fifteen or eighteen inches, for low or middling hedges, cut even at fides and top, but lofty hedges kept as thin at top as poffible, run up in a tapering manner, as before obferved.

$$
\begin{gathered}
\text { I T E A-(I T E A.) } \\
\text { Clafs and Order. }
\end{gathered}
$$

Pentandria Monogynia,

Five Males, One Female;

\section{Dr Flowers (Hermapbrodite) baving five Stamina, or Males, and one Pifillum, or Female.}

THIS Genus furnithes but one fpecies, an ornamental, deciduous, flowering-Thrub, for beantifying the hrubbery; is a Mrub of middling growth, adorned with Spear-Shape leaves, and terminal fpikes of white flowers, each flower having a monophyllous, five-parted calyx, a corolla of five petals, containing five ftamina and a permanent ftyle, fucceeded by an oval capfule, terminated by the perfiftent ftyle, and furnifhed with oblong feeds, by which the Thrub may be propagated; alfo by layers, cuttings, and fuckers.

\section{One Species, viz.}

IT E A virginica, Virginian Itea.

A middling, deciduous fhrub, growing five or fix feet high-the leaves (middle $f i z e$ ) fpear-hhape, alternate; and fpikes of white flowers terminating the ends of the fhoots very ornamentally in fummer.-Native of Virginia. (Moift, or any common foil.)

$$
\begin{array}{r}
\text { Varieties.-Major, or Greater Virginia Itea. } \\
\text { Minor, or Lefs Virginia Itea. }
\end{array}
$$

This beautiful, flowering-fhrub claims a place in all principal hrubberies, in which it will make a fine appearance in its numerous, floriferous fpikes; may be procured at the nurferies, for planting, which is performed either in autumn or fpring, allotting it a confpicuous fituation; and is propagated by layers and cuttings of the young thoots, in the above feafons: they will be rooted in one year; alfo by fuckers from the roots; likewife by feed fowed in the fpring, in a bed of light earth; or, as the feed fometimes remains in the ground till the fecond fpring, before it grows, it may be fowed in pots, to place in a fhady border in fummer, and under thelter in winter, or may be forwarded in 2 hot-bed in the fpring.

\section{IVA, FALSE JESUITS BARK TREE.}

\section{Clafs and Order.}

\author{
Monoecia Pentandria, \\ One Houfe, Five Males;
}

\section{Or Flowers, Male and Female, diffindt on one or ths fame Plant, and the Males have froe Stamina.}

THE Iva, confifting of one fpecies, is a large, deciduous thrub, adnitted in thrubberies to encreafe the variety; is of upright growth, garnifhed in fummer with fpear-fhape leaves, and clufters of fmall purple fowers, male and female, feparate on the fame plant; having a roundin, general calyx, containing many florets, of one funnel-fhaped petal in the males, no petals in the females; and in the former, five fmall ftamina; in the latter, two hair-like fyles, and fucceeded in the female flowers by naked feeds in the calyx; and by which, fowed in the $f_{P}$ ing, the tree is raifed, and likewife freely by layers and cuttings.

\section{Onc Species, viz.}

\section{Iv a frutefens, Shrubby, Falfe Jefuits Bark.}

A deciduous (hrub, of large growth-the ftems fhrubby; leaves (iong) fpear-flape, fawed; and cluf- 
ters of purple flowers.-Native of Virginia and Peru. (Any common foil.)

\section{VEGETABLE SYSTEM}

tive of Europe, 8xc. (Loamy, chalky, or 'any commoss
foil.)

The principal merit of this fhrub is to diverfify thrubberies, and other plantations in pleafure-grounds, and to encreafe the variety in the collection of deciduous fhrubs; is raifed, for fale, in all the nurferies, and nay be planted any time in the general planting feafon; and is propagated by layers and cuttings of the young wood; alfo by feed, commonly ohtained from Anerica by the feedfmen, in the fpring, and may thea be fowed in a bed or berder of common earth, or in pots placed in an ealterly border.

JUGLANS, WALNUT-TREE, and HICCORY. Clafs and Order.

$$
\begin{aligned}
& \text { Monoecia Polyandria, } \\
& \text { Onz Houte, Many Males; }
\end{aligned}
$$

Or Flowers, Male and Female, feparate or the fame Tree, with the Males baving numerous Stamina.

THE Family of JUGLAN confifts of feveral fpecies and varieties of large, deciduous, fruit, foreft, and ornamental trees, to plant in orchards and gardens for their production of nuts, with eatable kernels, and to diverfify large plantations in pleafure-grounds, parks, and other diftricts, being moftly of large growth, with confiderable branchy heads, garnifhed, in fummer, with large, compound, winged leaves, conpofed of from two or three, to five, fix, or feven pair of oblong folioles, or diftinct lobes, terminated by an odd or end foliole; and male and female flowers, feparate; the males collected into fmall, oblong, cylindric, fcaly catkins, each fcale forming a cup to one floret, and females growing in clofe-placed clufters, and have four-parted cups; the corolla, or flower, fmall, monopetalous, fixparted in the males, in the females four-parted; with many ftamina in the nuales, and in the female flowers an oval germen fupporting two ftyles; and the germen grows a large, oval, roundih, drupaceous, green fruit, two, three, or more, together in a clufter, containing each a rounciifh, or oval, furrowed, hard-fhelied nut, filled with a four-lobed eatable kernel, ripe in autumn, 2nd by which alfo the trees are commoniy raifed.

\section{The Species of JUGLANS are,}

I. Juglans regia, Royal, or Common Wainut Tree.

A large, deciduous tree, growing fifty, to fixty or feventy feet high, with a large, widely-branching head - the leaves (large, light-green) winged or pinnated, compofed of two or three pair of oval, fawed, fmooth, equal folioles, terminated by an odd one; and fmall greenith flowers, in April and May, fucceeded by large buts, ripe, for eating, in September and October.-Na-

\section{Varieties of the fruit.-Early, Oval Walnut. Round Walnut. \\ Large Walnut. \\ Double Walnut. \\ Late Walnut. \\ Tender-fielled Walnut. \\ Hard-helled Walnut. \\ Jagged-leaved Walnut Tree.}

\section{JUGlans nigra, Black Virginia Walnut-Tree.}

A large, deciduous tree, growing forty or fifty, to fryty feet high-the leaves (middling, dark-grecn) winged or pinnated, compofed of feren pair of fpearMape lobes, and an end-cne, the exterior folioles fmall. ett; and fmall hard-fnelled fruit.-Native of Virginia and Maryland. (Loamy, or any common foil.)

\section{Varieties.-Round-fruited Black Walnut. Oblong-fruited Black Walnut.}

\section{Juglans alba, White Virginia Walnut, or Hic- cory Nut.}

A middling, deciduous tree, thirty or forty feet bigh -the leaves (middling, ligbt-green) winged or pinnated, compofed of three pair of fpear-thape, fawed folioles, and an end-one feffile, or fitting clofe; and fmall whitih-fhelled fruit.-Native of Virginia. (Any common foil.)
Varieties. $\rightarrow$ Smooth-barked White Virginia Walnat, or Hiccory-tree.
Rough, or Shag-barked Hiccory.
Sinall-fruited Hiccory.
Larger-fruited Hiccory.
Oval-fruited.

4. JUGLANS cinerea, Cinereous, or Afh-coloured American Walnut-Tree.

A middling, deciduous tree, growing thirty or forty feet high-the leaves (middling) pinnated, of eleven fpear-hape lobes, the bafe fhorteft.-Native of North America. (Any common foil.)

Varieties of different Species.-Pecan, or Illinois Hiccory.

Balfam Hiccory.

Small White Hiccory.

Virgate, or Twiggy Hiccory. 
Of the bifferent fpecies of Fuglans, the Common Walnut is the fort commonly cultivated in this country, for its fruit, hoth to ufe green, for pickling, in July and Auguit, the green, outer cover, and internal part, together, before the nut begins to Reil hard; and more abundantly the ripe nuts, which attain maturity in autumn, in September and OEtober, and the kernels are then good for eating; all the other fpecies produce fruit of a fimilar nature, but fmaller, and moftly with a very hard Miell and fmall kernels, not'equal in goodnefs to the Common Walnut, which, in all its varieties, are the mort abundantly produced in this country, much larger and beft flavoured; and therefore this fort, ( Fuglains regia) is the principal fpecies to cultivate for its fruit; the others chiefly for variety, or, together alfo with Common Wainut trees, to affemble in ufeful and ornamental plantations.

The different fpecies of thefe trees, keing moftly of large and lofty growth, with confiderably fpreading branchy heads, are proper to introduce in large phentations of hardy, deciduous trees, and to arrange in groves, clumps, both in affemblage, and dillinct, as allo to dot fin'ty; and the Common Walnut to difpofe plentifully in rows, in parks, and other exteníve diftriets; in which, when of advanced growth, they will be very profitable in their annual productions of nuts, which always find a ready fale to thoie who fupply the riarkets; and Walnut trees are proper to introduce in forelt-tree collections, to advance in large ftandards for timbor, the viood being much efteemed, for many occafiors, in the cabinet-making branches, for various articles of houfenold furniture, and feveral cther particular purpofes.

All thefe trees delight moft in a loamy foil, bụt will alfo grow in any monerately-good ground, or where convenient, in common with other hardy trees, or in any common foil and fituation, as different premifes may afford.

Young trees, of all the forts, are kept in the nurferies, for public fupply, where they may be obtained in collection, or of any particular fpecies, required for planting; for which, generally have them of moderately young growth, of five, fix or eight feet height, efpecially for any confiderable planting; or, for particular occafions, the Comnion Walnut may fometimes be obtained of larger growth, with a good head of branches adranced to a bearing ftate, to plant for immediate bearers in a fmall degree in the beginning; though, when planted of younger growth, either fcr fruit or forelt- $t r e e s$, or for ornament, they always make the most thriving trees in the long run; and for foreft-trees particularly, if only three or four, to five or fix feet, they will -generally prove more fuccefsful; or fometimes the nuts are planted in the places where the trees are defigned to rtmain, and, not having any check by removal, they commonly advance in a more free and expeditious growth; and all the forts are eafily propagated, or raifed, by planting, or fowing the nuts in a nurfery, and the young plants of a year old tranfplanted therein, for two, three, or feveral years, and trained each with a fingle clean ftem, five or fix feet, branching above in full heads; and being thus ready for the intended plantations, they may be planted as required, at the proper feafons.

The feafon for planting the different forts of Walnut trees, is either in autumn, at the decay of the leaves, or in the fpring; or any time in open weather, from October or November, to March or April.

The propagation, or general method of raifing the Walnut trees, and Hiccories, in all the different fpecies, is principally by planting or fowing the nuts, either in autumn, or preferved found till the fpring, and then fowed, in February or March, in a bed or beds of common earth, which may be performed either in drilis, fix inches to a foot afunder, and two inches deep. placing the nuts in the drills, and earthed over; or raking the earth off the bed the above depth, for the nuts on the furface, and, with a fpade, prefs them into the bed, and cover them in with the earth that was raked off the bed for that purpofe; they will all come up freely the fame year: keep them clean from weeds all fummer; and, when the plants are one or two years old, they thould be tranfplanted into nurfery-row's, two feet and a half or a yard afunder, by eighteen inches or two feet in thelines; there trained each with a fingle ftem, preferving the leading top-fhoot intire, but any ftrong, lateral thoots, pruned up by degrees, to form a clean ften of five, fix, or feven feet, then pernitted to branch out above in full heads; and are then proper for final tranfplanting.

Obferve, when intending to raife the Common Walnuts principally for fruit-trees, thould be careful to procure nuts of the beft varicties for planting or fowing, chufing then large, with thin or tender niells, whereby there will be the greater chance of having the trees raifed therefrom produce good fruit in return; obferving the fame method of fo:ving, nurfery-planting, and training, as directed above: or fometimes the propagation of the approved varicties for fruit-trees, is tried hy grafting them upon ftocks of any of the Walnut kinds; though the greneral method for raifing the principal fupplies, is by the nuts, for general planting.

The trees, raifed as above, in all or any of the fpecies, they, when from four or five, to lix, eight, or ten feet growth, are of proper fize for general tranfplanting in the places where they are intended, in the proper feafons befure-mentioned.

When defigned to have the Common Walnut planted for its production of nuts, it may be planted in any open fituation, or in orcliards, either in continued rows, forty feet diftance, or placed principally only towards the outer boundary, and in any out-grounds, licdge-rows,

parks, 


\section{VEGETABLE SYSTEM}

parks, paddocks, fields, \&c. having them trained principally in full ftandards, with clean ftems of five, fix, or feven fect, branching out at thefe heights, to form the head ; and planted thirty or forty, to fifty feet, to admit of full fcope for their widely-extending branches; and, in their growth, parmitted to branch out freely all round, and arpire in height, wholly in their natural crder; except occafionally pruning any cafual, very irregular branch, or low ftraggler, and long-extending rambler, either in the early or advanced ftate of the trees, to preferve fome little regularity in the head, if thought expedient; permitting the other general branches to continue in their advancing growth.

Walnut trees feldom begin to produce fruit until of eight or ten years growth, nor do they bear any confiderable quantity till they are above double that age; but in their more confiderably advanced ftate, they, in favourable feafons, produce in great abundance: they bear moftly towards the extreme parts of the branches on the young wood of the laft year; the flowers appear in April and May, fucceeded by the fruit in June, which, in July and Auguft, is fit to gather green for pickling, and acquires maturity in the nuts towards the middle and latter end of September, and in October; when, being fully ripe, the outer green cover begins to open, or will readily feparate from the nuts, and hould then be gathered for prefent ufe, and for keeping for eating in winter.

In the moderate advanced growth of the bearing Walnut trees, the fruit may readily be gathered by hand; but in confiderably large trees, with high and widely-extended boughs, the ripe fruit is commorly beat down with long poles; the nuts thereby generally falling from the trees, in their hufks, or when fully ripe, many feparate therefrom; and being gathered up, thofe adhering faft in their covers, are laid in heaps, to heat a few days, till the green hufks readily part from the nuts, which then, before the hurks begin to become black, and rot, thould, while clean and dry, be feparated, and depofited in a dry room, and covered thickly with ftraw, to exclude the air and moifture, that they may keep longer in good perfection.

Por ornamental planting, and for variety, all the fpeeies and varieties of Walnuts and Hiccory are proper; and for which, they may affemble with other deciduous kinds, as before intimated, in compofing any general tree plantations, in woods, groves, avenues, \&c. or planted, diftinct, in groves, clumps, \&c. in extenfive grounds, fet thirty or forty, to fifty feet diftance.

Or for timber or foreft-trees, all the fpecies of 7 ug lans are eligible, and may be planted in young growth of three or four, to five, fix or eight feet, to form woods, groves, \&c: fet at fifteen to twenty feet diftance; or the Common Walnut planted in fome places double that diftance; and in their advanced growth, while growing for timber, they, in the interim, wils afford plentiful annual productions of nuts; or this fpecies is fometimes raifed for the above purpofes, by fowing the nuts at once in the places where it is defigned the trees thall continue, the ground being prepared by digging or ploughing, and drills made in which to fow the nuts; and when the plants are advancing, if they are too clofe, fome may be gradually thinned out, and planted in another place, if required, leaving a fufficiency of the molt promifing, where raifed, at eligible diftances, to grow for full ftandards; and in which all the others thould be trained, by pruning up lateral thoots of the ftem, by degrees, and low. under-branches of the head, and permitted to advance above in full growth.

JUNIPERUS, JUNIPER TREE, comprifing alfo feveral CEDARS, and the SAVIN.

\section{Clafs and Order.}

\section{Dioecia Monadelphia, \\ Two Habitations, One Brotberbood;}

\section{Or Male and Female Flowers, on two Separate Plants, and the Stamina joined in one Set, or Brotherbood.}

THIS Family, or Genus, of Funiperus, confilts of many fpecies of curious ornamental and ufeful evergreen fhrubs and trees of the fmall-leaved berry-bearing tribe; moftly very branchy from the bottom upward, of pyramidal and conic growth, three or four, to twenty, thirty, or forty feet high; very clofely fet with fmall or minute, narrow, awl-thape, and obtufe leaves, placed by threes and fours, and imbricatin, or lying over one another like fcales of fint and fmall male and female flowers, diltinct, on tivo feparate trees; the males growing in conical amentums, without petals, having three ftamina in one fet ; and the females, having three-pointed calyxes, and three petals, with a germen fupporting three ityles, and fucceeded by roundifh, umbilicated, flefhy berries, containing three oblongconvex and angular feeds, ripe in autumin; but, in this country, moft abundantly in the Common Juniper, and by the berries, \&cc. all the fpecies are principally raifed or propagated, and fome varieties, occafionally, by layers and cuttings.

\section{The Species of JUNIPERUS are,}

\section{JUNIPERUS communis, Common Juniper Tree.}

An ever-green thrub, four or five, to ten or fifteen feet high-the leaves (fmall, arvl-pape) placed by threes, fpreading, and dagger-pointed, and longer than the berries. - Native of Britain, and cold parts of Europe, on mountains and in woods. (Dry, or any common foil.) 
Varieties.-Shrubby, Common Juniper.

Tree-like Common Juniper.

('Funiticrus communis fuecia) or Sivedifh, Tree-like, Common Juniper-growing ten to fifteen, or eigliteen feet liigh.

z. JUNAPERUS Oxycedrus-(Oxycedrus) or Greater Spanifir Juniper.

A moderate, ever-green tree; growing twénty feet high, or more-the leaves (very fmall, awl-jbape) threed and forred, fpreading, harp-pointed, and fhorter than the berries; the berries largin red.-Native of Spain, Sic. (Dry, or any common foil.)

\section{JU N I P R US Virginiana, Virginia Red Cedar.}

$\Lambda$ larce ever-green trce, growing thirty or forty feet high-the leaves ( finall, dark-green) placed by threes, joining at the bafe; the young ones imbricated, or placed over one another, and the old ones fpreading.Native of Virginia and Carolina. (Dij, or any common foil.)

\section{Juni I ER Us Lycia, Lycian Cedar.}

A middling ever-green tree, twenty to thirty feet high-the leaves ( $\mathrm{fmall}$ ) placed by threes, ovate-obtufe, and every where imbricated. - Native of Spain, Callia, and Siberia. (Any common foil.)

5. Jux 1 PER us Pbanicea, Phœnician Yellow-berried Cedar.

A moderate ever-green tree, growing twenty feet high-the leaves (jmall) obtufe, placed by threes, Rightly imbricated.- Native of the fouthern parts of Europe, and the Ealt. (Warw, dry fituation.)

6. Juniperus tburifera, Thuriferous Spanifh Cedar.

A middling ever-green t:ee, growing thirty feet high-the leaves ( mall) acute, four-ranked, or ranged in four rows; and large black berries.-Native of Spain. (Dry, or any common foil.)

\section{JuNipER Us bermudiana, Bermudian Cedar.}

A moderate ever-green tree, growing twenty feet high-the leaves ( $f$ mall, by twos and threes) growing by threes below, and the upper ones by twos; decurrent or running at the bafe, awl-hape, fpreading, and acute.-Native of America. (Warm, dry fituation; and forme kept in pots, for folter in winter.)
8. Junipezus Sabina-(Sabina) or Savin Tree.

A thrubby ever-green, two or three, to fix or eight feet high-the leaves (fnall, linear) oppofite, erect, and decurrent, or running at the bafe.-Native of Portugal, Italy, Siberia, and the Ealt. (Any common: Soil.)

\section{Varieties.-Dwarf-fpreading Savin, two to three feet high. \\ Variegated-leaved Dwarf Savin. \\ Upright Portugal Savin, fix to eight, or ten feet ligh.}

All thefe fpecies of Juniperus are of the ever-green tribe, in eftimation principally for ornamental planting in fhrubberies, and other parts of pleafure-grounds, in which they make a confpicuous variety at all reafons; moftly of a clofe, branchy growth, from the bottom upward, and, in the greater part, grow in a fomewhat conic form; others fpreading, as in the Dwarf Savin, $\& c$. the branches very clofely fet with the minute leaves, in fome fpreading and pointing outwards, in others imbricated, or lying over one another, and fome ftanding ereet, and adorn the trees in conftant verdure; but the flowers, in their fmall amentums and minute florets, make no ornamental appearance: are fucceeded, in the females, by the roundith berries, whicl in fome forts ripen plentifully in this country, as the Common Juniper, Portugal Savin, and fometimes in the Virginia Red Cedar; though of this, and moft of the other Cedar kinds, in which the berries are not produced plentifully, they are obtained from abroad by the feed-dealers, for fowing; as all the forts, both Junipers, Cedars, and Savins, are raifed from the feed in the fpring, or fome, occafionally, by layers and flips of the young branches, as liereafter explained.

Thefe cver-greens, in moft of the forts; are more or lefs of a refinous nature, and impart an aromatie odour.

They are moftly tolerably hardy to grow in any common, moderately dry foil, and almoft in any expofure; except the Funiperus bermudiona, which, being tenderer, is generally cultivated as a green-houfe plant, but fometimes planted in the full ground; Thould have a warm theltered fituation, and defended from fevere froft; all the others may be planted in any fituation, in common with other hardy ever-green thrubs and trecs, or where they may be required, for ornament and variety in pleafure-grounds.

Moft or all the fpecies are defirable ever-greens, in their peculiar growth and foliage, toornament and diverfify hrubberies, and other decorative plantationg, and to plant fingly on plats, lawns, \&c, or fome of the larger 
tree fpecics, as the Virginia Red Cedar, \&c. may alfo aftemble in plantations of ever-green foren-trees: they may be procured at the nurferies, of proper giowth for planting, onc, two, or threc, to four or five feet, in proportion to the natural fizes of growth of the different fpecies, and planted in the proper feafons.

The principal feafon for removing and planting thefe trees, is either in autumn, the middle or latter end of September, any time in October and November, or all principally in the foring months; or the hardier kinds, Common Juniper, Virginia Cedar, and Sarins, might be occafionally planted in wirter, in mild, open weather, more efpecially where convenient to remove any with balls; and by which moit of the others may be tranfplanted, though, for the more tender forts, early autumn or fpring planting is moft advifcable.

With regard to the order of planting them, as before obferved, they having particular merit to plant in principal hrubberies, and other ornamental diftriets, in affemblage moftly in ever-green plantations, fhould be difpofed in a diverified manner, and placed according to their fizes of full growth, the lower ones ftationed, more or lefs, towards the front, and the taller behind; fome alfo planted fingly upon open fpaces of grafs-ground, of lawns and plats, and in fpacious borders, \&c. and, in their advancing growth, fuffered to grow nearly in their natural manner, branchy from or near the botton, in full growth upwards; or, occafionally, the larger tree kinds may be pruned up gradually, from lower branches, to advance with a clean ftem below; or the whole permitted to grow natural, only pruning up cafual, low, Atraggling, or diforderly branches, and encouraged to grow up full ajove.

Sometimes the larger, hardy Cedar kinds are affembled in ever-grcen foreft-trce plantations; particularly the Virginia Red Cedar, or the other tree forts occafionally; and, in their advancing growth, have the low, under branches pruned up moderately by degrees, to form them with clean ttems below; but this pruning of thefe kinds of refinous, ever-grcen trees, thould be performed with much difcretion, only gradually as they increafe in height, and permitted to branch out upward in full heads.

Formerly, fome of thefe fpecies of Juniperus were planted to form ornamental garden hedges; and fometimes planted detached, and trained in pyramidal figures.

The propagation, or method of raifing the different fpecies of Juniperus, is principally by feed ; and fome alfo occafionally by layers and Rips, or cuttings of the young Thoots, particularly the Savins; but the Juniper and Cedar kinds are moftly raifed from feed.

\section{VEGETABLE SYSTEM}

The feed is fowed in the fpring, in a bed of light earth, each fort feparate, and covered in with mold, half an inch to an inch decp; they will co ne up fome the fame year, others probably not ti" the fpring following; or fome of the foreign, or more tender forts, might be fowed in pots, and plunged in a hot-bed, to forward them the fame year, and hiou'd be expofed by degrees to the full air: keep the whole clean from weeds, and give moderate watering in dry, hot weather in fummer; and tie young plants, of one or two years old, tranfplanted in the fpring, in nurfery-beds, in rows fix inches to a foot afunder, to advance in growt?, for a year or two, and then tranfplanted in wider rows two feet difance, to acquire proper growth, generally permitting them to branch out from the bottom in their naturai way; or may only prune any low, under-ftrasgling thoots, and let all the others, and the top-fhoot advance in full growth, to proper fizes, for the intended plantations.

Or, to propagate them by layers, nips, or cuttings, it may be performed in any of the forts occafionally, in want of feed, or principally the Savins; chufing for iayers, the young, under-branches, furnithed with young thoots, which, in the fpring, lay in the earth, they will be rooted in one year; and flips or cuttings of the yuung fhoots, planted in March or April, will emit roots, and grow; and when the whole, both layers, cuttings, \&c. are properly rooted, next fpring, tran?plant thern in nurfery-beds, \&c. to obtain a requifite growth, as advifed in the feedling-plants.

\section{KALM1A-(KALMIA) Or DWARF-LAUREL:}

$$
\text { Clafs and Order. }
$$

$$
\begin{aligned}
& \text { Decandria Monogynia, } \\
& \text { Ten Males, One Female; }
\end{aligned}
$$

\section{Or Plants with Hermapriolite Flowers, having ten Stamina, or Males, and one Piffillum, or Female.}

THIS Gen:s, Kalmia, confits of two fpecies of very beautiful ever-green flowering-fhrubs, for adorning the fhrubbery, flower-borders, \&c. are of upright, moderate growth, with branchy, bufhy heads, ornamented with ovate and fpear-fhape leaves; and fine ornamental red flowers, in terminal and lateral, corymbus clufters, moft beautiful; having a five-parted permanent calyx to each fower ; the corolla, or flower monopetalous tubular, divided above into five fegments, and contain ten ftamina and one piftllum; ficceeded by a roundifh, quinquelocular, or five-cclled capfuie, furnined with fmall feeds; and by which the plants are raifed, likewife by fuckers and layers. 
The Species of KALMIA are,

1. Ka mi a latifolia, Broad-leaved Kalmia.

A moderate ever-green hrub, of branchy growth, four or five feet high-the leaves (middling) ovateobtufe; and corymbus buncles of flowers, terminating the branches; June and July; moft beautiful.- Native of Maryland, Virginia, Pennfylvania, \&c. (Moif, light, or any foil.)

Varicty.-Striped broad-leaved Kalmia.

2. KALM $1 \mathrm{~A}$ angrefifolia, Narrow-leaved Kalmia.

A moderate ever-green flurub, of branchy, bufhy growth, three or four feet ligh — the leaves (middling) fpear-fhape, longin ; and corymbus bunches of flowers, laterally, or at the fides of the branches; June, July, \&.c. very beautiful. - Native of Pennfylvania, and near New York.

Thefe are the moit delightfu! of all fhrubs, beautiful as ever-greens, and moft delicately-fine flowering-plants; demand admittance in every curious garden, to embellifh principal Mrubbery clumps: may be obtained at the nurferies, for planting, in autumn or fpring; and are propagated by feeds, layers, and fuckers, in the fame feafons.

Sow the feeds principally in the fpring, in a bed of light earth, or in pois; or, if the pots are plunged in a gentle hot-bed, it will forward the germination of the feed, and the plants in growth; they, in either method, will come up the fame year: give them thelter in winter, and in fpring prick them in a warm fituation, or into pots, for noving under protection from froft in winter for a year or two, then may be tranfplanted with balls into the full ground, eitlier where they are to remain, or in a nurfery, till advanced more in growth, for planting in the fhrubbery, \&c. or fome may be continued in pots, and in winter, placed under fhelter from froft.

Or by layers and fuckers, the former may be performed in autumn or fpring, in the lower, young trariches, layed down in the earth with the tops a few inches above ground; they will be rooted for planting off in autumn or fpring following; and fuckers arifing from the botiom, may be digged up in the fpring with rnots, fo as each forms at once a rooted young plant, which unay be planted either in a nurfery, or ftrong ones in the frubberies, \&c. where they are to continue.

Generally, for planting thefe curious ever-greens, in a thrublesy, or any where in pleafure-grous ds for or nament, they being of proper growth when two to three fcet high, the fpring, about March and April, is a good feafon, otherwife in autumn, about the middle or end of September, or in Oftober or November; and where any can be removed, or tranfplanted, with balls to their roots, either from the full ground, or pots, it will be an advantage.

They thould have a warm fituation, in the front of fome principal inrubbery clump, or in a border, \&c. where they may be confpicuous to fight, as they make a good appearance at all feafons; and very ornamental when in flower, in large, corymbus bunches.

\section{LAVANDULA, LAVENDER, of the}

\section{Clafs and Order}

Didynamia Gymnofpermia,
Two Powers, Seeds naked;

Or Plants with Flowers (Herm.) baving four Stamina, two being fuperior, or longer than the otbers; and Seeds naked, or witbout any Vejel or Cover.

THE LAVANDULA comprife two hardy, underfhrubby, aromatic ever-greens, eligible to plant in gardens and thrubberies, for ufe and ornament; are of upright, bufhy growth, two or three feet high, garnithed with fmall, narrow, and linear fpear-fhape leaves; of a hoary, whitinh hue, and long, erect fpikes, of fmall, tubulous, ringent or grinning flowers, blue, purple, \&cc. havirig one-leaved cups, a fmall, monopetalous corolla, tubulous below, and divided and ringent above; four ftamina, two fuperior in length to the other two; a four-parted germen, fupporting a fingle ftyle; and the germen grows four naked feeds, which are feldom ufed for fowing, as the plants propagate freely by planting flips and cuttings of the young thoots in fpring and fummer.

\section{The hardy Species of LAVANDULA ase,}

\section{Lavandula Spica-(Spica) Spike-flowering La- vandula, or Common Lavender.}

A fmall, Ihrubby, bufhy plant, growing two or three feet high-the leaves (fimall, narrow, whitißs-green) fpear-thapc, and intire; and long, erect fpikes of flowers, naked, or without leaves; June, July and Auguft.Native of the fouthern parts of Europe. (Any common foil and fituation.)

\section{Varieties.-Narrow-leaved Common Lavender. Broad-leaved Common Lavender. Divarf Lavender. Blue-fpiked Common Lavender. Purple-fpiked Livender. IVhite-fpiked Lavender.}




\section{Lavandula Stoecbas-(Stoechas) or French La- vender.}

A fmall, fhrubby plant, of two feet growth-the leaves (fmall, narrower) fpear-Thape, linear; and tufted fpikes of purple flowers; July and Auguft.Native of the fouthern parts of Europe. (Any common foil and futuation.)

Both thefe fpecies of Lavandula are fine, aromatic under-Thrubs, of upright, flender growth; produce numerous fpikes of flowers of great fragrance, and for which the Common Lavender is cultivated in kitchengardens, and producing its flowers in perfection in July and Auguft; are gathered for domeftic occafions, fuch as to put in fmall paper bags to lay among cloaths to perfume them with their aromatic odour; alfo in laiger quantities to diftil for Lavender water, \&c. and botl the fpecies are eligible to plant in hrubberies, as flowering-hrubs, difpofed towards the front parts, according to their degrees of growth, in afiemblage with other fmall fhrubs; likewife to plant in borders; and, in all of which, trained in buny heads, will make an agrecable variety at all feafons, and fower ornamentally in fummer.

They may be procured at the nurferies for planting, in autumn or fpring, and are eafily raifed plentifully by fijps and cuttings.

To propagate thefe plants, take off a quantity of the fide young fhoots, in March, April, or May, cither flipped of by hand, or cuttings with a knife, five, fix, eight or ten inches long; trim away the under leaves, and plant them in a fhady border, watered in dry weather: they will root freely and foon, the fame year, Shoot at top, and form little bufhy plants, by the end of the fummer, for tranfplanting, where they are to remain in autumn or fpring following.

When required for kitchen-garden culture, for the flowers, fhould cultivate principally the Common Bluespiked Lavender, and planted either in beds or borders, eighteen inches or two feet diftance, to grow in fingle, bufily plants, or occafionally planted as an edging along the front of a border, either in flips or cuttings, planted at once to remain fix inches afunder in the row, or in rooted young plants, raifed as above, and kept regular by clipping every fummer; or where confiderable fupplies of flowers are required, they may be planted in continued rows, three feet afunder, to have room to advance in full growth, to produce large crops of flowers accordingly: in fome of the extenfive kitchen grounds, in the neighbourhood of London, as about Batterfea, and places adjacent, they plant vaft quantities in fingle rows, between the large breaks of ground, to furnith large production of flowers for the fupply of the markets.
In the above different methods, the plants fhould be permitted to grow in full heads, and they will produce plenty of flowers every fummer, which attaining perfeetion in July and early part of Auguft, hould be gathered in dry weather, for the particular or differerts oconomical purpofes for which they are required and adapted; the plants will continue many years, and when they grow naked, ftubby, or of a decaying nature, raife frefh fupplies in due time to fucceed them in proper growth.

For thrubberies, borders, \&c. in the pleafure-groun $\$$, both the fpecies of Lavender are eligible, as betore intimated; and may be planted in any common foil, and fuffered to grow up in full heads.

\section{LAVATERA-(Lavatera) or T'REE MALLOW.}

\section{Clafs and Order.}

Monadelphia Polyandria,

One Brotberbood, Many Males;

Or Plants with Flowers (Herm.) baving all the Stamina joined in one Set, or Brotberbood; and numerous Males, or Stamina, in each Flower.

THIS Genus furnithes feverai fhrubby-ftalked, malvaceous plants, growing with an upright, fingle ftem, four or five, to eight or ten feet higin, terminated by bufhy heads; and garnifhed with large, roundin, three, five, and feven-lobed, foft, downy leaves, and terminating the top in a tuft; and largin, purple flowers, fingly and in clufters, compored of five heartThaped petals ; including many ftamina, monadelphous, or united below in one fet; an orbicular germen, fupporting a fhort ttyle, and fucceeded by many feedcapfules collected into a head, having each one kidney-fhape feed, and by which the plants are raifed; and fome alfo by cuttings of the ftems and. Thoots.

The hardy, fhrubby LAVATERAS are,

1. Lavatera arborea, Tree-like Lavatera, or Tree Mallow.

A tall, upright plant, with a fingle, herbaceous-like ftalk, growing eight or ten feet high-the ftem tree-like fingle; leaves (large, foft) feven-angled, plaited and downy; and peduncles or flower-ftalks at the axillas of the leaves and ftem, crouded, having each one purple flower.-Native of Italy. (Dry, or any common light foil.)

\section{Lavatera triloba, Three-lobed leaved Inrabby Lavatera.}

An upright, fhrubby-ftalked plant, growing four or five feet high - the ftem frrubby; leaves (large) fomewhat 
hearted, almoft three-lobed roundifh crenated, and heart-fhape ftipula; and peduncles or flower-ttalks aggregated, producing each one large, pale-purple flower. - Native of Spain. (Dry, warm, or jandy foil.)

\section{Lavatera micans, glittering Tree Mallow.}

An upright, Shrubby-ftalked plant, growing five, to fix or feven feet high-the ftem tree-like, fhrubby; leaves (large, foft) feven-angled, acute, cienated, plaited and hoary; and terminal racems of purple flowers.Native of Spain and Portugal. (D.y, or fandy foil.)

\section{Lavatera olbia, Olbian Thrubby Lavatera.}

Ar upright, Shrubby-ftalked plant, growing four or five feet high - the ftem fhrubby; leaves (large, foft) fivelobed, halbert-form; and large purple fowers, fingly. - Native of France, \&c. (Migfly dry, warm foil.)

\section{Lavatera lufianica, Lnitianian, or Portugal, Thrubby Lavatera.}

An upright, Mrubby-fralked plant, four or five feet high - the ftem fhrubby; leaves (larger, foft) feven-angled, plaited, and hoary; and terminal racems of purple flowers. - Native of Portugal. (Dry, rvarm foil.)

Of the above five Thrubby fpecies of Lavatera, the firft is the hardieft and the moft commonly cultivated in the full ground, the ftem tall and fingle; is fomewhat between a Rrubby and herbacenus nature; fome-, times decays in a year or two in winter, or if planted in a dry, lean, or rubbilhy foil, it will fometimes ftand feveral years: may be planted in any dry fituation in the fhrubbery, or where required; the other four are more tender, hould have a warm, dry fituation, or fandy foil ; and will continue of feveral years duration, in rcot and fem ; though it is alfo proper to have a plant or two of each of thole four forts in pots, to remove to thelter of a green-houfe in winter, as fometimes thofe in the open $\xi$ round are killed, or much cut, by the effects of rigorcus frofts in feverc feafons.

They being all propagated by feed, and the fhrubby kinds alfo by cuttings, thould generally be tranfplanted, young, where they are to remain; or the fced fowed in the places where they are to continue.

'To propagate thefe plants from feed, fow it in March or April, in a bed of light earth, for tranfplanting in fummer or next autumn, or following fpring, into the fhrubbery, \&c. to remain, efpecially the firft fpecics; or may be fowed in patches, in the places where the plants are to ftand, and thinned, while young, to one of the ftrongett in each patch; and thus continuing, not having any check by removal, they grow more ftrong, hardy, and durable; or the four tenderer Nhrubby forts, being fowed in beds, may both tranfplant fome young into thc fhrubbery, or borders, and fome fingly, in pots, to have protection in winter the firft year or two, then turncd into the full ground in the fpring; others continued in the pots for inuving undep Shelter conftantly in winter, in frotty weather.

Or to propagate the four thrubby forts by cuttings of the hoots, ftem, or branches, is performed in the fpring, March, or Aprii; when, taking of fome cuttings, fix or eight, to ten or twelve inches long, plant: them either in a border of light carth, or in pots of a fimilar foil, yiving moderate watering when the earth dries, they will root the fame year; or in a hot-bed, or covered down with hand-glafes, will 100 fooner, and thoot at top; and when fully rooted, and formed fome top growth, they may be traniplanted finally, fome into the fhrubbery, borders, \&c. others into pots, fingly.

$$
\begin{gathered}
\text { LAURUS, BAY TREE, of the } \\
\text { Clafs and Order }
\end{gathered}
$$

Enneandria Monogynia, Nine Males, One Fiemales;

\section{Or Plants with Flowers (Hermapbrodite) baving nine} Stamina, or Males, and one Piftillum, or Female.

THIS Genus, LAURUs, furnithes four hardy fpecies of moderate tree kinds, comprifing one fine aromatic ever-green, and three deciduous; all principally for ornamental plantations, fhrubberies, \&c. grow fifteen, to twenty or thirty feet high in the different fpecics; adomed with fpear-fhape, oblong, and threelubed lcaves, all of moderate fize; and fmall hexapetalous yellowish and whitih flowers, without any calyx, or cups; a corolla, compofed of fix oval petals, containing nine ftamina; an oval gcrmen, fupporting one ftylc; and the germen grows an oral, unilocular red berry, having one oval liard feed, or nut; and the berries ripen plentifully in autumn and winter, in the Common Bay particularly, for fowing; the others not fo abundant; but generally procured from Amcrica, by the feedfmen; and by which the different fpecies arc propagated, alfo by layers and cuttings of the young floots.

The hardy Species of I. AURUS are,

\section{L a u r us nobilis, Noble, or Common Bay 'Trec.}

A moderate ever-green tree, branchy from the bottom, growing twenty to thirty feet high-the leaves (middlingfize, dark-green) ovate-fpear-thape, veined, and perennial, or rcmaining all the year; and quadrifid 
yellowith flowers, that are dioicous or fometimes male and ferrale, on tivo different trees.-Native of Italy and Greece. (Diy, ligbt, or any common foil.)

Yarietics.-Broad-leaved Common Bay. Narrow-leaved Common Bay.

Wared-leared Common Bay. Striped-leared Common Bay. Double-flowered Common Bay.

2. LA U R U afticalis, Summer-leaved, or Deciduous Bay' 'I'ree.

A fmall, decinuous tree, growing ten or twelve to fifteen feet high - the leaves (middling) oblong-ovate, acuminate or pointed, reined, and annual or deciduous; and white fowers. Native of Virginia, near rivers. (Moijt or any foil, and warm fituation.)

\section{LAURUS Benzoin-(Benzoin) or Benjamin Tree.}

A fmall, decidions tree, growing twelve or fifteen feet high'- the leaves (middling, ligbt-green) ovate, enervate, or withcut veins, both ends poirted, deciduous.-Native of Virginia. (Warm, dry fituation.).

\section{LAuRus Safafras-(Saffafras) or Saffafras Tree.}

A fmall, deciduous tree, twelie or fifteen feet high -the leaves (middling, ligbt-green) three-lobed and intire.-Native of Virginia, Carolina, and Florida. (Warm fituation, moift or any common foil.)

\section{Varieties.-Three-lobed and intire-leaved Safiafras Tree. \\ Undivided, bay-leaved Saffafras Tree:}

All there fpecies of Laurus are defirable, ornamental trees, to affemble in principal plantations and hrubberies; the firft of which, in the different varieties, as fine ever-greens, trained either in taller ftandards with a fingle ftem, in which they will grow fifteen to twenty feet high, or more; but as the Bays often rife with feveral ftems, branchy to the bottom, in a fhrub-like srown, fome may alfo be cultivated accordingly; and the other three, being deciduous, are proper to introduce in the moft confpicuous plantations of deciduous Irees and fhrubs; and all of which, both of the evergreer and deciduous kinds, may be trained, fome in the tree way, with a fingle fem below, and full heads above, and others to grow fhrub-like, in a buny order; and the Common Bay, in its branchy growth, is likewife proper to train for handfome ever-green hedges, either kept regular by an annual clipping in femmer, or permitted to run up rough, nearly in a natural growth, and the long-projecting and rambling fhoots cut in with a knife: this tree alfo admits of training in ftandards, for introducing in ever-green tree plantations, having the lower and under boughs pruned up by degrees, and it will thoot up faft abore, form a beautiful head, and make a fine appearance at all feafons.

Moft of thefe trees are of at aromatic and odorifefous quality; and for which property, the leaves of the Common Bay are often ufed in culinary occafions; and this, and fome of the others, are alfo efteemed very falutiferous in a medicalway; but, particularly, the Saffafras is much recommended for Saffafras tea, being a ftrong, aromatic, and efficacious purifier; the wood of which, cut into fmall flips, is the part ufed, and of which great quantitics is inported in this country, for the druggifts; and being prepared into chips, aforefaid, is ready for ufe, as above, in which it is both palatable and wholefome, well fweetened with fugar, and mollified with plenty of milk, or crear..

Thefe four fpecies of Laurus are cultivated, for fale, at moft of the public nurferies, where they may be procured of proper growth, two, three, or four, to five or fix feet high, for planting; though, if only two or three to four feet, will generally be more fuccefsful than if tranfplanted of larger fizes, efpecially the Common Bay; and which, where convenient to remove them with balls of earth, will be of greater advantage, particularly for large full plants.

The general feafon for removing and planting thefe trees, of all the forts, is either in Ostober or November, or in the fpring months.

The propagation, or method of raifing the different fpecies, is by feed, layers, and fuckers.

The feed, or berries, for fowing, are obtained of the feedimen, and at many of the principal nurferies: they may be fowed in autumn or fpring; though as thofe of the deciduous kinds are commonly received from America, they feldom arrive before the fpring feafon: fow all the forts in beds of light earth, either in drills, or broad-caft, and covered in evenly an inch deep; or fome might be fowed in pots, in the fpring, efpecially the American kinds, and plunged in a moderate hot-bed to forward them; and in all of which give gentle waterings, kept clean from weeds all fummer, protected from froft in winter; and when the plants are of one or two fummers growth, fhould be tranfplanted in nurfery-beds, where, advancing in ftrength, one or two years, may be tranfplanted in wider nurfery-rows, or fome where they are to remain; or when thofe continued longer in the nurfery are from two or three, to four or five feet, are proper for the plantations in which they are intended. 
Or the Lasw aftivalis, being tenderer, it, and fome of the other American forts, may alfo be planted, while of young growth, rrom the feed-bed into pots, fingly, to place under thelter from froft the firft year or two, or till they obtain Atrength, then turned out, with balls, into the full-ground, in a warm fituation; efpecially the former mentioned.

Layers of the lower young thoots, in fpring or autumn, will root in one year; generally performing it by flit-laying, gafhing or fitting the fhoots a little on the under fide, that part layed in the earth, three inches deep, keeping the $\Omega i$ open, and the top upright above ground, pegged down, and earthed in the abcre depth; and when rooted, cut them from the itoo!s, and plant them in the nurfery, to acquire proper growth for the fnrubbery, \&c.

Suckers often arife abuadantly from the roots of the Common Bay, which may be digged up with roots to each, in autumn or fpring, and planted either where they are to remain, or in a nurfery, for one, two, or three years, to obtain larger growth for the intended purpores.

When the young trees, raifed by any of the above methods of propegation, are advanced two or three, to four or five fret in growth as before intimated, they are of properfizes for final tranfplanting in fhrubberies, and other places, where they are to remain.

In the final planting of thefe trees, in fhrubberies and other plantations, zenerally difpofe the Common Bay with ever-greens of limilar growth, either to grow up tall in ftandards, or to advance in bufhy heads, branchy almoft from the bottom; and the other three fpecies introduce principally with other deciduous kinds, in fomewhat fheltered, warm fituations, efpecially the Laurus aftivalis, or planted againit a fouth wall, as this is rather tenderer than moft of the other fpecies; or may alfo plant fome in pots, to remove under fhelter in winter, as being liable to fuffer by rigorous frofts, and is therefore aifo generally kept among the greenhoufe exotics, though, when planted in a Meltered place, as above, in the full ground, will ftand our ordinary winters tolerably well, and harden by degrees.

When defigned to plant the Common Bay, for a garden hedge, it thould generally be planted in young growth, of one or two to three fiet, fet a foot afunder; or if fpreading plants, may be planted eighteen inches diftance: permit them to run up at top, and the projecting fide-fhoots cut regular in fummer, never cut in winter; or may occafionally plant fome hedge. ways, to cover any naked, unfightly walls, palings, \&.c. and the branches nailed thereto in a fpreading man. ner.
LEDUM, MARSH CISTUS, or Wild Rofemary. Clafs and Order.

Decandria Monogynia,

Ten Males, One Fimale;

\section{Or Plants with Flowers (Herm.) baving ten Stamina and orre Piftillum.}

THIS Genus is compofed of low, under-fhiubly ever-greens, of fmall, buthy growth, ornamented witis finall, linear, and ovate leaves, and finall, corymbus bunches of reddifh fiowers, confiting of five fmail petals, ten ftamina, and one piftillum; fucceeded by roundifh capfiles, furnithed with many feeds, by which, fowed in a moift border, the plants are raifed; likewife by ofi-fet root-fuckers, lnyers and fips.

The Specics are,

1. LEDum palugtere, Marfh Ciftus Ledon, or Wild Rofemary.

A fmall, Iow, under-thrubby ever-green, two feet growth-the leaves (frroll, narrozu) linear, hairy on the under-fide, and fmall flowers in a corymbus.Native of the northern parts of Europe, in mariny ground. (Moift, or marky fituation.)

Varieties.-Larger, Upright, Wild Rofemary. Smaller, Procumbent, Wild Rofemary.

\section{LEDUM latifoliun, Broad-leaved Marfh Ciftus.}

3. LEDUM longifolizm, Long-leaved Marfh Cifus.

4. LEDUM thymifolium, Thyme-leaved Marh Ciftus.

Thefe are all fmall, under-hrubs, moftly intabitants of manthy and boggy fituations: they may be planted in fomewhat fimilar foils, or any moif firubbery clumps, borders, or where convenient, fur variety; and nie propagated by parting the roots, or detaching, or lip-. ping the off-fet fuckers, allo by layers of the branches; and by feed, forved in autunn or fpring, in a fhady, moir fituation; and planted out where they are to romain.

LIGUSTRUM, PRIVET.

Clais and Order.

Diandria Monogynia,
Two Mitles, One fimale;

Or Plaws with Hernapbrodice "Winvers, baving tako Stamiza, or Males, and one Pijtillent, or Finicte.

THE LigustP. UM confits of moft hardy, large, bafhy thrubs, decidwous and ever-green, elicible for 
the Anribbery, and valuabic for forming very neat and expeditious licdges; are of uvight, full growth, hranching thick and erectly fron the very hottom; clofely garni/hed with fmaliih, ovate-oblong leaves, oppofite; and many crect, oval fpikes, of Imall, whitifh flowers in fummer; having one-leaved cups, four-parted above, a fmall, monopetalous, funnel-thape corolla, quadrifd or four-parted; two thort ftamina and one pittillum, and the fpikes of fiowers fucceeded by clufters of roundin, black bcrries, containing four feeds, ripe in autumn and winter; proper for foxing to propazate the planis; which are alfo raifed plentifully by fuckers, Jayers, and cuttings.

\section{The Specics and Varietics of LIGUSTRUM are,}

\section{Ligustru ar algare, Common, Deciduous Privet.}

A large, upright, bully, deciduous hrub, growing eight or ten feet high - the leaves ( $m$ mallifh, darkgrecn; ovate-obiong, and oppofite; and eres, oval fikes of whitih flowers; June or July.-Native of England, and other parts of Europe. (Any foil and fitua:ion.)

Varieties.-Gold-frriped-leaved Deciduous Privet. Silver-firiped-leaved Deciduous Privet.

\section{LIGUSTRUM femper-virens, Ever-green Italian} Privet.

A large, ever-green fhrub, growing eight or ten feet high-the leaves ( mallifh, dark-green) ovateoblong, oppofite, and continue all the year; and ereet, oval fpikes, of whitifh flowers; July and Augut.Native of Italy, (Any foil and fituation.)

\section{LiguStRUM latifolium, Broad-leaved Carolina Privet.}

A large, ever-green thrub, eight or ten feet highthe leaves (larger, dark-green) ovate-oblong, oppofite; and erect fpikes of whitith flowers; July.-Native of Carolina. (Any common foil.)

Thefe Thrubs, being of large, erect, bufhy growth, are adapted for fhrubberies, and other plantation diftricts in pleafure-grounds, in affemblage with other hardy fhrubs and trees; and are remarkably well adapted for forming neat, clofe garden hedges, proper both for internal divifions and occafionally for outward fences, as they grow very clofe and expeditiouny; and are likewife proper to plant in a fpreading growth againft naked or unfightly walls, or palings, \&c. where required to have them covered, and for which the evergreen forts are molt eligible, on account of their con- tinuing leaves in conftant verdure at all fenfons: 1 that occafion, and hedges, any of the forts are clighice.

They are propagated by feeds, layers, fuckers, and cuttings.

Sow the feed in autumn or fpring, in a bed of common earth, in drills an inch or two deep, or broad-caft, on the furface, and earthed over that depth; they will come up freely in fpring, or beginning of fummer; and when the plants are of one fummer's growth, tranfplant them into nurfery-rows; and in which they may either be permitted to grow up rough or bufly from the bottom, both for hedges and Randard thrubs; or, for the latter, fone traincd with a fingle frem, pruning up the lateral fhoots and branches below, and encouraged to branch out full above in bufhy heads; and when two or three, to four or five feet high, are proper for final tranfplarting in thrubberies, or where they may be required; or for hedges, they being trained in a buthy, fpreading growth, feathered quite to the bottom; and of one, tivo, to three or four feet, are of eligible fizes to plant for that purpore.

Or to propagate them by layers, cuttings and fuckers, it may be performed in the autumn or fpring: layers of the pliant young branches and thoots will be abun. eantly well rooted in one fummer, for planting off in autumn or fpring foliowing; likewife cuttings of the year-old thoots planted, will emit roots, and grow freely; and fuckers arifing from the bottom of old plants, may be taken off with roots, and planted, forming at once proper rooted plants.

All the Privets, being moft hardy firubs, admit of planting any where in open or clofe fituations, or to plant in clofe places in towns and cities, where many other mrubs would not grow; and admit of removal for planting any time in open weather, from September or October, till March or April ; or, on particular occafions, might be tranfplanted fuccefsfully in May or June, as they have abundant roots, very fibrous, fo as they may readily be tranfplanted with balls, which, particularly in late planting as above, in the latter part of fpring, or in fummer, would be of greater advantage, by having them continued in groswth, without ftint, or much check by removall.

They are proper to plant in ftandard, bufhy fhrubs, for variety in thrubberies, or any general plantations of fhrubs and trees; and in which, as they often run into long, rambling thoots, they fhould be pruned to fome regular order, in fummer or winter, as may be required.

For Privet hedges, they may be formed, both by planting young plants of one, two, or three feet, planted a foot afunder in the row; or to form at once a 
full hedge, plants of three to four, or five feet, might be fuccefsfully planted; or by feed. fowed in a drill where the hedge is intended, and the plants to remain; and in either methods train them regular in their advancing growth, by clipping the fides once or twice every fimmor, and may either be kept of a moderate heig!t, of three or four feet, by clipping them at top to the height required, or permitted to run five, fix, or feven feet high, cutting the $\mathrm{m}$ in gradually narrowing or tapering, on each fide to the top, which, when of the defired heirht, may alfo be clipped even.

\section{JuluidaABar, STORAX, or SWeEt Gum TREE.}

Clars and Order.

Monoecia Polyandria,
One Habitation, Many Males;

Or Flowers, Male and Female, Separate, on one or the fame Tree, and the Males haring many Stamina.

THE LIQUIDAMBAR comprifes two fpecies of elegant, deciduous trees, for ornamental plantations, being of Atraight, handfome growth, rifing twenty to thirty feet high; adorned in fummer with largish, palmated-angular, and oblong folinge, imparting a fweet, gummy, fragrant fubstance, and male and female flowers apart on the fame tree; the males in conic amentums, and females globofe perianthums; have four-leaved and double involucrums, and with a bellhape cup to each floret, but no petals; numerous ftamina in the males, and in the females two piftillums or ftyles, fucceeded by a globular body of many roundish capfules, filled with oblong feeds; not ripening plen tifully in this country, but procured in abundance from America by the feedfmen, and by which, fowed in the fpring, the trees are raifed; and are alfo propagated by layers.

\section{Two Species, viz.}

1. LieUidaMBAR, Styracillua-(Styraciflua) or Styrax-fowing Liquidambar.

A middling, deciduous tree, growing twenty or thirty feet high-the leaves (moderately-large, lobated) palmated-angular. - Native of Virginia and Mexico. (Light or moift foil.)

\section{Liquid a ва asplenifolium, Spleen-wort-leaved Liquidambar.}

A moderate, deciduous trce, growing twenty feet high-the leaves (fmaller, cut-divided) oblong, alter- nate, finuated.-Native of North America. (Light or any common foil.)

Both thefe are fine ornamental trees, to affit in compofing principal decorative plantations in pleafuregrounds, and in forming curious thrubberies, clumps, \&c. in affemblage principally with other deciduows trees, and large ihrubs of the more curious, defirable kinds; or in any general or particular diftricts, as may be required, or thought eligible; and for which occafions, young trees, of proper growth, may be procured at moft of the nurferies, and planted in the general feafons of autumn or fpring.

The propagation of thefe trees is by feed and layers, in the fpring and autumn: fow the feed in March or April, in a bed of light earth, or in pots of the fame foil; and covered in with earth an inch dcep, they will come up the fame year : give the plants occafional protection in winter from fevere froft, and when of one or two years growth in the feed-bed, tranfplant them in the fpring into nurfery-rows; where train each with a fingle ftem, run them, with the top-hoot entire, to afpire in height, pruning off lateral growths below, and permitted to branch out above in regular heads; and when about four or five, to fix or eight feet, are proper for the plantations in which they are defigned.

Layers of the young wood, in the lower, pliant branches and moots, in the autumn, or early fpring months, will root in one year, and thould then be planted off in the above-mentioned feafons into the nurfery, and ordered as advifed for the feedling-trees.

The trees, raifed by either of the methods, as above, when of fome advanced growth in the nurfery, three, four, or five, to fix or feven feet, may have their final tranfplanting, as required, in the plantations where they are defigned to remain, for ornamenting the pleafure-ground: may be performed in autumn, in Oetober or November, or any of the fpring months, from February to April.

LIRIODENDRON (Lily Tree) commonly called TU. LIP TREE.

\section{Clars and Order.}

$$
\begin{aligned}
& \text { Polyandria Polygynia, } \\
& \text { Many Males, Many Females; }
\end{aligned}
$$

Or Plants with Flowers (Hlermaphrodite) having many Stamina, or Male generative Organs, and many Piftillums, or Females.

THIS Genus furnithes but one hardy fpecies; a fine, lofty-growing, deciduous tree, of handfome, Itraight 
growth, and beantiful in its foliage and fowcrs, for aforning any ornamental plantations; is garnifhed, in fummer, with large, lobated leaves, fingularly truncatcd at the ends, and many campanulate, or bellfhape, liliaceous, or lily-form flowers, fomewhat refentiling the form of a tulip; compofed of fix petals in tro feries, containing numerous itamina, and many germina, which grow a conic body of numerous, angular feeds, placed inbricatim, or lying over one another: ripening in autumn, though not abundant'y in England, but procurcd plentifully from America, and by which the trees are generally propagated.

\section{Ore hardy Species, viz.}

\section{LIRIODENDRON Tulififra-(Tulipifera Arbor) or TULIP TREE.}

A lofty-growing, deciduous tree, advancing with a ftraight ftem, and branchy head, forty or fifty fect high-the leaves (large, light-green) lobated, threcparted, with the niddle lobe truncated, as if cut of: at the end; and bunches of; fmall tulip-fhape fowers.Native of North Anerica. (Loamy or any common light foil.)

Variety.-Carclina 'Tulip Tree, with the leaves producted, more angled.

This curious, deciduous tree, merits attention to Fiant for ornament and variety, in principal plantations, in pleafure-grounds, parks, \&c. aflociated with other ornamental trccs of the deciduous tribe; in which it will difplay a diftinguiofable diverfity in its growth, and large, lobated, firgular, truncated leaves; and, when advanced to fome considerable fize, produces flowers confpicuouny in fummer, towards the ends of the branches: the tree is raifed in all the nurferies for public fupply, and may be obtained for planting at the rfual feafons; and is propagated by feed fowed in the fpring.

The feed of this tree, for fowing, is commonly procured from America, by the feedfmen, in the fpring; when, in March or April, it thould be fowed in a bed of light earth, and covered in an inch deep; and when the plants are of one fummer's growth in the feed-bed, tranfplant then in autumn or fpring, in nurfery-rows; and trained with fingle, clean ftems, of four, five, or fix feet, for ftandard trees, and to run up witb full heads.

When they are advanced about four to five, or fix fezt high, thcy are of proper growth for any intended plantátions.

\section{LONICERA, HONEY.SUCKLE}

\author{
Clafs and Order.
}

Pentandria Monogynia,
Five Nales, One Female;

Or Flowers (Herm.) baving five Stamina, or Male Parts, and one Piffillum, or Female.

T'HE LONICERA, or Honey-fuckle, confifts of many fpecies and varieties of ornamental, floweringfhrubs, volubilate climbers, and of upright, fhrubby growth, of great merit for adorning thrubberics, flowerlorders, \&c. in their numerous, beautiful, fragrant flowers, in fummer and autumn; are moftly deciduous, and fome ever-green; fome growing with long, flender, twining-climbing thoots, ten to fifteen, or twenty feet extent; others more upright growers, advancing three, four, five, to fix or eight feet; decorated with oblongoval, fpcar and heart-hhape, middling and fmall leaves; in the different fpecies moftly in pairs, oppofite, and foine fingly, others connected at the bafe, and perforated by the flalks, or branches; and numerous, long, tubulous, five-parted flowers, red, white, yellow, \&c. in bunches and in pairs; having fmall cups divided into five parts; a corolla monopetalous, or of one petal, tubulous below, cut above into five reflexed fegments, and furnifhed with five ftamina, a roundin germen, fupporting one ftyle; and the germen grows a rourdish, umbilicated, bilocular berry, red, blue, black, fome joining two or feveral together, and fome di?inct or fingle; containing roundifh and compreffed feeds, by which, fowed in the fpring or autumn, the plants are occafionally raifed, or more generally by cuttings of the fhoots and layers thereof.

The Species of LONICERA are, confifting of volubilate Climbers, and upright Plants, viz.

Volubilate k1NDs-or with long, Render, twin. ing-climbing fems and Boots; eitber truining round any adjacent fupport of trees, fakes, buffes, Esc. or trail on the ground; fo fhould gencrally bave fupport, or trained to walls, Er.

\section{Lonicer a Peryclimenum-(Peryclimenum) or Com- mon Climbing Honey-fuckle.}

A twining-climbing, deciduous Thrub, extending ten to fifteen or twenty feet length-thc leaves (middling) oblong-ovate, oppofite, all itanding diftinct; and oval, imbricated, terminal heads of flowers, white, red, \&c. June, July, and Auguft.-Native of England, Germany, \&c. (Any foil and fituation.) 
Parietics.-(Lonicera vulgare) or Common, Wild, White Honey-fuckle, or Woodbine of the Woods and Hedges.

Large, White, Common Honey-fuckle. Late White Common Honey-fuckle.

Red-flowered Common Honey-fuckle.

Oak-leaved Common Honey-fuckle.

Striped-leaved Coinmon Honey-fuckle.

Variegated, Oak-leaved Common Honey-fuckle.

(Lonicera germanica) German, or Large Dutch Red Honey-fuckle.

Long-blowing, Dutch Honey-fuckle.

Late-blowing German Honey-fuckle.

Ever-green German Honey-luckle.

- Lonicera Caprifolium-(Caprifolium) or Early Italian Honey-fuckle.

A twining-climbing, deciduous thrub, extending ten or fifteen feet-the leaves (middling) ovate-oblong, the top ores connate, or joining at the bafe, and perforated by the branch; and flowers verticillate, or in whirls terminal, and fitting clofe; May and June.-Native of the fouthern parts of Europe. (Any common foil.)

$$
\begin{aligned}
& \text { Varieties.-White-flowered Italian Honey-fuckle. } \\
& \text { Red-flowered Italian Honey-fuckie. } \\
& \text { Later Red-flowered. } \\
& \text { Yellow-flowered Italian Honey-fuckle. } \\
& \text { Ever-green, late Red Italian Honey- } \\
& \text { fuckle. }
\end{aligned}
$$

3. LoxiGERA femper-virens, Ever-green, Scarlet, 'Lrumpet Honey-fuckle.

A twining-climbing, ever-green Thrub, extending eight to ten, or fifteen feet-the leaves (middling) oblong-ovate, top ones connated at the bafe, and perforated by the branch; and naked fpikes of flowers, in verticils, or whirls terminal; the flowers long, trumpet-hape, fcarlet, (moft beautiful).-Native of Virginia and Mexico. (Any common foil, E̋c.)

\section{Varieties.-Greater Trumpet Honey-fuckk.}

Minor, or Lefs Trumpet Honey-fuckle.
4. Lonicera antericana, American Ever-green Ho- ney-fuckle.
(Balearica) Balearican, or Minorca Ever- green Honey-fuckle.

MORE UPRIGHT KINDS-OF more moderategrowth, acialb forwers, by fairs, on cach peduncle.
5. Lonicera Xylofeum-Xylofteun - or Fly Honeyfuckle.

A more upright, deciciuous fhrub, of fix or feven feet growth-the leaves (middling, whitib-grien) ovate-oblong, obtufe, entire and downy; and peduncles or flower-ftalks, having each two flowers, fucceeded by red berries, in pairs, diftinct.-Native of the cold parts of Europe, in liedges. (Any foil.)

\section{LoN 1 CERA aipigena, Alpine, Fly Fioney-fuckle.}

A moderate, deciduous Shrub, three to four, or five feet-the leaves ( $/$ mallif $\beta$ ) ovate, acute, and entire; peduncles having each two flowers; and red berries, in pairs, joined.-Native of the Alps of Switzerland, Pyrenees, \&zc. (Any common joit.)

7. Lon1crra pyrenaica, Pyrenean Fly Honeyfuckle.

A moderate, deciduous frrub, three to four, or five fee-the branches divaricated afunder; leaves ( $m$ malliß) oblong, fmooth; peduncles having each two flowers, funnel-thape, regular $\xi$ and red berries, in pairs, diftind, or not joined.-Native of the Pyrenean mountains. (Any cominon joil.)

\section{LoNICERA nigra, Biack-berried Alpine Honej- fuckle.}

A moderate, deciduous fhrub, four or five feet growth-the leaves ( $/$ mall) elliptic, ovate, and entire; peduncles, or flower-ftalks, having each two flowers; and black berries, in pairs, diftinct.- $\mathrm{Na}$ tive of the Alps, Switzerland, and France. (Any foil and fituation.)

\section{Lonicera carulea, Blue-berried Honey-fuckle。}

A moderate, deciduous thrub, of four or five feet -the leaves ( mallifh, or middling) ovate-oblong and entire, by pairs and threes; peduncles, or flowerftalks, having each two flowers; the ftyles undivided; and blue berries, in pairs, joined-globofe.-Native of Switzerland. (Any foil, Eं $\sigma_{0}$ )

10. LONICERA tatarica, Tartarian Red-berried Honey-fuckle.

A fmallifh, decidaous thrub, three or four feet growth-the leaves (middling) heart-fhape, obtufe, fmooth; peduncles having each tivo flowers, paleblum-coloured; and red berries, paired, dittinet.Native of Tartary. (Any foil, $\mathrm{C}^{2} 6$.)

UPRIGHT 
UPRIGHT GROWERS-or with fems erekt, and peduniles fufuaining many fouters.

11. LON1CERA Symphoricarpos-(Sumploricarpos) or Shrubby St. Peter's Wort.

An upright, deciduous thrub, three or four, to five or fix fcet high-the leaves (middling, or fmalliß) roundin-ovate, petiolated, or with foot-ftalks; and lateral heads of greenion flowers pedunculated, arifing at the fides of the branches. -Native of Virginia and Carolina. (Any common foil.)

\section{Lontcera Diervilla-(Diervilla) or Dwarf Yellow Honey-fuckle.}

A fmall, upriglit, deciduous hrub, three or four fect high:-the leaves ( $f m a l l i \beta$ ) oblong-hearted, faiscd, and racems of yellow flowers terminating the branches.-Native of Acadia and North America. (Any common foil.)

The Honey-fuckles are principal, ornamental, fiowering-fhrebs, in the climbing, trailing, and upriglit fpecies, for adorning thrubberies, pleafure-grounds, fower-gardens, borders, and other compartments, and to plant in pots; as in all of which they make a beautiful appearance in their numerous, fine, odoriferous flowers, feveral months in fummer, from May or June, till September or October, in the different fpecies and varieties; which, in the trailing, or climbing forts, particularly, are largeft, moft elegant and fragrant, and the firubs thereof are defirable ornaments in every garden, either to plant againft walls, palings, buildings, \&ec. to have fupport thereof, and on which, to train their long-extending, flender ftems, branches, and moots, or to have fupport of ftakes, or ftems of trees and arbours, whereby to train them in their volubilate growth; and in which different methods they are peculiarly adapted, as they all require fupport, otherwife the ftems and thoots would trail on the ground: all the other fuecies have alfo great merit, as flowering-fhrubs, to plant in frrubberies, borders, \&c. and will effect a confpicuons diverfity in their difFerent modes of flowering, and colours of the flowers, \&c. as likewife, in the different forts, the berries fucceeding the flowers make an agreeable variety in autumn.

All the forts, both climbers and upright kinds, are tardy thrubs, that will grow and profper in any common foil of a garden, \&c. and in moft fituations; but gene raliy flower ftrongeit, in the greateft perfection and beasty, jn open expolures.

They are obtained of proper growth for planting, at moft of the nurfery-gardens, in collection, or of 2Ry particular fpecies or varieties as required; and may be planted in autumn or fpring, or any time in mild weather, from October, to March or April; and are ail readily propagated plentifully by cuttings and layers of the young wood, which will be well rooted in one fummer, for tranfplanting in autumn or fpring following, and may be trained either with a fingle ftem a foot or two high, or more, then permitted to advance in branchy heads; or the climbing kinds defigned for training to walls, \&c. may train them with only a fhort ftem below, and to pufh out above in feveral branches; and the more firm or upright growers may be trained with a fingle ftem, from one to two or three feet, and full heads above, to plant for ftandards; or likewife, for the fame purpofe, the climbing forts, may occafionally be run with a fingle ftem, fupported each with a fake, and permitted to branch full at top, to form bufhy heads, pruning tine long thoots accord. ingly.

Thefe fhrubs, for planting, are moft proper, while they are of moderately-young growth, advanced, in the main ftem and principal head, one to two, or three feet, exclufive of the long-extending hoots.

The climbing, or trailing kinds, thould generally be planted either to have the fupport of walls and palings, or to train againft the wall of an houfe, or other build. ing, or to afcend over arbours; and in all.or any of which to have the principal thoots trained in regular order; cutting out the weak ftragglers, and prune the upper weak parts of the others, and nail them to the wall, either upright, or more or lefs horizontally, as the allotted fpace admits, five or fix inches afunder; or others planted to twine round ftakes, poles, or the ftems of trees; and fome to run over fhrubs, bufhes, hedges, \&c. in their natural order of growth; and likewife fome may be planted detached in thrubberies, and formed into low, bufhy, ftandard fhrubs, affifted by the fupport of a take to each, as formerly intimated, and trained with a fingle ftem, by cutting away the lateral hoots, and forming a full head above: prune the very long, rambling fhouts, to preferve the head within fome moderate compass and regularity.

But the more firm, or upright growers, may be planted for detached Itandards, in thrubberies, borders, \&c. trained principally witl a fing]e, upright ftem, one, two, or three feet; or any as feem to need fupport, have a ftake placed to each, the ftem tied thereto; and, in all of which, pruning away the other lateral fhoots, and fuffered to branch out above to form the head; and of which prune fraggling and rambling twigs, to keep the head in fome regular order.

Or any of thefe forts of Honey-fuckles may alfo be trained againft walls, \&c. as advifed for the common climbing kinds; efpecially fuch as produce long, running thoots, or of a trailing nature; or any others, as 
may be required for variety or ornament to particular compartments.

The propagation, or ways of raifing Honey-fuckles, is principally by cuttings and layers of the young fhoots, in fpring or autumn; fome alfo by fuckers from the roo:, efpecially the Lonicera Diervilla, or moit of the forts by feed.

By cuttings and layers, is performed in autumn or spring, chufing, for cuttings, fome frong thoots of laft fummer; cut them into lengths of fix or eight, to ten or twelve inches; plant them by dibble, in a fnady border, or wliere convenient, in rows a foot afunder, by fix inclies in the row, inferted half way into the ground, the will be weil rooted by the following autumn; and for laycrs, the yourg hoots, as above, are alfo proper, which horten to moderate lengths; or prunc down the weak tops, lay the fems in the earth, three or four irches deep, the top part feveral inches above ground, they will be well rooted by the end of fummer: for planting off in autumn or fpring, into the nurfery, or where they are to remain; and, in either method of propagation, train the young plant with a fingle item below, fhorter or longer, fix or eight, to twelve, fifteen, or eighteen inches, or two feet, or more, as required, for particular occafions, agreeable to the foregoing intimations; and permitted to fhoot out above into branches for the head, which may have the long ftragglers pruned more or lefs, as may feem neceffary, accordirig to their nature of growth, or order of training irtended, as before explained.

Suckers arifing from the roots of any particular forts, as the Diervilla, \&c. before hinted, may be llipped off with roots, in autumn or fpring, and planted in a nurfery; or ftrong ones, where they are to continue as may be thought convenient.

Or alfo by feed of the berries, fowed in the autumn or fpring feafon, in a bed of common earth, many young plants will come up, which, in autumn or fpring following, may be pricked into purfery-beds, in rows a foot afunder, and managed as advired for the cuttings and layer-raifed plants.

The plants, raifed by either of the above methods, when advanced one, two, or three feet in the principal ftem and head, are of proper fizes for planting in the different, or any particular compartment intended.

Thofe of the principal climbing kinds, defigned to plant againlt walls, one, two, or more plants, as thought expedient, thould have them run with feveral thoots or branches from near the bottom, and trained in mofly at their full length, in fummer; ar only prune very difordetiy Aragglers; and in winter, referving the ftrongeft, cut out the weak, and prune the weakly apfer parts of the remaining, and then nailed up re- gular; and thus forming a proper fread of branches, by degrees, to furnifh the allotted ipace, they will prozuce plenty of young wood, annually, in fumner. for flowering, which manage as above; and when any principal branches fail, have young fhoots trainea in below so fupply the place thereof.

Or where any are planted to twine round ftakes, trees, or to run over arbours, bufhes, \&c. their fhoots at firft, being conducted to their refpective fupports, will moitly attach themfelves thereto; giving occafional afiftance of tying, and extending where neccifary; and to prune diforderly, rambling thoots.

And thofe planted detached in fandard frrubs, trained with fingle ftems, more or lefs, and full heads, will require to have the long, ftraggling hoots, pruned in, to continue the head fomewhat regular, as before obferved.

\section{LOT US, BIRD'S-FOOT TREFOIL.}

\section{Clafs and Order.}

\section{Diadelphia Decandria,}

Two Bratberboods, Ten Malcs;

\section{Or Plants with Flowers (Herm.) baving two Sets of} Stamina, or Males, and ters Stamina in each Flower.

THE Lorus furnifhes two hardy fpecies of low, under-fhrubby flowering-plants, proper to admit in Ahrubberies; are of upright growth, garnithed with trifoliate, or three-lobed leaves, or compofed cach of three diftinct lobes; and heads of papilionaceous, or butterfy-Thape flowers, of four irregular petals; confifting of a roundion, reflexed vexillum, or ftandard, two broad, roundinh wings, a hort carina or keel below ; with ten Atamina in two fets, or nine joined, one feparate, and oblong, taper germen, fupporting a fingle ftyle, fucceeded by fmall, cylindric, and ovate, bivalve pods, having many internal partitions, contailsng each one feed, by which the plants are propagated; likewife by lips, cuttings, and off-fets.

\section{The Species are,}

\section{Lotus birfutus, Hirfuted, or Hairy Bird's-Foot Trefoil.}

A fmall, deciduous under-thrub, of low, upright growth-the ftcm cred, hairy; leaves (Smail) trifoliate; with hirfuted or faggy heads of flowers; and Thort, ovate, or egg-form feed-pods.-Native of France, Italy, and the Eaft. (Dry, warm fuluation.)

\section{Lot us ręus, Straight-podded Bird's-Fout 'Trefoil.}

A fmall, deciduous under-fhrub, of low, upright growth-the ftem crect; leaves ( $/$ mall) trifoliate: 
fuij-nisiofe heads of fiowers, and fraight, finooth Sict-pods Native of Fance, Sicily, and Calabria. (Dij, ruam farkicr..)

Thefe two fpecies are a fort of under-hrubby, herbaceous-like, percnnial plants, eligible to introduce in fimall thrubery compartments, horders, \&c. for ornamental fowering and variety: they are propagated by feed, fowed in the fpring, in a warm border, and the plants pricked in nurfery-beds for a year or two, to gain frength, then tranfplanted where they are to xemain; alfo by flips or cuttings of the fhoots in fpring or fuminer, planted in a thady border; and by off-fets of the roots, parted in the fpring or autumn.

\section{LYCIUA, BOX-THORN.}

\section{Clafs and Order.}

\section{Pentandria Monogynia, Five Males, One Female;}

\section{O.: Flowers (Hermaphrodite) baving five Stanina, or} Males, and one Piffillum, or Female.

THIIS Genus, Lycium, furnithes feveral hrubby eve-greens, of upright and trailing growth, admitted ix Arubberies for variety, fome of which being rather tender, require a warm, heltered fituation, others are of a more hardy nature; moftly armed with thorns, aid garnifhed with fmall and middling fpear-thape and ovate, oblong leaves; and funnel-thape, purple and white flowers; having five-parted, permanent cups; a monopetalozs corolla, funnel-rhape, tubular below, divided above in five parts; five ftamina, and a roundith germen, fupporting a fingle ftyle; and the gérmen grows a roundifh, bilocular berry, containing many kidney-thape feeds; by which the fhrubs are fometimes propagated, or more generally by layers and cuttings of the young wood.

The Species and Varieties are,

\section{v. Lxcium barbarum, Barbary Box-Thorn, or Rofe- mary-leaved Lycium.}

A middling thrub, with whitith branches, and of five or fix feet growth, armed with thorns-the leaves ( $/$ mall, whitißh) (pear-fhape, narrow, and of thickin fubftance; and the calyx of the flowers bifid or twoparted.- Native of Afia, Africa, and fouthern parts of Europe. (Warm, Beltered fituation, and dry joil.)

Varieties.-Upright, Barbary Box-Thorn.
2. Lycrum jine:ye, Chinefe, Trailing Box-Thorn;

(fupputed a variety of the Lycium iarbarais.)

A trailing, climbing, thrubby plant, extending ten or twelve feet, or more, armed with triorns-the leaves (middling) ovate tpear-Thape. Native of Afia, \&c. (Any comnon joil and waim fitiation.)

\section{Varieties.B:oad-leaved Chinefe Box-Thorn. Narrow-leaved Chinefe Box-Thorn.}

Thefe thrubs are proper to affemble in curious thrubberies; but being moftly fomewhat tender, more particularly the Lycium barbarum, fhould have a warm, dry fituation, or fome alfo kept in pots to remove under thelter of a frame, or green-houfe, in winter: the Chinefe fort is more hardy, to fucceed in any common expofures, or may be planted againft a warm wall, \&x. both for the advantage of training their trailing branches thereto, and to afford them fhelter more beneficially from froft; or if planted detached in the thrubbery, hould have fupport of itakes.

They may be procured at moft of the principal nurferies, for planting, which hould be performed either in autumn, about October or Novenber, or in the fpring.

The propagation of all the forts is principally by cuttings and layers of the young fhoots; plant the cuttings principally in the fpring, and may perform the laying alfo in that feafon, or in the autumn; they will be rooted in one year; or cuttings of fmall thoots might be pianted in pots, and plunged in a hot-bed in the fpring months, to forward them in rooting fooner; and, in either method of propagation, forward the plants in a fheltered part of the nurfery; or fome protected in winter, from frolt, till they obtain ftrength; then may be tranfplanted into hrubberies, or where they are to remain.

They are alfo raifed from feed, occafionally, where attainable ; fowing it in the fpring, in a wafm fituation, or in pots, and placed in a moderate hot-bed, in which the plants will come up fooner, and be forwarded in growth, giving them plenty of air, and occafional waterings, and have the full air all fummer; and, in either method, the young plants thould be pricked in fmall pots, fingly, to place under thelter a year or two, or till they acquire fome tolerable ftrength, and gradually hardened, then tranfplanted into the full ground; or fome continued in pots, of proper fizes, according to the advanced growth of the plants. 
MAGNOLIA-(MAGNOLIA) Or LAUREL-LEAVED TULIP TREE, of the

\section{Clafs and Order}

$\begin{array}{ll}\text { Polyandria } & \text { Polygynia, } \\ \text { Many Males, Many Females; }\end{array}$

Or Plants with Hermaphrodite Flowers, baving many Stamina, or Male Frubtifications, and many Pigillums, or Females.

THE MaGnolia comprifes fuperbly-beautifil ever-green trees, and deciduous kinds, all flowering very ornamentally, growing fifteen to twenty or thirty feet high, or more, in the different fpecies, decorated with moft elegantly large, and middling, oblong-fpearhape, and ovate-fimple leaves; and large, ornamental, ennepetalous, or nine-petalled, white flowers, imparting an agreeable fragrance; having three-leaved cups, a corclla of nine large, oblong, concave petals, numerous ftamina, and many germens and tyles; fuccecded by large, conic heads, of roundih-cluftered capfules, furnifhed with roundifh, baccated, or berried feeds, which, being difcharged from the capfules, are fufpended by flender threads; feldom ripening in perfection in England, but are obtained plentifully from North America, the place of their native growth, by the feedfmen; and by which the trees are propagated; alfo by layers and cuttings of the young fhoots; all principally in the fpring.

\section{The Species of MAGNOI,IA are,}

1. MagNoria grandifiora, Grand-flowered Evergreen Magnoliz, or Laurel-leaved Tulip Tree.

$\Lambda$ fuperb, ever-green tree, with an upright ftem, and large, branchy head, growing twenty to thirty, or forty feet high, or more-the leaves (mof large, lightgreen, ßsining) oblong, fpear-fhane, perennial, or evergreen; and large, white flowers, terminating the ends of the branches: Jume and July.-Native of Florida, Carolina, and other parts of Anerica, (Loamy, or any tolerable foil, and warm, dry fuuation.)

\section{Varieties.-Broad-leaved Ever-green Magnolia. Narrow-leaved Ever-grcen Magnolia. \\ Ferruginous, Ever-green Magnolia; with leaves irony, coloured under- neath.}
2. MA grolia acuminala, Acıminated-leaved, Deci- duous Mignolia.

A middling, a ciduous tree, growing twenty feet high, or morc-the leaves (moderately large, light- green) ovate-oblong, acuminated, or harp-pointed, and deciduous; and large, blueifh, or white flowers.Native of Pennfylvania, in North America. (Ligbt, loamy, or any tolerable foil, and Beltered fituation.)

\section{Magnolia tripetala, Tri-dependent petalled Mag- nolia, or Umbrella Tree.}

A middling, deciduous tree, growing twenty feet high, or more-the leaves (moft large, liglot-grecn) fpear-hape, difpofed in rays, expanding like an umbrella; and large white flowers, having the three exterior petals dependent.-Native of Carolina, and fome parts of Virginia. (Any tolerable foil and foeltcred fituation.)

\section{Magnolia glauca, Glaucous-leaved, fmalier De- ciduous Magnolia.}

A fmall, deciduous tree, growing ten or twelve feet high-the leaves (middling) ovate-oblong, glaucuus, or fea-green, whitifh on the under fide.-Native of Virginia and Pennfylvania. (Any common foil and ruarm fituation.)

\section{Variety.-Double-flowered, Glaucous Magnolia.}

All thefe fpecies of Magnolia are moft defirable, ornamental trees, for adorning the pleafure-ground; and have particular merit to affemble in curious collections of trees and furubs, in principal Rrubberies, in the moft confpicuous fituations; the Magnolia grandifora, in particular, being a magnificent, ever-green tree of fingular grandeur, and one of the molt beautiful of the ever-green tribe; claims univerfal attention, to plant for ornament, appearing delightful in its very large, fhining foliage, in conftant verdure tho year round: the other three fpecies being deciduous, are in foliage only in fummer; but effect a confpicuous variety in that feafon; and in all the forts, when advanced of fome confiderable growth, theye produce their beautiful, large flowers, at the ends of the branches; fo that, in the whole, thefe trees are of great eftimation for ornamental planting, in the moft confpicuous fhrubbery clumps, \&c. or the Ever-green Magnolia, to plant fingly on plats, lawns, and principal borders; generally difpofing all the forts in fone warm, defended compartments; and the ever-green kind, in particular, thould be defended from frolt with mats.

They are all raifed from feed, layers, and cuttings, as hereafter explained; and when the plants are tivo or three feet high, are of proper fize for tranfplanting into Thrubberies, or other parts of the pleafure-ground, \&c. 
But the Ever-green Magnolias, particularly, being rather tender, and liable to luffer by the effects of fevere froft, thould generally, in their minor groivth, be kept in pots, one plant in each, ready for moving under fhelter of a frame, or green-houfe, in winter, to protect them in rigorous weather, in that feafon, till they have acquired fome tolerable degree of ftrength; then tranfplanted, with the balls of earth to the roots, into the full ground, in a warm part of the pleafure-ground, or fhrubbery; and in which, to have alfo occafional fuelter in fevere winters, by an awning of mats, fupported upon a framing of poles and rods, arched over each plant; or fome planted againft or near a fouth wall, \&c. for the greater advantage of protection.

Or likewife, in the deciduous kinds, although of a hardier nature, it is proper to have fone in pots, as ahove, while young, for placing under thelter from fevere frolt, the firit two or three winters, till increafed in fome tolerable fize and ftrength, then turned out into the full ground; or others may be cultivated wholly in the open air, in a warm fituation.

The different fpecies of Magnolias are cultivated for fale at all the principal uurferies, where they may be obtained of preper fizes for planting, about two, to three or four feet high; either occafionally, fome growing in pots, convenient to tranfplant with balls, or fuch as aumit of removing therewith from the full ground, or with as full roots as pofrible.

The fearon for planting them is either in autumn, about the middle or latter end of September, or any time in October and early part of November, for the Ever-green Magnolia; the others in October or November aforefaid; or all the forts in the fpring months, when mild weather, in February, March, or April; and where convenient to remove, or tranfplant any with a ball of earth, either from pots, or the full ground, efpecially the Magnolia grandiftora, or any of the others, it will be of greater advantage in their prefent growth; though they will alfo fucceed without balls, where not convenient to remove them therewith, if :aken ûp with a full fpread of roots.

In planting them in firubberies, and other parts of the pleafure-ground, generally allot them a theltered fituation in fome principal compartments; and if in a fhrubbery, in affemblage with other ornamental trees and Thrubs, place them fomewhat forvard, where they may be confpicuous to fight; or the ever-green kind, in order to have it appeai more diftinguifhable in its fingular beauty, is fometimes ftationed fingly upon grafs-plats, \&rc. in fome defended, warm part, either forming a fmall clump of ground therein, for each plant, or the grafs continued clofe up round the ftem, to effect a more rural apwearance: and, in any of the metbods or orders of planting the different forts, they fhould be trained with a fingle ftem below, pruning away the lateral $\mathrm{fh}$ sots, $3 \mathrm{c}$ by degrees, and rasmirted to branclı out above in will heads; and in inter, it is advifeable, in the Ever-green Magn siil particulariy, as before obferved, to give protectiondrom ievere froft, by erecting fome thin, piiant poles, ruds, or hoops, arch-ivays over each plant, at the appe:rance of fevere weather, and when the frolt is rigoruus, cover with large Ruflia garden mats.

The propagation, or methods of raifi.g the different forts of Magnolias, is by feed, and lay irs and cuttings of the young thoots; each according to the following intimations.

The feed is commonly obtained in principal fupplies from America, by the feedfmen, in the fpring; and in which feafon, in Màrch or April, they are generally fowed, either in a bed of light, good earth, in a warm fituation, or in middling pots, filled with fimilar foil, and covered in with fine mold half an inch to an inch deep; and thofe fowed in pots may either be plunged in a moderate hot-bed, to forward them a little, or placed in a frame defended occarionally with glaffes, or fet under fome warm fence; but generally removed to a thady fituation in the heat of fummer, and wa tered, and placed under fhelter of a frame, \&c. in winter; and in the fpring, when the plants are a year old, thould be tranfplanted, forne fingly, in fmall or moderate pots, others in a norfery-bed, in a warm compartment; and if thofe in pots are plunged in a gentle hot-bed, or bark-bed, for three or four weeks, or more, having plenty of air admitted, and watered occafionally, it will promote their frefh rooting fooner, and run them off more effectually in a free growth; though, they will alfo fucceed without that afliftance; and in either method, give water in fummer, and protection from froft in winter; training each with a fingle ftem below, and branches above; and when increared in ftrength, the whole may be planted in the full ground; or having attained two or three feet growth. are of eligible fize for the thrubbery, \& $c$.

Or by layers and cuttings, the young fhoots are the proper parts; chufing, for layers, the pliant, lower branches, in autumn or fpring, bowing them down, and lay the young thoots into earth, in the ufual method; and for cuttings, take off fome young thoots, fix or eight, to ten or twelve inclies long, and planted in a bed or border; they will root the fame year, both layers and cuttings; or cuttings planted in pots, in March or April, and plunged in a bark-bed, will promote their rooting fooner; and the plants raifed by thefe different methods, may be managed as advifed for the feedling-raifed plants, till of proper growth for final tranfplanting.

Continue the whole in a heltered fituation during their young growth, in the nurfery, \& c. to have fome protection from fevere froft; or fuch as are contained 
in pots, may be moved under thelter of a frame, or awning in winter, and, when the weather is fevere, defended with glaffes, mats, \&c.

\section{MENISPERMUM, MOON-SEED, of the}

\section{Clafs and Order}

\section{Dioecia Dodecandria, \\ Two Habitations, Trwelve Males;}

Or Male and Female Flowers, feparate, on two difting Plants; and the Malis baving twelve Stamina.

THE MEN ISPERMUM furnifhes two hardy, thrubby, deciduous climbers, of volubilate, or twining growth, proper to introduce in hrubberies, \&rc. for variety; grow with long, flender, twining ftems, afcending upon trees, poles, \&c. many feet high; garnifhed with large, (hield-Phape, hearted, and lobated leaves, and loofe bunches of greenim flowers, male and female, on two feparate plants, compofed each of twelve oval petals; containing, in the males, twelve ftamina, and in the females, two germens and ftyles; fucceeded by roundilh, kidney-form berries, furnifhed with kidney-Thape feeds, by which the plants may be raifed, but are more generally propagated by layers, or lips of the off-fet hoots, or buttom-fuckers, and by parting the roots.

\section{The Species are,}

1. Menispermum canadenfe, Canada round-leaved Moon-Seed.

A volubilate-climbing, Inrubby plant, with long, fender ftalks, afcending twelve or fifteen feet high the leaves (large) peltate, or fhield-hape, hearted, roundih-angular; and nodding racems of flowers. Native of Virginia and Canada. (Light or any common foil.)

2. Menisperaum virginicum, Virginia lobatedleaved Moon-Secd.

A volubilate-climbing, fhrubby plant, afcending ten or twelve fcet high-the leaves (large) peltate, or hicld-thape, hearted, lobated; and loofe racems of flowers. - Native of Virginia and Carolina, near the fea. (Light or any common foil.)

Thefe two Thrubby climbers may be admitted for variety in Mrubberies, and other plantations in pleafure-grounds, to iwine round the ftems of large trees, or tall poles; and planted to run over arbours, rural feate, or where they may be required, to advance in a climbing growth, they will twine sound any fupport; or may be trained againft walls, or other fences; and for which occafions, plants of both the fpecies may be had at the nurferies, for planting in autumn or fpring; and may be propagated by layers of the hoots, and off-fet bottom-fuckers, and by llips of or parting the roots; all performed in the fpring or autumn; alfo by feed fowed in a bed of light earth; and when the plants, raifed by any of thefe methods, have attained one, two, or three years growth, they may be tranfplanted in the places where intended.

Generally, in planting thefe climbers, either allot them a place where they may have fupport of trees, arbours, \&c. to afcend upon, or to have tall ftakes or poles placed whereon, to climb in their volubilate manner; in which they may be permitted to run nearly in their natural order, except pruning cafual, ftraggling, or very diforderly thoots, and to cut out decayed parts; or if any are planted againft walls, or other fences, the ftems may be nailed thereto, as practifed for honey-fuckles, \&c. and to prune out the fuperabundant hoots, produced annually.

\section{Mespilus, (MEDLAR) or Mediar TREst. Clais and Order.} $\begin{array}{ll}\text { Icolandria, } & \text { Pentandriá, } \\ \text { Truenty, or more Males, Five Females; }\end{array}$

Or Plants with Flowers (Hermaphrodite) baving truenty or more Stamina, or Male Parts, and frue Piftils, or Females.

THE MEspizus, or Medlar, comprife fruit-trees, feveral fpecies of deciduous, flowering-fhrubs, and one curious, fhrubby ever-green; the fruit-tree kinds valuable to cultivate for their fruit, of fingular property; and likewife, together with the other different fpecies, are in eftimation to introduce in fhrubberies, and other decorative plantations, for ornament and variety: are of different degrees of growth, fifteen or twenty feet in the tree kinds, the fhrubs three or four, to five, fix, or eight feet or more; garnifhed with middling, large and fmall, fpear-fhape, oblong and oval leaves; and pentapetalous, rofaceous, large and fmall flowers, fingly, and in clufters, at the fides and ends of the branches; having monophyllous, or oneleaved cups, divided into five parts; five roundifh petals; tiventy or more ftamina, round germen with five ftyles; and the germen grows a globular, hard, umbilicated, baccated, or berried fruit, large, middling, and fmall in the different fpecies; and which, in fome, acquires the fize of middling, or frall apples and pears, as in the Common Medlar, (the principal eatable fort) others much (maller, and fome like fmall berries; but eatable principally only in the Common Medlar, aforefaid; and in all of which, contain five hard, gibbous feeds, by which the trees, \&c, raxy be raifed, alfo by layers, grafting, and inoculation. 
The Species of MESP1LUS, confiting of one Fruittree kind, and feveral thrubs, are

$$
\text { (Fruit-tree kinds, witblarge, eatable fruit) }
$$

1. Mespulus germanica, German, or Dutch Medlar $-($ Eatable fruited.)

A moderate, deciduous tree, growing fifteen or twenty feet, branching irregulariy-the leaves (middling-large) ovate-fpear-fhape, hoary on the underfide, and large flowers fingly, and fitting clofe; fucceeded by largith, rough, brown, eatable fruit, ripe in autumn and winter.- Native of Germany and the fouthern parts of Europe. (Any common foil and fituation.)

$$
\begin{aligned}
& \text { Vesieties.-Common Apple-haped, Greater Dutch } \\
& \text { Medlar. } \\
& \text { Smaller Apple-fnaped, or Nottingham } \\
& \text { Medlar. } \\
& \text { Pear-hape Italian Medlar. }
\end{aligned}
$$

Thefe being the common, eatable Medlars, the two former varictics are the principal forts: they acquire full growth in October, having a large, mmbilicated opening, or cavity, at top; are very hisd and autere, when firlt gathered, requiring to lie fome time in the fruitery, \&c. to mellow; and when becomc foft and tender, are then eatable, and prove an agreeable defert, winter fruit.

$$
\begin{gathered}
\text { (Shrub kinds, for wariety and ornameint, producing } \\
\text { jmall, berry-like, red, and purple fruit.) }
\end{gathered}
$$

\section{Mespilus arbutifolia, Arbutus-leaved Mecllar.}

A middling, deciduous fhrub, growing fix or eight feet high-the leaves (widdling) ovate-fpear-fhape, crenated, or notched, hoary underneath.-Native of Virginia. (Any common foil and fituation.)

\section{Mespilus Amelancbier-(Amelanchier) or Alpine Medlar.}

A middling, deciduous thrub, growing five or fix, to eight feet high-the ftem hairy; leaves (finalliß) oval, and fawed, villofe-hoary underneath, and blackih fruit.-Native of Switzerland, Auftia, France, ixc. (Any foil, \&ce.)

\section{Mespilus canadenfe, Canada Snowy Mefpilus.}

A largif, deciduous fhrub, growing feven or eight, to sen feet high $h_{1}$ the leaves (finallig) ovate-oblong, fmooth, fawed on the edges. - Native of Canada and. Virginia. (Any cominon joil, \&cc.)

\section{Mespilus Chama-Mefpilus-(Chanx-Mefpilus) Divarf Alpine Medlar, or Dwarf Quince.}

A moderate, deciduous fhrub, growing three to fou:. or five feet high-the leaves (imall) oval, and fawed, Atipula deciduous; and flowers growing in corymbus heads.-Native of the Alps of Auftria, \&c. (Any conmon foil, \&c.)

\section{Mespilus Coloneafer-(Cotoneafter) or Baftard Quince.}

A moderate, deciduous thrub, three to four, or five feet high-the leaves ( finall) ovatc-roundih, cntire. - Native of the cold parts of Europe, on hills, the Pyrenees, and Mount Ararat. (Any common foil. \&c.)

7. Mespilus Prracantha-(Pyracantha) or Evergreen Thorn, commonly called Pyracantha.

A largith, ever-green thrub, of flexuofe growth, with long, flexible branches, rifing, by fupport, ten or twelve feet high, armed with thorns-the leaves ( finall) fpear-fhape, ovate, crenated or notched; and numerous cluiters of fmall, white flowers in fummer, fucceeded by bunches of red berries, very ornamental in autumn and winter.-Native of France and Italy, in hedges. (Any foil and fituation.)

All thefe fpecies of Mefpilus are eligible for garden plantations, fome for ufe, and the greater part for or. nament and variety; the Common Medlar both as a fruit-tree, and alfo, together with all the other fpecies, is proper to affift in compofing fhrubberies, and other plantation diftricts in pleafure-grounds; wherein they will increafe the variety very dittinguifhably, and effect an agreeable diverfity in their different growths, foliage, flowers, \&c. the Pyracantha has likewife particular merit for training confpicuoufly againft walls, the fronts of buildings, \&c. appearing always green, and its numerous bunches of red berries, continuing in autumn and winter, are fingularly curious and ornamental in thefe feafons; or this, and all the forts planted in fhrubberies, \&c. flower abundantly in fummer; and the flowers fucceeded by plenteous fruits, in autumn; fome large, of the apple and pear form, others fmallei, as before obfcrved, and fome like hawberries; but thofe of the furfe fpecies only, the lifepilis germanica, are confridered of the eatable kind, acquiring full growth in Oetober, but not proper for eating till after being gathered, and laid in fome dry apartment, to foften; or may be forwarded, a few at a time, in moif bran, till foft and mellow. 
The feafon for planting all the forts, is any time in open weather, from October or November; to March or April.

They are all very hardy, and may be planted in any common foil and fituation, and do not require any particular expofure.

With regard to their refpective ufes in gardening, the Common Medlar, as a fruit-tree, demands culture in gardens and orchards, a few trees trained principally in full and half Itandards, or fome in efpaliers; all the other fpecies have merit principally to join or affemble in any general fhrubbery, and ornamental plantations, in pleafure-grounds, parks, and other premifes; difpofed in a diverfified order, with other hardy fhrubs and ornamental trees; and in which may alfo introduce the different varieties of the Common Medlar; all generally trained with a fingle ftem below, and to branch out above in full heads; and which, permitted to advance in their natural order, or only to give occafional pruning, to reduce any diforderly fhoots and branches, that may cafually occur in the advancing growth of the different fpecies.

In refpect to the propagation, or methods of raifing the different forts, it is effected by feed and layers; alfo by grafting and inoculation, in any particular fpecies, or to continue the varieties of the Common Medlar in theil refpective properties, and likewife to have the trees fooner attain a fruitful ftate.

The feed for fowing is obtained from the ripe fruit and berries, and which ma $y^{n}$ be fowed in autumn, about OAtober or November, or in the fpring, all in a bed or beds of light earth, each fort feparate, either in drills, or broad-caft, and earthed in an inch, or an inch and half deep; they will come up fome the firft fpring, others probably not till the fecond : keep the beds clear from weeds all fummer, both before and after the plants are come up; ard when they are of one year's growth in the feed-beds, tranfplant them in the autumn or fpring into nurfery-beds, in rows a foot afunder, and having increafed in growth, fhould be tranfplanted in wider nurfery-lines; and in which generally train each with a fingle ftem, pruning off lateral hoots below, and let them advance in full growth above; and when, according to their different fizes, they are three or four, to five or fix feet high, are proper for final tranfplanting in the intended plantations.

By layers of the young wood, they are alfo oceafionaliy propagated; chufing the young thoots, either thofe rifing naturally near the bottom, or branches furnithed therewith, bowed down to the ground; and, previcus to layin knife, a little on the under fide, in an upward cut, to promote their emitting roots fooner; lay them with the cut-part in:o carth three inches decp, keeping the tops uprightin above ground: they will moftly be rooted in one year, then hould be cut from the ftools, and planted in a nurfery, \&c.

And by grafting or budding, any of the fpecies may likewife be propagated; and by either of which it is eligitule to raife the Common Medlar, when defigned to have them principally as fruit-trees for their production of fruit for eating; performing the grafting in the fpring, by inferting grafts of the intended kinds into feedling Medlar ftocks, and the budding or inoculation, in fummer, in July, or beginning of Auguft, by inoculating buds into the fides of the fame kind of ftocks; one graft or bud inferted in each, at three, four, to five, or fix feet height, for half and full ftandards, or low in the ftock for trees intended for lower growth; the grafts will hoot the fame year, and the buds not till the fpring following; and when they have thot, and formed heads of one, two, or feveral years growth, they are proper for tranfplanting where they are defigned to remain.

The Common Medlars, when defigned for fruittrees, being generally raifed by grafting or budding the approved kinds into feedling-itocks of any of the varieties, principally trained for half and full ftandards, with ftems, three, or four, to five or fix feet; they, when advanced with heads, two or three, to feveral years growth, with fome tolerable fpread of branclies, are proper for planting in gardens and orchards, twenty or thirty feet diftance, their heads permitted to branch out full in their natural growth.

Or fome grafted or budded low in the ftock, within fix or eight inches of the ground, to plant in efpaliers, at fifteen feet afunder, and the branches arranged to the trellis horizontally, five or fix inches diftance, and extended moftly at their full length, as far as their allotted fpace admits, as directed for apples and pears, trained in efpaliers; as, like thefe forts, they bear principally upon fmall fpurs, along the fides, and at the ends of branches, and the fame branches continuing many years fruitful, do not admit of hortening ; and in this mode of planting, will require an annual pruning and training, according to the directions given for efpalier apples and pears aforefaid; for which, fec the Genus Pyrus.

The Medlar fruit, acquiring full growth in october, mould be gathered in dry weather, and depo. fited in the fruitery, \&cc. upon Shelves, till they become foft and mellow; or to promote which, more cffectually and fooner, fome may be laid in moift.bran cvery week; they will thus acquire matirity, in fuc. ceffive orde;, in thei peculiar nianner, foft, tender, and buttery, in which they will be in perfection, for eating, all winter, delicious, and agrecably. Aavoured.

$$
\text { Q2 MORUS, }
$$


MORUS, (MULBERRY) Or MULBERRY TREz. Clafs and Order.

\section{Monoecia Tetrandria, One Habitation, Four Males;}

Or Flowers, Male and Female, Separate on one or the fame Tree, and the Male Flowers baring four Stamina.

THE Family of MORus furnifines four fpecies of hardy, deciduous trees, of the bacciferous, or berrybearing kind; one geiserally cultivated as a defirable fruit-tree, the others principally for variety and ornament, as fome alfo occafionally for their fruit; are of middling, or large growth, moitly with full branching, regular-fpreading heads; adorned, in fummer, with largith, cordate, or hearted, and palmated, rough, and smooth leaves; and fmall, greeriin, male and female flowers, apart, and diftinct on the fame tree; the inales collected into long, loofe amentums, and females in round heads, with fmall, four-parted, fucculent calyxes, no petals; four thort ftamina in the males; in the females two ftyles; and each head of female calyxes grcis's a largifh, oval, fucculent, tubercled, eatable berry, ripe in autumn, continuing fmall feeds in each tubercle ; by which the trees are fometimes raifed, or principally by layers and cuttings of the young thoots.

\section{The hardy Species of MORUS are,}

\section{Morus nigra, Black-fruited, or Common Mul- berry Tree.}

A middling, or largith, deciduous tree, with a widely-branching head, growing twenty to thirty feet high-the leaves (moderately large, dark-green) cordate or hearted, roundifh, and rough ; and large, oval, black berries, ripe for eating in Auguft and September; being the principal fort ripening in perfection and abundance in this country. - Native of Italy, near the fea. (Light, loamy, rich, or any tolerably good foil.)

\section{Yariety._Jagged-leaved Black Mulberry Tree.}

\section{Morus alba, White Mulberry.}

A midding, deciduous tree, growing twenty or thirty feet high-the leaves (larger, light-green) oblique heart-mape, polihed or fmooth; and white berries; not ripening in great perfection and abundance in this country-Native of China. (Any light, tolerably good foil.)

\section{MORus rubra, Red Mulberry.}

A middling, deciduous tree, twenty feet high, or more-the leaves (large, dark-green) cordate, or hearted, villofe-hairy on the under fide; long, cylindric amentums of flowers, and red berries.-Native of Virginia. (Any lightifh, good foil.)

\section{Mor us papyrifera, Papyriferous, or Paper-barked} Mulberry Tree of Japan.

A moderate, deciduous tree, growing twenty-feet high-the leaves (large, light-green) palmated or handform; and hifpid-fruit.-Native of Japan, where is made paper of its bark. (Any lightijh, common foil.)

Of the above four fpecies of Morus, the Black, or Common Mulberry, is the principal fort to cultivate as a fruit-tree, for its production of fruit, which is produced the moft abundant, largett, and ripens in the greateft perfection, very juicy, and refrefhing to eat, as defert fruit, and to ufe occafionally for pies and tarts; or fome of the white and red kinds may alfo be introduced in the fruit-tree collection, for the variety of their fruit; though is neither produced fo pientiful, nor in equal goodnefs, as the Black: but thefe two forts, and the Morus papyrifera, are cultivated principally for obfervation and curiofity, in pleafurable plantations, and in which the Common Black Mulberry may alfo aftemble; and all of which will effect a defrrable variety and confpicuous appearance in their growth, foliage, fand fruiting; however, where required to have Mulberry trees, principally for the fake of the fruit, chufe chiefly the Black-berried fort, for the general fupply; and of which a few trees may be fufficient for the fervice of a private family, efpecially as, after being advanced to fome confiderable growth, they bear great quantities of berries; I have known a fingle tree produce a fufficiency for the fupply of a large family, every day, during the feafon of their maturity.

The leaves of the Mulberry tree are of fingular value, as the principal food for filk-worms; that in the counties where thefe curious infects are bred in great quantities for their production of filk, which they fpin from their bowels, large plantations of the trees are cultivated for the leaves, with which to fupply them daily, in their feeding feafon.

The different forts of Mulberry trees are cultivated in the nurferies for public fupply, and where they may be had in collection for planting, or any particular fpecies, efpecially the Common Black Mulberry, to plant as a fruit-tree; and which may be obtained of fome advanced growth, furnighed with a tolerable head of branches, and that will foon conmence bearers, or fometimes, trees that are arrived to a bearing ftate, which 
Fhich will be of particular advantage; as Mulberry trees are low growers, long before they acquire a proper fize for bearing in any confiderable quantity.

Thefe trees, being generally propagated by layers, cuttings, fometinies by grafting, and occafionally by feed, are mofly trained in ftandards, with a fingle, clean item, of four, five, or fix feet, branching at top into full heads; and fometimes the Black and White Mulberry are trained in dwarf-trees for walls and efpaliers, with Mort ftems of fix or eight inches, branching out low near the ground, and the branches trained in a fpreading order, to the wall and efpalier, horizontally, whereby they produce fruit a little earlier, and larger, than on ftandards; though, for the general part, they are principally raifed in ftandard trees, on which the Black produces abundantly, ripening in good perfection and flavour.

The feafon for planting Mulberries, is either in autumn, about Oetober or November, or in the fpring, February, March, or April; or may be planted in any of the winter months, in open, mild weather.

To plant Mulberries as fruit-trees, generally allot them a warm, dry fituation, and funny expofure, to have all poffble benefit of the fun, that they may ripen the berries in the utmolt perfection; having for ftandards, fuch as are trained each with a fingle, clean ftem, five or fix feet, and formed fome tolerable head of branches, more or lefs; and may be planted cither in a kitchen garden, orchard, or pleafure-ground, as may be convenient, or thought eligible, at thirty or forty feet diftance, or more; or it is alfo proper to plant one or more ftandard trees, upon open grafs plats, or lawns, or a circular plat of grafs, formed under the tree to the full extent of the branches, or wider, both for the greater convenience of gathering the fruit, and that, when the berries, fully ripe, fall from the trees, they may admit of being gathered up of the grafs clean and found, for ufe, if occafionally required.

The trees, planted as above, in ftandards, permit to branch out freely every way, in a regular, fpreading lead; and in regard to pruning, very little will be required, only juft to reform any cafual, low, ftraggling branch, or fhoot; or to reduce any diforderly rambler, and to cut out crofs-placed, or thin, very crowding branches; and, except in thefe cafes, let the general head advance in full growth.

A few trees may alfo be trained for walls anc efpaliers, as before oblerved, for variety, and to have them produce larger and carlier fruit; they being trained, for this purpofe, with thort ftems, of fix or eight inches, to branch out low, fhould be planted againit a fouth wall, fiftcen or eightcen feet afunder, and the branches nailed to the wall horizontally, four to five, or fix inches diftance; if any are defigned for efpaliers, allot them a fouth expofure to the full fun, planted the diftances as above, and the branches trained in the fame manner; and in both of which orders of planting them, the trees requiring to have a regular training, will need an annual pruning in fummer and winter.

Give the fummer-pruning in June or July, to regulate the fhoots of the year, felecting plenty of the beit-placed fide and terminal thoots to nail in; cut out the fuperabundant, with fore-right and other ill-placed Moots, and then train in all the others clofe to the wall and efpalier, moltly at their whole length, without Shortening, where there is room to extend them entire; continuing them clofe to the wall and efpalier all fummer, in the fame order.

A winter-pruning is neceffary, both in the young and older branches, more or lefs; retaining a fupply of the beft young thoots in all vacant parts, and a leader, or terminal thoot, to every main branch; cut out the fuperfluous and ill-placed, and part of the molt unferviceable, or very irregular, and unfruitful old branches, not properly furnished with eligible, young. wood for bearing, as they generally bear towards the extreme. part of the year-old hoots; fo that the improper old wood.may either be pruned down to the origin, or to any convenient, lateral young thoot, or branch, eligible to retain, to fupply the place of the old, cutting out alfo cafual, decayed wood; the general branches and thoots retained for training, continue principally intire, as far as room admits of extending them at full length; nail or train the whole regular to the wall or efpalier, in the order above mentioned.

Thus, in regard to training the Mulberry, in wall and efpalier trees, as above, they will generally produce fruit in the fineft perfection in fize, and fooner ripe than on ftandasds, as formerly obferved.

Though thefe methods are not gencrally practifed, being principally trained in half or full ftandards, Lut cliefly the iatter.

The Mulberry trees being generally of flow growth in the beginning, it is man'y years before they acquire a tolerable fize in the head of branches to bear in any confiderable abundance; but when arrived to fome advanced growth, they fhoot more freely, extend into large, full heads, and produce abundant, annual crops of berries; they generally bear on the young wood, cither towards the extrcme part of the laft year's fhoots, and upon fmall fide-fpurs, of one or two years growth; and the trees being late, or the weather fettled in warm, before they foliate and hower, moftly produce plentiful crops: they feldom begin to bud, or expand their lcaves, till after the middle or towards 
the latter part of May, and flower nearly about the fame time, or foon after, fucceeded by the fruit in June, increafing in growth till Augurft, then ripens; continuing advancing to maturity in daily fucceflion till September, which, in the Mornis nigra, or Cominon Black Niulberry, becomes of a deep. black-red colour, when in full pertection, and hould be gathered accordingly.

The propagation, or way of raifing the Mulberry trecs, is principally by layers and cuttings of the young thoots, and occafionally by grafting, and fometimes by feed.

But by layers and cuttings, is the molt general methods; the laying may be performed in autumn or fpring, either from young trees that have been headed down to the bottom, to form ftools to furnifh lower thoots near the ground, convenient for laying down in the earth, or the lower branches of grown-up trees, having pots of earth placed upon ftands, elevated near enough to admit of laying the branches therein; and, in either method, laying the young thoots in the earth, they will be rooted in one fummer, for planting off in autumn following: cuttings of the young thoots, planted in the fpring, in a fhady border, will grow, or may be planted feveral together in pots, and plunged in a hot-bed, it will forward their rooting fooner; alfo ftrong hoots of the year, planted in fummer, in a north border, will emit roots the fame feafon; and when the layers and cuttings are properly rooted, tranfplant them into nurfery-rows, and trained up each with a clean, fingle ftem, three or four, to five or fix feet, for ftandards; or any of the Common Mulberry, defigned for walls and efpaliers, train them with thort ftems, and low-branching heads accordingly, as directed for peaches, \&c.

Or by grafting, \&c. may propagate particular foecies, upon ftocks of the Common Black Mulberry.

Or likewife, to raife Mulberry trees from feed, it should be faved from the ripe fruit in autumn, and preferved dry till the fpring, then fowed in March or April, in a bed of light earth, half an inch deep; and when the feedlings are a year old, prick them into nurfery-beds, in the fpring, in rows a foot afunder, and after having advanced to two years growth, tranfplant them in wider nurfery-rows, and trained to proper fizes for final tranfplanting.

When the young Mulberry trees, raifed by the above methods, are advanced four or five, to fix or eight feet growth, they are proper for tranfplanting, either the common forts as fruit-trees, or this, and the others, in pleafurable plantations, for variety, each agreeable to the foregoing intimations.

\section{MELIA, BEAD TREE, of the}

\section{Clars and Order}

Decandria Monogynia, Yen pirales, One Female;

O. Wants wit. Hermathrodite Flowcrs, baving ten Stamina, or Male Genitals, and one Piftillum, or Fenasale.

IN the Family of MEL1A is one tolerably-hardy, deciduous, curious, ornamental tree, of moderate ttature, witl a fpreading, branchy head, adorned with large, doubly-pinnated, winged leaves, elegantly beautiful, and long bunches of quinquepetalous, blue flowers; having fmall, five-pointed cups; a corolla of five long, fpear-fhape, fpreading petals, and a monopetalous nectarium, as long as the corolla; ten ftamina, a conical germen, fupporting a cylindric Ityle ; and the germen grows a globular, drupaccous, foft fruit, including a roundin, five-furrowed nut, of five cells, furnifhed with five feeds, by which the tree is commonly propagated.

One Species, viz.

Mel1a Azedaracb-(Azedarach) or Bi-pinnatedleaved Bead Tree.

A fmall, or moderate, deciduous tree, growing. twelve or fifteen feet high-the leaves (laige, darkgreen) bi-pinnated, or doubly-winged; and long bunches of blue flowers.- Native of Syria. (Warm, diy fituation.)

\section{Varieties.-Common, Deciduous, Bi-pinnated Bead Tree. \\ Ever-green, Ever-flowering fead Tree, of Ceylon. (Tender, requiring con- fant protection in winter.)}

This curious, ornamental tree, highly merits a place in principal hrubberies, but muft have a theltered, warm, dry fituation, or planted againit a fouth wall; and fome kept in pots, to move under Melter- of a frame, or green-houfe, in winter; and is alfo retained in the green-houfe collections, to have conftant thelter in winter, along with other exotics in that confervatory; but admits of planting in the full ground, in a theltered compartment, as before obferved; in which it will make a fine, ornamental appearance in fummer; the ever-green variety requires the conftant protection of a green-houfe, or ftove, in winter.

They flower ornamentally in fummer, but do rot. ? always produce ripe fruit, or feed, in this country. 
For planting, young plants may be obtained at molt of the principal nurferies; the proper featon for which is March and April; and being generally in pots, they may readily be turned out, the ball of earth intire, to plant in the full ground; if required; or continued in pots, to move uncer fhelter in winter; or any planted in the natural ground, being allotted a warm fituation, may alfo have occafional covering of mats in fevere, frofty weather.

The trees are propagated by feeds, or occafionally by layers and cuttings; fow the feed in the fpring, in pots of light, rich earth, and plunged in a bark or dung hot-bed; and layers and cuttings of the young hoots in pots, may be affited by the fame means, efpecially the cuttings; and in either method of propagation, the raifed plants thould be fet fingly in pots, and fhelter in winter, till they obtain fome degree of frength, then fome may be tranfplanted into the full ground, in fituations before-mentioned.

\section{MED1CAGo (Medic) MOON TREFOIL. Clars and Order.}

\author{
Diadelphia Decandria, \\ Two Brotberboods, Ten Males;
}

\section{Or Flowers (Hermapbrodite) baving trwo Sets of united Stamina, or Males, and ten Stamina in each Flower.}

THE MEDICAGo affords one beautiful, Mrubby cver-green, very cominonly retained as a green-houfe plant, as being a native of the varm parts of Europe, is rather tenderion; but is alfo cultivated in curious firubberies, in a fheltered, warm fituation; is of moderate or middling growth, upright and buhy, clofely garnifhed with fine, trifcliate leaves, and papilionaceous, yellow flowers, in long clufters; having to each flower a bell-fhape calyx five-lobed; a corolla papilionaceous, of four unequal petals, confifting of an ovalreflexed ftandard, two oblong wings, and a bifid, reflexed carina, or keel; ten itamina, diadelphous, or united below, in tro fets or brotherhoods, an oblong, incurved, comprefled germen, and fhort Ptyle, fucceeded by a long, comprefed, inflexed, or bowed, moonated pod, with kidncy-fhape feeds, by which the plant is propagated, and by layers and cuttings.

\section{One Species, viz.}

Medicaco arborea, Tree Medicago, or Shrubby Neapolitan Moon 'Trefoil.

A modcrate, evcr-green thrub, of upright, branchy growtl, fix or feven feet high, with hoary, young branches-the ftem trce-lik: ; leaves (Jmall, boary) trifoliate, whitin, ycllor flowcrs; and fecd-pods lu- nated or mooned, with the margin entire.-Native of Naples and Rhodes. (Wrarm, dry fituation.)

This beautiful ever-green, flowering-fhrub, merits particular attcition, and may be planted in a warn?, Theltered part of the fhrubbery, in which it will effect a fine variety, and ornamertal appearance, in its perpctual verdure, and in its flowers in fummer; it is aifo proper to have fome in pots, to place in theiter fronz froft; and is likewife cultivated among the gieen-houre exotics, to have pretection of that apartment ail winter, as being of a tender nature; though will fucceed in the full ground all the year, when fationed in wars: compartments, and occafionally defended with mats, in fevere weather.

\section{It is propagated by feeds, layers, and cuttings.}

Sow the feed in the fpring, either in a bed or borde: of light earth, or in pots, plunged in a hot-bed, to facilitate and expedite their vegetation; give occafional watering; and the plants, when of one fummer's growth, planted fingty in fmall pots, and theltered is winter till they acquire fome tolerable ftrength; and when two or three feet high, fome may be planted in the Anrubbery, \&c. others continued in pots, to move under protection in winter.

By layers and cuttings of the young fhoots; perforre the laying in autumn or fpring, and the cuttings generally planted in the fpring months, or beginning of fummer; they will be rooted in one year, managint them as directed for the fcedlings.

Mrrica, CANDLE-BERRY MYRTLE, GaEi,
\&c. Clafs and Order. $\begin{array}{ll}\text { Dinccia } & \text { Tctrandria, } \\ \text { Truo Habitation: } & \text { Fost Malis: }\end{array}$

Or Flowers, Male and Femalc, feparate on truo difiris Trees, and the Males baref four Stamina.

'THE MYRICA furnifhes tivo laady fpceies of curious, deciduous, ornamental hrubs, of aromatic fratgrance, for adorning principal Ahrubberies; plants of moderatc, upright-1hrubby, and under-firrubly growth, garnifhed with longith, narrow, fpear-fhape leaves, and fmall male and female fowers diltinct, on two feparate plants, in oblong and oval fcaly anentums; th: fcales forming cuns to fmall Horets, without petals; having, in the males. four ftamina, and in the females an oval germen, fupporting two fty!es, uucceeded, is the femalc flowcrs, by bunches of fmall, uritiocular, fingle-fceded berries, of a waxy nature, of which, i:1 one fpecies particularly, candles are male in Ainerica, the place of its mative growth; and ly the feed of the 
berries the plants are raifed; and likcwife by fuckers, layers, and cuttings.

The hardy Species of MYRICA are,

I. MYRICA ierifera, Wax-bearing Myrica, or Common Candle-berry Mlyrtle.

A moderate, deciduous firub, growing four or five feet high-the Atem tree-like, upright; leaves (longi/h, narrow) (pear-fhape, nightly fawcd; and clufters of waxy berries. - Native of Virginia, Pennfylvania, $\mathrm{Ca}$ rolina, \&cc. (Any common joil, jomewhat freltered.)

$$
\begin{gathered}
\text { Farieties.- Narrow-leaved Candle-berry Myrtle. } \\
\text { Broad-leaved Carolina Candle-berry } \\
\text { Myrtle. } \\
\text { Ever-green, Carolina Candle-berry } \\
\text { Myrtle. }
\end{gathered}
$$

2. Mrrica Gale-(Gale) Sweet Gale, or Ditch Myrtle, or Sweet Willow.

A moderate, deciduous under-Thrub, three or four feet growth-the ftem under-fhrubby; leaves ( fmaller, fsorter) (pear-thape, flightly fawed, and dry berries. -Native of Europe and North America, in marhy places. (Moift foil.)

Thefe two fpecies of Myrica deferve admittance in principal Mrubberies, as delicate, curious thrubs, and the leaves imparting an agreeable fragrance, more particularly the Gale; allot them a front fituation: the Myrica cerifera, or Common Candle-berry Myrtle, fhould generally have a fomewhat theltered compartment, and the Gale, or Dutch Myrtle, delights in a moift foil; both the fpecies, and the different varieties, may be had at the nurferies for planting, which perform in autumn or fring, and may be placed, in affemblage with other fhrubs of fimilar growth, in fhrubbery-clumps, in fituations as above.

They are propagated by fuckers from the root, by layers, cuttings, and feed.

To propagate them by the three former methods, the fuckers may be taken up in autumn or fpring, with roots, and plantcd either in a nurfery, or at once where they are to remain; and layers and cuttings of the young hoots, in the fame feafon, will be rooted by autumn following; and being planted in the nurfery, train them a hort ftem below, and branchy above; and when of a foot and a half, to two or three feet growth, are proper for the fhrubbery.

And by feed, fow it in the fpring in a bed or pots of light moift earth, covered in with earth, half an inch to an inch deep; the plants will come up the fame year: give occafional ivatcring, and next fpring, tranfplane them into nurfery-beds; or fome of the Candle-berry Myrties may be planted in finall pots, fingly, to place under thelter from fevere froft, till they bave obtained Tome tolerable ftrength; and when the plants of both the fpecies are advanced in growth, as before obferved, half a yard to two or three feet, they are proper for the firubbery plantations.

\section{Nrss., TUPELO TREE.}

\section{Clafs and Order.}

$\begin{array}{ll}\text { Polygamia } & \text { Dioecia, } \\ \text { Many Marriages, Trvo Habitations; }\end{array}$

Or Florvers of feveral different Sexes, as Males, Hermapbrodites, and Females, feparate, on two diftinct Plants, or Habitations.

THIS Genus, Nrssa, furnithes but one fpecies; a curious, deciduous, aquatic tree, comprifing two or three varieties, and of utility principally for ornamental planting in thrubberies and other pleafurable plantations; is a tree of moderate or niddling growth, adorned in fummer with oblong, broad leaves, on long foot-ttalks; and flowers of different fexes, as males, hermaphrodite, \&c. on two feparate trees, without petals, growing in clufters, and fingly, in the different varieties, fucceeded by oval, drupaceous fruit, containing an ovate, pointed nut, by which the trees are propagated, alfo by layers, cuttings, and fuckers.

\section{One Species, and fome Variaties, viz.}

Niyss aquatica, Aquatic, or Water Tupelo Tree.

A moderate, deciduous tree, of upright growth, twenty to thirty feet high-the leaves (midding, lightgreen) oblong, broad, acuminated, or hharp-pointed, indented, and intire, in the different varieties; and peduncles many-flowcred, and one-flowered.-Native of North America, in watery, and upland fituations. (Moift foils.)

\section{Varizties.-Indented-leaved, Water Tupelo Tree. Intire-leaved, Upland Tupelo Tree. Round-leaved Tupelo Tree. \\ Multiflorous Tupelo Tree; the pedun- cles fuftaining many flowers. \\ Uniflorous, or One-flowered Tupela Tree; the peduncles having but one flower on each.}

This curious tree demands admittance in ornamental plantations of thrubberies, and other diftrias, in as femblage principally with other trees and Shrubs of 
the deciduous tribe; and delights in moift fituations, or will grow in any common foil: is raifed in moft of the nurferies, for fale, where it may be obtained in the different varieties, for planting in autumn or fpring, or any time in open weather, from October or November, till March or begin ing of April.

The trees are projagated by feed, layers, cuttings, and fuckers.

The feed, for fowing, is commonly obtained from America, by the feedfmen, in the fpring, and in which feafon it may be fowed in a hady, or eaft border; and when the plants are a year old, tranfplant them in a nurfery; train each with a fingle ftem, pruning up the lateral hoots by. degrees, the top permitted to advance in full growth, and when grown three or four, to five, fix, or eight feet high, are of proper fize for final tranfplanting in the refpective diftricts in which they inay be required, for ornament and variety.

By layers and cuttings of the young wood, or hoots, of one year's growth, layed and planted in the auturnn or fpring, will be rooted by the following autumn; and then managed as advifed for the feedling-plants.

Or fuckers fometimes rife from the roots of the trees that are of advanced growth, and may be dug up in atitumn or fpring, and planted.

\section{OLEA OLIVE TREE, of the

$$
\text { Clafs and Order }
$$

\section{Diandria Monogynia, Iwo Males, One Femalc;}

Or Plants with Hermaphrodite Flowers, having two Stamina, or Males, and one Pifillum, or Female.

THE OLEA, or Olive, comprife curious ever-greens, of moderate tree or thrub-like groivth, for adorning the pleafure-ground, but being natives of warm countries, require a theltered fituation; are upright growers, ten to fifteen, or twenty feet; very branchy, almoft to the bottom, with full hends, decorated with fmall, or moderate fpear-fhape, and oval Riff leaves, oppolite, in pairs, continuing in verdure at all fcafons; and fmall, funnel-hape, white flowers, at the axillas, in clufters; having fmall, monophyllous, or one-leaved, tubulous, quadridented cups, a monopetalous, funnelfhape corolla, four-parted, and fpreading above; two fthmina in each flower, a roundifh germen with a lingle nyle, and the germeis 'become oval, green, eatable ruit, called Olives; good for pickling, though feldom produced in plenty and perfection in this country for ufe, nor furnifh ripe feed thereof for fowing; but the urces propagate freely by layers.
One Species, furnihing feveral Varicties, viz.

Or EA europaca, European Common Olive Tiee.

A fmall, or moderate, ever-green trec, of mhublike growth, ten to fifteen, or twenty fect high-the leaves ( mal') fpear-hape, ftiff, oppofite; and cluters of finali, white fowers, fucceeded by oval fruit. - Native of the fouthern parts of Europe. (Warm, diy fruation, and jome kept in poss, 10 place under fbelser in winter.'

Varictics,-Round-branched, Common Olire Tree. 'Tetragonated, or four-angled branched, Common Olive T'ree.

Narrov-leaved, Common Olive Tree.

Brozd-leaved, Spanim, Common Olive Tree, with larger oval fruit.

Short, hard-leaved, Wild, Common Olive Tree.

Box-leaved, Common Olive Tree.

Shining-leaved, African, Common Olive Tree.

This fpecies, and different varieties, of Olive Tree, being exotics from the fouthern, warm parts of $\mathrm{Eu}$ rope, \&c. require a defended, warm fituation, in this country, where they may have fome protection in winter from fevere froft, and fome kept in pots, to place under fhelter of a frame, or green-houfe, in the winter feafon; though, on account of their tender nature, liable to fuffer-in rigorous weather, they are likewife generally introduced in the green-houfe collection, to have protection of that confervatory all winter; however, they will alfo fucceed tolerably well in the full ground, planted againft a fouth wall, a plant or two of each, for variety; and when rigorous frofts, cover them with large garden mats, and litter the ground with ftraw, over the roots.

They are propagated principally by layers of the young branches, in the fpring or autunin; will be rooted in one fummer; then cut from the parent tree, and plant fome under a warm wall, others fingly in pots, to place under fhelter in winter, till they gain ftrength; and fome may then be tranfplanted, with balls, into the. full ground, in a warm fituation, as above intimated.

$$
\begin{gathered}
\text { ONON15, REST-HARROW, of the } \\
\text { Clars' and Order }
\end{gathered}
$$

$$
\begin{array}{ll}
\text { Diadelphia } & \text { Decandria, } \\
\text { Two Brotberboods, Ten Males; }
\end{array}
$$

\section{Or. Plants wish Flowers (Herm.) baving two Sess of} united Stamina, or Males, and with ten Stamina in cach Flowur.

THE ONONis furnithes two or three fpecies of Imall, very ornamental flowering-(hrubs, of low, un$\mathrm{R}$ der- 
der-Thrubby growth, garnifhed, in fummer, with trifoliate leaves, formed of fpear-fhape, and linear and roundifh lobes; and large, papilionaceous, or butterfy-hape, red and purple flowers, in panicled clufters, at the fides and ends of the branches, in May and June; having, in each flower, a five-lohed, arched cup; a corolla papilionaceous, of four irregular petals, confifing of a heart-fhape vexillum or ftandard, two oval wings, and a pointed carina below; ten diadelphous ftamina, an oblong germen, with one ftyle, fucceeded by a turgid, rhomboide, bivalve pod, furnifhed with kidney-fhape feeds, by which the plants are generally propagated.

Three Species, two of them hardy, the other fomewhat tender.

1. Ononis fruticofa, Shrubby, Alpine Reft Harrow.

A low, deciduous, under-fhrub, growing two or three feet high-the leaves (middling) ternate, or trifoliate, fpear-fhape, fawed; with theathed ftipula; and lagre, red flowers, in panicle bunclies, each peduncle moftly three-flowered; May or June, \&c.Native of the Alps. (Any common foil aud futuation.)

\section{Variety.-White-flowered, Shrubby Reft Harrow.}

\section{ONoNis tridertata, Tridented Flefhy-leaved Reft Harrow.}

A low, deciduous, under-Thrub, of two or three feet growth-the leaves (fmall, harrow) ternate, or trifoliate, fub-linear, flemy, tridented; and terminal clufters of fmall, purple flowers, the peduncles moftly two-flowered.-Native of Spain. (Warm, diy fituation, or fome kept in pots, to bave jhelter fiom froft.)

\section{Ononis rotundifolia, Round-leaved, Alpine Relt Harrow.}

A low, fhrubby plant-the leaves (middling) trifoliate, roundifh; peduncles moftly three-flowered, with the calyx having three bracteal leaves. - Native of the Alps of Swizcrland. (Any common foil.)

Of the above three fpecies, the firft and third forts are hardy to grow in any common foil and fituation; the other, fomewhat tender, fhould have a warm fituation, or fome alfokept in pots, to have thelter from frolt; but of which three forts, the Ononis fruticofa is that which is the moft generally known and cultivated in thrutberies, as a hardy, ornamental, floweringfhrub; and may be obtained at moft of the nurieries, for planting, in autumn or fpring: allot them principal c mpartments, in affemblage with other Shrubbu kinds,

generally placed fomewhat forward, confpicuous to view, and they will make a very pleafing variety in fuinmer.

They are propagated by feed, fowed in the fpring, in a warm border, or bed of light earth; they will come up the fame year; and in fpring following may be tranfplanted into the nurfery, and fome in pot:, fingly; and when advanced about twelve, to fifteen or eighteen inches, or two feet growth, are proper for the fhrubbery.

\section{PASSIFLORA, PASSION-FLOWER, of the}

\section{$\mathrm{Clafs}$ and Order}

\section{Gynandria \\ Females and Males joined, Five Males, or Staminz.}
Or Plants with Hermapbrodite Flowers, baving both the Male and Female Parts growing upon a Column, or Style, togetber; and have five Stamixa, or Ma!es.

THE PASSIFLOR,A comprehends moft curious, ornamental, flowering-climbers; one of which is a hardy. . climbing-hrub, renowned for the beauty and curiofity of its elegant flowers, of fingular ftructure; is of trai!ing-climbing growtl, with long-extending fhoots, advancing feveral feet in length in one fummer; adorned with large, palmate-fingered leaves; and large, fpreading, many-parted, radiated flowers, blue and white, in the fame, of admirable form and fingularity; produced on long foot-ftalks, fingly; having each a threelobed involucrum, five-leaved calyx, five oblong, plane, fpreading petals, containing a fringed, triplyradiated, many-parted nectarium, formed of thready, circular, fpreading rays, and a triple coronet around a centrical, gynandrious piltil, or column, fupporting the male and female parts of generation, confitting of five fpreading ftamina, and crowned by a roundin germen, elevating three ftyles; and the germen grows a large, oval, fleshy, baccated fruit, with many oval feeds; the fruit not eatable, nor the feeds often ufed for fowing; the plants propagating freely by layers and cuttings.

\section{One hardy Species, viz.}

PAssiflor a carulea, Blue-radiated, or Common Paf iion-Flower.

A deciduous, Shrubby climber, with Iong, nender, trailing-climbing ftalks, afcending, by fupport, twenty or thirty feet high, or more-the leaves (large, dark-green) palmated-fingered, of five long, fpearfhape, intire lobes, attended by twining cirrhi or clafpers; and large, fpreading flowers, with a blue and purple, radiate nectarium; July and Auguft.-Native of the Brafils. (Dry foil and warm fituation.) 
This defirable, Mrubby plant, deferves a place in every garden, as an elegant ciimber, and for the beauty. of its fingularly curious flowers, produced on the young thoots of the fame year, in daily fucceftion; each flower being only of one day's duration, expanding about ten, eleven, or twelve o'clock, according to the power of the fun; often burfts open elaftically, all at once, continuing fully expanded till the fame time next day, then gradually huts and decays; but fucceeded by a conftant fupply of frefh flowers every day for fix weeks, efpecially in plants arrived to fome rolerable extént of growth, and make a fine ornamental appearance in July, Augutt, and September.

Proper plants, for planting, may be purchared at the nurferies, and planted in autumn or fpring; and may. be propagated plentifully by layers and cuttings of the. young fhoots, in the rame ferfons.

As this plant grows with very long, feeble ftems and floots, requiring fupport to elevate them from thie ground, it hould generally be planted againnt a wall, building, \&zc. in a warm fituation, in the full fun, both that it may have greater protection from $x$ igrorous froft, which fometimes damage the young Shouts; and that, by being in a warm, funny exporure, it flowers in the beft perfection and abundance; and fome may alfo be planted detached in warm Mrubteries and borders, and to have fupport of ftakes; or fome planted in pots, for moving therein, to adorn any particular compartment occafionally in fummer, while in flower; tho'igh, in the general part, it commonly flowers in the greatent perfection again a warm wall.

A plant or two, planted againft a wall, or other fence, will foon fpread over a large rpace, and run up many feet high, if required; and to which the ttems and branches mould be trained in regular order, four to five, or fix inches afunder, either upright, or more or lefs horizontally, as the allotted fpace adnits.

In its advancing growth againft walli, s-c. it hould genemlly be continued in fome tolerable regularity, iy occafional pruning, and nailing annually i that as it confanily produces many, or numerous thoots, every fummer, extending to confiderable length, and on which the flowers are principally produced the fanc year, it is proper to train in a plentiful fupply of thefe annually, for fowering, consinued moftly at their full length during the fummers growth; or only prune the fuperabundant, or fuch as ale very difordcrly, or extend out of hounds, either fide-ways, or above; and in winter, about November, \&c. or towards the fpring; cut out the weak and fuperahundant hoots of the lafe fummer, and any decayed, or improper old uood, retaining a fupply of the ftrongeft young floots, cutting away a proportionable part of thic old, and ste young thortened to a yard or more in length, ac- cording to their frength and fituation on the plant; and nailed up to the wall regularly, the diftances before mentioned.

Or likewife, as before intimated, fome miglit be planted in a warm, funny part of a principal thrubbery, or border, and the ftems trained up to ftakes; and alfo planted to run over ar'sours, or. fome planted in pots, having fupport of ftakes aforefaid; and in all of which, being in warm fituations, they will flower in tolerable perfection.

The propagation, or methods of raifing this fpecies of Pafifiora, is effected plentifully by layers and cut tings, which frecly emit roots and grow; the laying may be performed in autumn or fpring, chufing fome of the ftrongeft young fhoots, and lay them down in the: earth, pruning off the weak, top part; and for cuttings, take off, with a knife, fome ftrong fhoots in the fpring, cut into length of ten or twelve inches, and planted in a fhady border; they will be rooted by. nexit Ootober, both layers and cuttings, to tranfplant: either in a nurfery, for a year or two, to gain Atrength. or fome of the ltrongeft, to plant at once where they are defigned to remain.

It is alfo fometimes raifed from feed, fowed in a bed or pots of light earth, in March; the plantsiwill come up the fame year; fhelter them in winter from froft, and in March following tranfplant them in a warm. fituation.

But the propagation, by layers and cuttings, is the more general and effectual method, whereby to obtain frong plants, the moit expeditiounly for flowering.

\section{PERIPLOCA, VIRGIN SILK, OF CLIMBING DOG's BANE. \\ Clafs and Order. \\ Pentandria Digynia, Five Malis, Tiso Females;}

Or Flowirs (Herm.) broving five Stamina, or Alalcs, and two Piffilluns, or Female Parts.

OF the Genus PER1PLOCA, is one hardy, underMrubby, rolubilate climber, to adnit as fuch in flrubberies, and as a flowering-plant; is of extenfive growth in its long, fender, twining falks, running, by fupfort, many feet high; garnifhed with oblong leaves, and monopetalous, rotated, purple flowers, in clusters; having to each flower a five-parted cup; a corolla rotated, or wheel-flape plane, divided into five fegments; contains five ftamina, and two ftyles; fucceeded by two oblong, ventricofe or bellied, foliculate pods, furnifhed with many pappous, or downy feeds, feldom ufed for forving, as the plant is cafily propagated by layers and cuttings.

R 2

Ore 
One hardy Species, viz.

Periploca graca, Greck Periploca, or Virgin Silk, sic.

A volubilate-climbing, under-Thrubby plant, extending with flender, twining ftalks, twenty to thirty, or forty feet high, upon fupport-the leaves (middling, tright-green) lanceolate-ovate, oppofite; and purple flowers, hairy internally.-Native of Syria. (Any ightifs foil.)

This rolubilate climber, is admitted for variety in pleafure-grounds, fhrubberies, and other ornamental plantations, to climb upon poles, or round the ftens of trees, and to run over arbours, bufhes, and hedges, in all of which it will afcend naturally, in its twiningclimbing growth, and tower annualiy in fummer; or may likewife be trained againft high walls, nailing the fems thereto; and is propagated by layers and cuttings of the fhoots, in autunn or fpring, which will root freely in one year for tranfplanting.

\section{PHILADELRHUS, SYRINGA, or Mock-Orange.}

\section{Clafs and Order.}

Icofandria
Twenty or more Males, One Female;

\section{Or Plants with Flowers (Herm.) baving truenty or more Stamina, and one Pifillum, or Female.}

THIS Genus, Pbiladelpbus, comprifes two or three fpecies, and fome varieties, of upright, buthy, deciduous, ornamental flowering-fhrubs, of four or five, to eight or ten feet growth, or more, with very full heads, garnifhed with ovate fpear-Thape, indented, and intire leaves; and numerous, fmall bunches of tetrapetalous, or four-leaved, white flowers, odoriferous, and fcentlefs in different fpecies, very confpicuous a:ad ornamental in May and June; having each a permanent cup divided into four parts; a corolla of four large, roundifh petals; twenty or more ftamina, and a fourparted ftyle; fucceeded by oval, quadrivalve, capfular nuts, cortaining many fmall, obłong feeds; which are feldom ufed for fowing, the different fpecies being propagated principally by layers, cutings, and fuckers.

\section{The Species of PIILADELPHUS are,}

1. PHILADELPHUS coronarius, Coronous-flowered, or Common White Fragrant Syringa.

A largifh, deciduous fhrub, of buhy growth, four or five, to fix or eight feet high-the leaves (node- rately-large) oval-fpear-fhape, nightly indented; and many white fragrant flowers in May and June.Native of Verona. (Any common foil and fruation.)

\author{
Varietics.-Large, Common White Syringa. \\ Dwarf Common Syringa. \\ Double-flowered Common Syringa. \\ Striped-leaved Common Syringa.
}
2. Philadelphus inodorus, Scentlefs Caro!ina Sy- ringa.

A large, deciduous fhrub, growing fix to eight or ten feet high-the leaves (middling) oval, intire; and large, white, inodorous, or fcentlefs flowers; May and June.-Native of Carolina. (Any common: foil and fituation.)

Thefe two fpecies of Pbiladclpbus are principal ornamental flowering-thrubs, to a fint in furnihing thrubberies, or any decorative plantations, and to plant in fpacious borders, \&c. in the pleafure-ground; they growing with full, bufhy heads, make a fine appear-. ance when in flower, producing the fiowers in bunches, in great profufion, for three or four weeks, in May and June; very odorous in the firft fpecies, fomewhat refembling the fmell of Orange flowers; and which, in both thefe fpecies, being alfo fomewhat fimilar in appearance, are hence fometimes called Mock-Orange.

They are vesy hardy thrubs, will grow any where, and are eligible for all parts of thrubberies: may be had at all the nurferies, for planting, which may be done any time in open weather, from October or Novenuber, to March or April.

Sometimes the Common Odorous Syringa, planted in pots, are placed in a forcing-fove, or lot-houfe, in January or February, to forward them to carly. flowering.

They are propagated by fuckers from the bottom, and by layers and cuttings; the fuckers may be dug up with reots in autumn, and planted in a nurfery, to acquire a proper growth for the Shrubbery, or ftrong ones may be planted therein, at once to remain; layers and cuttings of the young hoots in autumn or fpring, will root in one year; and in all of which methods train them up in the nurfery, \&c. moftly with a fingle fem below, and to branch out above in full heads; and when two or three feet high, are of proper fizes for the fhrubbery diftricts, \&c.

PHIL-: 
Parzyrea-(PHILlyrea) or Mock Privet.

Clafs and Order.

Diandria Monogynia,
Two Nales, One Female;

Or Plants with Hermapbrodite Flowers, having two Stamina, or Males, and one Pifillum, or Female.

THE PHLLYREAS are very noted, ornamental, evez-green Mrubs, for bexutifying Mrubberies and other decorative plantations, and for variety, \&c. confifting of three fpecies, and feveral curious varieties; all of largin, upright, very branchy, buhy growth; adorned with fmall, ovate-lanceolate, linearnarrow, and broad cordate-ovate leaves, moltly all in pairs oppofite; and fmall, greenif flowers, of but little appearance, growing in clufters; each flower is formed of a funnel-maped petal, cut into five parts ; contains two ftamina, a roundifh germen, with one ftyle, and the germens grow a globular berry, having eacli one round fecd, ripe in autumn, and by which, fowed in that feason or fpring, the fhrubs are propagated; likewife by layers of the young branches. or thoots.

The Species and Varieties of PHILLYREA are,

1. Philezrza media, Middle, or Oval-leaved Phillyrea.

A Iarge, ever-green fhrub, of upright, buthy growth, fix or eight, to ten or twelve feet high - the leaves ( mallif, dark-green, ßining) ovate-lanceolate, moftly intire, and oppofite, by pairs.-Native of the fouthern parts of Europe. (Any common foil and fituation.):

\section{Varieties.-Common Oval-leaved Middle Phillyrea. Privet-leaved Phillyrea. \\ Olive-leaved Phillyrea.}

2. Phillyrea latifolia, Broad-leaved Phillyrea.

A large, cver-green thrub, of upright, bufhy growth, eight or ten feet high-the leaves (larger, broad, dark-grecn, fining) cordate, or heartcd-ovate, fawed, and in pairs, oppofite. - Niaive of the fouthern parts of Europe. (Any common foil and fatuation.)

Varisties.-Common Serrated, Broad-leaved Philtyrea.

Unferrated, Broad-leaved Phillyrea.

Prickly, llex-lcaved Phillyrea.
3. Phillyrea angufifolia, Narrow-leaved Phil-
- lyrea.

A middling, ever-green thrub, growing fix or eight feet high-leaves (narrow, dark-green) linear, fpearfhape, very intire, and by pairs, oppofite.-Nativ of Italy and Spain. (Any common foil and fituations.)

$$
\begin{aligned}
\text { Varicties.- } & \text { Rofemary-leaved Phillyrea. } \\
& \text { Lavender-leaved Phillyrea. } \\
& \text { Variegated, Narrow-leaved Phillyrea. }
\end{aligned}
$$

All thefe fpecies and varieties of Pbillyrea are very hardy, will grow in almoft any fituation and common foil; are fine, thowy ever-greens, branching numeroufly from the bottom upiwards, in a buhy growth, clofely garnithed with leaves, continuing all the year in conftant verdure ; and are defirable, principal, evergreen fhrubs, to plant in Anrubberies, and other compartments of pleafure-grounds, for ornament and variety; trained generally in bufhy ftandards, and introduced principally in affemblage with others of the ever-green tribe, and occafionally to diverfify deciduous clumps, or to dot fingly in borders, plats, lawns, \&c. they likewife admit of training for ornamental garden-hedges, and are particularly.well adapted to train in a fanned, fpreading manner, againft walls or palings, in fore-courts, or. any place where required to have naked or unfightly walls, \&c. covered; as they branch out quite from the bottom, and - admic of training to the wall in a.fpreading expanfion, to cover it completely, and appear always green.

The Pbillyreas,and Alatermus, are very fimilar in their growth and leaves, only the former having the leaves placed oppofite, by pairs, and the latter are alternate, or one above another, fingly.

The different fpecies and varieties of Phillyrea are cultivated in all the general nurferics, where any forts required may be had, of proper growth for planting; and for which, all or any of the fpecies are eligibic; but where room to admit the different fpccies and varicties, they will make a confpicuous diverfity.

The general feafon for planting thefe evcr-greens. is either in autumn, commencing towards the middie or latter end of September, or any time in October or early part of November, or principall: in the fpring months; or, in mild open feafons, might be performed occafionally any time in winter, efpecially where the firubs can be remored with balls of earth to the roots; othervife, autumn or fpring is molt advifeable for any general planting of thefe and other ever. greens.

They are propagated by fecds and layers, in the al:tumn or fpring.

Sow 
Sow the feed in autumn or fpring, in a bed of light earth, and corered in half an inch to an inch deep; they will come np, fome probably the firf jear, but wil! fometimes mollly reman dormant till the fecond fpring: keep the beds clean from weeds; and when the fecdling-plants are a year old, traniplant them into nuffery-beds, in March or April, in which remaining one ortwo years more, to acquire a little frrength; then tranfplanted in wider nurfery-rows, to advance in fu!l growth, citlier bufhy from the bottom, or fome pruned np below to a fingle ftem, of a foot length, and to branch out full above; and having adranced in bufiny heacs, half a yard to two or threc feet high, are proper for the thrubbery.

By layers, chufe fome pliant branches, well furnifhed with young wood; peg them down into the ground, then lay all the young thoots thereof; they will moftly be rooted in one year, and fhould then be tranfplanted into a nurfery, to obtain proper growth.

When the plants, raifed by either of the above methods, are grown with branchy heads, half a yard to three feet high, or more, they are proper for planting in thrubberies, and other ornamental plantations; in which difpore them in the different cempartments, and generally permitted to advance in full growth; or may occafionally prune diforderly, rambling branches, or low ftragglers, to continue the heads fomewhat regular and diftinct; and in giving any requifite pruning, perform it principally with a knife, either infpring, fummer, or autumn.

Or where defigned to plant any of thele ever-greens to cover walls, \&c. as before intimated, the oval and broad-leared kinds are the molt proper; or, for variety, may. have fome of each fort, fuch as are branchy to the bottom; plant thent clofe to the wall, two or three fect afunder; prune or cut away the forc-right, projecting branclics, if any; nail the others to the wall in a fpreading manner, three or four inches afunder, at their full length, and permitted to run in full growth, continued traincd to the wall, to cover it effectually, in a rcgular expanfion; and as many projecting hoots will advance annuahly, they thould be cut in, clofe and regular, in fumme:, either with a knife or garden-thears, to form the front even, like an hedge.

\section{PHLOM1S, JERUSALEM SAGE. Clafs and Order.

Didynamia Gymnofpermia,
Truo Powers, Seedsnaked;

Or Plants with Flowers (Herin.) having two of four Stamina fuperior in length to the otbers; and Seeds uncovered, or lodging naked in the Calyx.

THIS Genus furnithes two hardy fpecies, and fome varieties, of curious, upright, hoary, ever-green, flow-
ering-Thrubs, for adorning the Trubbery; plants nf moderate growth, witl hoary branches, garrifhed with roundin-oblong, and hearted downy-whitifn leaves, and large, verticillate burclies of tubulous, gaping. ycllow, and purple fiowers, difpofed in whirls around the branches; having five and ten-angled, perfiftent cups; a monopetalous corolla, of one oblong, tubulas petal, ringent, or grinning above; four Itamina, two of then fuperior in length to the other tivo; a quadrifid, or four-parted germen, fupporting a fingle ftyle; and the germen becomes foul oblong, naked feeds, refting in the permanent calyx; the feeds feldom ufed for fowing, as the plants propagate freely by layers, cuttings, and flips.

\section{The hardy Species of PHLOMIS are,}

1. PнLOM fs fruticofa, Shrubby, or Tree-like Phlomis, or Common Jerufalem Sage.

A thoderate, hoary, ever-green fhrab, of ftrong, upright, bufhy growth, four to five, or fix feethigh the ftem fhrubby; leaves (niddling) roundin-oblong, crenated, hoary-white; and whirled bunches of yellow flowers, having (pear-fhape involucrums. - Native of Sicily and Spain. (Dry, light, or any common foil.)

\section{Varieties - Broad-leaved Shrubby Phlomis. Narrow-leaved Shrubby Phlomis, Dwarf, Cretall Shrubby Phlomis.}

\section{Pн гомiss purpurea, Purple, Under-Shrubby Phlo- mis.}

A Imaller, under-Shrubby, hoary plant, of flender, buthy growth, three or four feet-the ftem underMrubby; leaves (middling) hearted-oblong, hoarywhite; and with purple flowers, having linear involucrums, frorter than the calyx. - Native of Portugal and Spain. (Dry or any commons foil.)

There plants merit culture in all principal thrubbe. ries, both as curious, hoary ever-greens, and orna= mental flowering-fhrubs; will effeet a diftinguithable and fingular varicty at all feafons of the year, in the hoary afpect of their branches and leaves; and fower very confpicuoufiy in fummer and autumn, produced in whirls around the upper parts of the branches and thoots; they are tolerably hardy, but are generally the molt profperous and durable in a dry, light foil, and fomewhat fheltcred compartment; though they will alfo fucceed in any common, moderately-dry ground, and may be planted in affemblage with other hardy fhrubs. 
Eoth thefe fpecies, \&c. may be procured at the nurferies, of proper growth for planting, which perform principally in autumn or fpring; or are eafily raifed to an eligible fize, by the following methods of prupagation.

They are propagated by layers, and cuttings or nips of the young thoots: layers of the young branches, in autumn or fpring, will be well rooted by the dutumn following, when, or in fpring, cut them from the parent plant, and planted in nurfery-rows, to acquire prope: growth for the firubbery; and cuttings or lips of the young thoots, in the fpring and fummer, planted in a hady border, and watered in dry weather, they will root freely the fame year, and Thoot at top: the plants raifed by the different meLiods, may either be prumed up below, fo: ming a hort, fingle ftem, to grow branchy above, or permitted to advance wholly in a bufhy growth; and when half a yard, to two or three feet high, or more, they are of proper fize for the fhrubbery plantations.

PINUS, PINE TREE, and FIR, CEDAR TREE, and $\mathrm{LARCH}$, \&c.

Clafs and Order.

Monoecia Monadelphia,

Two Habitations, One Briotberbood;

Or Floruers Male and Fernale, feparate on one or the fame Tres; and the Stanina of the Males united in one Set, or Broiberbood.

THE Privs comprifes many fpecies and varieties of confiderable ever-green trees, and one deciduous kind; all of remarkable value for timber and ornamental plantations, being trees. of the firft order, fiwift and ftupendcus growers, advancing with a ftraight, firgle, ereet ftem, thirty or forty, to fixty, eighty, or an hundred feet high, branching, in circular rays, regularly from the bottom, upward; the branches, diminifhing gradually to the top, form beautiful, conical, or pyramidal heads; clofely garnifhed with very narrow, fetole or brifle, and awl-fhape leaves, fome by two, three, and five together, others fingly, and fome in bundles, or many together from one point, pencil form; and fmall male and female flowers, feparate on the fame tree; the males in fcaly racems, or fpikes, and females collected in oval cones, of many rigid, fcaly calyxes; no petals; many united ftamina in the ma': r srets, in the females, a fmall germen, and fingle ityle; and becomes a hard, fcaly, imbricated, conical fced-vertel, or cone, from one inch, to three, four, five, to ten or twelve inches long, involving many fmall, nut-like, winged feeds, one generally under each fcale; ripening in winter and fpring, and by which, fowed in the laft-mentioned feafon, the trees are propagated.

\section{Many Species of the PINUS.}

Comprifing the Pine Trees, Firs, Cedars, and Larch; the former is diftinguifhed by the leaves growing two, three, and five together, in the different fpecies; the Firs have all the leaves placed fingly; and the Cedar kinds, confifting of the Cedar of Lebanus, and Larch Trees, have the leaves in bunches, or many produced from the fame point, fpreading out above; and in all the forts, the leaves fmall, narrow, briftle. and awl-fhape, two or three, to five or fix inches long, in the different Tpecies and varieties.

\section{Pine Kinds (PINEA.)}

Diftinguifhed by having the leaves placed by pairs, threes, and fives, together from the fame fheath, moftly of a dark and greyifh-green hue; and the trees produce feed-cones, from one or two, to eight or ten. inches long, or more.

With leaves in pairs, or zwo logetber.

x. Pinus fyluefris, Wild Pine, Pinafter, or Scotch Pine, commonly called Scotch Fir.

A large, ever-green tree, growing fifty to fixty feet high, or more - the leaves (finall, dark-greyifh green) growing by pairs; the primordial or firft leaves, fingly and fmooth; and acute cones, one or two, to feveral inches long, in different varieties.-Native of the northern parts of Europe, \&ic. (.Dry or any common foil.)

Varieties.-(Pinafer latifolizs) Broad-leaved Pinafter-the leaves broader, longer; and long, acute cones.

(Pincifter tenuifolius) Slender-leaved Pinafter-the leaves fmaller and fhortcr; purple fower racems, and fmall cones.

(Pinafer maritima altera) Talleft Sea Pinafter-leaves broader, longer; and longith cones.

(Pinafler pumila) Dwarf Pinafter-the leaves thorter, fmaller.

(Pinus virginiana) Virginia, Two. leaved Priclsly-coned Pine, growing fixty or feventy fect high - the leaves finall, lighter-green; and fmall cores. - Native of Virginia, \&s. (Moift or any common foil.) 
(Pinus balepsnfsi) Aleppo-Pine, growing thirty or forty feet high-the leaves longer, narrow, darker-green: and very fina!l cones. - Native of Afia. (Dry foil.)

(Pinus tatarica) Tartarian Pine, growing fifty feet high - the leaves fhort, broader, lighter-green; and fmall cones. - Native of Tartary. (Dry or any common foil.)

(Pinus rubra) Red or Common Scotch Pine, growing fixty feet high, or more-the leaves thorter, greyingreen; and fmallioh cones.-Native of Scotland, \&xc. (Dry or any common foil, and rocky, gravelly, or any dry, barren grounds.)

2. PInus Pinea-(Pinea fativa) Cultivated, or Italian Stone Pine.

A middling, ever-green tree, growing thirty or forty feet high - the leaves (lang, brigbt-green) placed by pairs; the primordial, or firft leaves, fingly, and ciliated on the edges; and large, turbinate or topthape, clofe, hard cones, containing large, eatable feeds. - Native of Italy, Spain, and fouth of France. (Any rommonfoil.)

With teaves by threes.

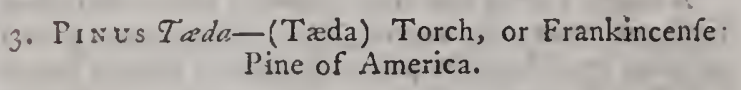

A large, ever-green tree, 'growing fixty or feventy feet high-the leares (long, narrow, light-green) placed by three together from the fame fheath; and large, loofe cones. - Native of Virginia and Canada, in liwampy places. (Moift or any common foil.)

Varicties. - (Pinus rigida) Rigid-coned Virginia Pine growing fixty or feventy feet highthe leaves long, flender, placed by threes; and ftiff, hard cones.-Native of Virginia, \&c. (Moift or any) common foil.)

(Pinus estrinala) Echinated, or Pricklyconed American Pine, growing forty or fifty feet high-the leaves long, flender, placed by twos and threes together; and prickly feed-cones. Native of North America. (Any common foil, छ̋c.)

(Pinus paluftris) Marh, or Swamp American Pine, growing fifty feet highVEGETABLE SYSTEM

the leaves long, deeper-green, placed
by threes Native of North Ameri-
ca. (Nioift fuation, or any comnanz
foil.)

\section{Viibleaves by fives.}

4. Pincs Strobus-(Strobus) New England, or Weymolith Pine.

A molt lofty, ever-green tree, growing feventy or eighty, to an hundred feet high - the ftem having a fmooth bark; leaves (longef, fender, ligbt-green) placed by fives from the fame point or theath, the margins rough ; and long, flender, loofe, pendulous cones. - Native of Virginia and Canada; firft cultivated in England, by Lord Weymouti, hence com: monly called the Weymouth Pine, a moft beautiful tree. (Any common foil and fituation.)

\section{P INus Cembra-(Cembra) or Mountain Siberian Stone Pine.}

A large, ever-green tree, growing thirty, to forty or fifty feet high-the leaves (finall, fetofe or briftly, decper-green) placed by fives, very (mooth; and with largin, ereet cones, the feeds or nuts thereof eatable and falutary. - Native of the mountains of Siberia, Switzerlaind, Valefia, Baldi, \&c. (Dry, or any cammon foil, Eंc.)

\section{Fir Kinds (ABIES.)}

Diftinguimable from the Pine Trees, by the leaves growing fingly, and thickly placed, but all difinit at the bafe; and with feed-cones, from an inch or two, to fix or eight inches long.

\section{iLeaves plased fingly.}

\section{Prnus Abies-(Abies) Common Spruce or Nor-} way Fir.

A large, ever-green tree, growing fixty or feventy feet high, or more - the leaves (fmall, dark-green) awl-thape, pointed, ranged two ways, fmooth, and placed fingly; and long, pendulous cones.-Native of Norway, other northern parts of Europe, and of Afia. (Any common foil.)

$$
\begin{aligned}
\text { Varieties. - Red Norway Fir. } \\
\text { White Norway Fir. } \\
\text { Long-coned Cornifi Fir. }
\end{aligned}
$$


The laft fpecies, Pinus Abies, and the firt two varieties thereof, are the common Pitch Trees, from which the pitch is obtained.

\section{PIxus canadenfis, Canada Spruce Fir.}

A largc, evcr-green tree, growing fixty feet high, or more-the leaves (Jmall, fbort, dark-green) linear, fomewhat obtufe fub-membranous, and placed fingly; and fmall, boofe cones.-Native of North America. (Ainj common foil, Ëc.)

\section{Varietj.-White Canada Spruce Fir. Red Canada Spruce Fir. Black Canada Spruce Fir. American Hemlock Spruce Fir.}

\section{Pravs Picca-(Picea, Turpentine Tree) or Sil-} ver Fir.

A Araight, lofty-growing', ever-green tree, feventy or eighty feet higli-the leaves (Hort, flat, dark-green) smarginated or end-notched, filvery underneath; and placed fingly; and very long, erect cones.-Native of the Mountains of Switzerland, Swedland, Bavaria, and the Highlards of Scotland. (Any common foil.)

9. Prous Balfamea-(Balfamea) or Balm of Gilead Fir.

A midding, ever-green tree, very branchy to the bottom, growing thirty or forty feet high-the leaves (jmall, flortißs, ligbt-green) obtufe, a little emarginated, or end-nicked, doubly linented, or with two white lincs on the under-fide, punctured, and placed fingly; difpofed in a pectinated order, like the teeth of a comb; and fhort, round cones.-Native of Virginia, Canada, \&cc. (Any common foil.)

\section{Cedar and Larch Kinds (LARIX.)}

Difinguifhed from the Common Pine and Fir Trees, by the lcaves being bundled, or growing many together, from one point, in pencil-form bunches, fpreading out each way; and large, oblong-roundish, and fmall, acute cones.

\section{Leaves, in bunches.}

10. Pixus Cedrus-(Cectros libani) or Cedar of Lebanon.

A large, evcr-grcen trec, of beautiful, fprcading rrowth, thirty, to forty or fifty feet high, or morcthe lcavcs (Small, frif, dark-grecn) acute-pointed, fafciculate, or in bunches; and large, oblong-roundin, clofe, hard cones. - Native of Syria, on Mount Libanus, 'Taurus, \&c. (Dry or ary common foil, E̋c.)

\section{PINus Larix-(Larix) Larch Tree, or Deci- duous Cedar.}

A large, deciduous tree, growing forty or fifty feet high-the leaves (fmall, britty, light-green) obtufe, fafciculate, or in bundles; many growing from the fame point, deciduous; and fmall, acute cones.-Native of the Alps of Switzcrland, Stiria, Corinthiz, Siberia, \&cc. (Any common foil.)

\section{Varieties.-Red Larch Tree. White Larch Tree. Black American Larch Tree. Horizontal-fpreading Larch Tre? Dwarf Siberian Larch T'ree.}

All, or molt of the foregoing fpecies and rarietic of Pinus, are of the firf-rate trce kinds, alpiring each with a fingle, eredt ftem, to the differcnt heights mentioned in the defcriptions of the refpective fpecies, generally in a tapering growth, and branch oat all around, in circulin rays, as already intiriated, mofti in regular, pyramidal heads, of beautiful grandeur : all of the cver-green tribe, except the Pinus Larix. which is deciduous; and in all the forts the leaves aie. fmall, flender, awl-thape, and brifte-like; the flowers are alfo fmall, in male racems, and female, conic heads; appearing in fpring and autumn ; faccceded by the cones : ripening in autumn, winter, and fpring following; and which, in molt of the fpecies, furnifh plenty of feed for fowing, whereby to propagate the different forts, as they are raifed only by that method.

Thefe trees are of confiderable valuc for ufeful and ornamental plantirg, beautiful in their growth, and their timber is of great worth for all kinds of building; and being moitly of a refinous nature, imore or less, but noore particularly the. Fine and Fir kinus, which abounding in a firong, rcinous fubitance, the ufeful articles, pitch, turpentine, rofin, Sic. is obtaincd, being extrakted from the tress, in the places where they grow, in confiderable woods, both in feveral parts of Europe and North Amcrica, in which there are naturat forens of valt extest, of the forts picculiar to the differes: countrics.

'The diferent fpezics of Pinus form a srand collection of fins trecs of great merit, to arange in all pleafureaisle and profitable plantations, for beatifying: pleafure-grounds, parls, and other premifes, and for the great improvencnt and embellithment of e!lates: the iraing all heauticul in their gicneral groweh, fivift anil foraigrist growcrs, arriving to a vait height and magnitude; and their timber is of the utmoft value, as the principal wood cmployed in all kinds of building, and of fuperior excellence in Mip-building, efpecially for fursifhing the finc? mans in the world; more particularly 
ticularly the Pine and Fir kinds, fuch as the Pinafter, Scofch, and Wermouth 'Pines,' being all moft lofty growirg trees; but the hatter generally furpafies all the others in attaining the greatef al citude, though mølt of the other fpecies acquire a confiderable height and buik for the above ufeful purpofes; and are ail exceedingly deferving of principal culture in confiderable planta.jons, or, acsor ung to the extent of ground and eftates, to p'ant for ormamert and profit; or to introduce in fmalier portions, cither in the whole, or any principal forts, to adom fhrublemis and cher decorative plantations, both in aff nublagge with other trees, and to form groves, walks, clunips, S.c. whoily of the Pinus kind.

All tlic frecies are very hardy, will grow freely in almoft any common foil and fituztion, and in any expofure, in gardens, pleafure-grounds, parks, ficlds, or any out premifes, low or high grountis, plains, fides, tops of hills, \&c. but the Pinafter and Scotch Pincs particularly, are fo hardy that they will grow and profper almoft any where, both in rich and poor land, dry and moift fituations, in fwanips and 'dry'; barren waftes; and on mountains and rocks, whore there is hardly any.foil, will penetrate their roots into the crevices, to a confiderabie depth and difance, in queit of nourithment; fo that in any walte, barren, or incultivated lands, thefe trees might be cultivated to profitable advantage.

They may be obtained, for planting, at the nurferies, either in full collection, or of any approved or defirablc fpecies, \&c. of proper.growth, two or three, to five or fix feet high, or more; or may be raifed plentifully from feed, in a home nurfery, to proper fizes, as above, in three or four years, for thic plantation intended; though it is generally advifeable to plant them finally, while in young growth, of one, two, to three or four feet, whilc the roots are of but moderate extent, and fibrofy; as when more confiderably advanced, the roots of moft of the forts become woody and naked of fibres, efpecially the Pine kinds, , do not tranfplant fuccefsfully, fo as to proceed in a profperous growth.

Or where any confiderable fupplies of the 'trees are required for large plantations, they may be raifed plentifully froin feed, in beds of common carth, and at a year old, planted in nurfery-rows, to grow to a proper fize of two, to three or four feet, for final tranfplanting in the places where intended, at the proper feafons.

The principal feafons for planting thefe trees, is autumn or fpring; or might be effected, occafionally, any time from October or November, to March or April, in open, mild weather; but, for fear

of being attacked with fevere froft, it woald be advifeable to plant principally, or as much as poltible, either in autumn aforefaie, where convenient, or in the fpring months, February, March, and beginning of April; though in tolerably mild winters, the planting may alfo be forwarded in that Ycafon, efpecially in the more hardy kinds, as the Scctch Yine, Finafter, Spruce Firs, axc. ol motk of the cther forts necafionally; of the whole principally in autumn or fpring, or morly in the latter, which is generally a fuccefsful feafon for planting thefekinds of ever-greens.

Any general planting or tranfplanting of thefe trees, is advifeable to be performed white they are young, as before intimated, when two, thrce, or four, to five or fix feet high at mont, efpecially as they will take root more fin ily and fooiner than large, or older plants, and advance in a more free growth; or for timber plantations particularly, it is of inportance to plant them finally, when of but haif a yard, to two, three. or four feet, that they may root freely, and proceed in a free, clean growth from the beginning, and thereby ritip up ftraight and fivifily, to a tall or lofty ftature, in which confils the principal nierit of thofe trces, both in appearance and utility.

For ornamental planting in pleafure-grounds, parks, Qcc. all the forts of $P$ inus are proper; or any principal or defirous fpecies, for particular difricts, as the Wcymouth Pine, Italian Pine, and the Pinis Cembra, Silver, and Balm of Gilead Firs, Cedar of Lebanon, and Larch 'Trees; though all the forts make a good appearance; and may be difpofed bcth in contipued plantations, in grores, thickets, Ecc. wholly of the Pinus kind, of difierent f?ecies: intermixed, to difplay the greater diverifity; or, in fome placcs, different fpecies in dintinet compartments; and likewife are proper to affemble in general plantations, frúbberies, clumps, \&c. in concert with other trees and large flirubs, principally of the ever-green kind, except the Pinus Larix, which being deciduous, may alfo be affociated with trees of that tribe; or likewife any of the other forts may be dotted thinly in deciduous plantations, for variety'; though they hould principally arrange with ever-greens, in: the gerie:al planting, and in plantations wholly of the Pinus tribe, as above obferved; and are proper trees to plant in fingle or double rows, to form grand walks and avenues, as alfo to difpofe in clumps, and fingly in detached fandards; obferving gcnerally, for fingle planting or dotting on lawns, and other capacious fpaces of grafs ground, allot principally fome of the handfomeftgrowing trees of the forts before fpecified, or of different fpecies and varieties, in which flould never omit that celebrated tree of folemn note, the Cedar of Lebanon, which, when of fome confiderable advanced growth, will fpread its branches in admirable gran- 
deur; likewife, the Larix or Lareh, being a tree of a fivift and beavififul growth, makes a fire appearance in ornamental planting.

In planting the different forts of $P$ inus for the above ornamental occafions, that where intended for continued plantátions, fóme mäy be plânted in open groves, in rows 'fifteen to twenty feet afunder, to give room for thcm to branch and fpread freely around in 'full heads; othersmay be planted-in elofe groves, thiekets, elumps, walks; \&c. fix or èight, to tén feet diftanee, and will draw one another up more expeditiouliy in a tall, fraight growth.

To plant thefe trees for timber plantations, all the forts may be admitted, or principally, only the hardieft and largeft-grouing kinds, fuch as the Pinafter and Scctch Pine, abundantly, for its fingular hardimeis. to gtow'. any where, in a quicks grow th, and for the great uffefulnefs; of: its rood; .likewife plenty of the Weymouth Pine, as a moft lofty-growing tree; alfo the Italian Stonc Pine, Swamp. Pine, Spruce Firs, Silver Fir, and the Cedar of Lebanon and Larches; al! of which may be planted in foils and fituations before menioned; and which, for foreft or timber-trees, deferve, cuftule.. in confiderable plantations, - in all places where they afford proper'extent of fpare ground to allot for that purpofe, which not only give an air of importance and crnament, but greatly improve tlie value of eftates; and in forming which plantations, they may, in fome places, be planted in clofe rows at firft, five or fix fcet afunder, to. draw one another up firaig,$t$, and more expeditiouly in height; and when of advanced growth, in eight, ten, or twelve years, fome might be thinned out for poles, \&c. and may rcpeat thinning out the underling trees, by degrees, lcaving the beft fanding at fíteen to twenty feet diftance, or mole, to acquire full growtil for timber ; or fome may be planted at once at the above diftance of sifteen or twenty feet, to remain wholly to grow to large ftandard's, beforc any arc cut down."

For the above plantaticns, the ground is fometimes prepared by ploughing, \&c. whcre the fituation admits, cfpecially for clofe planting; othcrwife, or fometimes in general, no otner preparaion is given, than only to dig holes in which to plant the trees.

Or fnmetimes plantations of the Scoteh Pinc, \&e. are formed by fowing tre focds in drills in the plaecs where the tiers are alwiys to remain, having the drills five or fis fict afurier; the ground being previcufly ploughed, cither ws.olly, or otherwife ploughed or digged along the plaees for the diills, for foiving the feed therein; and when the plants are come up in the firt and fecond year, thin them to eligible diftances, by drawing them out in autumn or fpring, leaving the mont thriving plants nanding two or thee feet afunder; and when of more advanced growtil, in two or three years, thin them more effectually, $b_{y}$ removing the weakeft, and leaving the frongeft fire or fix feet afunder, to remain till advineed to fome confiderable fize, then fome may be cut down in a thinning order, gradually, as intimated above.

With regard to the propagation, or method of raifing the different fpecies of Pincs, it is effected wholly by feed fowed in the fpring feafon, in beds of lighe earth.

The feed for fowing is obtained from the cones, which ripen in autumn and winter; and the feed is cleared therefrom either by expofnsthem in the fur, or towards a gentle fire, to make then open to diflodge the feed, which are elofely invelved in the fcales; or fome of the large, clofe, hard cones, as in the Italian Stone Pine, Cedar of Lebanion, \&uc. mut' be fnlit opeñ, by boring a hole througl: the midd!c', lorigitudinally, and driving a peg of fpike thcrein to divide them afunder, whereby to come at the freds, which, in all the fort's, clear out from the fcales, Kceping thofe of each fort feparate, for fowing diftinct accor ingly'; they thould be fowed principally in the fpring, any 'time in open wcather, in February, Mareh, or beginning "of April; and for'witich, prepare beds of light earth, three or four feet wide; rake fome earth off the top evenly, an inch deep, into the alleys; fow the feed tolerably thick, . broad-caft on the furface; eaeh fort feparate, and covered with the earth which was raked off the beds"; or may fow any particular forts in large pot's, fuch as the Cedar of Lebanon, \&c. in order for moving the pots of feedlings :o a thady place in fammer, and to a fheltered, warm, fituation in winter; more fccure from rigorous froft the firft year or two, in their tender growth.

All the forts will come up trie fame year, in fix or cight weeks; give moderate watering in their firft rifing, in dry weather: the plants rife vcry nender the firlt year, generally only with a few leaves, and' a fmali bad of the advancing thoot in the centre; or fome ifill probably make a fhort fhoot by autumn: keep them clear from weeds all fummer, and in winter, if fevere froft, occafional thelter to the Cedar of Lebanon in particular, woa!d be of advantage; the others will nce require any protektion.

In the fpritin following, they thould bəo nlanted out from the fecd-beds; draw them up with good ronts, and plant them in other beds, in rows fix or eight inches afunder; and having ardvaneed two years growih in the pianted-out beds, tranfpiant them in nurferyrow's two feet and a half diltance, and in whieh to rcinain to acquire proper fizc for final tranfplanting, permitting them to run with the top or leading fhoot intire, to afpire in height with a ftraight ftem, as få 
as poffible; and do not prune any of the laterat branches, except occafional, low tragglers, or only, hovever, the under growths, neal the ground; for thefe refinous ever-greens do not admit of any confiderable application of the lnifc; befides, thefe trees having their branches proceeding from near the bottoms, in their peculiar, natural order, adds exceedingly both to their beauty and profperity of growth.

The young trees having adranced in their nurery growth, as above, from about one, two, or three, to four, five, or fi: feet in height, as has been already hinted, may be tranfplanted finally, as required, in the places where they are to remain, either wholly, to folm, or to affift in forming, the different or particular planta, tions in which they arc defigned; for zenerally in moft of thefe kind of trees, when having their fnal traufplantation while in young growth, they, fooner, and more effectually take good root and grow profpe. roufly.

In removing or tranfplanting thefe trees, have them dug up with their full roots, as intire as pofible, preferving their extreme fibres as much as car be, and fill continue the top-fhoot intire, as allo the general branches ; or may only prune off very low; under ftragglers, and plant them at the proper diftances in the intended plantations; which, where for ornament, may be from ten, to fifteen or twenty feet, or more; and where defigned for foreft or timbertrees, they are planted , five orifix,' to teri or fifteen feet afunder, agreeable to the foregoing intimat tions.

As to future culture, after planting, thofe planted young, in places where weeds or grafs thoot up in rank growth, in fummer, fhould have thefe kept under till the trees are grotvn feveral feet in height, out of the reach, of being over-topped therewith; they will afterwards, in their fpreading bracchcs, keep down and prevent all,injury from weeds. \&c. or where they are planted in the thrubbery order, or in any continued or extending plantation, either diftinct, or affembled with other trees and fnrubs, in compartraents, in which the ground between them is annually dug, in winter or fpring; it is proper, where their fpreading branches do not cover the furface, to hoe down the weeds in fummer; and in the different plantations, \&cc. the trces in general, of thefe forts, Should, in theis advancing growtin, be perinitted to sun up in their top-fhoot, and to branch otr fully in their natural manner; or oniy, as they increafe in height, may prune up low, under branciles, by degrees.

In thefe, in timber plantations, where clofe planted at firft, they, when adyanced twenty feet bigh, or more, of frve or fix inches to a foot thick in the ftem, may have fome cut or felled in a gradual, thinning orcer, for poles and other occafions, leaving a regular fupply of the finett trees, at moderate diftances, to acquire large growth for timber.

As the Cedar of Lebanon, while young, is apt to trow bending at top, it Mould be trained to a ftraight take, in an upright growth.

\section{E:STACEA, PISTACHIA-NUT, OR TURPENTHE 'TREE: \\ Clars and Order. \\ Dioecia Pentandria, \\ Truo Habitations, Five Males, \\ Or Flowers Mate and Female, diftinct on two feparate Trees; and the Males baving five Stamina.}

THF. Piflacia furnithes three or four hardy fpecies of rieciduous and ever-green ornamental trees, of mo= derate growth, garnifhed, in fummer, with pinnated and trifoliate leaves; and fmall, apetalous, greenifh flowers, in amentums and clufters, male and female, diftinet on two feparate trees; the males collected into. loofe; fealy annentums, without petals, having five famina, crowned by large, four-cornered anthera; and feinales alfo without petals, growing in clufters, and furnifhed with trifid cups; an oval germen, fupporting three ftyles; and the germen grows an oval, berrylike, drupaceous fruit, in clufters, containing a fmooth, oval nut, witl an eatable kernel; and by the nuts, fowed in the fpring, the trees are propagated, likesuife by layers of the young wood.

\section{If ne.. The hardy PISTACIAS are,}

I. Pistaciatrera, True Piltachia Tree.

A fmall or moderate deciduous tree, growing eighteen or twenty feet high-the leaves (large) compleat pinnated, with fub-ovate, recurved folioles, in two, three, or four pairs, terminated by an odd or end lobe, - Nativc of Perfia, Arabia, Syria, and India. (Drk, warm fituation ot

2. Pistacra Terelintbus-(Terebinthas vulgaris) or Common Turpentine Tree.

A moderate deciduous tree, growing tventy fect high or more-tlic leares (large, dark-green) compleat pinnated, with ovate fpear-hine folioles, in three or four pairs, terninated by an end lobe.- Native of the fouthern parts of Europe, northern pait of Africa, and of India. (IV atw, diy fituation.)

3. Pistacia trifolia, Trifoliate or Three-leaved Piftachia Tree.

A moderate deciduous tree, growing eighteen or 'twenty feet high-the leaves (midding, dark-green) molty 
inoftly ternate or three-lobed, and fome pinnated; the lobes ovate-roundifh. - Native of Sicily. (Dry, warm fituation.)

\section{Prstacia narbonenfe, Narbonne Turpentine Tree.}

A moderate deciduous tree, twenty feet high or more-the leaves (large, light-grecn) pinnated and trifoliate, of three and five lobes, fub-orbiculate roundith ; and large, round fruit.-Native of Montpelier, Perfia, Mefopotamia, and Armenia. (Warm, dry fituation.)

\section{Prstacia Lentifus-(Lentifcus vulgaris) Com- mon Lentifcus, or Maftick Tree.}

A middling ever-green tree, growing twenty feet high or more-the leaves (large) abrupt pinnated; the lobes fpear-hape, in three or four pairs, not terminated by an end foliole. - Native of Spain, Portugal, Italy, and Palæítine. (Dry, warm-fituation.)

All thefe fpecies of Piflacia are admitted in collections of curious trees and fhrubs, for variety and ornament; but being natives of warm cliniates, are moftly of a tender nature, and are generally retained as green-houfe plants, in this country; though they are alfo fometimes planted in the full ground, in principal thrubberies, in warm, dry foil, and fheltered fituations, full to the fun in winter, and defended from cutting blaits in that feafon; or planted againft a fouth wall, and have occafional covering of mats in fevere weather: the different fpecies may be had at mort of the principal nurferies, generally in pots, to tranfplant with balls of earth, which Mould be performed in spring, when fettled, warm, weather, in March or April, in fituations as above; or may be raifed by fred and layers, to a proper fize for planting.

The fe trces are monly cieciduous when planted in the full ground; but when defended in a green-houfe, they often retain their leaves in winter; they flower in fummer, but are feldom fucceeded by ripe nuts in this country; thefe, however, are obtained plentifully from abroad, proper for fowing, ic.

Thcy are propagated by the fecd or nuts, fowed in the fpring, and by layers of the young hoots.

The feed or nuts for fowing, may be procurcd at moft of tic principal feed hiops and nurferies, in the fpring : fow them in March or April, fome in pots, an inch deep, and placed in a liot-bed to forward the grerminaticn of thic fecd, and tle young plants in grovith; and fome may be fowed in a bod of natural carth, in a varn fituation; and the young plants in autumn, trasifplanted fingly in fmall pots: kecp the whole in pois for two or three years, in order for placing under thelter of a frame, \&c. in winter, when frofty weather; or if fome are continued in the full ground, give occafional protection as above; and when increafed in ftrength, of two or three feet lieight, they may be tranfplanted into the full ground, in the fpring, turning them out of the pots with balls of earth to the roots, or renoved from the full ground in the fame maner, and planted in varm, dry fituations, before-mentioned.

But it is alfo proper, generally to keep fome conftantly in pots, to move under fhelter in winter, in prefervation, in cafe thefe in the full ground are killed by rigorous frofts.

$$
\begin{aligned}
& \text { Platanus, PLANE TREE. } \\
& \text { Clafs and Order. } \\
& \text { Monoecia, Poiyandria, } \\
& \text { One Habitation, Many Males; }
\end{aligned}
$$

Or Flowers Male and Female, difinet, or feparate or one or the fame Tree; and the Male Flowers baving many Stamina.

THE PLATAN US comprife noble, deciduous trees, of ftraight and lofty ftature, for ornamental and forefttree plantations, rifing with an upright $\mathrm{ft} \in \mathrm{m}$, to a confiderable height and fubftance, and large, branchy, fpreading heads; adorned, in fummer, with mort ample, palmated, lobated foliage, divided into three and five lobes, expanding fix or eight, to twelve inches broad, or more, meafured from the extremity of the fide lobes; and fmall male and female fowers, feparate on the fame tree; the males collected into globular amentums, of many fmall florets, with fcarcely vifible petals, containing numerous fmall ftamina; and female fiowers of many fmall petals, collected into large, roundith balls, fufpended in long, pendulous ftrings or pedicules, and furnithed with feveral germens and ftyles, fucceeded by numerous pappous feeds, growing in round, hard, rough balls, ripening in autumn; and by which, fowed in autumn or fpring, the trees are propagated, alfo by layers and cuttings of the young wood in the fame feafons.

\section{The Species of PLATANUS are,}

\section{Platanus crienfalis, Oriental or Eaftern Plane} Tree.

A lofty-growing deciduous trce, attaining fixty or feventy fcet high-the leaves (moft large, dark-gren) palmated, divided into five principal lobes.-Native of Afia, 'Taurus, Macedonia, Creti, \&c. (Leanj, moif, or any common foil.) 
Jaritj:-Maple-leared Oriental Plane-the leaves more flightly palmated or divided.

2. Phatanus occiacinalis, Occidental or Weftern Amcrican Plane Tree.

A large cleciduous tree, growing fifty or fixty feet ligh-the leaves (large, light-green) lobated, or moftly cut into thrce principal lobes. - Native of North America. (MLoif, loamiy, or any common foil.)

3. Platanus bifpanica, Spanifh or Middle Plane 'Trec, (fuppofed a Variety of the Occidentalis.)

A large deciduous tree, growing forty or fifty feet high-the leaves (very large) lobated, of three or five principal lobes.-Native of Spain and America. (Moift, icamy, or any cominon foil.)

Thefe are admirable fine trees, of beautiful, fately growitl, for ornamental planting, and to introduse in foref-tree plantations; they growing with ftraight, lofty fiems, and noble fpreading, branchy heads, which, cloathed in fummer with their luxuriant, elegant leaves, of large expanfion, make a delightful appearance, and form an agreable fiade; and the flowers produced in fufpended balls, on long, pendulous pedicules, effect a curious fingularity; ripening plenty of fieds $i_{i n}$ autumn, in moft fafons.

They are defirable trees to plant, hoth in afremblage in all principal ornamental tree plantations, for adorning pleafure-grounds, parks, \&xc. and to form groves whully of their own kind; and have confiderable merit to arrange with other large trees, in avenues, groves, groups, and elumps; and alfo to plant difinet, in clumps and in fingle ftandards, difpofed in parks, fields, and other capacious diftriets, and in rows towards cutward boundaries, \&c. likewife, to drop fingly, and in clumps, on fpacious grafs lawns; and are peculiarly adapted to plant in particular compartments, to form fnade in fummer, where it may be required, which, in their fpreading growth, and beautiful, luxuriant foliage, they will effect moft agreeably, as well as appear. fingularly ornamental; and in all of which orders of planting thefe trees, they affume a peculiar grandeur in their general appearance, confpicuoufly dittinguihable.

Thefe trees are alfo proper to affemble in foreft-tree plartations, as they grow with ftraight, lofty ftems, acquiring fome confiderable bulk; and may be afociated both with other deciduous timber trees, as Maoles, Beech, Chefnut, sxc. in forming woods for timber, and coppices for under-wood; and likewife planted in groves and thickets, wholly as the Platanus kind, for the fanc occafions; or the whole principally to grow for large ftandards.

The trees of the different forts are raifed plentifully in ail the principal nurferies, for public fupply, and wherc they may be obtained in proper growth, of five or fix, to eight or ten feet high, or more, for planting, in autumn or fpring; or any time in mild, open weather, from Oetober or November, to March: or April.

They arc propagated by feed, and occafionally by layers and cuttings.

To raife tlicm from feed, it is fowed in autumn or fpring, or principally in the laft-mentioned feafon: perform the fowing in a bed of light, mellow earth, fowed maderately thick, either at once, an the rourg is furface, and raked in evenly, or the ground previoufy raked fmooth; and then driw fome earth of the top of the bed, an inch deep, into the alley, fow the feed on the bed, fnooth it down into the earth. with the back of a fpade, and cover it over with the earth out of the alley, regularly, about half an inch to an inch in depth; or may be fowed in fmall drills, fix inches to a foot afunder; the plants will come up in April or May, or early part of fummer : keep them clear from weeds all that feafon; and when they are of one funmer's growth, tranfplant them in autumn or fpring, in nurfery-beds, in rows, a foot, to fifteen er eighteen inches afunder; and laving increafed in fize and flrength, for one or two years, or more, fhould be tranfplanted at wider diffances, or in which might be planted at once from the feed-bed, in nurfery-rows, two feet and a half afunder, in which, train them with fingle, clean ftems, prune off latera! fhoots, according, as the trees advance in height, preferving the tops entire; and when three, four, or five, to fix, eight, or ten feet, may be finally tranfplanted, as occafionally rcquired, for the intended plantations.

By layers and cuttings of the young fhoors, they may alfo be propagated, performed in the autumn or fpring; for layers, cliufc the young hoots produced from ftools, near the ground; gafh or cut a fmall upward fit on the under fide, lay them with that part in the earth, they will more frecly root, and form proper piants by the following autumn; and cuttings of the trong, clean, young fhoots, frincipally in the fpring, planted on a thady border, will allo emit roots and grow; and in both of which methods of propagation, train the plants as intimated for the fecdling trees.

In the advancing nurfery growth of the young trees raifed by the above differcnt methods, continue the whole trained with fingle fems, pruning away latcral thoots therefrom, and permit the top leader, and brancines of the head, to afpire in height. 
When the young trees, raifed by either or all of the different methods, are advanced in growth, about four or five, to fix, eight, or ten feet high, they are then of proper fizes for any plantations in which they may be required.

The few fon for trampituting or planting thefe trees, is principally either in autumn, at the decay of the leaves, or in the fpring, February or March; or in mild feafons, may be performed any time in open wea. ther, from O\&tober or November, to Marcl aforefaid, or beginning of April as formerly intimated: have them taken up with full roots, and planted as foon after as pofitible; and if any are of tall grúwth, in expofed fituations, they fhould have fupport of ftakes to preferve them upright.

In their future growtl, after the funal tranfplanting of the trees, may prune up lateral fhoots and under branches, by degrees, to run them with a clean, ftraight ftem, and permit them to run up freely above in full heads.

\section{POPULUS, POPLAR TREE.}

\section{Clars and Order.}

\section{Dioecia Oetandria, Tiwo Habitations, Eight Males;}

Or Flowers Male and Female, feparate on two differest Trees; and the Males baving eight Stamina.

THE Poplars are large and lofty-growing deciduous trees, moftly of the aquatic tribe, delighting to grow in moift fituations, valuable as foreft-trets, 25 alfo for variety and ornament; are generally fwift growers, with fpreading and upright heads in the different fpecies; garnifhed, in fummer, with largin and middling, roundion, cordate, and deltoid-hearted leaves; and fmall, greenin male and female flowers, diftinet or apart on two feparate trees, difpofed in oblong, fcaly amentums, each fcale forming a cup to one floret, without petals; containing eight fmall ftamina in the males, and in the females, a thort Atyle, crowned by a quadrifid ftigma, and fucceeded in the females by oval capfules, furnifhed with many downy, ovate feeds, by which the trees may be raifed; hut are more generally propagated by cuttings and layers, or particular varieties, by grafting.

\section{The Species of POPULUS are,}

1. Populus alba, White Poplar or Abele Tree.

A large deciduous tree, growing fixty feet high or more-the leaves (large and middling, light-green, whitif) roundin, dentated-angular, three, four, or five-lobed, the under fide hoary, white.-Native of the temperate parts of Europe. (Moifl, watery, or any common foil.)

Varieties.-Large-leaved White Poplar. Small-leaved Wlite Poplar. Varlegated-leaved Trhite Poplar.

\section{Popuzus nigra, Black Poplar Tree.}

A large deciduous tree, growing fifty or fixty fect high - the leaves (midling, dark'-grcen) delsoid-ovatehearted, pointed and ferrated, or fawed:-Native of the temperate parts of Europe. (Moift or any fiulution.)

\section{Pop ú us tremula, Tremulous or Trembling-leaved} Poplar, or Afpen Tree.

A large deciduous tree, growing fifty or fixty feet high-:he leaves (fincller or mitdling, ligbt-green) roundifh, dentated-angulate, fmooth on both fides, having generally a continual tremulcus or wavering motion, by the leaft wind. - Native of the cold parts of Lurope. (Moijt or any common foil and fittiatiois.)

\section{Por un Us biteropbylla, Various-leaved American Poplar Tree.}

A nio.t large deciduous tree, growing fifty or fixty feet high, or moie-the leaves (large, light-green) cordate or hearted, and roundin, the early ones downy.-Native of Virginia, \&ce. (Moift or any foil.)

\section{Varisty.-(Populus graca) Grecian or Athenian va- riable-leaved l'oplar, growing fixty feet high-the leaves (large, ligbt-gre'n) heart-form, \&c.-Native of Greece. (Any common foil.)}

\section{Populus balfamifera, Balfamatic Carolina Poplar.}

A large deciduous tree, growing fixty feet lighthe leaves (large) fomewhat heart-.form, denticulated or fine-notched; the buds abounding in a balfamatic, odoriferous, gummy fubftance. - Native of North America. (Moift or any fituation.)

\section{Variety.-(Populus Tacamabacca) (Tacamabacca) commonly called Tacamahac, or Bal- fam Tree.}

A middling deciduous tree, growing twenty-five or thirty fect high - the leaves (middling, light-grcen) obinng-ovate, and fome hearted, hoary on the under fide; the buds and leaves full of a balfamous fubftance, moft excellent for frefh cuts or green wounds. - Native of America. (Any common joil.) 


\section{Populus italicat, Italian or Lombardy Poplar.}

A lofty, moft fwift-growing deciduous tree, branching uprightly in a pyramidal growth, fifty or fixty feet high-the leaves (middling-large, ligbt-green, fbining) roundih-heart-form, acute-pointed, fmootl.Native of Italy, near the River Po. (Aizy foil or fituation.)

All the fpecies and varieties of Populus are principally of an aquatic nature, or that affect to grow in humid foils, or near waters, or moift fituations; but they alfo fucceed in almoft any foil and expofure, only are generally the moft profperous in moifture, in which they hootup in a very fwift growth; and therefore, may $\mathrm{b}$ e cultivnted in all fituations, and particularly, to confiderable advantage in any low, watery, or boggy foils, where many other trees, \&c. would not profper, and in which may be cultivated, both in ftandard plantations, for the timber, which is valued for its peculiar whitenefs, and light property, ufeful for many purpofes; and as under-wood, in coppices and hedges, and along the fides of rivers and brooks, or in moift places, to cut often in fmall growth, for poles and fpars, for various occafions; though they may alfo be planted in any foils and fituations where they may be required for ufeftil and ornamental planting, or for variety, in large plaistations.

For ufeful planting in woods, groves, coppices, for rimber and under-wood, any or all the forts may be introduced, both in affemblage with other deciduous kinds, and in plantations wholly of the Populus kind; or alfo, affociated with other aquatic trees, as willows, birches, \&c. in moift fituations.

Or for ornamental planting and for variety, or to diverfify large tree plantations, and for thade, fheiter, \&c. the principal forts are the Lombardy Poplar, White Poplar or Abele Tree, Balfamic or Carolina Poplar, and the Tacamahac, or any of the others occafionally; but, of the above kinds, the moit prevailing is the Lombardy Poplar, now in great repute for its. remarkably fivift and handfome, ereet growth, to plant both for ornament, to forn: fhelter, fhade, and blind, to particular diftricts; though all the forts are' welt adapted to join in any outward plantations, on the boundaries of parks, fields, fpacious lawns, and in any out grounds, as well as to affemole in clumps, groves, \&c. in parks and other extenfive ipaces; alfo to form decorative plantations in any low, marlhy, or humid grounds, either diftinct, or in concert with other aquatic trees, to effect the greater variety.

But the Lombardy Poplar particularly, being a tree of fingularly fivift growth, furpafing that of all other trees, growing with an erect, clofely-branching; pyramidal head, arriving to a lofty ftature, and large fize, in a few years, is peculiarly calculated for forming the moft expeditious plantation, either for Thelter, hade, or blind, as before hinted, to run up both in branchy, full ftandards, in fingle rows, groves, and thickets, and to plant clofe, hedge-ivays: is alfo particularly well adapted for planting in rows along any outward boundary, or next road fides, both for thade and blind, aforefaid, and to break of the duft in furrmer, as it foon runs up incredibly fwift, to a confiderable growth, for thefe occafions; and likewife, from it: clofe, branchy growth, admits of training i:1 regular hedges; and the trees admit of tranfplanting, both in fmall, middling, and larger growth, from thirec, four, five, or fix, to eight, ten, or twelve feet high.

However, the Poplars in gencral, are elimib?e to introduce in any of the fore-mentioned orders of planting, and in all of whicl will advance in expeditious growth; and that where any plantations are required to run up in fome confiderable growth, as foon as por. fible, the Poplars are commendable in any fituation, where thought neceffary, or affembled with other frift growing trees, or in any general plantation, of various furts of trees, in a diverfified manner; and are always eligible in moift fituations particularly.

Trees for planting may be procured at all the public nurferies, of proper growth, four, five, or fix, to eight or ten feethigh, or more; and are all eafily prepagated by layers, cuttings, and fuckers, that will foon advance to the above fizes, for final planting, as occafionally required.

As to the feafon for planting Poplars, they being all very hardy, may be removed and planted any time in open weather, from the decay or fall of the lenves, in Oetober or November, till March or April.

The propagation of all the forts of Poplars, is principally by layers, cuttings, and fuckers, or fome by feeds.

The layers may be of any lower, young floots, produced from ftools, ncar the ground, which may be layed in the autmm or fpring, laying the tems of the fhoots into the earth, three or four inches decp; will root freely, for planting off in the antumn following, into nurfery-rows, where train each with a clean, fingle ftein, and run the leading and other top-hoots intire, to afpire in height and fuil growth.

Cuttings of the young froots and branclies wiil alfo emit roots freely, and grow, eitlier the year old hoots, or larger growths, in potes and trunclicons, of two or three years old, of a yard or two long, occafionally planted in moif fituations, or along the fides of watery ditclies, brooks, rivers, \&c. to rcmain; but generally, when intended to raife a lupply of handfome plants, in a nurfery, for future plantations, fhould] have cuttings of the ftrong, cleat, young flnots, of a fum. 
a fummer's growth, cut into lengths of ten or twelve, to fifteen or eighteen inches; prune off he weak or bending tops, and planted in a moift part of the nurfery, in rows, a foot to half a yard afunder, they will root abundantly well in one year; train them as obferved for the layers, pruning of lateral thoots from the ftems, by degrees, as they encreafe in height, running the leader and other top-fhoots intire; and when they are of fome advanced growth, fhould be tranfolanted at wider difances, in nurfery-rows, two feet and a half, to three feet afunder; or, when of three, to four or five feet high, may be planted where they are to continue; or, as before intimated, cuttings of large growth, in poles or truncheons, of one or two inches thick, and a yard or two in depth, may be planted, for particular occafions, in moift fituations, above-mentioned, priacipally to remain where planted, admitting them a foot, to half a yard into the ground, they will put forth roots, and advance in frrong top-fhoots.

Suckers fometimes arifing from the bottom of trees of advanced growth, may be dug up, with roots to each, in the autumn, winter, or fpring, forming, at once, rooted plants, and planted in wide nurfery-lines, to grow to a proper fize for final tranfplanting, training them for that purpofe, as advifed for the layers and cuttings.

The young trees raifed as above, in the different methods, when grown three or four, to fix or eight feet high, may be finally tranfplanted in the places where they are intended for any of the different occafions before-mentioned; and which may be performed in autumn or fpring, or any time during the winter months, in open weather; and in their acivancing growth in the refpective orders of planting, keep them trimmed up below, to continue them with clean ftems, fix, to eight or ten feet, or more, according as they advance to fome confiderable height; and let the whole branch out freely above, in full heads.

When intended to plant the Poplars as foren trees, for rimber ftandards, and for uncier-ivood; they may be planted at five or fix, to eight, ten, or fiftern feet diftance; and in which, thofe planted in cinfe rows, five or fix feet afunder, when of feveral years advanced growth, fome may be cut down in a thinning manner, for poles, \&c. leaving the fineft growths to run for flandards; the others will thoot up. again froin the remaining ftools, in feveral ftems from euch, to fell for under-wood, in fix, eight, or ten years; but thofe growing in ftandards, for timber, fhould fland many years, till they acquire a large fize, of ten or tivelve, to fifteen or eig hteen inches thiskLes, or more, in the ftem, before any are cut down.
Potentilla, (Cineuffoil)-Cineuetori, SHRUB:

Clafs and Order.

Icorandria Polygynia,

Twenty, or more, Males, Many Females;

Or Plants with Flowers (Herm.) laving twenty, or more, Stanina, and many Styles.

ONE low, deciduous, flowering-thrub, of upright, buhy growth, with pinnated, or vinged leaves; and large, yellow, quinquepetalous flowers, in clutters, having a permanent cup; a corcila, formed oí five roundith petals, containing twenty, or more, ftamina, and many piftllums; fucceeded by a cluftered head be feeds reiting in the calyx, by which the plant may of propagated; but is generally raifed by fuckers, lay, ers, and cuttings.

\section{One Species, viz.}

Potentilla fruticofa, Shrubby Potentilla, or Cinquefoil Shrub.

A low, bufhy, deciduous hrub, three or four feet high-the Item fhrubby; the leaves (fmall) piunated, of five folioles, and clufters of yellow Howers; in July.- Native of England, \&c. (Moift or any common joil.)

This is a hardy, flrubby plant, may be admitted in any thrubbery compartments; and is readily propagated by fuckers, or by layers and cutings.

\section{PRINOS WINTER-BERRY. \\ Clafs and Order.}

Hexandria Monogynia,

Six Males, One Female;
Or Plants with Hermaphrodite Flowers, baving fix Sta- mina, or Males, and one Pifillum, or $\bar{r}$ emale.

THIS Genus furnithes two fpecies of large, ornamental Mrubs, one deciduous, the other ever-green, both for the Thrubby, growing fix or eight feet high, garnifhed with largith and middling, oblong and fpearhiape, fimple leaves, and rotated, or whecl-mape flowers, one, two, or three together; each flower having a fix-parted cup, and a rotated, fpre:ding, monopetalous coroila, divided into fix parts, contain. ing fix ftamina, and one ftyle, fucceeded by roundith berries, remainirg on the hrubs all the winter; furnithed with fix olscufe feeds; and by which, fowed in the fpring, the plants are proparated, likewife by laycrs and cuttings. 


\section{Two Species, viz.}

1. PRs:os ecrticiliatus, Verticillated, or Whirled Winter-Bery.

A deciduons mrub, growing feven or eight feet ritgh-the leaves (large, dark-green) oblong-fpearthapc, longitudinally fawed. - Native of Virginia. (Mijij, or any common foil.)

2. PRINos glaker, Smooth, or Ever-green WinterBerry, Yappon, or South.Sea 'Tea Shrub.

An cver-green finrub, growing fix or feven feet high -the leaves (middling fize) fpear-Mape, alternate, fawed at top, and ever-green.-Native of Canada, in North America. (Dry, ligbt, or any common foil.)

Thefe two curious thrubs deferve admittance in all rincipal collections in thrubberies, \&cc. to encreafe the variety, as well as for ormamert and obfervation; allotting them a confpicuous fituation: they may be had at the nurferies, for planting, in autumn, or spring.

They are propanated by feed and layers, and fometimes by cuttings: fow the feed in the fpring, in a bed or border of mellow earth, or in pots, plunged in a hot-bed, juft to forward its germination, and to bring up the plants the fame year; which tranfplant in autumn, or fpring, in a theltered compartment, or in pots, fingly; give helter the firft winter or two, from fevere frolt; and when advanced two or three feet in growth, may be planted in the Ihrubbery.

Or may try layers and cuttings of the young fhoots; or cuttings, planted in pots, may be placed in a hotbed, in the fpring.

\section{PRUNUS, PLUM TREE, comprifing alfo the CyERRY and APRICOT, LAUREL, \&c.}

\section{Clafs and Order.}

$$
\begin{array}{ll}
\text { Icofandria } & \text { Monogynia, } \\
\text { Truenty, or more, Males, One Fcnale; }
\end{array}
$$

Or Plants with Floweirs (Herm.) baving twenty, on more, Staniina, or Male Fruglifications, and one Piftillum, or Female.

THE PRUNUS comprifes feveral fpecies, and numerous varietics, of valuable fruit-trees, and others; compreliending, agreeable to the botanic fyftem, the Plumb Tree, Cherry, Apricot, and Laurel Tree, all fpecies of the fame Genus, or family, which alfo comprife feveral other fpecies; all of the hardy tree and turub kinds, molly deciduous, and fome crer-grecn; furnifhing, together, a large and valuable collection, both for the fruit garden, orchard, Thrubbery, and ornamental and forett-tree plantations, confifting of many fpecies, all of upright growth, from eight or ten, to twenty or thirty feet high; garnihed with fpearhape, oblong, and ovate leaves, in the different fpecies, and hernaphrolite, pentapetalous flowers; in April and May, \&cc. fome fingly, and in pairs, others in clufters, at the fides and ends of the branches; having in each flower a monophyllous, or one-leaved calyx, five parted; a rofaceous corolla, of five roundifh petals, inclofing twenty, or more, ftamina; a roundin germen, fupporting a fingle ftyle; and the germen grows a roundift and ovate foft fruit, of the drupe kind, various in fize and colour, in the different fpecies and varieties, inclofing a roundin, compreffed nut; and by which latter any of the trees are raifed; or feveral principal forts are generally propagated by grafting, inoculation, and by layers.

\section{The Species of PRUNUS are,}

Confifting of the Plum Kinds, Cherry, Bird-Cherry, Apricot, and Laurels.

\section{Plum Kinds.}

\section{Prunus domefica, Domeftic, or Common Plum Tree.}

A moderate, deciduous tree, growing fifteen to twenty feet high, or more-the leaves (middling) fpear-fhape, ovate, convolute; and peduncles, or flowcr-ftalks, fub-foliary, or moftly fingle; fucceeded by roundini and oblong- fruit, of many cifferent fszes and colours in the different varieties; rifening from July till October. - Native of the fouther, parts of Europe. (Ainy comnion joil.)

\section{Varieties of the Trees.-Striped-leaved Plum Tree. Gold-bloached-leaved Plum Tree. \\ Double blofiomed Plum Tree. \\ Damfon Tree. \\ Double-blofiom Damfon Tree.}

\section{Of the Fruit, configing of meny Varieties, the principal efteemed Sorts of which are-}

Primordian, or carly White Hative Plum -a fmall, oblongih-oval, whitihyellow fruit; ripe the middse or end of Fuly.

Azure Hative-a fmall, round, blueifh Plum; tbe end of $\mathcal{F}_{\text {ully. }}$.

Morocco, or Early Black Damajk Plum. -a middling-fize, round, black fruit, furrowed along the middle; the middle or end of 'fuly.

Little 
Little Black Damak-a fmall, roundin, blackifh-blue Plum, very fweet; the end of $\mathcal{F} u l y$ and beginning of $A u$. guft.

Orleans Plum-a middling or largini, round fruit, of a dark-red colour, covered with a farinous bloom; the tree a great bearer; the middle of Fuly.

White Orleans Plum-a middling-fize, round, whitifh-yellow fruit; the middle of Auguft.

Great Damaik Violet Plum of Toursa fine, largin, oblong-oval Plum, of a darkish-blue, covered with a vio. let-bloom; the end of $\mathcal{J} u ! y$ and in $A u-$ $g u f$.

Small Early Tours-fmall, roundith, dark-blue; the middle or end of $\mathcal{F}_{u l y}$.

Fotheringham Plum-a middling-large, oblong, dark-red; excellent fruit, deeply furrowed; the flem firm and ricli; the beginning and widdle of $A z-$ guft.

Little Queen Claude Plum-a fmall, round, yellowin-pearl-coloured fruit, rich and fugary; the end of Fuly or beginning of Augut.

Green Gage Plum-a fmallifh, round, green fruit, fweet juice; rife the beginning or middle of September.

Great Queen Claude, or large Green Gage Mlum-a fine middle-fize, round truit, of a yellowilh-green, often tinged with purple; moitt, rich, and delicious; being the true or fuperior fort of Green Gage; the beginning and niddle of September.

Bltre l'erdrigon. Hlum-a fine middlefize, oval fruit, of a blackin-blue colour, covered with a farinous violet bloom, moft rich and excellently fine flavoured; the middle of Auguft.

Violet Perdrigon Plum-a largih, fine, roundish-oval fruit, of a blucish or violet-red colour, exquifitely rich flavoured; the midale and end of Auguf.

White Perdrigon Plum-a middlingfize, ovate-oblong fruit, whitifh-yellow, rich and delicate; the end of $A u$ guft.

Maitre Claude Plum-a middle-fize, roundifh fruit, of a mixed red and yellow colour, rich and fine; the end of Auguf and in Siptember.

Roche Courbone or Red Diapre Plum - a large, fice round, sed fruit, pow- dered with a farinous bloom, richly flavoured; the end of Auguft, E'c.

Chefton Plum-a fine, middle-fize, oval fruit, of a dark-blue, moft rich and rood; the niddlle of Sepiember.

White Bonum Magnum, or Egg Pluin - a moft large, ovate, or egg-hape, yellow fruit, powdered with a farinous white bloom, efteemed principally to preferve for fweetmeats, alfo good to eat raw; the middle of September.

Red Imperial Plum, or Red Bonum Magnum-a molt large, oval fruit, deep-red colour, finely powdered, valued for fiveetmeats, and good for eating raw; the end of Auguft and in Sepiember.

Apricot Plum-a large, round, yellciv fruit, having a whitifh bloom; the flem firm and rich; the middle or end of September.

Myrobalan Plum-a middle-fize, round, dark, or purple-violet fruit, very sich and fweet; the end of Auguft, $\varepsilon^{2} c$.

Drap d'or, or Cloth of Gold Pluma middle-fize, ruund, bright-yellow fruit, red fpotted, rich and juicy; the middle of September.

Royal Plum-a fine, large, oval, lightred fruit, narrowing towards the ftalk, rich and fugary; the middle of Seftember.

La Mirabelle - a fmallifh-round, greenin-yellow fruit, molt rich and fweet; the end of Augugt and in Septemler.

St. Catharine Plum-a large, oral-oblong, compreffed fruit, amber-coloured, with a whitifh bloom, excellently rich and fweet; the middle or end of Septemoer.

Brignole Plum-a large, oval fruit, yellowinh and red, fweet and rich fla voured; the middle or end of September.

Wentworth, or Monfieur's Plum-a moft large, oval, yellow fruit, of a Tharp, acid flavour, good to preferve. or to eat raw, when fully ripe ; the end of September.

Imperatrice, or Emprefs Plum - a large, fine, round fruit, of a violetred colour, with a whitith bloom; the brgiuning of Oitobcr.

White Pear Plum-a middle-fize, oblongith, white fruit, of an acid fla'T z

voll's 
vour, better for preferving than to cat raw; the end of Scptember and in October.

Cherry Plum-a fmall, round, red fruit, the fize, hape, and colour of a large red-heart cherry, eftcemed chietly as a curiofity; Auguft or Septembir.

Damafcene, or Damfon Plum - a fmall, round, blackifh-blue fruit, very profitable for many kitchen purpofes, in tarts, pies, \&c. alfo for eating raiv, when fully ripe; Sestember and Octobir.

Mufcel Plum-a middle-fize, oblong, compreffed fruit, of a dark or blacksed colour; but of an indifferent fla. vour; the tree valued by the nurfery men, for frocks, on which to bud peaches, \&c. the end of September, छेc.

St. Julian Plum-a fmall, roundifh, oblong, violet-coloured fruit, with a farinous bloom; September.

Almond-Shape Plum-a middle-fize, oblong fruit, deeply furrowed, and of a whitih-yellow, tinged with red; September.

The above being the principal and moft generally known forts of Plums, there are many others of lefs note that occur in different parts of this and other countries; but this collection aftords a plentiful choice, to furnifh any garden with a proper variety.

The above varieties confif of many fine eating Plums, and for tarts, pies, and preferving; are various in fize, hape, and colour; fome being fmall, others middling and large, and in thape, round, oval, oblong, \&c. in colours, black, red, white, yellow, green, blue, \&c. and attain perfection, in the different varieties, from the middle or latter end of July, in regular fucceffion, till October; and all of which are produced plentifully, both on Itandard-trees, walltrees, and in efpaliers.

\section{PRUNUs infititia, Infititious Wild Plum, or Bul- lace Tree.}

A fmall, deciduous tree, growing fifteen or fixteen feet high-the branches fomewhat fpinous; leaves. ( $/$ mallifh) ovate, villofe, hairy on the under fide, convolute; and peduncles or flower-ftalks, moftly in pairs, the flowers fucceeded by fmall plums; ripe in September and Oetober.-Native of Germany and England. (Any common foil.)

\section{Varieties of the Fruit.-Black-Bullace. White-Bullace. Red-Bullace.}

The Bullaces are of the finaller and inferior forts of Plum, ripening late, of a tartih flavour; and a few trees merit admittance in the plum collection, in a garden or orchard, chieily in fmall ftandards.

\section{PRUNus fpinofa, Spinous or Thorny Wild Plum, or Sloe Tree.}

A fnall, deciduous tree, of mrubby, bufhy growth, ten to fifteen feet high-the branches thorny; leaves (finail) fpear-Thape, fmooth; and peduncles or flower-ftaiks, fingly, and by pairs; and fmall, berry-like black fruit, called Sloes; ripe the end of Oetober and November.- Native of noft parts of Europe, in woods and hedges. (Any foil and fituation.).

\section{Variety.-Double-blofiom Sloe Tree.}

The Sloes are confiderably the fmakteft of the Plum tribe, very auftere and four, but are in requeft in fome families, and for medicines.

\section{Cberry Kinds.}

Comprifing the Common Cherry in many varieties, the great Wild Cherry Tree, Bird-Cherries, \&c.

\section{Prunus Cerafus-(Cerafus) or Common Cherry Tree.}

A middling, deciduous tree, growing eighteen or twenty feet high, or more-the leaves (middling and large) ovate-fpear-Thape, conduplicate, fmooth; and flowers growing in umbels, fucceeded by bunches of round fruit; ripening from May and June, till Auguft and September.-Native of different parts of Europe. (Any common fertile foil.)
Varieties of the Tree.-Upright, clofe-branching Cherry Tree, as in molt of the Duke kinds, \&c.
Strong - fhooting, fpreading-branched Cherry Tree, as in the Heart kind.
Slender-branching Cherry Tree, as in the Morello Cherry.
Dwarf Cherry Tree.
Double-bloffom Cherry Tree, (very beautiful.)
Red-blofiom Cherry.
Pendulous-branched or Weeping Cher- ry Tree, (sery curious.)




\section{Of the Fruit; ripening from May to September.}

Early fmall May Cherry - a fmall, round, red Cherry, valued only principally for its early maturity, as being the firt ripe: the middle and end of May.

Early May Duke Cherry-a larger, fine, round, red fruit, ripening of a dark-red colour, and good flavour; the end of May, or mofsly in fune.

Arch-Duke Cherry - a large, molt fine, round, red Cherry, ripening of a deep-red colour, excellent when fully ripe; the middle or end of $\mathcal{F}$ une, and in Fuly till Auguft.

White-Heart Cherry - a middle-fize, roundih-heart-hape fruit, of a whitifh-yellow, and pale-red colour; Fune and Fuly.

Black-Heart Cherry - a middle-fize, roundith-heart-hape, black-red fruit ; Fune and Fuly.

Kentifh, or common red Cherry-a middling-fize, round, red fruit, very juicy, of a tharp, acid flavour, profitable for general or common ufe; the trees generally plentiful bearers; Fune, Fuly, and Auguft.

Hertfordhire-Heart Cherry - a larger, fine, roundiih-oval, red fruit, firm and good flavoured; the middle or end of July, till Auguft.

Large Spanih Cherry-a large, fine, round, red fruit, ripening of a deepred colour; the middle and end of Fune, till fuly.

Amber-Heart Cherry - a large, roundifh-heart-thape fruit, yellowish-amber-coloured, firm, and well flavoured, Fuly and Auguft.

Ox-Heart Cherry - a moft large, roundinh-heart-form, red fruit, flefhy and well-tafted; Fuly and Auguft.

Bleeding-Heart Cherry-a middling, roundih-hearted, dark-red fruit, often having a red drop at the end; Fuly and Augußs.

Eigeroon, or Harrifon's Duke or Heart Cherry - a fine large, roundith-hearted, beautiful red fruit, moft cxcellent; Fuly to Aug:ift.

Lukeward Cherry - a largin, fine, roundirh, black-red fruit, of a rich, good flavour; July' to Angufs.

Carnation Cherry - a large, roundionoval fruit, reddin and whitifh-yel- low-coloured, beautiful, with a firm fleth; August to September.

Yellow Spanih Cherry-a largifh, round-oval fruit, amber-yellow-coloured, of a fweetifh flavour; the end of Fuly and Auguft.

Turky-Hieart Cherry-a large, fine fruit; Fuly to Auguft.

Crown-Heart Cherry-a large, roundith-hearted fruit, blackih-:ed; $A$ guft.

Morello Cherry-a largifh, fine, round, red Cherry, ripening of dark-red colour, very juicy, of a fine, acid flavour, and valuable for its long and late continuance; good both for eating and preferving; when of full perfection, become almoft black; Auguft to September.

White Croffian Cherry-a large, roundifh, almof white fruit, firm fleth, well-fla voured; Fuly to Auguff.

There being the principal varieties of the common Cherry, are moftly large fruit of the Cherry kind, and are produced abundantly both in ftandards, wall-trees, and efpaliers, attaining perfection, for eating, on the different varieties, from May or June, till September.

\section{PRUNus avium, (Birds) or Great Wild Cherry Tree.}

A large, upright, deciduous tree, growing thirty or forty feet high - the leaves (largißh) oblong-ovatefpear-thape, conduplicate, downy on the under fide; flowers in clofe-fitting umbels, fucceeded by bunches of fmall, round fruit, ripe in Auguft.-Native of $\mathrm{En}$ gland and the northern pasts of Europe. (Any common foil and foruations)

$$
\begin{gathered}
\text { Varieties.-Small Black Wild Cherry. } \\
\text { Small Red Wild Cherry. } \\
\text { Larger Red Wild Cherry. } \\
\text { Large Black Wild Cherry, or Corroune } \\
\text { Cherry, } \\
\text { Double-bloffom Wild Cinerry Tree. }
\end{gathered}
$$

Of the abore varietics of Wild Cherry, the firft and fecond are fmall, the third larger, and the fourth fort is a middling-fize fruit, fuperior to the others in fize and perfection, for eating; all of which are of a bitterifh-fwect flavour; ripening the end of July and in Augur? 
Bird-Cheryy Kinds, the Fruit not palatable for eating.

6. PRUnus Padis-(Padiss) or Conmon Bird. Cherry.

A moderate, cieciduous tree, growing fifteen or twenty feet high, or more-the leaves (miduling) oblong-fperr-fhape, the bafe laving two glands underneath; and thowers produced in cluiers, fucceeded by fnall, black, round fruit, ripe in autumn; but inferior, or not agreable for eating. - Native of England and difsent parts of Europe. ( Ainy joil, Ëc.)

\section{PRugus virginiana, Virginian Bird-Chemy} Tree.

A michling tree, growing twenty feet high, or more-the leaves (midaling) ovate, the bafe glandulous in the fore part; flowers in clufters; fucceeded by largih, red and black fruit.-Native of Virginia and Carolina. (Asy.commoir foit.)

\section{PR U N U conadenses, Canada Bird-Cherry Tree.}

A fmaller deciduous tree, with very fmooth branches-the leaves (middling) broad-rpear-fhape, wrinkled, both fides downy; flowers in clulters, fucceeded by fmafl fruit.-Native of North America. (Any cominon foil, Éc.)

\section{PRUñ Mabalel-(Mahaleb) or Perfumed Cherry.}

A fmall, deciduous tree-the leaves (moderate) ovate, obtufe; flowers in corymbous bunches; and fmall cherry-ihaped fruit.-Native of Helvetia or Switzerland. (Any common foil, Evc.)

\section{Apricot Kinds.}

10. P RU N Armeniaca-(Armeniaca) Armerian Apple or Apricot Tree.

A moderate, deciduous tree, growing fifteen or twenty feet high-the fhoots reddifh; leaves (middling, or largifh) fub-cordate, or roundifi, heart-hape; flowers fefile or fitting clofe; and large, roundifh, and oval, firm, yellow fruit, ripe in the end of July, to the latter end of Auguft.-Native of Afia. (Loamy, or any good garien earth, and warm fituation.)

Varieties of the Fruit, ripening of the following Sizes, Shapes, and Colours, Eंc. from Fuly to September.

Early Red Mafculine Apricot-a fmall, roundin fruit, red next the fun, the other fide yellowifh, not rich flavoured, but early ripe; the leginning or midile, to the end of Fuly.

Early White Mafculine Apricot-a fmall, round, whitim-yellow fruit; the middle or end of fully.

Orange Apricot-a large, roundifl, deep-yeliow fruit; the end of Fuly or beginning of Aingif?

Roman Apricot-a large, roundinoval, yellow fruit, of a more juicy, rich flavour; the beginning of Auguff.

Algiers Apricot-a large, oval-hape fruit, fomewhat compreffed on the fides, pale-yellow; the end of $7 u l y$, beginning and middle of Auguft.

'I urky A pricot-a more large, globular, deeper-yellow fruit, firm, and rich favoured; the beginning of Auguft.

Templé Apricot-a large, fine, roundifh, ye!low and reddih fruit, firm, and well-flavoured; the middle of .Au$g u f t$.

Tranfparent Apricot-a roundifh, yellow fruit, with a clear pulp; the middle of Auguft.

Breda Apricot - a large, roundifh, deep-yellow fruit; the infide deeporange colour, of a high, rich flavour; the middle or end of Auguf, to September.

Dunmore Breda Apricot-a large, roundih, fine fruit, yellow and reddifh; Auguft and September.

Bruffels A pricot-a middle-fize, roundifh-oval fruit, red next the fun, tinged with dark spots, the other fide greenifh-yellow; firm flefh, with a high, rich flavour; the middle or end of Auguft, to September.

The Apricots, in their mature growth, are moftly firm-flefhed, if not too ripe, and of a fine, poignant relifh ; but if too mellow, are foft, mealy, and of but little flavour; fo hould generally be gathered while the fruit, in its mature ftate, is of a firm texture.

The above are the principal varieties of Apricots cultivated in the Brition gardens; all of which are produced in plentiful crops, in favourable feafons, on wall-trees, principally againft fouth and wert walls, and fome alfo on efpaliers and ftandards, in warm fituations; but as being moflly of the temperature of peaches and nectarines, and the trees bloffoming early in the fpring, generally when fevere cold, or cutting 
blats, or Tharp frofts often prevail, and the fruit in its embrio ftate, liable to be greatly injured, or cut off by inclement weather; the trees, \&c. therefore in moft of the varieties, require the protection of warm walls, both to defend the bloffom and young fruit more effectually in its early growth, to obtain a more certain, tolerable crop, and to forward them to maturity in the beft perfection of growth and flavour; they will likewife fucceed on efpaliers, or fome forts on ft indards, eipecially the Bredas and Brufiels Apricots, all as hereafter fully explained in their general culture of the trees. - See culture of the Apricot.

\section{Laurel Kinds.}

Which, being alfo fpecies of the Prunus, agreeable to the fyftem of botany, confifts of two fpecies, both very eminent and beautiful ever-greens, viz.

\section{PRUNus Lauro-Cerafus-(Lauro-Cerafus) Cherry Laurel, or Common Lâüel Tree.}

A large, ever-grcen thrub, or middling tree, growing twenty feet high, or more-the leaves (large, Bining-gicen) oblong-ovate, continuing always green, two glanded on the back; flowers in racemous clufters, fucceeded by cherry- hape black berries, ripe in autumn; not eatable.-Native of Trebifend, Afia; brought to Europe $15 ; 6$. (Any foil and fituation.)

\section{Varieties.-Broad-leaved Laurel Tree. Narrow-leaved Laurel Tree. Silver-friped-leaved Laurel Tree. Gold-ftriped-leaved Laurel Tree.}

12. PRUxus lafitonica-Portugal Laurel, or fmaller Laurel Tree.

A large, ever-green thrub, or fmall tree, of bufhy growth, eight or ten, to fifteen feet high-the leaves (maller or middling, dark-grcen) ovate-oblong, fomewhat doubling, continuing always green, englandulous, or without glands; and fowers in racemous clufters, fucceeded by fmall, berry-like fruit, ripe in autumn.- Native of Portugal and Pennfylvania. (Any common joil, E⿱宀.)

'The laft two fpecies are moft elegant ever-greens, of principal eftination, to plant, for ornament, in p!caiure-grounds, \&:c.

'This numerous family of Prunus affords a valuable collection of eminent trees and fhrubs, for ufe and ornament in gartens and plantations, in a compretienfive variety; and particularly in fome principal fruit-trees of different fpecies, furnifhing many fine varietics of their rofpective fruits, as in the l'um, Cherry, and
Apricot; fome alfo to cultivate as foreft-trees, and many forts principally for ornamental planting in fhrubberies and other ditrins, in pleafure-grounds: five or fix fpecies may be ranked in the fruit-tree collection, confifting of the common Plum and Cherry Trees, in their numerons varieties; the sreat Wild Cherry Tree, and Apricot; alfo occafionally the Bullace and Sloe 'Tree, in a fmall portion; but the threc former for principal culture, both for ftandards, walltrees, and efpaliers, or the Apricot chiefly in walltrees, for the general fupply, or for foreft plantations, the great Wild Cherry Tree, acquiring a lofty, large growth, is proper; and alfo the Prunus domeftica and Prunus Cerafus, in their natural growtl, are eligible to admit in timber-tree plantations, the wood being in requeft for various particular purpores, in feveral trades.

But all the other fpecies, confiting of the BirdCherry kinds, Perfumed Cherry, and the two fpecies of Laurel, are ureful principally for decorative planting, very defirable furniture for diverfifying thrubberies and other pleafurable plansations, for urnament and obfervation; or likewife any or all the fruit-tree kinds are proper to introduce in fimilar plantations in affemblage, in which they will affect a very difinguin. able variety, both in their growth, abundant bloffom, and production of fruits of their refpective different forts; and the Sloe Tree or Black-Thorn being very branchy, buthy, and armed with thorns, is employed in forming field hedges: the two fpecies of Laurel are very beautiful ever-greens, to plant as principal ornamental fhrubs of the ever-green tribe, for adorning fhrubberies, \&c. of which the Prunus Lauro-Cerafus, or Common Laurel, was alfo formerly trained for ornamental garden hedges; and is iikewife ftill occafionally planted to cover naked walls and palingys, \&zc. or alfo to plant for blind in any particular diftrict, or to cxclude from fight any difagreeable object; and in all of which, it appears always green and beautiful in its large, Nhining foliage; the Portugal Laurel is alfo elegant in its natural growth, in large, bufhy, ftandards; and the Common Laurel, attaining foine confiderable fize in the tree order, by pruning up the under branches by degrees, is alfo eligible to introduce in tree plantations, and to form Laurel groves, \&c.

In the fruit-tree kinds of Prunus, for general culture, the cominon or cultivated Plum, Clierry, and Aprico, and their refpective varicties, are the principal forts; the merit of which being univerfally known, they demand particular attention, and hould be admitted in every garden, efpecially a collection of the beft varieties, in regard to thofe of their refpective fruits, inore or lefs, according to the extent of ground; beth in tandards, for the principal produeson, particuhnty of the Plums and Cherries, and 
in wall-trees, for earlier and finer fruit, in the greateft perfection, and fome in efpaliers; or, where no walls or efpaliers, may have the two lant-montioned kinds wholly in ftardards, and in which moft of the varietics will producc fientiful crops in good maturity; but the Apricots thould gencrally be traincd in wall-trees, againt warm walls, and fome particular forts wiil alfo produce tolerable crops on ttandards and in efpaliers, as will be hereafter explained.

All the forts of Plum and Cherry trees produce the fruit principally upon Imall fpurs arifing at the fices and ends of the branches, of fion two or thrce to feveral years old, and the fame branches and fruit-rpurs continue many rcars fruifful: though the Cherries particularly fometimes alfo bear on the young thoots of a year old, or more generally in the Morello and fmall May Cherry, the moft abundantly, efpecially the Morello, which commonly produces the principal crops of fruit on the young year-oid wood.

Of the Plum kinds, to cultivate for the fruit, that of the Prunus Domeftica, or Common Plum tree, is the mot valuable, affording numerous varicties of the fruit in great diverfity, in fhape, fize, and colour, of red, white, yellow, blue, green, black, \&c. ripening, in the different varieties, in regular fucceffion, from July till the end of October, both for immediate cating and for pies, preferving, \&c and therefore the trees are very profitable to cultivate in gardens and orchards, for their production of fruit, efpecially as they will profper in any common fertile foil, either principally in ftandards, or forme alfo in wall-trees, where there is the accommodation of walls; in which it is eligible to allot fome of the molt eftecmed forts, both to obtain fome fruit as early ripe as pofible, and to have the whole, both early and other kinds, of an improve growth and maturity ; and of the Plum kind, nould ncver ounit having a few trees of the Damfon in Itandards, the fruit being very ufeful in a family: likcwife may admit fome of the Bullaces in fmall fandard-trees, to encreafe the variety; the fruit, when quite ripe, in September and October, is wholefome and of an agreeable acid fiavor; or may alfo have fome of the Sloe tree, the finit of which being likewifc of the Plum tribe, but confiderably the fmalleft of that kind, of an auftere quality, though palatable to fome perfons, and is ufeful in ieveral dometic occafions.

Of the Cherry kind, the principal fpecies for general planting is the Cerafus or Common Chery tree, comprifing its dificrent varieties, a collection of which merits culture in every garden; va!uable both for producing the carlief ripe fummer fruit, continuing, in fuccelison, two or threc montris, or more, from May and June till Auguf or September, in the early and late forts, all very refreshing to eat in hot weather, and exceedingly ufeful for feveral kitchen purpofes, and other occaiions in a family, as well as a very profitable fruit for market; and the trees of all the varieties generally produce plentiful anmual crops, both on Atandards, wall-trees, \&c. fo that they may be planted abundintly in gardens and orchards, in ftandards, for the principal production; and Cherry orchards are very profitable in the production of fruit for fale; and for wall-trees fhould allot fome of the beft varieties, both of early and late :inds, planted againft fouth and other walls, or fome may alfo be planted for efpaliers. The Prums avium, or Great Wild Cherry Tree, is proper to plant in full ftandards in orchards, parks, avenues, and hedge.rows, or alfo in gardens and pleafuregrounds; is a great bearer, the fruit fmall, but of an agreeable bitterifh=fweet flavor; though the large redfruited Wild Cherry, and the Black Couronne or Couroon, varieties of the Prunus avium, being tolerably good fized fruit, and of a very agreeable tafte, peculiar to thefe kinds, are deferving of culture in the bett collections of the Cherry kind, in gardens and orclards, principally in ftandards. - See the general sulture of the Cherry. Tree, \&ic.

The Apricot, confifting but of one principal fpecies, Prunus Armeniaca, furnithing many fine varieties, is cultivated principally in wall-trees, and planted moftly againft fouth walls, and occafionally thofe of weft and eafterly afpests; fome forts alfo in ftandards, fuch as the Breda and Bruffels Apricot, and in which, in favourable feafons, they produce plentiful crops of fruit, and ripen in good perfection; and thefe two forts are likewife fometimes planted in efpaliers, in which they alfo produce fruit very agreeably, in good maturity.

\section{General Culture of the Plum and Cherry.}

As the Plum and Cherry are nearly fimilar in their mode of bearing, and the fame method of culture is applicable to both the fpecies and their refpective varieties, thall thcrefore treat of them accordingly, together, under the fame general head.

All the forts of Plums and Cherries produce the flowers and fruit moftly upon natural fpurs or curfons, fmall, robuft thoots, half aninch to an inch of two long, emitted along the fides and at the ends of the branch. es, when of two or three to feveral years old, arifing firft towards the upper parts, then gradually incrcafing in number at the lateral cyes, the whole length of the branches, provided they are continued intire, not thortened; as their mode of bearing does not admit of ftortening, which would not only deftroy the firft fruitful parts, or where the fruit-fpurs generally begin to form, but alfo, by pruning away that part of the 
thoots or branches, it makes the fap flow ftrongly to the lateral eyes or buds, whereby they arc apt to pun forth vigorous wood thoots, inftead of forming fruitbuds for bearing, and therefore, in giving occational pruning to the trees, flould moftly preferve the general branches and thoots at their whole length, cxcept in particular inftances, to reguinte or reduce any fuperextcnded Thoots, or confiderable ftrolling growth, whicl may be pruned more or lefs accordingly, retaining all the others intire; and they will naturally furnifn the above-mentioned hort fpurs for fruit: the fame branches and fruit-fpurs continue many years in a prolific ftate.

Though in the Cherry particularly, the trees often bear on the year-old thoots immediately from the eycs thereof, as well as upon fpurs formed as above cxplained, on the two, three, and feveral years old branchcs; or more generally, however, the Morello Cherry, which always bears abundantly upon the yoting hoots of a year old, and alfo on fmall fpurs on the oider wood; but when trained in wall-trces, in which an annual pruning and nailing is requifite, fhould generally, in the Mortlo, leave a plentiful fupply of the young thoots of each year, for immediate bearers the enfuing feafon, and part of the naked, old wood cut out accordingly in the winter-pruning.

Both thefe fpecies of fruit-trecs, the Plum and Cherry, in their feveral varieties, are proper to cultivate plentifully in ftandards and wail-trees, in gardens and orcharcs, as before intimated; being generally raifed by grafting and budding upon frocks of their refpective kinds, trained each with a fingle ftem, four to five or fix feet high, for half and full ftandards, and to branch out at thofe heights, to form the head; but for the general fupply, are moftly trained in full ftandards, in ttems of about fix fcet height, and planted twenty or thirty feet diftance, and permitted to branch out fully above; and occafionally trained in dwarf and half ftandards, with ftems of one or two to three or four feet; and for wall-trees, fhould allot a collection of the beft varicties, trained principally in low ftems, only five, fix, or eight inches, to branch out near the ground, to cover the wall with branches, in a regular expanfion, quite from the bottom upwards, and planted againft walls of different afpects, as fouth walls for the carlief production, and on walls of other expofures, to furnifh fuccefion and late crops, planting them generally not lifs than twelve or fifteen to eighteen feet diftance; and the branches arranged to the wall horizontally four to five or fix inches afunder, all generally at their whols length, both in :he l'lums and Clierries, in which they will gradually form fruit-fpurs along their fedes for bearing : fome may alfe be planted in efpaliers and trained fimilar to tho'e in wall-trecs; and in both of wlich, to walls and efpalier-tree, shey will produce fruist in lupcrior perfiction, if regu- larly managed, by proper pruning and railing every year in furnmer und winter; but as to the ftandaró. they having full fcope to branch out freciy alro:e all around in full heads, they do ret requite any prunins; at leaf only occafionally, to reform any very irregula groivth, and to cut out cafuist, decayed ixood.

For ftandards, any or all the forts of plums and Cherries may be trained and planted in any common foil of a garden, orchard, Sc. and in which may either lave a full collection, wherc fufficient extent of ground, or have only an affortment of the principal or moft approved varieties.

But for wall and efpalier Plums and Cherries, generally have only the principal forts, valuable fome for their eaily production, others for the fuperior quality of the fruit, and fome for late ripening, thereby obtain Plums from July and beginning of Auguft to the end of Octobcr; and Cherries from May and June till September, of which the principal early forts are the May and other Duke kinds, fucceeded by the Heart Cherries, \&c. and of the late forts, the Morcllo is fuperior, as a grcat bearer and fine large Cherry, and which is commonly planted on north walls, as it bears abundantly in any afpect, and when in a north expofure, it continues in longeft perfection; but it is alfo proper to have fome on fouth walls, to enjoy the benefit of the fun, to ripen the fruit with a richer flavour, in which it proves a very fine large Cherry for the table; when fully ripe, of a black-red colour.

In ftandard Plums, generally have a principal fupply of the beft bearers and moit ufeful, both for ezting; and domeftic occafions; fuch as the Orleans, Greeri Gige, Imperial Plum, Bonum Magnum, Fothering ham, Imperatrice, Royal Plum, Myrobalan, Perdrigons, Queen Claude, Damafi I'lum, Nirubcile. iVhite Primordian, Wentworth Plum, $\mathrm{s} c$, and always fome Damfous.

And for ftandard Cherrics, all the Duke tinds are proper for principal fupplice, fome beil forts of Heam Cherries, and plenty of the Sentih or Flemin Chezry, bcing an abundant bearer and excellent C!serry, when fully ripe; alfo fome Morellos, and Black Corounc; but as to the Great Wild Cherry Tree, the common fmall Black and Red-fruited kinds are cultivated principally in large ftandards, in orchards and out-grounds, or occafionally in garden collections, to encreafe the varicty, and is very commonly planted in hadge-rows of ficlds, and in parks, \&c.

Proper collecions of the different varieties of Plum and Cherry, for planting, may be procured at tie public rurieries, boin in ftandards and wall-tree's; either young trees, with heads of oniy one or two year old. 
or fucl: as are three cr four, to five or fix years rrowtin, furnithed with a tcierable head of branches, advanced to a proper age for bearing.

The feafon for planting ali the forts of thefe trees is either principally in the autumn, at the decay of the leaves, in October or November; and the focner it is performed at that time the better; and they will bise a good chance of friking root the fame feafon; or plantc.t in the fpring montis, sbout February and March, or not later than the beginning of April; though they may a!fo be planied any time in open, mild, weather, from October till March.

The propagation or methods of raifing the different forts of Plums and Cherries, is princifi!ly by grafting or budding the defirable or refpecive varieties upon ftocks of their own kind, $i, e$. the Plums upon any fort of Plum Rocks raifed from the fones of the fruit, or fuckers taken from the rcots of old trees; and the Cherries upon any kind of Cherry ftocks, raifed chiefly from the ftones of the Cherries; $f$ ralthough Plum and Cherry trees may be raifed immediately from the fones of the fruit, they neither bear to foon, nor come with certainty of the defired forts, or, probably, not cne in many produce good fruit; but grafting or budding, boti continue the refpective forts invariably the fame, and the trees alfo fooner attain a bearing ftate, and bear more abundantly, which is the cafe with mo:t other fruit-trees.

Therefore, to raife fupplies of focks on which to graft or bud Plums and Cherries, having a quantity of the ftones of the fruit, they thould gencrally befowed in the autumn, in September, October, or November, or preferved in fand, till February, and fowed in beds of light earth an inch or two deep, either broad-caft and earthed in that denth, or in drills a foot diftance, they will come up in the fpring, in April or May; which, next autumn, or fpring following, or when of two fummcis growth at mof, fhould be tranfplarted from the feed-beds, in nurfery-rows two foot and a lialf afunder, in which to remain to acquire proper fize for grafting ard budding; likewife fuckers of Plums, defigned for ftocks, fhould be planted in the fame order; and when the ftocks, both of feedlings and fuckers, are advanced in grow/th from half an inch to an inch thick, they are of proper fize to receive the grafts and buds; or occafionally the operation may be performed upon focks of fmaller fizes, of from that of a large goofe quill to half an inch thiclincfs, efpecialiy for whip-grafting; training the whole with a clean, ingle ftem, five, to fix or feven feet higl:, for half and full fandards, and three or four for Divarf or Common Wall-Trees and efpaliers.
The operations of grafting or budding them is petformed, the former in the fpring, in February and March, and the budding in fummer, in July and beginning of Auguft, eitier of which methods of propagation is eligible; and at the proper feafons a above, chufing grafts and buds of the defirable $01^{\circ}$ intended varieties of the refpective trees, obferving, for grafts, to take cuttings of the young fhoots of latt fimmer's production; and for buds, thefe mun be detached from cuttings of the thoots of the fame year; and in both of which, to perform the grafting or budding higher or lower on the ftock, according as dejigned to have $\mathrm{ft}$ undards or dwarf trees; that for the former, fhould grait or bud upon tall focks, inferting the graft or bud, at fix feet height for full ftandards. three or foul for half, and at one or two feet for dvarf-ftandards; but for common wall-trecs ard effaliers, the grafting or budting is performed low in the ftock, within fix or eight inches of the bottom, in orier to obtain a proper fpread of branches below, near to the ground, to cover the wall compleatly ficm the bottom upward; or occafronally, for half-ftanciard wall-trees, they are grafted or budded at three or f́cur, to five or fix feet, whercby to have them furnifn an expanfion of branches at thefe heighths, and for planting betreen the Dwarf or Common Wall-Trees, to cover the upper part of high walls while the others are advancing below, and thereby have all parts of the wall fooner and more effectually occupied.

Having performed the grafting and budding at the proper feafons, as above, the grafts will fhoot the fame year, but the buds not till the following fpring; and in both of which they will make frorg fhoots in one fummer, the grafts probably advance in two or three fhoots, and the buds commonly but one; and in both of which, when the faid firit fhoots are of one fummer's growth, the trees may be tranfplanted, next autunin or fpring, into the gardcn, orchard, \&-c. where they are finally to remain, or continue two or three years longer in the nurfery, to form larger heads of feveral branches; but in either of which generally obfcrve, that when the above faid firft floots produced from the grafts and buds, are a vear old, next fpring it is proper, either if tranfplantcd into the garden, $\$ c$. or remain in the nurfery, to cut them down to a few eyes, in March, efpecially the bud-fhoots, or alfo the grafts, when only one or two fhoots, in order to pra mote their pushing forth lateral fhnots the fame year, near the head of the fem, to form the beginning head in an eligible expanficn of lo:ver banclies, as a proper bafis to fumiln others in a regular fupply upward; and fo: vall-trees particularly, alfo for ef alicrs, it is likewife fomerimes necefiary to prune down tha fecond year's thoots moderateiy, to obtain a further 1 ?ply of laterals; for when the firft hoots are wot hcaded down as above, but permitted to run, they are apt to ex- 
tend long and naked, without furnifhing laterals, only towards the extremity.

As above obferved, the young trees may be planted in the garden, either when they are of one or two years old, from grafting and budding, or of older growth, with heads advanced to two, three, or four years o!d, with a good fpread of branches, and that are advanced to a bearing ftate, both of the ftandards wall-trees, \&c.

The planting of ftandard Plums and Cherries may be performed in gardens, orchards, and pleafuregrounds, in any common foil and open fituation: have the trees removed from the nurfery with as good a fpread of full roots as polfible, and of which prune off any broken parts, and only thorten any very long fraggler, or may juft cut off the ends of the others, floping on the under fide; and as to the top, if furnifhed with a fupply of laterals, forming the head of feveral branches, they fhould generally remain intire, except where any crofs-placed or others of very irregular growth occur, which may be cut out, or pruned to order, as may feem neceffary, or occafionally to Thorten any long rambler, continuing all the rett in their full extent; or if the trees are only a year old, having but one or two firft hoots, thefe may be pruned down in the fpring, as advifed in the surfery culture, to obtain an encreafed fupply of branches, to form the head of a more full, fpreading order, and thefe permitted to advance in their full growth; and thus, agreeable to the above intimations, proceed to plant the trees in their allotted places, at twenty to thirty feet diftance, and if early in autumn, or late in the fpring, a moderate watering to the earth, about the roots, will be of advantage; and where fupport of ftakes may appear neceffary to trees with tall items and full heads, it thould be done as foon as planted, efpecially in expofed fituations, placing one or two ftakes to each tree; likewife, if very dry weather, in fpring or early part of fummer, occafional waterings would be very ferviceab?e.

In the future growth of the ftandard Plums and Cherries, after final planting, they, in the firt year from grafting and bualling, either while remaining in the aurfery, or after tranfplanting into the garden, having their firft thoo:s, if necefiary, pruned down, in March, to a few eves, to force out collaterals, to form the head of a more preading growth, hould afterwards be generally permitted to branch out around every way, in their natural manner; will require very little pruning, or only occafionally to prune to order any confiderable irregularity, fuch as to reduce any calial, lor:z rambler, or to cut out low firagglers, very rampant fhoots, and crofs-placed branches, or to thin fuch as are crinfiderabiy crowded, and to cut cut decayed wood; but, except in thefe intances, fuffer all the general regular branches to advance ir. their full growth, and they will furnifh fruit-fpurs abundant ly, and bear plentiful crops of fruit.

As to the wall, Plum, and Cherry Trees, they may be planted in the garden, either in their young growth of one or two years old, having the firft hoots, from the graft or buds, pruned down when a year old, in March, to furnirh a proper fupply of collaterals below, to form the head; or if they have been headed in the nurfery, and, in confequence thereof, are furnihed with a tolerable fpread of branches, it may be of greater advantage in regard to their being of larges expanfion, as at once to cover a good fpace of walling, \&c. from the beginning, and fooner commence bearers, or fometimes form immediate bearers the firt feafon, in a moderate degree, allotting fome principa! forts for fouth walls, to produce fruit earlier, and in fineft perfection, in fize, beauty, and richnefs of flavour; and may plant others on walls of different expofures, for fucceffion and late fruit; and for which, have the trees taken up with good roots, prune broken parts, \&c. thereof, and long ftragglers, as advifed for the Atandards, and cut out any projecting fore-right thoots of the head; then plant them not leis than twelve or fifteen feet afunder, or if fifteen to eighteen feet diftance, it will be of more advantage, in afrording proper fcope to extend the branches in their advanced growth, at their whoie length.

In efpalier trees, may alfo plant fome defirable kinds, both of Plums and Cherries, at the diftance above-mentioned for the wall-trees.

After planting the wall and efpelier Cherries, let the branches be arranged to the walls, \&ce. in reçular order, extended horizontally, four', to five or fix inches afunder, generally at their full length, for the reafons Ecfore explained; or in young trees, having only two or three principal thoots in the head, they may be pruned down half way, or to $f_{1 x}$ or eight eyes, in order to obtain a further fupply of bottom branches, which train to the wall in the above urder; or occafwnally, where it appears neceffary to have further fupplies of wood in particular parts, may fhorten contiguous thoots either the fame funmer they are prodiced, perforning it in June, or in the following winter or fpring-pruning, to obtain laterals to furnifh the vacancies; and afterwards, in the general pruning, commonly retain the fhoots and branches intire, and they will thus afford natural fruit-fpurs all along the fikes to the extremity, and the fane branches and purs contiras many years fruitful.

Then, with refpeet to the general culture of the wall and efpalier Plims and Cherries, it confefts of an an. ntial pruning, nailing, íc. every fummer and winter; a fnnmer-piuning to regulate the thoots of the year. and a winter-pruning, hoth in the young wood and U 2

olvar 
vijer hranches; for as the training them in wali-trees mu! efpatiers, cach tree being alioticd a certain fipace, $a * d$ the hanches arranged in regular order, four, to five or fix inches afunier, and as they will produce sumerous, improper, and fuper-abundant thoots every lear, the abrice amnual prunings is nccellary to reform irregularities, and to difflace fuperfuous and ufelefs woed, to preferve the regular expanfion of the trees within their aliotted bounds; but as the fame branches continue many years in a bearing ftate, upon fpurs betis-mentioned, they do not require a ronewal of a feneral furply of young wood for bcarers, as in Ieaclics, Nectarines, Apricots, Vines, \&c. which bcal rincipally upon the young fhonts of a ycar old; but when, after being traincd in a full expanfion, they only require occaficnal fupplies of young wood in cafual vacancies, or to fupply the place of any decayed or woin-out old branches, or fuch as become of an unfruitflil fatc; though in the Morello Cherry particulasly, it is proper to retain annual fupplies of young wood for principal bearers; and in the Plums and Cherries in general, thould commonly continue a terninal thoot at the cnd of every branch, where room 2disits ivi their cxienfion.

A flimmer-pruning and training, in the wall-trec and efpalier Plums and Cherrics, is neceffary every year, to regulate the general fhoots of the fame feafon only, and which fhould be ccmmenced in May or June, and continued, occafionally, in July, \&c. proceeding to the bufinefs firft by difolacing the ill-placed and evidently ufclefs or unrecefiary fhoots of the fame year, and to retain and train in proper fupplies of the well-placed fhoots in ail vacant pasts, and the leading fhoot to each main brancli, if room admits.

This work of fummer-pruning, if commenced early, the middle cr end of May, or early part of June, while the hoots are quite young and herbaceous, may be performed by rubbing oft the ufelefs thoot-buds and twigs clofe, with the finger and thumb; but when more advanced in a wooay growth, it muft be effected with a knife; and, by either method, difplace the fore-right hoots that grow immediately from the front of the branches, in a projecting direction, and fuch others as are not well placed, or improperly fituared for training to the wall, \&c. with regularity; as likewife any very luxuriant hloots, and others of improper growth; and alfo in the general fhoots, bhere tco numcrcus, prune out the fuperfiuous or over-abundant in a thinning order, taking the whole off clofe to the mother branclies, being careful, at the fame time, to fele 8 and retain a moderate fupply of the bet: wel!-plazcd fide-fhoots of middling-ftrong growth, arifing on the lateral part of the branches in the moft vacant fpaces, bcth in ycung and old trees, in orter for traiting to the wa!l accordingly, and to remán tili winter-pruning, ready as a reierve, either to furnith prefent or apparent future vacancios, if any, or to fupply the places of caftial decayed, worn-out, or unfruitful branches, obferving alfo to retain the terminal or leading fhoots, one only to each main branch, in all parts where room to extend them; and from the above-mentioned felest fhoots, cutting out the improper and fuper-abundart, continuing the referved fupply intire, or at their whole extent, let them diresty, or when of proper length, be nailed and trained to the wall in regular order, between the mother branches; and according as they advance in growtl, train them along at their full length all fummer, at leait not thortening any, except fuch as extend confiderably beyond their proper bounds, where not room to rum them in thcir full extenfion; and of the referved thoots, if any puth forth lateral twigs, they may be difplaced in thcir young growth, leaving the main fhoots clean and fingly, and continued trained to the wall and efpalier regularly as above.

Thus, giving the wall and efpalier Plums and Cherries the principal fummer-drefling, in May, Jume, July, \&c. and as the trees will continue flicoting, they fhould be looked over again accordingly, at dif ferent times, during their fummer's growth, to difplace any ufelefs after-fhoots, and to train in the referved fupply of proper fhoots in their advanced or encrcafing length, or that cafually ftart or project from the wall, both to prefcrve the regularity and beauty of the trees; and that by having the hoots trained clofe, in a regular manner, admits the benefit of the fun, air, rains, \&c. to improve the growth and goodnass of the fruit; fill continuing the principal hoots intire without thortening, or only occafionaily, agreeable to the foregoing intimations.

For thefe and all other fruit-trees that bear the fruit principally upon natural fpurs, arifing on the two, three, or feveral years old branches, do not admit of fhortening the fhoots, neither in fummer or winterpruning, without detriment to thcir nature of bearing, as it would force out numerous ufelefs or unneceffary lateral twigs from the eyes below, and prevent the formation of fruit-fpurs, which, as being the principal bearing parts of thefe kind of trees, you will, in the procels of the fummer-pruaing now under confideration, be careful to diftinguifh and prefcrve every where, they appearing of fhort, robuit grovtli, half an inch to an inch, or more, long, arifing along the fides, quite to the extremity of thc branches, gradually, if not finortened, or but as little as porfible, or not any, where room for thcir full extenfion, as formerly ouferved.

Though in particular in ianccs, fhortening may be occifionally practifed, fuch as, if in the procefs of the fummer regulation, in June, any confiderable viscancy occur, or in young trees, under training, requir- 
ing further fupplies of branches, fome ftrong firoots, contiguous to the vacant parts, miglit be fhortened in May, or the beginning of June, pinched or cut down to a few eyes; they will produce a fupply of collaterals the fame feafon, and thereby furnifh the vacancies more expeditiouny and effectual; liowever, except in the above inftance, continue the referved general thoots intire; and the whole remaining till winter-pruning, when, fciecting a fufficiency of the beft where wanted, and a leader to each branch, the reft muft be then cut out clofe to their origin, as explained in the followirg directions of Winter-Pruning.

The W1NTER-PRUNING of Plums and Cherries trained in wall-trees and efpaliers, which may be performed any time from the fall of the leaves in November till March, confitts of a general regulation both in the old branches and young wood, in which it muft be obferved, that as in thele and moft other of the fpur-bearing trees, or that produce the fruit moftly upon fmall, natural fpurs, the fame bearers continuing fruitful feveral years, and increafe in the number of fpurs as they advance in length, do not want a general renewal of young wood annually, as in trees which bear principally on the young Thoots of a year old; as in Peaches, Nectarines, Apricots, Vines, \&c. the fame general branches are to be continued from year to year, as long as they remain fruitful or well furninied with a proper abundance of cli sible fruit-fpurs for bearing, and only an occafional fapply of young wood is neceffary, either to furnifh young trees under training, with an encreafed fupply of branches, more or lefs, as required, or in old or full-trained trees, to fupply cafual vacancies, or the place of any infruitful, or worn-out old branches, which happen either to decline bearing, or cafually decay.

'That, according to the above intimations, in proceeding to the operation of winter-pruning of thefe trees againft walls and in efpaliers, examine both the general mother branches and the fupply of young fhoots which were trained in laft fummer; if in young trees, requiring fupplies of branches to encreafe or give the head a proper expanfion, retain well-placed young floots accordingly; and if old trees, or having a full cxpanfion of branches, fee if any bearers appear of an unfruitful, worn-out, or decaying fate, or affume any diforderly or bad growth, they hould now be retrenched, and their places fupplied with young wood, this being the only proper feafon for making any necerlary reform in the general branches in the operation of pruning; at the fame time obferve where fupplies of young wood is wanted in any vacant parts, or to furnith the places of inifroper old wond, as above, let the requifite fupply of the belt-placted fide-hoots of laft fummer to accordingly felected and retained in the proper places, cutting out therefrom all the fuper-abundant and illplaced thoots, pruning them clofe of to their origin on the mother branches, not leaving any ftump, fnag, or eye thereof, to Thoot forth again unneceffary wood, being careful to preferve on the bearing branches all the natural fruit-fpurs of half an inch to an inch or two in length, and only of which cut away fuch as are decayed, or affume a too-long projecting, or rugged, fumpy growth, which being cut off clofe, ncw ones will be recovered in or near the fame places; obferving in all vacant parts to leave fome well-fituated middling-ftrong thoots, as alfo retain fome in: any void fpaces below, or near any apparently declining or ill-hearing main branch, in old trees, in order for training up between the main branches to a bearing ftate, ready to fupply the places of the above improper old wood, when cut out in a year or two after; and always, where room, preferve the main leader, or terminating fhoot to each principal branch or bearer; or if more, thatn one leading floot, generally cut off all but the principal one; or if this appears too long for the allotted fpace, either above or on the fides, may occafionally fhorten it, or prune down the branch, more or lefs, to fome convenient lateral nhoot, to remain for the leader; and where any old branches are too crowded, or of a decayed ftate, cut them out either to fome lower branch arifing on the lateral parts thercof, or in default of fuch, take them clean out to whence they originate, retaining fome contiguous young fhoots to fupply the place; continuing all the hoots and branches intire, or at their whole length, at leaft, as far as there is room to extend them in their full growth, and they will thus emit fruitfpurs all along their fides, for bearing.

But likewife obferve, in winter-pruning of walltree and efpalier Cherries, that as fome forts bear alfo on the young thoots of a year old, immediately from the eyes thereof, without forning previous fpurs, as more generally occur in the fmall May and Morello Cherry Trees, and which alfo bear upon fmall fpurs on the older branches, it is advifeable, in thefe forts particularly, to retain plenty of the above-mentioned year-old hoots for bearing fruit the enfuing fummer, cutting out part of the naked, old wood in. proportion, pruned down, more or lefs, to fome eligible young thoots, or branches furnifhed therewith; or fome cut clean out, leaving contiguous hoots to fupply the place of the unferviceable, old branches, where thought nccclfary, or as circumftances may require, retaining the whole ftill at their full length, where room to extend them agreeable to the foregoing intimations.

Likewife obferve, in prosing thefe wall-trees, to preferve all the natural fruit-lipurs as are of found, good g:cwth, and only where any cafually affuine a dscayed 
decay'ed or barren Ante, cut them off cloí, alfo all naked, barren ftumps.

According as each tree is pruned, as above, let it be nailed to the wall, \&cc. in regular order, arranging the branches horizontally, all fill at their full length. three or four, to five or fix inches afunder, and nailed in ftraight, and clofe to the wall; or thofe in efpaliers have the branches tied and nailed occafionally to the rails of the trellis.

Thus far concludes the general culture of the Plum and Cherry, in ftandards, wall-trees, and efpaliers.

As to the other fpecies of the Plum and Cherry kinds, ccnfisting of the Bullace, Sloe, different forts of Bird-Cherry, \&c. they are aumitted in plantations, for vari.ty, and may be propagated by feed, the ftones of the fruit, foived in the autumn or fpring, and by layers, and fome by fuckers; or any particular forts are alfo raifed by grafting and budding, as obferved of the cultivated varieties of the Plum and Cherry.

Or alfo, to plant for variety and ornament, may introduce the common Plum and Cherry kinds, and great Wild Cherry Tree, \&c. and their refpective varieties; all raifed as above.

But thefe, and the Bullaces, Sloe or Blackthorn, great Wild Cherry, \&c. may, for common ufe in plantations, be raired abundantly from the ftones of the fruit; and the Sloe-Plum alfo, plentifully by fuckers from the root, where required to plant this kind for hedges, in fields, \&c.

Or any defirable varieties of the Bullace, Damfon, or great Wild Cherry, \&c. may be propagated by grafting or budding, to continue thefe forts in their improved Rate.

Early Plums and Cherries are obtained by having trees thereof in forcing-houfes, by the aid of which Cherries are ripened in April and beginning of May, and Plums in May and June: having, for this purpore, young trees of the moft efteemed early and other kinds, fenerally fuch as are advanced to a hearing ftate; both in dwarf trees, in fmall stanaards, and to train againft $z$ trellis, in the wall or efpalier-tree manner; and fome alfo in half and taller ftandards, efpecially Cherries, to elcvate the heads near the top glafies of the forcing-houfe; and may all be planted in autumn, abcut October or November, in the bordcrs ivithin; or alfo fome finall trees of Cherries, \&c. in pots introduced; or fometimes forcing apartments are albotted principally for Cherries, the bottom fpace being wholly of good earth, a proper depth, and the trees planted in crofs-roivs from the back to the front, in tall, half, and divarf Atandards.
Though in general forcing-houfes, fereral forts of fruit-trees are introduced in affemblage.

The forcing is commonly commenced by fire-heat, in the middle or end of January, or beginning of $\mathrm{Fc}$ bruary; or is occafionally effected by bark-bed heat; and the heat, in both methods, continued moderately till the fruit is advanced to perfection, in April, May, \&c. obferved for Peacbes and Nectarines, under the Genus Amygdalus.

\section{Apricot Kind's.}

The Apricot being confidered as a fpecies of the Prunus family, but requiring fome different management in the general culture, it is eligible to explain it under a feparate head.

This fpecies of Prunus, Apricot T'ree, differs fomewhat in its general mode of bearing from the Plum and Cherry; it, in all the varieties, produces the fruit principally upon the young wood of one year's growth, and likewife upon fmall, natural fpurs, arifing on the two and three years old branches; but generally bears the principal fupply of fruit moftly upun the young fhoots of a year old; that is, the fhoots produced one year bear fruit the year following, emitting the blofform-buds immediately from the eyes thereof along the fides; and of which young fhoots, in the operation of pruning the wall and efpalier Apricots, a general fupply of the beft-placed, of middling-ftrong growth, muft be retained every year in all parts of the trees, for fucceffional bearers, and the fuperfluous and improper thoots thereof, with part of the naked, old bearing-wood cut out in the winter-pruning, to make room for the young fapply; but where eligible fruit-fpurs appear on the two or three years wood, above-intimated, the faid branches and fpurs are proper to referve occafionally, as they alfo produce fruit in good perfection.

And as the young fnoots retained for principal bearers, as above, both produce fruit, and a fupply of young fhoots at the fame time, for next year's bearing, and which fhoots are alfo produced occafionally upon the older wood, and, in both of which, a plentiful abundance mult be referved in fummer, and trained in moltly at their full length all that feafon; but in winter-pruning, felecting a fufficiency of the well-placed froots, cutting out the fuper-abundancy and all ill-placed, with fingularly luxuriant fhoots, the remaining proper thoots fhould be then thortened moderately, both to encourage their producing collaterals more effectually, and properly fituated on the lower and middle, as well as the upper parts, to train in to felect from, for next year's bearers; as, when not fhortened in winter-pruning, the fucceffional bearingThoots are apt to advance principally on!y towards the upper parts of the mother fhoots or bearers, and which would moftly be naked below, whereby the 
lower and middle parts of the wall-trees would become unfurnithed with proper fupplies of young wood.

But as to the ftandard Apricot trees, they being planted detached, and having fuli f́cope to branch out freely every way in their natural manner, furnifhing, as they advance, both plenty of young bearing wood, in fucceflional annual fupplies, and fruitfui fpurs on the two or threc years branches, do not require any regular pruning annually, as in the wall-trees, on y need occarronal regulation, to cut ofr cafual, irsegular, and very crouded branches, and decaved wood, perriting the orher general branches to advance in their full growtin.

\section{Propagation or Metison of raifses the Trees.}

The propagation or method of raifing Apricot trees is principally by budding or iroculating buds of the different varieties, or of any dcfirable forts upon Plum ftocks, in July or beginnir.g $\mathrm{c}_{\text {i }}$ Augint, irferted into the fide of the ftoik onc bud in cach, at fix or eight inches, for cominon will-trees, and at three or four to five or fix feet height, for half and full ftaadards; and the buds remaining dormant till ncx+ fpring, when the flocks being then headed dowis a little abcve the infe:tion of the buds, thefe pufh forth each one ftrong fhoot, and forms the new tree of the refpective fort.

To proceed in the above propagation, proper fupplies of ftocks, $\mathrm{m}$ which to perform the budding, muft be raifed, and which fould be principally Plum ftocks being more hardy and durable then ftocks of their own kind, raifing them fro": fuckers or ft nes of the fruit, or both; though they are alfo budded occafionally upon thofe of Apricots raifed from the ftones; but the Plum ftock is moit advifeable for the general fupplies; and which, as above obferved, may either be young fuckers, produced from the roots of Plum Trees, taken off and planted in nurfery-rows in autumn, winter, or fpring, or by ftones of the Plims, fowed in autumn in beds of common earth, one or two inches dee $_{1}$, and when the feediing ftocks are a year old, or of one or two fummers growth, fhould be tranfplasted in auturis or fpring into the nurfery, in row, two or three feet afunder, in which to advance in growth, wie, two, or threc years; training the ftocks in $g$ al cuchi with a fingle ftem, and when talf an inch to an inch thick they are proper for budding; whisit thould be perfor med in July or beginring of Augurt, as befure inti ated; when, for the buds, take off a quartity of cuitivess of young thouts of the trees of the differcnt or refipetive varieties intended for propagation, and from thich fhosts take the buds for inocul :ion, one at a time, and inferted into the fide of the locks, which Thould previounly have the lateral shout pruned off, continuing the top entire, fo infert one bud into cach ftock, performing it low in the ftock, within about five to fix or eight inches of the bottom, for common dwarf wall-trees and for efpaliers ; and at three or four to five or fix feet for half and tall ftand ard vall-trees, to be planted occafionally between the common dwarf trees, to cover the upper parts of high walls, while the latter are advancing below, efpecially wh:ac required to have the walls completely covered as toon as pofible, to afford a more plentiful production of fruit; or like!vife fome may be budded on tall focks, as above, or budded low, and the firit moot run up for a ftem, for half and full common Itandards, to plant detached in the open ground, to branch out in full heads; particularly the Breda, Bruffels and Durmore Apricot, or any others, occa fionally.

Thus having performed the budding, the buds remaining dormant till the fpring following, and the head of the Atuck continuing, then, in the beginning of March, the ftocks hould be headed down, cutting them off hoping, three inches above the infertion of the bud, which will then foon after advance, each in a frong thoot, two or three feet in length, the fame year.

The young trees thus raifed, advancing at firft witk. one ftrong fioot, this, either the fame year, in fumnier, or the following fpring, thould be headed down to obtain lateral branches, to form the head; fo that to effect this, the above firft thoot may either be topped the fame year early in June, and will thereby furnifh feveral lateral thoots the fame feafon, or the faid firft main thoot is generally permitted to run in its full growth all fummer and continued intire till next $\mathrm{March}$, then headed down to about fix or eight inches, or to fo many eyes, and it will then foon after pufh forth four, five, or more, collaterals, to give the head its firft proper formation, training the lhoots, when of due length, in a fpreading order, to form the tree for the walls; or if any are defigned for detached ftandards, they being alfo headed do:wn as above, permit them to fhoot out freely every way to form full heads.

The young Apricot trees, as above, are proper for final tranfplanting into the garden, againtt walls, \&c. or occafionaily for detached fandards, when they are from one, two, or three, to four ur five years old, either of but one fummer's growth, with the firt hoot from the budding intire, and planted in the autumn or fpring following, and the faid firft hoot to be headed dow $n$ in March, as above advifed, to force out a fupply of lower lateral thoots; or the trees remain in the nurfery, for heading down, and trained therein for two or three years, or more, or till advanced in fome iolerable fpread of branches and arrived to a bearing ftate, then planted in the places where they are to continuc.

Or trecs for planting, of a proper growtir, as above, may be had at the public nurferies, in the different vat rieties, 
rieties, either young, of one or two years old, or that are more advanced, which the nurfery-men call trained trees, being ready trained with fome confiderable expanfion of branches to commence immediate bearers the firtt year they are planted.

The planting of Apricot trees may be performed either in autumn, in October, or beginning of November, to frike frefh root the fame feaforn; or miay be done any time in open wcather, from Odober till February or March.

In planting the different varieties, allot fome bet fouth walls, for the principal forts, others on weft and caft walls; having proper borders of good earth along the walls of the different afpects, three, four, or five, to eight or ten feet broad, and of two fpades, or at leaft one full fpade deep of fertile foil; and if the borders are naturally of good, rich garden mold, or of a loamy kind, it will be of particular advantage, and no more will be required than to dig or trench the ground, or only, for the prefent, to dig an aperture for each tree; but if the foil is bad, unfavourable, or of a very poor, light, unfubstantial nature, it thould be improved with fome ftrong, rich earth and rotten dung; or would be much benefited if augmented with a quantity of freth furface loam from a common or palture-ground; removing part of the bad or wort foil of the borders, in proportion to the quantity of frefh earth added; and which improvements may either be applied to the whole border, if thought eligible, or only to the places where the trees are to Itand, and the other parts enriched afterwards by degrees, in the two or threc following years, in winter or furing: however, it is proper alfo to intimate that thefe trees will profper in any common fertile ground of a garden, without any prefent additional improrement.

For planting the wall-trees, mark out places at twelve or fffteen to eigliteen feet afunder; obferving, if low walls, it is generally advifeable to allot a greater diftance than in thofe of more conkiderable height, that in default of good fcope of walling above, there may be fufficient room to extend the branches horizontally, and if any are defigned for efpaliers, they thould alfo be allowed the above-mentioned' diftances; and for both of which, have the trees digged up with all pofible good roots; prune any broken parts thereof, and horten any very long ftragglers floping on the under fide; and of the head, prt ne only, at prefent, any irregular projecting fore-riglit hoots; or if young year-old trees, leave the whole head intirc till Maich, or if planted in that month, may be headed foon after: dig a wide hole for each tree, in which place the roots in a fpreading manner, with the ftem thereof three or four inches from the wall, and the head inclining thereto; fill in the earth equally about the roots and fibres, fhaking the tree gently to make the ear:h fettie in clofe, and then tread it moderately to the roots; and if planted early in autumn, about Oetober, or late in the frring, and the ground is dry, give a moderate watering to the earth to moiften and fettle it clofe about the roots more effectually, and will alfo prove beneficial in afitting their rooting.

If ligh walls, and if defirous of having all parts covered as foon as pofible, you may plant ftandard wall-trees in the ipaces between the common divarf trees, either half Itandaris, with ftems of thrce or four fect, or with five or fix feet ftems, for more lofty walls; and thus have all parts of the wall expeditiounly covered; the common dwarf trees furnifhing the lower and middle, and the half ftandards, \&c. occupy the upper parts, while the others are advancing below; and as the common wall-trees are to be confidered as the principal refidentiaries for continuing, that according as they advance in a large expanfion upivard, the branches of the ftandards may be pruned away by degrees, or the trees tranfplanted elfewhere, to give proper fcope to extend the others in full growth to cover the wall regularly from the bottom to the top, in 2 continued expanfion of branches.

The trees planted, if they are young, having only the firt main bud-rhoot of a year old, this fhould be headed or cut down in March, to five or fix eyes, to promote a fupply of lower lateral fhoots the fame year to form the head, nailing them to the wall, Sxc. at their whole length, all fummer; and in winter-pruning, or towards the following fpring, cut or fhorten each fnoot about one half or third, according to their ftrength, to obtain a further fupply of well-placed collaterals to encreafe the head in a larger expanfion of branches; and then managed afterwards in the feveral methods of pruning and training hereafter explained; and when three or four years old, will begin to produce fome fruit.

But if trained trees are intended for planting, having been previoufly headed down in the firt thoot, in the nurfery, and, in confequence thereof, are furrifhed with a head of feveral branches, two or three to four or five years growth, thefe branches, \&c. are to be principally retained, or only prune any fore-right or other illplaced thoots not well fituated for training regularly to the wall, cutting them out clofe, and the remaining regular hoots be fhortened about one third of theirlength ; and then the general branches and fhoots nailed to the wall horizontally in a regular cxpanfion, four or five inches afunder, they will probably produce fome fruit the firft year, but in greater abundance and perfection the fecond, if a favourable feafon; and will increafe in the production annually, in proportion as they accuire a larger expanfion of branches and advance in age; and generally iil Apricot trees of fume confiderable growih, they bear more abundantly and the frui: richer fla- 
roured, and will continue fruitful a great number of years, in good perfection, with proper management in regard to pruning and training, as in the following direetions for their general culture.

For ftandard Apricots, may plant fome balf and full ftandards, detached from walls, in the open ground, in a warm, fheltered fituation, in the full fun, where they may be defended, as much as ponible, from the northerly quarter, in the fpring, when in bloffon, and fetting their fruit, and in which, they, in favourable feafons, will often produce plentiful crops, ripening in very good perfection.

\section{Their general Cuiture of Pruning and Nailing.}

As to the culture of the wall Apricot Trees, and fuch as are trained in efpaliers, it confints of a fummer and winter-pruning every year; and in both of which feafons of pruning, as thofe trees bear chiefly on the young wood, a general fupply of the young firoots of each year nutt be retained for principal bearers, and the fuperfuous and improper fhoots cut out; and according to the fupply of young, retained fnoots, a proportionable part of the ufelefs old wood cut out, to make room for the young.

The fummer-pruning confilts of a general regulation among the young hoots of the year only, to difplace the fore-right with other ill-placed and improper growths, and to retain a plentiful fupply of the weilplaced and proper moots, for requifite fupplies of wood, in vacancies, and for fucceftional bearers, the following year; and thould generally commence the bufinefs in May or June; and if proceeded in early, while the fhoot-buds, or advancing fhoots, are only about two or three, to four or five inches long, before they become very woody, the irregular and ufelefs productions may noflly be rubbed of, or difplaced expeditioufly with the finger and thumb; though, in the more advanced thate of the Thoots, and in the general fummer-drefling, mult always ufe the pruningknife; and by both of which methods, fhould now take off clofe all the fore-right thoots as arife immediately from the front part of the mother branches, in a projecting direction, and with others as arc illplaced, or not well fituated for training in regularly to the wail, together with fuch as are evidently improper, unreceftary, or fuperfluous, leaving an abunciant fupply of the proper, well-placed fide-fhoots, and with a terminal or leading fhoot to each branch; and in the further advanced growth of the moots in June and July, it is neceffary to prunc out, in a thinning manner, part of the confiderably fupcrfluous, or pver-abundant fhocts, and generally to cut away fuch as affect a very luxuriant, rank growth; and ail the retained, proper floots, fiould be moflly continued at their full length all fummer, as far as there is room to extend them, and all nailed, or faftened in clofe and regular to the wall, during that feafon, to remain till winter-pruning, ready to chafe from, in fufficient ylentty, for next year's bearers.

In this bufiness of fummer-pruning the wall Articots, it is always advifeable to commence the operation early in fummer, before the fhoots are very confiderably advanced, to affume a confufed, diforderly ftate; as when this work is performed while the fhoots are of but a moderately advanced growth, the neceffary regulation of pruning out the ufelefs, and retaining the ufeful fupplies, can be effected, both with much greater accuracy and expedition, and prove of particular greater advantage to the trees, and the prefent production of the advancing young fruit, wherelyy to obtain it in all polible perfection of maturity, in fizc, beauty, and flavour.

Therefore generally proceed in the firft regulation of fummer-pruning in the early growth of the floots, when from about three or four, to fix or eight inches, to a foot long, at mot?; or, as before obferved, may commenice the operation when the thoot-buds are advanced only two or three inches, which will be of fingular advantage juft to run over the trees, and difbud, or rub off the advancing fore-right buds and fhoots, and fuch others, in young growth, as a re improper, or ill-placed, for training to the wall, taking them of clofe ta whence they originate.

Then with regard to the general operation of fummer-pruning, that either after performing the early or firt pruning, or dißudding the evidently nfelefs productions, as above, in May or beginning of June, while in young growth; or if that bufinefs was omitted, fhould begin this principal regulation in the more advanced growth of the flioots, in the beginning or middle of June, at farthert, before the trees have thot into confiderable diforder, in which they both appear very unfightly, require confiderably more time and particular attcrition, as well as often occafion much perplexity in the confufed thicket of young wood, to perform the neceflary regulation in difplacing the ufelefs, and felecting the recguifite fupply of proper fhoots, and proves greatly detrimental to the advancing fruit.

Thus proceeding to this bufinefs in proper time, cut out clofe all remaining fore-right thoots, and others that are ill-placed, and carefully felecting a plentiful fupply of the beft regular-placed fide-fhoots, and a lcading one to each mother branch; all which to be retained for training in, to chufe from, for luccefional bearers, next fummer; leaving allo prop:s. fupplies in vacant fpaces, and below, to have adl part: 
of the trees tegularly furnished with bearing wood; the whole of the retained froors continued at their full length, at this feafon; and as generally a fuper-abundancy of fhoots are produced, or more than is wanted, or can be trained in with proper regularity, muft prune out the fuperfluous, cutting away the worlt hoots in a thinning order, retaining grcat plenty of the wellflaced, moderately-ftrong ones; cut out all fmail, weak twigs, both on the old wood, and fuch as arife on the felect referved thoots of the ycar; and, of the proper hoots, if two advance from the fame eye, or near together, leave but one, the moft promining, and cut the other cf: clofe; likewife prune off clofe all fuch as cafually affume a bad growth, as buriched, crooked, \&c. and fucil as are fingulaly luxuriant; and in this manner, cutting out tne evidently fuperfluous, and improper, retain a requifite abundance of the bett fhoots, for training in, to chute from in winter-pruaing, both for nextyear's bearers, and a further encreafe of principal branclies, where required, generally retaining doubly more, at least, than what may apparently be wanted, that you may have plenty from which to make a proper clioice in the winter-segulation, before obferved.

As you proceed in this regulation, let all the retained proper hoots be continued at their whole length, and let thofe of each tree, as you advance in the pruning out the improper young wood, be nailed or faftened in clofe and regular to the wall; not thortened during the fummer, except, occafionaily, where any extend confiderably beyond their limited bounds, at fides or above, which may be difcretionally fhortened, as it may feem expedient; but except on thefe confiderations, preferve the whole entire, as fnortening would force out many lateral twigs the fame feafon, hurtful to the principal hocts, and croud the trees with a thicket of ufelefs wood.

In the above fummor-regulation of thefe trees, if any have produced very mmpant, or remarkably luxuriant fhoots, of confidembiy more rank and vigorous ftrength than moft of the other fhoots of the fame tree, they fhould be moitly either cut out clofe to their origin, as not being adapted for bearing wood, and wouid draw the proper nourifhment away from the other adjacent or neighbouring thoots of moverate growth, proper for the production of fruit the jear enfuing; or where any luxtriant hoots advance in or near fome vacancy, or where future fupplies of wood wili be apparently wanted, one or more might be occafionally retained, and pruned down early in fummer, to a few eyes, to promote feveral collaterals the fame feafon, which, by dividing the exhuberancy of fap, may feparately prove of more moderate growth, proper to fupply the vacant fpace.

\section{VEGETABLE SYSTEM}

But where any trees affume a general luxuriancy of ftrong rank wood, of an unfruitful ftate, it is proper, in this care, to cut out fome of the moft rankly-vigorous, and retain as many of the beft-placed, lefs luxuriant firoots thereof, as can be commodioufly trained in with fome degree of regularity, in order to divide and carry off the redundancy of nourifhment amongft a confiderable expanfion, which, in a fmaller quantity, would break out in greater luxuriancy, in proportion; but being expended in a more confiderable number of branches, will be more effectually moderated by degrees, and the trees will gradually be reduced to a moderate growth, and commence a proper bearing ftate; and thus, in luxuriant trees, obferving the above method in the fummer-regulation, train in all the referved moots, clofe and regular, at their whole length, and laid as much horizontally as pofible, the more effectually to check the luxuriance.

Or, in fummer-pruning, if any of thefe wall-trees are of an infirm ttate, thooting weakly, and do not produce fruit in good perfection, prune out the illpiaced fhoots, and ali very fmall, weakly twigs; and felect, for training, principally only the ftrongeft, we1! placed fhoots, of beft growth, and train them regularly to the wall; and by thus continuing only. thie nott promifing ftrongeft thoots, the trees will gradually encreafe in furength, and improve in bearing accordingly.

Obferve, in the fummer-pruning any young Apricot Trees, of one, two, or three years growth, yet under training, be careful to difplace the fore-right, , and other ill-placed thoots, and fuch as appear confiderably over-abundant, together with any of very luxuriant growth, and leave as many of the regular, well-placed hoots as pofinble, that are properly fituated for training to the wall, to furnith an additional expanfion of branches, arranged horizontally in a regular manner, at thieir full length; or in any confiderable vacant parts, one or more fhoots, in or near the vacancy, may be pinched or pruned down, the beginning or middle of June, to a few eyes, in order to have them produce collaterals tive fame year, to fill the vacant fpace more effectually, as foon as poffibie.

And in the fummer-pruning of the wall Apricots in general, if any vacancies occur, be careful always to retain a proper fupply of young wood, in or as near the vacant parts as poffble; and likewife, if any vacant fpaces appear to require a larger fupply of wood than is at prefent produced, fome convenient thoots of the year, contiguounly fituated, may be pruned down early in June, to four, five, or fix eyes or buds, in order to force out and obtain an additional fupply of lateral young wood the fame year, in June and 
and July, from the remaining lower eyes of the fhortened firoots, whereby to furnifn the vacancy expeditioufly the fame feafon, with proper fupplies of young wood, or fome that will probably produce fruit the enfuing fummer.

After performing the general fummer-regulation in pruning out the improper, and training in the requifite fupply of proper thoots of the year, in regular order, it is neceffary to continue your attention in the further advancing fummer's growth of the trees and referved hoots, in order to preferve the proper regularity, by going over the trees once a week, or fortnight, as you fhall fee occafion, hoth to diveft them coniantly of all ufelefs or unnecefiary after-productions, particularly fuch as advance in a projecting direction, or any very irregular or diforderly growth; as likewife to regulate or adjuft auy diforderly growth in the retained fupply of the general, feleet hoots, that, according as they cncreafe in length, continue them ftill intire, and trained along clofe to the wall, in their full extenfion; and where any cafually detach, or project from the wall, train them in clofe and regular; and by thus preferving the requifite uniformity of thefe wall-trees, they not only appear beatifilly agreeable to the fight, but, by being continued cloiely trained in proper regularity, admits the effential benents of the full air, fun, rains, \&c. neceffary both to improve the growth and goodnefs of the fruit, the principal object; and alfo to promote a proper degree of maturity, in the young wood, for fuccelional bearing.

Thus, agreeable to the foregoing intimations, the practical bufinefs of the general fummer-regulation in the fhoots of the year of the wall Apricot Trees is conducted, and which thould be carefully performed every fummer, in May, June, July, \&c. being effentially neceffary, both for the profpcrity and beauty of the trees, when continued in the molt regular order during their fummer's growth, and that the fruit may thereby have every poffible advantagc to attain the utmolt perfection.

But before we conclude the fummer management of the trees, it will be proper to give fome niceffary intimations refpecting the fruit in its difierent ftages of growth.

Firft, that as fomctimes the Apricot, likc the Peach and Nectarine 'Ijecs, in favuriable feafons, fet fuperabundint productions of fruit, often in clutters, or clefe together, that they would neither have roons to grow profpcroufly, nor the trees be capable of bringing the whole to good perfeccion; and in which cafe of fuper-abundancy, the fruit thould be this red in its young growth, when not exceeding the fize of ordinary grcen goofcberries, or nuts, \&c. principally in May and early part of June; and at which time the fruit that is thinned off will be excrllent for tirtwhile green and young, before they begin to llone h.rd in the heart.

Therefore, in May and early part of June, at fa:thet, fhould proceed in the thinning, by degrees, when look carcfully over the general branches, and where the fruit is crouded, thin off the moft irregular, leaving proper fupplies of the beft, well-placed, at fomewhat regular diftances, three, to four or five inches afunder, according to the ftrength of the different trees, and that of the refpective bearing fhoots; in which thould generally leave the fruit thinner on trees of a weakly ftate than thofe of middling or ftronger, free growth; the felect, retained fruit will thus have room to advance freely in full growth, in their proper mape, fize, and colour, and ripen in good pcrlection and richnefs of flavour; but if permitted to remain croudedly-thick, the fruit would both affume an impoverifhed groivth, and in their advancing fiate, would, for ivant of room, thruft one another off, and not one in ten would attain good maturity; and befides, in their great fuper-abundancy, they would draw the whole nourifhmen;, and prevent the trees making proper fhoots for fucceffional bearers, \&c. and prove detrimental to their growth for two or three years to come; therefore thould not be omitted to give a proper thin. ning, when required, both for the advantage of the trees and profperity of the eligible crops of fruit; or even where not a general fuper-abundance, only here and there in clufters, they thould be thinned in thofe parts; and in all of which, ccmmence the thinning in proper time, while the fruit is young, from the end of April, or beginning of May, till June, as before obferved.

In the above occafional thinning the fuperabundant young Apricot fruit, thefe taken off are valuable to ufe for tarts, being of a fine, acid relith, and for which are in nuch eftimation as une of the firt' principal green fruit of the feafon, for tarts and pies; and may be thinned off, by degrees, for that occalion, in May, \&cc. both in wall-trecs, cfpaliers. and ftandards.

With rcgard to thic further care of the regular crop of fruit in its advancing ftate, give proper altention to continue the trees divclted of all ufelefs after-hoots, and to keep the others trained in clofe and regular, to admit the eflential benefit of the fun, air, rains, \&c. all moft necefiary to forward the growth and improve the gondnets of the fruit, to attain the utmolt perfection of naturity; obferving, likewife, when arrived to full growth toivards a ripening ftatc, in July and Augult, to continuc all the hoots clofe trained, to give free accels to the bencticial intluence of the fuil, to promote a proper flavour in its peculiar degree.

$$
\mathrm{X}=\text { Accord. }
$$


Accorting as the Apricots ripen in July and Augurt, they thou 1 be githered while in gond flavour, before they liccolne too foft and meally; thefe fruit bcing always $j, 1$ boft periection for ripeneis while they remain mosicratcly firm, and of a poignant relifh ; and gencrally, when in full ripenefs, if gathered in the early part of the day, before mlicil heated by the fun, it will be preferved in better flavour for eating.

As fometimes thefe trees are attacked, in fummer, with blights and infects, mould endeavour, as much as poftible, where it occurs, to ftop their pernicious effects, being difcoverable generally by the leaves crumpling, and the ends of the hoots becoming hunched and clanmy, either generally, or appearing firtt in particular parts of the tree, and will foon fpread confiderably, greatly detrimental to the progrefs of growth both of the trees and fruit; or are fometimes fuddenly attacked with a diry blight or blaft, of ten defructive without renedy; but where, in either of which maladies, the diforder comes on more gradually, or occafioncd by numerous minute infe?s, fome means may be ufed to ftop the depredation, by puiling off the mol inficted leaves, and cutting away the diftempcred parts of the young thoots, \&ce uing aifo the other affifant remedies advifed for the Peaches and Nectarincs, which are cafually attacked with the fame malady.

We now proceed to explain the operation of winterpruning thefe wall-trees, which is neceffary every year, any tine after the fall of the leaves in November, till March.

* The winter-pruning of the wall Aprico: Trees comprehends a general regulation in the young and old wood, both in the fupply of young thoots which were produced and trained in laft fummer, and mofty in the whole expanfion of older branches, as obferved for the Peaclies and Néctarines, Scc. in pruning out the moft irregular, improper, and fuper-abundant, to make proper room for training in a general fupply of fucceffional young bcaring wood, confiting of the laft fummer's fhoots, to produce the firuit the year enfuing; and the whole to be new-trained, or nailed to the wall, in a regular manner, four or five inches afunder.

Obferve, in performing this operation of winterfruning, to keep in mind, that as there trees, as in the Peach and Nectarine, produce the fruit principally upon the young wood or fhoots of laft furimcr, and often on fmall, natural fpurs arifing on the two years wood, though generally the principal producion of fruit is obtained on the laft year's fhoots, as formerly intimated, the bloffom:-buds arifing immediately from the eyes of the faid hoots, and feldom bear but once in the fame order, only on cafual, fmall fpurs, aforefaid, fometimes emitted from the fides in the fecond and third year, that a general fuccerional fupply of the beft young thoots of the preceding fummer, muft be annually preferved in all parts of the trees, in the winter-pruning, for bearing the principal crops of fruit the year following; and, likewife, to retain occafional fpurs, before-mentioned, which, furnifned with blofom-buds, alfo produce fruit in equal perfection; obferving, at the fame time, in this regulation, mult cut out the fuper-abundant, ill-placed and improper thoots, with part of the former bearers, and naked, or worn-out, old branches, not furnithed with bearing wood, to give room for retaining the requifite fupply of young bearers, four or five inches afunder, as before obferved; and all the retained hoots, or greater part, to be now fhortened about one third, more or lefs, according to their ftrength, to promote a production of thoots from the lower eyes thereof, next fummer, for Ixcceflional bearers the year aftcr, which, otherivife, would arife moftly towards the upper parts, that the trees vould thereby become naked bclow, or not well furnithed with proper fupplies of bearing wood, equally from the bottom upivards.

The feafon to commence the winter-pruning is foon after the fall of the leaves, or any time in mild or moderate wcather, from November till the fpring, and Thould be wholly compleated in February, or beginning of March, before the blorlom-buds are confiderably advanced.

Generally, in proceeding to this bufinefs of winterpruning there trees, that as it comprifes a regulation in the general expanfion, it is proper firft to unnail all the young thoots of laft fummer, and great part of the fmaller mother branches, in order botl to give proper fcope in ufing the pruning-knife, in cutting out the fuper-abundant and unferviceable wood, and to have an opportunity of training the proper branches and thoots with eligible regularity, according to the regulation made in the general pruning.

And being furnifhed with proper pruning-knives, a fnaller and larger, as explained for the Peaches and Nectarines, as alfo with proper threds and nails, proceed to the bufinefs of pruning and nailing the trees, agreeable to the following intimations.

In proceeding to the operation, give great attention to the fupply of young wood of laft fummer; and of which, to niake a proper felection of the beft in all parts of the trees, for training in three, four, or five inches afunder, as before intimated, for fuccerfional bearers next year, and fome for new wood occafionally, to increafc the number and expanfion of principal branches, where neceffary, chufing the moft regular-placed, middling-1trong thoots, fituated principally on the upper and under fides of the mother branches, and occafionally the leading or terminal 
Thoots in particular parts, whicre it may feem eligible, though every branch fhould terminate in a fingle fhoot, either, in fome, placed naturally at the end, or in other's, the branch hortened down to a proper fhoot, for a leader.

That in the general regulation obferve, in felecting the principal fupply of proper thoots, it is advifeable to prefer the moderately hort-jointed, that appear the beft furnihed with bloffom-buds, being round, plump, and fwelling; and from which, prune out clofe the fuperfluous or over-abundant, with any remaining fore-right and other ill-placed fhoots, not well fituated for training to the wall with proper regularity; cutting away alfo weak twigs, watery, unripened, autumnal fhnots, and fingularly rank luxuriants, taking them off. clofe to the old wood; likewife, if any of the retzined proper hoots, have fmall, lateral twigs, prune them off clofe, that the faid principal thoots may be clean and fingle; and to make room for the requifite fupply of young wood, a proportionable part of the former bearers, and naked, old branches, hould, in this pruning, be retrenched, either by hortening fome down, more or lefs, to proper young hoots, or fome cut clean out, fuch as are the leaft productive of eligible, bearing wood; obferving, in the procefs of pruning, to fhorten mott of the retained fhoots about. one third, or as hereafter explained.

And generally obferve, that where any fmall, natural fpurs, half an inch to an inch, or more, long, occur on the continuing two or thrce years old mother branches, and appear furnifhed with blofom-buds, they thould be carefully retained, as they often bear abundantly in as good perfeetion as the principal bearing fnoots; but cut out clofe, any long, projecting, and naked, barren fpurs, old ftumps, and all decayed wood.

But, to explain the above pruning as fully as poffible, it is neceffary to obferve, that as great part of the feleet or proper hoots, now requifite to retain, are produced chicfly upon the fmaller branches, or two or three years old wood, or principally upon the laft year's bearers, arifing on the lower and upper parts, and fome terminal or proceeding immediately from or near the extremity; and thercfore, in order to make room for the necenfary fupply of the young moots, a confiderable part of the faid mother branches mould be cut away, in proportion, either by hortening or cutting down, more or lefs, in particular parts, to fome principal floots, fituated on the refpective branches; or others of the worf, old bearers, cut away, as circumftances may require, whercby to liave fufficient fcope for training the requifite fupply of young bearing wood, cqually in all parts of the trees, for general bearers, the enfuing feafon.
Therefore, agreeable to the foregoing intimation, making clooice of the proper fhoots, and where fituated on the lower or middle part, \&c. of the former year's bearers, may thorten or cut down the upper parts thereof to the firft, fecond, or other moft eligible thoot thereon, which then commences the leading fhoot to the refpective branch; or if only the uppermoft fhoot feems neceffary to retain, cut away any others below it; or if two are neceffary to leave on the parent branch, retain one below and the other above; fo, in this manner, leaving on fome branches but one, and on others, two moots, or more, in particular wide fpaces, or as it thall feem expedient, according to what appears requifite to furnifh the refpcotive parts of the tree.

For example, that where two fhoots, or more, appear neceffary to retain on any mother branches, or former bearers, to fupply the particular parts, leave one of the beft above, either the terminal or end thoot, if a proper one is thus fituated; or if not, cut down the upperpart of the branch to the firft, good lateral fhoot, and leave the others below, at a proper diftance, and cut away any other intervening fhoots on the fame branch, if not wanted; or, in fome cafes, it may be proper to retain only the end or terminal fhoot, either placed naturally at the end, or where this would extend the branch too confiderably, the branch may be cut down to fome lateral noot, if any thereon, that would not extend beyond the limited fpace; or, in fome places, it may probably be neceflary to retain both a naturally terminal hoot, or one fituated near the termination of the parent branch, or o!d bearer, and a lateral one towards the middle or lower patts, cutting awad. any other intervening ones; and fometimes, where long-extcnded branches occur, or fuch as, in particular places, extend beyond certain limits, where not proper room, it may be requifite, occafionally, to cut down the extended part of the branches to fome beft lateral, or lower floot, that will not extend beyond the limits intended.

Though, as good thoots alfo often occur on the larger, old, principal branches, frequently on the lower parts, where the faid branches do not admit or require being cut away, and that where proper young fhoots are well-placed thercon, in parts of the tree in which they may appear neceffary, either to fupply a vacancy, for fuccefion bearers, or new wood for an encreafe of young branches, they thould be retained in all parts where thcy can be admitted or trained in with regularity, between the faid branches, to have all parts of the trees furnifned vith young wood, advancing in the bottom, middle, and uppir expanfion, in a rcgular progrcflion. 
But obferve likewife in this pruning, that where cafual, long-extended, old naked branches occur, not furnithed with proper young wood, adapted either for immediate beascrs, or for fursining fuch hereafter; or that any old, naked branches are fuper-abundant, or very irregular, of of a bad habit of growth, this is now the proper time to make the neceffary regulation, by cutting out fuch unferviceable old wood, either fome to their origin, if it feems expedient, and there is contiguous young wced to fupply their places, where required; or otherwife, pruned down, more or lefs, either to fome good, ftrong lateral hoots, that are eligibly fituated thereon, or to any convenient, younger motiler branch, or former bearer, proceeding from the lower parts of the old, and is furmifhed with one, or more, proper thoots, for bearing; and hereby Jave young wood in conflant fupplies, in all parts of the trees, advancing, in regular order, quite from the bottom and middle, to the extremities at top and fides.

It is material, in performing this pruning, generally to leave, or contrive, in cutting, to have a good young thoot to terminate the extreme part of the general branches, one to each, either fuch as is naturally fituated at or near the extremity, or when none of eligible growth is thus naturally placed, and that, when occafion to cut away fome unferviceable or extended parts of the branches, they thould be pruned down to a proper fhoot, to become a terminal or leader to the branch, not, where it can be avoided, to thorten any branch fo as to terminate in a naked ftump in the old wood, but generally to have a terminal fhoot, as above, leaving principally but one, as a leader to each branch; for a leading or terminal thoot is effentially neceffary, both in being conformable to the ways of nature, and to the good appearance and regular growth of the trees, as well as being of much advantage in dratving proper nourifhment to the fruit in its advancing growth.

Obferve further, in this generai pruning, that, in cutting out the fuper-abundant and imp-oper floots, and retaining the proper fupply, and that when neceffary to leave two or more hoots on particular parent branches, or former bearers, it is advifeable, where convenient, to have them on oppofite fides, in alternate order, at fome eligitle diftance, one above the other; though, as this niay not always be practicable, and that fometimes the coots proper to retain, will happen both, or all on one fide, in which it is not very material, only by being on different fides of the branch, as above, they generally admit of being trained with greater regularity to the wall, conformable to the requifite, regular difplay of the general expanfion.

As you proceed in the general regulation, agreeable to the fol e roing obfervations, in cutting out the unneceflary and improper wood, and retaining the necef- fary fupplies of the beft young fhoots of lat fummer, it is proper now, in the winter-pruning, as before obferved, to fhorten moft of the faid moots moderately, that by cutting off the weak, infirm, top part, they riay more effectually furnifh fupplies of young wood the enfuing year, properly fituated for fuccellion bearers the year after, as formerly explained, generally performing the fhortening as you advance in the general pruning, cutting the middling thoots about one third, the ftronger ones nearly the fame, in proportion to their length; and the moderate or fmall thoots may occafionally be cut a little more than thofe of Atronger growth; and generally obferve, that in ftrong-fhooting trees it is proper to leave the thoots longer than thofe of a more moderate or weakly fate, or generally cut below the weak, fappy, upper part, or autumnal production.

But in the general thortening it muft be reniarked, that where you prune principally for fruit, be careful, in thortening, not to cut below all the bloffom-buds, where they appear, or are expected to advance, difcoverable, by their round, turgid, or fwelling appearance; the wood-buds being oblong and thin; and hould generally perform the hortening with a floping-cut upward, just behind, and a little above a hoot-bud, to furnith a terminal thoot, for a leader, next fummer, to draw the nourifhment to the fruit more effectually in its advancing growth.

Or, in fhortening in particular trees, where neceffary to prune fonie hoots principally to furnifh wood to fupply vacant parts, they may be cut thorter than advifed above in the general hoots, which are defigned for bearers; and, on which occafion, fome may be cut to one half, or from five or fix, to eight, ten, or twelve inches, according to their ftrength, cutting the fmaller or moderate thoots fhorter, in proportion, than the ftronger ones, in the particular parts of the tree, where it may feem neceffary, whereby to have them more effectually produce the defired fupply of lateral fhoots the enfuing fummer, to furnith the vacancies; or fometimes fmall hoots on the lower parts of the old branches, where additional fupplies of new wood may appear requifite, may be cut to two, three, or four eyes, that they may furnith two or more thoots of ftronger growth, to train in between the mother branches, either to ferve prefent occafions, or as a referve to be ready to fupply the places of cafual, decayed, or any worn-out, or old, unferviceable ivood hereafter; and thus may always have young branclies advancing between the old ready, quite from the bottom, middle, \&c. both for prefent bearers, and to furnith others in proper fuccefion in ail parts of the trees, advancing in regular gradation.

It muft likewife be obferved in the winter-pruning, that where any trees are of confiderable, luxuriant growth, having generally ftrong, vigorous fhoots, running 
running greatly to rank wood, and not producing any tolerable crops of fruit, the fhoots fhould be left clofer, or in greater abundance, and thould mottly be, but very moderately fhortened, or fome of the moit luxuriant not hortened at all; or others, lefs vigorous, cut only about une fourth, or lefs, or fome only juit topped, or the fmall, upper part pruned only a few inches; and thus, in general, cut the retained fhoots very little, or the ftrongeft left moitly intire; as, in fuch vigorous trees, if much thortened, they would thoot with greater luxuriance to rank wood, and not become fruitful; but, in which, leaving the felect fhoots more abundant than in moderate fhooting trees, and thefe but little fhortened, agreeable to the above intimations, the redundant nourifhment will thereby be more divided and expended amongft a greater expanfion and extent of branches than in a fmaller number and lefs extenfion of wood; and nailing all the fhoots as much horizontally as poffible, which alfo contributes, in fome degree, in checking the luxuriancy, the trees, by thefe means, will be rcduced, by degrees, to a moderate ftate, productive of fruitful fhoots adapted for general bearing.

Likewife, in this pruning, if any trees as are generally of moderate growth, have produced cafual, very,rank thoots, confiderably more vigorous than the generality of the others of the fame tree, they fhould moftly be cut out clofe, that they may not exhauft, or draw the nourifhment too much from the adjacent, moderate fhoots; except any are produced in or near fome vacant fpace, or upon the lower parts of old branches, where a future fupply of young wood will be apparently wanted, fome may be retained fingly, and pruned down, more or lefs, to furnith feveral collaterals next fummer, which, feparately, may prove of a more moderate, kindly fate.

Though, where any tree of a generally ftrong growth, inclines rather to commence a vigorous habit of thooting, and that fome fhoots occur that are confiderably more luxuriant than the reft, one or more might be retained in different parts, to carry off part of the exhuberancy of fap from the others, to prevent, as much as poffible, too great luxuriancy taking place in the general expanfion; and, likewife, to afilt further in preventing the production of rank wood, it is advifeable, in retaining the requifite fupply of proper fhoots, to leave thcm clofer, or more abundant than in trees of moderate growth, and the fhoots in general but moderately fhortened, and thefe trained down as much horizontally, as room admits, in which they generaliy thoot lefs vigorous than in a more upriglit pofition.

Or, in winter-pruning fuch trces as affume a weakly ftate, either fhooting reluctantly, or producing inoßly fmall, wcak thoots, it is eligible to cut out suoft of the fmaller, infirm twigs, and rctain princi- pally only the ftrongeft thoots for the general fupply; and that to promote their furnifining a production of ftronger wood, they fhould be fhortened more than in trees of a free growth; or fome, in the moft vacant perte, may be cut to one half, or others, a little more or lefs, according to their ftrength and refpective fituations, or as fupplies of future wood may be required in particular parts of the trees; giving proper attention to keep the lower and middle parts fupplied as well as poffib'e; where, in vacancies, or where room to train between the mother branches, cut particular thoots to a fiw eyes, to obtain fome collaterals of ftronger growth, next fummer.

In the general winter-pruning, it being moftly advifed, in cutting out the fuper-abundant thoots, to prune them clofe to the old wood, yet, in fome cafes, it may be proper, in particular parts below, and the middle, \&c. in fuch as are produced on the fides of the larger, parent branchies, or in places where future fupplies of young wood may be the moft apparently wanted, fome of the fmaller thoots, thus placed in different parts, lower and higher, \&c. may be pruned to one, two, or three eyes, to furnifh one or more laterals next fummer, in cafe they hould be wanted, and trained up between the principal branches, till winter-pruning; and if not then required, may be cut away, or fome retained as a referve, ready to fupply any unforefeen vacancy; and by this means may have all parts of the trees always furnifhed with young wood, both for prefent bearing and future emergencies.

For in thefe wall-trees, as obferved of the Peaches and Nectarines, thould give good attention always to have a general fupply of young wood in all parts of the trees, quite from the bottom and middle, to the upper expanfion, advancing in regular gradation, as it. were, one under or after another, at proper, moderate diftances; and always keep the lower and vacant parts well furnithed with requifite fupplies of proper thoots, by the means explained in the general prunings; and thus the trees, even when advanced to a grcat age, may be continued every. where abundantly fruitful.

And it may be obferved of old Apricot wall-trees, when well managed, as abovc, they are particularly valuable, in being generally morc prolific than younger. and the fruit attains greater perfestion in richnefs of flavour, and therefore Mould give particular attention to encourage their growth, by preferving proper fupplies of young wood; and as dccayed, or worn-out, old branches ozcur, having young ready to fupply their place, fhould be cut out, now, in the winterpruning, either to the origin, or to fome lowcr, fruitful branch, or good thoot eligibly fituated; and th:us keep all parts well furnimed with bearing wood, by 
methods explained in the foregoing general directions, both in the winter and fummer-prunings; continuing the ge::eral branches extended in a fuli expanfion, as far as their allotted bounds admit, and they will remain abundantly fruitful, in a fuperior degree of perfection, to $a$ confiderable old age.

Young Apricot wall-trees, that are ftill in training, requiring additional fupplies of principal branclies to form the requifte expanfion, fhould, now, in the winter-pruning, be carefully managed, to retain the wellplaced fnocts where required, and to prune out the improper, giving good attention to prefcrve a proper fupply of the beft fide and terminal fhoots, both in the lower and advanced parts, where an encreafe of branches is wanted, both to multiply the expanfion, and to extend the o:hers in length, as well as for bearing wood; keeping the middle well fupplied, and both fides as equal as pofinble, both in the number, ftrength, and length of the branches and thoots; and from which cut out the irregular and fuperfluous, if any, with illgrowing fore-right and other ill-placed thoots; and if any fingularly ftrong luxuriants occur, which appascntly, by their vigorous growth, would draw the nourinment from the reft, they thould be cut out clofe, efpecially where on one fide of the tree and not on the other, that both fides and all parts may advance equally in ftrength; or if any are in a vacant bottom or middle parts, it may be occafionally retained and pruned down, to furnifh two, three, or more laterals to fupply the vacancies.

Thus far concludes the principal obfervations and directions relative to the winter-pruning of the wall Apricots, next follows fome intimations for nailing the trees to the wall.

According as you advance in the general winterpruning, or as foon as each tree is pruned, it is generally advifeable to have it nailed directly as you proceed, obferving in this bufinefs, that the fhoots and branches fhould be arranged, more or lefs, horizontally to the wall, in proportion to their general exparifion and extent, and as the refpective fpace of walling, \&c. admits, as obferved for the Peaches and Neciarines; and, being furnithed with proper wall nails and cloth finreds, cut about half an inch broad, and two to three inches long, arrange the branches ftraight and regular, at equal diftances, four or five inches afunder, proceeding with the lower branches firt, then wit? the others regularly upward, extending them equally on both fides to the right and left, and nailed ftraight and clcfe to the wall; obferving if any fhoots, \& $c$. were left too clofe in pruning, they, in the nailing, fhould be cut out, the moft irregular and inferior, that the others may be trained with proper regularity.
Where any Apricots are in efpaliers, they hould have the fame care in regard to pruning, \&c. as ad. vifed for thofe in wall-trees, both in the fummer and winter-pruning; and the branches alfo ranged and trained to the efpalier in the fame ordcr, either by nailing fome of them to the principal rails, or others tied thereto, or to the fmaller crofs bars, with oficr twigs, or occafionally with old thip rope yarn.

That as the Apricot Trees, as obferved of the Peaches and Nectarines, generaily begin to blofiom early in the fpring, when fharp frofts and cold cutting blafts fometimes prevail, and that the blofom and the fruit in embrio, and during its young ftate, is tender and liable to be deftroyed by froft, it would be of much advantage to afford them fome occafional protection, efpecially in trees of the moft efteemed principal forts, by covering them with large garóen mats, when inclement weather, as above, and which care is neceffary principally in March and April, when the blofioms expand, and the fruit fetting, as well as during its infant growth, until the middle or end of April, if cutting weather happens at that feafon, but particularly when frofts prevail; in which, nail up large mats againft the trees in the evening; to continue till after fun-rifing, or till nine or ten o'clock in the morning, or all day, if cutting froft and no fun; but when warm, funny, or in ail mild, open weather, take off the covering; or fome trees might be defended with cuttings of the fmall branches of ever-greens, as laurel, yew, fir, \&c. being furnifhed with the leaves, and fticking thern between the branches in a fpreading manner, to cover the bloffom and young fruit as well as poffible; and to remain conftantly night and day, they will break off part of the cutting effects of the froft; or, in the fame inanner, may occafionally ufe cuttings of the branches of dried fern; likewife, old fining nets are alfo fometimes fufpended before the trees, to remain conftantly, as intimated of the evergreens and fern.

And thus thefe different protections thould be continued until the fruit is well fet, and encreafed a little in fize to that of large peas, or middling, green goofeberries; afterwards, about the middle or end of April, or according as the feafon proves more or lefs favourable, all the covering thould be entirely removed away, to admit the free air, fun, \&c. fully to the fruit.

Then, about the end of April, or in May, and beginning of June, if the fruit is fet confiderably thick, or in clufters, it hould be gradually thinned, as advifed in the fummer management of the trees, leaving a fufficient abundance of the fineft fruit to attain maturity. 
T'he further care of the fruit, in its advanced growth, is explained in the fummer culture of the trees; it attains maturely for gatheing in July and Aiguft.

Standard Apricot Trees planted detached from walls, in warm fituations, in the open ground, often produce plentiful crops of fine fruit that ripen in good perfection; and as to their management, they having full fcope in the head to branch out freely every way, like other ftandard-trees; they only need occafional pruning, not regularly every year, as is necefiary for thofe in wall and efpalier-trees, but only to cut out cafual, diforderly brarches, or to thin others where confiderably crotided, or fometimes to reduce any of long, rambling growth, and to cut out decayed wood; and which occafional pruning fhould generally be done in the winter feafon, or early in the firsing.

Early Apricots are obtained by means of hot or fire walls, or forcing-houfes, by having bearing-trees planted therein, and forwarded by afficance of fire heat, communicated by fues extended within the forcing apartments along next the front and back parts, and fometimes alfo by bark-bed heat, in a capacious pit wichin; and by either or both of which methods of artificial heat, the forcing is generally ccmmenced about the end of January, or beginning or niddle of February, continued till May, when, and beginning of June, early ripe Apricots are obtained.

The trees, for this occafion, fiould be previoufly raifed to a bearing ftate, againft walls, \&c. in the open ground; or fome alfo in pots, that they may be more conveniently tranfplanted with the ball of earth about their roots, intire for immediate forcing; and, in either method, the trees fhould be planted in the autumn, in the borders within the forcing-houfe, and the branches trained to a trellis of wood work; and afterwards managed, in regard to the forcing and other particulars, the fame as explained for forcing early Peaches and Neetarines, under the article Amygdalus.

\section{Of the LiAURELS.}

The LAURELs, agreeable to the Linnxan fyftem of botany, being confidered as fpecies of the Prunus, conformable to the cbaraciers of their flowers and fruit, we have retained them accordingly, as fpecies of that Genus, arranged and defcribed each in its proper place, among the other fpecies thereof; and under this head is explained their general ufes and culture.

The two fpecies of Laurels are fine ever-greens, of the firft eftimation for ornamental planting in Ihrubberies and other plantations, in pleafurc-grounds, being of the large fhrub, or fmall or moderate tree kind, moft beautiful in the'ir continuing thining foliage, at all feafons; large, thick, and fplendent in the common Laurel, fimaller in the Portugal fort, and generally doubling a little; and both of which fpecies are moft defirable ever-greens, to plant both in afem. blage with others of that tribe, in clumps and running plantations; and alfo to admit in thofe of deciduous, ornamental trees and thrubs; and alfo to plant fingly in detached ftandards, in lawns, plats, borders, sic.

'The Common Laurel' particularly, is a fuperblynoble ever-green, of Atrong growth, and large, elegant leaves, of fingular beauty; and the tree is liardy to grow freely in any common foil and fituation, both in open expofures, and under thade of trees, \&c. or where required; defirable to admit. as a principal firftrate ever-green in all fhrubbery compartments, and, to form Laurel clumps and piantations wholly of that kind, which, in pleafure-grounds, parks, \&c. has a fine effect; and is alfo peculiarly adapted to plant: clofe for blind, or to cover or hide any difagreeable object, or naked, unfightly walls, palings, ditches, \&c. in gardens, or where thought eligible, as it will grow any where; it was alfo formerly trained for ornamental garden-hedges; though, in giving the neceffary annual clipping, the fhears, by cutting the large leaves, occafions them to appear unfightly, and fometimes, in hot, dry weather, make them afiume 2 rufty hue in the cut-parts; but when, inftend of clip-ping with thears, the projecting thoots are pruned in with a knife, without mangling the leaves, but preferved whole, the hedge will then continue beautiful at all feafons of the year.

The Portugal Laurel being likewife a handfomc ever-green, growing with a large, full, bufny head, is eminently adapted for adorning principal thrubberies, \&c. and to plant fingly in detached ftandard firubs, in borders, plats, lawns, or other confpicuous compartments, for ornament.

They may be obtained, in proper growth, for planting, at all the public nurferies, in plants two or three, to four or five feet high, and planted principally in the autumn orfpring; or may be raifed plentifully by the following methods.

Both thefe fpecies of Laurel are raifed from feed, cuttings, and layers; but as they grow very freely from cuttings of the young fhoots in autumn, that method is comnonly practifed.

However, they may be occafionally propagated by any of thefe ways; the feed ripens, in the berries, in autumn, and may cither be fowed in that feafon. in Scptcmber or Ostober, \&c. or in the fpriıg, in light $\mathrm{Y}$ 
eartb. half ain inch deep; and when the feedlingplants are of one or two year's growth, tranfplant them into nurrery-beds, \&ec. to acquire a proper fize for the thrublery'; cuttings of the young fhoots of the year, towards the latter end of Augult, and.in Septomber, or occafionally in the fpring, cut off about eight or ten, to twelve or fifteen inches long; or if cut off with an inch or two of the lat year's wood, at the lower end, it will be fome advantage to their friking : preferve the topsintire, diveft then of the under leares, and planted in a thady border, they will Atrike freely, and be well rooted in one feafon; and layers of the young wood, as above, in autumn or fpring, will alfo be properly well rooted, to plant off in the autumn of fpring following, in the nurfery.

And thus, by either of there methods, train the plants in the nurfery to a proper growth, either fome Tranch quite from the bottom, or others pruned up a dittle below, and, in both of which, permitted to branch out above in full heads; and when advanced two or three, to four or five feet high, are of proper fize for finåi tranfplanting.

The principal feafon for removing or planting the Laurels, is, as advifed for other ever-greens, either in autumn, from about the middle or latter end of September, to the end of October, or any time in November, in mild weather, or in the fpring, from February to April, not very generally in the dead of winter, or only occationally, when fettled, open weather prevails, or that the plants can be tranfplanted with good balls of earth about the roots, not to feel their removal; obferving in the general tranfplanting, they may either be removed with fimall balls of earth, where convenient, which would be of advantage in large plants particularly, and be alfo beneficial in thofe of (maller growth; or may, likewife, be fuccefsfully tranfplanted without balls, removing them carefully in their full fpread of roots; and in either of which, plant them as foon as poffible after removal out of the nurfery, \&c. and watered, efpecially if planted early in autumn, or late in the fpring.

In their future growth in the fhrubbery, \&c. they may grow nearly in their natural order, or only give occafional pruning to reduce cafual run-away, rude Thoots; or if any are planted sto cover walls, train the branches thereto at firlt in a fpreading manner; and if in hedges, train them alfo in proper order, for that purpofe; and in buth of which laft-mentioned methods, prune in the projecting thoots in funmer or autumi, if required to have them grow clofe and regular; os where this is not regarded, they may be permitted to run up in their natural growth.

\section{Ptelea, SHRUR-TREFOIL.}

Clars and Order.

Tetrandria Monogynia,

Four Males, One Female;

\section{Or Plants with Flowers (Herm.) baving four Stamine and one Piffillum.}

COMPRISES one hardy, deciduous, flowering-fhrub, of bufhy, moderate growth, adorned with trifoliate leaves; and fmall, yellow flowers, of four petals, having four fmall ftamina or male genitals, and one piftillum or female; fucceeded by roundith pericarpiums, or feed-veffels, containing obtufe feeds, ripe in autumn; and by which, fowed in that leafon or fpring, the firrub is propagated, and by layers and cuttings of the young fhoots?

\section{One Species.}

Ptelea trifoliata, Trifoliate-leaved Ptelea, or Shrub-Trefoil.

A middling, deciduous Thrub, of upright, bufty growth, four or five, to fix or eight feet high-the leaves (middling-fize, dark-green) ternate, or compofed of three folioles or lobes.-Native of Virginia. (Airy foil.)

This thrub is cultivated in thrubbery collections, makes an agreeable variety in its bufhy growth and irifoliate leaves, and appears ornamental as a fowering fhrub, continuing in flower a confiderable time in autumn: may be obtained at the nurferies, for planting in autumn or fpring, or any time in open weather, from Oetober till March or April.

It is propagated by reeds, layers, and cuttings, in the autumn or fpring; and when the plants are raifed to half a yard, or two feet growth, or more, are proper for the hrubbery.

\section{PU.NICA, PQMEGRANATE TREE. C.ars and Order.

$$
\begin{array}{cc}
\text { Icofandria } & \text { Monorynia, } \\
\text { Truesty, or mora, Males, One Female; }
\end{array}
$$

Or Plants ruith Flowers (Herm.) basing twenty, or more, Stamina, or Male Fructifications, and onc Pijtillum or Female.

THE Punica furnithes two fpecies, fmall or midding tree, and dwarf fhrubby kind, botli of a tender 
der nature, more particularly the latter, requiring protection of a green-houfe in winter; but the tree kind, common Poinegranate, is more hardy, admits of being planted in the open ground, in a warm fituation, or againft a fouth wall; cultivated principally for variety and ornament, as a fine fowering-tree and for the beauty of its fruit; is a tree of moderate growth, very branchy and bushy, adorned with narrow, fpear-fhape leaves; and very ornamental, fcarlet, quinquepetalous flowers at the ends of the branches; having oneleaved, bell-thape, five-parted cups, coloured and permanent; five roundilh expanded petals; twenty or more ftamina, a roundifh germen below, fupporting a fingle ftyle; and the germen grows a large, globular fruit, of feveral internal cells, full of a fucculent pulp, and many granulous feeds, good and delicious to eat; and by the feeds fowed the tree may be raifed; but is more generally propagated by layers of the young branches in the fpring.

\section{One hardieft Species, viz.}

\section{Punica Granatum-(Granatum) or Pomegranate I'ree.}

Moderate, deciduous tree, fifteen to eighteen, or twenty feet high-a tree-like ftem, very branchy from the bottom upward; the leaves (narrorv,) fpearThape; and many elegant, red flowers, in bunches, at the ends of the branches and young thoots, in fpring and early part of fummer; fucceeded by large, round fruit, fometimes ripening, in tolerable perfection, againft a fouth wall; fome kept in pots, to thelter in winter.-Native of Spain, Italy, and Mauritania. (Rich ground and warm funation.)

\section{Faricies.-Common Pomegranate Tree, with fin- gle flowers. \\ Double-flowered Pomegranate Tree. \\ Striped-flowered Pomegranate Tree. \\ Small-flowered Pomegranate Tree, with fingle and double flowers.}

This fpecies, in the feveral varieties, are defirable to plant for ornamental flowering-trees, allotting them a warm, defended fituation, in the full fin; and the common fingle-flowered kind may alfo be planted both as a fruit-tree and for ornament, one, two, or thrce trees againt a fouth wall, and the branches trained thereto, regularly, in the ivall-tree manner, in which they will both flower very ornamentally, and in favourable feafons produce large, beautiful fruit, in fome rolerable degree of matarity, in autumn; but in greater perfettion, if the trees are protected with glafs frames, in cold weather, in fpring, \&.c. while flowering, and in wet, cold weather, in autumn, when the fruit is ripening; though, at beft, they feldom ripen here with equal fiavour, as in their native countries.

However, confidered as ornamental fowering-trees, they merit culture in every curious collection, fome planted againft warm walls, or others trained in fnall ftandard-trees, in a buiny growth, for adorning the thrubbery, and in both of which, their elegant fcarlet flowers will make a beautiful appearance, more particularly the double-flowered kind, which are of fingular beauty, continuing in fucceffion, two or three months.

All the varieties are propagated by layers of their young branches, in the autumn or fpring, by flit layers, and will be well rooted, for planting off, by the autumn following, planting them in a warm fituation. or trained as above; or fome planted at once where they are to remain; or may alfo plant them in pots, fingly, to move under Thelter from froft in winter.

When defigned to plant any againft a wall, to produce flowers and fruit, fhould train the branches thereto four or five inches afunder; and it thould be obferved that as the tree produces the flowers, \&c. at the ends of the branches or thoots of the fame year, fhould annually prune them, in the autumn or fpring, cutting out the fmall, weak twigs, of the former fummers, referving the middling-ftrong Thoots; and thofe mortened according to their ftrength, that they may more effectually produce a proper fupply of fowering. Thoots; and when thus hortened train them to the wall, and in the following fummer, when young thoots advance, prune off any as are of vigorous projecting growth, and retain the others for fowering, \&c. and train them to the wall.

PYRUS, PEAR TREE, comprifing alfo the APPI, and $Q U 1 N C E$.

Clafs and Order.

Icofandria
Twentagynia
Twer more Males, Five Females;

Or Plants witb Herm. Flowers, baving twenty, er more, Stamina, or Males, and five Piftillums, or Frmales.

THE PYRUs, conformable to the fexual fyftem of botany, comprchends the Pear Tree as the principal. or original of this Genus; and the Malus, or Apple'Tree, and the $C_{j}$ donia, or Quince, formerly confidered as diftinct Genera, are ranged as feparate fpecies of the Pyrus family; which, confitting of four or five different fpecies, furnithing many varicties, are all of the deciduous tree kinds, molt valuable fruit-trees, or fome occafionally for ornaniental planting; but principally to plant abundantly as fruit-trces, in gardens and orchards, for their productions of fruit, of fuperior value, as the most 
volt generally ufeful and profitable, morc particularly the Pears and Apples, in their very numerous varieties, but lefs abundant and valuable in the Quinee; are trees of large, middling, and frnall growth, in the different fpecies; garnifhed, in fummer, with ovate, frear-fhape, and oblong leaves, of midciling fizes, and pentapetalous, rofaceous, white, and pale-reddin flowers, in umbellate bunches, and fingly, produced from the fides and ends of the branches, April and May: having monophyllous, or one-leaved, concave, fivelcbed cups, five concave petals, twenty, or more, Short ftamina; a roundifh, central germen, fupporting five ftyles; and the germen grows a large, pyramidal, roundifh, top-Thape, and umbilical, fleihy, eatable fruit ; sipe in fummer and autumn; furnifned each with five obiong feeds, or kernels, by which, feparated from : the fruit, and fowed, the trees may be raifed; xot, however, for general propagation, as all the defirable varieties are raifed by grafting and budding, whereby to have the forts continued permanent, and fooner commence good bearers; and fome are alfo raifed oeeafionally by layers and cuttings, and fome by fuckers.

The principal charatters of the Pyrus are-the flowers all hermaphrodite-have each a one-leaved, concave calyx, five-parted at the top-corolla, or flower, five roundin petals, concave, inferted into the ealyx-ftamina, twenty, or more, awl-hape filaments, crowned by fingle anthera-Piftillum, a roundin germen, under the flower, - fupporting gencrally ave ltyles within, and terminated by fingle ftigmas; and the germen grows a pyramidal, roundifh, ant top-Thape fruit, in the different varieties umbilicated at the top, and prociucted at the bafe, efpecialiy the Pears and the Quinces, but not the Apples; and all of which have nive internal membranous cells, containing each one. fmall oblong and pointed kerhe!, or feed.

This Genus confrfting of five or fix parent fpeeies, fome of which furnifh numerous varieties, particularly the Pear and Apple, Thall range the varieties -under each refpeçive fpecies.

\section{Pear Kinds. - .}

\section{PrRus commanis, Conmon Pear Tree.}

A large, deciduous fruit-tree, twenty or thirty, to forty feet high, growing with upright and fpreading branches, in the different varieties-the leaves (middling and largith) orate-oblons, fawed on the edges; and whition fowers, in pedunculated or foot-ftalked, corymbus bunches, in April and May; fucceeded by the fruit, in June, \&rc. pyranidal, oblong, roundilih, and tof-hape, he different forts; ripening from

July, to October and November.-Native of many parts of Europe. (Loamy or any common foil.)

Varieties of the Tree.-Common, cultivated, Pear Tree. (Many varietics of the fruit, as bereafter.)

Double-flowered Pear Tree.

Twice-flowering Pear Tree.

Stripe-leaved Pear Tree.

Varieties of the fruit.-Very numerous, confifting of fummer, autumn, and winter Pears; the fummer kinds, ripening, for eating, immediately off the irees, from the befinning or middle of July, to the end of Auguat or beginning. of September., and moftly or principally for prefent ufe, as they do not keep long, fome only a few days, others not above a week; the autumn kinds alfo, both ripen on the trees for immediate eating, in September and Oetober, and fome, after being gathered, will keep two, three, or four weeks, or more; and the winter Pears attain full growth in Oetober, but do not generally acquire maturity for eating raw, until after being -gathered, and lain in the fruitery rooms two, three, or four, to five or fix wecks, in the different forts, and fome two, three, or for: months, as expreffed below, in the different feafons of ripening, annexed to the names of the refpertive -varieties, both of the fummer, autumn, and winter Pears: though of the winter Pears, feveral forts, although not of maturity for eating raw as loon as gâthered, are proper for culinary oecafions, in baking, ftewing, \&c. and for making perry; and likewife fome of the winter kinds are proper principally only for baking, \&c. all which, as explained in the following regifter of the names, sze. of the different forts; ob- ferving, that as molt of the princjpal forts were originally obtained from - France, many are ftill known chiefly by the French names, and others by the Englih ; they are here ranged accordingly, by the names by which they are the moft generally known, with hort defcriptions of the different varieties, and their times of ripening or maturity, viz.

Supreme, or little Mufk Peas-a fmall, roundith, early fruit, ripening of a yellowith eolour, and rieh mut y flavour; beginuing and middle of July. 
Citron des Carmes, or Green Chiffel Pear -a fmallith, roundih, top-thape, early fruit, of a light green, or greenifh-yellow colour; the fleth melting, rich and juicy; middle or end of $\mathcal{J u l y}_{\mathrm{y}}$, and bcginning of Auguft.

Red Mufcadelle Pear-a lartith, beautiful, oblongifh, early fruit; ripening of a yellow colour, ftriped with red; the flefh fomewhat melting and rich flavoured; middle or end of Fuly.

Little Mufcat Pear-a imall, roundin, oblong fruit, ripening yellow and mu?ky Havoured; end of fuly and beginning of Auguft.

Primitive Pear-a finall, yellowifh and red fruit; middle and end of $\mathcal{F}$ uly.

Jargonelle Pear, fo called in England, but, from its thape, is more properly the $C_{u-}$ ife Madame (Lady's Thigh) - a large, long, pyramidal, early fruit, ripening of a ruffetty-green colour, or of an irony tinge next the fun; a molt fine, fummer Pear, the flefh tender, breaking, rich and juicy, fuperior to all other Pears of the feafon; beginning and middle of Auguft.

Cuiffe Madame, fo called, but is more properly the Jargonelle, as above; and is alfo very commonly called the Windfor Pear-a finc, large, oblong, pyramidal, early fruit, ripening of a yellowifh-grecil colour, and fometimes reddifn on the fide next the fun; fort, rich, and juicy, if not too ripe, but foon becomes meally tafted; the tree generally a great bearer; midille of Augujt.

IVindfor Pear, a variety of, and fomewhiat refembling the latt fort; a large, oblongih, top-Thape fruit, but fhorter and more fivelling towards the top than the Cuifte Madame, ripening of a yellowintgreen colour; foft or tender, and tolerably juicy, but foon becomes mcally; middle of Auguft.

Auguet Mlufea: or Averat Pcar-a middling-fize, roundith, flat fruit, of a whitilh colour, breaking fieth, rich, and juicy; a very fille fumner Pear: end of Auguft and beginning of Seprem. ber.

Orange Mufeat-a middile-f:ze, nortinh, gioivalar frut, yeilowith, black fpotted,

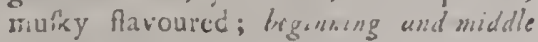
of Aluryl:.

Litule Bisuquette $\mathrm{Pes} \mathrm{r}-\mathrm{a}$ midd!n: or fmaller, round:th fruit, greenifli-yellow; tender juicy, and nullf:s; middide of Airsult.
Long-Stalked Blanquette-a widdle-fize fruit, romdih-oblong; breaking and rich, fugary; middle or end of Aliguf:

Red Orange Pear-a middling, roundifin fruit, yellowifh-green, and reddin purpie; melting, juicy, and perfumed; end of Auguet.

Murk Robine-a fmallifi, round, topthape Pexr, ripening yellowith; of a rich, nufiky flavour; middle or end of Auguft.

Early Ruffelet Pear-a middle-fize, oblong fruit, of a reddifin-ruffetty colour; melting and fugary; middle of Auguf.

Mufk Drone Pear-a middle-fize, roundith fruit, ripening yellowith; melting and murky; end of Auguft.

Mufk Orange Pear-a large, roundifn fruit, greenifh-yellow, the fleth meliing; end of Auguft.

Perfimed Pear-a middle-fize, roundihturbinated fruit, deep-red, fpotted with brown; neiting and perfumed; end of Augutt.

Rofe Pear, or Thorny Rofe-alarge, hort, roundifh fruit, yellowith-green, red next the fun; end of Auguft.

Autumn Ruffelet Pear-a large, oblor: fruit, of a brown colour, dark-red on the funny fide; foft, tender, and good; middle or end of September.

Hamdens, or Suinmer Bergamot-a largifh, round, flattened Pear, yellowintgreen; melting, and rich perrumed; mitidlle of Sepiember.

Cafifolette Pear-a middling-fize, longi? fruit, afh-coloured, or whitith; melting, juicy and perfumed; end of Auguft.

Onion Pear-mirldle-fize, roundith fruit, brownith and purple; mclting and good; end of Auguf:

Princes Pear-a fmall, roundifh, brightred and yellowiln fruit; melting and high favoured; middle to the end of September.

Pear Pouchet-a large, roundifn, whitinlycllow Pear ; foft, tender, and fugary; end of Aingufi.

Summer Bencrêtion, (Good Chrifian)a large, oblong Pear, bcautifully reddened next the fun, the othcr fide whit in-green; tender, juicy, and perfumed; luginning of September.

Salviati l'car-it modcrately-large, rourdinh, fili fruit, a little hollowed at bet's ends, sed rall yellow one fide, the othes whituh ; fof and fugary; beginsing of siserben.

Rofe - 
Rofe-water Pear-a large, round fruit, hollowed at the bafe, roughith, and of a brown colour; breaking and fugary; middle of September.

Great Mouth-water Pear-a large, round, finootl, green fruit; melting and very juicy; middle of September.

Autunu Bergamot-i middle-frze, roundifh fruit, ycllowith-green, reddifh next the fun ; juicy and rich; middle or end of September.

Swifs Bergamot $\rightarrow$ a middle-fize, roundift Pcar, greenifh, ftriped with red; melting, rich-juicy; beginning of October.

Deans Pear, or White Autumn Beurrea large, fine, roundifh-turbinated fruit, fmooth and yel!owith; melting and very juicy; beginning of Ontoter.

Rcd Beurre Pcar-a large, oblongin-topthape fruit, reddith-brown colour ; fott, melting fleth, molt juicy and rich; beginning of October.

Brown Beurre - a large, oblongifh, brownih-grcen Pcar; rich and very fine; beginning of Oczober.

Green Beurre-a large, grecnih Penr' mont rich and juicy; beginning of $O$ stober.

Autumn Verte Longue, or Long Green Pear of Autumn-a largith, long, green fruit; the fleth melting, very juicy and fugary; middle of Odolir to December, Ër.

Mufeat Fleuri, or Long-1talked Autunn Mufcat-a middle-fize, roundilh, very fine Pear, rufletty, or darkin-red; tender fleth, juicy and molt rich flavoured; middle and ind of Oczober.

Mefire Jcan, or Monfieur John Pear-a larginh, or midale-fize, roundifh-turbinated fruit, with a rough, brown $k$ in ; the fleth breaking, full of a rich; fugary juice; middle or end of Oczuber and Nozember."

Swan Egg Pear-moderatel; large, roundifh-turbinate, gradually fwelling in the middle, generaily of a greenifh-yellow, on one fide a little purplith ; molt juicy and delicious; Octuber and November.

Poire Pendar, or Knaves Pear-largihoblong, whitith-green fruit; tender, with a fugary juice; end of Oczober.

Rouffeline Pear, or Late Long-1talked Autumn Mufcat-a middle-fize, oblong, fmooth fruit, greenith-yellow, and dcepred next the fun ; very tender fleth, fugary and perfumed Havour; middle to the end of October.

Green Sugar Pear-middle-fize, oblongpyramidal fruit, fmooth green; buttery, fweet, and rich-fiavoured; cnit of O.80ber.

La Befideri, or wilding Pear-middle-fize, globofe, or round fruit, whitifh-yellow; better for baking, \&c. than eating raw; end of Oezcber or November, E̋c.

Craflane Pear, or Bergamot Crafiane-a middle-fize, roundifh-flat Pear, umbilicated, or hollowed at the crown and bottom, ripenirg of a greenifh-yellow, and rufietty ; very tender, buttery, and moft rich flavoured; end of October to the end of November or December.

La Marquife, or Marquis Pear-large, oblong-roundifl, fat at top, greenifh-yellow, reddifh next the fun; tender, fugary, and delicately-rich flavoured; beginning of Nowember to December, Eंc.

Dauphine Pear-middling-fize, roundifhturbinated, flat at top, of a yellowilh colour ; tender, rich, fugary, and mott excellent; end of Noventber, Esc.

Martin Sec, or Dry Martin Pear-largihoblong, deep-ruffet oin one fide, the other reddith; rich, fugary, and fine; end of November, Eंc.

Colmar, or Manna Pear-large oblong, the middle fwelling, and the head flat, deeply hollowed, grcenifh-yellow, or yellow-fpotted; very tender, and fugary juiced; December to January or February.

Virgouleufe-a mut fine, large, long Pear, of a greenifh-yellow, tlyc fleh melting and delicately-rich and juicy-Decenber to the end of 'January, E̋s.

Winter Verte Longue, (Long Green Pear of Winter)-large, roundifh-long, and citron-1hape, fmooth and green, ripening fomewhat yellowifh ; melting, buttery, and rich; end of December.

Amadot Pear-middle-fize, oblong-turbinate, or top-lhape, roughifh, ruffettycoloured, flefh dryith, muky-flavoured; December and Fanuary.

Chat-brulé, (Burnt Cat)-fmall, oblong, whitifh and ruffetty-brown; beginning of November, Ec.

St. Germain Pcar-a large, long, very fine winter Pear, ripening of a yellowifh-green ; melting, mort juicy and fweet, and is of much eftiniation; December till February or March.

Epine d'Hyver, or Winter Thorn-large, long-pyramidal thape, fmooth, whitithgreen, or ripening fomewhat yellowifh ; a fine eating winter l'ear, melting, buttery, 
tery, fiveet and high-flavoured Desember till March.

Poire d'Ambrette, or Ambret Pearlarge, roundin, and ruffet-coloured; fweet, and mufky-perfumed; December to the end of January or February.

Louibon, or Good Lewis-a large, long Pear, fmooth, greenifh-white, the flefh very tender and fweet-December, $\mathrm{Ja}$ nuary, Eृc.

Winter Boncrêtion-a moft large, longpyramidal Pear, often irregular, or knobby, generally of a yellowifn colour, tometimes a little reddifh next the fun; the fiefh breaking and tender, juicy and rich, and is a mont noted and muchefteemed winter Pear; January, February, and March, to April or May.

Marveille d'Hyver, or Wonder of Winter -middle-fize, roundilh-oblong, green, fomewhat fpotted; very rich and fine; December and January.

Refi de Chaumontelle-large, oblong, very fine winter Pear, whitifh-green, and purplifh next the fun; melting, rich, and delicious; November to Fanuary, Éc.

St. Martial Pear-large oblong, fmooth, yellowith and purplifh; melting, juicy, and fiveet; Fanwary, February, March, धृc.

Winter Ruftelet-a middle-fize, oblong Pear, greenißh-ycllow, inclining to brown; melting and very juicy; January, Februarj, धृce.

Great Orange Pear-large round, of a whitifn-yellow colour, the fleth breaking and tolerably good; end of November and December.

Martin-sire, or Lord Martin Pear-large, oblong-turbinated, unegual, or on one fide fivelling in the middle, fnooth, purplifh and yellow; melting, juicy, and rich-flavoured; December, Junuary, Ẽc.

Eafter Bergamot-large soundifh-oblong, or top-fhipe, greenifh-yellow, adfperfed with many rough protuberant fpots; breaking, and fweet juiced; Februarj, March," Afril,

Spulifh Boncrêtiou-a largere, handfome, pyramicial Pear, one lidc purple or red, with many black fpots, the wher fide yellow, the fich breaking and rich; Decembe" und "Januar.

Small Winter Beurre-a fmall shlongin Peitr, rellowifi, fposted with red ; meiting, rich-juic!; Dicember and 'January.
Eafter St. Germain Pear--moderately-large, long, and grcenill, melting and rich-ilavoured; February, March, or Atril.

Holland Bergamot - a large, roundion. greenifh Pear; tender, juicy, and lighflavoured; keeps good till March or Apsil.

German Mufcat - middle-fize, cblongroundih, ruffetty and red; melting, but tery, and munky-flavoured; March, April, till May.

St. Auftin Pear-middling-large, oblongith, of a citron-yellow colour, fpotted with red; tender, and moderately juicy ; December till Janusry or February.

Goldent End of Winter-large, roundith, or almoft globular, yellow fpotted with red; January till Morch.

Winter Citron Pear-moderately large, roundith citron, or orange-hape, and of a yellow colour; the flefh rather dry, but good for baking; December to March.

Pound Pear, Black Pear of Worcelter, or Parkinfon's Warden-very large, oblong-turbinate, roughifh, of a darkifl, obfcure red, on one lide, the other greenifh; hard and auftere; principally for baking, ftewing, Sc. November to Masch.

Union P'ear, or Uvedale's St. Germainvery large, long-pyramidal hape, moftiy decp-green, or fometimes reddifn next the fun; the flen hard, but excellent for baking, \&c. November to April.

Cadilac Pear-large, roundith-turbinate, moft part yellowilh, and reddifh next the fun; the fleth hard and juicy, but rather auftere; generally efteemed for baking, Itewing, \&c. No.vember to March or April.

Double-flowered Pear-large, fhort, and roundifl, fimooth, and yellowifn, and purple-red on the fide next the fun ; the, fleth rather hard, better for baking than cating raw ; December to April or May.

The foregoing being fhort defcriptions of the principal varieties of Pears, the following confilts both of fummer, autumn, and winter kinds, as in the foregoing Litt, are allo moltly good forts; thail mentio.s their geaerally-known numes and times of ripcring.

Katherine Pear; end of 'Yuly and besiuring of Auguti.

Orange Bergamot; Sppiember.

1.einon Pear; Sepiember.

St. James's P'ar: Sepremter.

Lord Cheyen's P'ar; Sefeonicer.

Red Aduirable; Scpiember und O pober.

Cravitore 
1,5

Craw forù Pear; September and Ociober.

French Bergamot; Osioler.

Brocas's Bergamot; Oacber.

Auchen Pear; Oztober.

Grey Good Wife; Ocioher.

Ganfil's Bergamot; Ociober.

Pear Piper; Septemter and October.

Scotch Bergamot; Septemler and Oalober.

Trumpet Pear; September ana OEzober.

Vicar Pear; September and October.

Echaffery; Novemler, December, Ëc.

Carline Pear; Oczober.

Chatea du Roi Bergamot; October.

Blood Pear; October, November, December, $\xi^{2} r$.

Carmeii.e Pear; Ozzobcr, November, December, Eซc.

Winter Bergamot; Osiober, Nowember, December, हु?.

Seven-elbowed Portugal Pear; Ociober, November, December, Ẽc.

Terling Pear; Otzober, Norember, December, छڤ\%.

Beurre blanc; Oclober, $\xi_{c}$.

Beurre d'Ore; Oslober, E̊c.

Of the different varieties of Pears, the following being very large, and fome too hard and auftere to eat, till improved by culinary preparations, in baking, \&ewing, \&x.

Pound Pear, or Black Pear of Worcefter. Cadilac.

Union, or Uvedale's St. Germain.

Double-flowered Pear.

Winter Citron.

Blood Pear.

Or may alfo bake or ftew any other large forts, fuch as
Winter Boncrêtion.
Spanin Boncrêtion.
Good Lewis.
Holland Bergamot.
Winter Thorn, \&c.

Thus far concludes the general regifter of the fpecies and different varieties of Pears, efpecially, of the principal forts; as there are ftill many more than is here enumerated, known in different parts of the kingdom by various names, peculiar to particular places; but as the foregoing lift comprifes a large affortment of principal varieties, from which to make a collection, more or lefs, of good kinds for planting, it would be fuperfuous to add a number of inferior forts, or of -thers, not fo generally known, of good qualities.
The trees of all the varieties of Pears, are propagated by grafting and inoculating the refpective forts upon any kind of l'ear ftocks, raifed from feed or fuckers; and upon Quince flocks to have trees of fmallcr or more moderate growth fo: walls, efpaliers, and fmall fandards; as more fully explined hereafter, under the article, the General Culture of the Pears and Apples.

$$
\text { 2. Apple Kinds. }
$$

Confifting of three fpecies, one of which is the Common Apple, (fuppofed originally the Crab) furnithing many fine varieties of the truit, attaining proper growt h for eating and culinary ufes, cyder, \&c. fron June, July, and Augult, to the end of Odtober; the fummer kinds, attaining perfection hefore September, do not keep long, but the late forts keep good in winter, and fome till next furing and fummer; and of the other fpecies, and fome varieties of the Common Apple, are alfo proper to plant for ornament.

\section{Pyrus Malus-(Malus) or Common Apple Tree.}

A moderate, deciduous tree, fifteen or twenty, to twenty-five feet high, generally with a fpreading, branchy head-the leaves (middling) ovate-oblong, and the edges fawed; and umbellate bunches of reddith rofaceous flowers, feifile, or clofe-fitting ; fucceeded by large, roundith, and oblong fruit, umbilicated at the top, and moftly hollowed at the bafe.-Native of moft parts of Europe. (Loainy or any common foil.)

Varieties of the Tree.-Common cultivated Apple Tree. -(Manywarieties of the fruit, as bereafter.) Double-flowered Apple Tree.

Wild Apple, or Crab, with fmall, round, very four fruit.

Whitih-yellow-fruited Crab.

Purple-fruited Crab.

Stripe-leaved Crab.

Dwarf, or Paradife Apple-a fmall, hrub. like tree, with very fmall fruit.

Dutch Paradife Apple-larger and ftronger.

Though of the above, the Crab and the Paradife Apples, are by fome confidered as diftinet fpecies, as they generally come the fame from feed, and which forts, are principally ufed for ftocks, upon which to graft or bud the different varieties of the cultivated Apples; the Crab ftocks being proper for large trees, and the Paradife ftocks to form fmall or dwarf trees; and are likewife admitted in pleafure-ground plantations, for variety. 
Fariestes of the Fruit of the Cultivated Apple Tree.

Thefe are numerous, attaining perfection for u\{e immediately off the trees, from June or July, to September, \&x. in the fun:mer and autumn kinds, but do not keep long; and in the winter apples, acguiring full growth in Oftober, fome both for immediate eating, and which, and the other different vaxieties of that fersen, being gathered and houfed, coninue in perfection one, two, or three, to feveral months, in the different forts; conliting of the following fummer, autumn, and winter Apples-

Gennetting, or June-eating - a fmall, soundin, yellow and red fruit-for eating fometimes in the end of June and in July, when growing againft a fouth wall, and on ftandards in Auguit.

Codlin Apple, or Codlin-a middling, or largioh collong Apple, fomewhat angled lengitudinally, and of a greenithyellow, or ripening to a yellowish and rc 1 colour; is gencrally the firft Apple for principal ufe-June and July in young growth, and of full maturity in Auguft.

Margarate Apple-a middle-fize, round. ith fruit, reddith next the fun, the other fide whitih-green; beginning of Augu't?

Dutch Codlin-large, oblong, fine Apple, much larger than the common Codlin, of a yellowin-green; excellent for culinary purpofes; Auguft and Seftentber.

Summer Pearmain - a largin, oblong, Apple, red-ftriped; Augu/: and Seplember.

Summer Calville - largin, oblong Apple, whitigh-yellow; Auguft and S:ptember.

Summer Rambour-a large, fine Apple, red and yellowifh-green-ftriped; end of Auguft ard in Sepremter.

Summer Pippin-a middle-fize, roundion Apple, of a yellowin colour; Sepiembur and Ucioler.

Red Autumn Calville-a large, oblongin Apple, of a beautifu! red next the fun; good for cating, baking, \&c. Sefritr:bor, Oczoler, Ë،

White Autumn Calville-largith, ob!ong, whitih-yeliow App!e; Siptcmber and Oipeber.

Red Winter Calville; O.̈cker, November, till March.

Nune-Such-a middle-fize, rouridilt, vellowift-green, and recdish A-pple; S.f. bintir, Ocicker, Nivember.

I.van's Yearnain-midide ike, culur:- ifh, handfome Apple, beautifully red next the fuil, the other fide red-itriped; September, O.gober, and November.

Golden Rennet-a middle-fize, rourdin, oblong, beautiful, fine cating Apple, bright-red and yellowinis; Sepitmber, or Cuader, to March, or langer.

Aromatic Pippin-a midile-fize, roundith-oblong Apple, rufietty-coloured next the fun, of a fine aromatic flavour; $\mathrm{O} c$ tober, Nuaveriber, Egce.

Holland Pippin-a fine, large, cblorgroundith Apple, of a greenith-yeilow, good both for eating and culinary pus. pofes; Ociuber, Nowesnber, till Marcl.

Golden Pippin-a fmall, roundifh-oval, fine eating Apple, of a golden-yellow colour, Src. Octoter, November, till March or April.

Pomme d'Anis, or Anife Apple-a middle-fize, oblongith fruit, of a greyint green; rpicy-tafted, like anife-feeds; September, Oagoter, EOc.

White, or French Rennet-a large, handfome, roundifh fruit, of a whitifh-green, becoming yellowifh when ripe, good both as a defert Apple, and for kitchen ufes; Oczober, Norvinber, to 'Ganuary.

Violet Apple-moderately-large, roundin fruit, yellowifh-green, with red Itripes, of a fugary tafte and violet flavour; OElober, हैं $c$.

Tranfparcist Apple-a middle-fjze, roundith-oblong fruit, yellow-coloured, of a fomewhat tranfparent nature, efteemed more for curictity than eating; Septcmber and $\mathrm{O}$ czober.

Quince Appls-a fmallih, oval-oblong fruit, quince-thaped, ruffet and yeliowint Sejtember and OETolier.

White Contin-a largih, or middle-fize, roundih, white Apple; September, October, हैंc.

Kientih P'ippin - a fine, large, oblong Apple, whitish-green, good both for eating baking, \&c. Oczobcr, November, Deccmber, Ecc. 10 March.

Ecarlet Pearmain-a handfome, large, oblongith Apple, of a fine red colour, good for eating and kitchen ufes; September, Oraber, Novenber, Esc.

Golden Rurfet-a middle-fize, roundih Apple, of a yellowinh and rufiet colour; Siftomber, ORober, Nozember, Eco.

A Luwnu Ruffet-a large, roundifh-oblong Apple, of a ruffetty-yellowin colour; Siftembir, O.Fober, and Novenber.

Winter, or Hertfordinire Pearmain - a fine, muderarcly-large, oblonginh . Ipple, red 
on one fide, the other vellowifh-redftriped; Oczobci, Noruinter, Decembcr, $\because c$.

Royal Rufit-a läge, molt excellent Ap. ple, roundih-oblong, brotd at the baje, wholly of a deep-ruffet colour, fometimes tingel with yellow, fuperior for baking, boiling, and very good for eating raw; Ociober, November, to March or April.

L mbroidered Apple-a moderately-large, oblongith fruit, yellowith and broad red Rripes; O.Zober, November, December, Ëc.

Erey Leadington Apple-a largifh, handfome, oliong fiuit, of a greyih-green colour, excellent both for eating, baking, boiling, \&cc, OAlober, November, Jैc.

Hes Rufet-a middle-fize, roundih-oval fiuit, ruffet colour on one fide, the cither a darkifn-green, of a tharpinh fiavour; OGoler, and all winter and spring.

Kentih Pippin-a large, fine, oblong Apple, of a yellowith-green colour; October, November, till fring.

Norfolk Beeffin-a middle-fíze, oblong, reddith Apple; October, November, to Fanuary or February.

Leathercoat Rufet-a fmaller, middlefize, roundifh apple, dark rufretty green, of a fharply acid flavour; November, and all winter and pring.

Wheeler's Ruffet-a good, middle-fize, roundifh Apple, fomewhat flat, of a lightion ruftet, and pale-yellow colour; Oclober, and all winter and spring.

Stone Pippin-a middle-fize, roundifh, whitin, lard Apple, for long keeping; OElober, all winter and Spring, till May or Fune.

Monftrous Rennet- -3 very large, oblongin Apple, reddin on one fide, the other fide greenith; principally for baking, boiling, \&c. Orober, November, and December.

Nonpareil-a moft eftimable eating Apple, finaller-middling-fize, roundith and flat, of a rufietty-green colour ; Cizober or Noveniber, or all winter and Jpring, till May.

Large, Green Nonpareil-a larger, roundifh Apple, of a brighter, rufiet-green colour; Oezober and November, till Spring.

Royal Pearmain-large, fine, ob!ongifh Apple, reddith and yellow; October and November.

Cour-pendu, or Hanging Body-an exceeding large, oblong Apple, with fereral longitudinal, rising angles or

\section{VEGETABLE SYSTEM}

ridges, and reddif on one fide, the other a pale-colour; having a long, flender ftalk, thlat the fruit is alivays in a pendulous, or hanging pofition; October, November, $\varepsilon^{2} c$.

WhiteCour-pendu; OEzober, November, Ėc.

Rennet Grife-a middle-fize, roundi . oblong Apple, of a deep greyin green, or one fide tinged with yellow; Ostober and November.

Pomıne D'apis-a fmallifh, roundifh Apple, bright-purple and yellowifh-green, very beautiful, with a firm fleth; September, OEtuber, Norventer, Éc.

Kirton, or Kirk-Town Pippin - a middlefize, roundifh Apple, of a whitifl-yelluw colour; OEtober, Nownterber, and moft part of winter.

Kitchen Rennet-a fine, large, roundifhoblong Apple, of a yellowifh colour; october, november, Eve.

Winter-greening-a largih, roundifh-oblong, green Apple, principally for kitchen purpoles; October, November. and moft part of winter.

Winter Rembourge-a large, fine Apple, vellowin-green, and red; Ociober, Nowember, and great part of winter.

Two-Year Apple - a fmallih, roundirh fuit, of a ruffetty colour, hanging on the trees till the fecond year; valued chiefly as a curiofity.

Fig Apple-fo called, as fuppofed, like the fig, not to have any vifible, or confpicuous, previous flower; or which is very fmall and fugacious or quick-fading, foon dropping, before it is generally obferved.

The above lift comprifes the names and flort defcriptions of the fizes, fhapes, colours, $\varepsilon$ c. of the principal varieties of apples; the following are alfo cul-. tivated in different places, and many of them very good fruit, deferving of culture where plerity of room to admit a large collection; thall juft mention their names and times of perfection.

Summer Stubbard; Auguf and September.

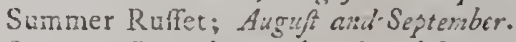

Summer Queening; Auguff and September. Kentilh Codlin; Auguft and September.

Lemon Pippin; Sepiember, October, Ẽc.

Virgin Apple; September, OErober, Ëc.

Newton Pippin; O\&ober to fanuary, $F_{b-}$ bruary, है?.

Pomnie de Gelée; OEzober, E̊c.

Pomme Pigeonette; Oacbrr, $\mathfrak{V}^{\circ} c$. 
John Apple; Oczober, and all winter, till May or fuac.

Lawman's Apple; Ocrober, and all winte', till May or Fune.

Lord Hay's Coldear Pippin; OEzober, Esc. SFitfenber Apnie; Nowenber, December, to April or May.

Sperzer's Pippin; O.7ober, Novenber, till String.

Catsllead; (wery large, roundijo-oblong) Ozober, Nowewuer, illijiring.

Pipy Ruftet; Ociober, hovember, tillspring. Achlam Livfet; Osabur, November, Ëc. Miargil Apple; Ocioter, November, Ëc. Englifh Rennet; Ociober, Eॄc.

Autumn Rennet; Septcmber, E゚c.

Barnard's Baking Apple; October, Novennber, December, हैc.

Glory of the Weit Aople; OEzober, Novem ber, Decenber, हुं.

Queen Charloste Apple; OEtober, Eंc.

Freneh Piprin; O-iober, Norvember, $D_{e-}$ cember, Er.

Black Pippin; O ت̈ober, November, Decenber, Esc.

Salmon Apple; Ocaber, Novinber, $D_{e-}$ cembir, Eテc.

Kentifh Wilding; OElober, Noveraber, December, Ẽc.

Partridge Apple; Os:ober, Novcmber, December, EFc.

Coftard Apple; OJober, November, December, Éc.

Norfulk Paradife; OEioker, November, December, EFc.

Gillificwer Apple; Osobcr, November, December, Ẽc.

Pomme du Roi; OElober, Novenber, December, Eैc.

Aromatie Ruffet; Ofober, Nowember, $D_{i-}$ sember, Ẽc.

American Apple: O.quber, September, Ëc.

Drap d'or; Seftember and Ocioour.

Sparith Rennet; Octoter, Esc.

Canada Rennet; Octeber, Esc.

Norfolk Storing; Osiober, Noucmler, Deceinber, Éc.

The followingare efeemed prineipally as eyser Apples, though any of the others of the auturn and wintcr kinds; where plentiful, may alfo be tifed for the famic occafion-

Red-freak Apple; Orober, Novcriler, şe.

Devonthire Royal Wilding; O ctor, Jorember, Ėc.

Gennet Mcyle; OSiober, Nozember, Ẽc.

Everlafting Ilanger; OElober, Nivember, Deccmler, Ẽc.

White-Scur: Ocluber, November, Deccmber, Eंc.
John Apple; Oaloki, Nouenber, December, éc.

Blackmoor Apple; Orioler, November, Decemler, हैंs.

Styre Apple; Osoler, Nowember, Deiember, $\theta^{2} c$.

Herefordnhire Under-leaf; Osober, November, Decemter, Ecos.

Wond-Cocks; Orbber, Noryemler, De. ce»ber, E̊c.

Fox-Whelps, with foveral others, chietly known in the eyder countries; Uncor, Noventer, Decinber, Éc.

Thus far finifhes the general eatalome of the privcipal, or moft generally known and cilcemed varictica of Apples; the trees of which are all propagated ant continued the fame, by grafting the different refpecinge forts upon the fiocks of any of the Apple kind, raifol principally from the feed or kersels of the fruit; or fome by fuckers; raifed to two, three, or four, to five, fix, or feven feet high, for rrafting them for tandardtrees, efpaliers, \&c. generally ufing Paradife or Codlin ftocks to form fmall or moderate trees; and on free ftocks, as thofe raifed from the kernels of erabs, or any kind of Apples, indifferently, for eommon largs trees, efpecially full ftandards; and all of which commence bearing in two, three, four, or five years after grafting; as explained in the article of their general culture.

Of the foregoing general lift of the different varieties of cultivated Apples, hould allot a proper afiortnuent of the beft middling and fmaller kinds, for eating, or defert Apples; fuch as fome of the Gennetting and Margarate Apples, for early eating; with fome of the other fummer kinds to attain maturity in fueceffion; and for general eating Apples in autumn, Winter, "rc. have a more plentiful fupply of the Pearmains, Golden Renncts, Golden Pippins, Holland Pipfins, Aromatic Pippins, Nonpareils, fome beft Rufiets, and fonse other principal forts; and for hitehen $\mathrm{An}$ ples, allot plenty of the common Codlins for the earlief, fome Dutch and Fentifl Codlins, large Rennetj, Ruffets, the Holland, anci other large Pippins, Pearmains, \&ce, and where reguired for eyder, may either allot, prineipally, a collection of the varieties mentioned before, under the lif of Cyder Apples; or any others of the autumn and winter linds in the general litt, wherc plentiful to fpare from other occafious, may aifo be employed for making eyder.

The following are other fpecies of the Apple kind, and cultivated chiefly for varicty and curiofity.

3. Prous (Malus) coronaria-Coronatel odorcusfowering Wild Apple, commonjy cai'cd Siveetfeented Virginia Crab.

A fmaller tree, or:oiving ten or twelve, to fifteen feet $Z_{2}$ lish- 


\section{$\checkmark$}

higri-the leare: (midding) oblong-ovate, fawed-anEuist.d, and unibris of fweet-fecnted flowers, pelunculated or foot-ltalked; fucceeded by fmall roundilh Appies, ripe in Eeptember, \&c. - Native of Virginia. (siny cominon fill.)

\section{Parieties.-Common Decidunus Sweet-fcented Crab. Ever-green Sweet-fcented Crab.}

\section{Pyrus (Malis) baciata-Berried-Fruited Apple, commoniy called Siberian Crab.}

$\Lambda$ fmall deciduous tree, five or fix, to eight or ten feet high-the leaves (fmallifi, light.grecn) oblong and faved; and crouded peduncles of whition flowers, ucceeded by very fmall berry-like Apples, reddin and yellow; Auguit and September.-Natire of Siberia and America. (Any common foil.)

Variety. - Red American Crab-a very fmall, rountin, berry-like, deep-red Apple, thickly crouded on the branches.

Thefe two laft fpecies and varieties of Apples, are cultivated principally for variety and curiofity, as before obferved: the Sweet-fcented Virginia Crab is introduced in fhrubberies, \&c. as a flowering-fhrub, and fometimes forits fruit, by way of variety, aforefaid; and occalionally ured for ftocks, on which to $\mathrm{graft}$ the other prircipal forts of Apples, in order to have them of moderate growth for efpaliers and fmall itandards; and the Siberian Crab is eligible to cultivate for its fruit, which both appear curious in its growth on the trees, and makes a pretty variety in a defert; comes early in autumn, and is agreeably flavoured; and the trees being of fmall growth, are cultivated in dwarf-fandards in borders and in fots; likewife occafionally in efpaliers and wall-trees, and is alfo fometimes planted in Rrubberies.

Thefe forts may be raifed from feed; but in order to have them continued more permanent in their refpective kinds, and to flower and bear fooner, it is advifeable to propagate them principally by grafting or inoculating them upon feedling-ftocks of their own, or on the Paradife Apple, or Codlin; or may alfo be raifed by layers and cuttings.

\section{Quince Kinds, (CYDONIA.)}

\section{Praus Cydonia-(Cydonia) or Quince Tree.}

A moderate or fmall deciduous tree, growing twelve to fifteen or eighteen feet high, with very flender branches-the leaves (middling) ovate intire, fomewhat, downy, or hoary undcrneath; and roficeous frowers produced fingly at the fides of tine fmaller branches; fuccceded by large, rcurdifi and oulong, yellow fruit; ripe in September and Oetober.-Naive of Aufria, near the Danube, \&c. (Muifs or any foil.)

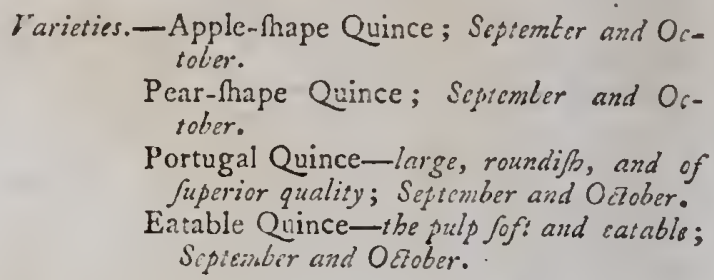

Thefe fruit, when ripe, impart a frong, fragrant odour, but mottly hard and aufere; ufeful principally for kitchen purpores, in balking, feving, \&x. and for making Maimalade and Quince Wine.

The Quince Trees are raifed both by grafting and budding the defired varictics upon their own or P'ear focks, and alfo by fuckers, layers, and cuttings of the young fhoots; but thofe ried by grafting and budding will bear fooner than the others; each inethod as hereafter explained.

Thefe trees are alfo in much eftimation for ftccks on which to graft anu bud Pears, to furm trees of mode. rate grow th, efpecially for walls and efpaliers, and will gencrally bear fooner than thofe on free or Pear tociss.

\section{Culture of the Pears and Apples.}

The Pear and Apple 'irees, in their numerous refpective varieties, being not only fpecies of the fame Genus or family, but alfo fimilar in their nature of growth, temperature, and mode of bearing, that one method of general cuiture is ncarly applicable to the whole in thcir different Atages of growth, fhall, therefore, give the effential directions for their cultivation under one principal head, relative to the methods of proprazation, raifing, planting, pruning, training, \&c. hoth for ftandard-trees, efpaliers, and walltrees, wh neceftary diftinctive intimations regarding the refpective nieits and other particulars relating to the trees and fruit, \&zc. of each of thefe two fpecies; and as they are cultivated in ftandard-trees, generaliy for principal pianting, to furnith the main fupplies of fruit, and in efpalier and wall-trees, aforefaid, to obuin their refpective fruits in a fuperior degree of maturity, fhall explain each method under its proper head.

The trees ate raifed or propagated by grafting and budding the cefired or intended forts upon ftocks of their own kind; that is, Pears are grafted or inocu. lated upon any fort of feedling Pear itocks raifed from kernels of th:e fruit, and fometimes fuckers from the roots of Fear Trces; and both of which ftocks 
being generally ftrong growers, are principally to graft or bud upon for full ftandards, and other trees of large growth, and upon Quince ftocks, to form fmaller trees, or of moderate growth, for principal wall-trees and efpaliers, and to bear fooner; and Apples, raifed principally by grafting, are grafted upon feedling-frocks, raifed from the kernels of any fort of Apples or Crabs, which, being of a free growth, are prope- for common large trees, and upon Codlin and Paradife ftocks, to have fmaller and dwarf-trees, and that they may fooner commence bearers; and in all of which, both Pears and Apples, when the trees, after being grafted or budded, have formed heads of one, two, or three, to four or five year's growth, they are proper for final planting in the places intended, and will begin bearing, fome at three, four, or five years old, others longer before they attain that ftate, efpecially Pears; and all of which, by grafting and budding, produce fruit the fame as that of the parent trees of the refpective varieties from which the grafts and buds were obtained; hence comes the utility of grafting, \&c. for although the trees may be raifed from feed, $i . \varepsilon$. the kernels of the fruit, and by which all the fine varieties were firft accidentally obtained, it is long before they commence bearers; and even then, though raifed from feed of the finct Pears and Apples, they feldom produce the fame kind of fruit in return, but vary to other forts, and probably not one tree in twenty give fruit inheriting any defirable property; but when any new varieties of good fruit from the feedling-trees occur, they being propagated by grafting or budding them on proper ftocks, as above defcribed, they are multiplied aud continued invariably the fame; as is the cafe with all or moft other defirable varieties of fruits; and the trees fo raifed, always bear fome years fooncr than feedling-plants.

But, for immediate planting, the trees may be had, ready raifed, at the public nurferies, in full collection, or as rezired, in different varieties, of two or three years old, or more, or that are advanced to a bcaring fate, to produce fruit the firft year, and may be planted any tinie in open weather, from Oetober till the end of March: the ftandards planted twenty to thirty, or fixty feet afunder, and the efpalier and walltrees fiftecn to eighteen or twenty feet difance.

All the varicties of Pears and Apples, in the different orders of training, bear thcir fruit upon fral!, natural fpurs, or curfons, being Aort, thick, floots, of about half an inch, to one or two inches long, arifing on the files and ends of the general branctes, commencing when of three or four, to five or fix years old, feldom fooncr in Pears; or fometimes in thefe trees, are cight or ten years before they begin to form tolerable bearers, efpecinlly thore grafted on crab or free ftocks; but when on Quince ftocks, they often bear in half the time; 23 alro Apples, which, grafted on Codlin and Paradife ftocks, often commence bearing in two or three years; and in all of which, the fame branches and fruit-purs continue many years fruitful, and, according as the branches encreafe in length, they muliply in the number of fruit-fpurs, continued quite to the extremities, and often formed at the termination thereof, if permitted to extend in their fuli $g$ owtin; ind, according as the trees encreafe in age confiderably, they bear moftly towards the upper and extreme parts of the finaller branches; though, in the wall and efpalier-ticts, by proper pruning and training, to cut cut nalked and barren, old wood, having young, advancing hoots to fupply the place, they are continued fruitul the whole length of the branches; and it fhould therefore be remembered, in performing the oscafional or neceftary pruning, that the branches and hoots of thefe trees muft not be fhortened, but permitted to ex:end always fu'ly in ftandards, alfo in efpalier and wall-trees, as far as room admits.

As Pear and Apple Trees furnifh many different varieties of their refpective fruits, moft valuable, ufeful and profitable, both for eating in their natural ftate, and for many principal culinary purpofes, in baking, boiling, \&c. occafionally, great part of the year; and for making cyder and perry, the trees merit culture more abundantly than moft others of the eatable fruit-bearing tribe, as being not only fuperior in their productions for domeftic occafions, but alfo very profitable to cultivate in confiderable plantations, in gardens, orchards, parks, fields, \& c. for public fupply in the markets and other occafions, as may be required, or convenient.

It is therefore advifeable to admit plenty of there trees, according to the extent of room which the refpective gardens and orchards, and other grounds wherein they are intended afford; generaily allot a larger portion, in Itandards, to produce the principal fupplies of fruit for general ufe, both for domeltic occafions and public confumption, where required; and have alfo a collection of the principal or moft $\mathrm{cf}$ teemed varietics, in efpalicrs, to obtain the fruit in greater perfection; likewife to have fome fineft forts of Pears in wall-trces, for the fame advantage as in the efpaliers, in a fuperior degree; and may alfo allos a few trees of the choiceft eating Apples, to plant on fouth or weft and eafterly walls, for early ripening in the forward forts, or in uthers to acquire a fuperior favour: however, as all the varietics of Pears and Apples attain good maturity on ftandard-trees and $e$ palie1s, thould allot plenty of the fe where $500 m$ admits, generally moft abundanily in Itandards, and in which have principally more of Apples than Pears, as being the molt generally ufeful fruit, and obtained in loager faccefion, in good perfection and abundance: but sut omiling to have fome proportional quantity of 
Pear Trees, or nearly equal to that of the Apples, if thought expedient.

In the intention of planting Pcars and Apples, ro time thould be omitted, not to lofe a feafon or more, efpeciaily as it hould be confitered that it will be feveral years before the trees begin to produce any tolerable quantity of fruit, and in which, the Pears are generilly longer than the Apples.

The trees of all the forts thrive in any common foil of a garden, or in ground of fimilar quality, in orchards, fields, hedge-rows, sic.

As Pears confilt of a grcat variety of fine eating fruit, defirably-valuable for ufe in fummer, autumn, and winter, both for eating, baking, ftwing, \&c. and alio, where in confiderable quantity, are of much eftimation for making perry, the trees thould be admitted in collection of different varieties, more or lefs, according to room, in gardens, orchards, \&c. to piant in ftandards, wall-trees, and efpaliers; the fummer and autumn kinds, attaining perfection for eating immediately off the trees in thore feafons, and will not keep long, efpecially the fummer Pears, ripening in July and Augut, which feldom kcep good but a few days; but the autumn kinds, attaining maturity in September and beginning of Octoher, will keep longcr, though fome of the forward varieties of that feafon continue only two or three weeks, and fome of the later forts near doubie that time, ferving for ufe till the winter Pears are in perfection; the winter Pears acquiring full growth on the trees, the beginning, middle, and towards the latter end of October, for gathering; few forts, however, for immediatc eating, except for culinary ufes, and being houfed, become mellow as they lie in the fruitery; attaining perfection ir the different varieties, in regular ficcelfion, during the winter, \&c. from November and December, till March, April, and May.

So that of the Pears, may plant plentifully in full and other ftandards, both of the fummer, autumn, and winter kinds, for the principal production, planted in gardens, orchards, \&c. twenty, to thirty or forty feet afunder; and fome of the beft varieties allot for efpaliers, for producing fruit in fuperior perfection, planted in the outward borders of the kitchen garden, Sc. in a row, fifteen to eighteen or twenty feet diftance; and likewife, fome of the moft efteemed forts, in wall-trees, of the fummer and autumn kinds, planted the fame diftance as the efpaliers, fome upon fouth, and others on eaft and weft walls, to ripen fruit early, and in fucceffion, of improved growth and rich flavour; allotting alfo a larger portion of the principal eating winter Pears, on walls of the fame afpeets, to attain all poffible perfection of full growth, that they maykeep well after being gathered, and acquire good maturity of mellownefs and rich flavour, more effec. tually, according to their refpective kinds in different varieties.

All the varieties of Pear Trees are raifed or propagated by grafting or budding the intended forts upon any kind of Pear ftocks, railed from the feed or kernels of the fruit and fuckers; forming what are called free frocks of Atrong growth, for large trees or full ftandards, \&c. or for extenfive efpaliers and wall-trees; and on Quince ftocks to have fmaller trees, both for ftandards, wall-trees, and cfpaliers; and which alfo fooner become bearers than thofe on Crab or free ftocks.

Or all the forts, or any defired varieties, may be procured at the nurferies, ready raifed, of a proper growth for immediate planting; or may occafionally obtain fuch as are well advanced towards bearing; or that are fully arrived to that ftate, where required to have bearing-trees as foon as polfible.

That as Pear Trees are generally feveral years before they bear, no time hould be loft in the defign for raifing or planting, as they are commonly longer than molt other fruit-trees before they bear in any tolerable abundance; as generally from the time of grafting, \&c. it is five or fix yeurs, or fometimes longer, before they give fruit; efpecially when grafted on Crab or free ltocks, which occafions their affuming a ftronger growth; running more confiderably to wood than thofe on Quince ftocks; for thofe latter being of a very moderate growth, the trees grafted or budded thereon, not running fo greatly to wood, foon commence bearers; fo that it may be proper both to have fome worked on free ftocks, for larger trees in full ftandards, and for extenfive wall and efpalier-trees, as before obferved; and others on Quince ftocks, for fmall ftandards, and for general efpalier and wall-trees, and to bear fooner.

Apples being a fuperior valuable fruit, in a more extenfive degree, than the Pears, of great ufe at mof feafon ; of the year, the trees in ftandards fhould be introduced more abundantly in every garden, and in orchards, hedge-rows, \&c. than of moft other fruittrees; and where good extent of ground, have great plenty of the ftandards aforefaid for the principal production; and to allot a portion of the principal forts for efpaliers in gardens, to produce fruit in fuperior goodnefs in growth and flavour; generally, in the whole, have an affortment of the fummer, autumn, ans winter kinds, as much as room admits, to obtain the fruit in proper fuccefion from the earlieft to the lateft feafon; the fummer and autumir Apples beinis proper for ufe immediately of the trees, trom june and July till Oetober; fome in young growt: in June or July, quarter or half grown, as in Coclins, \&c. to ufe in feveral culinary occaíons; and, 
their more advanced Pate, in the end of July and in Auguft, \&c. feveral forts are proper, both for the fame purpoles, and attain fome degree of maturity for eating in their natural ftate, as table or defert fruit, as obfcrved of the Pears: though rone of thefe early forts, even when full grown, will keep long, only a few days, or a week or two, or but little more; but the autumn kinds, acquiring full growth in September, confifting of many principal forts, are in perfection, both for immediate eating off the trees, and, that when gathered, will keep feveral weeks; and the late or winter Apples, attaining maturity of full growth, principally by the latter end of September, and in Cctober, proper both for prefent ut, and being then gathered, houfed, and thickly covered with dry ftraw, will keep in good perfection two or three months, or more; and fome forts will continue found and good till May or June following; cr fome, even till the production of young Apples for uí the enfuing fummer.

And therefore, as the varieties of Apples are very profitable fruit, both for many ufeful culinary purpofes in baking, bailing, \&c. and for eating, and of great value for making cyder, that where eligible icope of ground in gardens, orchards, parks, hedgerows, \&ic. Thould have plenty of the trees in ftandards, planted twenty or thirty, to forty feet diftance, or more, according to room; as likewife in gardens have a fortion of the fineft forts in efpaliers, planted in the borders of the kitchen garden, \&c. next the walks, in a row, fiftcen to eighteen or twenty feet diftance, to have their branches trained to the efpalier or trellis of pofts and rails, in the manner of walltrees; or likicwife a few of the fineft early Apples may be traincd againft walls.

In planting a collection of Apple Trees, morc or lefs, thould generally allot fome gocd portion of Codlins in ftandards, as being the firit moft ureful $\mathrm{Ap}$ ples, for kitchen ufes particularly, or for eating when of advanced rrowth; and the trees being moderate fhooters, no: fpreading contiderably, they niay be planted ciofer than the larger ftandard-trces, and will foon cecome picntiful bearers.

All the forts of Apples are propagated by grafing the refpectirc varieties upon Crab or any kind of Applo flocks raifed from the kerncls of the fruit, which being what are called Crab or free ftocks, are principally for larger ftandard-trces, and occafionally for efpaliers, when required to have any of extenfive growth; and others are $\xi$ rafted upon Codlin Rocks, raifed from fucl:ers from the roots, \&ic. of old trees, which being of more moderatc growth than frce ltocks, are more profer for fmall or modcratc ftandards, and principal efyalier-trees; and upon Paradife and Siberian $C_{1} a b$ itocks, being of dwarf growth, arc proper to form fmall or dwarf ftandards, and for efpaliers of fmall extenfion, and to bear fooner than on fronger ftocks; and in all of which, the grafting is always performed in the fpring: the grafts fhoot the fame year; and when of one or two, to three, four, or five years old, from grafting, are proper for planting finally in the places where they are intended to remain, and will begin to bear in two, three, or four years; gene-rally fooncit in thofe on Codlin and Paradife ftocks, more particularly the latter, which fornetimes commence bearers the fecond or third year; but thofe on large ftrong ftocks, running more ftrongly to wood, are longer before they bear.

But, as obferved of the Pears, young trees of ali, or any of the principal varieties of Apples for iminediate planting, may be had at the common nurfery-gardens, in good perfection; either in young growth, with fmall branchy heads, of one, two, or three years old from grafting, or in a more advanced growth, as may be required; and fuch as are become bearers, to produce fruit immediately, or the firft year of planting.

Pear and Apple Trees, in their different orders of training, confift of full ltandards, half ftandards, divarf ftandards, efpaliers, and wall-trees; the ftandard-trees being fuch as are planted detached in the open ground, to branch out every way, generally moft of the full ftandards being trained with a tall ftem, fix or feven feet high, to branch out at that height, and form large heads, for the general production of fruit; half ftandards in three, four, or five fect ftems, to branch out in lower heads for occafional planting ; and dwarf ftandards with thort ftens, fix, feven, or eight inches, to one or two feet, to grow in fmall, low heads, to plant occafionally, in borders and fmall compartments; and the efpalier and wall-trees, being fuch as have the branches regularly trained, the former to a trellis of ftakes and rails, and the latter to walls, are trained with a low ftem, fix or eight inches, to branch out near the ground, to furnith the cfpalier and wall with a regular expanfion of branches, quite from the bottom upward; or fometimes for high walls, Pears, in particular, are trained in half ftandard wall-trccs, with tall ftems, four or five, to fix or feven feet, to branch out at that height, to clevintc the branches accordingly.

The full fandards, being fuch as are trained with a tall fingle fem, fix or feven tect high, are generally worked on free ftocks, which being run up tall are grafted or budded at that height; or fonetimes Pears, \&c. are budded low, and run up with a fingle Soot for a ftcin. and in eithcr method, having the ftem tall, clcan, an? fingle, to branch out above, at the afore-mentioncd height, forming the firft fet of branches, fix or fcren fect from the ground, that the head may be clevated both to admit the benefit of the frce air, fun, \&ic. underneath; and that the frreading bratickes being 
it a diftance from the earth, gives liberty for the cultiration of the ground below, and the growth of under s:ops, either garden-rlants, or grafs, corn, \&c. and likewrife the branclies keing high, the fruit is more out of the reach of invariers; the head of branches permitied to extend freely every way, all round, in full growith, that in the procels of time they form a large ixparion, to prodice confiderible tupplies of frut accordingly; as fometimes a fingle tree, with a large, speading and lofty heid will pruduce one or two, to fsveral or many bulhe in a feafon; and therefore, of full trandards, wisere plenty of room, thould be admitted ihundantly both of Pears and Apples, in different variciss, to furnith the pincipa! crons of fruit for general fuppiv, as all the forts will attain proper maturity on frandard-trees; and which, in their growth, geriptaliy permitted to branch out in theirnatural order, or crily to give necalional pruning, to cut out cafual irregular-pliced, and crofs-growing branches, and de ad in ood.

Half ftandard Pear and Apple Trees being fuch as are trained occafionally with middling ftems, three, to four or fwe foet, the branches beginning at that height, and for which, fome good forts are grafted on dwarf focks, or thofe that are but of moderate growth, as Pears upon Quince or Medlar ftocks; and Apples on Codlin or fometimes Paradife ftocks, in order to have them advance with fmall or moderate heads; and that, as the branches commence lower than full ftandards, they may rot extend confiderably to overfpread the ground; and likewife being on moderate ftocks, the trees not fhouting ftrongly to wood, will bear fooner, and the heads being lower and of lefs extenfive growth, fhews the fruit in its growing ftate, to better advantage; and admits of gathering fome occafionally by hand, more readily, when required, without climbing, \&c. and therefore, on thefe confiderations, fome half ftandards are admitsed in gardens, more or lefs, as may be thought eligible; all permitted to branch out regularly every way, nearly in their natural manner, agreeable to the intimations mentioned for the full ftandards, and they will bear fruit abundantly in all defirable perfection.

Divarf ftandard Pear and Apple Trees being grafted or budded on fmall frocks, are occafionally introduced in fmall and other gardens, both that thej may take up but little room, and to have them foon become bearers, is likewife for variety and curiofity; they being raifed with low ftcms, fix or eight inclies, to one or two feet, or a yard high, by grafting and budding at the fe lieights, upon dwarf-growing ftocks; $i . e$. the Pear grafted or budued upor Quince Itocks, as formerly intimated; and the Apples on Paradife ftocks, for the fnalleft dwarf-trees; and on the Codlin ttocl, to have them of a middling growti; and, in all of which, the trees are intended to grow with low branchy heids, commencing at one, two, or three feet at noit from the ground; and to branch out regularly all round, in a moderate expanfion, kept to three $0 i$ four, to five or fix feet extent; and are proper to plant in fmall compartments, or in borders, \&c. or fome Apples on Paradife ftocks, to plant occafionally in pots; and thus, in the whole, the trees, by being on clwarf ttocks, fhoct moderately, do not run much to wood, will bear foon, and very agreeably, in fine fruit, and abundantly, according to their extent of branches.

Thefe divarf-trees may be of any varieties of the choiceft Apples and Pears, and of which, when defired to have the trees of fmalleft growth, mould graft the Apples on Paradife ftocks; and may be kept to two, three, or four feet high; or grafted on Codlin ftocks, for larger divarf-trees, may be kept to four, five, or lix feet; and Pears grafted or budded upon Quince tocks, will grow low and bear in two or three years; whereas thofe upon free or Crab itocks run much to wood, and are often eight or ten years before they bear fruit.

In this their dwarf growth, they are trained fometimes with concave or hollow heads, the branches pruned out in the middle, the outward branches continued in a fomewhat circular order; and all thoots that advance in the middle, pruned away to preferve the concavity; others are trained with convex or full heads, having an upright leader advancing in the middle, encouraged to branch out fide-ways all round from the bottom upwards; and of which, cutting out the irregular and fuper-abundant, and leave the others in a regular manner, the lower ones longett, diminifhing gradually above to promote the convexity in a fomewhat pyramidal form; and fome are permitted to branch out from the bottom in feveral principal branches to grow in a natural order, and unly cutting away cafral irregular growth, and to thin fuch as are too abundant or croudedly thick; likewife fome dwarf-trees, particularly Pears, are trained with feveral branches proceeding from near the bottom, and thefe trained in a fpiral manner to ftakes placed in the ground in a circular form round the tree, three, four, to five or fix feet high.

Thus dwarf ftandard Apples and Pears, trained as above, may be planted in any principal outward borders adjoining main walks, in a row, ten to fifteen feet afunder; or where ftraitened for room, fome dwarf-trees on Paradife ftocks, may be planted only eight or ten feet diftance; in the whole, the branches generally permitted to advance moftly in their full growth, without much fhortening, except where any afrume an irrcgular direction, or extend too confiderably in length beyond the others of the general expanfion, or that exceed the intended limiss of growth ; 
or, likewife, to prune out cafual ill-placed, and fuper-abundant branches, and fuch as grow acrofs the others in a diforderly manner; and generally, in performing any occafional thortening of too-advanced branches, fhould cut to fome lower, moderate hoot, if any occur that do not exceed the bounds; or if none, cut'occafionally, either to a lateral fruit-fpur, or a thoot-bud; but, except in fuch inftances of particular branches rambling confiderably from the others, it is moft advifeable to preferve them at their natural length, and they will furnifh fruit-fpurs all along the fides to the extremity.

Though fometimes dwarf Apple ftandards, on $\mathrm{Pa}$ radife ftocks, are kept down, by pruning, to half a yard, or two or three feet high; or, however, when on Paradife ftocks, and permitted to take their full growth, they will always remain perfect dwarfs, of only three or four, to five or fix feet high.

However, notwithftanding that thefe dwarf-trces generally bear fooner, and produce fruit in great perfection, thcy, from their fmall extent or expanfion of branches, efpecially thofe on Paradife ftocks, cannot furnifh it in confiderable quantity, as in full and large half fandards; and therefore are chiefly proper to cultivate either principally to become bearers more expeditiounly than large trees, or to furnifh fome fruit till the latter commence a bearing ftate, and as alfo to take up but little room in a garden, or for fmall compartments; and likewife to introduce in gardens, both for variety and curiofity, to have trees of fuch fmall dimenfions producing, proportionally to their fize, abundant crops of fruit in the fulleft maturity of growth, according to the refpective varieties or kinds; and being worked on dwarf-ttocks, they foon become good bearers.

The efpalier-trees are fuch as are trained, in a fanned expanfion, to ranges of ftakes and rails, to which the branches are faftened in a fpreading manner, in the order of ivall-trees; have low ftems, only a few inches high, branching out, near the ground, in a regular expanfion upivards, and extended horizontally on both fides, till the branches of the different trees meet, and thereby forming a fort of hedge, thence fometimes called efpalier hedges, and are applicable, not only to Apples and Pears, but to Plums, Cherries, Figs, Grapes, Apricots, \&ec. but generally more of Apples and Pears than other fruit-trees; and in all of which, the efpalier-trees being generally planted in the borders bounding the large quarters of a kitchen garden, or any other, where convenient, in a row longways the borders next principal walls, and the branches being extended only to the right and left, in a fraight sange, to the efpalier, or trellis of ftakes and rails, four, to five or fix feet high, take up no room, bear on both sides, equally in the frons and back part; and the branches being thinly and regularly arranged at equal diftances, have the full benefit of the fun and air, to forward the fruit to the utmoft perfection of maturity.

The trees for efpaliers are always trained with thore fems, only fix or eight inches long, in order to have the branches commence near the ground, that they may cover the trellis, \&c. of the efpalier, in a regular expanfion, equally from the bottom upward, four, five, or fix feet high, having the branches arranged horizontally, four, to five or fix inches afunder, one above another, moftly extended always at their full length, to the utmoft extent of room in the efpalier.

So, that in raifing Pear and Apple T'rees for efpaliers and wall-trees, they thould be grafted, \&cc. low in the ftocks, or at five, fix, or eight inches from the bottom, either fome on free ftocks, for largeft trees, in extenfive gardens, where room to fpread in a confiderable extent, in their full growth, or worked moftly on middling and dwarf-ftocks, for the general fupply, as on Quince ftocks, principally for Pears; and Apples on Codlin and Paradife ftocks, in order both in the Apples and Pears, to obtain trees of fmaller or moderate growtl, and to have them bear in a thorter time than thofe on Crab or free ftocks, which, thooting ftrongly to wood, are longer before they form fruit-fpurs plentifully; but, when on dwarf-ftocks, they fhoot moderate, and fooner furnith fpurs more abundantly for bearing.

Or proper trecs, for efpaliers, may be obtained at the common nurferies, of proper growth for inmediate planting.

In efpaliers it is particularly advifeable to plant a collection of the fineft eating and culinary Pears and Apples in cvery garden of any tolerable extent, or even in fmall gardens, to adinit only of a few trees in that order of training; and in which, the trees being trained in a fpreading expanfion, in the wall-tree manner, generally produce fruit in a fuperior degrce of perfection; and befides, the trees do not take up much room, and have alfo an ornamental appearance, as well as afford fome thelter to the adjacent under-crops in the ground, in winter, and fhade in fummer.

And wall-tree Pears, more particularly than Apples, being advifeable to have a collection of the choiceft kinds in every garden accommodated with walls, \&ic. thev are mon coininonly trained with dwarf ftems, as obferved for the efnaliers, about fix or eight inches, graftel or budcled at that height, that the branches may come out low, to cover the wail regularly from the bottom to the top; thould generally be grafted, Eic. on Quince ftocks, to have- the trees thoot moderately, and foon become bearers, and that, in advanced growth, they may continue within moderate bounds, A a by 
by which, both to admit of having a larger portion of different varieties on the allotted fpace of walling, and that they may fooner bear plentifully than when grafted or budded on frce ftocks; though, where there is large extent of walls, may alfo have fome that are worked on Pear ftocls, in which the trees will fpread a confiderably larger extent, and, when planted, fhould be allowed a greater diftance between the trees accordingly:

Cr fometimes Pears are trained in ftandard walltrecs, or with tall fiems, five, fix, or feven feet high, the branches commencing at that height, and ferve either, fome to plant occarionally between the common divarf wall-trees, where there are lofty walls; or fometimes to plant againt the ends of high busildings, in fituations open to the power of the fun and free air; and in which, if much expofed, the item of the trees being tall, elevates the head above the immediate reach of the hand, to preferve the fruit both from being pilferingly plucked by ftrangers, or other perfons who have lefs right to the product than the proprietor.

However, for the general fupply of wall Pears, allot principally thofe trained in the common wall-tree manner, with dwarf or low ftems, branching out near the ground, and to plant them againt fouth and other walls; for it is effential to have fome of the moft efteemed varieties of the fineft eating Pears in wall-trees, both fome of the earlier and late kinds, but more abundantly of the latter, confifting of the beft autumn and winter forts, that they may attain the utmoft perfection of full growth and rich favour, for eating ; planting the trees fifteen, to eighteen or twenty feet diftance, the branches'extended to the wall horizontally, four, to five or fix inches afunder, always moftly at their full length, as obferved of the efpalier-trees, and they will emit fruit-fpurs all along the fides, and produce fruit, both of the early and late kinds, in a fuperior degree of maturity.

Or likewife for walls, may have a few trees of the choicest varieties of eating Apples, to ripen earlier, and of fuperior flavour, as Golden-Pippins, \&c. planted and trained as mentioned for the Pears.

The propagation, or way of raifing Pear and Apple Trees, being by grafting and budding the refpective varieties of each upon ftocks of their own kinds, as before obferved, is performed according to the following intimations.

The Pears are propagated both by grafting and inoculating them upon Pear and Quince ftocks, which, in the former, are raifed from the feed or kernels of the fruit of any forts of Pears fowad in the autumn or fpring, and likewife by fuckers from the roots of Pear Trees, though the feedling-ftocks are rather preferable; and either or both of which ftocks being of ftrong, free growth, are commonly adapted for large trees in ftandards, wall-trees, and efpaliers ; and upon Quince ftocks raifed from feed of the fruit and from fuckers, cuttings, and layers of the Quince 'Trees; which being of moderate or fmall growth, as before intimated, are proper ftocks whereon to graft and hud Pears, to have finall ordwarf-trees accordingly, both in fmall findards, efpaliers, and wall-trees, where required to have the trees in thefe different orders of training continue of a moderate or dwarf growth, both that they may take up lefs room in a garden, and to admit of planting a larger variety, as well as to commence bearers fooner than trees on free ftocks; however, for the general fupply of common large or full Atandards, the Pear tocks are the moft eligible for that purpore.

And the Apples are principally raifed by grafting them upon Apple or Crab ftocks, raifed from the feed or kernels of the fruit of any kind of Apples, Sic. which being what are called Crab or free ftocks, generally" of a ftrong growth, are proper whereon to graft, to obtain large or full ftandards, or occafionally large, fpreading efpalier-trees; and on Codlin focks, raifed by fuckers from the roots and cuttings of Codlin Trees, to form fmaller ftandards and efpaliers of noderate growth, and fooner become good bearers; and Paradife ftocks for dwarf-trees of fmalleft growth, and to bear as foon as poffible in fmaller productions, according to their fize.

To raife fupplies of proper ftocks for Pears and Apples, from feed, fuckers, cuttings, \&c. the feed or kernels for fowing, are obtained from decayed or rotten fruit, or any others in the autumn or fpring, from October or November, till February or March, and fowed in beds of common earth an inch deep, they will come up in the fpring, for planting out in nurferyrows the autumn or fpring following; the fuckers, cuttings, layers, \&c. may be planted in the fame feafons; all of which, both feedling and other ftocks, to be planted in a nurfery, in rows, two feet and a half, to a yard afunder, to have two or three, so four or five years growth, for grafting, \&c.

Sometimes, where large fupplies of common ftandard Apple and Pear Trees are required, and that there is proportionable extent of ground in fields, ftocks, for grafting, are occafionally raifed or planted in hedge-rows, to remain for that purpofe; or fome places where Crab ftocks grow naturally in hedges, they are trained up in proper Rems; and in either of which, they are grafted as required, and permitted to remain always in the fame places, to acquire full growth in ftandards, and to produce their fruit accordingly. 
The feafon for grafting and budding them is, for the former, in the fpring, from about the middle or latter end of February, to the end of March or beginning of April; and the inoculation or budding is performed in July and beginning of Auguit.

In the grafting and budding thefe trees, allot generally tall itocks for full ftandards, to graft or bud at five, fix, or feven feet high, to branch out at thefe heighths to form the head; or for half or fmall ftandards, graft, \&c. at three, four, or five feet, to form the head accordingly; or occafionally, in both cafes, may be budded on fmaller itocks, low or near the ground, and the firft main thoot run up fingly for a ftem to the proper height, to furnih branches as above; and for dwarf ftandards, graft or bud at fix or eight inches, to one, two, or three feet, to branch out in low heads; but for general wall and efpalier-trees, they muft be grafted, \&c. low in the ftock, at fix or eight inches from the bottom, to form the firf fet of branches near the ground; or when intended to have tall or ftandard wall-trees, efpecially Pears, to plant between the common dwarf wall-trees, where lofty walls, or againft the end of buildings, as formerly mentioned, may be grafted, \&c. either on tall ftocks, at four, five, or fix feet, as for common ftandards, or budded low in the ftock, and the main thoot trained for a ftem to the requifite heighth ; and then, in either method, permitted to thoot above and furnifh the proper expanfion of branches.

After grafting and budding, as the foregoing, the grafts will thoot the fame year, and the budded trees not till the following fpring; and in all of which, in the advanced growth of the fhoots and branches, from the grafts and buds, train the trees, for the purpofes intended, in ftandards, wall-trees, and efpaliers; the frandards run with clean ftems below to branch out above regularly every way, in full heads: cut out only any i!l-placed productions, and the general branches permitted to extend in full growth; and the wall and efpalier-trees, train the branches in full cxpanfion, cutting off projecting, fore-right thoots, and extend the others torizontally to the right and left, and nailed, \&c. to the wall or ranges of ftakes, in regular order, at equal diftances, at their whole length; and when thus, in the different methods, they have formed heads of one, two, or three, to four, five, or fix years growth, they are fit for final tranfplanting into gardens, orchards, \&c.

But previoufly obferving in the young growth of the trees, that whether they remain in the nurfery, or planted in the garden, \&ic. the firft and fecond year from grafting and budding, it is fometimes or generally proper to give a particular pruning while of that age, to the firtt hoots, to promote an elizíble fet of branches to form a regular head from the beginning; for infance, if, in the firft year, the young trees have advanced with only une or two fingle hoots, it is proper, in the following fpring in March, to prune down the faid thoots to a few eyes, or within fix or eight inches of the bottom; and they will thus fend forth feveral lateral thoots from the remaining lower eyes in fumber, to give the head its firt proper formation; and which, heading down, is more particularly nece?fary in the wall and efpalier-trees, in order to obtain a proper fpread of firf branches, advancing regularly from the bottom, whereby to furnith the wall and efpalier with a full expanfion of branches from that part upward; or likewife, in ftandard-trees, if required to have them form fpreading heads, commencing immediately from or near the top of the ftem, the firt year's hoots may alfo be headed down, to have them branch out below accordingly, in feveral branches, to - form the head more full and regular; but when required to have ftandards form more upright afpiring heads, they may be permitted to advance in their firft fhoots in a natural growtl; and in thofe headed down in the firf thoots, both of wall, efpalier, and ftandardtrees, if they furnifh others fufficiently to form the head properly in a firft regular fet of branches, as above, no future general fhortening will be required, except probably to particular thoots in the fecond and third year, \&c. efpecially the wall-trees and efpaliers. to promote a further encreafe of branches.

However, if the trees headed down, and the fecond production of thoots being not fully fufficient to form a proper expanfion, as a foundation to furnifh all the other regularly upward, they may alfo be pruned or fhortened, more or lefs, as it may appear neceffary, in the winter-pruning or in the fpring, and from which there will generally be enough produced in fummer to give the head a firt regular formation of feveral well-placed branches; after which, they may generally or molly be permitted to advance in full growth, without any future thortening; the ftandards to advance moltly in their natural oider, and the wall and efpalier-trees to have the branches always trained regularly to walls and efpaliers, at their full length; and which will require prunintg and training every year to continue them in proper regularity, as hereafter directed.

Or fometimes wall-tree Pears, \&c, are trained with a fingle uprigtht thoot, and this promoted to branch out latcrally fioin the fide eyes, cutring off the foreright thoots, and retaining the fide laterals at regular difances, are extended to the right and left in a perfect horizontal potition; the upright in the middle being continued in advancing growth, or topped occafionally, to encourage its producing a further fupply of colaterals, more cffectually to furnith the wall regularly upward, trained in the fame horizontal manner; fo 
fo that all the branches proceed immediately from one upright middle ftem, and extended to both fides, five or fix inches afunder.

But when defigned to procure the intended fupply of trees from the nuiferies for planting, they may be obtained in a plentiful choice in the different orders of training, either in young growth, of one, two, or three years olid head, or of a more advanced ftute, for immedute bearine; and may occafionally have trees leaty trained of a proper growth for walls and eipaliers.

All the forts of Pears and Apples, both in ftandsrds, efpaliers, and wall trecs, being very hardy, will profper in any common fertile foil of a garden, orchard, field, \&ce. and in any onen fituation in ground not liable to be very wet of much continuance, which thould be avoided as much as poffible, as, in fuch, the trecs would not thrive; but in a moderately-dry mellow earth they will be profperous and durable; or, where a moderate loamy ground, it will prove beneficial to their growth; and, in which eligible foils, the trees may be planted without any additional preparation; or, however, if the ground is unavoidably bad, fuch as very gravelly, or other unkindly foil, it fhould be improved, if only for the prefent, in the place where each tree is to ftand, by removing the bad foil, and adding a proportional fupply of fubitantial good earth, either of fresh loam, where attainable, or any other good fertile foil, or a compolt of earth and rotten dung; or in a low very wet fituation which cannot be avoided, or no other choice for planting, it would be of advantage to raife the ground, or occafionally in a gradual fiwell for each tree, with additional earth, to have the roots out of the water; and afterwards, the fides of the raifed places, may be augmented by degrees: however, as before obferved, the trees will thrive abundantly well in any common ground of a garden and cultivated field-land, either of grafs or corn ground, or both, as may be required, or convenient to the planter.

And therefore, the trees may be planted both in kitchen gardens and pleafure-grounds, in ftandards, wall-trees, and efpaliers; and in any out-grounds in fields and enclofures for orchard-plantations in full flandarás.

And as to the preparation for planting, that if entire new ground, and for a general plantation in gardens, it may be trenched or digged one or two fpades deep, either wholly or only for the prefent, along where each range of trees is intended; or at leaft in the places where each tree is to ftand, three or four feet in width, or more; or in cultivated or any tolerable good ground, may only dig a wide aperture or hole for the reception of. each tree; obferving that where the wall and efpalier-trees are intended, the borders thould be four or five, to fix or eight feet wide; and if not before cultivated fhould be trenched two, or one full fpade; or if in cultivation before, may either be wholly trenched, or only at planting, to dig a hole for each tree, and the other parts digged afterwards, at forne convenient opportunity.

The feafon for planting thefe trees is principally the fame as for others of the fruit-tree kind, \&c. any time from the decay of the leaves, in Oitober or November, in open weather, till the end of March, or occafionally the beginning or middle of April, but not to exceed the midale of the lalt-mentioned montli ; or, however, if planted foon in the autumn, they moftly ftrike root the fame feafon, or be advanced in good preparation for ftriking freely in the fpring; but may alfo be planted any time in winter, in mild feafons, and in the early fpring nonths, generally more fuccefsfully than late planting, that they may be effectually well ftruck in that feafon, to proceed in a free growth the following fummer.

The diftances for planting thefe trees as Itandards, wall-trees, and efpaliers, is, the former, in full ftandards, fhould not be lefs than twenty or thirty feet, to allow for advanced growth in large fpreading heads; and where plenty of ground room, thirty to forty or fifty feet, would be more eligible, efpecially for any continued plantation; but fmall ftandards may be planted at half the diftance; and the wall and efpaliertrees, planted not lefs than tivelve to fifteen feet, thofe on dwarf-ftocks, or larger trees, eighteen or twenty, to tiventy-five feet afunder.

Of the full ftandards, thofe defigned for garden plantations, may be planted twenty to thirty feet in the row, or thirty to forty or fifty, or more, between, where room admits, both that there may be proper Ptope for the branches, when of full growth, and to allow for the growth of under-crops on the ground between the trees; but where defigned for orchard plantations, in grafs ground, or any other, they are commonly planted at equal diftances, and to range in lines every way, thirty to forty feet afunder, as before obferved; though fometimes in extenfive orchard plantations, in cultivated fields, where confiderable quantities of Apples are wanted for cyder, \&c. the trees are planted thirty to forty or fifty feet, or more, in the row; by fifty or fixty, to an hundred feet between the ranges, to admit of good room in the intervals to plow, fow, and cultivate the ground, in corn, grafs, \&x. as may be required; and the fame order of planting might be obferved in the large farming and other extenfive kitchen-garden grounds, as in the neighbourhood of London, in which ftandard Pear and Apple 'Trees and others may be planted to great advantage, in their production of fruit; and, being in rows fifty or fixty feet, or more, afunder, would admit of fufficient room to cultivate the ground in kitchen crops; and the planta- 
tion of trees would give an air of greater importance and value at all times, and more confiderably when in fruit.

But in fmall ftandards, as Pears grafted on Quince ftocks, and Apples on the Codlin or Paradife ftocks; which growing with moderate heads, or of fmall extent, may be planted in gardens only twenty feet afunder in the rows, or lefs, where itraitened for ground room; or fmall dwarf ftandards planted in borders, ten, to fifteen or twenty feet apart; or fome fmall dwarf Apple T'rees on Paradife ftocks, may be planted in pots, for moving them into any particular compartment, occafionally, while in flower and fruit, for variety or curiofity, or to ferve up in deferts with the fruit growing on the trees.

In procuring the trees for planting, they mould be carefully taken up with their full extent of roots, or as intire as poffible; for this is of much importance to the future profperity of the trees.

To prepare them for planting, prune out the broken parts of the roots, and horten the ends of very long itragglers, and examining the head, cut away or reduce to order any diforderly branches or thoots; or in the wall and efpalier-trees, giving attention to the proper expanfion of regular branches, prune off fore-right projecting, and any other irregular or illplaced Moots; and generally, in the whole, preferve all the proper regular branches intire, both in the ftandards, wall-trees, and efpaliers, not hortened, except where any branches extend confiderably longer than all the reft, they may be reduced or pruned to fome lateral moot, sic. conformable to the extent of the general branches, to form the head in fomewhat regular order, of nearly equal extent; cutting away all hoots from the ftems below the head.

Proceeding to the planting, obferve at the proper diftance to dig a wide round hole for each tree, a foot or more deep, and capacious enough to receive all the roots freely to their full extent; place the tree therein upright, or in the wall and efpalier-trees, incline the heads to the wall, \&c. trim in the earth over the roots, thake the tree a little up and down, to make the earth fall in clofe between the roots and fibres, filling up the hole at laft, and tread the earth gently down to the roots; firft, round towards the outfide, continuing it inward to the ftem; and if early planting, in dry weather in autumn, or alfo in the fpring, efpecially late in that feafon, and the ground cry, may give each a moderate watering to fettle the earth more effectually about the roots, and to promote their ftriking frefh root more expeditioufly; and if a continuance of very dry weather in the advanced part of the fpring, tivo, threc, or more occafional waterings, in April, Mav, \&.c. would prove very beneficial; obferving, likewife, in the tall ftandard-trees, it would be of much advantage to give fupport of ftakes, by driving one, two, or three long ftout ones into the ground near eacli tree, inclining the tops of them to the upper part of the ftem, which tie in that part to the ftakes with a piece of cord, rope yarn, \&c. previounly winding fome hay band round the ftem to prevent the bark beingr rubbed againft the ftakes by the motion of the uind.

The wall and efpalier-trees to be planted in the fare manner as the foregoing, allotting principa'ly l'tars for walls more generally than Apples; fome planted on fouth and other walls, as before obferved, of disferent varieties of early and late kinds, fet at the diftance formerly mentioned, fifteen to eighteen feet for thofe on dwarf ftocks, and if on Crab or free focks, plant eighteen or twenty feet diftance, or more, as, in their ftrong growth, they will extend more confiderably than the others: open for each tree a hole of proper width and depth to contain the root freply, place the tree therein near to the wall, inclining the ftem and head thereto; fill in the earth about the roots, tread it down gently, keeping the head clofe to the wall; and may then nail the branches finally, or rather defer it a littie time, till the earth and tree together is fully fettled, and then trained to the wall, as hereafter explained.

The efpalier-trees are planted in a fingle range along any principal borders next the main walks; or generally in borders which furround the large quarters of a kitchen-garden; or in any other garden diftrifts where thought eligible, moltly in a free fituation open to the fun and air; having the borders four or five, to fix or eight feet wide, the trees planted towards the back part, in a row, three or four, to five or fix feet from the outer edge next the walk, at eighteen or t.venty feet diftance in the row, thofe on free ftocks, and thofe on moderate or dwarf ftocks, plant not lefo than twelve to fifteen feet afunder in the row, that, in both of which, there may be proper room to extend the branches; and, in the whole, obferve the fame method of planting as directed for the ftandards, \&c. and when thus planted, thould have either a regular efpalier or trellis of ftakes or of poft and rails, erected clofe behind the trees; or only for the prefent, fome fakes placed a foot apart, as far as the trees now extend; and in their advanced growth encreafe the trellis-work by degrees, or form at once a full trellis, either of tall ftakes driven into the ground a foot afunder, ftanding three and a half, to four or five feet high, and a rail nailed along the top, both to keep then more fteady, and for the greater regularity; or have a regular of palier framed the fame height, with polts, five or fix feet diftance, and three, four, ur nuve ranges of horizontal rails, ald to thete, have occafionally, fmall up right crof; bars, twelve, to fifteen inches afunder. 
Obferving, of thic wall and efpalier-trees, the branches rust be regularly trained to the wall and efplier, in a fpreading expanfion; firit, give any requifite pruning, whcre neceflary, to cut out fore-right or other ill-placed fhoots, and retaining the others at their full length; and trais them in horizontally to the wall and trellis of the efpalicr, by nailing the brasches of the wall-trees with nails and Anreds; and the $t$ fpalier branches may either alfo be inoftly nailed to the trellis or rails, or tied thereto with ofiers, or fome nailed and tied uccafionally, as convenient; and in which, both wall and efpalier-trces, arrange the branchcs four, five, or fix inches afunder, and in their full extent, not fhortening any, efpccially the gencral branches, defigncd for bearers, but continued always at their whole length, both in their young and advanced growth, as far as there is room to extend them; as, from their nature of bcaring, Apple and Pear 'Trees do nct admit of thortening, and is only to be praftifed occafionally, where any extended thoots advance beyond their limited fpace of rocm, or in any very irregular growth, or to prune cafual decayed ends; or fometimes where any principal branches extend confiderably out of bounds, they are pruned or cut down to fome lateral hoot, or lower branch, that adnits of training within the proper limits, the terminal part thereof cortinuedintire, at leaft as far as the utmoft extent of the allotted fpace of walling and efpalier for each tree allows, and crly thorten agreeable to the above intiniations, where they extend beyond their proper bounds.

For, as before obferved, all the varieties of Apple and Pear Trees being of the fpur-bearing kinds, fortening the branches, or fhoots, forces them greatly to wood, without furnifhing fruit-fpurs, confifting of hort robuft hoots, of half an inch to one or two inches long, produced naturally at the fides and extreme part of the branches, when from two or three, to many years old, and always fooner and more abundant when not hortened, but all or mofty left intire; as thortening not only retards their bearing, by cutting away the upper or extrcme bearing part of the branches in which fruit-fpurs would arife, but alfo, by reducing them above, occafions their fending forth ftrong lateral wood-hoots below, in the parts where natural fruitSpuis would otherwife have been formed by degrecs; and thereby every shortening retards the branches one or tivo years longer, before they fo:m bearers; which, therefore, determines that in the general pruning of thofe trees, the fhoots as are defigned for bearers, muft not be hortened, but pernitted to extend in their whole length to the utmoft extent of their allotted bounds in the wall and efpalier; they will thus proceed in a moderate growth, and grielually form fruitful fpurs at the lateral eyes, along the fides, and at the extremity for bearing, and the fame bearers contirue many years fruitful.

\section{VE GETABLE SYSTEM}

And as, in thefe trees, the fame branches and fruit: fpurs continue encreafing in fruitfulnefs and remain many years in a pleniiful bearing ftate, they fhould be conftantly retained accordingly; except when in wivanced age, any branches decay or become unfruitful, hould fore-caft to have young wood advancing below or between the old, ready to fupply the place when neceffary to cut any away as unferviceable; as like. wife, when any fruit-fpurs appear of a worn-out or unfruitful ftate, they being cut avary, new ones are often acquired in or near the fame places to fucceed them on the fame parent branches; fo that thefe trees, in walls and efpaliers, in the procefs of pruning and training, only require renewals of young wood, occalionally, in the above inftances, not annually, as in trees bearing principally on the year-old wood, but the fame bearers remaining fruitful are continued from year to year in long duration.

Refpecting the culturc of Pear and Apple Trees, it confifts principally in giving occafional pruning to the ftandards; and to the wall and efpalier-trees a gencral pruning is necefiary every year.

The pruning of ftandard Pears and Apples is orily required occafionally, as before obferved, to reform cafual irregularities of diforderly hranches, and to cut out decayed or worn-out barren branches in old trees; and which occafional pruning in the ftandards, as they, having full fcope of growth, branch out freely every way, may probably be only necefiary once in feveral ycars; and when requifite, it hould generally be performed principally in winter, any time from the fall of the leaves in November, till March or April; obferving in this bufinefs that the ftandards muft be permitted to advance in their full growth in a regular expanfion of branches all round and above; and only in which, if any confiderable irregularities occur, either in young or old trees, they fhould have requifite pruning as you thall fee occafion; fuch as to cut out crofs-placed or any of very diforderly growth in the branches; and where any are greatly crouded in wood, Thould not omit to prune out the vorft and moft irregular, in a thinning manner, both in the larger and fmaller branches, wherè it may feem neceffary, whereby to keep the general branches moderately thin or clear of one another, in fome regular order; alfo, occafionally to reduce any diforderly, long rambling boughs, cut or fhortened down to fome lateral branches thereon, confiftent with the gencral extent of the head; likewife to prune up low ftragglers, or underhanging branches in the fame proportion; and generally cut away any ftrong upright crouded thoots in the middle of the head and other parts; and to cut out cafual decayed branches and dead wood; and eradicate fuckers from the root and ftem of the trees; and thus, giving the above occafional regulation, permit 
the general expanfion of the regular branches to extend in their natural grcivth, and they will produce proper fruit-fpurs abundartly all along the fides to the extreme parts, for plentiful bearing; and the fane branches continue many years in good fruitfulnefs.

Sometimes old ftandard Pears and Apples are greatly infelted with mofs growing on the branches, hurtful to their growth, that the production of fruit is of inferior quality; it is therefore advifeable to clear the branches from the greffeft part of the mors as well as poffible, which generally perform in winter, by fcraping it off with fome finall inftrument of iron or wood, a little hollowed on the edge; and where any trecs thus infefted, are very abundant in wood, in a crouded diforder, give them a proper thinning, to admit the fun, air, \&c. and the roughe? of the mofs cleared away, they will foon improve accordingly, by degrees, in a revived growth, and fuperior goodnefs of the fruit.

For it is generally advifeable in the ftandard-trees, when any cafually become confiderably crouded in wood of a diforderly growth, to give them fome neceffary thinning, keeping the general branches moderately thin, to grow moftly clear of one another, in fomewhat regular order, wliereby you will always have the fruit of fuperior quality, in proportion.

The pruning of the wall and efpalier Pear and Apple Trees, is required conftantly every fummer and winter, to preferve the regularity of growth, and good fruitfulnefs in the peculiar degree of perfection, whicl, by proper management, is generally obtained on trees in this order of training; and in which different prunings, that in fummer comprehends a regulation among the young thoots of the year only; and the winterfruning includes a general regulation both in the young wood and older branches occafionally, cach as explained below, uner their feparate heads.

The fummer-pruning is neceffary, as before intimated, to regulate the thoots of the fame year, which generally, in full-trained trees, are produced numerouly, or fuper-abundantly more than is wanted for training, as well as many that are ill-placed, not admitting of beirg trained with proper regularity; and in both of which inftances, many of the year's thoots wiil require cutting out, efpecially in trees alrendy furnifhed with a full expanfion of branches; for as thefe trees continue bearing many year's on the fame branches, they only require occafional fupplies of young wood, either to furnifh vacant parts in yourg or oiner trees, or to fupply the place of cafual, wornout, old branches and decayed wood; therefore, beginning the fummer-pruning in May and June, when the thoots will be confiderably advanced, cut awa: all fore-right and others as are ill-plased for training, and this out the fuperfluous or over-abundancy of the other more proper thoots, retaining only fome of the beft well-placed thereor, in the moft racant partis, with generally the terminal or leading fnoot to each branch; obferving, however, of the beft latiral fide-fhoots, generally to leave rather more than what may appear juft necefiary, in order that there may be plenty to chufe from in wint ar-pruning, in cafe they thould be wanted; cutting all tine unnecefiny or improper fhoots clofe to the old wood, not leaving any ftump or bottom fnag thereof to thoot again; and let all the retained thoots be continued at their full length, and tied in regularly to the trellis of the efpalier; and after the firft gencral regulation, keep the trees cleared from all after-fhoots, except any of proper growth occur in a vacancy where wood is wanted; and continue all the other referved proper fhoots trained along at their whole length, during their fummer's growth, to remain till winter-pruning.

The winter-pruning of the wall and efpalier Pears and Apples is performed any time in Noncinber $\theta^{\circ}$ December, till March, or not later than the beginning of April; confits of a general regulation, more or lef, both ainong the fuper-abundant and improper yourg wood of lait fummer, and occafionally in the older branches; obferving, now, in this pruning, that, as the farne general mother branches formerly trained, either now prefent bearers, or advancing to that ftate, continue many years fruitful, they are to be retained accordingly; and therefore, in trees of full expanfion, a renewal of young wood is only required occainonally to fupply the place of cafual, worn-out, or decay. ed branches, or to furnith accidental vacancies; but in young trees, ftill under training, a requifite fupply of young thoots muft be retained for the neceffary encreafe of branches for bearers.

Thus, in proceeding to the winter-pruning, obferve, agreeable to the above intimations, to examine the general mother branches or bearers, and fill retain all that are of found and good fruitful growth, or advancing to that maturity; conformable to their mode of bearing, and only to cut out any worn-out, barren, or decayed wood, and examining the fupply of young thoots which were trained in lait fummer, and, as probably more were then retained than is now required, the fuper-abundancy and ill-placet, if any, mut be pruned out, and felceting only what may be wanted of the beft well-placed fide-fhoots thereof, of moderately ftrong growth, to fupply any wants or vacant parts in ycung or old trees, as above; or where any old branches appear on the decline, or of a barren, unfruitful ttate, leave fome contiguous young wood, advancirg between, to a bearing ftate, ready to fupply the piace of the cafual unfruitful bianches; obferving always to continue one good terminal or leading fhoot, and no imser, to each of the mother branclies; o1 vihere wo or more fioots occus at or a the end. 
cut of all but one, either that naturally placed at the termination of the branches, where room to extend them therewith; or in branches very confiderably extended, may occafionally prine them down to fome cligible literal moot, to remain for a terminal to the branches; all the retained thoots to be left at their whole length, none thortened where room for their full exiention; and let all the others, not wanted, fore-right, or other ill-placed thoots, be cut off clofe to the old ivood, not leaving any ftump or fnag to thoo: again; hut be careful to preferve all the natural fruit-inurs appearing along the fides and at the extreme parts of the feveral years old branches.

Further obferve, in winter-pruning thefe trees, or efpecially thofe of fome confiderable age, that, in the older branches, if any cafually become of an unfruitful or worn-out, declining or decayed ftate, cut them away; retaining young to fupply the place, if neceffary, cutting the improper old wood either clean out to the bottom, or pruned down to any good lateral branch properly fituated on the lower part, or may previounfy fore-caft to have young wood advancing below, between, or contiguous to any apparently, declining, old branches, one, two, or three years, forwarding to fruitfulnefs, ready to fupply occafional deficiences; or alfo where any old branches are very croudedly too abundant or irregular, cut them out, or pruned agreeable to the foregoing intimations; but, except in the above inftances, retain always the fame principal branches or bearers, as long as they continue in a fruitful ttate, furnined with plenty of good bearing fruit-fpurs, and permitted to extcnd at their full growth without fhortening, as far astheir allottedbounds admit, that they may not thoot vigorouny in ufelefs wood, but furninh bearing-fpurs the whole length, being careful to preferve the faid fpurs, and only cut off fuch as cafually decay, or become barren or unfruitful, or that project too confiderably in length in a fore-riglit growth, and cut away any large, barren and old ragged ftumps and fnags, clofe to the branches, leaving only the good natural fpurs; and by cutting off clofe the worn-out fpurs and ufelefs wood fumps, new bearing fpurs are often obtained in or near the fame places in a year or tivo after; and thus, agreeable to the above methods, thefe wall and efpalier-trees are continued always regular and abundantly fruitful to the longeft duration.

Generally obferve, in old trees, or where it may feem neceffary, it is advifeable to have, in any moit vacant parts helow, fome well-placed young wood trained in occafionally, to be advancing between the main branches, ready either for prefent fupply or for any future deficiency.

Likewife obferve in this pruning, that, in cutting cut the unneceftary and improper lnoots, \& $\&$, and re- taining the ufeful, always cut clofe the former, not leaving any bottom ftump or fnag, which would thoot from every remaining eye the enfuing fummer, in a profufion of ufelefs wood; and in the requifite fupply of proper hoots now retaincd, cut off any lateral twigs thereon, clofe to the main thoots, preferving the whole of the latter at their full length, not hortened, which, as in the ftumps, would alfo occafion a production of much unneceffary wood, and retard their forming fruit-fpurs, for bearing; but, being continued intire, will gradually emit natural fpurs at almoit every eye, their whole length.

Sometimes very old Pears and Apple Trees, in walls, efpaliers, \&c. have become almott wholly unfruitful by falfe pruning, all the branches covered with numerous large, projeeting, ragged fpurs, of barren growth, formed by the remaining bottom parts of thortened fhoots, year after year, multiplied and encreafed by every pruning, both rendering the trees very unfightly, and unprolific or bad bearers; and in which cafe, the only remedy is, at this pruning, to cut off all the largeft and moit irregular ftumps clofe to the mother branches, and fometimes natural fpurs will be obtained in or near the places, or fome of the moft unpromifing large, old barren branches may be cut away, leaving young ones to fupply their place; and have alfo young fhoots in training from below, bctiveen the old branches, which, according as the young advance to bearing, may be cut away by degrees; and the trees will thereby be gradually recovered, and furnifhed with a! general expanfion of proper branches for good bearing, being managed agreeable to the foregoing directions in the fummer and winter-pruning and training.

Or where any old wall and efpalier-trees, \&c. either through bad pruning or other caufe, have advanced in large, barren wood, or branches of a decaying or worn-out ftate, the whole may be cut down low, to thoot out in the fpring and fummer, in young wood, and of which to retain a general fupply of the beft regular thoots, cutting away the unneceffary and improper, and train the others to the wall and efpalier, at their whole length, in the ufual manner already explained; and will thus form a fet of new branches, furnifhed with fpurs, for more plentiful bearing, in two or three years, and encreafe in abundant fruitfulnefs by degrees.

In any old trees or othcrs, of the wall and efpalier Pears and Apples, where vacancies or want of wood occur in any particular parts, and that no young fhoots arife naturally in or near the vacancy, it may fometimes be obtained by cutting a notch on the lower parts of any contiguous large branches, which having a fomewhat fimilar effect as thortening, promotes the enilfion of thoots in or near the cut or notched part. 
Sometimes old Pear and Apple trees, being either of bad forts, or become of an unfruitful growth, are cut down in the fpring, and fome of the principal, beft-placed branches are grafted with hoots of any defirable varieties; the larger branches by crowngrafting, or fmaller ones cleft-grafted; and they will thus renew the head of branches, and fooner become good bearers than quite young trees.

Where there are young trees of the wall and efpalier Pears and Apples, that are ftill under training, not furnifhed with the requifite expanfion of branches, fhould, in this pruning, give proper attertion to retain an eligible fupply of the beft-placei young thoots, cutting out the fore-rights, and continue the others at their natural length, and trained to the wall and efpalier in regular order; and, as obferved in the general pruning, extend the whole, both of the prefent and former training, atways in their full growth, except it may appear necefiary to fhorten any particular middle thoots or others, where further fupplies of wood are required in vacant parts to form the neceffary expanfion of branches; but when this is obtained, continue them wholly at their full length, and they will emit and form fruit-fpurs abundantly, and form plentiful bearers in due time accordingly; fome beginning to produce fruit at two or three, others four, five, or fix years old, and fome, efpecially Pears, \&c. on free ftocks, will fometimes be five, fix, or eight years, or more, before they commence tearing in the general branches.

According, in the general pruning, as each tree is proned, it is advifeable generally to train them to the wall and efpalier, nailing the branches of the walltrees with nails and fhreds, and the efpaliers, fome branches may both be nailed occafionally to the ftakes and rails, and others or the whole tied thereto, with Imall ofier twigs, or old, tarred rope yarn; and in all of which arrange the branches horizontally, more or lefs, according to the gencral expanfion, at four, five or $f_{1 x}$ inches afunder, equally to both fides, both in the number and pofition of the branches, all laid fraight and parallel, nailed and tied clofe to the wall and efpalicr in the moft regular order; obferving that where, in the pruning, any confiderable retronchment was made in cutting out unferviceable, large branches in old trees or others; thould now, in the nailing, \& c. be carcful to regulate the others according'y, by training fome higher or lower, that the whole may arrange at equal diftances.

Thus far finifies the general culture of the trees, Shall next give fome intimation s relating to the maturity of growth of the fruit to: gathering, \&x.

The fruit, in the differert varieties of Pears and Apples, acquire maturity, to gather for ufe, from June and July till Oetober, immediately of the trees for prefent occafions; and the late kinds, attaining full growth in September and October, and being then $\mathrm{g}^{\mathrm{a}-\mathrm{m}}$ thered, continue in good perfection all winter. Several of the different forward varieties of the Apples particularly acquire proper growth, to gather for ufe immediately off the trees, both in their young groivith and more advanced fate, in fummer and auturn, in June, July and Auguft, efpecially for varions culinary purpofes, for which Codlins in particular, and fons others, are eligible for thefe occafions, bota when of quarter and half growth and when full grown; and i1: many forts, both of Apples and Pears, they attain a proper degree of mature growth the latter part of fummer and early in autumn, to gather off the trees for immedia'e eating in their naturdl ftate, as defert fruit, \&c. fome earlieft forts in July, but more abundantly in Augult, though thefe will not keep in perfection above a week or two, or fome of the forwarder forts but a few days, efpecially Pcars; but many of the autumn Apples and Pears attaining full growth the be ginning and middle of September, are proper to gather and houfed for keeping a hort tinie, till the late kinds acquire maturity in the latter end of September and in October, for ufe both at that time, and for long keeping in winter, and fome till next fpring and fummer.

The late kinds of Pears and Apples, confifting of many principal varieties, hould generally, or thofe defigned for keeping, be peimitted to have their full growth on the trees before they are gathered for that occafion; they acquiring naturity of full growth, in the different varieties, from the latter end of September to the beginning, middle and end of October, many of them are proper both for immediate ufe, particularly moft forts of the Apples, and fome forts of Pears, and for keeping; but many fineft eating Pears do not acquire maturity for eating till after being gathered and lain fome time in the fruitery; fome probably two, three, or four weeks, others double that time, or unore; and, both in Apples and Pears, many principal varieties continue good in the houfe for feveral months; and all of which are valuable for thcir property of keeping a confiderable tin:e in perfection, and for their generally fuperior quality, both as eating or defert fruit, and all culinary purpofes in which Pears and Apples are commonly ufed; as well as for making cyder and perry; therefore, permitting thefe latc $\Lambda$ pples and pears to remain on the trees till they have full growth, they thould be then gathered accordingly, as they attain perfection: or fome as wanted for prefent fupply, anu a laige portion for kecping.

Or wherc large quantities of Apples are wanted for cyder, or Pears, for perry, many of the autumn kinds of September are proper, if ufed foon aficr being $5=-$ B b thered. 
thered, or before they fpoil or decay; but of the late forts, they may either be ufed for that purpofe, both as foon as gathered, or will admit of keeping longer for that occafion at a future opportunity.

The maturity of full growth in Pears and Apples, after attaining their refpective full fizes on the trees, according to that of the different varieties, is difcoverable fome by changing, more or lefs, to a fomewhat yellowifi colour, and in many alfo by their neellow, palatable tafte and flavour, efpecially of the fummer and autumn kinds, ripening in the end of July and in Auguft, or ea:ly part of September; others, both of thofe forts and the later varieties, not changing colour in any material degree, but either indicate tokens of maturity by their mellow or agreeable flavour, aforefaid, or fome, both of the forwarder and late, or winter kinds, or more generally many of the latter, not difcovering any particular degree of perfection, as above, on the trees, but which, and in Apples and Pears in general, having attained a peculiar plumpnefs in fize, their full growth is apparent by their readily quitting the trees on being plucked, or by gently turning fome of the fruit upward; and likewife often by the fruit frequently dropping from the trees naturally: however as many of the late autumn and winter Pears, \&c. Shew but fmall indications of maturity, while on the trees, it may be obferved that all thefe late Pear's and Apples attain full growth for gathering in the end of September to the middle and end of Oetober.

So, according to the above intimations, of mature growth in thefe fruit, they thould be gathered in their proper feafons, that as many of the fummer and autumn kinds acquire a mellow eatable ftate on the trees, they thould be gathered accordingly, as wanted, for immediate occafions; and the fucceeding and late forts acquiring a more durable ftate, for future fupply, they, in the proper feafon, may be gathered both fome for prefent ufe, and a principal quantity for keeping; as none of the forward forts are eligible for that purpofe, efpecially thofe attaining riponefs before September, which keep good fome but a few days, or a week or two; or othery of the later autumn Pears, \&c. will keep fome timelonger; and therefore allotting moft abundantly of the winter Pears and Apples for keeping all winter, fping, \&c. in the different varieties; for, as above renarked, the forward forts do not keep long after being gathered; but the late kinds attaining full growth from the middle and end of September to the end of Oetober, hould then be finally gathered and houfed for keeping, fome thrce or four, to fire or fix weeks, and many principal forts to keep good feveral months.

Generally, in proceeding to gather Pears and Apples for keeping, chufe dry days, and when the trees and fruit are alfo quite dry; and likewife obferving that, for the fame occafion of good keeping in perfection, they fhould be moftly or all gathered by hand, that they may not be bruifed, as would unavoidably be the cafe if naken down, as fometimes pratifed in the common ftandard fruit, which, by their falling on the ground and againft one another, being confequently much bruifed, foon begin to decay: and therefore all the principal fruit, both on Itandards and efpaliers, \& $\mathrm{c}$. fhould be carefully hand-gathered in bafiets.

Though fometimes any of the more common forts on large ftandard-trees, wanted to gather in laafe for immediate fupplies, and not required for long keeping, may occafionally be thaken down, or efpecially where not convenint to reach or time does not admit of hand-gathering in any confiderable quantity for any prefent ufe required.

According as the Pears and Apples, defigned for keeping, are gathered, they thould be houfed in the fruitery or Come dry apartment; and the different varieties depofited feparately, in proper divifions, upon fhelves, and the floor, \&x. or where previoufly convenient to lay them together in heaps, to fweat and difcharge the watery juices, and then all wiped clean and dry, they will keep the better and be of improved flavour; that in depofiting them finally in the fruitery, it would be eligible, in the principal keeping forts, to lay firft fome clean, dry ftraw, and upon which place the fruit either thinly, more or lefs, thicker together, as room admits, laying them gently, not to bruife one another; and if then clofely covered with clean ftraw, a foot thick, to exclude the external air, damps and froft, they will thereby keep longer found, in good perfection; or fome choiceft eating Pears may be packed clofe in boxes, jarrs, or hampers, having ftraw at bottom, fides, and top; and the whole cfterwards covered thickly with ftraw, as above; and thus the fruit will keep in good condition for winter and following fpring.

Obferve, during the winter, \&c, to examine the fruit occafionally, to draw out fuch as decay in due time, before they affect the others adjoining.

\section{Of the QUINCE. \\ (Py r us Cydonia.)}

The Quince, formerly conftituted a difin denominaied Cydonia, but by the modern botanifts is now ranged as a fpecies of the Pyrus, as being fimilar in the generic cbaracters, confiltent with the fexual botany of Linnxus, and in which we have placed it accordingly, having defcribed the fpecies, and its refpective varieties of the fruit, in the proper place: 
fhall, under this head, proceed to give fome general intimations relating to the fruit and culture of the trees, which being principally raifed in Itandards, and occafionally in efpaliers, and, in both of which, their mode of bearing being nearly fimilar to that of the Pears and Apples, already explained, there is no very material difference in the methods of cultivation.

Quinces, however, are of inferior value to Apples and Pears, with regard to the general utility of the fruit; and a much fmaller postion of the trees is required, or probably not more in proportion than one to ten or twenty, or more, for any general culture for the fupply of a family ; for thefe fruit, although beautiful in their large growth and golden-yellow colour, impart a high fragrance, are moftly too hard and auftere to eat without fome previous preparation in cookery, \&c. and from their very ftrong flavour and tafte, a fmall portion of the fruit ferves for thofe occafions; but as they are likewife ufed for making marmalade and Quince wine, larger quantities will be required accordingly.

The Quince fruit, therefore, being too liard and aftringent to eat raw, are valued principally for fome culinary or kitchen purpofes, in which they, being of a fingular ftrong flavour and tafte, are ufed occafionally to flice in apple pies, tarts, apple fauce, \&cc. to improve the flavour in a high relifh, where required; and, as before intimated, are in eftimation for making marmalade, Quince wine, and fome other domeftic occafions; and for all of which purpofes, the fruit attains perfection in autumn, in Seprember and Oetober, both for immediate ufe off the trees, and being gathered in Oetober, when of full growth, houfed and covered clofe with ftraw, will keep good fome confiderable time to ufe occafionally.

That according as Quinces may be in requeft for the above purpofes, the trees may be admitted in a fmaller or larger portion, from two or three, to feveral or many.

The trecs are cultivated principally in fmall ftandards in gardens, orchards, or any out-grounds, or by the fides of ponds, watery ditches, \&rc. as they delight in moift places; though they will alfo grow in any common foil and fituation; and fome may likewife be trained in efpaliers, in affemblage with thofe of Pears and Apples, but in a fmaller portion, by way of variety to diverfify the efpalier plantations in different kinds of fruit, and the trees will appear ornamental both in their bloffom and fruit, which will alfo acquire an improved growth, and, when full grown, appear beautiful in its large fize, and golden-yellow colour; however, the fruit attains abundant perfeetion onftandards, which mi.y be planted any where in open expofures, and raif- ed both in half and full ftandards, with ftems, three or four, to five or fix feet, and to branch out at thefe heights to form the head.

Thofe trees are of very moderate growth, the brancies flender, producing the bloffom and fruit upon fmail natural fpurs emitted at the fides and toward the extreme part of the branches, nearly fimilar to the pears, \&c. but the bloffoms, \&c. generally come fingly, ard the fruit produced confequently in the fame mainer, only one in a place; and obferving that, as in their n ture of bearing, the fame branches continue mai y years fruitful, furnifhing bearing fpurs quite to their extremity, they fhould not be fhortened, but permitted to extend in their full growth.

They are raifed or propagated, either both by grafting and budding upon ftocks of their own kind, raifed from the feed or kernels of ripe Quinces, or fuckers from the roots of Quince Trees, or occafionally upon Pear ftocks, to have trees of larger growth; and may alfo raife the trees wholly from fuckers, layers, and cuttings, to run naturally without grafting, \&ic. or likewife, occafionally, from the feed or kernels of the Quinces, but thefe will not bear near fo foon as grafted trees, or thofe raifed from layers, curtings $\& c$. of the young branches and thoots of trees of the defired varieties.

Or young ready-raifed Quince Trees, for immediate planting, may be procured of proper growth at the general nurferies in the common planting feafuns.

But when defigned to raife fupplies of the trees, if intended by grafting, \&c. provide eligible flocks, raifed either from kernels of the fruit, or fuckers from the roots, in autumn or fpring, and when of proper growth, of two or three years, or more, graft them in the fpring, or bud them in fummer, upon the proper ftocks, at three, four, to five or fix fect, for Itandardtrees, and at fix or eight inches for efpaliers; or raif the trees wholly from fuckers, layers, or cutting which may be planted in autumn, about Optober, November, and December, or in the fpring; or may for $k$ crncls of the fruit at the fame feafons, either for natural trecs, or ftocks for grafting : the fuckers from Quincc roots are proper to plant off, for the above pulpofcs, when of one or two years growth, and planted in nurfery-rows, and for layers and cuttings, thould generally be of the young wood of a y'ar old, which will root in one year; and all of which young plants may be traincd up in nurfery-rows, either in thocks for grafting, \&c. or continued in their natural dite. as may be thought convenient.

In the above difierent methods, the trees may be raifed in half and full fandards, trained in fingle. $\mathrm{L}_{\mathrm{b}} 2$ 
clean ftems, three or four, to five or fix feet, either grafted, \&c. cr run up in their natural growith, to thofe keights, and then to branch out to form the head accordinglv; or fome may alfo be trained in dwarf ftandards, in low ftems, fix or eight inches, to one or two feet; or alfo for efpalier-trees, in ftems of fix or eight inches, to branch out low in fpreading heads, as obferved of Pears and Apples for the fame occafion; and when, in either of the above methods, the trees have formed heads of two or three, to four or five years growth, they may be finaliy tranfplanted where they are to remain.

The ferfon for planting the trees is autumn or fpring, or any time in open weather, from Octoker or Novemeer, till March or April.

The trees may he planted in ary common foil, either in kitchen gardents, pleature-oronkds, orciards, hedgerows, \&c. as formerly intimated, fifteen or twenty feet afunder, the ftandards, and the heads of which be permitted to branch out every way in their natural manner; and for efpaliers, may plant fome, for variety, in affemblage with thofe of Pears, Apples, Scc. and the branches arranged horizontally to the trellis, at regular diftances, generally at their whole length, to the full $e x t e n t$ of their allotted fpace.

Or Quince Trees may alfo be admitted in Mrubberies and other ornamental plantations in pleafure-grounds; ard in which will difplay an agreeable variety, in their fowering and fruit, in fummer and autumn.

In the general growth of the Quince Trees, their culture is, in the ftandard's, to give only a little occafional pruning, when any diforderly growth in the branches occur; and in the efpalier-trees, they require an annual pruning every fummer and winter, to preferve the requifite regularity in that order of training; and in regard to the methods, both in the ftandard and e?palier pruning, may obferve nearly the fame as directed for Pears and Apples, which in general is applicable to the Quinces, as being fimilar in their growth and ways of bearing, and to which we therefore refer for the particulars, relating to the article of pruning and training thofe trees.

The Quinces attain full growth, for ufe, in September and OEtober, moftly large, yellow, and impart a high odour; and may then be gathered, both for prefent occafions, as wanted, and likewife for keeping, laying them in a dry apartment, and covered thick with clean ftraw, to exclude the air, \&c. and they will keep in perfection fome time, for future ure, as may be required.

\section{EGETABLE SYSTEM}

\section{Fut ther Obferrations relating to the different Species of the Apple, Pear, and Quince Kinds.}

In the different Species, \&c. of the Pear, Apple, Crabs, Quinces, \&c. fome may alfo be introduced, with fropriety, in pleafurable plantations, for variety and crnament.

The Siberian Crab and American Dwarf Apple, being trees of fmall, nender growth, producing fingularly fmall fruit, of the Apple kind, of a curious appearance, are proper to cultivate both fome as fruittrees, in fmall ftandards, efpaliers, \&c. and to plant in fnrubberies, for variety; they ripen fruit in autumn, and are agreeably flavoured, particularly the Siberian Apple, and both forts make a pretty variety in a defert; the trees bcar the fruit in clufters, on fmall fpurs, the fane manner as the Common Apple, and like them raifed by grafting, \&cc. or by layers of the young branches, or occafionally by feed of the fruit; and trained both in fmall, dwarf and half ftandards, to plant detached in borders and other fmall compartments, or alfo fome occafionally in pots; and likewife fome trained in low, fpreading heads, for efpaliers and wall-trees; and in all of which, they, in their mode of flowering and abundant fruitfulnefs, will have a pleafing effeet; and in their culture of pruning, \&c. is the fame as the Common Apples, explained in its proper place.

But the Sweet-fcented Virginia Crab, both of the deciduous and ever-green kinds, are efteemed principally to admit in fhrubberies, borders, \&c. of pleafure-grounds, for variety, in which they will make an agreeable appearance in their ornamental and fiveetfcented fowers; and the ever-green kind continues in verdant foliage the year round; and both forts will fometimes produce fruit very agreeably, more defirable, however, for variety or curiofity, than eating: are raifed by feed or kernels of the fruit, and by grafting or inoculation, and by layers; and trained in low or fmall ftandards; may be planted at the general feafon of removal, in any common foil and fituation, the heads permitted to branch out fully, or give only occafional pruning, to reform any confiderable irregularity of growth, in diforderly branches, \&c.

For ornamental planting may introduce occafionally any forts of Pear and Apple Trees, and Quinces, in tree plantations, to encreafe the variety in their general growth, or more particularly in their bloffoms and production of fruit, which latter will allo be profitable for ufe; but the forts which are more generally employed for ornament or variety, in pleafurable plantations, are the double-bloffom, twice-flowering, and friped-leaved Pear, double-bloffom Apple, and occafionally fome varieties of the Quince, with fometimes the two-year and Fig Apple, tranfparent Apple, \&zc. 
the Siberian Crab, American Apple, and the fweetfcented Virginia Crab, both of the deciduous and evergreen kinds.

Likewife; for forelt-tree piantations, may admit the Pear Tree partizularly, raifed in a natural state, from feed of the fruit and fuckers from the roots, to run up in tall, ftraight ftems, without grafting, or, if thought proper, fome budded or grafted, and trained each with a fingle hoot, to form a tall, clean ftem of fome confiderable length; as the trees grow lofiy and of a large fize, and the wood is uferul in feveral trades, as turners, button-mould makers, \&c. and may therefore admit them in afremblage with other deciduous kinds, as maple, beech, elm, an, oak, \&c. to form timber plantations and coppices of under-wood, and permitted to run up in their natural growth; and for which occafions, they may be raifed either by the kernels of the fruit in a nuriery, and alfo fuckers from the roots of Pear Trees, or fome by budding, Sc. and in all of which train up the plants in clean, fingle ftems, the topfloot entire, to afpire in height; and when three or four, to five, fix, or feven feet growth, tranfplanted where they are to remain, as above; or feeds or kernels may be fowed in drills in the places where the plants are always to ftand, to grow up for large trees, or as required.

Quercus, OAKTRE.E.

Clars and Order.

Monoecia, Polyandria, One Habitation, Many Males;

Or Plants with Male and Female Flowers, diftinct and apart, on the fame Tree, and the Males baving many Stamina.

THE Quercus furnifh many fpecies of fuperior, large, deciduous, and ever-green trees, for ufeful and ornamental plantations, moftly of great utility and value as foreft or timber trees, excceding many others in the ftrength and durability of their timber, growing foriy or fifty, to fixty or feventy, or fome near an hundred feet high, with confiderable branchy heads, garnifhed with middling and largin, oblong and ovate, and fpear-Thape leaves, finuated, pinnatifid, and intire in the different fpecies, and fmall, yellowih male and female flowers, feparate on the fame tree, all without petals or fowerleaves; the males produced in lcofe catkins or amentums, each florct having a five-parted cup, and many fhort ftamina; and female flowers in clofe-fitting buds in hemifpherical, rough, thick, one-lcaved, intire calyxcs, with a 7 oval germen, and fingle, five-pointed fiyle; and the germen grows an oval nat or acorn, fixed into the rough, permanent cup, ripening in autumn; and by which, fowed in that feafor or fpring, the trees are generally propagated..
The Species of OAK, confifting of deciduous and evergreen Kinds are,

\section{Deciduous Kinds.}

\section{Quercus Robur-(Robur) or Common Englilh Oak.}

A moft large, lofty, deciduous tree, growing fixty to near one hundred feet high-the leaves (middlingfize, dark-green) oblong, broadeft toward the top, finkated-acutely, with the angles obtufe.-Native of Er. gland and other parts of: Europe. (Loamy or any common foil.)

Varieties.Common Oak, with the acorns fizting ctofe to the branches.

Common Oak, with pinnatedly-finuated leaves, and acorns on long foo-ftalks. Striped-leaved Common Oal.

2. QurRcus alka-White American Oak.

A large, deciduous tree, growing fifty or fixty feet high, with a whitifh bark - the leaves (middling or large, lighter-green) oblong, obliquely-pinnatifid, with the finufes angular-obtufe.- Native of.Virginia. ( $(A x y$ common foil.)

\section{Quercus nigra-Black American Oak.}

A middling, deciduous tree, thirty or forty feet high, with a dark-brown bark-the leaves (broad upward, Bining-green) wedge-fhape, flightly.three-lobed.Native of Virginia. (Any common foil.)

\section{Qurrcus Prinus-(Prinus) or Chefnut-leaved American Oak.}

A moft large, deciduous tree, fixty or feventy feet high-the leaves (large, long, brigbt-green) oblongovate, pointed at both ends, finuated-fawed; the den. ticles round, uniform; and very large acorns.-Native of North America. (Loamy or common foil.)

\section{QuqReus Pbellos-(Phellos) or Willow-leaved Oak.}

A large, deciduous tree, growing forty or fifty feet high-the leaves (middling, pale-green) fpear-fhape, fmooth, and intire.-Native of North America. (Axy sommon foil.)

Varicries.-Long-leaved, Willow-leaved Oak. Short-leaved, Willow-leaved Oak. Variable-leaved, Willow-leaved Oak. 


\section{VEGETABLE SYSTEM}

\section{Qu s R cus rubia, Red or Scarlet Virginia Oak.}

A large, deciduous tree, growing forty, to fifty or fixty feet high-the leaves (large, bright-green) oblong, finuated, whth the finufes obtufe, briftly-pointed; green in the fpring, changing to a bright-red or fcarlet colour.-Native of Virginia and Carolina. (Aity) common foil.)

$$
\begin{aligned}
& \text { Variety.-Thrce-pointed-leaved Red or Scarlet } \\
& \text { Oak. }
\end{aligned}
$$

7. Quercus Efculus-(Efculus) Horfe-Chefrut-

A large, deciduous tree, forty or fifty feet highthe leaves (broad, light-green) oblong, deeply cut, or pinnate-finuated, and fmooth; and longin acorns fitzing clofe to the branches.-Native of the fouth parts of Europe. (Loamy or any common foil.)

\section{Quercus Cerris-(Cerris) Lyrate-leaved Spa- nifh Oak.}

A large, deciduous tree, fifty or fixty feet highthe leaves (middling, dark-green) oblong, lyrate-pinnatifid, or indented in the middle in a lyrie-thape form, tranfverfe-jagged, in acute points, downy on the under fide.-Native of Spain, Auftria, \&c. (Any common foil.)

\section{QuERCUs Egilops-(Agilops) or Prickly-cupped Spanin Oak.}

A moft lofty, large, deciduous tree, of beautiful growth, fixty or feventy feet high, or more, widely branching-the leaves (middling, pale-green) ovateoblong, fmooth, with the edges fawed-dentated; and acorns in very large, prickly cups.-Native of Spain and the Levant. (Loamy or any common foil.)

\section{Toe following are Varieties of different Species.}

Quercus bumilis, Dwarf American Oak. Quercus oxonienfos, Exeter or Luccombe's Oak.

\section{Ever-green Kinds.}

20. Quer.cus Ilex-(Ilex) or Common Ever-green Oak.

A largifh, upright, ever-green tree, thirty or forty feet high-the leaves (middling, dark-grctn) ovate- oblong, undivided, \{awed, thining-green above, downy underneath, placed on foot-ftalks; and fmall acorns. - Native of the fouthern parts of Europe. (Any common foil.)

\section{Varieties.-Broad-leaved Ever-green Oak. \\ Narrow-leaved Ever-green Oak. \\ Sawed-leaved Ever-green Oak. \\ Intire-leaved Ever-green Oak. \\ Various-leaved Ever-green Oak, with leaves narrow and broad, fome fawed, others intire, and fome prickly-edged; fometimes all on the fame tree.}

I\%. Quercus gramuntia, Gramuntian or Hollyleaved Ever-green Oak.

A largith, ever-green tree, thirty or forty feet high-the leaves (middling, darkiß-green) oblongoval, finuated-fpinous-edged, downy underneath, ferfile or fitting clofe, without foot-ftalks; and glands peduncled or font-ftalked.-Native of the fouth of France. (Any common foil.)

\section{Qugrcus Coccifera-(Coccifera) Scarlet-bear- ing or Kermes Oak.}

A fmaller, ever-green tree, fifteen or eighteen feet high, of bufhy growth-the leaves (middling, brightgreen) oval, undivided and (mooth, with the edges prickly-indented, fcarlet glands on the branches and leaves, called Kermes, ufed in dying.-Native of France, Spain, Italy, the Eaft, \&c. (Any common foil.)

13. Quercus carolinienfis, Carolinian, or American Live Oak.

A largifh ever-green tree, thirty or forty feet high -theleaves (middling, dark-green) ovate-fpear-fhape, intire, and fhort foot-ftalked; and fmall, oblong acorns.-Native of Carolina and Virginia. (Any common foil.)

\section{Quercus Suber-(Suber) or Cork Trec.}

A large, ever-green tree, thirty or forty feet high, having a rough, fungous, and cleft bark, which is the cork-the leaves (niddling, dark-green) ovateoblong, undivided, fawed, and downy on the underfide.-Native of the fouthern parts of Europe. (Any) consmon foil.)

Moft of the fpecies of Oak being of the largeft tree kind, growing with ftems or trunks of a confiderable 
bulk and ftature, more particularly fome of the deciduous kinds, are valuable to cultivate as foreft-trees, for the great worth of their timber, to ufe for many fuperior purpofes where ftrength and long duration is neceffary and required; is of particular value as the principal timber employed in fhip-building, and various other occafions, for ftrength and durability; and for which, cre of the fpecies in particular, the 2uercus Robur, or Common Oak, furpaffes moft of the others in its valt dimenfions of growth in this country, and fuperior quality of its wood, as well as the great utility of the bark of the tree, as the principal material for tanning of leather; and when after being ufed for that valuable purpore, becomes of fingular ufe to the gardener, for making tanner's-bark hot-beds, commonly called tan or bark-beds, peculiarly ufeful in hot-houfes or pineries, for the culture of the Pine-Apple, and in forcing-houfes and frame hot-beds occafiunally; though feveral or moft of the other fpecies, being trees of fuperior growth in height and magnitude of their trunk, are alfo eligible to affemble with foreft-trees, and occafionally in large, ornamental plantations, in parks and any out-grounds; and in all the forts, their production of acorns ripening in autumn, are good to fatten fwine and deer, when they fall from the trees, in September, OEtober, \&c.

In feveral fpecies of the Oak are produced glands, or roundiin, protuberant excrefcences, larger and fmaller, upon the young hoots and leaves in May and June; very abundant in the Common Oak, and which are commonly called Oak Apples, generally occafioned by infects, and are of no particular ufe, except in the 2uercus Coccifera, or Scarlet-bearing. Oak, where the trees grow naturally, being the Kermes, called Scarlet Grain, and is collected for the ufe of dyers, \&c.

All the fpecies of Oak may be employed in exterfive plantations, both as foreft-trees, in large ftandards, for timber, and in under-wood, to ufe in fmaller growths occafiona!ly; likewi ife, to plant, for variety and ornament, in affemblage with other.large trees, in confiderable pleafure-grounds, parks, fields, hedge-rows, and in any out diftricts; but, for ufeful plantations in foreft or timber-trees, the Common or Englinh Oak generally claims preference for principal culture, as fuperior in growth, and for the known value of its wood; and abundance of the trees may be cultivated, to great advantage, in ail extenfive grounds, to form Oak woods, both by raifing the trces in a nurfery, and tranfplanted where they are to continue, and by fowing the acorns in the places where the trees are always to rcmain; likewife, hould introduce fome, or as many of the other !pecies as may be thought expedient, as they will grow to handfome timber-trees, and cffect an agrecable diverfity in the plantations, in their different growths, foliage, \& c.
Or for ornamental planting in confiderable grounds, or to embellin different parts of eftates, any of the fpecies of Oak may be admitted in forming extending plantations in affemblage with other large trees, or in fimilar plantations towards the out-boundary of pleafure-grounds, extenfive lawns, parks, \&c. and in forming clumps, ranges, and fingly, both in parks and any extenfive out-grounds, as above-intimated : or may alfo be introduced in large, running fhrubbery plantations, for variety; or for garden thrubberies. may have principally fume of the fmaller kinds, and. any of the ever-green Oaks, as they will appear orramental at all feafons, in their conftant verdure.

Moft of the Oak Trees are flow growers, and continue, for ages, in an advancing growtis; the Connmon Oak particularly continues growing. many ceraturies.

The Oaks mofly fucceed beft in a loamy ground, and will alfo thrive in any common foil, not very wet or marfhy; or, however, where the ground, intended for plantations, is of a loamy nature, it will be of advantage in promoting a more expeditious, ftrong. handrome growth; but they may likewife be planted fuccefsfully in any common ground, of a fomewhat fertile nature, or of fome tolerable cultivating ftate, as may occur in the places where defigned or convenient to have plantations thereof, either for profit or ornament; though, for the latter, the fertility of the foil is not fo material as for the former, where intended to plant principally for timber plantations.

All the forts of Oaks are propagated or raifed by fowing the acorns in autumn or fpring; and the young feedling plants, when a year old, tranfplanted in nurfery-rows, to advance to three or four, to five or fix feet growth, for the intended plantations, as more fully directed hereafter.

Or young trees, seady raifed to proper fizes, as above, may be obtained at the public nurferies, for planting.

Bat when defigned to have confiderable plantatiors of the Common Oak, and of any other forts, to form Oak woods, for timber-trees and under-wood, it is moft advifeable, where convenient, to raife propes: fupplies of young trees in home nurferies, to a due fize for tranfplanting, as required for thefe occafions; or the acorns fowed at once in the places where the plantation is intended, and the trces to remain where thus raifed, and they cflablining their roots more cffeetually from the beginning, not having any check by tranfplanting, they will generally make the moft profperous trees, of long duration, in a thriving growth; or, however, if raifed in a nurfery, to tranfplant for the forezoing purpoles of timber-srees particularly, it. would 
would be noft fuccefsful to perform it while they are young, of three or four, to five or fix feet high at moft, in which they will more effectually root firmly in the ground, and grow more profperous than fuch as are tranfplanted larger.

The proper reafon for planting Oaks is either in the autumn or fpring, or may be done any time in winter, in open-wenther, from November, to February, inarch, or whoily compleated by the beginning of April.

When defigned to form Oak woods for timber-trees, it may be effected either by young plants previouny raifed from the acorns fowed in a nurfery, and when two or three, to four or five feet high, tranfplanted in the places intended, in rows, four or five, to ten or twenty feet diftance, or the acorns fowed at once in drills where the plantation is intended, and as they remain where raifed, will generally grow more expeditious and profperous than thofe which are tranfplanted, having the ground previoufly prepared for their reception, by ploughing and harrowing; and, in both of which methods, may either be difpofed in wide rows, ten, to fifteen feet afunder, or in clofe rows, only four or five feet diftance, in order that, when of advanced growth, they may admit of thinning out fome of the underling trees gradually, either fome fmall, for tranfplanting, or larger, for other purpofes, and of cutting down fome for under-wood, every eight, ten, or twelve years, and will thoot up again for the fame occafion, leaving a fufficiency of the fineft ftems from the beginning, to run up for large ftandards, at from ten to twenty feet apart at firft; and when thefe are confiderably encreafed in fize, 'fome may be cut down in a thinning order, for fmaller timber, \&c. reciaining the reft at twenty or thirty feet diftance, to acquire fill growth; the retained ftancisds, both in their young and advanced tain, $\Omega_{1+1}$ be pruned up below, by degrees, each in a clean, fingle ftem, preferving the tops intire to run up in height.

Or, where intended to raife a nurrery of Oaks, "for tranfplanting, it is effected in the following manner.

The propagation or method of raifing all the forts of Oaks, being by fowing the acorns, both of the Common Oak, which ripen abundantly every where in auttmn, and of the other forts that can be obtained; all either fowed foon after they are ripe, in autumn, or preferved clofe and dry till the fpring, about $\mathrm{Fe}$ bruary or beginning of March, or as foon as the inrended forts can be procured; or fome are occafionally raifed by grafting or budding on Common Oak ftocks, efpecially any of the foreign forts, of which the acorns are not attainable; or alfo any particular varieties to continue the fame, as the Oaks fe!dom fuccecd well by layers or cuttings; and the grafting, \&ce. is only practifed occafionally in the above inftances, and by which they will take upon ftocks of any of the Oak kind; though, for the general propagation, it is always effected by fowing the acorns.

Therefore, to raife the principal fupply from the acorns, and having procured a requifite quantity of thofe of the Common Oak, for the general plantation, and of fixch others as may be intended for variety, prepare beds of any comnon, light earth, in the autumn or fpring, aforefaid: fow the acorns either in drills two inclies deep, and the drills fix or eight to twelve inches afunder; or by broad-caft, firt raking two inches depth of earth off the furface of the beds, then fcatter the acorns evenly on the bed moderately thick, prefs them into the earth with the back of a . fpade, and cover them in with the earth that was raked off evenly about two inches deep: they will come up in the fpring; keep them clean from weeds all fummer, and when the plants are of one or two year's growth, they thould be tranfplanted, either in the autumn, in Oetober or beginning of November, or in the following tpring, in nurfery-rows, two or three feet afunder, by fifteen or eighteen inches diftance in each row.

In the nurfery-rows, let them have three or four years growth, training each with a clean, fingle ftem, by pruning off the ftrong fide-fhoots, preferving the top-fhoot intire; and when advanced three, four, or five, to fix or eight feet high, they are of proper fize for final tranfplanting.

When defigned to propagate any particular forts by grafting or budding, it may be performed upon any feedling-ftocks of the Common or other kind of Oak; the grafting performed in the fpring, and the budding in July and Auguft; and, in botl of which, train the young trees as above.

The young Oaks raifed as above, to a proper growth for final tranfplanting, three, four, or five, to $f_{1 x}$ or eight feet, as before obferved, they fhould be planted out accordingly where they are to remain, in the proper feafon; have them dug up with as full roots as poffible, and of which, only cut away broken parts, or prune any long, naked, tap-root, of down-right growth, and horten any very long ftraggler; cut off ftrong, lateral thoots from the ftem, or may prune any rambling or very irregular branches at the head, preferving the main top leaders intire, and plant them at the diftances formerly mentioned, five or ten, to fifteen or twenty feet, agreeable to the foregoing intimations, particularly thofe defigned to form Oak woods or any other plantations of the Oak kind, or at ten, fifteen, to twenty or thirty feet, to form clumps, \& $x$. in parks and fields, or in affemblage with other large 
trees, either in forming profitable or ornamental plantatiuns, for the improvement and embellifhment of eftates.

Bat, in forming Oak woods defigned principally for large timber trees, they thould generally either be planted in young growth, or the acorns fowed in the places where the trees are to ftand; and in which latter methoi, as not being tranfflanted, they do not reccive any chec's in their growth: root more effectually, grow fafter, more profperous, and continue of longer duration, in a free growing Itate.

The young plantations for woods, \&x. as above, fnould be defended by fome furrounding outward fence, either a ditch, ftake and buth hedge, hurdles, palings, \&c. and in the young or fmall growth of the rrees, keep them clear from large, afpiring weeds in fummer; and the trees defigned to run for ftandards, both in their young and adranced ftate, have the ftems pruned up from firung lateral hoots, and permit the sops to afpire in height in tieeir full growth.

RHA®NUS BUCKTHORN, comprifing alfo the Frangula, Paliurus, and Alaternus.

\section{$\mathrm{Cl}_{3}$ fs and Order.}

Pentandria, Monogynia,

Five Males, One Female;

Or Plants, with Hermapbrodite Flowers, having five Stamina, or Males, and one Pifillum, or Female.

THE Rhamnus comprifes feveral hardy fpecies of deciduous thrubs, and one ever-green kind; all employed for variety in thrubberies, \&c. are moltly of the large and middling Thrub kinds, of upright growth, fix or eight to tivelve or fourteen feet high; fome armed with thorns, others not; and adorned with middling and fmall, oblong, oval and fpear-fhape fimple leaves, and fmall, greenifh-yellow flowers, in clufters, at the fides and ends of the branches; moftly funnel-Shape, four or five-parted at the top, each containing five itamina, a roundim germen, fupporting a fingle fyle, crowned by a quadrifid ftigma; and the germen grows a fmall, roundifh berry, feveral together, in cluters, furnifhed with three or four roundigh hard fceds, ripening in autumn, and by which, fowed in that feafon or fpring, the plants may be propagated, alfo by layrrs and cuttings.

\section{The hardy Species of RHAMNUS are-}

1. RнamNus catbarticus-Cathartic or Common P'urging Buckthorn.

A large, deciduous Arub, branching irregulasly ten or twelve feet high-armed with terminal thorns: the leaves (middling, dark-green alove) oval, fpearthape, and fmall, quadrifid or four-parted, dioicous flowers, in ciufters, fucceeded by bunches of fmall, roundifh berries; ufed in medicine.-Native of England, \&c. in hedges. (Any foil.)

\section{Varieties._Common larger Buckthorn. \\ Jwarf Buckthorn. \\ Long-leaved Dwarf Buckthorn.}

\section{Rнамхиs Frangula-(Frangula) or Berry-boar- ing Alder.}

A large, deciduous furub, branching irregularly ten or twelve feet high-unarmed or thornlefs; the leaves ( mallifh, dark-green) ovate-oblong intire; and hermaphrodite, monogynous or one-ltyled flowers, in cluiters, fucceeded by bunches of fmall, black, round berries.-Native of England, \&cc. in hedges. ( $\$$ ny roil.)

\section{Variety.-Dwarf Berry-bearing Alder.}

\section{RHAмNus alpinus-Alpine Berry-bearing Alder.}

A large, deciduous Thrub, ten or twelve feet highunarmed or without thorns; the leaves (larger, rough) ovate-oblong, doubly-crenated or notched; and dioi. cous flowers, fucceeded by fmall, round, black berries.-Native of the Helvetian mountains. (Any foil., 4. Rham Nus Paliurus-(Paliurus) cammonly called
Chrilt's Thorn.

A large, deciduous Thrub, with vender, pliant branches, growing eight or ten feet high-armed with thorns in pairs, the lower ones refiexed; leaves ( fmaller, pale-green) ovate-roundin, and clufters of fmall, greenith flowers, trigynous or with three piltils; fucceeded by roundin, comprefied fruit.-Native of $\mathrm{Pa}$ lentine, Italy, Spain, Portugal, the Levant, \&c. (Any common joil.)

This fprcies, as being a naive of Judea, \&c. is by many travellers sippored to be the tree of which was compofed the crown of thorns which was placed on the head of our Saviour, hence called Cbrif?'s Thornthough others fuppofe the following is the rcal plant.

\section{Rнамus Spina-Chrifi-(Spina-Chrifi) Chrifts 'Thorn, win ftraight Spines.}

A deciduous fhrub, with fiender branches-armed with ftraight thorns, by pairs; tlic ieaves (fma!l) oval; 
and rinall yellow fiowers, fucceeded by round berries. - Natire of Paleftine, Syria, Rthiopia, \&c. (Dry, warm fituation, or againft a fouth wall, or fome in foits, to place in a green-boufe in owintir.)

6. Rиамкus lineatus,-Iineated-leaved, Chinefe Rhamnus, called Supple Jack.

A large, deciduous fhrub, with long, pliant ftems and branches-unarmed, or without thorns; the leaves (finall) ovate, lineated, repand or ferpentined, netted on the under fide; and hermaphrodite flowers. Nirtive of China. (Any contmon foil.)

7. RuAM U Alaierrus - (Alaternus) commonTy called Alaternus.

A large, ever-green fhrub, of branchy, buthy growth, eight, ten or twelve feet high, or more-unarmed or without thorns; the leaves (finall, darkgreen) ovate, firm and thining, fawed and intire,. in difierent varieties; and fmall, greenith, dioicous fowers, with a triple ftigma; fucceeded by fmall, round berries: Native of the fouthern parts- of Europe. (Any foil and fituation.)

This fpecies (Alaternus) bears a great refemblance to the Pbillyrea, but differ in the fituation of their leaves, which in the latter grow in pairs oppofite, and in the Alaternis is placed alternate or one above another, fingly..

Varieties.-Common green-leaved Alaternus.
Broad-leaved Alaternus.
Narrow-leaved Alaternus.
Jagged-leaved Alaternus.
Bloached-leaved Alàternus.
Silver-ftriped-leaved Alaiernus.
Gold-ftriped-leaved Alaternus.
Sawed-leaved Alaternus.
Intire-leaved Alaternus..
3. R̆autus lycioides, Lycium-like Spanifh Buck-
thorn.

A middling ever-green Throb, eight or ten feet high-thorny; armed with terminal thorns; the leaves (fmall, dark-green) ovate linear.-Native of Spain. (Warm, dry, fituation.)

\section{Rhannus Olcoides-(Oleoides), or Olive-leaved Spanißh Buekthorn.}

A middling ever-green thrub, eight or ten feet high -thorny, armed with terminal thorns; leaves (Jmall, dark-green) oblong and intire.-Native of Spain. (Warm, dry fituation.).
All the above hardy fpecies of Rlawriks ate ex.ployed in firubbery plantations, to encrease the variety, in their different growths and foliage, and fome to introduce as ornamental fhrubs, particularly the Alaternufjes as elegant ever-greens, more beantiful for decorative planting than moft of the deciduous fpecies of this Genus; though none of the fpecies thereof are of the ornamental-flowering kind; at leat, the flowers, being fmall and of a greenifh colour, they do not make any confpicuous appearance; but the plants, trained in bufhy ftandards, ferve to diverfify large Thubbery compartments, in affemblage with other firbs and trees; or the Alaternus, however, in its different vz. rieties, being very fine ever-greens, are defirable thrubs to affit in adorning: the principal thrubbery clumps, fpacious borders, and other pars of pleaforegrounds, for ornament; and the Common Buckthorts is fometimes planted for outward hedges, but is inferior to the hawthorn for that purpofe.

The above different fpecies of Rbamrus are moftly hardy to grow in any common foil and fituation; are generally of a free growth, with branchy, full heads, clofely garnifhed withleaves, and produce flowers in May and June, fmall and greenifh, moftly hermaphrodite, $c t$ fome dioicous, or male and female apart, on feparate trees; fucceeded by plenty of berries in the Comman Buckthorn, Berry-bearing Alders, and the Alaternus, but not fo common in the others in this country; are of utility principally for fowing, or fome for medicine; and where the berries for fowing are not attainable, all the forts are raifed abundantly from layers.

They are trained principally in Atandard ' hrubs, to Granch out in full heads, either branchy from the bottom, or occafionally pruned up below to a fingte: ftem, one, two, or three feet, or more, and to branch out buthy above.

Or the Alaternuffes are alfo proper to plant in a fpreading expanfion againft walls or buildings, in fore-courts or other parts where required to have naked walls or palings, \&c. covered therewith to appear. green at all feafons; and for which occafion the Bloached and Striped-leaved kinds are generally preferred, though the common green fort, in its ftronger growth, will fooner fpread and effect the intended purpofe; however, any or all the varieties may be employed, planted clofe to the walls; \&c. two or three feet afunder, and the branches expanded and nailed to the wall or palings; and in their advancing growth, cut off all projecting thoots in fummer and autumn.

Likewife the Alaternuffes were formerly trained into ornamental, ever-green hedges, though are feldom ufed now for that purpofe, as in the prefent ftile of laying out gardens, moft forts of internal hedges are rejęted. 
Mof or all the foregoing fpecies of Rhamnus, may be obtained at the common nurferies for planting, of two or three to four or five feet growth, and may be planted in the autumn or pring or any time from October to March or April, in open weather; ir all the forts may be raifed by the different methods of propagation.

They are propagated by feed, layers and cuttings; by feed, pmcure the ripe berries, or feed; in autumn or fpring, of fuch forts as ripen in this country, or can be obtained; fow them in beds of light earth, -ach fort feparate, about an inch deep; they will come up in the fpring, or fometimes not all freely till the fecond year; and when the plants are one or two years old, tranfplant them in nurfery-beds, and trained to a proper fize for final tranfplanting; or by layers of the young branches in autumn or fpring, lit-layed, or cutting a fmall gafh on the under fide, laying that part in the earth, raifing the tops above ground, they will readily emit roots and be well rooted for planting off in autumn following; and by cuttings of the young twigs, in molt of the forts, planted in the above feafons, will put out roots and grow, though not all fo freely as the layers; and generally obferve of the Alaternuffes, that the Bloached and Striped-leaved kinds, and other varieties, muft be propagated principally by layers, cr occafionally by cuttings, or budding, \&c. as they do not come with certainty the fame from feed; and thus, in the above different methods of propagation, the young plants being planted in the nurfery, train them two or three years, or more, to a proper growth for final tranfplanting.

When the plants are advanced two, three, or four feet high, they are of proper fizes for tranfplanting freally into the intended plantations of fhrubberies, \&ec. where they are to remain; and in which permit them to branch out in full heads, either branchy from the bottom, in fome, pruned up below, more or lefs, to branch out above; and in all of which, may advance in full growth, or only prune rampant, runaway, or other very irregular hoots and branches, to continue the heads in fomewhat regular order.

\section{RHODODENDRON, DWARF ROSE-BAY.}

$$
\text { Clafs and. Order. }
$$

$$
\begin{aligned}
& \text { Decandria, Monogyria, } \\
& \text { Ton Males, One Femele; }
\end{aligned}
$$

Or Plants with Flowers (Herm.) having ten Stamina, or Male Parts, and one Pifillum, or Female

THE RHODODENDROR: confift of feveral fpecies of fmall and middling, deciduous and ever-groen fine ornamental flowering-hhrubs, growing two or three to fix or eight feet high, moftly of bufhy growth; garnifhed with oval and fpear-hape leaves; and rotate or wheel-form, funnel-fhape flowers, in clutters, and fingly, at the ends and fides of the branches; having monophyllous or one-leaved cups, cut into five parts, a monopetalous, wheel-fur:1,el-fhape, five-parted corolla, ten finall ftamina, a five-cornered gernen, fupporting a fingle ftyle, crowned by an ebtufe fticrma: and the germen becomes an oval, quinqueloculas capfule, containing many fmall feeds, by which the plants may be raired, alfo by layers and fuckers.

\section{RHODODENDRON birfutum-Hairy-leaved Rl:O- dodendron.}

A rmall, deciduous under-thrub, two or three feet high-the leaves (finall, flining) ovate-\{pear-(hape, hairy-ciliated, naked ; and funnel-pape pale-red fow:ers, in bunches, at the ends of the branches; May and June.-Native of the Alps, Aultria, and Stiria. (Any dry foil.)

2. RHODODENDRON ferrygireum-Ferrugineous, c: Iron-coloured Rhudoderidron.

A fmall, deciduous thrub, about three feet high the leaves (small) fpear-fhape, fnooth, with the under fide leprofy or fcurfy iron-coloured; and funnelThaped, rofe-colourcd flowers, in bunches at the ends of the branches, in June.- Native of the Alps and Pyrenean mountains. (Any moderatcly-dry foil.)

\section{RHODODENDRON maximum - Greater Laurcl- leaved Rhodociendron.}

A middling-fize, molt beautiful ever-green thrubs, fix or eight feet high, of bufhy growth - the leaves (moderately-large, light-green) oval obtufe, glonty-hining and veined, with the margins acute reflexed; and reddith flowers in coryribus bunches, the peduncles one-flowered.-Native of Virginia. (Any moderatelydry foil.)

\section{RHODOEENDRON particum-Pontic, Laurel-leav: ed Rhododendron.}

A moderate fize, very beautiful ever-green Mrub, five or fix feet high, of bufhy growth - the leaves (middling, darkcr-green) fpear-thape, fmooth on both fides, gloffy; and terminal racems of large, purple flowers, June, July, \&ec.-Native of the Eaft and near Gibraltar. (Any comrron foil.)

$$
\text { C } 52 \text { S Rно. }
$$




\section{RHODODEN DRON datricu-Daurian Dwarf Rofe-} Eay.

A finall, deciduous under-Mrub, two or three feet high-the leaves (jmall) oval, fmooth and naked on both fides; and larger, wheel-thape, rofe-coloured flowers, in June.-Native of Dauria. (Moderatelyiry joih)

\section{RHODODENRRON Cbamacifus-(Chamæciftus)} or Dwarf-Ciftus of Mount Baldi.

A fmall, deciduous. Thrub, two or three feet highthe leaves (fmall, Bining) ovate-1pear-fhape, ciliatid hairy edged, and rotated or wheel-fhape; purple fowers.-Native of Mount Baldi. (Moderately-dry foil.),

Of the forcgoing $\sqrt{ } \mathrm{ix}$ fpecies of Rhododendron, the frif four forts are the moft generally known in the nurferies and garden plantations, and of: which the two latter are greatly. efteemed both as moft beautiful ever-greens, and fine elegant flowering-Thrubs; tho' all the forts are very ornamantal in their flowering; proper to plant for variety and ornament, in the principal and mott confpicuous thrubbery-compartments, difpored moftly towards the front, in affemblage with nther curious thrubs of fimilar growth; and in which they will make an agreeable variety, beautiful in their flowers in fummer, and the ever-green kinds particularly will both appear ornamental in the continuing leaves all the year, and alfo fingularly delightful in their feafon of flowering:

They fould have a moderately-dry foil, and-fomewhat fheltered fituation.

Moft of the fpecies are cultivated in the public. nurferies, where they may be obtained for planting, efpecialiy the firft four forts, before remarked; and may fometimes be had in pots, in particular the ever-green kinds, to tranfplant with the ball of earth about the roors.

\section{They may be planted in autumn or fpring.}

All the forts are propagated by feed, and occafionally by layers, and fometimes by fuckers: fow the feed in the fpring, in a bed, or pots of light earth; make the furface fmootl, fuw the feeds thereor, and cover them in with fine mold, a quarter or near half an inch deep; or pots with the feeds may be placed in a gentle, open hot-bed, to forward their germination, and juft to hring up the plants fooner in a free growth, then placed in an eaft border all fummer, and Theltered in winter, and in fpring tranfplanted; giving them protedion for a year or two in winter, from froft, till they attain a little ftrength; likewife by layers of the young thoots both of the deciduous and ever-green kinds, in autumn or fpring, or may try cuttings in the fpring in pots, affifted by a bark-bed or other hot-bed; or where any fuckers occar, plant them off in the fpring or autumn.

When the plants raifed as above are advanced one or two feet high, they may be tranfplanted in the fpring into the thrubbery, \&c. where they are to remain.

R.H U S, S UMACH, and Toxicodendron.

$$
\begin{gathered}
\text { Clafs and Order. } \\
\text { Pentandria, Trigynia, } \\
\text { Five Males, Three Females: }
\end{gathered}
$$

Or Plants: with Hermaphrodite Flowers, having frot Stamina, or Males, and three. Piffillums, or Femals Parts.

THIS Genus furnifies féveral 'pecies of hardy deciduous, moderate tree and Thrub kinds, motly. upright, and fome of trailing growth; all principally. to:plant for variety and ornament in hrubberies, \&c. growing three, four or five to ten, fifteen or twenty feet, in the different species; fome garnifhed with long pinnated leaves, of many pairs of folioles, all terminated by an odd one, others with fimple leaves, and fome trifoliate, or compofed of three lobes; and numerous fnall, pentapetalous, purple and other coloured flowers, at the termination and fides of the branches, in fingular paniculated fpikes, and fome in clifters; having fmall, five-lobed, permanent calyxes, five fmall, oval petals, containing five hort ftamina, a roundifh germen, very fhort ftyle, or rather three fmall Atigmas; and the germens grow fmall berries, furnifhed witl roundifh feeds, not generally ripening in this country, in all the fpecies; and by which, obtained and fowed in the fpring, the plants are raifed, alfo fome by layers, cuttings, and fuckers.

\section{SUMACH Ǩinds.}

\section{Rhus Coriaria-(Coriaria) or Tanner's Sumacli.}

A.finall, deciduous tree, eight or ten feet high, of irregular branchy growth-the leaves (large) pinnated, of feven or eight pair of oval-fpear-niape lobes, obtufely-fawed, and the under-fide hairy; and clofe fpikes of whitilh-yellow, flowers, in loofe panicles, at the end of the branches.- Native of Turky, Paleftine, \&c. where the branches and bark. are ufed for tanning of leather. (Any, conmon foil.). 


\section{Rнus typhinum, Stag's Horn, Virginia Sumach.}

A fmall, deciduous tree, ffteen or eighteen feet high, with crooked, irregular branches and thoots, covered with a velvetty down-the leaves (large, dark-green) pinnated or winged, of fix, feven, or more, pair of fpear-Rhape lobes, Charply-fawed, and downy on the under-fide; and clofe tufty fpikes of flowers at the ends of the branches, fucceeded by large, woolly, purple fpikes of feeds, remaining in autumn and winter.Native of Virginia. (Any common foil.)

\section{Rн Us glabrum, Smooth or Scarlet Sumach.}

A fmall, deciduous tree, ten or twelve feet high, with irregular fpreading branches-the-leaves (large) pinnated, of many pair of fpear-Thape fawed lobes; naked or fmooth on both fides; and large terminal paniculated fpikes of a deep-red or fiarietcolour.-Native of North America. (Any commin foil.)

Variefy, - Carolina Scariet Sumach - with large compact panicles of bright-red flowerfpikes.

4. Rнчs Cofallinum-(Copallinum) or Lentifcusleaved Sumach.

A deciduous (hrub, fix or eight feet high, with fpreading branches-the leaves (middling) pinnated, of four or five pair of narrow fpear-\{hape intire lobes, with the foot-ftalks having membraneous borders, and jointed; and terminal loofe panicles of yellowifh flowers. - Native of North America. (Any common foil.).

\section{Rния Coiizus-(Cotinus) Venice Sumach, or}

A deciduous hrub, ten or twelve feet high, with irregularfpreading branches-the leaves (middling, ligbtgreen) fimple, or of one lobe, obverfe-oval; and bunches of purple and white flowers at the ends of the branches.-Native of. Italy,. Spain, \&c. (Any sommon foil.)

\section{Toxicadendrons, or. Poifon Treez.}

6. R*us Toxicodendron-(Toxicudendron) or Downyleaved Poifon Tree:

A decidious thrub of five or fix feet growth - the Item radicant or emitting roots; leaves (large) ternate or trifoliate, of three ovalioh lobes, foot-ftalked, angulated, indented and downy; and fhort fpikes of greenifh fowers.-Native of Virginia and. Canada; the wood poifonous. (Any common foil.)

V.aricties.-Indented Downy-leaved Poifon Tres.
Intire-leaved Downy Poifon Tree.

Greater Rough Downy-leaved Poifon Tree.

\section{Ravs radicans-Radicant Smooth-leaved Poifor Tree.}

A deciduous thrab, of trailing and upright growth, three or four, to five, fix, or eight feet-the item radicant, or emirting roots; leaves (middling) trifoliate, of three ovate intire lobes, foot-1talk naked or mooks. and loofe panicles of greenifh flowers.-Native of Virginia and Canada. (Any common Joil.)

\section{Varieties.-Smaller traiing frnooth Poifon Tree. Larger twining-ftalked fmooth Poifosg Tree. \\ Upright fmooth Poifon Tree.}

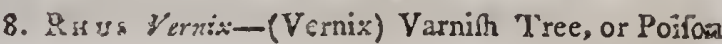 AR.}

A middling deciduous tree, growing twenty feet high, or more-the leaves (large, dark-coloured) pinnated, of three or four pair of oval-fpear-fhape intire lobes, with the foot-ftalks intire and equal; and panicles of greenifh Alowers.-Native of North America and Japan; fuppofed the true Varnin. Tree from which the Varnifh is obtained. (Any commonfoil, warmfituation.)

\section{Rнus fuccedanum-Succedanous, or fpurious. Var- nifh Tree.}

A modèrate tree or Shrub-the leaves (middling, Bining) pinnated, of three or four pair of intire lobes, perennial.-Native of Japan and China. (Any common foil.)

Thefe eight or nine fyecies of $R$ bus are cultivated principally for ornament and variety, in Shrubberies, and other decorative plantations, ir. pleafure-grounds, in aftèmblage with other ornanental thrubs and trees, in which they form a confpicuous variety in their pinnated, and trifoliate, and fimple leaves, in fummer, when properly contrafted; and leveral of them alro in their long paniculated fpikes of Howers; and in fome of the Surrach kinds, purticularly, they diftinguifh themfelves agreeably at all feafons: their elegant pinnated foliage and large panicles in funimer and autumn, difplay an entertaining diverfity, and appear fingular in winter, in their large ftag-horn-like, brown, velvetty fhoots, terminated by the continuing large, red panicles of downy feeds: likewife the Toxicodezdrons ferve to encreafe the variety in an agreeablemanner, in their different growths, foliage, and flowers; though the latter being fmall and grecrifl, are not conspicuoufly ornamental. 
All the forts flower in fummer, about May, June, July, \&c. continzing, in moft of the Sumachs, conficuous till autuinn, in their large red fpikes, but are net generally fucceeded by plenty of feeds in this countiy; but thefe, however, for fowing, of the forts ufually or occafronally raifed therefrom, may be obtained a: inc nurferies and principal feed hops in the fpring.

The plants of all the fpecies are hardy to grow in the open ground, in any common foil and fituation, in general with other hardy fhrubs; and may all be obtained at moft of the principal nurferies, of proper growth, of two, three, or four feet, for planting in the proper feafons of autumn or fpring; or may be planted any time in open weather, from Oetober till March or April; placing them in thrubberies, clumps, fpacious borders, and any decorative plantations of thrubs in pleafuregrounds, in which difpofe them in a diverfified order, and more or lefs towards the front, or backward, in their refpective compartments, according to their different growths.

They are propagated or raifed by feed, fome by layers and fuckers, and others by their radicant or rooting branches.

By feeds, all the forts may be raifed, or of fuch as the feeds are attainable, and by which, mott of the Sumachs in particular, are occafionally propagated; as may alfo any of the other fpecies: fow the feed generally in the fpring, in a bed or border of light earth, or in pots of fimilar foil, and covered in with earth, half an inch to an inch deep; or, if fowed in pots, fome might be plunged in a moderate tan or dung hotbed, and the plants will fooner come up; but fhould be expofed to the full air: give water in fummer, and protection from fevere froft in winter; and when the plants are a year old, plant them in nurfery-rows, to advance in proper growth, two or three years, to an eligible fize of two, three, or four feet, for final tranfplanting where intended, in thrubberies, \& c .

By layers, any of the forts with pliant branches may be propagated in autumn or fpring, chufing the lower young wood, lit-lay or gafh the under fide a little, laying that part in the earth; they will root freely, for planting off from the parent plant, the following autumn.

And by fuckers and rooting branches, the Sumachs and fome of the others, of ten fend up many fuckers from the roots, which may be planted off in the autumn or fpring, either in the Anrubbery, \&c. to remain, or in the nurfery for a year or two; and infeveral of the Toxicodendrons, they propagating both by the rooting ftems and branches, and by fuckers, may befeparated with roots, and planted in nurfery-rows, or fome at obee where they are to remain.
In the above different methods of raifing the? plants, generally in the tree kinds, run them with a fingle ftem, two or three feet, or more, to branch out above; and the others of nore inrubby growth, may branch out below, or quite from the bcttom; and, in all of which, when of fome advariced growth, two or threefeet, are proper for the nirubbery; permit them to branch out in full heads, according to their natural order; only prune occafional rambling or very irregular thoots and branches; and clear off fuckers from the routs.

\section{RIBES, CURRANT TREE, ard GoOsEBERR. BU.S.H.}

-Claís and Order.

Pentandiria Monogynia,
Five Males, One Female;

Or Plants with Hermapbredite Flowers, having fise Stamina, or Males, and one Pigillum, or Femaico

THIS Genus, Ribes, by the laws of Botany, comprife. the Currants as the original, and the Grofilataria or Goofeberry as fpecies of that family, confifting of feveral fpecies of each; moftly valuable for their large production of berries, excellent both as culinary and table fruit; are all of the deciduous hrubby kind, of buihy growth, garnifhed with middling and fmall fimple tri-lobated leaves, and very fraall pentapetalous greenifh ftowers, produced in fmall clufters along the fides of the branches; having in each flower a monophyltous or one-leaved, bellied, five-lobed calyx; a corolla of five fmall obtufe petals, attached to the border of the cup; including five hort ftamina, a roundifh germen under the flower, fupporting a bifid internal ityle, and the germens grow globular and oval, umbilicated berries, fmaller and larger in different fpecies, of one cell, full of a juicy pulp and many fmall feeds, by which the plants may be raifed, but more generally propagated by cuttings and fuckers.

They confift of feveral fpecies, farnifhing many varieties of the fruit.

\section{Currant Kinds;}

Hoving fmeoth or thornless Branches, largef Leaves, and the Flowers and. Fruit in longef pendulous Clufters.

1. R1 BES rubrum, Red-fruited, cr Common Currant Tree.

A middling deciduous thrub, of bufhy growth, four, five, or fix feet high, or more-unarmed or thornlefs; the leaves (middling) tri-lobated or cut in three lobes; and fmooth pendulous clufters of plane flowers, fucceeded -by bunches of fmall berries.-Native of 
Englind and other parts of Europe, in koods and. hedges. (Any foil and fituation.)

Farietics of the Fruit.-Common fmall Red Currant; Fune, Fulj, Auguf, Ẽc.

Large Red Dutch Clirrant; Fune, Fuly, Auguf, $\sigma^{\circ} c$.

Long-bunched Red Currant; $\mathcal{F} u n e, \mathcal{J} u l y$, Auguft, \&ैc.

Pale-red, or Champaign Currant; Fune, $\mathcal{J} u l y$, Auguf, $\mathfrak{E}^{\circ} \mathrm{c}$.

White Currant; June, Fuly, Auguff, Eेc.

Large Dutch White Currant; Fune, $\mathcal{F}_{u l y}$, Auguf, Eंc.

The above different varieties ripen in June, Jufy, and Auguf, continuing to September or Odtober.

\section{Varieties of the Tree. - Y ellow-bloached-leaved Cur- rant Tree. \\ Siver-Atriped-leaved Currant Tree. \\ Gold-ftriped-leaved Currant Tree.}

\section{R1zEs rigrum, Black Currant Tree.}

A middling or largifh deciduous thrub, growing five or fix feet high, or more, of bufhy growth, with ftrong brown thoots-unarmed or thorniefs; the leaves (larger) trislobated; and hairy clufters of oblong flowers, fucceeded by. bunches of larger black berries, of a frong flavour; and the whole plant of a ftrong rank fcent.- Native of Sweden,. Switzerland, \&c. (Any. foil and fituation.)

Variety. - Pennfylvanian Black Currant Tree, with fmaller fhoots, leaves, and fruit; not fo rank-fcented.

\section{Kr BES alyinum, Alpine eredt-flowered Currant- \\ Tree, or Sweet Alpine Currant.}

A fmall deciduous firub-unarmed or thornlefs; the ieaves lobated; and erext flower-clufters, with the bracrea longer than the fower, and fmall fweet-fruit. $-\mathrm{Na}$ tive of Sweden, Helvetia, and England, in hedges. (Anyfoil.)

\section{GoOSEBERRY T'RIBE;}

Hawing prickly Branches, finuller Leaves; and tbe Floweers and Fruit in fraller Clufters, fitting clofer, and the Fruit larger, round, and wval.

\section{Rı веs Grofularia-(Groffularia) Grofiar or Com- mon Goofeberry.}

A deciduous bushy Shrub, four or five feet high-the branches prickly; the leaves (fualler) tri-lobated, with petioles or foot-falks ciliated hairy, and large hairy
berrics.-Native of England, and moft parts of Europe. (Anj, foil and fituation.)

5. R1вES (Grofularia) reclinatum, Reclining-branched Goofeberry.

A deciduous buthy fhrub, four or five feet highbranches fomewhat prickly and reclining; the ieaver (broader) tri-lobated; peduncles or flower-ftalks threeleaved, and large fruit:- Native of Germany, Switzerland, \&c. (Any common foil.)

\section{R1вEs (Groflularia) oxyacanthoides, Hawthorn-like, molt prickly Goofeberry Tree.}

A larger deciduous thrub, five or fix feet highbranches prickly on all fides; leaves (larger) tri-loba. ted.-Native of: Canada, Hudfon's Eay, \&ee. (Ang) foil.)

\section{Riв ks (Grofularia) Uva crifpa-(Uvz crifpa) or fmooth-fruited Goofeberry Bulh.}

A deciduous buthy fhrub, four or five feet highbranches erest, prickly; theleaves ( $(m a l l)$ tri-lobated; fmooth berries, with the pedicles one-leaved.-Native of the northern parts of 'Europe. (Any foil.)

\section{RI BE.S (Groffularia) cynofbati-Prickly-fruited Goofeberry.}

A deciduous thrub, three or four feet high-the branches prickly, moftly at the axillas or angles: leaves (Small) tri-lobated; berries prickly, growing in clufters.-Native of Canada. (Any foil.)

Of the cultivated Goofeberry Trees, are numerous varieties of the fruit, of round and oval berries, fmaller: and larger; confifting of reds, greens, yellows, and whites, and of fmooth and hairy kinds. viz.

Reds.

Small Early-Red Goofeberry; Fune. Early Black-Red Goofeberry; Jume Hairy-Red Goofeberry; $\mathcal{F}$ une and $\mathcal{J} u l y$.

Smooth-Red Goofeberry; June and $\mathcal{F}_{\text {uly.. }}$ Deep-Red Goofeberry; Fune and Fuly.

Large Black-Red Goofeberry; June and July.

Damfon Black-Red Goofeberry; Fune and Fuly.

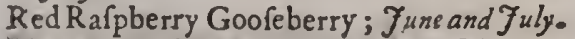

Mogul, or Large Tawney Goofeberry: June and $\mathcal{J u l l y}_{\text {. }}$

Warsington 
Warrington Large-Red Goofeberry; $\mathcal{F}$ ix: and $\mathfrak{Y}_{u l y}$.

Red Globe Gooreberry; June and Tuip.

Long-Red Goofeberry; ' $\mathcal{f}$ use and ' $Y$ risy.

Red-Oval Gooleberry; $\mathcal{F}$ une and $\mathcal{F} u$ iy.

Rough-Red Goofeberry; Fune and Jully.

Smooth-Scarlet Goofeberry; Fure and $\mathcal{F} u 6 \%$.

\section{Greens.}

Early-Green GocTeberry; Yume.

Hairy-Green Goofeberry; June.

Smooth-Green Goofeberry; $\mathcal{f}$ use and Tuly.

Green Gafcoign . Goofeberry; $\mathcal{F}$ une and July.

Green Walnut Goofeberry; Fune and.Fuly.

Green-Gage Goofeberry; $\mathcal{J}_{u n e}$ and $\mathcal{F}_{\text {uly. }}$

Green Globe Goofcberry; June and ' Fuly.

Green Dorington Goofeberry; June and July.

\section{rellowes.}

Early-Yellow Goofeberry; I Iune.

Yellow Globe Goofeberry; Tune and Juily.

-Great Oval-Yellow Goofeberry; June and July.

Long-Yellow Goofeberry; June and July.

Great Amber-Yellow Goofeberry; 'June and $\mathcal{F} u l y$.

Golden Goofeberry; $\mathcal{F}$ une and $\mathcal{J}_{u l y}$.

Hairy-Amber Goofeberry; June and Fuly.

\section{Wbites.}

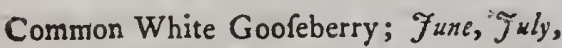
and Auguf?.

Large Globe-White Goofeberry; June, Fuly, and Augufs.

Large Oval-White Goofeberry; $\mathcal{J}_{u n e}, \mathfrak{F}_{u-}$ b, and Auguft.

Great White Cryftal Goofeberry; $\tilde{J} u n e$, Fuly, and Auguf?.

White-Veined Cryftal Goofeberry; June, fuly, and Auguft.

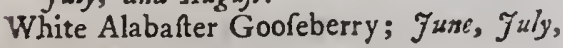
and $A u g u f$.

White Walnut Goofeberry; $\mathcal{F}_{u z e}, \mathfrak{f} z l y$, and Auguft.

White Mogul Goofeberry; Fune, July, and Aingufs.

Other varieties of different colours, as above, known by the following names-

Rumbullion Goofeberry; $\mathcal{J}_{u n}, \mathcal{J}_{\text {uly }}$ and Anguft.
Great Ironmonger Goofeberry; $\mathcal{F}$ ure, $\mathcal{f} \mathrm{u}$ ly, and Auguft.

Srnooth Ironmonger Goofeberry; $\mathcal{J}_{u m e}$, 'fuly, and Auguft.

Kunt's Goofeberry; June, July, and Ausult.

Liairy-Globe Gcofeberry; $\mathcal{F}_{u n e}, F_{u l y}$, and Auguf?.

Lancalinire Goofeberry- (many forts) june, Tuly, a: Auguft.

Large Champaign Goofeberry; $\tilde{J} u n e, ~ \tilde{J} u$ by, asid Augu/t.

In the difierent varieties of Goofeberries the early forts ripen in June and beginning of July; the others from the end of June and beginning of July to the. end of Auguft.

The above being the general principal varieties of Goofeberries, there are many others of the fame colours, firapes, \&rc. which of late years have bsen raifed from feed in Lancahire, and other parts, differing only principally in regard to fize, and darker and lighter colours, \&r. and are encreafing annually, and denominated either by the names of the perfons or places where raifed, or various fancy names.

The different varieties of Currants and Goofeberries ripen their fruit in June, July, and Auguft; and if, when ripening, fome are defended with nets, or garden-matts, from the birds, and thaded from the fun, they will continue ionger in perfection; or Currants planted in different fituations, and fome againft walls of different afpects, will be obtained early and late, in fucceffion, for two or three months; or, if protected from bira's, and Thaded from the fun, as above, they may be continued in good maturity till October or November.

The plants of all the fpecies and varieties of the Currant and Goofeberry, are hardy Mrubs, of buthy growth, generally branchy from the bottom, and moftly very procuctive of fuckers ad vancing from the roots, but which fhould be cleared away, kept to clean fhort ftems bclow; and regular buifhy heads above; produce their fruit both on the young fhoots, and on the oider wood upon fmall natural fpurs and fnags along the fides of the branches; and the fame branches and fpurs continue feveral years in good fruitfulnefs; and according as they become very old or worn-out, they being pruned out, retaining young wood to fupply the place, the bufhes may be continued long in plentiful bearing, and the fruit large; keeping the branches moderately-thin and regular, and not too greatly fhortened or cut down in a ftumpy manner, or only jult to prune long rambling thoots, to preferve the head regular, as hereafter more fully explained. 
They are trained principally in ftandard-bufhes, for the general plantation, with a fhort ftem, fix, to twelve or fifteen inches, to thoot out branchy above, in bufhy heads, and planted in rows in the open quarters of a kitchen-garden, or where required; and fome trained in a fpreading growth, againft walls, palings, and efpaliers, more efpecially Currants, to produce early, larger, and late fruit; or like:vife a few Goofeberries againft walls, "\&c. both to furnifh fome early green fruit for tarts, and fome for early ripening.

Thefe buthes have general merit to cultivate plentifuily in every garden, for the great ufefulnefs of their abundant production of berries, proper for ufe feveral months in fummer, in their young green growth and ripe ftate together; more efpecially the Red and White Currants, and the Goofeberries; but not fovaluable in the B!ack Currants, which, on account of its peculiar ftrong flavour, is not in general efteem as a table fruit; it being more valuable to prepare in a medicinal way, particularly for fore throats or the quinfey, in which they are efteemed of great efficacy; and hence are often called Squinancy Berries.

Eut the Red and White Currants, and the Goofeberry, aforefaid, are valuable family fruit, excellent both when young and green, efpecially the Goofeberries, as fome of the firt ufeful green fruit for tarts, pies, fauces, \&c. in April, May, and June; alfo in their full-grown and green ftate, for bottling, to keep for autumn and winter; and when ripe in June, July, and Auguft, are moft agreeable and wholefome eating fruit; and the Currants likewife, of the Red and White linds particularly, are fometimes ufed occafionally, while green, for tarts, \&c. but in their mature ripe growth, are fine and refreshing to eat raw; and the Red kinds, in their ripe tate, are alfo exceedingly ufeful for tarts, pies, currant jelly, \&c. and both Red and White forts are efteemed for Currant wine; and for which occafions, are in perfection from June to September; or fome may be continued, in good maturity, on the trees till Oetober or November, if Thaded from the fun in autumn, and defended from the birds.

So that in confideration of the great utility of thefe fruit, both of the Red and White Currants and Goofeberries, for the fervice of a family, and profitable to raife for market, great plenty of the bufles thould be admitted in every garden, botli of large and fmall extent; having the principal fupply in itandard-buthes, as before intimated, for the general production, planted in a row round the quarters of a kitchen-garden, fix or eight feet afunder; or fome in crois rows to divide large quarters of ground into breaks of twenty or thirty, to forty or fifty feet wide; likewire, in extenfive grounds, are planted in contiaued clofe plantations, in rows, fix, eight, or ten feet afunder, by fix feet in each row, as commonly practifed in many of the large kitchen-grounds round London, to furnish confi derablequantities of fruit for the markets of that metropolis: Rould likewife allot a portion for training aguint? ivalls, particularly the Currants, to improve the fize and flavour of the fruit; or alfoa few Guofeberries for eariy fruit; and likewife may train fome in efpaliers, both of Currants aud Goofeberries.

The Black Curralit fhould alfo be admitted in the collection, in a fmaller portion, or as may be required, either principally in ftandard-buthes, or fome againit walls.

Young trees for planting, may be obtained, of all thy. forts, at the public nurferies, of proper growtin, of two or three feet, furnithed with handfome full heads for immediate bearing, plentifuily the firt year, if planted in the proper feafon, either in autumn about Odtober or November, or any time in winter in open weather, or in the fpring in February or March, before they begin to bud or thoot confiderably; or all the forts may be raifed expeditiounly and plentiful by the following methods.

They are propagated or raifed principally by cuttings of the young thoots; or may alfo be raifed abundantly by fuckers rifing from the roots; or alfo by. layers of the branches; or by feeds, to obtain new varieties, efpecially the Goofeberries, which run into ditferent varieties very abundantly, but not in the Currants: however, the principal propagation of both Currants and Goofeherries is generally effected by cutting and fuckers, in the autumn or fpring. 'The cutting. muft be young fhoots of the laft fummer; chure tho: of middling-itrong growth, cut off about ten ortwelie, to fifteen or eighteen incheslong; prune the weak, benciing tops, if any, and plant them by dibble in rows, a foot afunder, inferted about one third or half into t':e ground; they will emit roots freely below, and thoo is at top; and by fuckers from the roots, thefe are proper when of one or two years growth; dig them up any time in open weather, from Octuber to March, with roots to each; cut away frde-fhoots, and prune weal, long, or crooked tops; or any fuckers with full heads may have them continued, or only cut off irregular thoots. thereof; and thus plant them, either in a uurfery for training, efpecially the finaller; or itrong fuckers may be planted at crece where they are intended to remain.

Obferve, gencrally in planting the cuttings and fuchers, or particulasly the latter, that in thofe defigned for upright ftandard-buhes particularly, flould not cut them very hort, but retain fome of propser lingtil, to form a ftem abo:e ground of ix, eight, or ten isches, or more, according to their ttrength, to bitnch out at fome dittance frem tho ground, to form the heud.

D d (): 


\section{VEGETABLE S Y S T E M}

Or, in the propagation by fuckers, that where any trees have been permitsed to run up in fuckers from the bot:om, in feveral ftems, two, three, or feveral years growth, advancing quite from the root, and fometimes furnifhed with branchy heads above; the trees may either be wholly digged up, and divided into as many feparate plants as they admit, with roots to each, or only the encreafed tems detached from the parent trees, as they ftand; and may all be planted at once where they are to continue; and which, being fometimes of advanced branchy growth, forming at once handfome plants, will commence immediate tearers.

But the propagation by fuckers, is by fome rejected, as fuppofing the trees raifed by that method are apt to run more to fuckers, and not form bearers fo foon, nor plentiful, as trees from cuttings, though I never obferved any very material difference, for raifed in any method, all the tribe of Currants and Gnofeberries are much difpofed to produce many fuckers from the roots.

Layers, either of the young wood or bearing branches, in autumn, winter, or fpring, will moft readily root, to tranfplant in autumn following, though this method is feldom practifed.

To raife new varieties of Goofeberries from feed, this is obtained from the ripe fruits in autumn; fow it either the fame feafon or the fpring, in a border or bed of light earth; and when the plants are come up a'oout one year's growth, tranfplant them in a nurfery to advance to a proper fize for bearing, when, if any produce fruit of fuperior property in fize, \&c. they may be marked for culture, to propagate from by cuteings, fuckers, \&c. as in the common method.

In the advancing growth of the young trees in general, raifad from cuttings, fuckers, \&c. thofe defigned for ftandard-bufhes, fhould coinmonly be trained with a fingle ftem below, of fix or eight, to twelve or fifteen inches, by cutting off all collateral under-fhoots from the inain one, and then permitted to branch out freely above in fuil heads, cutting out irreguhar, crofs-placed, and fuperfluous thoots, leaving the others at equal moderate diftances; or if thefe firft fhoots are not fufficient in number to form the head in the beginning, they may be pruned down low to promote their thooting out fu!l and ftocky; but after which, do not thorten the gereral retained hoots before they advance of fome tclerable growth in height; except very long rambling or ftraggling fhoots, which may prune, more or lefs, equal to the extent of the general branches.

Thofe intended for walls and efpaliers may generally be trained with thort ftems, of only half a foot, or le!s, to branch out from or near the bottom, in a fpreading expanfion, cutting off the projecting hoots, and have the others range in a line to the right and left.
The ftandard-bufhes, trained as before advifed, with a fingle ftem, fix or eight, to ten or twelve inches, or more, is neceffary, that they may branch out above at fome diftance from the ground, in which they will both appear of handfomer growth, and not incommode any under-crops, as when they branch out immediately from the bottom, and which alfo renders it troublefome to dig or perform other neceftary culture to the ground or crops thereon, near the buthes, as well as more detrimental to the faid crops.

When the trees, raifed and trained as above, are of two or three feet growth in height, they are proper for firal planting, which may be performed any time: from OEtober to March, in open weather.

Plant the ftandard-buhes principally in the kitchengarden, or round any main quarters or divifions, or in: the furrounding borders thereof, in a fing!e row, fix or eight afunder feet; or fome alfo planted in crofs-rows to divide the large quarters of ground into breaks, as before obferved; which will both appear regular, afford fome Thelter to the ground in winter, and encreafe the quantity of fruit; or fome may likewife be planted in continued clofe plantations, where large quantities of the fruit are required, planted in rows eight or ten feet afunder, by five or fix feet in the rows, as formerly intimated.

And in all the above different orders of planting the frandard-buthes, generally keep them ftill trained in a fingle ftem below, by clearing away all root-fuckers and lateral hoots from the ftem; and let them branch above in full heads, but keep the heads regular by requifite pruning, to cut out any diforderly crofs-placed growths, and thin others where fuperfuous or crouded, whereby to have the general principal branches five or fix inches afunder; forming the head either concave or hollowed in the middle, by cutting out the central branches, to admit the fun and air more effectually to the fruit; or permitted to run up branchy in the middle, the branches kept thin, as above: and, in either method, they may be permitted to advance in full growth, in large heads; or only thorten any ramblers; or if required to keep the heads down, or within fmaller compafs, they may be thortened more in proportion, but by no means cut the fhoots down ftumpy, or fhorten them confiderably, which would occafion their running into numerous uielefs thoats in fummer, in a diforderly tnicket.

But as thefe bußnes generally fend out many unneceffary fhoots annually, from the fides and ends of the mother branches or main bearers, they will require fome pruning every year, to retrench the fuperfluous growths; performing the principal pruning in winter, or any time from October to March, in which, cut out all the unneceffary and improper lateral thoo!s clofe to the main branches, whence they originate; retaining 
good thoots in any vacant parts, and preferving a terminating or leading young fhoot to each branch, either naturally placed at the termination thereof, or where any branches and terminating fhoots advance confiderably too long, the branches may be occafionally pruned down, more or lefs, to fome convenient lateral hoot, friuduted lower on the branch, to remain for a leader, leaving but one to each branch; the retaired fhoots but muderately frortencd, or nor at all, in the Goofiberries particularly, except where any extend too iong, or is of a crooked or inclining growth, and which may be fhortened difcretionally.

At the fame time, in this pruning, if any old branches affume a bad habit of growth, worn-out ftate, or are become of a barren nature, o: any growing in an irregular manner, pruse them out either to their origin, or cut down tofome eligiblelower-thoot or young branch; or retaining young wood to fupply the place of the unferviceable olj, where it may feem requifite; or alfo where the general branches of any tree are too much crouded, prune out fome of the worft in a thinning manner, leaving the others at proper dittances, in fomewhat regular order.

Bcing alfo careful, in this pruning, to retain good thoots occafionally below, or where requifite, in cafual vacant parts, molty at their full length, efpecially thofe below, till advanced to a proper growth in height or length, confiftent with the extent of the general branches; and each main branch terminating generally in a young moderate thoot for a leader, agreeable to the intimations before mentioned; and which, and the retained thoots in general, may either, in fonie, be thortened moderately, or principally only any extreme thoots that are of longeft extenfion, or the others of lefs or moderate extent, continuing within regular bounds, may cither be generally left intire, or fome longeft extreme fhoots hortened a little, retaining the others at their full length; or in the Goofeberries particularly, I would advife to thorten but very fparingly, or not at all, except only to reduce any rambling extreme fhoots that extend beyond the general expanfion of the others, or that ftraggle in any diforderly direction, and fuch as recline ftragglingly downwards, \&c. as too fevere fhortening in thefe bufhes, both of the Currants and Gocfeberries, forces out numerous lateral thoots the following fummer, filling the trees with a thicket of ufelefs wood, excludes the benefit of the fun and frec air, and the confequence is, they rroduce finall illnourifhed fruit, not sipening witls is full flavour.

But the general branches bcing continued moderately thin and fomewhat regular, and the thoots not ftumped or cut very fhort, to occation a thicket of fummer wood, but remain open to the action of the fun, air, \&c. the fruit wïl be large and ripen in fuperior maturity.

Obfcrve, in pruning, that as thefc Mrubs produce their fruit both on the year-old wood, and branches of feveral years growth, upon fmall fpurs and fnags rifing along the fides of the branches, the fame branches muft be pieferved as long as they continue fruitful; or in old trees, where any of the fruit-fpurs or bearing fnags become of a decayed, worn-out, or carkery ftate, cut them off clofe, new ones will fometimes rife in or near the farne places, efpecially the Currants.

Sometimes Currant and Goofeberry Buhes are trained in fanned dwarf-itandarás, with the branches ranging only two ways, in a line to the right and left, both that they may take up lefs room, and to admit the full power of the fun and air to both fides, and the branches being fewer than in the common bufhy fandards, the fruit will generally be fuperior; they are trained with fhort ftems branching out near the bottom, cutting cof thofe projecting in front and behind, and make the fidebranches extend the way of the row; and they will produce abundance of large fine fruit in a very agreeabie manner.

Likewife for the walls hould have a good portion of the red and white currants, trained with fhort ftems, to branch out low, and the branches extended in a fanned expanfion; planting fome againft fouth walls to produce earlieft fruit, others on weft and eaft walls or palings, to produce fruit in fucceflion; and fome on north walls to ripen fruit late in the feafon; and by having them on walls of different afpects will obtain ripe fruit from the beginning or middle of June till September, or of thofe on north walls, or others defended with nets or mats from the birds and thaded from the fun, when ripening, will continue good on the trees till October or November; they fhould be planted eight or ten to twelve feet diftance, and the branches arranged horizontally, and nailed to the wall four, five, or fix inches afunder, extended at their full length, to the extent of the allotted fpace of walling for each tree; and will require pruning evcry fummer and winter, to keep them in proper regularity, and to have them bear plentifully in fuperior perfection.

Some may alfo be trained in efpaliers in the fame manner as thofe againf walls, and will produce large, fine fruit.

In the culture of thofe againft walls and efpaliers train the branches horizontally, or upright, according as the fnace of walling admits, and generally extend the branches at their whole length, as far as the limited hounds of the wall and efpalicr allows; and as the branches will find out mary finerfluous and ufelefs fhoots in fummer, thcy muft be pruned in that feafon, in Junc, July, Scc. cutting off the fore-riglit thoots, and fuch as appear unneceffary or not wanted for training, retaining only fome good, fide, lateral fhoots, in the moft vacant fpaces, where further fupplies of branches are receftary; and nail them in clofo, at their D d $z$ foll 
full length, till winter-pruning; when, any time from Octsber to March, examine the general branches, retaining all thofe of former training that are good, and if mcre are ftill wanted to complcte the expanfion, leaic fome proper fhoots of laft fummer; or if any old brancines appear of a bad growth or decayed, cut them nit, leaving young fhoots to fupply their place; and all hoots which were trained in laft funmer, not now wanted for the above occafions, or nor required in any vacant fart, prunc off clofe, generally retaining a leading hro: ic eacls mother branch, and cxtended in length :i: fat is : icir cytreme bounds, and cnly fiortened when weyced their alloted limits at fides or top; and having finified the pruning, nail cach tree accordingly i. escitur order to the wall, sce.

Some beft Goofeberrics are alfo proper to plant againit fouth walls to obtain early fruit, both to gather recen for t:rts, and for ripening in early perfection of improved fire and flavour: the-trees trained and managed as advifed for the Currants in the fame order of training.

Obferve in the generalculture of Currants and Goofeberries, in the foregoing different orders of training, it. is advifeable to keep the trees conftantly cleared from all root fuckers, which commonly rife every year, eradicating them clean out to the bottom.

In the Red and White Currants, when ripe, in July, Auruat, irc. fome trees may be defended with nets or. mats from the birds; or thofe in funny fituations, covered with mats from the full fun, during the hot, dry weather; and the fruit may thus be preierved in good. perfection, on the trees, till September, Ottober, and. November.

Currants and Goofeberrics may be forwarded to. carly fruiting, by intreducing fome of the trees in forci: g houfes; having full bearing plants, cither plantcd in the borders within, in autumn, or fome growing in rots, introduced in that feafon, or in due tine for forcing, in January. or beginning or middle of February.

\section{ROBINIA, FALSE ACACIA. \\ Clafs and Order. \\ Diadelphia. Decandria, \\ Tavo Brotberboods, Ien Males;}

\section{Or Plants with Papilionacesus Flowers, (Herm.) baving two Sets of Stamiza, or ten Stamina, or Males, in two Sets, or Brotberlioods.}

THE Robinias confit of feveral fpecies of hardy, decidious, ornamental trce and fhrub kinds, for adorning the fhrubbery and other decorative plantations; are of large, middling, and fmallgrowth; fome thitty or forty fect high, or more, others half or quarter that height, and fome not exceeding three or four feet; garnifhed moftly with long, winged, or pinnated leaves, of many pairs of folioles; and fome with quaternate or foured leaves, or placed four together; and papilionaceous or butterfy-fhape white, red, and yellow flowers, in long, pendulous bunches, of ornamental appearance in June; having monophyllous, four-lobed calyxes or cups; a corolla of four unequal petals, confuting of a preading vexillum or ftandard, two oval: wings, and a roundih carina below; ten diadelphous ftamina, an oblong, cylindric germen, fupporting $a$ bent ityle, and is fucceeded by oblong, compreffed pods, containing kidney-fhape feeds, ripe in autumn: and by which tie plants are raifed; alfo by fuckers, layers, and cuttings.

\section{The hardy Species of ROBINIA are,}

\section{x. Robinia Pfeud-Acacia-(Pfeud-Acacia) Falfe or. Baftard-Acacia, or Locuft Tree.}

A large, deciduous tree, growing thirty or forty feet, or more, making ftrong thoots - the branches thorny: leaves (large, light-green) complete pinnated, of nine or ten pairs of oval lobes, terminated by an odd one; and. long clufters of papilionaceous, white flowers, in June, one flower on each pedicle; and prickly ftipula.- $\mathrm{Na}_{2}$ tive of Virginia. (Light or any common.foil.).

Varieties.-Common Falfe-Acacia, as above, with. oblong compreffed pods.

(Pjeud-Acacia echinata) or Prickly, Shortpodded, Falfe Acacia.

\section{(PSeud-Acacia bifpida; flora rofea) hifpid-ftalked, or Rofe Acacia.}

A fmaller tree, of Shrub-like growth, ten to fifteen feet high-the branches and fower-ftalks hifpid, in fmall, briftly fpines; large, pinnated leaves; and bunches of large, moft-beautiful, deep, rofe-coloured or fcarlet flowers; in June or July.-Native of North America. (Light or any common foil.).

\section{Rов IN IA Caragana-(Caragana fiberica) Siberian Caragana.}

A deciduous fhrub, growing eight or ten feet high, or more - the leaves (middling, dark.green) abruptpinnated, of five or fix pair of oblong lobes; not terminated by an odd one; and fimple peduncles or flowerfralks, with ycllow flowers, in May or June.-Native of Siberia and Tartary. (Ang foil.)

\section{Rов INIA frutefcens-Shrubby, Four-leaved; Sibe-} rian Robinia.

A deciduous fnrub, eight or ten feet high, with erect branches and golden-coloured bark-the leaves (niddling, 
(middling, decper-green) quaternate, or placed by fours, on very fhort foot-ftalks; and moft fimple peduncles, with yellow flowers, Miay or June.-Native of Siveria and Tartary. (Any joil.)

\section{RoвINIA fggmaa-Dwarf; Four-leaved Shrubby Robinia.}

A fmall, deciduous thrub, three or four feet highthe leaves (. maller) quaternate, or placed by fours, fotting.clofe, narrow wedge fhape; and mor fimple peduncles, or fiower-ftalks, with yellow flowers, May or June.-Native of Siberia. (Any foil.)

Thefe four fnecies of Robinia are defirable furniture to affift in decorating finrubberies and other plantations in pleafure-grounds, as ornamental flowering-trees and fhrubs: they appear confpicuoully beautiful in fummer in their elegant long, pinnated, and fingular quaternate leaves, in the different fpecies; and produce their fowers in May and June very agreeably; which in the Rofe Acaria in particular, is of fuperior beauty in their fcarlet or rofe colour, and for which the fhrubs merit a place in the principal nhrubbery clumps or fpacious borders, efpecially as they generally begin flowering when but of fmall young growth, very ornamentally; however, all the others alfo deferve admit tance, and will effect a plesing variety, in affemblage with other decorative trees and fhrubs, difpofed in a diverfified order.

A!l the forts are cultivated for fale in the nurferies, and may be obtained of proper growth for planting in autumn or fpring.

They are propagated by feed, fuckers, layers, and cutings; or fome varieties occafionally by.grafting.

The feeds may be fowed in the fpring, any time in March or beginning of April, in a bed or borders of light earth, the plants will noftly come up the fame fpring: keep them clean from weeds till the autamn or fpring following, then tranfplanted in the nurfery in rows, to encreale in growth, two or three years, and then will be of proper fizes for final tranfplanting into the fhrubbery or where they are to remain in the intended plantations.

By fuckers, layers and cuttings, the Common Falfe Acacia, and fome others, fend up fuckers from the roots occafinrally, which may be taken up in autumn or fpring with roots to eacli, and planted as above; and layers and cutiiligs of younz thoots, in the fpring or autumn, will be rcoted by autumn following, or of the Ccmmon Faife Acacias, cuttings of roots in the fpring are fometimes planted in pets, plunged in an apen tot-bed, will put out fhoots above and form ghints.
Or any particular variety, fuch as the Rofe Acacia, \&c. may be propagated by grafting it in the fpring upon ftocks of any of the other kinds.

When the plants, raifed by the different methods, are two or three to four or five feet growth, according to that of the different fpecies, they are of proper fizes for the feveral plantations in which they may be intended; may be tranfplanted in the autumn or fpring or any time in mild weather, from October to March or. April; and in performing which difpofe them according to their refpective fizes they attain in full growth; the larger kinds place towards the back part, thofe of lower growth plant more or lefs forward; and being thus finally planted, let them advance in full growth, or only prune cafual, ftrolling, diforderly, fhoots, to preferve the heads a little regulas.

\section{RosA, ROSE TRE E.}

Clafs and Order:

$$
\begin{array}{cl}
\text { Icofandria, } & \text { Polygynia, } \\
\text { Twenty or more Males, Many Femalcs; }
\end{array}
$$

Or Plants with Hermaphrodite Flowers, ba-ving twentys. or nore, Stamina, or Males, and numerous Piffillums, or Females.

THIS Genus comprizes many fpecies, and numerous varieties, of the Rofe tribe, forming. a grand collection of thofe moft eminent ornameital floweringInrubs, mottly of the deciduous kind, and one evergreen; all of great merit for adorning the pleafureground in fhrubberies, flower-borders, \&c. in their molt beautiful, large, odoriferons flowers, feveral months in fummer; are generally of buhy growth, two or three to fix or eight feet high; moftly armed, more or lefs, with thorny prickles, and garnifhed with middling and fmall, pinnated or winged leaves, of two. or three pair of oblong-oval folioles, terminated by. an odd lobe; and many large, dolightful flowers, of five petals, in the common fingle kinds, but numerous in the doubles; confifting of reds, whites, yellows, \&c. in vaft varicty; having to each flower a monophyllous or one-leaved bellied, flefhy, caly'x, divided intofive long narrow fegments above, but globular and flefhy at the bafe and permanent; a corolla, of five obverfe-heartmape petals, increafing numeroufly in the double varieties, in many feries, one within another to the centre; tiventy o: more hair-like famina, and many fmall gernina in the bottom of the calyx, fupporting numerous ftyles; the conunuing flefhy bafe of the calyx becomes is curbinated-oval flefhy, unilocular red bersy, filled with many oblong, hairy feeds, ripe in autumn, and by which the plants may be raifed, for new varicties; but molt of the forts propagate abiuncastly by fuckers rifing pleitifully from the roots every 
year; and fome curious forts, not very productive of fuckers, are propagated by layers, budding, icc. lefs.

Many fpecies, moftly furnifhing varieties, more or

1. Rosa canina-Canine or Dog-Rofe; or WËd Rofe of the Hedges.

A deciduous fhrub, fix or eight feet growth-the tems armed with thorny prickles; leaves (middling) pinnated, with prickly foot-1talks; and ovate gremmina, and fmooth peduncies or flower-flalks; and fmall fingle flower. - Native of England and moft parts of Lurope, in hedges, \&c. (Any foil.)

$$
\begin{aligned}
& \text { Naricties.-White-flowered Dog Rore. } \\
& \text { Red-flowered Dog Rofe. }
\end{aligned}
$$

\section{Rosa arvergis, Field or Corn Rofe.}

A deciduous fnrub, five or fix feet-the ftem and leaf petioles prickly; pinnated leaves, globofe germina, fmonth peduncles, with fmall flowers in a corymbus.-Native of England, \&c. (Any.foil.)

\section{Varieties.-White Field Rofe. Red Field Role.}

\section{Rosa alba-White Rofe Tree.}

A deciduous thrub, of Atrong, branchy growth, fix or feven feet high-prickly ftems and petioles; leaves (middling, light-green) pinnated; and ovate Imooth germina; hifpid peduncles, with a large white flower; June and July.-Native of Europe. (Any. foil.)

\section{Varieties.-Double White Rofe. \\ Large double White Rofe. \\ Semi-double White Rofe. \\ Dwarf fingle White Rofe. \\ Maidens-blufh White Rofe.}

\section{Ros a gallica-Gallican, or Common Red Rofe.}

A various deciduous thrub, three or four to five or fix feet high, or more, in the different varieties-the ftems, and petioles or leaf foot-ftalks, hifpid-prickly; leaves (largif and middling) pinnated, of three to five oval lobes; and oval, hifpid germina, and nifpid peduncles, with large, red flowers.-Native of the South of Europe. (Any common foil.)

$$
\begin{gathered}
\text { Varieties.-Suppofed to confift of the following- } \\
\text { Common deep Red Rofe. }
\end{gathered}
$$

Double-flowered Red Rofe.

Semi-double Red Rofe,

Rofa Mundi, or Atriped Red Rofe.

York and Lancafter, or variegated Red Rofe.

Belgic Red Rofe.

Blufh Belgic Red Rofe.

Red Monthly Rofe.

Striped Monthly Rofe.

White Monthly Rofe.

Red Damalk Rofe (pale red.)

White Damafk Rofe.

Velvet Red Rofe.

Marbled Red Rofe.

Double Virgin Rofe.

Red and Yellow Auftrian Rofe; red or copper colour, on the outfide, yellow witbin.

Yellow Rofe (Common fingle.)

Double Yellow Roie.

Frankfort Rofe -- of large, ftrong growth; with red flowers, but oftel irregular, and not fo odorous as molt of the others.

\section{Rosa centifolia-Hundred-leaved Rofe.}

A various deciduous thrub, three to four or five feet high-the ftems hifpid-prickly; fmooth petioles or leaf-ttalks; the leaves (middling, dark-green) pinnated of three or five ovate lobes; oval hifpid germina, and hifpid peduncles, with large, very double red flowers. - Native of Europe. (Any common foil.)

\section{Varieties-Supposed the following-}

Dutch Hundred-leaved Rofe-(deepred.)

Blufh Hundred-leaved Rofe.

Provence Rofe-very large, deep red.

Cabbage Provence Rcfe-large, full double; the petals involving one another like a cabbage.

Pale Provence Rofe.

Childing Provence Rofe; fmaller Rofes, growing from the fide of the larger.

Bluth Provence Rofe.

Mofs Provence Rofe-moft curious in the peduncles or fower-ftalks and calyx; being covered with a Maggylike kind of mofs; the ftems brown and very clofely armed with fpines.

Singleton's Blufh Hundred-leaved Rofe. Pompone Rofe; delicately beautiful.

\section{Rosa cinnamomea-Cinnamon Rofe.}

A deciduous thrub, three or four feet high-the ftems 
ftems having fpines only principally at the joints and Ripula, under the leaves; the leaves (middling) pinnated, of five or feven foliolcs, petioles almoft fmooth; globofe, fmootli germina, and fnooth peduncles with imall, double, reddifh fowers, imparting an odour like Cinnamon.- Native af the fouth of Europe. (Any common foil.)

\section{Rosa carolina-Carolina Rofe Tree.}

A larger deciduous thrub, five to fix or feven feet high-the ftcms fnooth, purple, prickles, in pairs, at the flipula of the leaves; the leaves (midaling) pinnated, of feven oval foliolcs, fmooth fnining, fawed, the petioles-prickly; globore, hifpid germina, and peduncles fomewhat hifpid; with fmall, livid-red flowers, moftly in clufters. - Native of Carolina. (Any common foil.)

$$
\begin{gathered}
\text { Varicies.- Common Single-flowered Carolina } \\
\text { Rofe. } \\
\text { Pennlylvania Rofe; Double-flower- } \\
\text { ed; very beautiful. } \\
\text { Pale-red-flowered Pennfylvania Rofe. }
\end{gathered}
$$

8. Rosa villofa-Villofe-leaved, or Applc-bcaing Rofe.

A larger deciduous Ihrub; feven or eight feet high, with lirong ftems-the ftems armed with feattered fpines; leaves pinnated (large, roolly) of five or feven folioles, downy on both fides, petioles prickly; globofe, prickly germina, peduncles hifpid, and large red flowers, fuccceded by large, roundith, apple--hape, catable heps; fometimes ufed for fwcetmeats, \&c.Native of England, in hedges. (Aizy foil.)

$$
\begin{gathered}
\text { Irarieties.- Common fingle-flowered Apple Rofe. } \\
\text { Doublc-flowered Apple Rofe. } \\
\text { Semi-double-flowered Apple Rofe.. }
\end{gathered}
$$

9. Rosa fimpinellifolia-Pimpinella-leaved, or Burne:-icaved Rofc.

A fmall deciduous thrub, thrce or four feet highthe ftems flesder, clofely armed with frait fittered fpincs; leaves (jmall) pinnated, of fevcr (mall, roundif folioles, petioles rough; globole, fmnoth germina, and fmooth pecuncles, with fmall, fingle flowers.-iNative of England, \&c. (Aiy foil.)

\section{Varictics.-White-fowered Burnet-leaved Rofe. Red-flowered Burnet.lcaved Rofe.}

10. Rosa alpina-Aipine Thornicfs Rofe.

A Imall deciduous thrul, threc or four feet highthe ftcms unarmed or without prickles; leaves (mid- dling) pinnated fmooth; ovate germina, and peduncles fomewhat hifpid, with deep-red fingle flowers. $\mathrm{Na}$ tive of the Helvetian Alps. (Any foil.)

\section{Rosa Spinofifima-Moft-fpinous, or Dirarf Scotch Rofe.}

A dwarf deciduous under-Thrub, one, two, or three feet high-the ftems very clofely armed with fpines; leaves (mo/t $\mathrm{fmall}$ ) pinnated, petioles very prickly: ovate fmooth germina, and prickly pedincles with fmall white odorous fowers. - Native of Scotland and fome other parts of Europe. (An; foil.)

Varietics.-Common White-flowered Scotch Rofe. Red-Howered Scotch Rofe.

Yellow-flowered Scotch Rofe.

Stripe-flowered Scotch Rofe.

Marble-flowered Scotch Rofe.

12. Rosa pendula-Pendalous-fruited Rofe.

A deciduous thrub, four feet high-the Items hifpid; leaves (middling) pinnated, of five or feven folioles; ovate fmooth germina, peduncles hifpid, red flowers, and long pendulous or hanging fruit. - Native of Eu- rope. (Any foil.).

\section{Rosa rubiginofa-Rubiginous, or Rufty-leaved: Rofe.}

\section{Ross:fempervirens-Ever-green Mufk Rofe.}

A middling, ever-green, Thrubby plant, of flender, fomewhat inclining or trailing growth, five or fix feet -the ftems armed with fpines; leaves (middling flining-gren) pinnated of five or feven oval acute-pointed folioles, petioles prickly; ovate hifpid germina, and hifpid peduncles, with white mufky flowers in clufters.

-Native of Germany. (Any joil.)

\section{Varicties.-Single-flowered Mufk Role. Double-flowered Mufk Rofe. Deciduous Muik Rofe.}

\section{Rosa eg!antcria-Eglantine Rofe, or Sweet-Briar.}

A deciduous thrub, fix or feven feet high, of ftrong growtl — the ftems armed with ftrong, erect, fcattcrcd ipines; leaves ( $\int$ mall) pinnated, of five or feven fmall aciate folioles, of a fivect oduur, petioles rough; glo.. bofe fmooth germina, and fmooth peduncles with finall flowers, - Nütive of England, Switzcrland, \&ec. (Any foil.) 
Variefies.-Common fingle-flowered Sweet-briar. Double Red-flowered Sweet-briar. Semi-double-flowered Sweet-briar. Blufh-red double Sweet-briar. Yellow-flowered double Sweet-briar.

\section{Ros a indica-Indian, or Smooth China Rofe.}

A finall deciduous firrab-the ftems almoft with thorns; leaves (middling) pinnated, of five folioles, the end one largeft, petioles prickiy; ovate fmooth gersuina, and fmooth peduncles. - Native of China. (Any (joil, siarm fotuation.)

\section{Olber varieties of different Species, viz.}

Burgundy .Dwarf Rofe.

Thornlefs Rofe.

Rofe de Meux $\rightarrow$ a delicate Biuth-red Rofe.

Stepney Rofe.

Portland Rofe.

St. Francis's Rofe.

Double Velvet Rofe.

Bluh Velvet Rofe.

In themumerous different varieties of Rofes, it is rather difficult, in many of them, to determine exactly to which fpecies they belong, efpecially as many of them which are ranged under fome of the refpective fpecies, as in the Gallican Rofe, differ very confiderably in the appearance of their general growth, and the fizes of the plants, as alfo in the appearance of their flowers in fize and colour; they, however, agreeable to the ipecific diftinction, are ranged as near as could be porfibly judged, under their proper fnecies.

They are all mot defirable flowering-hhrubs, eminent as general ornaments in every garden, in their numerous beautiful fowers, large, elegant, and odorous, and fingularly ornamental in flower-borders, Thrubberies, s.c. and the plants mott hardy to grow in any foil and jituation; and peculiarly adapted to all gardens, both of large and fmall extent, and any expofure, as noft of the forts will grow freely any where without trouble, or require but litileculture, flower abundantl y every fummer, and multiply exceedingly by fuckers rifing from the roots; and the fuckers being planted off in autumn, will flower the firtt or fecond year, and continue encreafing many years in a floriferous growth.

Moft of the Rofes growing in a buthy.order, branching out loiv, often advancing with feveral ftems from near the bot:om, and many fuckers from the root, they may either accordingly, on fome occafions, be permitted to grow in their natural buhy manner, or all fuckers rifing immediately from the root cleared off, leaving only one, or more, principal ftems to thoot out in a natural branchy growth; and fome may alfo be trained with only a fingle ftem, and this pruned up below, from all lateral branches, to a clean fraight growtl, one, two, to three or four feet ligh; and to branch out above at thefe heights, and form buny heads; or fome may be trained fpreading with feveral bottom ftems, againft walls, palings, or rails; and alfo to form Rofe hedges along the front or back part of particular borders, or other compartments, to produce large quantities of flowers, where reçuired.

Rores, in their mode of flowcring, produce the.flowers principally upon the young thoots of the fame year, in May, June, July, \&c. arifing at the enits and fides of the fhoots, often feveral together, in different ttages of growth, full flowers, and buds advancing in fucceflion.

The principal feafon of Rofes flowering, is June, July, and Auguft, in the different fpecies and varieties; or fome, as the monthly Rofes, in a warm fituation, or againft a fouth wall, fometines flower in May; and which, and fome other forts, as the Murk Rofes, likewife flower late in the feafon, or till the end of fummer and autumn; the laft-mentioned forts in particular, generally flower principally in the autumn, after molt of the other kinds are done flowering.

Or when required to have fome of any forts of Rofes flower late, to obtain a longer fucceffion of flowers, it may be effeeted occafionally, either by tranfplanting fome late in the fpring, about April or begin. ning of May, well watered, and by checking their firtt growth, by the late tranfplanting, they will thoot later in the feafon, and flower in the latter-part of fummer; or in others, not tranfplanted as above, but by pruning the tops of the young hoots of the fame year, in May and beginming of June, it retards the firt flowering. and they emitting frefh thoots the fame feafon, will produce Rores late in fummer and autumn.

Sweet-briar is efteemed for planting principally for the odorous fcent of its leaves; and occafionally, in the different forts, to effect variety, in affemblage with any of the Rofe tribe.

Rofes for planting, may be had in collections, or as tequired, at the common nurferies, in proper plants for immediate flowering the firf year; and, in the greater part, may be propagated plentifully by fuckers, rifing from the roots annually in fummer, to plant off the autumn, winter, or fpring following; the larger ones planted at once where they are to remain; or the fmaller plants, if wanted, fet in a nurfery for a year or เพพo.

The feafon for planting Rofes is any time in open weather, from October or Noxember, to March or April. 
All the different fpecies and varieties of Rofes may be planted any where as principal fummer ornaments ro every garden, proner to adorn borders, Mrubberies, and other compartments, where thought eligible, in almoft any foil, fituation, and expofure, planted either in fingle ftems, cutting or clearing away all lateral and bottom thoots and hranches therefrom, and fhorten long, ftraggling tops and rambling fhoots; or others, growing branchy from the bottom, cutting out any very irregular growths, may be planted in that order, to grow at once more bufhy, if required; and, in planting, difpofe them generally in fome front or confpicuous fituations next the walks, lawns, \&c. where they may appear ornamental when fowering.

In their advancing growth, either trained fome with fingle ftems, as above intimated, of one or two feet, or more, by clearing away all fide-fhoots and fuckers fiom the roots, in which they will form the handfomeft plants, with regular heads, and produce larger flowers; or others may be permitted to branch out from the bottom in a more full and bethy manner; and in all of which, as they will fometimes run out in rambling fhoots, they fhouid have occafional pruning, either fometimes in fummer, in very rude fhoots, or principally in autumn, winter, or fpring, to regulate general diforderly growths, and to cut out decayed wood, alfo to eradicate fuckers from the roots.

As fome forts have flender, ftraggling branches, as in the ever-green and Muk Rofes, and fome others, it is proper to give them fupport of Atakes, to keep them in an upright growth; or fome of thefe forts srained to walls.

Likewife, Rofes are fometimes planted and trained in low hedges, two or three feet high, both for ornament and to produce large quantities of Rowers, to gather either for bocquets or oconomical occafions; and, for which purpofe, having a quantity of fuckers or full plants, they may be planted in a fingle row, eithcr along the back or front of a border, a foot afunder ; and when all are planted, cut the tops even to an equal height, of half a yard or two or three feet; and as they will annually fhoot out ftrongly at fides and tops, they thould be cut in regular with a knife or garden flicars, either in autumn, when done flowering, or in winter or fpring.

The Eglanteria or Swect-briar, for its fweet fcent, is alto fo:med into fmall hedges occafionally, either by foiving the feed in a drill where the hedge is intended, and the plants to remain; or by planting young feedling plarts from a nurfery, when of one or two years old, as they do not fucceed well when tranfplanted of large growth; the roots are apt to be woody and naked of fibres, that will not ftrike frecly, like young plants.
Or Rofes may alfo be planted arciain will or nat ings, and the branches nailed thercio is regular order. in which they will flower very agrecably; or fome monthly rofes, or any principal or more deficubic firts planted againt fouth walls, it will promote their early flowering; and as fome forts are of ftraggling grow $t$. as in the ever-green and Mufk Rofes, \&rc. it would be eligible to plant fome againft walls or rails, in which to train the branches regularly.

Some principal forts may alfo be planted in pots, for moving therein, when in flower, to adorn any particular parts.

Alfo, where any are required for forcing, they thould be planted in pots, ready to introduce in horhoufes or forcing-frames, Sic. of artificial heat, in the proper feafon, winter or early in the fpring; and in which they may be forvarded tn an early bloom, in February, March, and April, two or three months before their natural feafon in the open ground.

The general propagation or method of increafing and raifing moft of the different kinds of Roles, is principally by fuckers from the root, fent up very abundantly every fummer, fit to plant off next autumn or winter, \&c. or alfo occafionally by layers, or efpecially where any do not furnith fuckers freely, fuch as in tie Niofs Provence Rofe, which is generally fparing in fuckers; and, in default thereof, this and any other curious forts of fimilar nature are either raifed by layers of the young branches, or by budding them upon any conimon Rofe ttocks.

However, the propagation by fuckers obtain more or lefs in all the forts; they being produced in fpring and fummer, may be fcparated or digged up, when of one or two years growth, in altumn, winter, or fpring, with roots to each; prune long, ftraggling parts of the root, and florten the weak tops; and nuy be planted, either fome in a nurfery for training to proper growth, or ?rong ones siay be planted at once where they are to continue for flowering.

As Rofes often, in their natural ftate, run up witle feveral fickers, whinh, permitted to remain, become in many fems in a large, buthy growth, in which cate the vhole plant may occafionally be taken up, and the cncreafed parts divided into ferarate ltems, with roots to each, and planted, each forming a diftinet plant.

Layers, where intended, muft be of the young fhoots, laying them in the autumil or fping, ant the? will be rooted in one fummer for planting in the alitumn following.

Or may raife Rofes from the feed to obtain new la rictics; and may be fowed in the autumn or fpring, in E c 
s bed or toruer of light earth; and the feedling-plants, when a year old, tranfplanted in a nurfery.

But the Siveet-briars are generally raifed or propagated from feed in the common fort; or the different rarieties of double kinds, \&c. by fuckers and layers, though the Briars are very reluchant in fuckers: fow sile feed in autumn or fpring, either broad-caft and saked in, or covered in with earth half an inch to an inch deep, or fowed in drills that depth, both in drills a foot afunder, for occafional tranfplanting; and fome may be fowed in a fingle drill, along the edge of a border in the fore or back part, or of any other compartment, to form a fort of hedge, if required, either to remain, or fome tranfplanted while of young frowth, for they will not tranfplant fuccefsfully when lirge.

Or the double and other varieties of the Sweetbriars, if they do not afford fuckers for propagation, they may be raifed by layers of the young wood in the fpring or autumn, or budded, in fummer, upon any of the Briar ar Rofe ftocks.

RUBUS, BRAMBLE and RASPBERRY.

Clafs and Order.

$$
\begin{array}{ll}
\text { Icorandria, } & \text { Polygynia, } \\
\text { Trenty, or more, Males, Many Females; }
\end{array}
$$

Or Plants with Hermathrodite Flowers, baving trventy, or more, Stamina, or Male Frutificasions, and many Pifillums or Females.

THIS Genus, Rubus, furnifhes fix or feven fpecies, and many varieties of ander-fhrubly, trailing, and upright, Rirubby plants, cultivated for variety, ornament, and fome for their production of fruit; all of Alender growth, with trailing and upright ftalks in the different fpecies, garnihed with pinnate and ternate, digitated leaves, compoled of five and three lobes; and pentapetalous, white and purple flowers, in clufters, at the fides and ends of the thoots, in June and July, having, to each flower, a one-leaved, fiveparted, permanent cup; five roundion petals, containing twenty, or more, fhor ftamina, and numerous germina and flyles; fucceeded by clufters of cornpound, roundifh, fucculent berries, of many fmall acini, furnithed each with one feed; the berries and feed ripening in autumn, in Auguft and September, fi)me for eating, others not; and the feeds are feldom ufed for fowing, as the plants propagate abundantly by cuttings, iayers, and fuckers.

\section{Several Species, viz.}

Confatiig of trailing 'kinds, with long, trailing falks, of feveral years duration, and upright kinds, with the ftems of but one year's continuance, but renewed annually every fpring or fummer from the root.

\section{BRAMBLE KINDS.}

\section{Ilaving mofly long, trailing, durable Stems.}

\section{RuBus fruticofus-(Shrubby Rubus) Common Bramble or Black-berry Plant.}

A trailing, deciduous, fhrubby plant, with long. flender, trailing ftems, extending ten or twelve feet the ftems armed with prickly fpines; leaves quinate and ternate, hand-Thape, (misiling, dark-grzen) of five and three lobes; and white and purple flowers, fucceeded by black-berries. - Native of England and all parts of Europe, in hedges. - (Any foil and fituation.)

\section{Varieties.-Common Elack-fruited Bramble. White-fruited Bramble. Double-bloffom Bramble. Unarmed or fmooth Bramble. Cut-leaved Bramble. Striped-leaved Bramble.}

\section{RuBus cefius, Blue-berried Bramble or Dew- berry.}

A fmaller, weak, trailing, deciduous, under-Rhrub, with trailing ftalks, extending four or five feet-the ftem round and prickly; leaves ternate, (middling) of three larger, almoft naked, lobes; the lateral ones bilobated; and fmaller, bluint-black fruit.-Native of England, \&c. among bufhes. (Any foil.)

\section{Ruвus bifpidus-Hifpid Canada Bramble.}

A trailing, deciduous, under-firub-the ftems long, trailing, hifpid or brifty; leaves ternate, (middling) of three naked, fmooth lobes, petioles hifpid; and fmall berries.-Native of Canada. (Any foil.)

\section{RASPBERRY KINDS.}

Having the Stems upright, feveral rifing from each root, fome lafing but one year, and renewed every fpring.

\section{Ruвus idaus-(Rubus of Mount Ida) or Com- mon Rafpberry Plant.}

An upright, under-fhrubby, deciduous plant, rifing with feveral ftems, four or five, to fix or eight feet 
high-the ftems prickly; leaves quinate-pinnated and ternate, (middling, light-green) of five and three folioles; petioles or foot-italks channelled; purple and white flowers, fucceeded by clufters of fine, large, eatable berries; July, Auguft, and September.-Native of England, \&c. in woods. (Any common, fertile foil.)

\section{Varicties.-Purple-flowered Rafpberry. \\ White-flowered Rafpherry. \\ Red-fruited Rafpberry. \\ White-fruited Rafpberry. \\ Twice-bearing White and Red Rafp- berry, producing two crops of fruit annuall:-; the firtt in July and Au- guft, the fecond in September. \\ Black-fruited Rafpberry. \\ Prickly-ftalked Rafpberry. \\ Smooth-ftalked or Cane Rafpberry, of ftronger and taller growth. \\ Great, Yellow, Antiverp Rafpberry, growing with very tall, ftrong, ftems; and large, yellowifh fruit.}

This fpecies, Rubus idaus, and different varieties, are the principal forts of the Rubus family, to cultivate for their fruit; and for which, they demand culture in every garden, the berries being large and agreeable to eat both in their natural growth, and for tarts, Rafpberry-jamm, and for making the diftilled liquor, called Rajpberry, \&cc.

\section{Ruzus odcratus-Odoriferous or Virginia Flower- ing Rafpberry.}

An upright, larger, deciduous, Thrubby plant, with ftrong items, five, to fix or feven feet high-the ftem unarmed or fmooth, with numerous, fimple leaves, (large, light-green) palmated or hand-hhape; and many large, purple, ornamental flowers, and fmaller, black fruit, of but little flavour.-Native of Virgiria and Canada. (Any common foil.)

\section{Ru Bus occidentalis-Occidental or Weftern Ame- rican Rafpberry.}

An upright, deciduous, Mrubby plant-the fems prickly, with ternate leaves, (middling) of three, or inmetimes five lohes, downy on the under fide; pezioles or foot-ftalks round; and fmall, black fruit.Native of America. (Any foil.)

\section{Rueus canadenfis-Canada, fmooth Rafpberry.}

An upright, deciduous, thrubby plant, with purple fems-the ltems unarmed or fmooth, digitated or fin- gered leares, (middling) of ten, five, and three fmall, fpear-hape lobes.-Native of Canada. ( $A n$ ) common foil.)

All thefe fpecies of Rubus are hardy, farubiny plants, that will grow in any common foil and fituation; are cultivated in gardens, fome, or all the forts, for variety and ornament in fhrubberies, borders, sc. and one fort, Common Rafpberry, and its feveral va. rieties, is in the moft general efteem and cultivation for their production of fne eatable fruit, being larger and more agreeably-flavoured than that of any of the other fpecies; though the fruit of all the fpecies of Rubus, both of the Bramble and Rafpberry linds, is alfo eatable, even the Common Wild Bramble, or Black-berries of the hedges; but all greatly inferior to the Common Rafpberries, fo that the other forts are principally admitted for variety, to diverfify fhrubberies, \&c. as allo fome varieties, or all the forts of the Common Rafpberry occafionally.

But the Ruвus idaus, or Common Rafpberry, and moft of its varieties, are the moft valuable in culture for their abundant crops of excellent berries, both of the Red and White forts; ripening in July and AuguR; and the twice-bearing fort produces both in that feafon and a fecond fmall crop in September; and the great Yellow Antwerp Rafpberry, introduced within thefe few years in the Englin gardens, grows much ftronger and taller than any of the other varieties of the fame fpecies, and the fruit moft large and fine, ripening about the fame time as the others; all of which are hardy to grow in any common, fertile foil of a garden: thould have an open fituation in the full fun; are commonly planted in rows, four and a half or fivé feet afunder, for full plantations, and occafionally planted fingly in borders, \&cc.

All the Rafpberry kinds grow with upright items; generally feveral from each root, rifing annuaily in the fpring or fummer, produce fruit the following lummer, and decay the enfuing winter, for the fime individnal ftems never bear but once, and always dic in the winter after, being, provioufly fucceeded by $z$ produstion of fren ftems in the preceding fummer, for fucceffional bearers the enfuing year; as they always bear the fruit on the young or year-old hoots of the former fummer's production, wlich, rifing abundantly in fuckers inmediately from the continuing roots, in the fpring, attain full growth the fame ycar, bear fruit the fummer following, principally upon fmall, lateral froots of the fame year, arifing froin the fides of the main ftems; and the whole decaying down to the root in wirter, as before obferved, a proper fucceftion of young lteris being produced i:1 fummer, the old cises muft be cut out to the buttum, in winter os fpring, to make room for young fupply,

$$
\text { E e } 2
$$


Iraving three, feur, or five of the Atronget upon eacl itoc!, clitting the othcrs away clofe to the ground, ingetiver with the decayed ftems aforefaid; and the remaining fuccelison thoots pruned at top, or thortened abcut one-third or fourth of their length.

The cther fpecies of Rutus are valued principally to introduce as flowering-thrubs and for variety, in diverfifying fhrubbery plantations or any decurative compartments in pleafure-grounds, flower-gardens, borilers, sec. or, likewife, may introduce all or any defira's varieties of the Common Rafpberry for the fane occafion, in affemblage with the others, or any principal forts thereof, fuch as the Rubus odoratus, 0 : Odorous, Virginia Flowering-Rafpberry, and the occidertal kind, or any curious forts of the Bramble tribe; though the Common Bramble is rarely aimitted, or only fometimes a plant or two in t.rickcts or any rough plantations, for obfervation; but the White-fruited, Double-flowered, and other varieties thereof, together with the other two Branble fpecies, are proper to admit in curious hrubbery culenions.

For the above occafions of planting in decorative pompartinents, thrubberies, Epacious borders, \&c. all ur any defirable fpecies and varieties of the Rubus fomily, being eligille, and if difpofed in a varicd oider, they wiil difplay a very agreeable variety in sheir oc:ueral groweh, flowering and fruiting in fummer and autu:nn.

Dut the Flowering Rafpberry in particular, being very multitolicus in its large, palmated, finiple leaves, and prociucing numerous, large, confpicuous flowers, nake a very urnamental appearance.

All the principal forts may be procured at the general nurferies, for planting, which may be performed in the autumn or fpring, or any tine, when fettled, open, weather, from Oetober to March; and will moultiply or encreafe plentifully in their different or respective ways of propagation.

The propagation of the Brambles is effected abundaritly by layers at any feafon of the year, and by suttings in the fpring or autumn.

But the Rafpberries are propagated moftly by fuckers, rifing auntally from the roots in many ftrong, upright ftems, in the fpring and fummer, of proper growth for traniplasting in autumn, \&c. or fpring following, with roots to each, and either generally planted at once where they are to remain, or fome in a nurfery, tiil wanted for future occafions; and will all flower and fruit the enfuing fummer; or may likex ife be propagated by layezs and cuttings of the thoots in the autumn or fpring feafon; but fuckers, forming immediate rooted plants, of proper growth, are noa eligible for general planting.

The Common Rafpberries, when cultivated for their fruit, thould have an open fituation to the full $f_{t i n}$, in any good foil of a gard. $r$; are gencrally planted in kitchen gardens, but may be planted whe:e thought convenient, either in full plantations, in continual, wide rows, a yard and a ha!f, or five feet afunder, to admit of proper room for their full growth in fummer, and free accefs of the fun and air between the rows, to promote the growt's and flavour of the fruit in full perfection; or fome may alio be plinted in a fingle row, along the back part or front of a bo:der, or on the fides or along the edges of any large quarters, and in fingle, crofs rows, in the divifions of the latter; or, likewife, may difpofe fome in fingle pants, or tivo or three tngether, in borders, S.c. to grow in diftinct, fingle branches.

Likewife, fome may be occafionally planted againl: fouth and other walls, and in efpaliers, and the ftems. trained tk:seto, whereby to obeain the fruit of fupesior growth and flavour.

In all the above methods have the ground prepared for their reception, by proper digging or trenching.

Provide for planting, as above, proper fupplies of young fuckcrs, of fome good bearing plants, in autumn, or any time from September or Oetober, to Marcl or beginning of April, in open weather, digging them up with good roots to each plant; and, of which, prefer thofe of ftrong, ftraight growth, with the moft fibrofy roots, as the roots of fome are apt to be woody and naked; and obferving, that where fometimes fmall, advancing, buds appear on the roots, near or at a fmall diftance from the frem, the plants are defirably eligible, as the buds are rudiments of future thoots for the following fummer; prune any long, very Atraggling, and naked, woody part of the roots, and Thorten the weak, bending tops; and then, the ground where they are to be planted being digged, plan: thofe defigned for a full plantation, in wide rows, four feet and a half, or five fect afunder, and two or three feet diftance in each row; or, for the larger kinds, five or fix feet, or more, between the rows, vould be eligible, to allow fufficient room for their fpreading growth in fummer, and to admit the free air and fun, in that feafon, to the fruit, as alfo to have good room to pafs between the rows, to gather the produce.

Others may be planted in fingle rows, in particular parts, as before intimated, or fome difpofed in patches, in borders, Sic. fingly, or two or three plants toge- 
ther, in a fort of clump, and fome againft walls, palings, rails, and efpaliers.

They will mofly or all produce fruit the firft year, but more abundantly and in full perfection the fecond fummer, and continue feveral years in a plentiful, bearing ftate; though, as fometimes after four or five years production, the fruit will be fimailer and lefs abundant, it would be advifeable to make a new plantation of young plants, once in three, four or five years.

The Rafpberry fruit, attaining maturity in July and Auguft, in the principal production, when ripe, it will not continue good on the plants above two or three days, and fhould be gathered accordingly, in fmall baikets, to contain only a fmall quantity together, that they may not bruife; and, likewife, after being gathered, they require to be almoft immediately ured for the purpofes intended, as they foon fpoil, or in a day or tivo become mouldy, and full of maggots, peculiar to this fort of fruit.

With regard to general culture of the plantations of fruiting Rafpberries, they will require an annual drefing of pruning and digging the ground between, \&ce. every autumn, winter, or fpring; generally keep them clear from large weeds all fummer, by occafiona] hoeing, and, at the fame time, clear out all ftrolling fuckers arifing in the fpaces between the main plants, which permit to advance in full growth during the furnmer; and muft have a general pruning, \&c. in autumn, or any time from Oetober or November, to March; and in which operation, it muft be remembered, that as thefe plants always bear only on the young ftems or fuckers of a yearold, and as the fame ftems or fhoots never bear but once, they decaying in the winter following, young ones having been produced from the roots in the preceding fummer, to fucceed them in bearing, the old fems muft therefore be cut away in autumn or winter, \&c. aforefaid, clofe down to the ground, and, at the fame time, felecting three or four of the ftrongeft, young ftems, of the lait fummer, on each ftool, cut away the weak or fuperabundant clean to the botton; and, in thofe retained, prunc or fhorten the tops, or only cutting off the weak, bending part thereof; and when thus pruned, clearing way the cuttings, \&c. dig the ground between the rows, eradicating any ftraggling fuckers that are produced between or at a difance from the main nools, ftirring and levelling the ground clofe about the bottom of the continuing plants, and in the intervals.

After pruning, if, where the fems are long, they Araggle mucb afunder, they may either be tied or plaited two or three together, to preferve them in upsight growth, or occafionally thofe of the fame or of differen ftools may be falcued archways together, wove.
In old plantations of two or three years gro:vth, or more, it would be of advantage to manure. ti:e ground with rotten dung, applied and digged in any time ia winter, \&c. after pruning the piants, as above; it will revive and give frem vigour to the roors, promote a ftrong, free growth in the Rems, and the fruit will be large and full-flavoured accordingly.

\section{SAM в U C S, ELDER TREE.}

\section{Clafs and Order.}

$\begin{array}{ll}\text { Pentandria, } & \text { Trigynia, } \\ \text { Five Males, } & \text { T'bree Fenales; }\end{array}$

Or Plants with Hermaphrodite Flowers, baving five Stamina or Male Parts, and three Piftillums or Females.

THIS Genus, SAMBucus, furnithes three hardy fpecies of deciduous tree and thrub kinds, of the berry-bearing tribe, to cultivate for ufe and variety, and the betries for Elder Wine; are of moderate growth in regard to general fize, producing ftrong thoots, full of a white pith, garnifhed with large, pinnated, or winged leaves, of two or three pair of oblong lobes, terminated by an odd or end foliole; and fmall, monopetalous, wheel-fhape, white flowers, in large, cymofe-umbellate bunches, having, to each plant, a a fmall, five-parted, permanent calyx, a corolla of one fmall, rotated petal, cut into five obtufe fegments, containing five aivl-fhape ftamina, terminated by roundin anthera; an oval germen, crowned with three obtufe thigmas; and the germen grows a fmall, roundifh, unilocular berry, many together in a bunch, each furnifhed with three feeds; ripe in autumn; and by which the trees may be raifed; but are more generally propagated by cuttings.

\section{The Species are-}

\section{SAMBUCUS nigra-Black-berried or Common. Elder Tree.}

A fmall, deciduous tree, eighteen or twenty feet high, with jointed, Atrong fhoots, full of pith-the ftem tree like; leaves (largifh, dark-green) pinnated, of two pair of lobes and an odd one; and large, fiveparted, cymofe umbels of white flowers, fuccecded by large, umbcllate bunches of black-berries, valuable for making Elder Wine.-Nativc of England, Germany, \&cc. in hedges, banks, old walls. \&c. (Any foil and fituation.)
Varietics.-Common Black-berried Elder. White-berried Eldcr. Grcen-berried Elder. (Laciniata) Laciniated or Jagged-leav- ed, called Parflcy-leaved Elder - the leaves cut into narrow fegments. 
Gold-ftriped-leaved Elder.

Silver-frriped-leaved Elder.

Silver-dufted-leaved Elder.

\section{SAM U UUS racemofa-Racemofe-flowering, or Red-berried Elder.}

$\Lambda$ fraller, deciduous tree, of thrub-like growth, ten to fifteen feet higli-the ftems arboreous; leaves (Jaller, ciark-green) pinrated, of two and one pair of lobes; terminated by an odd one; flowers in compound, oval clufters, jucceeded by bunches of red berries.-Native of the fouthern parts of Europe. (Aiy foil.)

\section{SAMBU CUS canadenfis-Canada, under-fhrubby Elder.}

A deciduous, under-fhrubby plant-the ftem fhrubby; leaves (middling) fub-bipinnated, or doubly-winged, and ternate; and cymofe, five-parted umbellate bunches of flowers.-Native of Canada. (Any foil.)

Of thefe three fpecies of Sambucus, the Common Elder is that the moft generally known and cultivated; planted principally in out-parts, both in ftandards for their berries, and in hedges for outward fences, either to run up rough to afford plenty of berries for Elder Wine, or the hedge kept down low and clofe, by annual clipping, \&.c. though this, and its varieties, are alfo admitted in large ornamental tree plantations, to diverfify the collection; as likewife the other two fpecies are introduced for the fame occafion; all of which, however, are admitted in fuch plantations more for variety than ornament; and as Elders in general, when in flowcr, impart a ftrong, difagreeable, unwholefome fcent, they are not proper to plant near habitations, or muchfrequented walks, \&sc.

They are all very hardy to grow in any foil and fitu ation; and the Common Black Elder grows any where, in fhady or open expofures, moift or dry places, fides of ditches, or tops of dry banks, and often grow out of crevices of old walls, from fcattered feeds; and which, and all the other forts, are raifed plentifully by cuttings of the young fhoots, thruft into the ground in autumn or fpring, which will readily frike 1:00t below, and thoot above.

But in regard to the Common Elder, when defigned to cultivate the trees, either in ftandards or hedges, the black-berried fort thould be principally ufed, and is the proper fort to cultivate for its berries for Elder Wine; and which may be trained, both in detached fingle ftandards, in hedge-rows, or along the fides of ditches and banks, or in any bye or wafte grounds, or planted for heriges for outward fences; and, if in which it is re. quired for a production of berries, fhoula be permitted to run up rough at fides and top: and in all of which, the trees will produce abundant annual crops of berries, ripening in Auguft and September, and are then valuabie to gather, with which to make that moft excellent cordial called Elder Wine, bein $\tilde{b}_{0}$ a very agreeable beverage in winter and cold weather, when made warm and properiy fweetened.

Or Elder Trees may alfo be admitted in timber or foreft-tree plantations, or places by themfelves, to grow large for that purpofe; as, when old, the wood is hard, and is fometimes fubftituted inftead of box-wood, for fome occafions.

The Common Elder is alfo employed occafionally, in forming fencible hedges expeditioufly in outward boundaries, along the tops or fides of banks, or fides of ditches, \&c. is effected by planting cuttings of the frong young fhoots in the autumn or fpring, planted in the place where the hedge is intended; either in fhort cuttings, half a yard or two feet length, thruft down or introduced into the earth half-way, a foot afunder; or, if larger ftrong fets of a yard or two long, infert them either into the top or fide of a bank, flanting or upright, or on level ground, as may be required, planted the dif-. tance as above; or alfo ftrong cuttings of three, four, or five feet, may be planted flanting, the way of the row, acrofs one another, chequer ways, to form an immediate fence; they will all readily frike root, and thoot ftrongly at top; obferving, as thefe hedges will thoot vigorouny, they thould be lept regular by clipping them every year, that they may grow clofe and thick from the bottom upward, to render them effectual fences.

T'he propagation of Elders for general ufes, is principally by cuttings of the ftrong finoots, as already intimated; and occafionally by the feed or berries; but as cuttings is confiderably the moftexpeditious, that method of propagation thould be generally practifed; and they may be planted any time in open weather, from September to March.

Chufe always cuttings of the young fhoots of laft fummer, one, two, or three feet, of ftraight, clean growth, or occafionally longer fets of four or five feet length, or more; all planted either in the places where they are to remain, or fmall ones in a nurfery, to raife rooted plants of a year or two old, for particular occafions, inferting the cuttings in general, fix or eight to ten or twelve inches, or more, according to their length : may either be planted with a dibble, or the ends Tharpened and thruft into the ground; they will all root freely and fhoot at top in ftrong growth in the fpring and fummer.

Likowife by feed of berries, thefe ripening in au- 
tumn, bruife them to feparate the feeds, and may be fowed in any bed or border, raked or covered in with earth, half an inch deep; and when the plants are of three or four, to five or fix inches growth, in the end of fummer, or in autumn or fpring, tranfplant them in 2 nurfery to obtain ftrength.

\section{VITIS, VINE, or GRAPE VINE.}

$$
\text { Clars and Order. }
$$

Pentandria Monogynia,
Five Males, One Female;

\section{Or Plants with Herm. Flowers, baving five Stamina, or Male Fructifications, and one Piffillum, or Female.}

THE VITIs afford 3 feveral hardy fpecies, moltly of long, trailing, climbing, Thrubby growth, fome moft valuable for their fruit, others for variety; but for the former, one fpecies in particular, the Common Vine, furnifhing many fine varieties, is of great eftimation and value to rank in the collection of fruit-trees, forthe production of their moft excellent fruit the Grape ; are all of the deciduous tribe, grow with very long flexible branches and hoots, requiring fupport of walls, \&cc. by which they afcend or extend to a confiderable height or length; producing numerous long, trailing, jointed fhoots, annually, extending many feet in one fummer; garnithed at the joints with large, fimple, lobated leaves, divided into three or five lobes, and in fome pinnated; attended by oppofite climbing tendrils or clafpers, and fmall clufters of minute, greenilh, quinquepetalous fowers at the cyes of the fame year's hoots; having to each flower a fmall quinquedented cup, five fmall deciduous petals, containing five thort ftamina, an oval germen, no fyle, only an obtufe figma; and each germen grows a roundifh and oval, unilocular, five-feeded berry; many together in oblong cluftered bunches, black, white, red, \&c. ripening in autumn, from July to Oetober, rich and delicious; the feed feldom ufed for fowing, as the plants propagate plentifully by layers and cuttings.

\section{The principal Species are-}

\section{Vit1s vinifera-(Wine-bearing Vitis) or Com- mon Vine, or Grape-Vine.}

A trailing-climbing decidusus tree, extending twenty feet length, or more - the leaves (large) lobated, of three or five lcbes, finuated, naked; and flowers fucceedcul by large bunches of roundith and oval berries, or Grapes, black, white, red, \&c. rich and delicious fur enting ard making wine. - Native of the four quarrers of the wor!d, in warm, temperate parts. (Diy, risb, or any common fortile foil.)

\section{Varieties of the Fruit.}

Early Black July Grape-fmail, roundin, black berries, in clofe hort bunches; ripe fomotimes in the end of $7 u l y$, or mofly in the beginning or middle of Auguft.

Early Black Sweet-water Grape--fmall, roundith black berries, in clofe thort bunches; fweet juice; rige the beginning or middle, to the end of Auguft, Ecc.

Early White Sweet-water Grape-larger, round, whitih-green berries; often irregular in fize, growing in oblongift bunches; fweet juice; beginning and middle, to the end of Auguft.

Black Mufcadine Grape-mialle-fize, round, blackith berries in longith bunches; rich juice; September.

White Mufcadine Grape-middle-fize, round, whitith berries, in long loofe bunches; fweet and rich flavoured; end of Auguft and September.

Royal White Mufcadine-larger round berries, whitifh-amber-coloured, growing in large oblong bunches, dividing above into fide--houlders; moft rich and excellent; ripening in September.

Black Clufter Grape-fmall, roundifhoval, black berries, growing in very clofe, fhort, roundin bunches; juicy and rich; the tree remarkable in its hoary downy leaves; fruit ripe in Sepiember.

Frankindal Grape-large, round whitifh berries, in large oblong bunches; rich and fomewhat muky-towered; ripe is Sepiember.

Red Chaffelas Grape-largion round berries, growing in oblong bunclies, of a dark-red colour; middle of Sepromber.

White Chaffelas Grape; September and October.

Black Burgundy Grape-largifh oval berries, black-red colour, growing in roundith-oblong bunches, more valuabie for making wine than for the table; ripe is September.

Black Corinth Grape-fmaller, roundin, deep-black berries, in fhort bunches; fivect juice; end of Seprember and in Octobsr:"

Black Frontignac Grape-largifh, rourd, black berries, in fhortin bunches; ve. $y$ rich fweet juice; end of September and in Oclober.

Grilly, or Red Frontignac Grape-large round berries, of a brick-red colour, in longer bunches; Septcmber and October.

White Frontignac Grape-large, reurd, whicis 
whitith berries, in large clofe bunches; Sepremter and Oczoter.

Black Hamburgh Grape-middling, roundith-oval berrics, in large oblong buncl-es; Octoter.

Fed Hamisurgh Grape-roundin, tawneyred berries, in large bunches; Octsher.

Alexandrian White Murcat Grape-large oval white berries in long bunches; molt rich; ripens the moft effectually by artificial heat, or under glafies; October, or, by forcing, 'June, 'July, and Auguft.

Red Alexandrian Múcat-large, oval, red berries, in long loofe bunches; ripens, more fully, by artificial heat, or under glaftes, \&c.-Ockober, or, by forcing, 'fune, Fuly, and Augufl.

Yiolet Mufcat Grape-large berries, in long bunches; OEtober, or earlier, by forcing, or under glafes.

St. Peter's Grape-largeft oval berries, of a deep-black colour, in remarkably large long bunches; ripens, more effectually, under glafles, Sac.-Ockober, or, by forcing, Fune, Fuly, or Augi:f, छc.

Red Raifin Grape-large blackifh-red berries, in large long bunches; ripening in beft perfection, by artificial heat, erc.OEtober, or, by forcing, July, Auguft, September, Eै?

White Raifin Grape-large white berries, in large loofe bunches; September or $\mathrm{O}_{c}$ tober, or, by forcing, Fuly and Auguft.

Syrian Grape-large roundifh-oval white berries, in exceeding large bunches; ripening, by artificial heat, under glafles, scc. in Fuly, Auguft, or September.

Tokay Grape-large white berries, in oblong bunches; Ociober, or, by forcing, $7 u$ ly, Auguf, Eृc. (Moft rich.)

Red Tokay Grape-large bunches and red berries.

Gibraltar Grape-large berries and bunches, tawney or blackifh-red; Septcmber or Oczober, or earlier, by forcing.

Pafle Mufque Grape-large white berries, very rich; Ozlober, or earlier, by forcing.

Red Mufque Grape; September or OEtober.

Chaffelas d'Ore-large yellow berries, in oblong bunches; September or OEzober.

Chaffelas Violet Grape; September and $\mathrm{O} c$ tober.

Chaffelat de Fontainbleau; end of September, $\varepsilon^{\circ} c$.

The foregoing being the prineipal varieties of the iruit of the Conmon Grape-Vine; the trees of which are hardy to grow in any common foil and fituation; but thould generally have a dry, warm funny expofure, againft fouth walls, to have the fruit ripen in good perfection; and fome require antifance of at tificia! heat, or protection of glafies, \&c. in order to obtain the fruit in full maturity, as intinated under the namcs, \&c. of the reSpective forts.

All the varieties of Vines bear on the young thoots of the fame year, arifing from the laft year's wood; fo that a general fupply of the young thoots inuft be preferved every year, in fummer and winter-pruning, for fucceffional bearers.

They are propagated or raifed by layers and cut tings of the young hoots and branches, in autumn or fpring, which will be well rooted in one feafon.

Vines, being of long extending, trailing, or climbing growth, require the fupport of walls, \&c. on which to train their branches; and allotted fome beft fouth walls, or of a foutherly afpect, to enjoy all poffible benefit of the fun to forward the growth and ripening of the fruit, in good perfection; may be planted in autumn or fpring, or any tine from Oetober to March, or beginning of April, fet ten to twelve or fifteen feet difance; and the branches trained to the wall, either horizontally, or more or lefs upright, according as the allotted tpace of walling admits, arranged fix or eight, to ten or twelve inches afunder.

The Vines require a drefling or pruning every year in fummer and winter.

The fummer-pruning confilts of a general regulation of the young thoots of the fame year only, conmencing it in the latter end of April, or in May or beginning of June; and difplace all weakly fhoots advancing from the old wood, except in vacancies, being careful to preferve all the immediate fruit thoots, and others as are ftrong and wetl-placed in all parts, for future mother bearers or fupply of branches; and nail the whole regular to the wall all firmmer, and, when confiderably extended, may be fhortened difcretionally.

The winter-pruning comprifes a general operation both among the old branches and young wood, any time from October till March, obferving, in which, to felect a general fupply of the beft hoots of laft fummer, in all par is, for next year's mother bearers, \& c. fix or eight to ten or twelve inches diftance, cutting out the fuper-abundant, with part of the laft year's bearers and naked, old wood, to make room for the fucceffional young, which Thorten, more or lefs, by cutting each to three, four, five, or fix eyes, or joints, according to their ftrength; then nail the whole, bo:t young and old branches, regularly to the wall, eights ten, or tivelve inches diflance. 




i $\therefore$ : ;. $\vdots 9=$

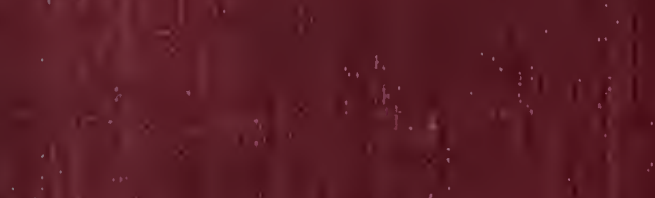
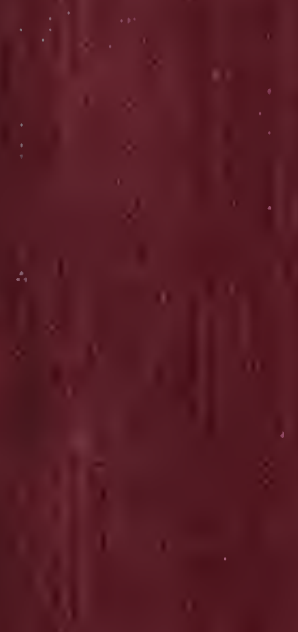

(4) 